$$
\begin{gathered}
\text { UNIVERSIDADE DE SÃO PAULO } \\
\text { FACULDADE DE FILOSOFIA, LETRAS E CIÊNCIAS HUMANAS } \\
\text { DEPARTAMENTO DE GEOGRAFIA } \\
\text { PROGRAMA DE PÓS-GRADUAÇÃO EM GEOGRAFIA HUMANA }
\end{gathered}
$$

\title{
ROSALINA BURGOS
}

\section{Periferias uRbanas da metrópole de São Paulo}

Territórios da base da indústria da reciclagem no urbano periférico

São Paulo

2008 


$$
\text { UNIVERSIDADE DE SÃO PAULO }
$$

FACULDADE DE FILOSOFIA, LETRAS E CIÊNCIAS HUMANAS

DEPARTAMENTO DE GEOGRAFIA

PROGRAMA DE PÓS-GRADUAÇÃO EM GEOGRAFIA HUMANA

\section{Periferias urbanas da metrópole de São Paulo}

Territórios da base da indústria da reciclagem no urbano periférico

\section{Rosalina Burgos}

Tese apresentada ao Programa de Pós-Graduação em Geografia Humana do Departamento de Geografia da Faculdade de Filosofia, Letras e Ciências Humanas da Universidade de São Paulo, para a obtenção do título de Doutora em Geografia.

Orientador: Profa. Dra. Odette Carvalho de Lima Seabra

São Paulo 2008 


\section{SUMÁRIO}

Resumo $\quad$ …

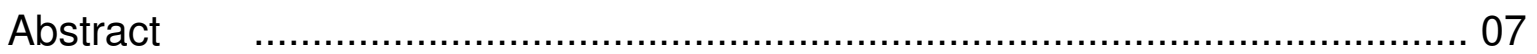

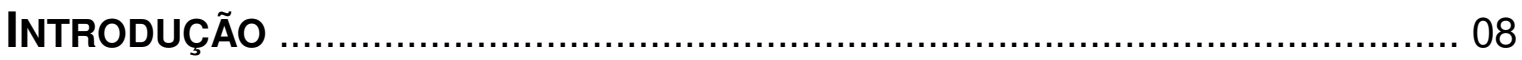

Capítulo I - Periferias urbanas da metrópole de São Paulo 29

1.1. Formação territorial da periferia urbana da metrópole de São Paulo 32

1.2. Transformações recentes das periferias urbanas da metrópole de

São Paulo no contexto do mundo do trabalho 38

1.3. A noção de urbano periférico

1.3.1. A relação centro - periferia na metrópole fragmentada 38

1.3.2. Periferias urbanas - metrópole fragmentada 39

1.3.3. Territórios empobrecidos no urbano periférico $\quad 45$

Capítulo II - Trabalhadores sobrantes na base da indústria da reciclagem: catadores de materiais recicláveis

2.1. Trabalhadores sobrantes: os catadores de materiais recicláveis

2.2. O trabalho do catador sob a perspectiva do materialismo histórico $\quad 67$

2.2.1. O trabalho do catador no comércio de recicláveis 68

2.2.2. O trabalho do catador na estrutura industrial 71

2.3. O chão dos catadores: territórios de usos dos catadores avulsos $\quad 73$

$\begin{array}{ll}\text { 2.3.1. Pesquisas sobre moradores de rua, albergados e catadores } & 79\end{array}$

2.3.2. O processo de trabalho realizado pelos catadores avulsos carrinheiros 85

Capítulo III - Terceiro Setor no contexto das políticas neo-liberais 95

3.1. O Terceiro Setor da indústria da reciclagem 97

3.1.1 Discursos e ações na institucionalização da base da indústria da reciclagem 104

3.2. O Terceiro Setor no contexto do neo-liberalismo: revisão conceitual 110

3.2.1. O Terceiro Setor como parte constitutiva do Estado em reforma 111

3.2.2. Governança urbana, empreendedorismo e Parcerias Público-Privadas 114

3.2.3. A mediação das ONG's nos investimentos destinados às demandas sociais

3.2.4. O papel das ONG's na institucionalização dos movimentos sociais 119

3.2.5. Discursos ideológicos da Responsabilidade Social Empresarial 121

Capítulo IV - A estruturação recente da indústria da reciclagem 123

4.1. Reciclagem e Coleta Seletiva: a caminho de (re)definições 123

4.2. A produção de matérias-primas a partir da base da indústria da reciclagem

4.3. Um novo estágio no processo de estruturação da indústria da reciclagem

4.3.1. A organização da base da indústria da reciclagem: as cooperativas 147

4.4. Os bilhões ganhos com a reciclagem 150

4.5. Panorama recente dos Índices de Reciclagem no Brasil 157

4.6. Panorama da Coleta Seletiva no Brasil e a medida da desproporção 172

Capítulo V - A base da indústria da reciclagem no Município de São Paulo

$\begin{array}{lll}\text { 5.1. A Coleta Seletiva no Município de São Paulo } & 176 \\ \text { 5.2. Milhares de catadores \& toneladas de recicláveis } & 189\end{array}$

5.2.1. Grupos de catadores organizados 
5.2.2. Catadores avulsos: estimativas 191

5.2.3. Coleta Seletiva \& catação: a medida da desproporção 194

5.3. A distribuição espacial dos locais com atividades da reciclagem 197

5.3.1. Grupos de catadores organizados: a institucionalização da base industrial nas periferias urbanas da metrópole 197

5.3.2. Cooperativas, sucateiros e recicladores: estrutura piramidal da indústria 202

5.3.3. A distribuição espacial dos locais com atividades da reciclagem 205

5.5.4. A produção de matérias-primas no urbano 218

CAPÍTULO VI - A organização da base da indústria da

reciclagem no território de Itaim Paulista: a Cooperativa Fênix-Ágape 224

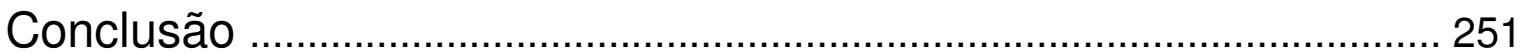

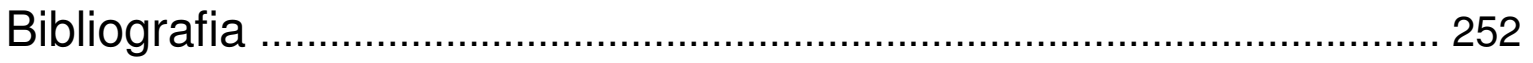

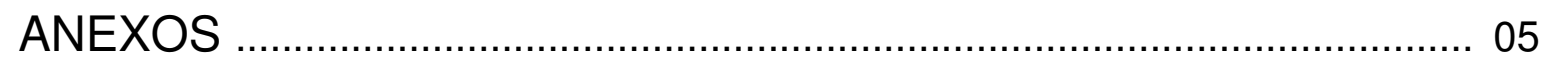


Anexos dos capítulos I a V

01 Revisão conceitual do CAPÍTULO I

02 Revisão conceitual do CAPÍTULO II

03 QUESTIONÁRIO do Trabalho de campo: entrevista com catadores avulsos

04 Incursões no chão dos catadores: relatos sobre catadores avulsos carrinheiros

05 Relato do $5^{\circ}$ Festival Lixo \& Cidadania

06 Cooperativa ASMARE e a Fábrica de plástico da Rede Cata-Unidos (BH/MG)

07 Projeto Ações de desenvolvimento social junto catadores de materiais recicláveis" - OAF/MDS (2004-2006)

08 Encontro Nacional e Marcha dos Catadores de Materiais Recicláveis (Brasília)

09 Considerações sobre o Documento "Análise do custo de geração de postos de trabalho na economia urbana para o segmento dos catadores de materiais recicláveis"

10 Classificação Brasileiro de Ocupações : catadores de materiais recicláveis

11 Identificação de tipos de plástico (pelo cheiro obtido com queima de amostra)

12 Relatório de Visita e Vistoria na Central de Pinheiros - LIMPURB (fev/2006)

13 Metodologia - estimativa do número de catadores em São Paulo

Anexos do Capítulo VI

14 - Abaixo assinado - reivindicação de Central de Triagem

15 - Agentes Comunitários de Saúde - relatos sobre os núcleos de reciclagem

16 e 17 - Diário Oficial de São Paulo: Câmara de Animação Econômica

18 - Relatos das bases da Rede Cata-Sampa

19 - Prospecto Casa do Fazer 


\section{Resumo}

Esta Tese tem como questão central o processo de transformações recentes das periferias urbanas da metrópole de São Paulo, no contexto do mundo do trabalho (políticas neo-liberais pós anos 70). Com base neste questionamento, realizou-se uma pesquisa sobre a estruturação da indústria da reciclagem, enquanto objeto plenamente implicado pela questão inicialmente posta.

A pesquisa foi desenvolvida a partir de três premissas. A primeira diz respeito ao processo de formação da periferia urbana, bem como de suas transformações recentes, tendo como fundamento as determinações do mundo do trabalho. A segunda premissa se refere às formas de inserção dos trabalhadores pobres urbanos no processo de industrialização-urbanização. Parte-se do pressuposto de que o urbano sempre ocupou contigentes de trabalhadores pobres não inseridos em atividades formais. Trata-se, nesta pesquisa, de compreender os termos pelos quais, no contexto da urbanização crítica (Damiani), a indústria da reciclagem se ergue arregimentando milhares de catadores, na condição de trabalhadores sobrantes. A terceira premissa se remete ao fortalecimento do Terceiro Setor, enquanto parte constitutiva do Estado em reforma, cujo fundamento se encontra no contexto das políticas neo-liberais, pós anos 70 .

Com base nestes fundamentos, a pesquisa foi realizada de acordo com os Níveis e Dimensões do urbano (Henri Lefebvre, 1999) correspondentes aos níveis do real. Por sua vez, privilegiou-se o Nível Misto, propriamente urbano. Enfatiza-se a (re)inserção produtiva de trabalhadores sobrantes nas atividades inscritas no urbano periférico, noção desenvolvida no escopo da Tese. Neste contexto, as periferias urbanas constituem territórios da base desta indústria, inclusive como frentes de formação de capital. Caracterizam-se, neste sentido, como territórios de expropriação, ou ainda, como território de escassez da riqueza produzida.

Palavras-chave:

periferias urbanas, indústria da reciclagem, catadores, matérias-primas, trabalhadores pobres urbanos, Terceiro Setor 


\section{ABSTRACT}

The central question of this thesis is the transformation process of the recent urban peripheries in the city of São Paulo, concerning to the world of work (neoliberal policies after 70s). Based on this question, was held a search on the structuring of the recycling industry, while object fully involved in the issue originally called.

The research was conducted from three premises. The first concerns the formation of the urban periphery, as well as its recent changes, with the plea determinations of the world of work. The second premise refers to integration forms of poor urban workers in the process of industrialization-urbanization. It is assumed that the city always held contingent of working poor not entered into formal activities. It is, in this research, to understand the terms by which, in the context of urbanization critical (Damiani), the recycling industry is built recruit thousands of cart-pullers on the condition of spare-workers. The third premise is referring to the strengthening of the Third Sector as a constituent part of the reforming State, whose foundation is in the context of neo-liberal policies, post 70s.

Based on these reasons, the search was carried out according to the Levels and Dimensions of Urban (Henri Lefebvre, 1999) corresponding to the levels of reality. In turn, the emphasis is the Mixed Level, as a proper urban. We emphasize the productive (re) integration of spare-workers in the activities shown in the peripheral urban, developed concept within the scope of the thesis. In this context, the outskirts of urban areas are underpinned this industry, including as fronts for capital formation. They are characterized, in this sense, as areas of expropriation or, as territory of the shortage of wealth.

Key words:

urban peripheries, the recycling industry, cart-pullers, raw materials, urban working poor, Third Sector 


\section{INTRODUÇÃO}

Esta Tese teve início com um questionamento sobre as transformações recentes das periferias urbanas da metrópole de São Paulo, no contexto das mudanças ocorridas no mundo do trabalho (políticas neo-liberais pós anos 70).

Neste sentido, formulou-se a seguinte questão: o que acontece com a periferia urbana, enquanto locus histórico da reprodução da força de trabalho, num mundo do trabalho em crise? Diante da complexidade envolvida nesta questão, e admitida a dificuldade em lidar com este processo em toda sua magnitude, buscou-se um objeto de pesquisa que implicasse, e estive plenamente implicado, (n)o processo de transformação recente das periferias urbanas da metrópole.

Assim, a pesquisa desenvolvida no escopo da Tese diz respeito à estruturação da indústria da reciclagem. Processo que envolve os mais diversos agentes sociais, e que tem no urbano os elementos essenciais para sua realização: abundância de resíduos sólidos urbanos; trabalhadores pobres urbanos, sobrantes dos mais diversos setores produtivos; territórios empobrecidos nos quais se realiza o conjunto de atividades inscritas na base desta indústria.

Isto não quer dizer que o objeto, da forma como agora se apresenta, já estivesse dado. Foi preciso trilhar um percurso metodológico para desvendá-lo.

Assim, antes de mais nada, devemos esclarecer que a pesquisa foi realizada de acordo com os Níveis e Dimensões do urbano (Henri Lefebvre, 1999) ${ }^{1}$ correspondentes aos níveis do real.

Em primeiro lugar, no que diz respeito ao contexto das políticas neoliberais (pós anos 70), a pesquisa destacou as implicações da reestruturação produtiva e das reformas do Estado (engendradas no Nível Globaf, na ordem distante) sobre as condições de (re)inserção produtiva dos trabalhadores pobres urbanos, enquanto trabalhadores sobrantes dos mais diversos setores. São trabalhadores sobrantes porque, neste contexto de mudanças estruturais no

\footnotetext{
1 Lefebvre, Henri. A revolução urbana. Belo Horizonte: Editora UFMG, 1999.

2 (...) Esse nível global é o das relações as mais gerais, portanto, as mais abstratas e, no entanto, essenciais: mercado de capitais, políticas de espaço. Ele não deixa de reagir mais e melhor no nível prático-sensível e no imediato. Esse é, portanto, o nível do que chamaremos 'o espaço institucionalizado'). (Lefebvre, 1999:79)
} 
decurso do processo de modernização, tornam-se paulatina e massivamente supérfluos aos processos produtivos ${ }^{3}$.

Porém, estes trabalhadores, ao não conseguirem vender sua força de trabalho no setor formal, ingressam nas mais diversas atividades informais desenvolvidas nos interstícios do espaço urbano (no Nível Misto, propriamente urbano, nele inscrito o Nível $P$, na ordem próxima) ${ }^{4}$. Na pesquisa, estes trabalhadores correspondem aos catadores de materiais recicláveis, (re)inseridos produtivamente no conjunto de atividades inscritas na base da indústria da reciclagem. Mas é preciso deste já esclarecer que esta (re)inserção produtiva é contingente, no sentido de que estes catadores realizam o conjunto de atividades inscritas na base da indústria da reciclagem, sem que se tornem trabalhadores da indústria propriamente dita. Há que se considerar que os catadores são antes consumidos do que reproduzidos enquanto força de trabalho. Assim, a (re)inserção produtiva dos catadores não os retira da condição de trabalhadores sobrantes. Por isso, entende-se que são trabalhadores pobres urbanos (re)inseridos produtivamente na condição de sobrantes. E é nesta condição que participam do processo de produção da mercadoria matéria-prima, a ser consumida produtivamente. Por isso a compreensão de que se trata de uma (re)inserção produtiva. Como será visto no corpo da tese, não estamos diante de relações assalariadas ${ }^{5}$, mas de um processo complexo que envolve, inclusive, formação de capital.

Portanto, para os extratos mais pobres dentre os trabalhadores pobres, as estratégias de sobrevivência (Pochmann, 2001) podem significar, tão somente, a reprodução do irrisório da vida. Mais do que isto, o irredutível da vida pode se tornar tão reduzido, que no limite, o que lhes resta, é o consumo da própria energia vital (a não-reprodução, enfim, a morte). Sendo assim, o vivido (no Nível Privado, do 'habitar') é dramaticamente restringido, estando sob as determinações

\footnotetext{
${ }^{3}$ Nas últimas décadas, foi ficando cada vez mais evidencia aquilo que já se sabia - o capital pode se desenvolver muito e, ao mesmo tempo, precisar menos do trabalhador. Porque uma das características do capital é substituir trabalho por máquina, por tecnologia e conhecimento científico. (Martins, 2002:29)

${ }^{4} O$ nível $M$ (misto, mediador ou intermediário) é o nível especificamente urbano. (...) uma forma relacionada com o sítio (o meio imediato) e com a situação (o meio distante, condições globais). Esse conjunto especificamente urbano apresenta a unidade característica do 'real' social, o agrupamento: formas-funções-estruturas. (...) Mesmo se o nível M só se define como 'mediador' (misto) e não como essencial e central [Nível $P$, o 'habitar'], ele é, a esse título, terreno e motivo da luta. (Lefebvre, 1999:79-80; 88)

${ }^{5}$ Exceto para o caso dos catadores que são assalariados dos comerciantes de recicláveis. Mas este universo não foi o enfoque dado pela pesquisa. Esta, por sua vez, concentrou-se no processo de trabalho realizado por catadores avulsos, bem como no contexto da formação de cooperativas.
} 
e contingências do urbano que ocupa. Este é o nível correspondente aos territórios de uso, que são instaurados pela prática socioespacial do catador, os quais denominamos de chão dos catadores. Sobre este "chão", e portanto sobre a vida destes milhares de trabalhadores sobrantes, incidem todas as determinações dos níveis superiores, edifício arquitetado no contexto das políticas neo-liberais.

Por sua vez, a pesquisa foi realizada a partir do Nível Misto, propriamente urbano. Justamente porque sobre ele incidem as determinações do Nível Global, ao mesmo tempo em que nele se inscreve o plano do vivido, correspondente ao Nível Privado. Ademais, no processo de institucionalização da base desta indústria, as ações dos agentes sociais (em suas relações, mediações e discursos) têm no nível propriamente urbano o lugar e o terreno onde as estratégias de confrontam, mas também de uma prática urbana $(\ldots)^{6}$. Este é o nível em que se inscrevem as cooperativas, cuja organização do processo de trabalho visa a configuração aprimorada dos materiais recicláveis como matériaprima para os mais diversos setores produtivos.

Neste sentido, buscou-se o reconhecimento dos principais agentes sociais envolvidos na totalidade concernente ao objeto da pesquisa:

$\left.1^{\circ}\right)$ Estado, principalmente no âmbito do poder local;

$\left.2^{\circ}\right)$ Terceiro Setor, com destaque às entidades que atuam nas demandas sociais relacionadas com a reciclagem, do que resulta a denominação de Terceiro Setor da indústria da reciclagem;

$\left.3^{\circ}\right)$ Iniciativa privada, as indústrias recicladoras e comerciantes do ramo;

$\left.4^{\circ}\right)$ Trabalhadores pobres urbanos, na condição de trabalhadores sobrantes, os quais experimentam uma (re)inserção produtiva como catadores de materiais recicláveis. Estes atuam tanto individualmente (catadores avulsos) quanto em grupos organizados (cooperativas, associações, núcleos);

$\left.5^{\circ}\right)$ cooperativas, enquanto modelo que responde melhor aos desígnios de estruturação da indústria da reciclagem, ajustando o processo de produção de matérias-primas.

\footnotetext{
${ }^{6}$ (...) O fenômeno e o espaço urbanos não são apenas 'projeções das relações sociais, mas 'lugar e terreno onde as estratégias se confrontam. (...) Aí incluído o que concerne especificamente ao nível $M$, a saber, as instituições, organismos e 'agentes' urbanos (...). Nem por isso , o fenômeno e o espaço urbanos deixam de ter uma realidade e uma vitalidade específicas, isto é, há uma 'prática urbana' que não se reduz nem às ideologias e instituições globais (...) nem às atividades particulares denominadas 'urbanísticas' (...). Lefebvre (1999:85).
} 
Uma vez identificados os Níveis do Urbano e os agentes sociais em relação ao objeto da pesquisa, foram estabelecidas três premissas essenciais para o desenvolvimento da Tese.

A primeira premissa diz respeito ao processo de formação da periferia, bem como de suas transformações recentes, tendo como fundamento as determinações do mundo do trabalho. Ou seja, entende-se que a periferia urbana, enquanto forma correspondente a conteúdos sociais concretos, está diretamente relacionada com a reprodução da classe trabalhadora. De acordo com Kowarick (1994:49) “(...) falta ainda muito esforço teórico e de pesquisa para obter instrumentos conceituais adequados que dêem conta da problemática referente à ligação entre exploração do trabalho e espoliação urbana que, segundo tudo indica, só por razões de facilidade analítica podem ser abordados de maneira separada. Ou seja, falta ainda quebrar a separação que usualmente se faz entre as esferas da produção e da reprodução da força de trabalho."7

De acordo com este pressuposto, as mudanças processadas no mundo do trabalho, repercutem em transformações nos conteúdos socioespaciais da periferia.

Neste sentido, foi traçado um breve histórico acerca do processo de formação da periferia urbana da metrópole de São Paulo, como fundamento para a compreensão de suas transformações recentes.

Neste ínterim, identificou-se a necessidade de se repensar a relação centro-periferia no contexto da metrópole fragmentada, com base numa revisão conceitual dedicada ao tema da urbanização e, mais propriamente, sobre a periferia . Portanto, mais do que uma Revisão Bibliográfica, trata-se de uma leitura interessada no processo de formação da periferia, bem como sobre suas transformações recentes. No cerne destas leituras e reflexões, chegamos à noção de urbano periférico. É o que desenvolvemos no CAPÍTULO I - PERIFERIAS URBANAS DA METRÓPOLE DE SÃo PAULO. A referida revisão conceitual compõe o ANEXO 01 da Tese.

Resulta deste conjunto de reflexões as seguintes proposições:

$1^{\text {a) }}$ O binômio "bairro dormitório - local de trabalho" vem sendo conjugado num só espaço, ou seja, na própria periferia. O trabalhador sobrante, que já não "ateia fogo" à produção de valor no chão da fábrica, recebe agora "o

\footnotetext{
${ }^{7}$ Kowarick, Lúcio. São Paulo: As lutas sociais e a cidade: São Paulo passado e presente. 2. Ed. Rio de Janeiro: Paz e Terra. [1988] 1994, p.49.
} 
convite para causar incêndio" no seu próprio território. Neste sentido, as atividades desenvolvidas no setor informal têm possibilitado a sobrevivência de um contingente populacional sem precedentes, oriundo da classe trabalhadora, massivamente desempregada, mas que reproduz fora das fábricas, e no seu próprio território, processos de trabalho inseridos num circuito inferior que se vincula ou é diretamente mantido por curiosos nexos com o circuito superior da economia urbana (Santos, 2004) ${ }^{8}$. Face à conjugação, cada vez mais freqüente, das duas modalidades de espaço historicamente relacionadas à reprodução dos trabalhadores (local de moradia - local de trabalho) a periferia urbana já não se apresenta mais tão homogênea quanto em seu processo de formação, como pôde ser compreendida sob o predomínio do padrão periférico de crescimento (Kowarick, 1979).

$\left.2^{a}\right)$ Embora o referido padrão periférico de crescimento continue expandindo a periferia nos limites territoriais urbanos (confinando e segregando os pobres urbanos nas "franjas" da metrópole), a periferia urbana não se refere, tão somente, à periferia distante, consolidada e/ou em contínua formação. $\underline{A}$ periferia urbana, enquanto condição social da pobreza, corresponde aos territórios empobrecidos da metrópole, os quais estão presentes tanto na periferia quanto no centro propriamente ditos. Isto requer que repensemos a relação centro-periferia. $\mathrm{Na}$ metrópole fragmentada, como é o caso de São Paulo, o binômio centroperiferia cede lugar ao binômio metrópole fragmentada-periferias urbanas ${ }^{9}$.

$3^{a}$ ) Enquanto condição social da pobreza, as periferias urbanas (assim no plural), estão sob o domínio do urbano periférico. Trata-se de uma noção desenvolvida no escopo da Tese. A noção de urbano periférico se refere, sobretudo, à negatividade do urbano, a qual se faz presente tanto na periferia quanto no centro da metrópole fragmentada, no contexto da urbanização crítica (Damiani, 2004). O urbano periférico é próprio da metrópole fragmentada. $\underline{A}$ noção não nega o estatuto teórico da relação centro-periferia, mas busca explicar o que há em comum nos territórios empobrecidos tanto no centro quanto na periferia propriamente ditos. Assim, o urbano periférico, entendido como presente no centro e na periferia, é próprio do Nível Misto, especificamente urbano (Lefebvre, 1999). Esta noção está fundamentada tanto sob uma perspectiva

\footnotetext{
8 Santos, Milton. O espaço dividido. Os dois circuitos da economia urbana dos países desenvolvidos. 2 ed. São Paulo: EDUSP, 2004.

${ }^{9}$ Com base em no binômio proposto por Seabra (2004): metrópole-periferias.
} 
sociológica quanto numa perspectiva geográfica. Ou seja, compreende-se as periferias urbanas enquanto condição social da pobreza, possibilitando admitir sua presença tanto na periferia quanto no centro propriamente ditos. Em termos geográficos, a noção corresponde aos territórios de (re)inserção produtiva do trabalhador pobre no urbano (no urbano periférico), o qual no processo de modernização social sobrevive na condição de trabalhador sobrante.

$4^{\mathrm{a}}$ ) Se, por , um lado, no processo de industrialização-urbanizaçãometropolização, o urbano sempre se revelou capaz de ocupar contingentes de trabalhadores à margem do mercado de trabalho formal (Pinto, 1984; Pochmann, 2001), enfatiza-se aqui a (re)inserção produtiva de trabalhadores sobrantes nas atividades inscritas no urbano periférico. Estas atividades se concentram em territórios empobrecidos, instaurados nas periferias urbanas da metrópole. Neste sentido, as periferias urbanas são mobilizadas pelas frentes de formação, acumulação e expansão do capital produtivo. Caracterizam-se, neste sentido, como territórios de expropriação, (já pressuposta a exploração e a espoliação). Embora as periferias urbanas sejam mobilizadas para a produção da riqueza, permanecem em sua condição social de pobreza, como territórios de pobreza. Ou ainda, como território de escassez da riqueza produzida, em que a riqueza neles produzida se realiza no alhures, na indústria, enquanto permanecem na condição social da pobreza.

$\underline{\left.5^{\circ}\right)}$ Em relação à indústria da reciclagem, a noção de urbano periférico traduz sua presença-ausente no urbano, no qual se encontram os fatores elementares sobre os quais esta indústria se ergue: a abundância dos resíduos do consumo (próprio desta sociedade urbana sob as determinações do sistema produtor de mercadorias); o verdadeiro "exército" de trabalhadores pobres sobrantes (que experimentam uma reinserção produtiva no conjunto de atividades inscritas na base estrutural da indústria), bem como os territórios de escassez da riqueza produzida (presente nas periferias urbanas, seja na periferia ou no centro propriamente ditos). Constituem, por assim dizer, um tripé, que não se encerra nele mesmo. Ao contrário! Ele está completamente implicado pelas ações, relações, mediações e discursos dos mais diversos agentes sociais mobilizados no processo de estruturação da indústria da reciclagem: a iniciativa privada, o Estado, o Terceiro Setor, enfim, a sociedade inteira convocada a participar de uma nova racionalidade. Esta, por sua vez, incorpora os preceitos da sustentabilidade e da justiça social, sendo apresentada pelos agentes 
hegemônicos (iniciativa privada, Estado e Terceiro Setor) como um "novo paradigma na gestão dos resíduos sólidos urbano", sob o qual avança o processo de metamorfose do lixo em matéria-prima. Processo que se realiza no Nível Misto, enquanto lugar e terreno onde as estratégias se confrontam (Lefebvre, 1999:85), sob o domínio do urbano periférico. Neste sentido, o urbano periférico refere diretamente "ao lugar e ao terreno" no qual sobrevivem os pobres na urbanização crítica, onde o urbano não é para todos (Damiani). Mas que ainda assim segue abrigando os contingentes de trabalhadores sobrantes que procuram sobreviver nos interstícios do urbano. Assim, o urbano periférico reúne fragmentos da sua negatividade (o acúmulo exacerbado de lixo, um exército de trabalhadores pobres sobrantes, territórios empobrecidos tanto no centro quanto na periferia), os quais, em relação uns com os outros, tornam-se a base para/desta nova indústria.

A segunda premissa diz respeito às formas de inserção dos trabalhadores pobres urbanos no processo de industrialização-urbanização. Parte-se do pressuposto de que o urbano sempre ocupou contigentes de trabalhadores pobres não inseridos em atividades formais (Pinto, 1984; Valladares, 1991; Pochmann, 2001). Este entendimento contou com uma revisão conceitual que integra o ANEXO 02 da Tese, estando contemplada no CAPÍTULO II - TRABALHADORES SOBRANTES COMO CATADORES DE MATERIAIS RECICLÁVEIS.

Com base nesta premissa, a pesquisa identificou aspectos importantes da relação capital - trabalho, revelando processos produtivos que se realizam no urbano, para além do "chão da fábrica".

O CAPítULO II, além de ser dedicado à análise do processo de trabalho, expõe uma compreensão sobre a formação de capital no âmbito da indústria da reciclagem, justamente porque põe ênfase no processo de trabalho realizado pelos catadores na sua base estrutural. Portanto, buscou-se o desvendamento da relação [capital (industrial) - trabalho (produtivo)], ou ainda [industria (reciclagem) - trabalhador (sobrante)], cindida pela intermediação dos comerciantes de recicláveis (em cujo nível se encontra o capital comercial). Assim, no processo de redução do emprego formal industrial (Singer, Pochmann, 2001; Barelli, 2003), no contexto da reestruturação produtiva inscrita no plano mais geral das políticas neo-liberais (Pochmann, 2001, Antunes, 1999, Davis, 2006), observa-se novas formas de relação capital - trabalho. 
Desde já é necessário esclarecer que não estamos diante da produção de mais-valia, que se traduz no lucro auferido pelas indústrias. Essencialmente porque não estamos diante de uma relação assalariada; não se trata de uma relação entre patrão e empregado, correspondente à igualdade jurídica sob a qual se realiza a desigualdade econômica ${ }^{10}$. Contraditoriamente, os catadores são trabalhadores sobrantes, cujas atividades realizadas (catação, transporte, triagem, etc...) corresponde ao processo de trabalho destinado à produção de matérias-primas para os mais diversos ramos industriais. Para a indústria, trata-se da aquisição de matérias-primas mais baratas que resultem em redução de custos com capital constante (em sua parte circulante), participando do aumento da taxa de lucro ${ }^{11}$. Porém, as matérias-primas oriundos do processo de reciclagem - como todas as demais matérias-primas - não são dádivas da natureza $^{12}$. Resultam de processos de trabalho, e no caso das atividades realizadas pelos catadores, trata-se de trabalho não-pago. O que é pago aos catadores corresponde aos preços dos recicláveis, definidos ao nível do comércio $^{13}$, e não ao trabalho por eles realizado (catar, transportar, triar, etc...). Assim, a relação capital (produtivo) - trabalhador (sobrante) deve ser desvendada no processo de produção de matérias-primas, segundo os interesses da própria indústria. Não só por que reduz custos com energia, água, extração de minerais, entre outros, que possibilita aumento da taxa de lucro. Mas porque no referido processo há trabalho não-pago.

Neste sentido, no Capítulo II é apresenta uma "breve incursão" no universo dos catadores avulsos, ou carrinheiros, através de trabalhos de campo

\footnotetext{
${ }^{10}$ (...) a desigualdade econômica entre o capitalista e o trabalhador só pode ocorrer com base na igualdade jurídica sob a qual eles se defrontam. (Martins, 1981:155)

${ }_{11}$ Marx (O Capital; v.III, tomo I, Pp.62-63) define como "segundo grande ramo da economia (no sentido de economizar) nas condições de produção a retransformação dos resíduos em novos elementos de produção. (...) Esses resíduos - abstraindo os serviços que prestam como elementos da produção - barateiam, à medida que se tornam novamente vendáveis, os custos da matéria-prima (...). A diminuição dos custos dessa parte do capital constante eleva proporcionalmente a taxa de lucro com dada grandeza de capital variável e dada taxa de maisvalia.

${ }^{12}$ (...) Todas as coisas, que o trabalho só desprende de sua conexão direta com o conjunto da terra, são objetos de trabalho preexistentes por natureza. (...) Se, ao contrário, o próprio objeto de trabalho já é, por assim dizer, filtrado por meio de trabalho anterior, denominamo-lo matéria-prima. Toda matéria-prima é objeto de trabalho, mas nem todo objeto de trabalho é matéria-prima. $O$ objeto de trabalho apenas é matéria-prima depois de já ter experimentado uma modificação mediada por trabalho. (Marx, O Capital, v.I, p.150)

${ }^{13}$ Envolve fatores como custo de produção das matérias-primas (vulgarmente denominadas de "matéria-prima original" ou "matéria-prima virgem"); demanda da própria indústria que repercute na oferta e procura pelos recicláveis; variações do mercado financeiro (em relação à moeda internacional, o dólar); incremento de inovações tecnológicas nas linhas de processamento dos recicláveis; dentre outros fatores observados no decorrer da realização da pesquisa.
} 
realizados no Itaim Paulista ${ }^{14}$ (periferia consolidada e distante); nas imediação da Praça da República e na Baixada do Glicério (região central). Os catadores foram abordados nas ruas, sem a mediação de instituições ou espaços normatizados (tais como entidades filantrópicas, ONG's, albergues) ${ }^{15}$. Trata-se de uma incursão num território de uso conflituoso ${ }^{16}$, mas que ainda assim pôde ser adentrado de acordo com os objetivos estabelecidos. As entrevistas se orientaram por um Roteiro de questões (ANEXO 03), que privilegiou o processo de trabalho realizado por estes catadores: a própria catação bem como o transporte dos materiais. Foram ainda incluídas questões mais gerais sobre: a) seu histórico de inserção no mercado de trabalho; b) sua percepção sobre a institucionalização da base da indústria; c) aspectos de sua vida cotidiana.

Os principais objetivos destas "incursões" foram:

$\left.1^{\circ}\right)$ conhecer o processo de trabalho realizado pelos catadores avulsos. Este procedimento fundamentou o entendimento de que o conjunto de atividades realizadas pelos catadores corresponde a um processo de trabalho que participa do aumento da taxa de lucro industrial e formação de capital. O que, por sua vez, também pode ser reconhecido no trabalho realizado pelos grupos organizados de catadores (cooperativas, associações, núcleos). Porém, a ênfase aqui dada ao trabalho do catador avulso, carrinheiro, está na atividade dispersa da catação ou coleta, nela incluída o transporte dos recicláveis (embora estas atividades sejam também realizadas pelos grupos organizados, sob a forma de coleta seletiva porta-a-porta). Tratava-se de pôr em evidência como estes trabalhadores são, eles próprios, com seus corpos, consumidos nessa atividade que parece situada muito distantes da indústria, no processo global de produção de matérias-primas oriundas da reciclagem.

$2^{\circ}$ ) Recuperar um breve histórico da experiência anterior destes trabalhadores no mercado de trabalho. Observou-se que, além de serem trabalhadores sobrantes, são trabalhadores precarizados porque já tiveram lugar no mercado de trabalho

\footnotetext{
${ }^{14}$ Território onde se concentrou a pesquisa empírica sobre a institucionalização da base da indústria da reciclagem.

15 No sub-capítulo dedicado aos catadores avulsos constam informações de três pesquisas realizadas pela Prefeitura de São Paulo: a primeira sobre moradores de rua, a segunda sobre albergados e a terceira sobre catadores. Além desta última, nas demais também aparece 0 catador avulso. Portanto, há que se considerar o catador morador de rua, o catador albergado, o catador domiciliado. A abordagem dos catadores nas ruas estava aberta a este conjunto diversificado de catadores.

${ }^{16}$ À margem do mercado de trabalho formal, as atividades realizadas pelos catadores são traspassadas por diferentes normas, interesses, poderes. Portanto, sua prática socioespacial é tecida num campo conflituoso, próprio do Nível Misto, no qual se insere.
} 
(reproduzindo-se como trabalhadores assalariados), e passaram a sobreviver como catadores.

$3^{\circ}$ ) Evidenciar a situação dos catadores avulsos, carrinheiros, frente ao processo de institucionalização da base da indústria da reciclagem. Além de ser o mais "sui generis" dentre os catadores ${ }^{17}$, o catador avulso está sob todas as determinações da estruturação da indústria, as quais incidem sobre ele. Todos os discursos e práticas envolvidos na institucionalização da indústria da reciclagem, sob o modelo de cooperativas, são proclamados em nome dos catadores, e nisso se inclui os catadores avulsos. Mas, parte significativa dos trabalhadores pobres urbanos que ingressam nas cooperativas não tiveram um histórico anterior como catador. Portanto, parece haver um descolamento entre o conjunto de políticas de "geração de trabalho e renda com inclusão social" direcionada aos catadores (com seus programas, projetos e financiamentos) e o universo dos catadores avulsos. Para estes, resta o chão dos catadores, sobre o qual incidem o peso do processo de institucionalização da base industrial.

$\left.4^{\circ}\right)$ Buscou-se também a apreensão de aspectos da vida cotidiana destes trabalhadores sobrantes, em cuja estratégia de sobrevivência a própria vida é consumida. Assim, logo nas primeiras entrevistas (realizadas em meados de 2007), evidenciou-se que em sua prática socioespacial, definem-se territórios de uso que passamos a denominar de chão dos catadores. Enquanto território de uso, trata-se do cotidiano destes trabalhadores pobres, na relação entre trabalho, família e lazer (Henri Lefebvre, $A$ vida cotidiana no mundo moderno). Porém, as entrevistas realizadas no trabalho de campo, demonstraram a necessidade de uma pesquisa muito mais ampla e dedicada a este propósito, pois nele está o desenrolar da vida sobrevivida por estas pessoas nos interstícios do urbano. $O$ que, por sua vez, demandaria uma pesquisa que, para além do enfoque no mundo do trabalho adentrasse com a necessária profundidade no cotidiano propriamente dito ${ }^{18}$. Frente a isto, privilegiou-se a análise sobre o processo de trabalho, bem como a relação existente entre estes catadores e a

\footnotetext{
${ }^{17}$ Legaspe (1996) descreve os diversos tipos de catadores (conferir Capítulo II). As entrevistas foram realizadas com os catadores avulsos, ou carrinheiros, cujo principal instrumento de trabalho é um carrinho (geralmente uma carroça).

${ }^{18}$ Ressalta-se a importância de que outras pesquisas se dediquem ao tema do cotidiano dos catadores, sem contudo negligenciar as determinações do Capital na vida destes trabalhadores. As pesquisas que vem sendo realizadas sobre o trabalho dos catadores buscam soluções para a "inclusão social" dos mesmos, conjugada à promoção da reciclagem. Sob as mais diversas ideologias reside a relação perversa entre indústria e catador, além da exploração admitida e amplamente divulgada em relação aos comerciantes atravessadores.
} 
institucionalização da base da indústria. Ainda assim trouxemos para o escopo da tese as impressões e relatos obtidos sobre o cotidiano destes trabalhadores.

De acordo com o pressuposto de que o catador é um trabalhador pobre urbano, (re)inserido produtivamente na condição de trabalhador sobrante, apresentamos as seguintes proposições, formuladas a partir da pesquisa sobre 0 processo de trabalho realizado pelos catadores na base da indústria da reciclagem:

$\left.1^{3}\right)$ Os catadores são trabalhadores sobrantes, ou seja, são trabalhadores que perderam seu emprego no setor formal (no contexto da reestruturação produtiva), ou que nunca conseguiram nele ingressar. Neste sentido, não se incluem na denominada classe-que-vive-do-trabalho (Antunes, 1999), noção cuja chave interpretaria é o assalariamento. Tão pouco o catador se insere na interpretação feita por Singer, a respeito do trabalho informal, analisando-o como integrante da categoria marxista de população relativamente excedente, em sua parte estagnada ${ }^{19}$, ainda vinculadas às relações assalariadas. Portanto, também não é este o lugar do catador. Mas, neste mesmo Capítulo de O Capital, existe a definição da "esfera do pauperismo", situada entre as categorias propriamente ditas da população relativamente excedente (fluída, latente e estagnada) e o lumpemproletariado. Para Pochmann, os trabalhadores informais correspondem justamente ao lumpemproletariado, com suas estratégias de sobrevivência à margem da sociedade salarial. Os catadores moradores de rua parecem corresponder à categoria de lumpemproletariado, enquanto os catadores avulsos (pobres e miseráveis) estariam na "esfera do pauperismo", em sua parte apta para o trabalho. Já os catadores das cooperativas estariam deixando a esfera da pobreza e do chamado setor informal (segundo Singer). No caso dos catadores assalariados dos comerciantes de recicláveis, a condição de pobreza, e neste caso de exploração do trabalho, pode ser ainda pior ${ }^{20}$. Portanto, em todos os casos, trata-se de trabalhadores pobres urbanos, (re)inseridos produtivamente sob a condição de trabalhadores sobrantes.

\footnotetext{
${ }^{19}$ Marx, Karl. O Capital. v.1. Capítulo 23: Diversas formas de existência da população relativamente excedente.

${ }^{20}$ A pesquisa não abrangeu o trabalho destes catadores, mas a Dissertação de Legaspe (2006) oferece estas informações como um importante registro documental, sendo referência para esta Tese.
} 
$\left.2^{3}\right)$ No processo de produção das matérias-primas há consumo da energia vital dos catadores ${ }^{21}$. O que os catadores ganham pelo material trocado no comércio de recicláveis corresponde a uma ínfima parte, a menor possível, dos preços definidos no mercado, como já assinalado. Ou seja, o que comerciantes e indústrias pagam aos catadores corresponde ao preço dos recicláveis, e não ao trabalho por eles realizado. 0 consumo da energia vital do catador participa, através do consumo produtiva da matéria-prima mais barata, do aumento da taxa de lucro industrial. E se apresenta no próprio catador, ele mesmo como expressão da expropriação, no desgaste de suas condições físicas, psíquicas e emocionais ${ }^{22}$.

$\left.3^{a}\right)$ O conjunto de atividades inscritas na base desta indústria pode ser compreendido como trabalho produtivo, e não apenas (embora também seja) uma simples troca comercial. Para que o trabalho realizado pelo catador possa ser explicado como produtivo é preciso compreender que a base estrutural desta indústria se realiza no urbano. E que o urbano é social, e que portanto, todas as partes estão relacionadas. Neste sentido, é a partir dos termos da urbanização (entendida como crítica) que se encontra os termos da estruturação recente desta indústria, a qual tem no urbano os elementos a partir dos quais ela se ergue: a produção exponencial de resíduos sólidos urbanos, derivados do consumo em massa (concentrado no centro e disperso nas periferias); a disponibilidade de um exército de trabalhadores sobrantes (reinseridos produtivamente como catadores de materiais recicláveis); bem como a presença de territórios empobrecidos que resolvem a equação entre geração dispersa dos resíduos e a necessidade de concentrá-los em determinados pontos do espaço (tanto na periferia quanto no centro propriamente ditos, na realização do conjunto de atividades que correspondem à base industrial), formam um tripé sobre o qual esta indústria se ergue. Este tripé, na sua complexidade, traduz-se na noção de urbano periférico.

$\left.5^{a}\right)$ Por fim, compreende-se que as periferias urbanas, ao abrigarem a base da indústria da reciclagem, são mobilizadas como frente de formação do capital, nos negócios desta indústria.

\footnotetext{
${ }^{21}$ Exceto no caso dos catadores que trabalham como assalariados dos comerciantes, pois há salário, e portanto, a relação é de exploração da força de trabalho (mais-valia).

${ }_{22}$ Ao "resgate da cidadania" anunciada pelos cursos de capacitação aos catadores que ingressam nas cooperativas, perversamente corresponde ao restabelecimento das condições físicas, psíquicas e emocionais dos catadores, para que produzam mais e melhor. Neste sentido, é muito comum os cursos de capacitação conterem "Módulos" dedicados ao resgate da auto-estima dos catadores. Objetivo em si mesmo louvável, mas habilmente à serviço do próprio Capital.
} 
A terceira premissa refere-se ao papel que o Terceiro Setor desempenha no processo de estruturação da indústria da reciclagem. E de modo mais preciso sobre a atuação de seus agentes sociais na institucionalização da base desta indústria. Parte-se do pressuposto de que o Terceiro Setor, do ponto de vista da estrutura social, é parte constitutiva do Estado em reforma, cujo fundamento se encontra no contexto das políticas neo-liberais, pós anos 70 (Harvey, 2005; Davis, 2006; Arantes, 2004; Sevcenko, 2007). É o que desenvolvemos no CAPítULO III - TERCEIRO SETOR NO CONTEXTO DAS POLÍTICAS NEOLIBERAIS, o qual contou com uma revisão conceitual que integra seu $2^{\circ}$ subcapítulo, aprofundando este debate na Geografia ${ }^{23}$. Em relação ao Terceiro Setor foram desenvolvidas as seguintes proposições relativas ao objeto da pesquisa:

$1^{\mathrm{a})}$ No âmbito do poder local (relativo ao Nível Misto), o empreendedorismo e as políticas públicas sob o modelo das Parcerias PúblicoPrivadas se caracterizam como emblemáticos da denominada Governança Urbana. Estas parcerias contam com a atuação sistemática das entidades do Terceiro Setor. Nela, a gestão da pobreza se apresenta como um amplo campo de atuação para as ONG's, no processo de "balcanização" dos serviços públicos. Neste sentido, a pobreza urbana é a nova mercadoria anunciada, negociada e vendida nos Projetos destinados à "geração de trabalho e renda com inclusão social”. Este é o campo de atuação do Terceiro Setor nos Projetos destinados à organização do trabalho na base da indústria da reciclagem.

$\left.2^{a}\right)$ As ONG's atuam como mediadoras dos investimentos públicos e privados destinados ao suprimento das demandas sociais não atendidas pelo Estado em reforma (Davis, 2006; Arantes, 2004). Para tanto, elaboram e executam projetos, sempre com financiamentos públicos e/ou privados (portanto, não se trata de práticas voluntárias). Frente às exigências de produtividade dos financiadores (poder público ou iniciativa privada) é possível compreender o descolamento existente entre os discursos e as práticas do Terceiro Setor. Ou seja, seus agentes proclamam a possibilidade de um outro mundo (sob o slogan "outro mundo é possível"), mas este parece restringido pela própria lógica do mercado. Os resultados anunciados em seus relatórios nem sempre corresponderem ao real, e seu "público alvo" (Arantes, 2004) acaba muitas vezes

\footnotetext{
${ }^{23}$ Nos Capítulos I e II, a revisão conceitual traz temas já caros à Geografia, e foram inseridos como ANEXOS da Tese. No caso do Capítulo III, a Revisão Bibliográfica, organizada em eixos temáticos, caracteriza-se como SUB-CAPÍTULO.
} 
desconhecendo os investimentos que em nome dele foram mobilizados. Desta forma, os consultores ${ }^{24}$ do Terceiro Setor (esta parece ser a melhor denominação para seus agentes) obtém parte significativa dos recursos destinados ao atendimento das demandas sociais. No âmbito da reciclagem, isto ficou muito claro. Mesmo porque a reciclagem no Brasil, além de constituir um setor produtivo, envolve uma questão social, pois está assentada no trabalho dos catadores. Nisto tem lugar tanto as práticas assistenciais, sobretudo direcionadas aos catadores moradores de rua, como as políticas empreendedoras, executadas pelas ONG's, para "geração de trabalho e renda com inclusão social".

$\left.3^{a}\right)$ As ONG's possuem um lugar central na institucionalização dos movimentos sociais. Seja pelo fato das entidades do Terceiro Setor modificarem os movimentos sociais tradicionais, seja pelo fato dos novos movimentos sociais serem formados a partir das ONG's (Cohn, 1997). Em ambos os casos, os movimentos se tornam cada vez mais institucionalizados, cujas lideranças deixam a arena das reivindicações para se ocuparem com práticas administrativas, burocratizadas ${ }^{25}$ pelos financiamentos.

$4^{a}$ ) O Terceiro Setor engendra um novo léxico, uma nova linguagem forjada sobretudo pela sociedade civil organizada, no bojo de arranjos institucionais pactuados entre Estado, Terceiro Setor e iniciativa privada (nos negócios da reciclagem e na denominada Responsabilidade Social Empresarial). Assim, para compreender este campo de atuação é necessário ingressar em seus espaços de atuação. Isto justifica o fato de que parte da pesquisa tenha sido realizada no âmbito dos eventos com participação do Terceiro Setor envolvido na reciclagem $^{26}$. É preciso desvendar os novos sentidos dados para antigas e novas palavras, a exemplo das noções de "mercado justo" e "preço justo", que parecem deslocar o sentido da palavra "justiça" para aquele de "ajustado".

$5^{a}$ ) Por fim, a pesquisa ressalta a atuação dos agentes sociais do Terceiro Setor que atuam diretamente no processo de estruturação desta indústria. Neste sentido, correspondem ao Terceiro Setor da indústria da reciclagem. Buscou-se a relação e a distinção entre os discursos e as ações

\footnotetext{
${ }^{24}$ O Terceiro Setor têm absorvido contingentes de profissionais com nível superior, caracterizando-se como mais uma faceta das mudanças no mundo do trabalho.

${ }^{25}$ Este é o caso emblemático do Instituto Cata-Sampa, formado por um grupo de lideranças do Movimento Nacional de Catadores de Materiais Recicláveis - MNCR. Este, por sua vez, já havia sido criado no contexto das ações, então filantrópicas, da Ong OAF.
} 
destes agentes na institucionalização da base industrial, em processo de estruturação. Os discursos, que ornamentam as práticas, difundem os aspectos ideológicos envolvidos na reciclagem. Seja no âmbito da educação ambiental, que convoca toda a sociedade a participar da prática da reciclagem, seja no âmbito da Responsabilidade Social Empresarial, que nela encontra um campo fértil para seus Projetos (justamente porque respondem ao "tripé" que envolve o social, o econômico e o ambiental).

Após expostas as premissas da Tese, bem como as proposições que foram desenvolvidas, apresentamos a seguir uma súmula dos Capítulos da pesquisa sobre a indústria da reciclagem, em cuja base se encontram as periferias urbanas em seu processo de transformação.

O CAPÍTULO IV - A ESTRUTURAÇÃO RECENTE DA INDÚSTRIA DA RECICLAGEM, inicia com um sub-capítulo que recupera a discussão conceitual em torno da Reciclagem e da Coleta Seletiva, no sentido de repensá-las sob a perspectiva do materialismo histórico. Assim, apresenta-se uma contribuição teórica sobre a relação existente entre o processo de (re)inserção produtiva dos trabalhadores sobrantes (os catadores) e a formação de capital (na indústria de reciclagem). Entende-se que a primeira etapa da reciclagem, denominada de recuperação, é integrante do processo global de produção da matéria-prima (juntamente com as etapas sucessivas de revalorização e transformação). Além de uma reflexão sobre o funcionamento desta indústria, que se realiza incrustada no comércio de recicláveis, também é discutido o que denominamos de "um novo estágio" no processo de estruturação desta indústria: a institucionalização de sua base sob o modelo de cooperativas.

Conclui-se que esta parece ser a tendência de ajuste no processo de produção de matérias-primas oriundas da reciclagem, sem contudo equacionar a seguinte questão: o aumento de produtividade atribuído às cooperativas a serem implantadas (com financiamentos disponibilizados por políticas públicas) parece não comportar o número de catadores existentes. Isso aponta para uma situação em que a base da indústria mantém um caráter dual, formal e informal, ao menos a longo prazo. Para este tema, contamos com um documento ${ }^{27}$ elaborado no bojo

\footnotetext{
${ }^{26}$ Os Relatos de Projetos, Eventos, e reuniões, tais como Festival Lixo \& Cidadania, Encontro Nacional e Marcha dos Catadores em Brasília (MNCR) contam nos ANEXOS da Tese. Conferir ainda a lista de eventos no item "c" dos "procedimentos da pesquisa" ao final da Introdução.

27 "Análise do custo de geração de postos de trabalho na economia urbana para o segmento dos catadores de materiais recicláveis", MNCR/OAF/MDS, 2006.
} 
de um Projeto destinado à organização dos catadores no país, o qual propõe a criação de 39.000 postos de trabalho em cooperativas de catadores. Por outro lado, estima-se que exista cerca de 500.000 catadores em todo o país, portanto, o referido projeto corrobora com nossa interpretação. Uma análise detalhada deste documento consta como Anexo da Tese, sendo um importante complemento para nossos argumentos. Também contam como anexos os relatos sobre o trabalho de campo realizado na cooperativa ASMARE (considerada modelo nacional) e na Fábrica de plásticos da Rede Cata-Unidos ${ }^{28}$. Este é um exemplo importante da relação entre discursos e práticas envolvidos no processo de institucionalização da base desta indústria, inclusive com a proposta de "domínio da cadeia produtiva". As duas últimas partes deste Capítulo tratam de evidenciar o que denominamos de um aparente paradoxo. Por um lado, o sub-capítulo "Os bilhões ganhos com a reciclagem" mostra os índices crescentes de reciclagem no Brasil, com informações sobre os faturamentos anuais dos segmentos considerados (latas de alumínio, plásticos, vidro e papéis). Por sua vez, o sub-capítulo "Panorama da Coleta Seletiva no Brasil" evidencia a ínfima participação da coleta oficial nos montantes de materiais reciclados, anunciados pelos índices de reciclagem. Este aparente paradoxo é explicado pelo trabalho realizado por milhares de catadores, majoritariamente no setor informal em todo o país.

O Capítulo $V$ é dedicado à apresentação da base da indústria da reciclagem no Município de São Paulo. A partir de um breve histórico sobre a coleta seletiva neste Município, e sua situação no período atual, procurou-se demonstrar ao menos três aspectos da base desta indústria em São Paulo: a) a distribuição espacial dos locais com atividades da reciclagem, bem como dos catadores organizados em grupos; b) a discussão do que se denominou de "a medida da desproporção", problematizando a discrepância entre os índices de reciclagem em São Paulo e a coleta seletiva oficial; c) acerca da distribuição a diferenciação espacial centro-periferia na geração de resíduos sólidos urbanos, com destaque para a relação concentração-dispersão.

O Capítulo VI apresenta a pesquisa realizada no território de Itaim Paulista (periferia consolidada, na zona leste de São Paulo). O desenvolvimento da pesquisa empírica teve como núcleo central o processo de institucionalização da base da indústria da reciclagem, na periferia urbana consolidada da metrópole

${ }^{28}$ Rede de cooperativa da Região Metropolitana de Belo Horizonte, articulada em torno da ASMARE. 
de São Paulo. Mais exatamente, no acompanhamento do processo de formação da Cooperativa Fênix-Ágape, no período de 2005 a 2008.

Este procedimento não encerrou a pesquisa empírica num estudo de caso. Ao contrário! A partir do processo de formação desta Cooperativa foram identificadas as mais diversas relações e mediações envolvidas na organização da base desta indústria: o poder público local e demais instâncias governamentais (municipais, estaduais, federais); ONG's, Movimentos e Fóruns (no âmbito do Terceiro Setor); instituições bancárias, organismos internacionais, grandes empresas, entidades religiosas e filantrópicas, além do trabalhador pobre urbano em sua experiência de (re)inserção produtiva como catador de recicláveis.

Conforme a pesquisa foi sendo desenvolvida, o universo de investigação, como já sugerido, tornou-se cada vez mais complexo ${ }^{29}$. A cada nova etapa foram surgindo novos agentes, invariavelmente envolvidos em algum Projeto, sendo recorrente o modelo das Parcerias Público-Privadas. Portanto, a pesquisa empírica, que em princípio poderia tender para o particular - o território de Itaim Paulista, a Cooperativa Fênix-Ágape - revelou-se, desde o início, apontar para o mais geral - as periferias urbanas da metrópole, o processo de institucionalização da base da indústria da reciclagem.

Devemos ainda esclarecer que o processo de formação da Cooperativa Fênix-Ágape (no Itaim Paulista) envolveu tanto a dinâmica interna dos núcleos de reciclagem a ela vinculados, quanto as relações e mediações deste coletivo com as diversas instâncias envolvidas na institucionalização da base da indústria. Destaca-se neste processo o ingresso da Cooperativa Fênix-Ágape na Rede de comercialização Cata-Sampa, tendo se tornado pólo de comercialização desta Rede na zona leste de São Paulo. Por outro lado, parte do trabalho de campo se realizou no âmbito de eventos e reuniões que envolveram catadores, poder público, iniciativa privada e Terceiro Setor.

Além da pesquisa de campo centralizada no processo de formação da cooperativa Fênix-Ágape (no Itaim Paulista), em suas relações e mediações com as mais diversas instâncias, também realizamos "incursões no chão dos catadores", sobre o qual incidem todas as determinados dos Níveis superiores. Esta pesquisa de campo ofereceu elementos tanto sobre a situação do catador

${ }^{29}$ Descobrimos o essencial do fenômeno urbano na 'centralidade'. (...). Não importa qual ponto possa torna-se central, esse é o sentido do espaço-tempo urbano. A centralidade não é indiferente ao que ela reúne, ao contrário, pois ela exige um conteúdo. E, no entanto, não importa qual seja esse conteúdo. (Lefebvre, 1999:110) 
avulso no contexto da institucionalização da base da indústria, quanto acerca do processo de trabalho que se realiza na periferia e no centro propriamente ditos da metrópole. Desta forma, foram entrevistados catadores avulsos no território de Itaim Paulista, onde se concentrou a pesquisa empírica, e nas imediações da Praça da República e Baixada do Glicério, no território da Sub-Prefeitura Sé, conforme já exposto nas proposições relativas à $2^{\underline{a}}$ premissa da Tese.

Assim, do percurso de desenvolvimento da pesquisa, destacam-se os seguintes procedimentos:

a) identificação dos principais agentes/instituições sociais envolvidos no processo de organização da base da indústria da reciclagem no território de Itaim Paulista:

$1^{\circ}$ ) Câmara Temática de Reciclagem (integrante da Câmara de Animação Econômica CAE, da Sub-Prefeitura de Itaim Paulista);

$\left.2^{2}\right)$ Movimento Nacional de Catadores de Materiais Recicláveis (MNCR);

$3^{\text {) }) ~ R e d e ~ C a t a-S a m p a ~(P r o j e t o ~ d o ~ I n s t i t u t o ~ C a t a-S a m p a / M N C R, ~ c o m ~ f i n a n c i a m e n t o s ~ d a ~}$ Petrobrás, dentre outros);

$4^{\circ}$ ) Projeto Brasil Canadá (com recursos do governo canadense, via Fundação Santo André);

$\left.5^{\circ}\right)$ Instituto GEA (ONG do Terceiro Setor da indústria da reciclagem);

6') Fórum Recicla São Paulo e Fórum Lixo e Cidadania (instâncias de atuação dos agentes sociais envolvidos na estruturação da indústria da reciclagem, com destaque as Organizações Sociais);

7) Instituto Ressoar de Responsabilidade Social (Rede Record)

b) acompanhamento do processo de criação da Câmara de Animação Econômica (CAE), e da Câmara Temática de Reciclagem, da Sub-Prefeitura de Itaim Paulista:

$\left.1^{\circ}\right)$ Análise do Projeto de Desenvolvimento Local da Sub-Prefeitura de Itaim Paulista;

2) Projeto "Desenvolvimento de estudos e pesquisas necessários à definição, análise, implementação e avaliação de políticas de ocupação e renda para o Município de São Paulo (Arranjos Produtivos Locais - APL's)

$\left.3^{\circ}\right)$ Desenho e Implantação de Projeto Piloto de Arranjos Produtivos Locais e suas oportunidades de geração de trabalho e renda na Sub-Prefeitura de Itaim Paulista. (no âmbito do Projeto de Cooperação Técnica Internacional BRA/05/033, firmado entre SMTRAB, PNUD e FESP-SP).

c) participação, no período de 2005 ao início de 2007, de diversos eventos, com o reconhecimento de discursos e ações do "Terceiro Setor da reciclagem", atrelados às políticas públicas, tanto para "gestão dos resíduos sólidos" quanto para "geração de trabalho e renda com inclusão social". Segue abaixo a relação dos principais eventos:

$\left.1^{\circ}\right)$ III Encontro Internacional de Economia Solidária: desenvolvimento local, trabalho e autonomia, promovido pelo NESOL - Núcleo de Economia Solidária da USP, no período de 13 a 15 de novembro de 2005.

$\left.2^{\circ}\right)$ Encontro Nacional de Catadores dos Materiais Recicláveis MNCR) - Brasília, 21 a 23 de março de 2006

$\left.3^{\circ}\right)$ Conferência Internacional Empresas e Responsabilidade Social 2006, promovida pelo Instituto ETHOS, de 20 a 22 de junho de 2006 no auditório do Hotel Transamérica (acompanhada via Internet) 
$\left.4^{\circ}\right)$ IV Encontro Internacional de Economia Solidária - desenvolvimento local, trabalho e autonomia, promovido pelo NESOL, na Faculdade de Educação/USP, 21 a 23 de julho de 2006.

5) XXII Encontro da Rede de Compromisso Social da CDHU, no auditório da CDHU, em 27 de julho de 2006.

$\left.6^{\circ}\right)$ Festival Lixo \& Cidadania - Belo Horizonte, no Galpão da ASMARE, em agosto de 2006.

7) Inauguração da Fábrica de telhas ecológicas da Associação Vira-Lata, no Jaraguá, com financiamento da Petrobrás ao Projeto Vira-Lata: inclusão social e geração de renda através da reciclagem. Em 30/05/2006

$\left.8^{\circ}\right)$ I Seminário Regional de Resíduos Sólidos: instrumentos para gestão integrada e sustentável, promovido pela ABES, no SENAC de Santos e Praia Grande, 06 a 08 de junho de 2006.

$\left.9^{\circ}\right)$ II Recicle CEMPRE - Seminário de Resíduos Sólidos, promovido pelo CEMPRE no Auditório do Expo Center Norte, de 08 a 10 de novembro de 2006.

$\left.10^{\circ}\right)$ Colóquio I Semana de Animação Econômica da Sub-Prefeitura de Itaim PtaV.Curuçá, no CEU Vila Curuçá, 5 a 7 de dezembro de 2006

$\left.11^{\circ}\right)$ Palestra Um encontro com o lixo no centro de São Paulo, realizado pela Associação Viva o Centro, com a bióloga Patrícia Blauth, em 12/03/07.

12) Seminário "Políticas de ocupação e geração de renda no Município de São Paulo: análise da implantação e avaliação". Realização: SMTRAB/FESP-SP/PNUD, 29/03/2007

13") Apresentação do Projeto "Fortalecimento da rede de comercialização dos grupos de catadores(as) de municípios do $A B C$ ", do Instituto GEA, com financiamentos da Petrobrás, no valor de $R \$ 247.625,00$.

$\left.14^{\circ}\right)$ Congresso Ibero-americano sobre Desenvolvimento Sustentável - Sustentável 2007, realizado pelo CEBDS - Conselho Empresarial Brasileiro para o Desenvolvimento Sustentável. Realizado no Auditório do Ibirapuera, de 24 a 26 de abril de 2007. Este foi o último evento que participamos no âmbito das ações e discursos do Terceiro Setor.

d) visita a cooperativas e outros empreendimentos no âmbito da institucionalização da base da indústria da reciclagem:

$\left.1^{\circ}\right)$ Cooperativa COOPERCOSE (modelo semelhante à Cooperativa Fênix-Ágape), localizada em Perus.

$2^{\circ}$ ) Cooperativa CRUMA (cujo presidente é o principal representante do MNCR e do Instituto Cata-Sampa), em Poá.

$\left.3^{\circ}\right)$ ASMARE, considerada modelo nacional de Cooperativa, em Belo Horizonte.

4) Fábrica de Plástico da rede de cooperativas da Grande Belo Horizonte.

5) Fábrica de telhas ecológicas do Projeto Vira-Lata, no Jaraguá.

6) Bases da Rede Cata-Sampa na zona leste de São Paulo: CRUFFI (Cohab Itaquera), Projeto Pantanal (S. Miguel Pta.), Jacupia (Itaquera) e Magnália Dei (Itaim Paulista)..

\section{e) análise de Projetos diversos sob o modelo de Parceria Público-Privada (PPP's):}

$\left.1^{\circ}\right)$ "Análise do custo de geração de postos de trabalho na economia urbana para o segmento dos catadores de materiais recicláveis". Relatório Técnico Final, 2006. Este Relatório Técnico resultou do Projeto "Ações de desenvolvimento social junto aos catadores de materiais recicláveis", apresentado pela Organização de Auxílio Fraterno (OAF) ao MDS.

$2^{\circ}$ ) Carta de Acordo n. 407-1564 (no âmbito do Projeto de Cooperação Técnica Internacional "Políticas de Ocupação e Desenvolvimento Humano Sustentável no Município de São Paulo, denominada BRA/05/033", firmado entre SMTRAB, PNUD e FESP-SP. 
$\left.3^{\circ}\right)$ Relatório do Projeto "Desenvolvimento de estudos e pesquisas necessários à definição, análise, implementação e avaliação de políticas de ocupação e renda para o Município de São Paulo (Arranjos Produtivos Locais - APL's): Desenho e Implantação de Projeto Piloto de Arranjos Produtivos Locais e suas oportunidades de geração de trabalho e renda na Sub-Prefeitura de Itaim Paulista". Relatório n.03, janeiro de 2007.

$\left.4^{\circ}\right)$ Relatório do Projeto "Desenvolvimento de estudos e pesquisas necessários à definição, análise, implementação e avaliação de políticas de ocupação e renda para o Município de São Paulo (Arranjos Produtivos Locais - APL's): [Arranjo Produtivo da Reciclagem]. volume 1, janeiro de 2007.

$\left.5^{\circ}\right)$ "Desenho e implantação do Projeto Piloto de Arranjos Produtivos Locais e suas oportunidades de geração de ocupação e renda" (Carta de acordo n 407-1564 PNUD - SMTRAB - FESPSP)

$\left.6^{\circ}\right)$ Programas da Secretaria Municipal do Trabalho e da Secretaria de Serviços e Obras (Depto. de Limpeza Urbana - Limpurb) da Prefeitura de São Paulo, entre outros.

f) Pesquisa de publicações oficiais e reportagens sobre 0 tema da reciclagem e geração de trabalho e renda (com inclusão de catadores) no Município de São Paulo:

1) Diário Oficial do Município de São Paulo (janeiro de 2006 a março de 2007)

2) Portal de Notícias do site da Prefeitura de São Paulo

$\left.3^{\circ}\right)$ Boletim CEMPRE - Compromisso Empresarial para a Reciclagem (mensal desde 2005)

$\left.4^{\circ}\right)$ Relatórios Mensais do Programa de Coleta Seletiva (Limpurb - Secretaria Municipal de Serviços), anos de 2005 a 2008.

$\left.5^{\circ}\right)$ Diretrizes e Planos para a gestão dos resíduos sólidos no Município de São Paulo Seletiva (Limpurb - Secretaria Municipal de Serviços)

$\left.6^{\circ}\right)$ Conjunto de leis no âmbito da gestão dos resíduos sólidos (municipal, estadual e federal) obtidos no site da ABRELPE - Associação Brasileira das Empresas de Limpeza Pública e Resíduos Especiais (www.abrelpe.org.br)

$\left.8^{\circ}\right)$ Planilhas do "Grupo de Trabalho Coleta Seletiva", sobre os grupos de catadores organizados em São Paulo. Este Grupo de Trabalho, que reúne diversos agentes sociais envolvidos na organização da base da indústria da reciclagem, foi criado para realizar um diagnóstico dos grupos de catadores organizados, a serem beneficiados com recursos do Programa de Aceleração do Crescimento (Governo Federal).

$\left.9^{\circ}\right) \quad$ outros diversos...

h) Pesquisa junto à Supervisão de Vigilância Sanitária (SUVIS):

Levantamento de informações sobre os denominados Pontos Estratégicos, os quais são estabelecimentos monitorados para controle do mosquito da dengue. Alguns dos Pontos Estratégicos correspondem a locais com atividades de reciclagem, das mais diversas modalidades (terrenos, galpões, quintais, garagens, baixos de viadutos, entre outros) o que por sua vez nos indica a vulnerabilidade dos catadores à inúmeras doenças, tanto a dengue quanto a leptospirose, uma vez que a concentração do lixo contribui para a proliferação de vetores como roedores e mosquitos. Com base nos dados e informações obtidas com os diversos levantamentos, sobretudo os da SUVIS e do "GT Coleta Seletiva", elaboramos quadros, gráficos e tabelas, além de um Mapa síntese, sobre a distribuição espacial dos locais que concentram atividades da base da indústria da reciclagem na metrópole de São Paulo.

i) Entrevistas com "catadores avulsos", no Itaim Paulista e na área central (imediações da Praça da República e Baixada do Glicério): 
Foram entrevistados 43 catadores avulsos, sendo que 20 deles foram abordados nas ruas do Itaim Paulista e os outros 23 nas ruas da região central (12 nas imediações da Praça da República e 11 na Baixada do Glicério). A entrevista teve como base um Questionário com perguntas fechadas e abertas (Anexo 03), sendo que 0 enfoque das questões foi sobre o processo de trabalho realizado pelos catadores.Como já esclarecido, este procedimento visou fundamentar a interpretação do conjunto de atividades realizadas pelos catadores como processo de trabalho produtivo, bem como evidenciar a situação dos mesmo sob o processo de institucionalização da base da indústria da reciclagem.

Período: em meados de 2007 (antes da Qualificação) e no início de 2008 (antes da redação final da Tese) 


\section{CAPÍTULO I}

\section{Periferias urbanas da metrópole de São Paulo}

\subsection{Formação territorial da periferia urbana da metrópole de São Paulo}

A formação territorial da periferia urbana da metrópole paulistana, integrada ao processo de industrialização-urbanização-metropolização da cidade de São Paulo, foi tema fundamental de pesquisas no âmbito da Geografia, e das ciências humanas em geral. Entre as décadas de 70 e 80 foram desenvolvidas importantes contribuições teóricas que se tornaram clássicos desta literatura ${ }^{30}$. Desde a análise das transformações dos subúrbios paulistanos em periferias urbanas, diversas pesquisas contribuíram para o conhecimento de aspectos econômicos, políticos e sociais da produção destes espaços, tais como as lutas populares direcionadas à melhoria das condições de vida nestes territórios (do direito à moradia ao direito à cidade), as políticas estatais e a ação (e especulação) da iniciativa privada, centrada no setor imobiliário e na construção civil, bem como a violência generalizada, a exclusão, a segregação e a fragmentação socioespaciais, entre tantos outros enfoques.

Em uma perspectiva crítica, pôde-se compreender e explicar esta forma de urbanização enquanto locus de reprodução da força de trabalho (conforme o entendimento dado por autores como Manuel Castells, 1972) com ênfase à questão da moradia da classe trabalhadora, nos períodos históricos que levaram à consolidação da metrópole de São Paulo, também definida como metrópole do trabalho ${ }^{31}$.

Estes espaços foram sendo produzidos segundo um padrão periférico de crescimento, como sendo o fora e distante da cidade propriamente dita: (...) $A$ partir de então [meados da década de 50] surge no cenário urbano o que passou a ser designado de "periferia": aglomerados distantes dos centros, clandestinos ou não, carentes de infra-estrutura, onde passa a residir crescente quantidade de mão-de-obra necessária para fazer girar a maquinaria econômica (Kowarick,

\footnotetext{
${ }^{30}$ Autores como Lúcio Kowarick, José de Souza Martins, Juegen Langenbuch, Ermíria Maricato, e também Nabil Bonduki, entre outros.

${ }^{31}$ Definição encontrada em obras de autores como Márcio Pochmann, Walter Barelli, entre outros.
} 
1979:31) $)^{32}$. Desde os anos 40 existiu a necessidade de tipificar o processo de urbanização que sob o padrão de crescimento periférico explodiu de forma generalizada na década de 60. Este universo "do fora, do distante e da pobreza" teceu uma cultura própria, que se manifesta através da produção doméstica da habitação, identificada como sistema de auto-construção das moradias nos loteamentos periféricos (segundo Bonduki). $\mathrm{Na}$ década de 70 , a área urbanizada com grandes conjuntos habitacionais na zona leste de São Paulo, estendeu a periferia para muito mais distante. Contudo a auto-construção continuou presente e predominante na produção destes espaços periféricos nas décadas seguintes e houve, inclusive, um deslocamento para a região sul e norte da metrópole.

Algumas pesquisas dedicadas aos estudos urbanos demonstram como neste período de 1940 a 1970 predominou a expansão da periferia sob o binômio loteamento-ônibus (Langenbuch, 1971) ${ }^{33}$, correlato ao binômio subúrbio-estação (José de Souza Martins). Tornaram-se a forma predominante do padrão periférico de urbanização, numa lógica espacial estruturada em função do deslocamento de trabalhadores dos "bairros dormitórios" para os locais de trabalho. Outras formas de moradia, ligadas à pobreza urbana, também estão historicamente presentes no espaço urbano da metrópole, como os cortiços e as favelas, estas últimas em ritmo crescente em direção ao término do período considerado. A partir da década de 70 , sob o regime militar, predominaram as políticas habitacionais que deram origem a inúmeros e enormes conjuntos habitacionais, sem contudo conterem a "auto-construção" e a favelização, que permanecem na atualidade como continuidade da desigualdade social deste processo histórico. Pochmann (2001:88-89) fala da desigualdade nas condições de reprodução na cidade de São Paulo expresso, entre outros aspectos, pela crescente pressão por moradia popular, que levava à elevação dos aluguéis e à especulação imobiliária. Observemos os dados apresenta pelo autor, com base em Kowarick (1994):

Somente entre 1940 e 1960, a cidade de São Paulo aumentou em 2 milhões a quantidade de seus habitantes, o que exigia cerca de 500.000 novas moradias. Entre 1937 e 1964, apenas 124.000 unidades habitacionais foram construídas, sendo 24.400 unidades em São Paulo. Durante o regime militar, quando foi constituído o Banco Nacional de Habitação (BNH), somente 25\% das habitações populares foram financiadas para famílias que recebiam menos de cinco salários mensais (...). Para grande parte das famílias de baixa renda não sobrou alternativa a não ser a invasão e a autoconstrução, 0

\footnotetext{
${ }^{32}$ Kowarick, Lúcio. A espoliação urbana. RJ: Paz e Terra, 1979. Entre outras obras.

${ }^{33}$ Langenbuch, Juergen Richard. A estruturação da Grande São Paulo: estudo de geografia urbana. Rio de Janeiro: IBGE, 1971.
} 
que terminou levando à alteração do modo de habitação popular. Os cortiços, que em 1961 abrigavam 18\% da população na área central da cidade, passaram a representar 9\% da habitação em 1972.

Deste mesmo contexto, temos ainda que considerar o processo de valorização desigual dos espaços intra-urbanos, onde algumas formas urbanas entram em desuso e/ou têm suas funções redefinidas. A partir da década de 70, sob a influência da cultura automotiva e ligada aos fenômenos de deslocamento e concentração da atividade comercial (hipermercados e shoppings) as classes de maior renda dispõem de mobilidade crescente no espaço intra-urbano, concomitante ao enfraquecimento de muitas das funções centrais da cidade (principalmente o comércio). Já na década de 80 , em meio à desconcentração industrial e fatores como o uso massivo do automóvel, aumento da violência urbana e disseminação dos condomínio fechados (presentes no processo de periurbanização), acentua-se a saída das camadas de maior renda da cidade e dos bairros centrais, que em conjunto perdem população. Neste contexto, é possível ainda afirmar que, cada vez mais, a "periferia usa o centro"34. Neste sentido, observa-se a intensificação das atividades informais, seja no comércio (onde se destaca a figura do camelô, ainda que nas últimas administrações municipais seja marcante as ações de "limpeza" do comércio ambulante dos espaços centrais) ou nas atividades produtivas (tais como as oficinas de confecção na região do Brás e Pari que sub-empregam imigrantes, como os bolivianos, em boa parte residentes nestes antigos bairros do "além Tamanduateí ${ }^{35}$ ). Pochmann (2001:134-135) relaciona o conjunto de transformações ocorridas no mundo do trabalho na cidade de São Paulo nas últimas décadas, sobretudo nos anos 90, a uma mudança significativa da habitação, com um incremento das áreas encortiçadas no entorno da área central da capital paulistana: nas duas últimas décadas (...) tem-se registrado novamente, no entorno do centro da cidade, o reforço de cortiços, como nos bairros da Barra Funda, Brás, Bela Vista, Bom Retiro, Liberdade, Santa Cecília e Sé. A estimativa para os anos 90 era de que mais de 3 milhões de pessoas se encontrassem vivendo em cortiços, algo como um terço da população paulistana, contra cerca de 18\%, em 1985, e apenas 9\%, em 1972 (Kowarick, 1994).

\footnotetext{
${ }^{34}$ ROMANI, Valquíria. "A Periferia Usa o Centro". FFLCH - TGI - 1993.

${ }^{35}$ Os estudos desenvolvidos por Maria Margarida de Andrade e André Martin são referências sobre o tema do bairro "além Tamanduateí" na cidade de São Paulo, no processo de industrialização.
} 
Tais atividades operam para a formação de um mercado consumidor popular que trabalha e consome $n(0)$ centro, ainda que de forma precária ${ }^{36}$. A evidência de esvaziamento das classes médias e deterioração da área central de São Paulo, gerou uma mobilização na sociedade civil e por parte do Estado no sentido de requalificar este espaço, sobretudo em termos econômicos. A partir de então, os planos de gentrificação passam a comandar as discussões sobre o centro da cidade, cujas estratégias impõem um confronto direto com a situação anterior, onde se inclui o banimento da pobreza urbana então presente no centro da cidade. Deste processo, as periferias urbanas tornaram-se expressões mais complexas e completas da denominada urbanização crítica ${ }^{37}$, contendo as marcas de continuidade e aprofundamento das relações de expropriação, exploração e espoliação urbana, sempre repostas na produção e reprodução do espaço urbano.

Ao processo de "periferização da população trabalhadora" (Seabra, 2004), que correspondeu à formação das periferias urbanas, parece se impor a lógica da fragmentação e da dispersão. Tanto que os conteúdos históricos relativos à reprodução da força de trabalho que corresponderam ao padrão de crescimento periférico (Kowarick, 1979), com a "implosão-explosão" da cidade, no que hoje é a metrópole, irrompem em seus interstícios. Seja porque a vasta extensão territorial homogênea característica das periferias urbanas também participe de novas frentes de valorização urbana, desencadeando morfologias espaciais mais heterogêneas do que antes. Seja porque, na metrópole fragmentada, os imperativos da sobrevivência se instauram para além do que possa corresponder à "periferia propriamente dita": uma extensão que parece incalculável, um mar de casas e de barracos construídos muito precariamente, muitas vezes até sem ruas abertas, que começou aparecer na paisagem urbana de São Paulo nos anos 1940 (Seabra, 2004:295).

\subsection{Transformações recentes das periferias urbanas da metrópole de São Paulo no contexto do mundo do trabalho}

São Paulo é uma metrópole que se desenvolve em correspondência com o atual "período técnico-científico-informacional" (segundo a concepção de

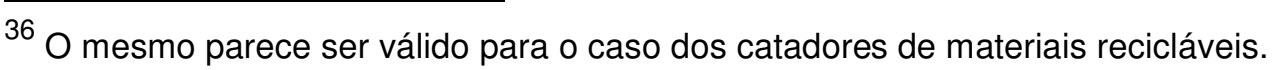


Milton Santos), com altos níveis de uso da técnica, da ciência e da informação. Não faltam atributos que subsidiem os argumentos de que São Paulo se articula mundialmente no nível das cidades globais. Sob a hegemonia de uma economia financeirizada, uma miríade de negócios da indústria imobiliária, com fundos públicos associados, encontra em São Paulo situações determinadas para tais investimentos ${ }^{38}$.

Porém, em São Paulo são continuamente aprofundadas as separações originais que sob a forma de uma segregação socioespacial exacerbada, segue reproduzindo o "processo de periferização da população trabalhadora" (Seabra, 2004). Nas metamorfoses desta cidade, decorrentes da industrialização, seus habitantes pobres e segregados, aqueles que não encontravam lugar nos lugares estruturados pela propriedade (...), cresceram muito mais e em ritmo acelerado, em progressão geométrica e ampliadamente, aliás, no mesmo processo e da mesma forma que cresce [e que se reproduz] o capital como forma de riqueza da sociedade (Seabra, 2004: 277). Condição que só fez aprofundar as desigualdades fundantes de uma moderna sociedade de classes (com continuidades arcaicas profundas). Assim, face às transformações no mundo do trabalho, muitos dos pobres urbanos são massivamente transformados em consumidores sem poder de consumo ${ }^{39}$, monetarizados sem salário e sem emprego, por isso sobrevivem no chamado setor informal ou ainda no "circuito inferior da economia urbana" (Santos, 2004). Ainda que trabalhadores à margem do mercado de trabalho formal estejam historicamente presente no espaço urbano de São Paulo (Pinto, 1984), na atualidade esta presença ocorre de forma ampliada e aprofundada. Sob tal perspectiva, a análise está centrada na negatividade desta urbanização (Damiani, 2004), da qual resulta o longo "processo de periferização da população trabalhadora" (Seabra, 2004) destinada a viver o urbano como experiência de expropriação-exploração-espoliação, tão bem traduzida na expressão "urbanização crítica" apresentada por Damiani (2004). Por certo que existem outras abordagens, mas esta última está implicada diretamente aos objetivos da pesquisa.

\footnotetext{
${ }^{37}$ Questão problematizada por Amélia Luisa Damiani em suas pesquisas.

${ }^{38}$ Seria possível desenvolver muito mais os diversos argumentos apresentados pelas pesquisas dedicadas ao tema das cidades globais ou mundiais, mas o mesmo ultrapassa o escopo desta Tese.

${ }^{39}$ Senão pela recente disseminação do crédito popular, inclusive cada vez mais utilizados para os itens da cesta básica, a exemplo dos sistemas de crédito oferecidos em supermercados.
} 
De fato, trata-se de uma mesma metrópole correspondente a uma única totalidade, e as pesquisas sob diferentes enfoques temáticos e teóricos, em seu conjunto, nos dão noção do quão complexo tem sido analisar e compreender a urbanização recente. Como nos diz Silveira (2004:59), face a uma macrometrópole complexa e multifacetada como São Paulo, em tempos de globalização, perspectivas múltiplas e interdependentes parecem necessárias, mais do que nunca, para uma compreensão mais aprimorada dos fenômenos.

Neste sentido, consideremos que o padrão de crescimento periférico (Kowarick, 1979) correspondeu a um determinado período histórico diretamente vinculado à reprodução da classe trabalhadora, no processo de industrialização sob o modelo fordista de produção. Neste contexto, a periferia urbana foi produzida segundo os fundamentos desiguais dessa sociedade, enquanto locus sui generis de reprodução da força de trabalho. Neste sentido, tem-se como referência a idéia de que a forma urbana corresponde a conteúdos sociais concretos. (Seabra, 2004:220) Ao que perguntamos: o que acontece com esta morfologia do urbano reconhecendo-a como um 'tecido urbano que prolifera', resultado da implosão-explosão da cidade (Seabra, 2004:287), no momento atual que acumula, e já transborda, seus efeitos negativos manifestos nesta "urbanização crítica" (Damiani, 2004)? Ou ainda, nas palavras de Silveira (2004:63), o que acontece nesta cidade - São Paulo, chamada a ser moderna a cada momento histórico, [mas que] entra em crise - mais ou menos visível - por não poder, enquanto viabiliza as condições para a reprodução das novas manifestações do modo de produção, manter as mínimas condições de vida para a grande massa trabalhadora?

Nas últimas décadas, a função até então essencialmente residencial da periferia distante, muitas vezes qualificada como "dormitório", passou a comportar um diversificado e capilar "setor informal", conjugando as funções de moradia e de trabalho (definido também como atípico, precário), constituindo novas ou reinventadas formas de emprego do tempo e uso do espaço. Não que estas práticas não existissem antes nestes espaços periféricos. Ao contrário, o trabalho informal (no qual se insere o conjunto de atividades realizadas pelos catadores ${ }^{40}$ ) está presente desde a gênese da formação do mercado de trabalho urbano em

\footnotetext{
${ }^{40}$ Será nos anos 80 e 90 que o conjunto de atividades da reciclagem realizadas pelos catadores passa a se apresentar de modo mais intenso e generalizado por todo o espaço urbano, inclusive com a formação de cooperativas, num contexto de mobilização da sociedade como um todo sobre este tema.
} 
São Paulo. Porém, não podemos neglicenciar as mudanças quantitativas e qualitativas do fenômeno nas últimas décadas (sobretudo no pós anos 70 , no contexto das políticas neo-liberais). Para abordarmos as transformações recentes da metrópole de São Paulo em relação ao tema do trabalho, uma importante referência é o livro “A metrópole do trabalho”, de Márcio Pochmann (2001).

Segundo Pochmann (2001:23-24), ainda que São Paulo tenha se constituído numa das maiores concentrações do proletariado industrial na periferia do capitalismo, não chegou a absorver todo o contingente de trabalhadores no processo de produção social, mesmo em períodos de predominância do assalariamento: na dinâmica da acumulação de capital não é toda a população que encontra condições de participar diretamente do processo de produção social. (...)a manifestação do assalariamento, mesmo quando chegou a ser majoritária, não levou à homogeneização das remunerações e das condições de trabalho, conforme registrado nas nações avançadas. (Pochmann, 2001:23-24)

Ademais, mesmo entre os assalariados era majoritária a parcela de trabalhados com baixa qualificação profissional, segundo dados do Senai (para o ano de 1974) apresentados por Pochmann (2001):

(...) Somente $18 \%$ do total de ocupados industriais da cidade de São Paulo (...) foram considerados qualificados segundo relatório do Senai de 1974, o que indica, em contrapartida, que $82 \%$ dos trabalhadores paulistanos não possuíam qualificação e, por que não dizer, escolaridade. Ou seja, o capitalismo periférico foi capaz de se reproduzir com sucesso usando desenfreadamente mão-de-obra analfabeta e com baixa qualificação, por meio de baixos salários e trabalho informal. (...) O impacto dessa situação sobre a estrutura de consumo foi imediato. (...) Destaca-se a permanência de uma forte restrição à alteração profunda do padrão de consumo das famílias de baixa renda na cidade de São Paulo (...) (Pochmann, 2001:85-86)

Por outro lado, Pochmann (2001) identifica duas alterações primordiais na dinâmica econômica de São Paulo no decurso do último quartel do século $X X$, as quais repercutiram diretamente nas condições de trabalho e sobrevivência dos trabalhadores concentrados nesta metrópole. A primeira, observada a partir da década de 70, refere-se à desconcentração da produção, alterando o denominado padrão de industrialização nacional concentrado nas regiões Sul-Sudeste, direcionado, sobretudo, à cidade de São Paulo e Região Metropolitana de São Paulo. A segunda refere-se a um novo modelo econômico, com uma série de restrições à produção e ao emprego nacional, paralelamente à reforma do Estado 
(desmonte do setor público, reformas administrativas, privatizações) resultando no abandono de políticas de desenvolvimento regionais que, por sua vez, mobilizou governos estaduais e municipais à prática da guerra fiscal como forma de atrair empresas para seus territórios. Ainda segundo Pochmann (2001) a desestruturação do mercado de trabalho, que ocorre no decorrer das décadas de 80 e 90, se caracteriza pela presença simultânea e combinada do desemprego aberto em larga escala, do desassalariamento (redução dos empregos assalariados no total da ocupação) e da geração de postos de trabalho precários. Nos anos 90, segundo dados deste autor, ocorreu o decréscimo anual de quase 16.000 postos de trabalho, em contrapartida a uma pressão demográfica com ingresso de cerca de 97.600 pessoas, cuja tendência para aquela década era de que aproximadamente 113.500 pessoas não teriam ocupação, num quadro de queda de algo em torno de $30 \%$ do emprego industrial, repercutindo também no decréscimo do emprego formal. Assim, (...) enquanto na década de 1980 a evolução média anual do emprego formal foi positiva, de 2,2\%, nos anos 90 foi negativa, de $-17,8 \%$. (...)Os recentes movimentos de estruturação, reestruturação e desestruturação do sistema produtivo têm influenciado direta e indiretamente a evolução das ocupações na cidade de São Paulo. (Pochmann, 2001:110-114)

Compreende-se que é no cerne do que foi exposto anteriormente que emerge o conjunto de atividades inscritas na base da indústria da reciclagem, realizada por milhares de trabalhadores pobres urbanos, sobrantes dos mais diversos setores, como será discutido no próximo Capítulo.

No mesmo sentido, num contexto mais amplo que envolve diversas grandes cidades do hemisfério sul, Davis (2006:23) menciona o processo de desindustrialização. Neste contexto, o autor ressalta que as cidades desindustrializadas fazem uso intensivo de mão-de-obra, o que não significa oferta de empregos, mas sim uma forma da reprodução da pobreza: a 'superurbanização', em outras palavras, é impulsionada pela reprodução da pobreza, não pela oferta de empregos. Essa é apenas uma das várias descidas inesperadas para as quais a ordem mundial neoliberal vem direcionando o futuro. (Davis, 2006:26). O autor avalia que os Programas neoliberais impostos por organismos internacionais aos governos do Terceiro Mundo estão entre as 
causas da queda da oferta de empregos nas grandes metrópoles industriais da América Latina ${ }^{41}$.

Por sua vez, Maria da Glória Cohn, em seu livro "Teoria dos Movimentos Sociais: paradigmas clássicos e contemporâneos" (1997) afirma que para se entenda as mudanças ocorridas no processo de desenvolvimento brasileiro nos anos 90, é necessária uma compreensão sobre as transformações econômicas e as políticas sociais neste período. A autora ressalta a ênfase dada ao mercado informal de trabalho neste processo marcado por políticas neoliberais: o resultado das novas políticas tem sido uma grande ênfase no mercado informal de trabalho e uma redefinição de seu papel no conjunto do processo de desenvolvimento social. (...) A promoção do setor informal autoriza, em parte, a retirada do próprio Estado da esfera social. (...) Invertem-se situações, pois o informal é apresentado como plataforma para a retomada do crescimento econômico e, ao mesmo tempo, como estratégia de desenvolvimento das capacidades humanas, desde que as ações relacionadas tenham como objetivo a elevação da produtividade. (Cohn, 2004:295296)

Assim, as atividades desenvolvidas no setor informal têm possibilitado a sobrevivência de um contingente populacional sem precedentes, oriundo da classe trabalhadora, massivamente desempregada, mas que reproduz fora das fábricas, e no seu próprio território, processos de trabalho inseridos num circuito inferior que se vincula ou é diretamente mantido por curiosos nexos com o circuito superior da economia urbana (Santos, 2004). O binômio "bairro dormitório - local de trabalho" vem sendo conjugado num só espaço.

Portanto, se existiu um determinado momento do processo de urbanização no qual a formação espacial da periferia urbana coincidiu com os conteúdos sociais da reprodução da classe trabalhadora, sob o padrão de desenvolvimento periférico, parece que estamos na atualidade lidando com um outro tempo. As mudanças do mundo do trabalho redefinem o lugar da classe trabalhadora no processo de modernização social, tornando-se, sob muitos aspectos, desnecessária aos processos produtivos, sobretudo os mais desenvolvidos. Por sua vez, estas mudanças sociais se traduzem como

\footnotetext{
${ }^{41}$ (...)Em todo o Terceiro Mundo, uma nova onda de PAEs e programas neoliberais voluntários aceleraram a demolição do emprego estatal, da indústria local e da agricultura para o mercado doméstico. As grandes metrópoles industriais da América Latina - Cidade do México, São Paulo, Belo Horizonte e Buenos Aires - sofreram enormes perdas de vagas na indústria. Em São Paulo, a participação da indústria na oferta de empregos caiu de 40\% em 1980 para 15\% em 2004. (Davis, 2006:166)
} 
transformações recentes das periferias da metrópole, na qual se instauram territórios, tanto para as estratégias de sobrevivência dos pobres urbanos na condição de sobrantes, quanto para a formação, acumulação e expansão do capital. Neste sentido é que a pesquisa centrada na base da indústria da reciclagem pode nos revelar aspectos importantes destas transformações.

\subsection{A noção de urbano periférico}

Antes de mais nada, a noção de urbano periférico, deriva das indagações e reflexões teóricas suscitadas no decurso de realização da Tese, instigadas, de modo especial, pela revisão conceitual que integra o ANEXO 01. As contribuição de Seabra (2003; 2004) foram decisivas e imprescindíveis para esta formulação. Também as contribuições de Damiani, em seus estudos sobre a urbanização crítica, dentre outros autores referenciados ao longo da Tese.

\subsubsection{A relação centro-periferia na metrópole fragmentada}

O modelo espacial centro-periferia pode ser entendido como uma tradução da relação espaço-indústria-periferia. Ou seja, a relação entre os conteúdos da indústria (capital), da periferia (trabalho) e suas modalidades espaciais, pode ser explicada e compreendida como relação centro-periferia. Este entendimento marca as formulações teóricas acerca dos padrões periféricos de urbanização, de modo particular sobre o processo de metropolização da cidade de São Paulo, sobretudo na segunda metade do século XX.

Entretanto, parece necessário não nos limitarmos a esta forma de explicação. Sobretudo nas últimas décadas (passagem do século XX para o XXI), quando a dualidade presente na concepção espacial centro-periferia parece ceder lugar a arranjos e padrões espaciais muito diversificados, ainda que outros modelos, tais como o das global cities indiquem nova dualidade ou polarização da estrutura socioespacial. Neste sentido, propomos uma reflexão acerca da relação centro-periferia.

Num primeiro momento, à relação subúrbio-cidade e subúrbio-periferia acrescentemos a relação cidade-periferia. Nesta relação, a cidade, ao se reproduzir como periferia, desloca da relação o subúrbio que, segundo Martins 
(2001:79), é a negação da periferia. Por sua vez, a cidade ao se reproduzir como periferia, reproduz sua própria negatividade (sobretudo em relação ao que São Paulo chegou a ser em meados dos anos 50, "uma cidade de bairros"): este importante capítulo da geografia e da história urbana situa-se na seqüência temporal das formas urbanas (cidade-bairros-subúrbios-metrópole-periferias)" e corresponde a deslocamentos necessários, relativos à aceleração das formas de uso do tempo e sem, necessariamente, apagar os traços do que veio antes (Seabra, 2004:271). Ainda segundo Seabra (2004:280), a estruturação genética do espaço urbano metropolitano, na metamorfose das formas (...) em correlação ao desenvolvimento desta formação social (cidade-bairro-subúrbio, periferiametrópole) acumulam, necessariamente "o velho e o novo". Neste sentido teve lugar uma problemática própria que é a desta Cidade com seus bairros num embate que daria lugar à metrópole (...) [n]um processo avassalador que subssumia a estrutura física e normativa da cidade, ao mesmo tempo em que a periferização da população progredia. (Seabra, 2004: 281) Industrialização e urbanização formavam um único processo (...) no contexto que era da sociedade do trabalho em curso.

No decurso do processo de urbanização, considerada a metamorfose das formas que correspondem a conteúdos sociais concretos (Seabra, 2003), a periferia emerge como negatividade do urbano. Neste mesmo sentido, uma outra relação parece corresponder ao momento atual que resulta do processo de metropolização: periferias-metrópole, já indicada por Seabra.

\subsubsection{Periferias urbanas-metrópole fragmentada}

Assim, chegamos à relação periferias urbanas -metrópole fragmentada. Aqui o termo periferia vai no plural, o que, como nos diz Bonduki (2001), não se trata de uma novidade. Pelo contrário, indica questões que estão postas ao debate e aos estudos urbanos, ao menos desde a década de 70. É no âmbito desta última proposição que desenvolvemos nossa reflexão sobre as transformações recentes das periferias urbanas, seja na "periferia propriamente dita", ou nas áreas desvalorizadas, empobrecidas, do "centro propriamente dito".

Ademais, as transformações recentes no mundo do trabalho implicam em mudanças na relação centro-periferia. Assim, partimos da idéia de periferias urbanas (onde a noção de periferia se refere à condição socioespacial da 
pobreza), idéia que vai além da compreensão da periferia como o outro da cidade. Desta forma, não se trata da noção de periferia que guarda apenas o atributo do fora, do distante.

As noções de hiper-periferia, peri-urbanização, poli-centralidades, entre outras, querem dar conta das mudanças recentes do processo de urbanização das metrópoles, posto que já não se trata mais do dentro e do fora, do perto e do longe. Tais noções fazem referência à diferenciação espacial com implicações para a redefinição das relações de oposição (sobretudo na relação concentraçãodispersão) concernentes ao binômio centro-periferia.

De acordo com Seabra,

O movimento que fraciona e que aprofunda as separações na vida social em função da divisão manufatureira do trabalho $e$ das necessidades incessantemente repostas para a reprodução capitalista da sociedade, agora sob os imperativos de um capital que circula livremente pelo mundo, é um processo que separa, mas que reúne e potencializa enormemente aquilo que reúne. Este é o traço mais fundamental do processo de modernização geral da sociedade. Ao fim e ao cabo, na metamorfose da forma urbana a metrópole contemporânea acabava por configurar-se como uma anticidade: uma superfície de urbanização contínua, de centralidade múltipla e móvel, hiperfuncional, por onde se desloca a multidão, domínio do quantitativo, com aparência de caos, porque movida por inúmeras estratégias. (Seabra, 2003:48)

Não obstante, a centralidade da reprodução do capital, ainda comanda a produção do espaço urbano, mantém e repõe os termos da relação centroperiferia, guardando claramente uma tendência à dispersão. A simultaneidade da expansão e acumulação do capital, conjugadas à escassez da riqueza socialmente produzida - com a manutenção dos territórios empobrecidos - está presente nas longínquas periferias tanto quanto nos centros históricos das cidades. Neste sentido, os fundamentos da desigualdade ao se reproduzirem levam ao aprofundamento das separações (segregação socioespacial), enfim, aos termos da barbárie. Segundo Seabra:

O urbano como modo de vida estaria destinado a superar as separações, reunindo os fragmentos dos conteúdos da vida social, e a propor uma síntese capaz de negar a negação, da qual a metrópole é expressão, possibilitando, num nível superior, a apropriação dos fragmentos dispersos. Mas o urbano, utopia real e modo de vida, âmbito da comunicação e da troca generalizada, da simultaneidade, onde se desfaz a ordem próxima e a ordem distante, (o imediato e o mediato), não vai bem. Há um déficit de negatividade, as desigualdades sociais se aprofundam, configura-se um estado crítico, com contingentes expressivos de população [des]assistida. Assim, a temática do 
urbano inevitavelmente tratará da desigualdade na fragmentação do urbano. Nestes termos, proclamar o direito à diferença chega a ser uma ironia, porque em tudo subjazem os fundamentos da desigualdade. A atualidade da urbanização mostra profundas clivagens e separações. A miséria e a riqueza andando lado a lado. Não obstante generaliza-se o sistema de trocas e as comunicações redefinem as relações entre pessoas, instituições e Estados. Em suma, foi na metrópole que o movimento da forma afirmou a negatividade da cidade, com seus bairros, sem contudo franquear o urbano, sob dominação ampla, rígida, formal e quantitativa do valor de troca. Não obstante, o uso do espaço e do tempo não necessariamente coincidem com o valor de uso, antítese lógica do valor de troca. (Seabra, 2003:46)

De diferentes modos, esta pesquisa converge para a consolidação da idéia de que os territórios empobrecidos da metrópole, nos quais habitam, trabalham, enfim sobrevivem os trabalhadores pobres urbanos, são dramaticamente urbanos. Não são outra coisa senão demasiadamente urbanos: esta é a nossa urbanização, reproduzida como sua própria negação, mas sem meios de agravar as contradições, pois há um déficit de negatividade, o que parece configurar a própria barbárie.

Resultado de um processo de "urbanização avassaladora", tão bem apresentado por Seabra (2003; 2004) em seu estudo que desvenda a metamorfose da cidade de bairros nesta metrópole fragmentada. "Periferização da população trabalhadora" (Seabra, 2004), por sua vez, traduzida de modo tão cabal na compreensão de Damiani sobre esta urbanização que se realiza de forma crítica, num urbano que não é para todos.

A negatividade exacerbada que pesa sobre o cotidiano vivido pelos pobres sem trabalho na metrópole do trabalho, não chega ao ponto de superar as contradições, no sentido de um outro devir. Se por um lado, a negatividade do urbano pode ser mais profunda na periferia urbana propriamente dita, por outro, 0 déficit de negatividade sendo maior no centro, faz com que os territórios empobrecidos estejam sempre na iminência de serem suprimidos (a exemplo da Operação Urbana). Ou seja, se por um lado, o urbano enquanto negatividade é mais completo na periferia (o que é a própria periferia), por outro, o déficit de negatividade maior no centro, não chega ao ponto de permitir a positividade plena do urbano; positivo-negativo ficam em conflito. Estas reflexões conduzem à noção de urbano periférico.

No urbano periférico estão presentes as contingências desta cidade ilegal que definem os termos de uma urbanização por demais restritiva entre nós, mas que continua progredindo. (Seabra, 2004:300) Assim, o urbano periférico 
ganha concretude no esfacelamento e ausência de uma outra cidade, naquilo que correspondia ao ideário das elites como obra e promessa da modernidade capitalista no Brasil, com cidadania plena, direitos civis, direitos políticos e o trabalho com dignidade. Esta urbanização nos afasta daquilo que fora preconizado como um direito à cidade porque as exclusões, as separações e a violência definem um quadro de vida problemático. (Seabra, 2004:300) (...) 0 quadro de carências acumuladas (Seabra, 2004:303), concluímos, está sob domínio do urbano periférico.

Neste sentido, compreende-se que o urbano periférico é próprio da metrópole fragmentada, contém e revela sua totalidade. Porque cada fragmento, qualquer que seja, contém o todo. Esta noção não nega o estatuto teórico da relação centro-periferia, mas busca explicar o que há em comum nos conteúdos da urbanização, entendida como crítica, tanto no centro quanto na periferia propriamente ditos. Assim, o urbano periférico, entendido como presente no centro e na periferia, é próprio do Nível Misto, especificamente urbano (Lefebvre, 1999). Por sua vez, não corresponde à posição geográfica periférica existente na relação centro-periferia, mas à condição constrangida de apropriação do urbano pelos pobres. O que não significa prescindir da diferenciação espacial e da situação geográfica que determinam as condições de formação dos territórios de uso (Seabra, 2003). Estes sim qualitativamente diferentes em função de estarem na periferia distante ou no centro. Exatamente porque estes territórios são instaurados na articulação dos três níveis do urbano, resultando em diferentes combinações.

A noção de urbano periférico apresenta uma inversão intencional dos termos (de periferia urbana para urbano periférico), pois a idéia de periferia, como fenômeno relacionado a um centro, domina a expressão "periferia urbana", que remete à estruturação espacial, geometricamente orbital, em torno do centro urbano. Ou ainda, o urbano só está presente na periferia naquilo que revela sua ausência nas formas determinadas da pobreza, da segregação e da exclusão, fortemente vinculado ao contexto do "padrão periférico de crescimento". Porém, o que propomos é destacar, pôr ênfase no urbano que é periférico: o urbano presente e possível, ainda que pleno de constrangimentos, nas atuais bases da produção e reprodução sociais (Damiani, 2004:30). Nele, uma população que encontra habitação e/ou trabalho (sobre)vivem a negatividade de uma socialização completa, monetarizada, mas na condição de trabalho que sobra. 
Os resíduos do consumo - ou simplesmente lixo (matéria sobre a qual o catador se debruça, para dele retirar os materiais a serem reciclados) são gerados em toda a extensão do espaço urbano, de forma concentrada no centro e de forma estendida na periferia. Porém, tão logo os resíduos sejam descartados, devem ser encaminhados, o mais rápido possível, para seu destino final. No caso da reciclagem, antes de chegar à empresa recicladora (como matéria-prima para os processos produtivos) os resíduos devem ser "desviados" para locais que antecedem seu envio à indústria, tais como baixos de viadutos, cooperativas, depósitos, ferros-velhos, entre outras modalidades, que geralmente se localizam em territórios empobrecidos.

O fato destes territórios estarem presentes tanto nos espaços centrais quanto nos espaços periféricos da metrópole, trouxe para nós um problema conceitual em torno da relação "centro-periferia", como já apontado. Por isso, a necessidade de um raciocínio que não se limite, nem tão pouco negue, a relação centro-periferia, mas que permita desvelar conteúdos socioespaciais comuns a ambos espaços qualitativamente distintos. Disto decorre a noção de urbano periférico.

Neste sentido, o urbano periférico é uma noção formulada tanto sob uma perspectiva sociológica quanto numa perspectiva geográfica. Com a primeira, pode-se compreender as periferias urbanas enquanto condição social da pobreza. O que, por sua vez, permite admitir sua presença tanto na periferia quanto no centro propriamente ditos. Na segunda perspectiva, a noção ilumina ${ }^{42} 0$ espaço da (re)inserção produtiva do trabalhador pobre urbano. Mais propriamente, dos territórios de (re)inserção produtiva do trabalhador pobre no urbano - no urbano periférico - o qual no processo de modernização social sobrevive na condição de trabalhador sobrante. Segundo Seabra (2003:3), as estruturas técnicas e de inovações que a modernização pela industrialização desencadeou, atingiram a sociedade inteira e novas e sucessivas formas de emprego do tempo iriam acontecendo até alcançar a casa, a família, a criança, a mulher e os idosos. A reprodução da sociedade envolveu o tempo e o lugar da reprodução da vida, e seguiria produzindo o cotidiano como uma seqüência lógica e necessária desse mesmo processo. (Seabra, 2003:3) Por isso, o urbano periférico é próprio do processo de transformação recente da periferia urbana,

\footnotetext{
${ }^{42}$ Referência aos espaços opacos onde vivem os homens lentos definidos por Milton Santos, em A natureza do espaço, de 2002.
} 
locus histórico de reprodução da classe trabalhadora, que vive sob as contingências do próprio processo de modernização. No referido processo, contingentes cada vez maiores de trabalhadores pobres urbanos sobrevivem na condição de trabalhadores sobrantes, buscando lugar nos interstícios do urbano com suas estratégias de sobrevivência. Estas que, pelos mais curiosos e dissimulados nexos, ligam-se abstratamente às estruturas industriais, situadas concretamente no alhures, mas também no cotidiano destes trabalhadores.

O urbano periférico se refere à centralidade do urbano, a qual, por definição (ao menos segundo as contribuições de Lefebvre), é encontro, reunião, concentração, simultaneidade, inclusive das diferenças, das separações e dos conflitos. As periferias são urbanas, mas nelas o urbano é periférico, traduzindose como possibilidade constrangida do urbano. É o urbano negado aos pobres, os quais sobrevivem sob o peso de sua negatividade, no decurso mesmo da reprodução capitalista. No urbano periférico, restitui-se a relação capital (produtivo) - trabalho (sobrante), desvelado na pesquisa pela relação entre catador e indústria da reciclagem. Esta que arregimenta o trabalho sobrante indiferenciado (oriundo dos mais diversos setores) na atividade do catador que se debruça sobre o lixo, seja no centro ou na periferia.

A noção de urbano periférico não nega a relação centro-periferia, pois a diferenciação espacial se impõe de diversas formas: na qualidade e densidade dos resíduos gerados; no processo de trabalho realizado pelos catadores; nas modalidades de locais com atividades da reciclagem, entre outros fatores. Assim, sem contradizer a relação centro-periferia, a noção de urbano periférico busca contribuir para a compreensão sobre as formas de (re)inserção produtiva dos trabalhadores sobrantes. Parece ser este o lugar reservado aos pobres na urbanização crítica, onde o urbano não é para todos (Damiani). Mas que ainda assim segue abrigando os contingentes de trabalhadores sobrantes que procuram sobreviver nos interstícios do urbano. Urbano que historicamente ocupa os contingentes de trabalhadores pobres não absorvidos pelo emprego formal. Proletarizados, sem emprego e sem salário, ingressam nas mais diversas atividades engendradas no processo de industrialização-urbanização, no denominado setor informal da economia urbana.

Frente ao exposto, devemos ressaltar que o urbano periférico está relacionado com a pobreza urbana generalizada, seja nas periferias distantes, consolidadas ou em formação, seja nas áreas centrais empobrecidas, nos centros 
comerciais ou de negócios. Nele se concentram aqueles para os quais o lixo - ou melhor qualificando, os materiais recicláveis, são a única senão última possibilidade de inserção num processo de trabalho que o ocupem em troca de algum dinheiro que Ihe permita uma sobrevivência ordinária (em seu duplo sentido) ${ }^{43}$.

\subsubsection{Territórios empobrecidos no urbano periférico}

O conjunto de atividades que corresponde à base da indústria da reciclagem, tende a se concentrar nos territórios empobrecidos da metrópole, sob domínio do urbano periférico.

São territórios tanto para o catador em sua prática socioespacial (o chão dos catadores), quanto para a indústria que neles tem a sua base estrutural e se caracterizam como territórios de escassez da riqueza produzida. Em primeiro lugar, porque concentram o processo de trabalho realizado pelos catadores que, sob a perspectiva estrutural da indústria, pode ser entendido como trabalho produtivo e não pago ${ }^{44}$. Portanto, são territórios de expropriação, pois viabilizam a formação de capital que se realiza no alhures, na indústria propriamente dita. Por sua vez, permanecem sob a condição de pobreza, portanto, são territórios de pobreza. Neste sentido é que se localiza a formação de capital para a indústria que neste contexto se ergue ${ }^{45}$.

Em segundo lugar, trata-se de territórios nos quais se concentram os locais com atividades da reciclagem ${ }^{46}$. Seja pelo fato destes locais estariam

\footnotetext{
${ }^{43}$ Ordinário adj. 1. Que está na ordem das coisas habituais; comum, habitual, useiro, vulgar. (...) 5. De pouco preço, de qualidade média ou inferior. (Dicionário Prático Michaelis, v.5.1, DST Software Brasil Ltda).

${ }^{44}$ Como já explicado, o que os catadores ganham corresponde a uma diminuta parte dos preços dos recicláveis (definidos ao nível do mercado pelas próprias indústrias) e não pelo trabalho que realizam.

${ }^{45}$ É o capital de composição orgânica alta que regula a taxa média de lucro. (...) nos setores periféricos das economias subdesenvolvidas, que tendem à baixa composição orgânica do capital, a acumulação primitiva do capital tende a se tornar um componente de acumulação originária constante. (...) A forma de acumulação originária pode se outra, mas sua função permanece, recria-se nos setores e territórios em que o capital se expande de modo insuficiente, onde a expansão capitalista significa criar as condições de reprodução ampliada do capital a partir de relações não capitalistas de produção. É neste contexto que tem lugar o reaparecimento da escravidão ou a recriação de 'formas não-contratuais de emprego da força de trabalho. (Martins, 2002:155) Grifo nosso.

${ }^{46}$ Comércios (depósitos, ferros-velhos, sucateiros, etc.) e grupos de catadores (cooperativas, associações, núcleos, grupos) dos mais diversos portes e modalidades.
} 
fundamentalmente associados aos atributos do lixo ${ }^{47}$, seja pela informalidade e precariedade com que funcionam, ou ainda porque são os pobres que se inserem neste conjunto de atividades. Sob esta perspectiva, são evidentes as razões pelas quais os locais com atividades da reciclagem tendem a se concentrar nos territórios empobrecidos da metrópole. São locais de convergência dos materiais recicláveis, nos quais se concentram as atividades de triagem, prensagem e enfardamento (entre outras correlatas) após concluída a atividade dispersa da catação ou coleta. Neste sentido, estes locais de convergência equacionam o ajuste necessário para a produção da matéria-prima que se inicia na Primeira Etapa da Reciclagem (coleta, triagem, prensagem e enfardamento). Ou seja, como todo processo produtivo, as atividades da reciclagem necessariamente devem se concentrar em determinados pontos do espaço. Assim, a reciclagem parece não poder superar a forma dispersa que caracteriza a atividade da catação/coleta (posto que os resíduos sólidos urbanos ${ }^{48}$ são gerados de modo disperso e difuso em toda a extensão do espaço), mas resolve esta contradição concentrando as demais atividades em pontos determinados do espaço (como já assinalado). Neste sentido, estes locais conformam uma rede horizontal de "entrepostos" de materiais recicláveis inscritos no urbano, Nível no qual se encontra a base da estrutura piramidal da indústria.

Territórios de pobreza: em relação à indústria propriamente dita, são territórios de escassez da riqueza produzida; em relação aos trabalhadores pobres urbanos, são territórios de expropriação. Próprios das periferias urbanas, estes territórios constituem a base da indústria da reciclagem, sob o domínio do urbano periférico.

Neste sentido, são mobilizados para a formação de determinados tipos de capitais que consomem o trabalhador sobrante, numa relação capital-trabalho mediada por curiosos e dissimulados nexos, no âmbito da esfera do comércio. Portanto, para a indústria da reciclagem, os territórios de escassez da riqueza produzida não correspondem aos denominados "territórios-reserva" ou "territórios

\footnotetext{
${ }^{47}$ Impactos de vizinhança, sujeira, insalubridade, periculosidade, vetores de insetos e doenças, dentre outros.

${ }^{48}$ A pesquisa focaliza os resíduos sólidos urbanos, considerando tanto os resíduos das atividades que se concentram no centro (sobretudo resíduos do comércio e serviços), quanto os resíduos domiciliares, predominantes nas vastas periferias urbanas.
} 
adormecidos" (Robira, 2005:10) ${ }^{49}$. Segundo esta autora, estes territórios possuem "particulares estruturas urbanas, sociais e econômicas, subprodutos do processo de acumulação territorial, [que] invalida-os temporariamente para a própria

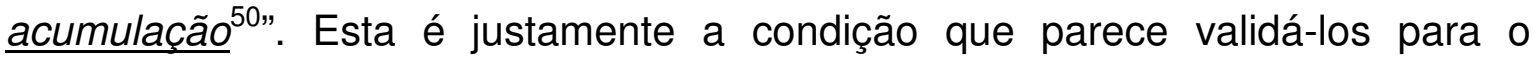
conjunto de atividades inscritas na base da indústria da reciclagem! Em outras palavras, para determinados tipos de capitais (como parece ser o caso da reciclagem) os territórios empobrecidos são mobilizados para formação de capital, caracterizando-se como "territórios de escassez da riqueza produzida". Ao mesmo tempo, para outros tipos de capitais (imobiliário, financeiro, sob ação das políticas de espaço, tal como a Operação Urbana), constituem "territórios-reserva", "onde se produz a acumulação de escassez" (Robira, 2005:17).

Harvey (2004:124), em "O novo imperialismo" discorre sobre aquilo que denomina de "acumulação por espoliação":

A acumulação por espoliação pode ocorrer de uma variedade de maneiras, havendo em seu 'modus operandi' muitos aspectos fortuitos e casuais. (...) O termo-chave aqui é, no entanto, excedente de capital [por vezes acompanhados de excedente de trabalho]. O que a acumulação por espoliação faz é liberar um conjunto de ativos (incluindo força de trabalho) a custo muito baixo (e, em alguns casos, zero). O capital sobreacumulado pode apossar-se desses ativos e darIhes imediatamente um uso lucrativo. (...) se o capitalismo vem passando por uma dificuldade crônica de sobreacumulação desde 1973, então o projeto neoliberal de privatização de tudo faz muito sentido como forma de resolver o problema. Outro modo seria injetar matérias-primas baratas no sistema. Os custos de insumos seriam reduzidos e os lucros, por esse meio, aumentados.

Encontramos nesta passagem da obra de Harvey uma explicação que parece corresponder ao que se passa nos territórios empobrecidos nos quais se realiza a base da indústria da reciclagem. Primeiro, o entendimento de que a acumulação por espoliação pode ocorrer de várias formas, nas quais o capital se apodere de "ativos" liberados a custo baixo ou mesmo custo zero. O autor menciona a força de trabalho como um destes ativos, que no caso dos catadores parece corresponder ao referido custo zero. Outro "ativo" seria os territórios empobrecidos nos quais se realiza o conjunto de atividades da reciclagem.

49 ROBIRA, Rosa Tello. Áreas metropolitanas: espaços colonizados In CARLOS, A. F.; CARRERAS, C. (orgs.). Urbanização e mundialização: estudos sobre a metrópole. São Paulo: Contexto, 2005. Pp. 09-20

${ }^{50}$ Grifos nossos.

${ }^{51}$ HARVEY, David. O novo imperialismo. São Paulo: Edições Loyola, 2004. Pp:115 -148 
Exatamente porque, para o capital industrial propriamente dito, estes territórios nos quais se concentram os locais com atividades de reciclagem, nada custam. Sejam eles espaços públicos, tais como calçadas, áreas comuns dos conjuntos habitacionais das periferias, baixos de viaduto nas áreas centrais, ou mesmo áreas privadas que representam custos para os comerciantes. Por último, o autor se refere justamente ao mecanismo de obtenção de matérias-primas mais baratas com vistas à elevação dos lucros. Ora, no caso das matérias-primas produzidas pelo processo de reciclagem, a caracterização desta mercadoria como sendo mais barata inclui justamente os dois "ativos" anteriormente citados: o custo zero do processo de trabalho realizado pelos catadores, cujas atividades se concentram nos territórios empobrecidos da metrópole. Por fim, a própria abundância de resíduos sólidos urbanos, passíveis de serem transformados em matérias-primas, encerra o último, e mais importante, "ativo" que o capital toma posse, configurando assim o tripé sobre o qual a indústria se ergue. É emblemático que o lixo, denominado de "passivo ambiental" pelas teorias econômicas destinadas aos cálculos de sustentabilidade, sejam transformados em "ativos" no processo de reciclagem. Cabe ainda ressaltar que as indústrias encontram uma saída pela tangente em relação à responsabilização por estes "passíveis ambientais": livram-se da possibilidade de pagarem taxas enquanto coresponsáveis pela geração dos resíduos (já que são as indústrias que produzem as embalagens que se tornarão lixo) e ainda "agregam valor" às suas mercadorias que levam o selo da reciclagem. E mais, quando determinada empresa passa a comprar os materiais recicláveis das cooperativas, ganham "pontos positivos em sua carteira" de Responsabilidade Social e Ambiental.

Por tanto, os territórios empobrecidos da metrópole constituem para a indústria da reciclagem "territórios de escassez da riqueza produzida": porque a riqueza é neles produzida, mas sem que resulte na superação da pobreza que os qualifica. Ao contrário: neles a escassez da riqueza é mantida ${ }^{52}$.

A (re)inserção produtiva dos catadores, na condição de trabalho sobrante, está diretamente associada com estes territórios. Porém, devemos observar que o chão dos catadores, enquanto territórios de uso no urbano periférico, vai além destes locais de convergência dos materiais recicláveis.

\footnotetext{
${ }^{52}$ Porque, não nos iludamos, o capitalismo que se expande à custa da redução sem limites dos custos do trabalho, debitando na conta do trabalhador e dos pobres o preço do progresso sem ética nem princípios, privatiza ganhos nesse caso injustos e socializa perdas, crises e problemas sociais (Martins, 2002:11)
} 
Porque a coleta se estende por toda a trama fina do espaço urbano, onde o catador realiza a coleta ou catação, atividade elementar do processo de reciclagem.

Se o catador, enquanto trabalhador pobre urbano, é (re)inserido produtivamente na base desta indústria, por outro lado seu processo de trabalho não se apresenta numa relação direta com a indústria. Como esta separação (capital industrial - trabalho produtivo) se realiza espacialmente, geograficamente? Como superar esta alienação que arregimenta um exército de catadores, auto-disciplinados em função de sua própria fome, sem que exista a figura de um capataz, um patrão, que o castigue ou demita na infração de suas obrigações? Como se dá esta total sujeição, este despojamento do corpo amalgamado à carroças tão pesadas quanto seus próprios "fardos"?

Há que se compreender que a (re)inserção produtiva do catador no conjunto de atividades que compõem a base desta indústria acontece porque $\underline{0}$ urbano ocupa. A urbanização completa da sociedade, o urbano como social, pode nos oferecer uma chave interpretativa. No urbano são produzidos incessantemente uma infinidade de desejos de consumo, toneladas e mais toneladas de dejetos do consumo, resíduos em excessos de todos os tipos: de mercadorias, de lixo, de gente, riqueza e miséria. Justapostos, entrepostos, sobrepostos. Como é próprio da metrópole fragmentada. Lixo gerado por todos os lados, catadores que percorrem ruas e avenidas de todos os cantos, desde centros empresariais e comerciais às áreas residenciais ricas e pobres. Não há limite territorial para a produção de lixo. Entretanto, uma vez "desviados" para a reciclagem, ele tem destino certo: os territórios empobrecidos da metrópole sob domínio do urbano periférico.

A forma urbana pode permitir que esta indústria esteja presente onde ela mais pareça ausente e distante: é ela quem arregimenta este exército de catadores, sem retirá-los da informalidade, fazendo-se presente em meio ao desemprego resultante da sua própria reestruturação. Esta indústria requer um processo de trabalho espacialmente pulverizado: seus "operários" (o que, evidentemente, não são, como já assinalamos) não trabalham concentrados em unidades fabris ou em cooperativas incubadas com a "eficiência" do seu Terceiro Setor. Pelo contrário. Ao menos meio milhão de pessoas percorrem os arranjos mais finos dos espaços urbanos, catando em avenidas, ruas, calçadas, passeios públicos e em milhares de domicílios em todo o país. A indústria da reciclagem 
estende seus tentáculos, instalando-se sob viadutos e pontes, fundos de quintais e garagens, terrenos baldios públicos e privados, onde quer que a pobreza possa dar lugar à formação e expansão de seus negócios. Inclusive sob a forma da acumulação primitiva, na expropriação-exploração-espoliação dos catadores, enquanto se apropria dos territórios empobrecidos da metrópole paulistana.

Por fim, entende-se que a urbanização, nos moldes em que ocorre, expressa a socialização capitalista do espaço e do tempo. Portanto, mesmo quando a indústria propriamente dita aparece como ausente no espaço urbano, a urbanização pode revela-la. Justamente porque a urbanização está estritamente relacionada com os processos produtivos. Assim, o parâmetro de raciocínio sobre o urbano diz respeito aos efeitos dos processos sociais envolvidos na industrialização. E neste sentido, a indústria não precisa estar materialmente presente para que seja entendida como a força estruturante do capital, o qual incide, inclusive, sobre o capital comercial. Os catadores de materiais recicláveis trabalham sob esta determinação: com seu trabalho, participar da reprodução da riqueza, e sobreviver na miséria. 


\section{CAPÍTULO II}

\section{TRABALHADORES SOBRANTES NA BASE DA INDÚSTRIA DA RECICLAGEM: OS CATADORES DE MATERIAIS RECICLÁVEIS}

No contexto recente das transformações no mundo do trabalho (políticas neo-liberais, pós anos 70), trabalhadores pobres urbanos, sobrantes dos mais diversos setores, vêm sendo (re)inseridos produtivamente como catadores de materiais recicláveis no conjunto de atividades inscritas na base da indústria da reciclagem, em pleno processo de estruturação.

Este conjunto de atividades apresenta a seguinte contradição: 0 catador realiza/não realiza um processo de trabalho que possa ser compreendido como produto, posto que sua experiência de (re)inserção produtiva não faz dele nem um "trabalhador autônomo", nem tão pouco um "assalariado". O conjunto de atividades que o catador realiza aparece como separado do processo produtivo, mas pode ser entendida como trabalho que participa da formação de capital . Isso porque a indústria da reciclagem parece não somente economizar capital constante na aquisição de matéria-prima mais barata (os materiais reciclados). Temos que considerar que tal matéria-prima é mais barata justamente porque nela está o trabalho não pago ao catador.

“Indústria da reciclagem”... quem são seus operários? De fato, o catador não o é, na acepção correta do termo; mas sob determinada perspectiva ele o corresponde, substituindo-o. É preciso um exercício de desvelamento da relação capital - trabalho, dissimilada por curiosos e dissimulados nexos existente entre o circuito superior e o circuito inferior da economia urbana (Milton Santos), aqui analisados com base nos Níveis e Dimensões do urbano (Henri Lefebvre). 


\subsection{Trabalhadores sobrantes: os catadores de materiais recicláveis}

A denominação trabalhadores sobrantes se refere aos trabalhadores pobres urbanos que, à margem do mercado de trabalho, são (re)inseridos produtivamente, sem contudo se emanciparem da condição de sobrantes. São trabalhadores que perderam seu emprego no setor formal (no contexto da reestruturação produtiva), ou que nunca conseguiram nele ingressar. Mais do que isto, são trabalhadores que sequer participam da denominada classe-que-vive-dotrabalho, noção ampliada de classe trabalhadora, formulada por Antunes (1999). Esta noção tem como chave interpretaria o assalariamento, que abrange os trabalhadores informais assalariados, mas este não é o caso dos catadores ${ }^{53}$. Tão pouco o catador se insere na interpretação feita por Singer (em O Mapa do Trabalho Informal, de 2000) a respeito do trabalho informal, analisando-o como integrante da categoria marxista de população relativamente excedente, em sua parte estagnada ${ }^{54}$. Embora esta categoria faça parte do exército ativo, e não do exército industrial de reserva (uma importante contribuição da interpretação feita por Singer), aqui ainda se trata de relações assalariadas (Segundo Marx, máximo de tempo de serviço e mínimo de salário). Portanto, ainda não é este o lugar do catador. Entretanto, além destas categorias marxistas mobilizadas pelos referidos autores (as quais têm como fundamento as diversas formas como o trabalhador vende sua força de trabalho, inclusive fora do setor formal), há neste mesmo Capítulo de O Capital a definição da "esfera do pauperismo" ${ }^{\text {"55 }}$. Esta se situa entre as categorias propriamente ditas da população relativamente excedente (fluída, latente e estagnada) e o lumpemproletariado. Para Pochmann, os trabalhadores informais correspondem justamente ao lumpemproletariado. Em $A$ metrópole do trabalho (Pochmann, 2001), este autor reconhece que parte da população excedente realiza estratégias de sobrevivência, à margem da sociedade salarial.

\footnotetext{
${ }^{53}$ Devemos esclarecer que a pesquisa não incluiu os catadores assalariados dos comerciantes.

${ }^{54}$ Marx, Karl. O Capital. v.1. Capítulo 23: Diversas formas de existência da população relativamente excedente.

55 Finalmente, o mais profundo sedimento da superpopulação relativa habita a esfera do pauperismo. Abstraindo vagabundos, delinqüentes, prostitutas, em suma, o lumpemproletariado propriamente dito, essa camada social consiste em três categorias. Primeiro, os aptos para o trabalho. (...) sua massa se expande a cada crise e decresce a toda retomada dos negócios. Segundo, órfãos e crianças indigentes. (...) Terceiro, degradados, maltrapilhos, incapacitados para o trabalho. São notadamente indivíduos que sucumbem devido a sua imobilidade, causada pela divisão do trabalho, cujo número cresce com a maquinaria perigosa, minas, fábricas químicas, etc. (...) Sua produção está incluída na produção da superpopulação relativa, sua necessidade na necessidade dela, e ambas constituem uma condição de existência da produção capitalista e do desenvolvimento da riqueza. Marx, v.1, 208-209. Grifo nosso.
} 
Parece-nos que os catadores correspondem melhor a estas duas últimas categorias. Os catadores moradores de rua parecem corresponder à categoria de lumpemproletariado. Os catadores avulsos, com diferentes níveis de pobreza (que chega à miséria, tanto quanto aquela dos catadores moradores de rua) estariam na "esfera do pauperismo", em sua parte apta para o trabalho. Já os catadores das cooperativas estariam deixando a esfera da pobreza e do chamado setor informal (segundo Singer). Mas, as cooperativas ainda representam uma estratégia de sobrevivência, pois seus rendimentos raramente atingem o patamar do salário mínimo, e as condições de trabalho permanecem por demais precárias $^{56}$. No caso dos catadores que realizam as atividades de triagem, prensagem e enfardamento sob uma relação assalariada (geralmente informal) nos comércios de recicláveis, a condição de pobreza pode ser até mais perversa $^{57}$.

Portanto, em todos os casos, trata-se de trabalhadores pobres urbanos, (re)inseridos produtivamente sob a condição de trabalhadores sobrantes. E sob esta condição estão sempre na iminência de serem novamente excluídos do processo produtivo. Inclusive parece ser este o horizonte para a grande maioria dos catadores, em relação ao processo de institucionalização da base da indústria da reciclagem. Institucionalização que prevê aumento de produtividade, sem resolver a conseqüente redução do número de catadores necessários à produção da matéria-prima pelas cooperativas (com lugar assegurado apenas para os melhores capacitados). Portanto, permanecem sob a condição de trabalhadores sobrantes. São sobrantes dos mais diversos setores produtivos, inclusive da própria indústria de reciclagem quando institucionaliza sua base... Assim, parece provável que esta indústria seguirá comportando uma característica dual, inscrevendo sua base tanto na informalidade quanto na formalidade, mesmo admitindo o incremento das cooperativas a longo prazo.

Portanto, o catador é um trabalhador pobre urbano, (re)inserido produtivamente na condição de trabalhador sobrante na base da indústria da

\footnotetext{
${ }^{56}$ É o que procuramos expor, sobretudo, nos Relatos diversos, obtidos em trabalho de campo junto a cooperativas e núcleos de reciclagem. Também da análise do Documento do MNCR que propõe a criação de 39.000 postos de trabalho para catadores. Estes constam nos ANEXOS da Tese.

${ }^{57}$ A pesquisa não abrangeu o trabalho destes catadores, mas a Dissertação de Legaspe (2006) oferece estas informações como um importante registro documental, sendo referência para esta Tese.
} 
reciclagem. Justamente porque esta indústria se ergue em conformidade com a reestruturação produtiva, no que também se inclui a formação das cooperativas.

Ou seja, tal indústria arregimenta o trabalho sobrante, que ao ser mantido nesta condição, permite que a mesma se realize sem o correspondente contingente de operários, o que evidentemente os catadores não são (como já assinalado). Assim, de um lado, a indústria da reciclagem se faz presente-ausente na figura do catador. Por outro, na ausência de operários (trabalho produtivo) "no chão da fábrica" (para as etapas iniciais do processo de reciclagem: triagem, prensagem, enfardamento), está presente o trabalho pretérito (consumido justamente nas etapas anteriormente referidas realizadas pelos catadores) consubstanciado nos resíduos que chegam à indústria em estágio já adiantado de seu processamento. Portanto, a contradição fundante está na relação entre capital e trabalho, dissimulada pelos curiosos nexos tecidos no âmbito do capital comercial, onde atuam os atravessadores (comerciantes de diversos portes situados entre o catador e a indústria), com os quais o catador realiza a venda dos materiais por ele coletados.

De fato, o conjunto de atividades realizadas pelos catadores na base da indústria da reciclagem está inscrito na informalidade. Porém, como nos adverte Silveira (2004: 68), o trabalho informal não se confunde exatamente com o circuito inferior da economia. Por outro lado, o trabalho informal está presente em São Paulo desde tempos remotos: na gênese e desenvolvimento da formação do mercado de trabalho livre neste país (Pinto, 1984), ganhando maior visibilidade no contexto atual de transformações no mundo do trabalho (Pochmann, 2001; Antunes, 1999). Ou seja, em São Paulo sempre se reproduziu, no cerne mesmo do processo de industrialização-urbanização-metropolização, um contingente populacional ocupado em atividades não-formais em crescente diversificação, num fenômeno próprio ao desenvolvimento capitalista.

A gênese e o desenvolvimento, as transformações e as condições atuais do mundo do trabalho em São Paulo indicam a coexistência, a conjugação e o conflito entre o velho e o novo, o formal e o informal, bem como os nexos que os unem numa única e complexa totalidade. Destacam-se, sobre este assunto, a obra Cotidiano e sobrevivência: a vida do trabalhador pobre na cidade de São Paulo, 1890-1914, de Maria Inez Machado Borges Pinto (1984) ${ }^{58}$. Em "Cotidiano e

${ }^{58}$ Pinto, Maria Inez Machado Borges. Cotidiano e sobrevivência: a vida do trabalhador pobre na cidade de São Paulo, 1890-1914. Tese. Depto. História, FFLCH/USP, 1984. 
sobrevivência", cuja análise é sobre a cidade de São Paulo, vê-se que trabalho formal e informal vão juntos no processo de industrialização-urbanização.

Consideremos que o pós anos 50 marca, efetivamente, o desencadeamento do processo de formação da metrópole, num contexto histórico nacional com o advento do predomínio do urbano sobre o rural. Porém, já na passagem do século XIX para o XX pode-se encontrar, no âmbito da formação do mercado de trabalho livre para as fazendas de café, o desenvolvimento concomitante do mercado de trabalho urbano. Importa destacar que sua gênese leva a marca do "sub-emprego, e o desemprego temporário" (Pinto,1984:13). Este antecede e se desenvolve, inclusive, para além e nos interstícios da estruturação do operariado industrial, nos quadros da consolidação do emprego formal em massa, no decurso da industrialização. A autora cita a procura por "tarefas urbanas", ou "atividades urbanas", por parte dos colonos em fuga das fazendas cafeeiras para as cidades ${ }^{59}$.

A referida obra é fundamental para a compreensão de que $\underline{0 \text { urbano }}$ sempre ocupou um contingente de trabalhadores pobres urbanos, para além do emprego formal, industrial, no decurso da própria urbanização e correspondente aprofundamento da divisão social do trabalho. Além de apresentar um diversificado quadro da economia informal em São Paulo do início do século $X X$, nele se encontra negociante ambulante de ferros-velhos, que parece apresentar correspondência com certos comerciantes do ramo de sucatas do período atual. Mas também sobre a existência de uma "gente pobre dispostas a carregar fardos", inserindo-se em atividades urbanas informais.

Neste contexto, a autora observa o papel fortalecido da estrutura familiar no enfrentamento das adversidades do desemprego (Pinto,1984:22). A autora adverte que, a expansão das atividades produtivas na metrópole paulistana, a despeito da profunda diversificação da sua estrutura ocupacional, não foi suficiente para empregar a massa de trabalhadores estrangeiros, trazidos pela grande imigração, que se acumulou na cidade e, muito menos ainda, os migrantes rurais produzidos pelos sucessivos deslocamentos de colonos do campo para a área urbana.(...) (Pinto,1984:32)

\footnotetext{
59 Isto apesar do intenso controle que fizeram da Hospedaria dos Imigrantes, agência de colocação, uma espécie de prisão, da qual o colono só saia mediante um contrato de trabalho para os cafezais (Pinto,1984:14)
} 
O capítulo Pequenas ocupações autônomas e trabalho informal: a economia invisível, é dedicado à exposição do peso significativo do setor informal no mercado de trabalho da cidade de São Paulo [o qual] pode ser globalmente observado, tendo em vista os dados demográficos e ocupacionais da metrópole no início do século XX. Em 1900 a cidade possuía cerca de 239.820 habitantes, na sua maioria composta por elementos das camadas inferiores, sendo que em 1901 apenas 50.000 formavam a população operária (Pinto,1984:103). Neste contexto, a autora descreve a situação de uma massa de trabalhadores itinerantes que vivem "à cata de serviço"- expressão usada em diversas passagens da obra, os quais eram muitas vezes confundidos pelos contemporâneos com os vadios e mendigos. (...)

Neste mesmo contexto, surge um número considerável de estrangeiros que, saídos das fazendas do interior paulista, passaram a se estabelecerem em "pequenos negócios próprios ou no trabalho temporário" na cidade. Não só a família era integrada à atividade produtiva autônoma destes pequenos empreendedores, como também o imóvel onde residiam, o qual também servia ao uso comercial e à função rentista: trabalhando com um custo operacional mínimo, inúmeras famílias sobreviviam aproveitando o quarto da frente de sua própria casa para estabelecer pequenos armazéns de secos e molhados, quitandas de frutas e legumes, vendas, botequins, "bodegas", bares de bebidas e petiscos; outras separavam um quarto para o casal e os filhos e nos outros cômodos montavam pensão (Pinto,1984:110).

A autora relata que muitos prosperaram a custa de trabalho de madrugada a madrugada; outros porém, sob falência e dívidas foram levados ao suicídio (Pinto, 1984:111-113). Ainda neste quadro, o colapso e a decadência das indústrias estáveis eram sempre seguidos pela expansão do comércio casual, pelo aumento crescente do número de comerciantes ambulantes de quinquilarias (Pinto, 1984:115).

Na descrição feita pela autora acerca destes comerciantes ambulantes, a carroça é o principal instrumento de trabalho para o transporte dos diversos tipos de produtos ou para prestação de serviços: flagrantes do grande fluxo de vendedores ambulantes de alimentos e produtos mais pesados, deslocando-se ao longo dos itinerários habituais, mostram sempre a enorme utilidade das rústicas carrocinhas de madeira, dos mais variados tipos, empregadas como meio de transporte das mercadorias a serem comercializadas. (Pinto,1984:118) (...) 
Interessa-nos aqui, de modo especial, um relato acerca do "comércio de compra e venda de ferros-velhos exercido basicamente por imigrantes espanhóis e seus descendentes":

havia ainda muitos trabalhadores pobres, dentre os quais destacavam-se os espanhóis, que viviam da compra e venda dos resíduos aproveitáveis do consumo industrial. Estes ambulantes compravam, a baixíssimos preços, entulhos reaproveitáveis da economia doméstica, tais como: garrafas, sacos vazios, latas, materiais descartáveis que contivessem chumbo, metal, cobre e ferro-velho. Apesar de pagar um preço insignificante por estas mercadorias, muitas das quais nem compravam, porque recebiam gratuitamente das senhoras abastadas e que gozavam da fama de generosidade, estes ambulantes prestavam um bom serviço às donas-de-casa, retirando de suas despensas entulhos de pouco valor econômico e sem nenhuma finalidade. (Pinto, 1984:136)

Outro relato importante é sobre um grande número de trabalhadores pobres [que] se dedicava a pequenas atividades autônomas, associadas ao setor de transportes, tais como: charreteiros, cocheiros, carroceiros, barqueiros e carregadores ambulantes de sacos, fardos variados, malas e mudanças: estes profissionais independentes, em geral "gente pobre", eram profundamente úteis. Exerciam funções fundamentais à vida cotidiana da cidade. (...) Executavam tarefas menores, dedicavam-se a ocupações de pouco ganho, que devido à baixa lucratividade não foram assimiladas pelos setores mais dinâmicos da economia capitalista. As classes populares prestavam pequenos serviços autônomos baratos, associados ao setor de transporte, essenciais à rotina diária da cidade, mas, como proporcionavam baixíssima margem de lucros, não interessava ao empresariado progressista e aos órgãos públicos encampá-los (Pinto,1984:137). Enfim, são (...) homens sem qualificação profissional, ex-desocupados, operários especializados, que não encontravam emprego fixo permanente, imigrantes italianos, portugueses, espanhóis, alemães, pretos, mulatos, brancos e brasileiros de origem humilde, [que] valiam-se de sua força física, boa saúde e juventude, para estabelecer-se por conta própria como carroceiros e carreteiros (Pinto, 1984:139).

Por último, queremos destacar o relato sobre o trabalho daqueles que, para fugir do desemprego crônico, ex-operários juntavam-se à multidão de trabalhadores sem especialização, casuais, que desde a madrugada se agrupavam em torno da zona cerealista central de São Paulo, ponto de contratação de carregadores avulsos (Pinto,1984:141). Neste relato, aparece a 
prática da catação das sobras mutiladas de alimentos (...) um dos motivos que atraíam de imediato e provisoriamente, desempregados famintos, sem qualquer recurso de sobrevivência momentâneo, para este tipo de serviço. (Pinto,1984:142) (...) Na verdade, o grande contingente de homens disponíveis e dedicados a carregar fardos, era composto por uma massa heterogênea de mulatos, brancos e imigrantes paupérrimos, procedentes de várias nacionalidades (...), e o estado de profunda penúria, a pobreza comum, generalizada, eram os critérios para a identificação destes profissionais. (Pinto,1984:144-145)

Por outro lado, observamos que a origem remota do atual trabalhador que se põe à atividade da catação - o catador de materiais recicláveis - não tenha correspondência com o referido comerciante, mas sim em relação aos denominados "trabalhadores pobres", constitutivos de uma "gente pobre" que já no início do século se caracterizava como homens disponíveis e dedicados a carregar fardos, sendo que o estado de penúria profunda, a pobreza comum, generalizada, eram os critérios para a identificação desses profissionais (Pinto,1984:137;144). Ainda assim, deve-se ressaltar que a análise sobre o catador não o interpreta como "profissional", nem como "autônomo", mas como um trabalhador pobre urbano que, na condição de sobrante, tem sua energia vital consumida nas atividades da reciclagem.

É preciso compreender que estamos diante do processo de produção das matérias-primas, numa estrutura industrial cujo conjunto de atividades consome a energia vital dos catadores ${ }^{60}$, sejam eles avulsos ou organizados em grupo. De um modo geral, os catadores trabalham majoritariamente de modo informal. Os que trabalham individualmente são chamados de catadores avulsos ou carrinheiros, pois seu instrumento de trabalho elementar é um carrinho, comumente sob a forma de carroça (daí também serem denominados de carroceiros). Os catadores organizados em grupos trabalham coletivamente, sendo esta a proposta do modelo de cooperativas. Se por um lado é possível encontrar trabalhadores sobrantes que, vivendo da catação e/ou coleta, reproduzem-se na condição de trabalhadores pobres, por outro, há catadores que sobrevivem na mais profunda miséria (principalmente quando são moradores de rua). Porém, em ambos os casos, o que os catadores ganham corresponde a uma ínfima parte, a menor possível, dos preços dos materiais recicláveis definidos no

${ }^{60}$ Exceto no caso dos catadores que trabalham como assalariados dos comerciantes, pois há salário, e portanto, a relação é de exploração da força de trabalho (mais-valia). 
mercado pelas próprias indústrias. Esta situação também é válida para as cooperativas, pois o aumento da retirada dos cooperados é determinada, sobretudo, pelo aumento do volume dos recicláveis (ganhos de escala). Esta é a condição vigente para venderem diretamente para as indústrias, obtendo o preço por elas pago (sem a intermediação dos comerciantes que compram para vender mais caro). Ou seja, o que comerciantes e indústrias pagam aos catadores corresponde ao preço dos recicláveis (definidos ao nível do mercado) e não ao trabalho por eles realizado.

Devemos ainda apontar a distinção existente entre a noção de trabalhadores sobrantes em relação ao trabalho sobrante. No primeiro caso, tratase de trabalhadores que se tornam desnecessários para os mais diversos setores produtivos. Situação agravada no processo de reestruturação produtiva resultante da Terceira Revolução Técnico-Científica, pós anos 70. Estes trabalhadores, que já não conseguem vender sua mercadoria força de trabalho em relações formais de trabalho, em troca, portanto, de salário, nem por isso deixam de possuir a capacidade viva de trabalho que produza valor, e mais-valia. Ocorre que no conjunto de atividades que corresponde ao processo de trabalho inscrito na base da indústria, os trabalhadores sobrantes são (re)inserido no processo de produção de uma mercadoria a ser consumida produtivamente. Ou seja, na produção de matérias-primas.

Porém, os trabalhadores que realizam o referido conjunto de atividades, sobretudo as etapas iniciais - catar e separar os materiais - não são assalariados. O dinheiro que ganham corresponde a uma parte, a menor possível, dos preços definidos no mercado de recicláveis, envolvendo fatores como: custo de produção das matérias-primas derivadas de outros processos (vulgarmente denominadas de "matéria-prima original" ou "matéria-prima virgem"); demanda da própria indústria que repercute na oferta e procura pelos recicláveis; variações do mercado financeiro (em relação à moeda internacional, o dólar); incremento de inovações tecnológicas nas linhas de processamento dos recicláveis; dentre outros fatores observados no decorrer da realização da pesquisa.

Por sua vez, o que estes trabalhadores ganham em troca do material vendido corresponde ao irrisório para uma sobrevivência ordinária (em seu duplo sentido). E este ganho não significa pagamento pelo tempo de trabalho socialmente necessário (integrante do salário) que supostamente permitiria a sobrevivência e reprodução destes trabalhadores enquanto força de trabalho. 
Portanto, se estes trabalhadores sobrantes, mobilizados como catadores de materias recicláveis, não são reproduzidos como trabalho socialmente necessário, parece que estamos diante do consumo integral destes trabalhadores, que numa analogia ao conceito de trabalho sobrante, corresponderia a uma mais-valia de $100 \%$. Como diz Martins (2002:136) o trabalhador volta a se confundir, como acontecia na escravidão, com o trabalho propriamente dito. Este é o trabalho puro, que não envolve nenhum encargo social, nenhuma responsabilidade de ninguém.

Mas este trabalho não pago corresponde a um processo de trabalho ao término do qual a mercadoria matéria-prima, oriunda da reciclagem, será consumida produtivamente.

A catação, e demais atividades realizadas pelos catadores, apresentam a seguinte peculiaridade. Este conjunto de atividades entra num fluxo inverso àquele que normalmente existe no mercado. $O$ comércio de recicláveis não tem exatamente a função de realizar o valor das mercadorias através de sua venda ao mercado consumidor (consumo improdutivo). Ao contrário, Este ramo do comércio, como outro qualquer, compra para vender mais caro, mas o circuito de produção e consumo da mercadoria está direcionado ao consumo produtivo. Pois estas mercadorias entrarão na massa da parte circulante do capital constante, enquanto matérias-primas mais baratas, representando redução de custo com capital constante e, portanto, aumento da taxa de lucro. Matérias-primas mais baratas pois contém trabalho não-pago. Ademais, são mercadorias que adquirem um "valor agregado" enquanto "ecologicamente corretas", por sua vez anunciadas pelo chamado marketing verde das empresas enquanto práticas de Responsabilidade Social e Ambiental. Retomaremos esta discussão posteriormente.

Neste sentido, entende-se que o processo de trabalho realizado pelo catador começa no ato da retirara dos recicláveis da condição de lixo (matéria que perdeu seu valor de uso e de troca). O catador ressuscita parte do trabalho pretérito contido naqueles materiais, ou seja, restaura no objeto descartado como lixo um valor pelo qual troca por pagamento em dinheiro. Obviamente não o valor de uso original (garrafas plásticas e latas de alumínio para envase de bebidas, papel para escritório, jornais e revistas para leitura, etc.), mas aquele que reside nas propriedades físico-químicas dos materiais (diferentes tipos de plástico, metais, papéis...). Pois, enquanto produtos, não são dádivas da natureza, mas 
provém dos recursos naturais transformados, tais como o petróleo, a celulose, os metais, incluindo os custos com energia, desgaste dos meios de produção, entre outros.

Porém, para que os recicláveis sejam negociados como novos produtos - materiais recicláveis - entre catadores e comerciantes, é necessário que sejam apresentados em quantidade ${ }^{61}$. Para o catador - sobretudo aquele que trabalha individualmente, invariavelmente com uso de uma carroça - a medida desta quantidade é o quilo, pelo qual ele troca por dinheiro (moeda) contados à base de centavos. Ele precisa reunir dezenas de quilos de materiais recicláveis para que a troca por dinheiro saia da casa dos centavos... Estes centavos, insistimos, correspondem ao preço dos materiais que constituem os recicláveis, e não ao trabalho do catador. Como são milhares de catadores (algo em torno de 500.000 a 800.000 em todo o país, e entre 20.000 a 40.000 em São Paulo ${ }^{62}$ ), evidentemente que as quantidades de recicláveis vão exponencialmente aumento em direção ao topo das cadeias produtivas, calculadas em toneladas e bilhões de reais (ver no próximo Capítulo).

Portanto, a catação e as atividades que a sucedem, tais como separar e transportar com dispêndio da força do próprio corpo, constituem processo de trabalho que não é remunerado como trabalho. Os catadores são trabalhadores que não conseguem vender sua força de trabalho numa relação formal, sendo porém (re)inseridos produtivamente deste conjunto de atividades. Não são trabalhadores autônomos pois, ainda que de forma indireta, há subsunção ao capital produtivo que os mobiliza. Mas, como suas atividades se realizam na esfera do comércio, os catadores aparecem como uma espécie de autônomo, que trabalha por conta própria.

Por outro lado, como sua atividade resulta em benefícios diretos e indiretos para toda a sociedade, seja em termos de limpeza urbana ou da gestão integrada dos resíduos sólidos, os catadores também aparecem como prestadores de serviço. Mesmo porque, a limpeza urbana e a gestão integrada dos resíduos sólidos são de responsabilidade das administrações públicas locais e dos geradores dos resíduos sólidos, propiciando certa vantagem para os

\footnotetext{
${ }^{61}$ É a abundância, correspondente a escala, desses resíduos que os torna novamente objetos de comércio e, assim, novos elementos da produção. Só como resíduos da produção em comum, e portanto da produção em larga escala, eles ganham essa importância para o processo de produção, continuam a ser portadores de valor de troca. (Marx, v.III, tomo I, Pp.61-62)

${ }^{62}$ Conforme as respectivas fontes: MNCR, ABRELPE, POLIS, e estimativa feita nesta Tese.
} 
agentes que deixam de arcar com os custos de disposição final (prefeituras e empresas geradoras de resíduos, cuja escala ultrapassa o volume coletado pelos serviços públicos). Esta é a visão difundida por algumas administrações públicas, que acabam implantando cooperativas em seu sistema de limpeza urbana, bem como uma visão que permeia o debate no âmbito do Terceiro Setor e empresas.

No bojo das interpretações que evitam associar o catador a um trabalhador implicado pela indústria, encontra-se ainda a noção e o discurso do empreendedorismo, no processo de formação das cooperativas de catadores. Esta noção é freqüentemente utilizada para definir o trabalho da catação, no contexto da chamada "economia solidária" que, contraditoriamente, apresenta-se como uma válvula de escape para as mazelas do neo-liberalismo. Aqui, o catador é associado a um empreendedor, em vias de alcançar sucesso com seu "empreendimento", neste caso, a cooperativa. Esta é a visão difundida pelo SEBRAE.

Por sua vez, a noção de "reinvenção do trabalho" (Barelli, 2003:18) parece corresponder à idéia de reinserção produtiva vivenciada pelos trabalhadores sobrantes tornados catador. Pedreiros, eletricistas, encanadores, ajudantes gerais, entre outros, encontram na catação a principal atividade para sua sobrevivência. Ao mesmo tempo, as atividades ligadas à sua profissão tornam-se "bicos" complementares. É o que relatam alguns dos entrevistados da pesquisa de campo: "às vezes aparece um "servicinho" aqui, outro ali, coisa pequena, um cômodo pra erguer, um vazamento pra consertar. Quando acaba, a gente volta pra reciclagem, que na falta de serviço é o que tem pra não ficar parado".

Outra noção que à primeira vista se aplicaria ao "exército de catadores" é a de "exército industrial de reserva". Ainda que as condições de trabalho sejam péssimas mesmo em "cooperativas modelos" como a ASMARE, em Belo Horizonte, são sistemáticos os relatos sobre filas de espera para ingresso nestas cooperativas. Estas, por sua vez, correspondem à alternativa para estes trabalhadores que enfrentam condições ainda piores sob a exploração dos comerciantes de recicláveis, ou ainda, como catadores avulsos à margem de qualquer representação jurídica. Desta forma, há sempre um contingente de trabalhadores sobrantes prestes a ingressar no processo de trabalho na base da indústria da reciclagem. O quadro é totalmente crítico. 
Ainda assim, diversos autores, como Barelli (2003:18) parecem otimistas ao apostarem no empreendedorismo e no voluntariado como iniciativas que "vão contra a corrente" do quadro crítico do desemprego e da precarização do trabalho: Digna de nota é a iniciativa da formação de associações ou cooperativas populares, que unem desempregados que usam seus conhecimentos para conseguir uma pequena renda. (...) O trabalho voluntário ou o chamado terceiro setor é outra oportunidade. Principalmente os jovens encontram no voluntariado ou nos estágios em ONGs sua maneira alegre de participar. Muitos adquirem conhecimentos que passam a Ihes ser úteis, como a reciclagem de materiais e muitos organizam esse e outros trabalhos na comunidade. ${ }^{63}$

Os entusiastas da economia solidária podem encontrar um suporte para defender a formação de cooperativas que, em tese, restabelece a relação entre trabalhador e meios de produção ${ }^{64}$. Isto sob a hipótese de que os cooperados se apropriam coletivamente dos meios de produção encerrados na cooperativa, além de saírem da esfera de exploração dos intermediários. Nas cooperativas ou associações de pequeno porte, onde é comum a presença de grupos familiares, compadrios, vizinhos de um bairro, e onde os meios de produção são irrisórios e a solidariedade entre os membros é maior, pode-se até afirmar a possibilidade de que os meios de produção pertencem ao grupo, de forma igualitária. Porém, não é isto o que encontramos, principalmente no caso das cooperativas de grande porte. Ao contrário, o que temos na maioria dos casos, é uma relação de exploração dissimulada pela aparência de um sistema cooperativado, onde há uma grande oscilação no quadro de cooperados, que ao deixarem a cooperativa sequer recebem suas "cotas-parte" (sendo este, aliás, um termo praticamente esquecido pelas "diretorias" das cooperativas, e/ou desconhecido por parte dos "cooperados"). Os trabalhadores (podendo, ou não, ser catadores) que por sua vez ingressam na cooperativa o fazem nos moldes de um trabalhador assalariado que no final de terminada jornada de trabalho receberá um "salário". Mesmo que exista a noção de que o dinheiro recebido pelos materiais vendidos será dividido entre os cooperados (incentivando o aumento da produtividade do trabalho, pois maiores quantidades de materiais vendidos significa aumento no pagamento, remetendo à noção de trabalho por

\footnotetext{
${ }^{63}$ Grifo nosso.

64 (...) compreender a classe trabalhadora hoje, de modo ampliado, implica entender esse conjunto de seres sociais que vivem da venda da sua força de trabalho, que são assalariados e são desprovidos dos meios de produção. (...) (Antunes, 2006:201)
} 
peça $a^{65}$ ), a relação continua sendo a de estranhamento em relação aos meios de produção, os quais pertencem "à cooperativa".

É interessante observar que esta indústria não vem mobilizando "trabalhadores com experiência" (Barelli, 2003), mas "braços" disponíveis sobretudo para as etapas iniciais do processo de reciclagem. Etapas que exigem do trabalhador grande dispêndio de energia absorvida na atividade da catação e do transporte dos materiais, bem como nas etapas sucessivas que envolvem maior ou menor grau de conhecimentos técnicos e do uso de instrumentos, como é o caso da triagem, da prensagem e enfardamento. Destas últimas, a triagem é aquela que requer um maior grau de "experiência" do trabalhador, pois exige que o mesmo conheça cada material com sua respectiva tipologia (a exemplo dos diferentes tipos de plásticos).

Porém, com o processo de estruturação do setor, cresce também as exigências de capacitação dos catadores, organizados em cooperativas. Observemos, que este tipo de trabalhador se encontra geralmente vinculado às associações, cooperativas ou mesmo em estabelecimentos comerciais como depósitos ou sucateiros que adquirem conhecimentos técnicos e instrumentos necessários ao beneficiamento dos materiais. Trata-se de "agregar valor" visando alcançar condições mais favoráveis para a negociação com grandes comerciantes ou com a própria indústria recicladora, situados em níveis mais elevados da cadeia produtiva.

Se de fato, como nos diz Singer (2001:12) existe uma incompatibilidade da organização dos trabalhadores informais, mediante formação de um sindicato (dada a ausência do contrato de trabalho com determinada empresa), e por isso o modelo cooperativado tem sido a forma adotada para a organização do trabalho , nem por isso o trabalho realizado nas cooperativas deixa de estar sob a exploração de empresas em termos permanentes. Tanto é que são estas que

${ }^{65}$ O salário por peça nada mais é que uma forma metamorfoseada do salário por tempo, do mesmo modo que o salário por tempo é a forma metamorfoseada do valor ou preço da força de trabalho. O salário por peça parece, à primeira vista, como se o valor de uso vendido pelo trabalhador não fosse função de sua força de trabalho, trabalho vivo, mas trabalho já objetivado no produto, como se o preço desse trabalho não fosse determinado, como o do salário por tempo, pela fração: valor diário da força de trabalho / jornada de trabalho de dado número de horas, mas pela capacidade de produção do produtor. (...) Dado o salário por peça, é naturalmente do interesse pessoal do trabalhador aplicar sua força de trabalho o mais intensamente possível (...). Do mesmo modo, é interesse pessoal do trabalhador prolongar a jornada de trabalho, pois com isso sobe seu salário diário ou semanal. (...) o trabalhador toma a sério a aparência do salário por peça, como se the pagassem seu produto e não sua força de trabalho (...).(Marx, v.l, tomo 2, p.139-144) 
determinam as características do produto (qualidade, quantidade, freqüência) fornecido pelas cooperativas, condição para que as mesmas se libertem da espoliação de intermediários, estando mais livres para relacionar-se diretamente com a indústria. Melhor dizendo, como parte da indústria.

Assim, sob a perspectiva estrutural da indústria, o processo de trabalho realizado pelo catador pode ser explicado como trabalho produtivo. Mas para isso, é preciso compreender que a base estrutural desta indústria se realiza no urbano. E que o urbano é social, e que portanto, todas as partes estão relacionadas. Assim, no Nível do urbano, torna-se inteligível a conexão entre indústria e catadores, entre capital e trabalho, na formação de capital. Por fim, compreendese que as periferias urbanas, ao abrigarem a base da indústria da reciclagem, são mobilizadas como frente de formação do capital, nos negócios desta indústria.

Sob este enfoque, compreende-se aspectos importantes da produção de matérias-primas oriundas dos materiais recicláveis, a serem consumidas produtivamente por diversos segmentos da indústria de transformação. Para tanto, foram desenvolvidas duas interpretações (sob a perspectiva do materialismo histórico) sobre a forma como o trabalho do catador participa da formação de capital, tanto comercial quanto produtivo, no processo de produção de matérias-primas. Em ambos os casos, entende-se que estes trabalhadores sobrantes não recebem salário. Portanto, em síntese, o trabalho realizado pelos catadores no início do processo de reciclagem se revela como trabalho não pago, como consumo de sua energia vital. Ou seja, se o setor produtivo consegue reduzir custos com capital constante ao adquirir estas matérias-primas mais baratas (como parte integrante do capital circulante), devemos justamente ressaltar que, na primeira etapa do processo de reciclagem ${ }^{66}$, há trabalho não pago. Não em termos de mais-valia, pois não há salário. Mas no consumo do próprio trabalhador.

Mas com o avanço da institucionalização da base desta indústria, sob o formato das cooperativas e empreendimentos correlatos, e diante das exigências crescentes das empresas compradoras desta matéria-prima (qualidade, quantidade e freqüência), observa-se uma tendência ao aumento da produtividade do trabalho no interior das cooperativas, com base no trabalho

\footnotetext{
${ }^{66}$ O processo de reciclagem é composto por três etapas: recuperação (que reúne as atividade de coleta, triagem, prensagem e enfardamento, concentradas na base da indústria), revalorização (beneficiamento) e transformação. (ver Capítulo IV).
} 
combinado. Esta tendência parece apontar para a desnecessidade de mobilização de uma enorme massa de catadores avulsos.

Ademais, como a característica principal destes últimos é a de serem carrinheiros - ou seja, sua atividade está diretamente vinculada à catação com uso de carrinho puxado à tração humana - outro ponto crucial é que o aumento da produtividade nas cooperativas é determinada pelo uso de veículos motorizados, culminando com o uso de caminhões, os quais representam um elemento de modernização da base do setor. Por outro lado, o circuito de catação dos catadores avulsos, ao ser traspassado pelas rotas dos caminhões das cooperativas, define uma competição evidentemente desigual, em prejuízo dos primeiros.

Nessa perspectiva, a massa de desempregados mobilizada num primeiro estágio do processo de estruturação da indústria da reciclagem seria paulatinamente descartada. Corrobora esta tendência o próprio documento elaborado por entidades do Terceiro Setor, em parceria com o Movimento Nacional de Catadores de Materiais Recicláveis, sobre a criação de 39.000 postos de trabalho para catadores organizados em cooperativas. Número que parece atender à capacidade de absorção dos recicláveis como matéria-prima pela indústria. Ora, se a estimativa é a de que existe algo em torno de 500.000 a 800.000 mil catadores em todo o Brasil, qual é a proposta para os catadores que restam, literalmente, desta política de investimentos públicos, e privados, no setor?

Por fim, a pesquisa aponta para a situação crítica que também envolve a formação das cooperativas, bem como as iniciativas em nada voluntárias do Terceiro Setor. Neste caso, a "formação de associações ou cooperativas populares, que unem desempregados que usam seus conhecimentos para conseguir uma pequena renda" (Barelli, 2003:18), está estritamente relacionada aos interesses das empresas recicladoras. Isto implica em controle do processo de trabalho, no preparo do material reciclável para que chegue à indústria da forma a permitir seu funcionamento em grande escala, parecendo indicar por suposto a expansão do setor.

A Revisão Conceitual deste CAPÍTULO, com base em estudos sobre o trabalhador pobre urbano, sobretudo no contexto das transformações recentes no mundo do trabalho, consta como ANEXO 02 da Tese. Estas obras constituem a nossa principal referência sobre o tema, com base nas quais discorremos sobre o 
trabalhador sobrante, (re)inserido produtivamente na base da indústria da reciclagem.

\subsection{O trabalho do catador sob a perspectiva do materialismo histórico}

São aqui apresentadas duas perspectivas de interpretação sobre 0 trabalhado do catador, enquanto trabalho social que participa do processo de estruturação da indústria da reciclagem. Na primeira, a análise está centrada no comércio. Nela, tanto a relação entre catadores e comerciantes, quanto entre comerciantes e industriais se mostram de forma muito clara, contribuindo para a identificação dos agentes que atuam neste setor. Na esfera do comércio, o trabalho do catador aparece como trabalho improdutivo. Isto porque a relação entre catadores e indústria não é clara, e o trabalho realizado pelos catadores aparece muito distante da indústria propriamente dita. Ademais, do ponto de vista do comércio não importa se o trabalho do catador é produtivo ou improdutivo. $A$ formação e acumulação do capital mercantil está numa relação direta com 0 volume dos materiais recicláveis, sob a prática do comprar para revender mais caro.

Noutra perspectiva, segundo uma abordagem estrutural da indústria, o trabalho do catador pode ser compreendido como trabalho produtivo. Aqui, o trabalho do catador se realiza no urbano, no qual se insere a base da indústria da reciclagem. Neste sentido, só pensando o urbano como social, em que todas as partes estão conectadas, é que se pode desvendar a relação entre catador e indústria.

Assim, a primeira perspectiva não é negada, mas se demonstra insuficiente para a compreensão sobre a estruturação da indústria da reciclagem, no que tem lugar o processo de trabalho realizado pelos catadores em sua base.

Para ambas perspectivas foi analisado o conjunto de atividades tipicamente realizado por catadores avulsos. Diferentemente da cooperativa, que pode vender os recicláveis diretamente para a indústria, os catadores avulsos necessariamente vendem os recicláveis para comerciantes. Isso permite que utilizemos o mesmo conjunto de atividades nas duas perspectivas: no contexto do comércio, e naquela da estrutura industrial. 


\subsubsection{O trabalho do catador no contexto do comércio de recicláveis}

Nesta primeira perspectiva, o trabalho realizado pelo catador está restrito à esfera da circulação, onde se realiza o comércio. Aqui se situam as atividades de catação (a coleta), transporte e finalmente 0 ato da venda dos materiais recicláveis para comerciantes do setor (sucateiros, ferros-velhos, depósitos, reciclagem, entre outras modalidades).

Deste ponto de vista, o catador realiza uma troca comercial, pela qual recebe um pagamento em dinheiro pela venda (troca simples) do material reciclável obtido na atividade da catação. Neste sentido, atua como uma espécie de trabalhador autônomo, segundo uma disciplina - um ritmo, em termos de tempo e de organização das atividades elementares do "processo de trabalho", quais sejam: catar, separar, transportar, vender.

Mas já aqui não podemos desconsiderar a possibilidade de algum beneficiamento dos materiais recicláveis. Seja a simples separação dos diferentes tipos de materiais catados (papéis, vidros, plásticos, metais), o que pode acontecer nos próprios espaços públicos como ruas, calçadas, sob viadutos. Ou ainda triagens mais detalhadas, de acordo com classificações desses mesmos materiais (diferentes tipos de papéis, de plásticos, de metais, de vidros).

Por outro lado, atividades como prensagem e enfardamento demandam ao menos mais um instrumento, a prensa, mas o catador avulso normalmente possui apenas uma um carrinho, o qual pode ser emprestado dos comerciantes $^{67}$.

Quanto mais dependentes de técnicas e equipamentos especializados estejam as atividades da reciclagem, mais distantes se encontram do alcance do catador que trabalha "por conta própria" e de forma individual. Geralmente, somente as empresas, que se especializam no ramo da reciclagem, seja sob a forma jurídica de cooperativa ou outra modalidade, possuem a infra-estrutura necessária para executá-las, embora nem sempre em condições adequadas. É o caso de associações e cooperativas de catadores que realizam tais atividades

\footnotetext{
${ }^{67}$ Com este "empréstimo", o catador fica praticamente obrigado a vender os recicláveis somente naquele estabelecimento. Um mecanismo de exploração, pois o catador fica à mercê das condições impostas pelo comerciante. Uma destas condições é justamente o fato do catador não poder vender seus materiais em outro estabelecimento que lhe pague melhor.
} 
improvisando os instrumentos de trabalho, como bancadas para triagem e uso de prensas manuais, entre outras alternativas encontradas.

Nesta perspectiva, enquanto trabalhador autônomo restrito à esfera da circulação, o catador não possui patrão, nem salário. Trabalha por conta própria, estabelece seu itinerário, faz seu próprio horário. Sobrevive com o dinheiro que recebe, geralmente no final de cada dia, em troca do que consegue catar e vender. Não produz nenhuma mercadoria, nem valor, nem mais valor (mais-valia). O dinheiro que chega às suas mãos é calculado de acordo com os preços estabelecidos para cada um dos materiais recicláveis, variando conforme seus respectivos mercados (o de papel e celulose, o de vidros, o de plásticos, o de sucatas metálicas, etc.). Vale destacar que neste mercado participam indústrias especializadas em embalagens, e indústrias produtoras de mercadorias para o consumo em geral, as quais demandam embalagens para seus produtos finais. Além disso, os preços dos materiais recicláveis oscilam em relação ao custo de produção das matérias-primas, bem como de acordo com as inovações tecnológicas de processamento dos recicláveis, ou ainda em decorrência de incentivos e financiamentos do Estado (no que se inserem as políticas públicas que disciplinam o funcionamento do setor).

Com esta primeira abordagem, o trabalho do catador poderia ser entendido como trabalho improdutivo que se realiza no âmbito da circulação, viabilizando indiretamente os lucros auferidos pela indústria da reciclagem.

Ainda sob esta perspectiva, deve-se considerar que o dinheiro que 0 catador recebe em troca dos materiais provém, num primeiro nível, da própria esfera da circulação. Ou seja, o dinheiro chega às mãos do catador por intermédio dos comerciantes, geralmente de pequeno porte. Estes valores correspondem a uma porcentagem, a menor possível, do montante de dinheiro (já sob a forma de capital comercial ${ }^{68}$, prestando-se à função de comprar para vender mais caro) que é injetado nesta esfera da circulação onde se dá o comércio da reciclagem. No sentido inverso, os comerciantes compram dos catadores, aos menores preços, e revendem para as indústrias, ao preço que se forma no

${ }^{68}$ (...) Cada novo capital pisa em primeira instância o palco, isto é, o mercado, mercado de mercadorias, mercado de trabalho ou mercado de dinheiro, sempre ainda como dinheiro, dinheiro que deve transformar-se em capital por meio de determinados processos. (...) a forma $D-M-D$, transformação de dinheiro em mercadoria e retransformação da mercadoria em dinheiro, comprar para vender. Dinheiro que em seu movimento descreve essa última circulação transforma-se em capital, torna-se capital e, de acordo com sua determinação, já é capital (Marx, v.1, 1988: 121122). 
mercado. Devemos observar que esta não é a única forma de transação comercial que os referidos comerciantes praticam, mas ficaremos nela em função dos objetivos da presente exposição ${ }^{69}$.

Por sua vez, os comerciantes que atuam nos diferentes níveis das cadeias produtivas da reciclagem (desde o dono de um pequeno depósito até o grande aparista, para exemplificar), participam da distribuição desigual do valor total deste capital comercial, conforme o diferencial que possuem em termos de propriedade. Assim, são as empresas mais capacitadas do setor (sejam elas depósitos, sucateiros ou cooperativas) as que conseguem vender os materiais recicláveis diretamente para recicladores e indústrias produtoras de mercadorias. Justamente porque atendem os requisitos exigidos pela indústria, tais como: qualidade (separação, limpeza, idoneidade, etc.), quantidade (toneladas) e freqüência dos recicláveis. O que, por sua vez, implica num nível maior de organização do processo de trabalho.

É neste contexto que entram as cooperativas, pois geralmente adotam o sistema da coleta seletiva porta-a-porta, convocando cada domicílio a "fazer a sua parte"70, separando na fonte os materiais recicláveis a serem coletados em datas pré-estabelecidas. O material reciclável separado na fonte (evitando sua contaminação pelo lixo), apresenta-se desde o início como de melhor qualidade, além da coleta porta-a-porta, por sua própria natureza, garantir uma certa freqüência. O aumento do volume, neste caso, depende do porte dos meios de transporte (que pode ser desde uma frota de carrinhos até caminhões) e do percurso percorrido (potencializado por veículos motorizados).

No caso dos depósitos (e demais modalidades correlatas), o fluxo de entrada de materiais oscila de acordo com a dinâmica das atividades dos catadores avulsos, além de outras fontes de compra de materiais ${ }^{71}$. Nisto reside um dos conflitos na competição existente entre depósitos e cooperativas. Enquanto os depósitos compram os materiais, as cooperativas possuem como princípio não realizarem compra, substituindo esta prática pela coleta seletiva

\footnotetext{
${ }^{69}$ Existem outras modalidades de transações, das quais podemos indicar desde a dona de casa que vende os materiais recicláveis, oriundos do consumo familiar, ao comércio de sucatas mais próximo de sua casa (ou àquele que lhe pague um melhor preço), até entidades que doam os materiais recicláveis às cooperativas de catadores, para ficarmos somente nestes dois exemplos.

70 Do ponto de vista do processo industrial de produção da matéria-prima, o "fazer a sua parte" significa que também os domicílios estão entrando na composição da base estrutural desta indústria.

${ }^{71}$ Desde a dona de casa que leva os resíduos do consumo familiar em troca de algum dinheiro, até grandes geradores, como mercados, escolas, shoppings, etc.
} 
porta-a-porta e captação de doações. A este respeito, as cooperativas podem participar de projetos ou programas de responsabilidade social e ambiental das empresas geradoras de resíduos (tais como Suzano Papel e Celulose, Banco Real, Makro hipermercados, Rede Pão de Açúcar, shopping-centers, entre muitos outros).

\subsubsection{O trabalho do catador no contexto da estrutura industrial}

Em primeiro lugar, na análise sobre a origem do capital comercial que se forma no nível dos comerciantes de recicláveis, deve-se compreender que o mesmo não surge da esfera da circulação $^{72}$, mas provém da indústria que demanda e compra os materiais recicláveis. Seja como matérias-primas de seus próprios processos produtivos, seja para transformá-los em novas matériasprimas para outras indústrias dos mais diversos ramos ${ }^{73}$.

Aí está um ponto de inflexão, que aponta para outra perspectiva de análise do trabalho do catador.

Os materiais recicláveis têm entrado nos processos produtivos enquanto matérias-primas mais baratas, diminuindo custos com capital constante, em sua parte circulante. Isso é geralmente explicado como decorrência de economias diversas, seja em relação ao processo de extração dos materiais in natura (o que também implica tributações de ordem ambiental, sobretudo quando resulta em impactos ambientais, o que costuma ser a regra e não a exceção), seja pelo menor consumo de energia e de água (conforme os cálculos apresentados pela pesquisa de Sabetai Calderoni, Os bilhões perdidos no lixo, de 1997).

Mas, a produção da matéria-prima oriunda da reciclagem, como qualquer outra mercadoria, ocorre na esfera da produção. Por sua vez, o

\footnotetext{
${ }^{72}$ Mas já que é impossível explicar por meio da própria circulação a transformação de dinheiro em capital, a formação de mais-valia, o capital comercial parece impossível na medida em que se permutam equivalentes, só sendo ele, portanto, dedutível do duplo prejuízo infligido aos produtores de mercadorias que compram e vendem pelo comerciante que se atravessa parasitariamente entre eles. (...) Para que a valorização do capital comercial não seja explicada por mero engodo dos produtores de mercadorias, é preciso dispor de uma longa série de elos intermediários (...). (Marx, v.I, tomo I, Pp. 136-137)

${ }^{73}$ A exemplo, as garrafas tipo PET que são transformadas em matéria-prima para a indústria têxtil, como fio sintético.
} 
processo integral de reciclagem começa no seu nível de base, onde se encontra o conjunto de atividades realizadas pelos catadores. Segundo esta perspectiva, $\underline{0}$ trabalho do catador, que aparece separado do processo produtivo, pode também ser compreendido enquanto trabalho integrado ao capital produtivo.

Em qual sentido? Ao menos de duas formas. Primeiro, o conjunto de atividades realizadas pelos catadores, na primeira etapa do processo de reciclagem, é parte constitutiva e imprescindível do processo de reciclagem. Por sua vez, como explicado em relação à esfera do comércio, o que os catadores ganham na troca simples que realizam com os comerciantes, corresponde a uma porcentagem diminuta dos preços de mercado. Corresponde, portanto, a trabalho não pago. E este entendimento deve estar presente na explicação sobre porque estas matérias-primas são mais baratas do que as denominadas "materiais primas originais". Em segundo lugar, como são matérias-primas mais baratas, permitem o aumento da taxa de lucro (economia de gastos com capital constante em sua parte circulante). Mas estes resultados só vão aparecer no nível da própria indústria, portanto muito longe do processo de trabalho realizado pelos catadores, mas não independe deles.

Vejamos: trata-se de um exército de desempregados lançados à catação dos materiais recicláveis que, histórica e culturalmente, são descartados enquanto resíduos da sociedade de consumo, numa só palavra: lixo. Enfatizemos, um exército de catadores: ao menos 500.000 catadores em todo o Brasil $\left(\right.$ ABRELPE $^{74}$ ); de 20.000 (Instituto Polis ${ }^{75}$ ) a 40.000 catadores somente na cidade de São Paulo, segundo estimativas de pesquisas realizadas por entidades que se dedicam ao tema, e com base em estudos realizados nesta Tese.

São milhares de catadores, trabalhadores pobres urbanos, (re)inseridos produtivamente numa sociedade incessantemente produtora de mercadorias e vorazmente consumidora: são eles que vão ao lixo, são eles que realizam, feito máquinas, o momento tênue e brutal no qual acontece a mudança de qualidade do lixo em material reciclável. Neles reside uma síntese-contraditória do mais sui generis dos operários (o que, evidentemente, não são), cuja força vital (literalmente força) é empregada na transformação da "natureza" (não mais a "primeira") em novo produto, mercadoria a ser consumida pela indústria sob a

\footnotetext{
${ }_{75}^{74}$ Associação Brasileira das Empresas de Limpeza Pública e Resíduos Especiais.

${ }^{75}$ Entidade do da Sociedade Civil que atua no Fórum "Lixo e Cidadania" no Município de São Paulo.
} 
forma de matéria-prima. Este é o ato exato, e primeiro, que insere o catador no processo de produção de matéria-prima para as indústrias dos mais diversos ramos. Trabalho totalmente não pago. É preciso insistir: o que é pago ao catador corresponde a uma ínfima parte dos preço formados no mercado de recicláveis, estabelecidos pelas próprias indústrias consumidoras desta matéria-prima. Quanto poderia valer o trabalho do catador? Não cessam de surgir novos discursos, promovidos pela própria industria da reciclagem, veiculados sobretudo por seu Terceiro Setor, acerca da importância do seu papel como agentes ambientais. Também não faltam depoimentos favoráveis a isto, provenientes dos próprios catadores, capacitados e certos de que prestam um dos mais importantes serviços para a sociedade inteira. E qual é o tempo de trabalho socialmente necessário para a produção de " $n$ " toneladas de materiais recicláveis durante " $x$ " horas de jornada de trabalho? Depende. Há um silêncio sobre estes termos. Como resposta, multiplicam-se teorias diversas sobre como agregar valor aos materiais recicláveis, aumentar a produtividade, eliminar atravessadores, vender direto para a indústria a "preços justos". Sob qual modelo? Cooperativas. Prestadoras de serviço para a indústria que se estrutura com apoio do governo, da sociedade civil, da imprensa, da sociedade inteira. "Postos de trabalho são assim gerados". Todos agradecem: desempregados que agora são convocados, como nunca antes, a serem os baluartes do empreendedorismo. Enfim, toda a sociedade que agora pode consumir sem ferir os preceitos da responsabilidade social e ambiental. Afinal, quem promove efetivamente aquele retórico " $R$ " da Redução, o último a ser lembrado na "Trilogia dos 3R's"? Quando muito, ele é timidamente citado por conferencistas que explicam a eficiência de suas teorias, como esta dos 3, ou 4 ou 5 "Rs" (reduzir, reutilizar, reciclar, repensar, etc..). Este é o outro mundo possível, onde certamente viverão as futuras gerações... de capitalistas.

\subsection{O chão dos catadores: territórios de uso dos catadores avulsos}

Além de representar o mais "sui generis" dentre os catadores, é preciso compreender que os catadores avulsos estão sob todas as determinações da estruturação da indústria, as quais incidem sobre ele. 
Legaspe (1996) descreve os diversos tipos de catadores: carrinheiro (que trabalha com uso de carrinho), saqueiros (que recolhem sacos de lixo, com ou sem pontos fixos ${ }^{76}$ ), cabeceiro (que leva papelões na cabeça, também definido como "a morte andando", pois já não tem força para puxar carroça e coletar sacos). As entrevistas foram realizadas com os catadores avulsos carrinheiros, que por sua vez também recolhem sacos de lixo.

Nesta "breve incursão" no universo dos catadores avulsos, ou carrinheiros, foram realizadas entrevistas, tanto no Itaim Paulista, onde a pesquisa empírica já vinha sendo realizada, quanto nas imediação da Praça da República e na Baixada do Glicério (região central). Optou-se pela abordagem aos catadores nas ruas, sem a mediação de instituições ou espaços normatizados, tais como entidades filantrópicas, ONG's e albergues. Por sua vez, são apresentadas informações de três pesquisas realizadas pela Prefeitura de São Paulo: a primeira sobre moradores de rua, a segunda sobre albergados e a terceira sobre catadores. Além desta última, nas demais pesquisa também aparece o catador avulso. Portanto, há que se considerar o catador morador de rua, o catador albergado, o catador domiciliado. A abordagem dos catadores nas ruas estava aberta a este conjunto diversificado de catadores.

Apesar desta escolha implicar na dificuldade de incursão num território de uso que se realiza como conflituoso, os resultados obtidos foram esclarecedores para os propósitos da pesquisa. À margem do mercado de trabalho formal, suas estratégias de sobrevivência são traspassadas por diferentes normas, interesses, poderes. Portanto, sua prática socioespacial é tecida num campo conflituoso, próprio do Nível Misto, no qual se insere. A pesquisa encontrou o poder de polícia, o tráfico, as políticas de espaço e higienistas, a exemplo dos arrastões comandados pela Prefeitura para recolhimento das carroças, bem como o fechamento de espaços sob viadutos, nos quais diversos catadores moram e armazenam os recicláveis.

O campo no Itaim Paulista foi realizado nos dias da coleta oficial (Prefeitura), sempre antes do caminhão passar, pois este é o horário em que os catadores certamente estão nas ruas. Os dias e horários da coleta oficial se alternam nos diversos bairros existentes naquele território. Isto faz com que o

\footnotetext{
${ }^{76}$ Os pontos fixos correspondem aos locais onde os catadores mantém uma fidelidade para coletar, com exclusividade, os matérias recicláveis. Também pode corresponder ao local onde reúnem os sacos antes de transportá-los.
} 
catador também oriente seu percurso, a cada dia da semana, de acordo com o cronograma da coleta oficial. O que, por sua vez, evidencia a predominância dos resíduos domiciliares como objeto da catação para, e já indicam as longas distancias que devem ser percorridas, uma vez que os resíduos são depositados ao longo das ruas (normalmente nas calçadas e lixeiras).

No caso da região central, o trabalho de campo se concentrou ao final da tarde, quando se encerram as atividades comerciais e de serviços. Estas, evidentemente, constituem as principais fontes de resíduos coletados pelos catadores. Também foram realizadas entrevistas no período da manhã sob os viadutos da Baixada do Glicério, quando normalmente os catadores fazem a triagem do material antes de vendê-los aos comerciantes. As entrevistas se orientaram por um Roteiro de questões (ANEXO 03), que privilegiou o processo de trabalho realizado por estes catadores, enquanto consumo produtivo do tempo: a própria catação (que tem implícita uma primeira triagem, geralmente refeita com mais detalhe nos locais com atividades da reciclagem), bem como o transporte dos materiais (uso de carrinho/carroça). Foram ainda incluídas questões mais gerais sobre: seu histórico de inserção no mercado de trabalho; sua situação em relação a institucionalização da base da indústria e também aspectos de sua vida cotidiana.

Este trabalho de campo contribuiu, principalmente, para dois pontos importantes da Tese. Primeiro, para que o processo de trabalho realizado pelo catador pudesse ser analisado como produtivo, sob a perspectiva estrutural da indústria cuja base se realiza no urbano. Ou seja, como trabalho integrante da produção de matérias-primas, as quais repercutem na redução de custos com capital constante (parte circulante) para os mais diversos setores produtivos. Segundo, para demonstrar a distância existente entre os discursos e práticas envolvidos na institucionalização da base desta indústria, que mobiliza toda a sociedade, inclusive com fluxos monetários (financiamentos diversos) em nome dos catadores. Porém, muitos dos catadores avulsos permanecem à margem deste processo, circunscritos aos seus territórios de uso.

Portanto, estas incursões ofereceram elementos importantes para restituir, analiticamente, a relação capital (produtivo) - trabalho (sobrante), para além de uma simples troca comercial realizada entre catadores (geralmente entendidos como autônomos) e comerciantes (intermediários entre catadores e indústrias). 
O que, por sua vez, também pode ser reconhecido no trabalho realizado pelos grupos organizados de catadores (cooperativas, associações, núcleos). Mas, tratava-se de pôr em evidência como estes trabalhadores são, eles próprios, com seus corpos, consumidos nessa atividade que parece situada muito distantes da indústria, no processo global de produção de matérias-primas oriundas da reciclagem. Portanto, além da coleta, transporte, triagem, prensagem e enfardamento (analisadas no trabalho de campo centrado no processo de institucionalização da base da indústria), fez-se necessário analisar a catação e o transporte realizados pelos catadores avulsos.

Ademais, trata-se de analisar, mais detidamente, na atividade dispersa da catação ou coleta, nela incluída o transporte dos recicláveis (embora estas atividades sejam também realizadas pelos grupos organizados, sob a forma de coleta seletiva porta-a-porta). Ou seja, catar e transportar não constituem uma "atividade autônoma" desvinculada do processo global da reciclagem, o que corrobora a afirmação de que o catador não deve ser entendido como um autônomo.

Ao entender o catador como trabalhador sobrante oriundo dos mais diversos setores, procurou-se recuperar um breve histórico da experiência anterior destes trabalhadores no mercado de trabalho. Neste sentido, foram encontrados catadores que tiveram uma ou mais profissões, inclusive com carteira assinada, ainda que nos extratos de menor exigência e remuneração profissional. A baixa escolaridade (e o analfabetismo), a idade avançada, a intermitência entre emprego e desemprego, a passagem pelo crime e o alcoolismo são algumas das contingência envolvidas no percurso que leva estes trabalhadores sobrantes à catação. No trabalho de campo, cerca da metade dos catadores entrevistado tinha mais de 40 anos; outros estavam alcoolizados no ato da entrevista, e alguns relataram sua dependência alcoólica, dentre outras dependências químicas. Também entrevistamos um catador de 50 anos, que teve 18 anos de carteira assinada (como eletricista, cozinheiro e numa refinaria de açúcar na Moóca), mas após passar 20 anos na cadeia, e por conta de sua idade avançada, só Ihe restou a catação como estratégia de sobrevivência. Neste sentido, pode-se dizer que além de serem trabalhadores sobrantes, são trabalhadores precarizados porque já tiveram lugar no mercado de trabalho (reproduzindo-se como trabalhadores assalariados), e passaram a sobreviver como catadores. 
Em relação à situação do catador frente à institucionalização da base da indústria, existem alguns problemas que devem ser destacados. Em primeiro lugar, há que se considerar que numa cooperativa o catador deve se comportar com certa disciplina, cumprir deveres, apresentar condições físicas e psíquicas para a realização do trabalho combinado. Mas, nem todos os catadores avulsos apresentam condições e/ou estão dispostos às exigências impostas pelo trabalho organizado. Durante o trabalho de campo encontramos catadores avulsos não dispostos ao trabalho em cooperativas. Dentre as justificativas, encontra-se a necessidade do aprimorado do processo de trabalho (essencialmente a triagem) o que, por sua vez, requer maior capacitação. As regras a serem cumpridas (horários; não estarem alcoolizados), a porcentagem da retirada para o fundo da cooperativa e "atrasos nos pagamentos" foram também citados.

Por outro lado, todos os discursos e práticas envolvidos na estruturação da indústria da reciclagem, mais precisamente direcionados à institucionalização de sua base, são proclamados em nome dos catadores, e nisso se inclui o catador avulso. Aliás, é exatamente em nome dele. Aliás, o argumento de que estes catadores serão libertados da opressão dos atravessadores é recorrente, inclusive com a promessa de que dominarão as cadeias produtivas ${ }^{77}$... Porém, grande parte dos trabalhadores sobrantes que ingressam nas cooperativas não tiveram um histórico anterior como catador. Porque o catador avulso (o catador mesmo!) está muito distante das práticas e discursos envolvidos na institucionalização da base da indústria, no que se inserem as cooperativas. Portanto, embora também se caracterizem como trabalhadores pobres sobrantes, os cooperados muitas vezes (embora nem sempre) são a abstração do catador propriamente dito; daquele que permanece como avulso, carrinheiro.

Enquanto isso, parte considerável dos catadores avulsos continuam sendo consumidos em seu trabalho solitário e invisível. Para estes, resta o chão dos catadores, sobre o qual incidem o peso do processo de institucionalização da base industrial. Afinal, parece inevitável que, ao aumento de produtividade embutido na proposta de organização do trabalho em cooperativas, verifique-se a redução do número de trabalhadores sobrantes necessários à produção destas matérias-primas. Ou seja, trabalhadores sobrantes que se tornaram catadores,

\footnotetext{
${ }^{77}$ Ver relato de campo à fábrica de plásticos da Rede Cata-Unidos, Belo Horizonte (ANEXO 03).
} 
parecem condenados a permanecer como sobrantes, até mesmo para a reciclagem.

Buscou-se também a apreensão de aspectos da vida cotidiana destes trabalhadores sobrantes, em cuja estratégia de sobrevivência a própria vida é consumida. Assim, logo nas primeiras entrevistas (realizadas em meados de 2007), evidenciou-se que na prática socioespacial destes catadores, definiam-se territórios de uso que passamos a denominar de chão dos catadores. Uma denominação formulada em contraposição à "esfera dos discursos" que legitimam o processo de institucionalização da base da indústria da reciclagem: da subida à esfera dos discursos à descida ao chão dos catadores.

Enquanto território de uso, trata-se do cotidiano destes trabalhadores pobres, na relação entre trabalho, família e lazer (Henri Lefebvre, $A$ vida cotidiana no mundo moderno). Porém, as entrevistas realizadas no trabalho de campo (denominado de "incursões no chão do catador") demonstraram a necessidade de uma pesquisa muito mais ampla e dedicada a este propósito. Ou seja, uma pesquisa sobre os territórios de uso dos catadores demandaria uma incursão muito mais profunda no Nível $P$, para além do enfoque sobre sua (re)inserção produtiva, analisada com base no seu processo de trabalho. Portanto, há que se admitir que no "chão do catador" cabe um mundo! Pois nele está o desenrolar da vida sobrevivida por estes trabalhadores sobrantes nos interstícios do urbano. Nele, os catadores avulsos, carrinheiros, percorrem a trama fina e densa na qual são gerados os resíduos do consumo na metrópole. Nele está o lugar da vida e da morte, da luta e do luto, das virtudes e dos vícios, do conflito, do drama e da festa. Porque o irredutível da vida persiste na negatividade do urbano. Caso contrário, seria a admissão da exclusão absoluta, mas não é disso que se trata. Se por um lado, a pesquisa não lida com trabalhadores inseridos no mercado de trabalho, tão pouco se encontra diante de indivíduos que deixaram de ser trabalhadores. Estão, decerto, fora do mercado formal de trabalho, mas plenamente, dramaticamente, perversamente incluídos no processo de produção de uma mercadoria, tão "sui generis" quanto o próprio catador, entendido como trabalhador sobrante. Ou seja, são sujeitos que têm a vida consumida num processo produtivo, industrial, cuja formação de capital se realiza em pleno setor formal, portanto distante destes "trabalhadores fora do mercado de trabalho".

Assim, admitida a necessidade de "incursões" mais profundas e mais extensas no chão dos catadores, privilegiou-se a análise sobre o processo de 
trabalho, bem como a interpretação sobre a relação existente entre estes catadores e a institucionalização da base da indústria. Ainda assim trouxemos para o escopo da tese as impressões e relatos obtidos sobre o cotidiano destes trabalhadores. Apresentamos os relatos dos catadores avulsos entrevistados durante a realização do trabalho de campo (ANEXO 04 da Tese).

\subsubsection{Pesquisas sobre moradores de rua, albergados e catadores}

Nesta Tese, o catador é entendido, antes de mais nada, como trabalhador sobrante oriundo dos mais diversos setores. Em segundo lugar, entendemos que este trabalhador sobrante experimenta uma (re)inserção produtiva no conjunto de atividades que integram a base da indústria da reciclagem.

Antes da exposição sobre o processo de trabalho realizado pelos catadores avulsos, elaborada com base nos relatos obtidos junto aos catadores no trabalho de campo, apresentaremos informações disponibilizados por pesquisadas realizadas pela Prefeitura de São Paulo.

Em primeiro lugar, apresentamos informações para demonstrar que muitos dos moradores de albergues e dos moradores de rua são catadores, conforme duas pesquisas realizadas pela Secretaria de Assistência Social. Em segundo lugar, apresentamos informações de uma pesquisa realizada pela Secretaria Municipal do Trabalho, na qual foram aplicados questionários junto a 500 catadores. Esta última demonstrou, entre outros aspectos, que a maior parte destes trabalhadores já tiveram uma profissão, com inserção no mercado de trabalho formal.

No primeiro caso, a pesquisa Estimativa do Número de Pessoas em Situação de Rua da Cidade de São Paulo, realizada em 2003 pela Secretaria Municipal de Assistência Social, com execução da FIPE, ${ }^{78}$ demonstrou que em 23\% dos 2.223 "pontos de pernoite" de pessoas em situação de rua havia a presença de carrinhos (carroças) de catadores. Segundo o relatório desta pesquisa:

A estimativa do número de carrinhos de catação presentes entre as pessoas das rua foi preocupação explícita de SAS, haja vista a

\footnotetext{
78 PREFEITURA DE SÃO PAULO. Estimativa do Número de Pessoas em Situação de Rua da Cidade de São Paulo. SAS/FIPE, 2003.
} 
importância dessa atividade para a obtenção de renda monetária para esta população. Uma das demandas localizadas pelas pessoas de rua, que são catadores, é a possibilidade de guardar seus carrinhos (ou carroças) nos albergues, possibilitando a guarda desse instrumento de trabalho durante o pernoite. (SAS/FIPE, 2003:29-30)

A referida pesquisa também abrangeu os moradores de albergues. Pôde-se observar a presença de catadores dentre os 3963 albergados pesquisados, inclusive com informações sobre os principais materiais coletados pelos mesmos:

As pessoas albergadas também são catadores, usuários de carrinhos de catação. Estima-se que pelo menos $31,3 \%$ dos albergados sejam catadores de sucata Os produtos mais procurados pelos catadores são a latinha $(85,8 \%)$ e o papelão $(52,0 \%)$. Pelo menos $21,7 \%$ dos que catam utilizam carrinho, desses, $60,7 \%$ não são proprietários dos carrinhos. (SAS/FIPE, 2003:43-43)

No Quadro 01 a seguir, estão apresentadas as atividades remuneradas exercidas pelos moradores de albergues. A atividade de biscateiro, juntamente com a de coleta de sucata, representa cerca de $50 \%$ dos casos:

QUADRO 01 Atividade remunerada exercida na última semana (respostas múltiplas)

\begin{tabular}{l|r|c}
\hline Atividade & Freqüência & \multicolumn{1}{c}{$\%$} \\
\hline exerceu atividades remuneradas & $\mathbf{3 6 9 6}$ & $\mathbf{1 0 0}$ \\
\hline Biscateiro/coleta sucata & 1938 & 52,4 \\
\hline Trabalhadores de serviços/comércio & 714 & 19,3 \\
\hline Construção civil & 372 & 10,1 \\
\hline Frente de trabalho & 263 & 7,1 \\
\hline Artesão & 97 & 2,6 \\
\hline Empregado Doméstico & 80 & 2,2 \\
\hline Outros & 232 & 6,3 \\
\hline
\end{tabular}

Obs. Dos 3696 albergados que alega ter exercido atividade remunerada na última semana, 3.464 declararam o tipo de atividade em resposta múltipla. Fonte: (SAS/FIPE, 2003:29-30)

Entre dezembro de 2005 e janeiro de 2006 a Secretaria Municipal de Assistência e Desenvolvimento Social (SMADS) e FIPE (Fundação Instituto de Pesquisas Econômicas) realizaram outro estudo sobre população de rua, destinado especificamente aos Usuários dos Albergues conveniados com a Prefeitura. Foram entrevistados 631 homens adultos (com 18 anos ou mais), sendo divididos em 205 jovens (18 a 29 anos), 229 adultos (30 a 54 anos) e 197 adultos mais idosos (com 55 anos ou mais), encontrados em 22 albergues. 
Em relação ao exercício de atividades de trabalho, esta pesquisa apontou que $74 \%$ dos albergados trabalhavam. Destes, $69 \%$ realizavam trabalho informal, e apenas $5 \%$ tinham carteira assinada. A pesquisa identificou ainda que $36 \%$ dos albergados eram catadores de materiais recicláveis, também inseridos no universo do trabalho informal.

Observa-se que em relação à pesquisa anterior houve uma redução da porcentagem de catadores, de $52,4 \%$ para $36 \%$. Mas, devemos considerar que na primeira pesquisa (2003), a atividade "coleta de sucata" encontra-se junto com a atividade de "biscateiro". Portanto, é possível relativizar a redução que aparece quando comparamos os dados das duas pesquisas, em relação ao número de moradores de albergues que são catadores.

Outra pesquisa foi realizada pela Secretaria Municipal do Trabalho em 2005, com a proposta de identificar o perfil dos carroceiros em São Paulo. Para a realização da pesquisa foram aplicados questionários junto a 500 catadores, divididos entre algumas Sub-Prefeituras, conforme exposto no Quadro 02 apresentado a seguir:

\section{QUADRO 02}

\begin{tabular}{|l|r|r|}
\hline APLICAÇÃO DAS PESQUISAS & No. & $\%$ \\
\hline CACHOEIRINHA & 38 & $8 \%$ \\
\hline CENTRO & 166 & $32 \%$ \\
\hline IRIRANGA & 21 & $4 \%$ \\
\hline JAGUARÉ & 11 & $2 \%$ \\
\hline LAPA & 28 & $6 \%$ \\
\hline MOOCA & 144 & $29 \%$ \\
\hline PINHEIROS & 39 & $8 \%$ \\
\hline STO. AMARO & 39 & $8 \%$ \\
\hline VILA MARIANA & 10 & $2 \%$ \\
\hline VAZIAS & 4 & $1 \%$ \\
\hline
\end{tabular}

Fonte: SMTrab (2005).

Dentre os 500 catadores entrevistados, $90 \%$ eram homens e apenas $10 \%$ mulheres. De fato, esta é a tendência observada em diversas pesquisas sobre a atividade da catação, sendo esta a situação encontrada na pesquisa de campo que realizamos.

Quanto ao local de moradia, 55\% dos catadores declararam residir em domicílio residencial (casa), 37\% em albergues, $5 \%$ em pensão, 2\% no próprio local de trabalho. Ou seja, a associação que comumente é feita entre catadores e 
moradores de rua deve ser relativizada. Embora quase $40 \%$ dos catadores entrevistados pela pesquisa da Secretaria Municipal do Trabalho seja de albergados - o que não deixa de ser muito representativo - mais da metade deles eram domiciliados. Esta informação aponta para ao menos dois aspectos: primeiro, que estes catadores apresentam algum nível de inserção social (possuem endereço, alguma privacidade, provavelmente uma família, entre outros aspectos) que permite aos mesmos não se caracterizarem como população de rua. Segundo, podemos inferir que a atividade da catação, em maior ou menor grau, oferece a este catador a condição (ainda que mínima) de morar num domicílio. No trabalho de campo que realizamos, os catadores do Itaim eram todos domiciliados. Os catadores do centro que eram domiciliados, predominantemente, passavam a semana no centro e retornavam para casa, fora do centro, no final de semana. Outros moravam na "periferia do centro", a exemplo dos moradores da Baixada do Glicério.

Outra informações levantada pela SMTrab foi em relação à idade. A pesquisa demonstra que os catadores são predominantemente maiores de 40 anos, conforme apresentado no Quadro 03 a seguir:

\section{QUADRO 03}

\begin{tabular}{|c|r|r|}
\hline IDADE & anos & $\%$ \\
\hline 15 A 18 ANOS & 22 & $4 \%$ \\
\hline 19 A 25 ANOS & 36 & $7 \%$ \\
\hline 26 A 30 ANOS & 47 & $9 \%$ \\
\hline 31 A 40 ANOS & 132 & $27 \%$ \\
\hline 41 A 55 ANOS & 236 & $48 \%$ \\
\hline ACIMA DE 56 & 27 & $5 \%$ \\
\hline \multicolumn{2}{|c|}{ Fonte: SMTrab (2005) }
\end{tabular}

Como podemos observar, estes catadores adultos, não-jovens (maiores de 30 anos) representam $80 \%$ dos entrevistados. Um quadro crítico, pois sugere justamente que estes trabalhadores adultos não encontram mais outra oportunidade de trabalho que não seja a catação. Esta foi também a situação predominantemente encontra nas entrevistas que realizamos. O que, por sua vez, expressa de modo cabal, o consumo da energia vital destes trabalhadores, os quais, apesar da idade não jovem, aparentam ser mais velhos do que de fato são, em função do desgaste ao qual são submetidos no cotidiano do trabalho nas ruas. 
Outra informação que também revela o quanto estes catadores se caracterizam como trabalhadores sobrantes, com restrições à inserção em outras atividades que exigem maiores qualificações profissionais, diz respeito à escolaridade. Quanto a esta informação, 57\% possuem o Ensino Fundamental incompleto, sendo que $19 \%$ têm apenas os anos iniciais de alfabetização e ainda $13 \%$ são analfabetos:

QUADRO 04

\begin{tabular}{|l|r|r|}
\hline ESCOLARIDADE & No. & $\%$ \\
\hline $1^{\circ}$ A $3^{\circ}$ & 92 & $19 \%$ \\
\hline $4^{\circ}$ A $5^{\circ}$ & 122 & $25 \%$ \\
\hline $6^{\circ}$ A 7 & 52 & $10 \%$ \\
\hline FUND. COMPLETO & 92 & $18 \%$ \\
\hline FUND. INCOMPLETO & 13 & $3 \%$ \\
\hline ANALFABETO & 65 & $13 \%$ \\
\hline NÃO RESPONDERAM & 1 & $0 \%$ \\
\hline ENSINO MÉDIO COMPLETO & 39 & $8 \%$ \\
\hline ENSINO MÉDIO INCOMPLETO & 22 & $4 \%$ \\
\hline ENSINO SUPERIOR COMPLETO & 1 & $0 \%$ \\
\hline ENSINO SUPERIOR INCOMPLETO & 1 & $0 \%$ \\
\hline
\end{tabular}

Fonte: SMTrab (2005)

Por outro lado, quase $100 \%$ dos catadores declararam ter exercido outra atividade antes de ser catador, sendo que 61\% trabalhavam com carteira assinada. Neste sentido, podemos afirmar que estes trabalhadores passaram por um processo de precarização do trabalho.

\section{QUADRO 05}

\begin{tabular}{|l|r|r|}
\hline DE QUE FORMA TRABALHAVA & No. & $\%$ \\
\hline REGISTRADO FORMAL COM CARTEIRA & 290 & $61 \%$ \\
\hline AUTÔNOMO & 72 & $15 \%$ \\
\hline COOPERADO & 4 & $1 \%$ \\
\hline ASSOCIADO & 0 & $0 \%$ \\
\hline INFORMAL & 78 & $16 \%$ \\
\hline FORMAL SEM CARTEIRA & 34 & $7 \%$ \\
\hline
\end{tabular}

Fonte: SMTrab (2005)

Quanto ao último emprego que tiveram antes de se tornarem catadores, a maioria declarou ter trabalhado na construção civil (39\%), seguido pelo comércio (23\%), tanto formal quanto informal. Destacam-se ainda os que trabalharam com limpeza, serviços domésticos e afins (10\%), segurança e porteiro (8\%), motorista e manobrista (4\%), dentre outros diversos (15\%). É neste sentido que afirmamos que os catadores são oriundos dos mais diversos setores. 
Em relação à questão sobre há quanto tempo estes trabalhadores eram catadores, as respostas também nos revelam algo importante. Vejamos:

QUADRO 06

\begin{tabular}{|l|r|r|}
\hline TEMPO DE CATADOR & No. & $\%$ \\
\hline MENOS DE 1 ANO & 41 & $11 \%$ \\
\hline 1 ATÉ 4 ANOS & 166 & $43 \%$ \\
\hline 5 ATÉ 9 ANOS & 98 & $25 \%$ \\
\hline 10 A 20 ANOS & 54 & $14 \%$ \\
\hline MAIS DE 20 ANOS & 19 & $5 \%$ \\
\hline NẤO LEMBRAM & 7 & $2 \%$ \\
\hline \multicolumn{2}{|c|}{ Fonte: SMTrab (2005) }
\end{tabular}

Com base no Quadro 06, podemos observar que a maioria dos entrevistados são catadores a menos de 10 anos (79\%), seguido por cerca de $14 \%$ que exerce esta atividade entre 10 a 20 anos. Ou seja, esta informação está coerente com o fato desta atividade se disseminar amplamente no pós anos 90 , tendo crescido sobretudo nos últimos anos, seguindo a tendência de desenvolvimento da indústria da reciclagem. Por sua vez, como $43 \%$ dos entrevistados são catadores a menos de 4 anos, isto aponta para uma tendência recente de incremento de trabalhadores pobres urbanos nesta atividade, tanto quanto a institucionalização da base. Isto sugere que a base da indústria da reciclagem seguirá, ao menos a longo prazo, apresentando uma característica dual, formal e informal, pois o aumento da produtividade com a organização do trabalho nas cooperativas, não parece comportar o número sempre crescente de catadores avulsos.

Sobre a renda obtida como carroceiro, cerca de 50\% recebiam até $R \$ 15,00$ ao dia, sendo que $28 \%$ declararam receber de $R \$ 6,00$ a $R \$ 10,00$ por dia. Existem ainda aqueles que declararam não saber o quanto ganhavam, ou ainda que recebiam menos de $\mathrm{R} \$ 6,00$ por dia, conforme exposto no Quadro 07 a seguir:

QUADRO 07

\begin{tabular}{|l|r|r|}
\hline QUANTO GANHA POR DIA? & No. & $\%$ \\
\hline $6 \mathrm{~A} 10 \mathrm{R} \$$ & 136 & $28 \%$ \\
\hline $11 \mathrm{~A} 15 \mathrm{R} \$$ & 106 & $21 \%$ \\
\hline $16 \mathrm{~A} 20 \mathrm{R} \$$ & 93 & $18 \%$ \\
\hline $21 \mathrm{~A} 25 \mathrm{R} \$$ & 41 & $8 \%$ \\
\hline 26 OU MAIS & 68 & $13 \%$ \\
\hline NAिO RESPONDERAM & 12 & $2 \%$ \\
\hline OUTROS MENOS QUE 6 R $\$$, & 48 & $10 \%$ \\
RECEBE FIXO, VARIA, NAिO SABE & & \\
\hline
\end{tabular}

Fonte: SMTrab (2005) 
Como já assinalado, este ganho corresponde ao preço dos recicláveis, e não trabalho realizado pelo catador. Se uma menor porcentagem destes catadores conseguem obter um ganho maior, está sobretudo relacionado ao maior volume que conseguem catar e transportar. Para tanto, necessariamente precisam apresentar condições físicas, as quais, por sua vez, são consumidas no transporte dos volumes de materiais. Nas entrevistas que realizamos, os catadores que carregavam cerca de 700 quilos eram jovens e obstinados a carregar o maior volume que seus corpos suportassem.

Por fim, estas informações demonstram a situação de pobreza na qual a grande maioria destes trabalhadores se encontram. Portanto, os catadores são trabalhadores pobres urbanos, que na condição de sobrantes são (re)inseridos produtivamente nas atividades da base da indústria da reciclagem.

Assim, enquanto o setor industria da reciclagem anuncia Índices de Reciclagem crescentes, alcançando bilhões de reais ao ano (cerca de 8 bilhões em 2007, como exposto posteriormente), os catadores de materiais recicláveis inseridos na base desta mesma indústria sobrevivem na mais profunda pobreza.

\subsubsection{O processo de trabalho realizado pelo catador carrinheiro}

O conjunto de atividades - aqui entendido como processo de trabalho realizado pelos catadores carrinheiros está concentrado na primeira etapa do processo de reciclagem, ou seja, na base da indústria. Esta etapa integra, essencialmente, as atividades de catação/coleta, transporte, triagem, prensagem e enfardamento. Os catadores avulsos realizam principalmente a catação/coleta, transporte e triagem.

Os catadores comumente também realizam as etapas de prensagem e enfardamento, cujos equipamentos são de propriedade dos comerciantes e/ou recicladores do ramo, bem como das cooperativas. Neste caso, são catadores que trabalham em relações assalariadas (no caso daqueles que trabalham nos estabelecimentos comerciais, normalmente sob grande exploração) ou ainda em cooperativas. Existem ainda aqueles que trabalham em grupos informais. A pesquisa realizada no Itaim Paulista também contemplou estes dois últimos (cooperados e grupos informais).

Porém aqui serão apresentados elementos referentes ao processo de trabalho realizado pelo catador avulso. Ou seja, o conjunto de atividades 
realizadas pelo catador-carrinheiro, pelo catador com sua carroça, nas atividades iniciais da primeira etapa do processo de reciclagem.

Para este conjunto de atividades, o catador utiliza essencialmente um carrinho, instrumento de trabalho no qual emprega a força do próprio corpo. Estes catadores geralmente levam consigo alguns materiais auxiliares, tais como: martelo, cordas, alicate, capa de chuva, arame, faca/facão, lona ou plástico para proteger os papéis da chuva, à vezes luva.

$\mathrm{Na}$ região central, podemos identificar dois grandes grupos de catadores avulsos. No primeiro deles, estão os catadores moradores de rua. Este catador carrinheiro, maltrapilho, andarilho, identificado por Legaspe em sua pesquisa $^{79}$, é comumente encontrado pelas ruas dos centros urbanos. São geralmente os catadores mais debilitados, muitos dos quais apresentam dependência alcoólica e química, e que devido às suas condições físicas e mesmo emocionais, puxam carroças menores e mais leves (geralmente de madeira), nas quais carregam de tudo o que encontram e que possa ser comercializado junto aos comerciantes do ramo (ferros-velhos, depósitos, reciclagens). No segundo caso, estão os catadores que possuem pontos fixos (estabelecimentos nos quais coletam sistematicamente os resíduos gerados), e geralmente mantém a fidelidade da venda para um determinado comerciante, ou está vinculado a uma cooperativa.

No caso dos catadores que atuam nas periferias, encontramos desde catadores mais debilitados, sobretudo em função de sua idade avançada, quanto catadores que possuem uma rede de pontos fixos. Estes catadores da periferia que aqui correspondem aos catadores do Itaim Paulista - usam carrinhos menores em relação àqueles verificados no centro, coletando também menores volumes. É comum o uso de carrinhos feitos com cascos de geladeira, que pesam em torno de 40 quilos e nos quais carregam em média 130 quilos. Estes catadores consequentemente ganham menos do que os catadores que atuam na região central, pois atuam num território onde os materiais recicláveis são gerados em menor escala. Ademais, nas periferias, os catadores catam/coletam sobretudo os recicláveis oriundos dos resíduos sólidos domiciliares, enquanto na região

\footnotetext{
${ }^{79}$ Encontramos dados surpreendentes que explicavam que a reciclagem do papel no Brasil tinha como principal fornecedor de matéria-prima o catador, este paupérrimo e maltrapilho andarilho da cidade que percorre as ruas coletando de tudo que encontra, conhecido também por carroceiro ou (...). (Legaspe:1996:5)
} 
central os catadores absorvem a geração dos resíduos produzidos principalmente pelos estabelecimentos comerciais e de serviços.

\section{Catadores carrinheiros no Itaim Paulista}

As informações a seguir apresentadas estão pautadas nos aspectos mais gerais dos depoimentos de catadores do Itaim Paulista, integrados no urbano periférico, na periferia distante e consolidada da metrópole de São Paulo.

Para começar, a principal fonte de geração de materiais recicláveis é a domiciliar, composto principalmente por embalagens de produtos alimentícios, formados por plásticos, como o PET, metais constitutivos de latas, papelão das caixas de utilidades domésticas e outras embalagens que constituem 0 denominada material misto, de baixo valor comercial.

Estes catadores percorrem uma vasta extensão territorial, densamente ocupada de forma fragmentada em inúmeras vilas, bairros, favelas, conjuntos habitacionais, entrepostos por centros comerciais secundários ou ainda por pequenos centros comerciais locais. São neles e nos principais eixos viários (nos quais também se estende o comércio), que os comércios de reciclagem se encontram. Para estes locais com atividades de reciclagem convergem os materiais recicláveis coletados pelos catadores que percorrem estes territórios diariamente com carroças (geralmente feitas do "casco" de geladeiras).

Como a principal fonte geradora corresponde aos domicílios, os principais dias de catação são aqueles nos quais o caminhão da prefeitura passa recolhendo o lixo. Assim, para o caso do Itaim Paulista, os catadores percorrem as ruas logo que o dia amanhece, ou na madrugada (após a meia noite), seguindo o horário da coleta convencional. Procuram materiais recicláveis nos sacos ou montes de lixo depositados pelos moradores nas lixeiras ou calçadas. Segundo relato dos próprios catadores, nestes dias a catação fica praticamente limitada ao percurso que deve ser feito antes da passagem do caminhão, sendo que depois deste horário resta muito pouco para a catação. Mas nos demais dias da semana eles também catam, e geralmente fazem duas viagens, uma no período da manhã e outra no período da tarde. Geralmente vendem os materiais recicláveis no mesmo dia, estabelecendo uma prática de fidelidade com 0 depósito que ofereça um preço melhor pelo material, ou quando se estabelece entre o catador e o dono do depósito alguma relação de dependência, como 
manutenção ou "empréstimo" da carroça, recebimento eventual de cesta-básica (às vezes somente no final do ano), ou o que consideram "um bom atendimento". Existem ainda relações que expressam deliberadamente a exploração, como é o caso de alguns depósitos que mantém galões de pinga "à disposição" do catador, para que consumam e "pendurem a conta" a ser descontada no pagamento dos materiais. Já se vê aqui um mecanismo de exploração perversa destes catadores.

Praticamente em toda sua totalidade os catadores residem naquele mesmo território, sendo que muitos moram "de favor" num cômodo à parte na casa de algum parente, o que indica a impossibilidade de pagamento de aluguel. Mesmo quando já possuem casa própria (é o caso de catadores que já tiveram outra condição de trabalho, alguns com profissão e emprego com carteira assinada), o que ganham limita-se às despesas de manutenção com alimentação e outras de primeira necessidade. Ademais, muitos declararam moram nos conjuntos habitacionais da CDHU.

\section{Catadores carrinheiros na região central}

A pesquisa no centro foi realizada em duas áreas: na Baixada do Glicério e nas imediações da Praça da República. num dos baixios de Viaduto (formado pela ligação leste-oeste) na Baixada do Glicério.

De um modo geral, os catadores tem sempre a mesma rotina diária, que permite uma analogia à "jornada de trabalho": por volta das 17:00 horas saem dos locais com atividades de reciclagem ${ }^{80}$ e iniciam seus itinerários de coleta dos materiais recicláveis. Percorrem ruas da Liberdade, Parque Dom Pedro, Sé, República, Santa Cecília, Consolação, Bela Vista, entre outros Fazem uma única viagem com carrinhos feitos de madeira ou ferro, que pesam desde $80 \mathrm{~kg}$ (exemplo de um carrinho puxado por uma das catadoras entrevistadas) até 200 $\mathrm{kg}$ (a exemplo dos carrinhos de ferro). Fora o peso do próprio carrinho, levam em média 300 kilos de materiais por viagem. Voltam após às 21:00 horas, retornando ao locais com atividades de reciclagem até por volta das 24:00 horas. Após deixarem carrinho e material nos respectivos locais, alguns vão para casa, geralmente em territórios empobrecidos do centro (Baixada do Glicério ou Liberdade), outros permanecem nos referidos locais (onde realizam a triagem).

\footnotetext{
${ }^{80}$ Esta expressão inclui desde os baixios de viadutos, quanto os comércios de recicláveis, além de associações e cooperativas de catadores.
} 
Alguns entrevistados declararam passar a semana no centro (nos estabelecimentos comerciais, normalmente denominados pelos catadores como depósitos, ou sob algum viaduto) e retornar no final de semana para a casa localizada na periferia distante e até outros Municípios, como Guarulhos e Ferraz de Vasconcelos. A justificativa é sempre a mesma: o gasto com transporte é inviável para possam ir e voltar todos os dias.

Na manhã seguinte, retomam o trabalho por volta das 8:00 da manhã, para separação dos materiais coletados (triagem), até o horário de voltarem novamente para as ruas (ou seja, no final da tarde). No caso de grupos e cooperativas visitadas na Baixada do Glicério (sob os viadutos) os diferentes tipos de materiais separados vão sendo guardados em sacos durante toda a semana, até que na sexta-feira seja levado para venda nos depósitos localizados no próprio Glicério. No caso dos comércios, há sempre caçambas dos grandes aparistas ou recicladores, o que para Legaspe (1996) representava a presença do capital industrial nestes comércios.

Os catadores do centro costumam vender os materiais semanalmente ou até quinzenalmente, sendo esta uma forma do dinheiro "render mais", pois se receberem todos os dias, o dinheiro "picado" acaba desaparecendo... Assim, ao conseguirem uma soma relativamente maior de dinheiro no final da semana, conseguem montantes para pagar dívidas, como aluguéis atrasados ou prestações diversas adquiridas com consumo pessoal. Tal economia para destinar uma certa quantia de dinheiro ao aluguel ou prestação de algum bem ou serviço, acaba sendo retirado da manutenção diária com os itens mais básicos para a sobrevivência destas pessoas, como é o caso da alimentação.

Muitos catadores avulsos afirmaram que não valia a pena trocar a "autonomia de trabalhar por conta", principalmente porque sabem o quanto vão ganhar com o trabalho que fizerem, podendo receber à vista ou semanalmente, do que trabalhar numa cooperativa. Outro motivo apontado é que na cooperativa existiam reclamações de que, além de receberem quinzenalmente, havia atrasos nos pagamentos. Outra questão levantada foi quanto às exigências a se cumprir, principalmente a necessidade de separar com maior rigor os materiais vendidos diretamente para a indústria, o que requer mais tempo e disciplina para 0 processo de separação. Os depósitos nos quais vendem os materiais não fazem grandes exigências quanto à separação, pois do jeito que o material chega no 
depósito é encaminhado para os compradores (possíveis atravessadores num patamar acima destes depósitos).

Encontramos catadores carrinheiros que realizam a prática sistemática de retirada do lixo da frente dos estabelecimentos comerciais e de serviços, que constituem seus "pontos fixos". Neste sentido, estes catadores formam uma rede de pontos fixos, com os quais definem seu percurso de coleta, instaurando um território próprio. Estes catadores, geralmente mais jovens e com melhores condições físicas, fazem uso de carroças maiores, mais reforçadas e pesadas, a exemplo das carroças com estrutura de ferro. Estas carroças chegam a medir 5 metros de comprimento, pesam em torno de 200 quilos (ou 120 quilos no caso de carroças menores usadas por mulheres), nas quais podem carregar até 1 tonelada de materiais recicláveis. Geralmente transportam verdadeiras "montanhas" de sacos de lixo, material que será triado no depósito ou em locais como baixos de viadutos, localizados no urbano periférico. Neste último caso, o catador transporta lixo misturado aos recicláveis. Por um lado, o catador livra o estabelecimento comercial do lixo depositado em sua calçada (geralmente em quantidade maior do que o recolhido pela coleta da Prefeitura). Por outro, este mesmo catador garante uma fonte certa para obtenção dos resíduos (os referidos pontos fixos), e a grande quantidade coletada e transportada acaba compensando a porcentagem de recicláveis obtidos em relação ao rejeito (lixo propriamente dito). Já o catador morador de rua que percorre as ruas em busca dos materiais que possa encontrar, tendo ou não pontos fixos para coleta, relata não querer transportar "lixo". Estes catadores procuram selecionar os materiais (realizar a triagem) nas próprias calçadas, antes de serem transportados. Este procedimento é reprovado pelos comerciantes, o que intensifica a condição de "andarilho" destes catadores que acabam não estabelecendo pontos fixos. Portanto, seus territórios são menos delimitados do que aqueles dos catadores que estabelecem pontos fixos. Porém, não significa que estes territórios estejam apartados. Ao contrário, estão sobrepostos no mesmo espaço. A pesquisa evidenciou que, enquanto os catadores de sacos de lixo ${ }^{81}$ precisam se deter nos pontos fixos para não perdê-los, os catadores sem pontos fixos (geralmente moradores de rua)

\footnotetext{
${ }^{81}$ Os sacos de lixo dos estabelecimentos comerciais e de serviços contém geralmente papéis brancos, copos plásticos e rejeito (inclusive papel higiênico, também comercializado, quando "separada as partes limpas"...), o que se caracteriza como uma estratégia dos estabelecimentos para se livrar do lixo que excede o volume coletado pela Prefeitura, que é de $50 \mathrm{Kg}$.
} 
buscam outros tipos de materiais também fartos pelas ruas do centro, tais como papelões, latinhas e garrafas.

Pode-se ainda identificar uma questão de gênero na divisão das atividades inscritas na base da indústria da reciclagem. De um modo geral, os catadores carrinheiros são em sua grande maioria homens, enquanto as catadoras se concentram nos locais com atividades da reciclagem, principalmente para a atividade da triagem. Isto pode ser observado na divisão do trabalho nas cooperativas. E mesmo nas modalidades de comércios de recicláveis (depósitos e reciclagens), onde os homens realizam as atividades da coleta, ou catação, transporte e prensagem, enquanto as mulheres realizam principalmente a triagem dos materiais recolhidos pelos homens. Trata-se de uma divisão de gênero determinada pelas características de cada atividade integrante deste processo de trabalho. Enquanto a coleta/catação pressupõe 0 transporte com grande dispêndio de força de trabalho, atribuída principalmente aos homens, a triagem dos materiais recicláveis se caracteriza como uma atividade mais minuciosa e cuidadosa, cabendo normalmente às mulheres.

\section{O chão dos catadores no urbano periférico: relação centro-periferia}

O urbano periférico, entendido como presente no centro e na periferia, é próprio do Nível Misto, especificamente urbano (Lefebvre, 1999). Por sua vez, não corresponde à posição geográfica periférica existente na relação centroperiferia, mas à condição inserção dos trabalhadores pobres sobrantes no urbano. O que não significa prescindir da diferenciação espacial e da situação geográfica que determinam as condições de formação dos territórios de uso (Seabra, 2003), neste caso, o chão dos catadores. Estes sim qualitativamente diferentes em função de estarem na periferia distante ou no centro. Exatamente porque estes territórios são instaurados na articulação dos três níveis do urbano, resultando em diferentes combinações.

Façamos aqui uma breve comparação: os catadores da região central usam predominantemente carroças de ferro, ou madeira, que pesam cerca de 200 quilos, nas quais transportam uma média de 300 quilos de materiais recicláveis, podendo chegar ao dobro ou mais (conforme relatos de catadores que carregam 700 quilos numa única viagem), numa "jornada de trabalho" que oscila entre 7 a 16 horas, pelas quais recebem predominantemente de $\mathrm{R} \$ 20,00$ a $\mathrm{R} \$ 40,00$ por dia 
(os catadores moradores de rua foram os que declararam os menores rendimentos). Os catadores do Itaim Paulista usam freqüentemente carroças feitas de "casco de geladeira" que pesam 40 quilos, nas quais carregam em média 130 quilos de materiais recicláveis (podendo ser bem menos, a exemplo de catadores mais idosos que carregam apenas 70 quilos), numa "jornada de trabalho" de 7 a 12 horas, recebendo de $\mathrm{R} \$ 10,00$ a $\mathrm{R} \$ 20,00$ por dia.

Observa-se assim, algumas diferenciações que envolvem as atividades realizadas pelos catadores em relação à sua inserção no centro ou na periferia. Em primeiro lugar, os catadores do Itaim Paulista ganham menos porque coletam, transportam e vendem menos quilos de materiais do que os catadores do centro. Isto aparentemente pode comprometer sua sobrevivência diária, já que ganhando menos ele está sob a condição de ter que gastar menos com requisitos básicos, como a alimentação. Mas, contraditoriamente, o fato de carregar menos peso o preserva de um maior desgaste do próprio corpo, ao contrário dos catadores do centro, com suas enormes e pesadas carroças, acrescidas de montanhas de resíduos. Em segundo lugar, ao contrário de uma parte dos catadores do centro, que mesmo quando são domiciliados retornam para casa somente no final de semana, os catadores do Itaim moram num domicilio para o qual retornam diariamente após o "dia de trabalho". Não raro, declararam morar na casa de algum parente, ou ainda em Conjunto Habitacional (CDHU). Não significa que estejam em condições melhores do que os catadores do centro, pois os catadores do Itaim vivem o cotidiano da própria periferia, com toda sua negatividade. Se por um lado contam com a solidariedade reinante entre os pobres (ganha-se menos para comer, mas também sempre há um parente, um conhecido que the arrume "o de comer"), por outro não experimentam as possibilidades que a centralidade oferece, inclusive de uma apropriação simbólica daquilo que é o próprio centro. Mas nisto se inclui o que há de melhor (a possibilidade de fazer outros "bicos", um carreto, ganhar um "agrado" de algum comerciante), mas também o que há de pior. Justamente, porque os catadores do centro estão aí incluídos sobretudo naquilo que é a sua negatividade: a violência, o poder de polícia, o preconceito, o tráfico, a luta acirrada pelo território. Porque se é certo que na periferia propriamente dita a própria segregação potencializa a violência, no centro é a própria centralidade que a potencializa, onde "positivo-negativo" ficam em conflito. Se na periferia o catador está, por assim dizer, no seu lugar, no centro o catador precisa lutar para nele se inserir e permanecer. E de modo a voltar vivo para 
casa, quando localizada na periferia, no final de semana. Se no Itaim encontramos mais catadores idosos do que no centro, parece que o fato está diretamente relacionado ao grau de dificuldade com que um idoso consegue entrar e permanecer no chão dos catadores. Neste sentido, a catação para o idoso na periferia "vai devagar e sempre", conforme relata um dos entrevistados, e no centro este "ir devagar e sempre" condenaria a própria inserção produtiva deste catador! Mesmo porque, dada a concentração territorial da geração de resíduos no centro, o chão dos catadores é também mais denso, em todos os aspectos. Se os resíduos são gerados de forma concentrada, também há mais catadores concentrados num mesmo território, o que aumenta a concorrência e a luta para nele se manter.

Podemos acrescentar diversas outras comparações, mas já se vê que em ambos os casos, no centro e na periferia propriamente ditos, o chão dos catadores está sob o domínio do urbano periférico. Mesmo que seja muito evidente a diferenciação qualitativa destes territórios, observadas pelas próprias características do processo de trabalho realizado no centro ou na periferia propriamente ditos. Portanto, seja no centro ou na periferia, o catador avulso, dito autônomo, "liberto" de qualquer vínculo que não seja aquele de catar, separar, transportar e vender para o primeiro "atravessador", é entendido nesta pesquisa como trabalho consumido produtivamente, na primeira etapa do processo de reciclagem. Assim, embora exista uma diferenciação espacial, em ambos os casos os catadores são (re)inseridos produtivamente no conjunto de atividades que integram a base da indústria da reciclagem. Para esta, é indiferente a particularidade do catador - se está no centro ou na periferia, pois todos tomam a forma indiferenciada de dispêndio de força de trabalho, consumida na produção das matérias-primas oriundos dos materiais recicláveis.

Vejamos que em todas as atividades enunciadas há dispêndio de força física. O dispêndio da força física é mais do que evidente na tração das carroças, nas quais o catador emprega seu próprio corpo. Conforme estes trabalhadores envelhecem, vão perdendo esta capacidade, consumida no conjunto de atividades da reciclagem, com destaque para a tração das carroças. Durante a pesquisa de campo, ficou muito evidente a deterioração destes trabalhadores. A declaração de suas idades nos causa surpresa e indignação, pois geralmente aparentam ser mais velhos do que realmente são. De fato, trata-se de um processo de trabalho que consome estes trabalhadores. A perspectiva de uma 
velhice amparada, parece sucumbir pela tragédia da total falta de direitos trabalhistas $^{82}$. Ainda desolador foram os depoimentos de catadores que evidenciaram a preocupação de que continuariam na catação "enquanto o corpo ajudasse".

Além da força física, há também dispêndio do intelecto, pois o catador precisa conhecer minimamente os diferentes tipos de materiais, requisito indispensável para a triagem e venda dos mesmos. Também uma certa logística espacial para definir seu trajeto de coleta/catação, e temporal para ajustar seu percurso aos horários em que os resíduos são dispostos nas ruas. Conduzir sua carroça em meio ao tráfego de veículos, acondicionar os materiais para maximizar o volume possível de ser transportado numa carroça, equilibrando-os numa montanha de sacos; conhecer a topografia das ruas por onde anda, identificando ladeiras pelas quais possa descer quando os carrinhos estejam cheios, são mais alguns aspectos que caracterizam o processo de trabalho realizado pelos catadores. E com base na realização deste conjunto de atividades vão sendo definidos seus territórios de uso, os quais denominados de chão dos catadores.

Resta ainda uma pergunta que não quer calar: por que não fizemos este percurso antes? Por que não iniciamos a investigação pelo catador despojado de qualquer instituição, pelo simples catador avulso, carrinheiro? Será que fomos também "seduzidos" pelos discursos que envolvem este complexo setor? Talvez... Mas como poderíamos nos aproximar do mais elementar - o catador avulso - sem compreender seu lugar nesta indústria que sobre ele se ergue? Ainda que este procedimento pudesse comprometer justamente a compreensão de quem ele era, este foi o caminho que encontramos para compreender a totalidade do processo. E para superar o catador enquanto abstração... Por isso tantas perguntas antes de vê-lo de frente!

\footnotetext{
${ }^{82}$ Barelli (2003:14) ao abordar as conseqüências da reestruturação produtiva destaca justamente a situação dos mais idosos: (...) Os mais idosos têm mais dificuldades. Isso aparece claramente quando verificamos o porcentual de desempregados com quarenta anos e mais. Em 1985, correspondia a $11 \%$ dos desempregados. Em 2001, era de 20,4\%, tornado esse grupo aquele que teve maior crescimento no número de sem emprego. Perder o emprego para o idoso passa a ser trágico, se ele ainda não contar tempo para a aposentadoria. (Barelli, 2003:14) Grifo nosso.
} 


\section{CAPÍTULO III \\ TERCEIRO SETOR NO CONTEXTO DAS POLÍTICAS NEO-LIBERAIS}

A consolidação do Terceiro Setor, ou das entidades da sociedade civil organizada, na plataforma de reformas prescritas pelas políticas neo-liberais pós anos 70 - período no qual se configura o quadro de reformas do Estado e de reestruturação produtiva - é aqui compreendida como parte constitutiva de uma mudança estrutural da sociedade em curso. Portanto, não se trata apenas de uma mudança conjuntural, pois a atuação das ONG's converge para aquilo que Harvey (2005) nos explica sobre as formas pelas quais o Estado exerce o poder, para além do aparato governamental propriamente dito ${ }^{83}$.

Neste sentido, a fragmentação das instituições - a exemplo do que possa ser a miríade de ONG's parceiras do Estado - parece coerente com a necessidade de gerenciar os desequilíbrios entre riqueza e pobreza, ou entre dominantes e dominados, inerentes ao sistema capitalista de produção ${ }^{84}$.

Ao processo de recuo do Estado em relação ao atendimento das demandas sociais, e ao concomitante incremento da massa de trabalhadores sobrantes que resulta da reestruturação produtiva, abre-se o campo de atuação do Terceiro Setor. Atuam no diversificado e amplo espectro das demandas sociais, destacando-se a execução de Projetos na vertente das chamadas políticas públicas de "geração de trabalho e renda", que tiveram maior repercussão a partir da década de 90. A este respeito, devemos deste já assinalarmos alguns pontos importantes sobre o Terceiro Setor, e de modo particular sobre o Terceiro Setor da indústria da reciclagem.

O Terceiro Setor da indústria da reciclagem, para além de atuar em projetos destinados à "inclusão social com geração de trabalho e renda", também faz frente às questões de ordem ambiental (estritamente vinculadas às questões

\footnotetext{
${ }^{83}$ HARVEY, David. A produção capitalista da casa. São Paulo: Annablume, 2005.

84 (...) De fato, o Estado deveria ser visto, como o capital, como uma relação (...) ou como um processo: nesse caso, um processo de exercício de poder por meio de determinados arranjos institucionais.(...) o Estado é muito mais do que o exercício do poder por um governo, tendo de incluir todas as possibilidades pelas quais o poder pode ser exercido. (...) Muitos desses aspectos talvez sejam inteiramente conjunturais, mas o efeito líquido da fragmentação das instituições é, provavelmente, facilitar a obtenção da "formação e superação dos equilíbrios instáveis" entre frações do capital e entre o dominante e os dominados. (Harvey, 2005:88;90)
} 
econômicas), como é próprio das questões relativas ao gerenciamento dos resíduos sólidos urbanos.

Outro ponto a destacar diz respeito à atuação do Terceiro Setor de modo generalizado, que se faz presente nos interstícios da sociedade em curso, desde a difusão da educação ambiental aos novos arranjos produtivos, atuando comumente sob o modelo das Parcerias Público-Privadas - PPP's, as quais expressam justamente a presença-ausente do Estado.

Ou seja, o Estado continua presente na atuação das entidades do Terceiro Setor, haja vista as inúmeras parcerias estabelecidas entre as duas esferas, invariavelmente com financiamento público, podendo ainda contar com investimentos privados. Desta forma, a arena do denominado "setor público nãogovernamental" deve ser compreendida como uma das formas pela qual o Estado capitalista vêm desempenhando suas funções no contexto das políticas neoliberais, no sentido de "organizar a produção material e a vida cotidiana" (Harvey, 2005: 93 $)^{85}$, ao mesmo tempo em que ocorre a mercantilização das funções do Estado. É neste sentido que a pobreza se torna a nova mercadoria, negociada principalmente nos projetos que anunciam sua superação por meio de Projetos executados por Parcerias Público-Privadas para geração de trabalho e renda.

Neste contexto, a pesquisa desenvolvida nesta Tese ressalta a atuação dos agentes sociais do Terceiro Setor que atuam diretamente no processo de estruturação desta indústria. Neste sentido, correspondem ao Terceiro Setor da indústria da reciclagem. Buscou-se a relação e a distinção entre os discursos e as ações destes agentes na institucionalização da base industrial, em processo de estruturação. Os discursos, que ornamentam as práticas, difundem os aspectos ideológicos envolvidos na reciclagem. Seja no âmbito da educação ambiental, que convoca toda a sociedade a participar da prática da reciclagem, seja no âmbito da Responsabilidade Social Empresarial, que nela encontra um

${ }^{85}$ Com o amadurecimento do capitalismo, e depois da criação de todas as instituições estatais necessárias, da redação das leis, das interpretações da lei estabelecidas por precedentes jurisprudenciais, a questão do Estado pareceu se desvanecer num segundo plano (...). De fato, talvez haja um movimento na direção da privatização das funções públicas. (...) Simplesmente, corresponde à insistência de que se deve permitir que certas funções do mercado funcionem com liberdade. (...) É bem possível que o Estado tenha mudado suas funções com o crescimento e $o$ amadurecimento do capitalismo. No entanto, a noção de que o capitalismo alguma vez funcionou sem o envolvimento estreito e firme do Estado é um mito que merece ser corrigido. (...) De um modo ou outro, o Estado capitalista precisa desempenhar suas funções básicas. Se não conseguir fazer isso, então esse Estado deve ou ser reformado, ou então o capitalismo deve dar lugar a algum outro método de organizar a produção material e a vida cotidiana. (Harvey, 2005:92;93) 
campo fértil para seus Projetos (justamente porque respondem ao "tripé" que envolve o social, o econômico e o ambiental).

Organizou-se um sub-capítulo que traz uma revisão bibliográfica que discute esta tema. Esta revisão foi organizada em eixos temáticos diretamente relacionados aos propósitos da Tese.

\subsection{O Terceiro Setor da indústria da reciclagem}

No processo de estruturação da indústria da reciclagem, mais especificamente na institucionalização da sua base, diversos agentes sociais são mobilizados, articulando esfera pública, setor privado e sociedade civil organizada, definindo um Terceiro Setor da indústria da reciclagem.

Antes de mais nada, é preciso destacar que a reciclagem no Brasil, além de se configurar como um novo setor produtivo, também se apresenta como uma questão social. Isto porque esta nova indústria está assentada sobre o trabalho de milhares de trabalhadores pobres urbanos, sobrantes dos mais diversos setores produtivos.

No decurso do processo de estruturação desta indústria, a questão social nele envolvida, a dos catadores, enquanto trabalhadores sobrantes, parece encontrar resolução na proposta de organização dos catadores em cooperativas. Por um lado, as cooperativas de catadores (ou trabalhadores pobres urbanos que se tornam "catadores" ao ingressar nas cooperativas) caracterizam uma válvula de escape à demanda de "geração de trabalho e renda com inclusão social". Por outro, parece oferecer à indústria o modelo ideal para a organização da base de suas cadeias produtivas.

Para tanto, os milhares de catadores avulsos, ou grupos de catadores informais, devem ser devidamente organizados, segundo os requisitos que atendam às exigências da indústria, formando assim um seleto grupo de cooperativas fornecedoras de materiais recicláveis.

Parece evidente que para além dos discursos envolvidos no repertório do "tudo pelo sustentável" (e aqui também cabe o "tudo pelo social") reside a obtenção de maiores lucros, sempre. Não sejamos ingênuos. Mas, não faltam argumentos: a implantação das cooperativas gera trabalho e renda, inclui o catador, transforma-o num agente ambiental... Ou ainda, numa outra vertente, por 
assim dizer, "verde": a reciclagem ajuda a salvar o planeta, enfim, a natureza, o que nos faz lembrar do slogan recente do maior banco privado do Brasil: o banco do planeta...

Ora, o que a institucionalização da base da indústria promove é um ajuste jurídico que mantém velada e cindida a relação capital - trabalho. Porque, afinal de contas, as empresas socialmente corretas investem na implantação das cooperativas, e sobretudo pressionam o governo a faze-lo (ainda que em nome do seu Terceiro Setor), gerando trabalho e renda... indiretos. Ou seja, nos seus Relatórios de Sustentabilidade, os postos de trabalho criados nas cooperativas são perfeitamente contabilizados como "pontos positivos" na carteira de Responsabilidade Social Empresarial. Agora, seriam acaso contabilizados como economia em capital variável, tanto quanto a economia em capital constante que resulta da obtenção destas matérias-primas mais baratas?

Matérias-primas mais baratas (que indica o aumento da taxa de lucro); trabalho não-pago (expropriação, base para formação de capital); atuação em projetos de Responsabilidade Social (aquisição de selos, incentivos/isenções fiscais, "agregação de valor" à marca dos produtos "ecologicamente corretos", válvula de escape da responsabilidade pela geração dos próprios resíduos), e o que mais? E mais o espaço urbano, na presença-ausente da indústria nos locais com atividades da reciclagem, que se encontram nos territórios empobrecidos, territórios de escassez da riqueza produzida, pelo uso dos quais a indústria propriamente dita nada paga...

Neste contexto, a própria pobreza urbana se torna nova mercadoria, vendida nos projetos que anunciam a "geração de trabalho e renda com inclusão social", no contexto das políticas neo-liberais sob o formato das Parcerias PúblicoPrivadas. O papel do Terceiro Setor, em particular o Terceiro Setor da indústria da reciclagem, é o de organizar a base desta indústria, com sua plataforma de ações, relações e mediações. Organizar catadores e seus territórios para institucionalizá-los, tornando mais incisiva (e produtiva) as determinações do próprio capital $^{86}$.

Reinseridos produtivamente na base das cadeias produtivas da indústria da reciclagem, classificada como sub-setor da indústria de

${ }^{86}$ (...) Mas, por fim, só a experiência do trabalhador combinado descobre e mostra onde e como economizar, como efetivar de modo mais simples as descobertas já feitas, quais os obstáculos que precisam ser superados na efetivação da teoria - sua aplicação no processo produtivo - etc. (Marx, O Capital, v.III, tomo I, p.80 
transformação (CNAE/RAIS), os catadores de materiais recicláveis podem ser entendidos como "síntese de múltiplas determinações". Isto é tanto válido para os milhares de catadores que trabalham individualmente, quanto no caso dos catadores que se organizam ou são organizados em grupos, cujo modelo mais ajustado é das cooperativas.

Assim, a indústria da reciclagem se faz presente onde mais aparece como ausente, arregimentando o trabalho sobrante que o próprio processo de reestruturação produtiva vem produzindo no pós anos 70 . Trata-se de uma indústria que se ergue em conformidade com o contexto da reestruturação produtiva que se traduz como um mundo do trabalho em crise, pois é fato que os catadores não são operários. Mas, como já foi dito, eles os correspondem, substituindo-os.

Ou seja, a formação das cooperativas de catadores (ou trabalhadores pobres que não são catadores mas ingressam nesta atividade a partir da formação das cooperativas) atendem à demanda de "geração de trabalho e renda com inclusão social", ao mesmo tempo em que oferece à indústria o modelo ideal para a organização da base de suas cadeias produtivas. Para além de uma iniciativa "socialmente responsável", a indústria obtém fornecedores de matériasprimas de acordo com suas exigências.

Embora os catadores possam ser divididos em grupos com diferentes níveis de organização (desde os moradores de rua que sobrevivem como catadores avulsos até o catador inserido como "agente ambiental" em programas oficiais de coleta seletiva), todos representam demandas sociais de diversas ordens. Estas demandas podem ser divididas em dois grandes eixos.

Num primeiro, estão as políticas públicas assistenciais, destinadas sobretudo à população de rua, no que se insere parte significativa dos catadores, sobretudo nos centros urbanos. Num segundo eixo, estão as políticas empreendedoras para "geração de trabalho e renda", apresentadas como alternativa ao desemprego que atinge principalmente os trabalhadores com baixa qualificação profissional, muitos dos quais se tornam catadores. Frente a este quadro, o empreendedorismo vêm sendo disseminado, principalmente no pós anos 90, através de políticas públicas sob o modelo das Parcerias PúblicoPrivadas, contrapondo-se às políticas assistencialistas e ações filantrópicas que vigoravam até então. 
Estas Parcerias Público-Privadas contam com a atuação das organizações sociais do Terceiro Setor que, no caso do processo de organização da base da indústria da reciclagem, configura um conjunto de entidades que executam projetos em atendimento às demandas sociais, oferecendo os mais diversos serviços e produtos.

Em São Paulo, podemos citar como uma das mais importantes ONG's que atua neste setor o Compromisso Empresarial para a Reciclagem - CEMPRE, mantida por um conjunto de empresas do próprio setor produtivo, interessadas no desenvolvimento da reciclagem. Em seu portal na Internet, o CEMPRE afirma que:

O Compromisso Empresarial para Reciclagem (Cempre) é uma associação sem fins lucrativos dedicada à promoção da reciclagem dentro do conceito de gerenciamento integrado do lixo. Fundado em 1992, o Cempre é mantido por empresas privadas de diversos setores. O Cempre trabalha para conscientizar a sociedade sobre a importância da redução, reutilização $e$ reciclagem de lixo através de publicações, pesquisas técnicas, seminários e bancos de dados. Os programas de conscientização são dirigidos principalmente para formadores de opinião, tais como prefeitos, diretores de empresas, acadêmicos e organizações não-governamentais (ONG's). As empresas associadas ao Cempre são: Alcoa, AmBev, Beiersdorf/Nivea, Cargill, Carrefour, Coca-Cola, Femsa, Gerdau, HP, Johnson \& Johnson, Klabin, Kraft Foods Brasil, Nestlé Waters, Nestlé, Pão de Açúcar, Pepsico do Brasil, Procter \& Gamble, Philips, Sadia, SIG Combibloc, Souza Cruz, Suzano Bahia Sul, Tetra Pak, Unilever Brasil e Wal Mart Brasil.

Algumas de suas ações são: disseminar a reciclagem junto às indústrias; implantar a coleta seletiva nas prefeituras; difundir a educação ambiental nas mais diversas instâncias da sociedade; articular e elaborar propostas e projetos para a criação, ou subsídio, às políticas públicas da reciclagem; dentre outros.

Além do CEMPRE, destaca-se também o Instituto ETHOS de Responsabilidade Social, que atua junto ao setor empresarial na difusão da chamada "Responsabilidade Social Empresarial - RSE".

Uma das vertentes de atuação das empresas no sentido de se enquadrarem como "empresas socialmente responsáveis" é a implantação de Projetos de reciclagem com inclusão social de catadores.

Tanto o CEMPRE quanto o Instituto ETHOS expressam, justamente, a atuação das empresas no direcionamento da estruturação da indústria da 
reciclagem, ajustando as demandas sociais às suas próprias vicissitudes. É o que parece ser o caso das propostas e projetos para formação de cooperativas de catadores.

Dentre as entidades da sociedade civil que se destacam no âmbito da reciclagem podemos citar o Instituto POLIS. Embora não seja uma organização social restrita ao Terceiro Setor da indústria da reciclagem, o POLIS se caracteriza como assessor e consultor de políticas públicas destinadas à "gestão integrada e compartilhada dos resíduos sólidos, com inclusão social dos catadores de materiais recicláveis".

A "gestão integrada e compartilhada dos resíduos sólidos, com inclusão social dos catadores de materiais recicláveis" é, por sua vez, o mote dos Fóruns que reúnem os agentes envolvidos na estruturação desta indústria, com destaque para as organizações sociais do Terceiro Setor. Podemos destacar o Fórum Lixo \& Cidadania, com atuação nos âmbitos nacional, estadual e municipal.

O Fórum Lixo \& Cidadania realiza anualmente o Festival Lixo \& Cidadania. O referido evento acontece em Belo Horizonte, onde se localiza a ASMARE, considerava "modelo de cooperativa" no Brasil. Apresentaremos um breve relato sobre $05^{\circ}$ Festival Lixo \& Cidadania realizado em 2006 (ANEXO 05), bem como a visita à ASMARE (considerada modelo nacional de cooperativa) e à Fábrica de Plástico da rede de cooperativas Cata-Unidos articuladas pela ASMARE, com a mediação de ONG's atuantes em Minas Gerais (ANEXO 06).

Dentre as ONG's que atuam no âmbito da reciclagem, algumas são especializadas na difusão da educação ambiental, na elaboração e desenvolvimento de projetos destinados à implantação da coleta seletiva (em cidades, condomínios, empresas, escolas, entre outros) e, de modo particular, na formação de cooperativa de catadores. Como exemplo, podemos citar o Instituto GEA, cuja atuação se dá por intermédio da execução de projetos financiados principalmente por fundos públicos, a exemplo do Fundo Nacional para o Meio Ambiente - FNMA. A este respeito, veremos como a Cooperativa Fênix-Ágape se tornou o principal "empreendimento fomentado" pelo referido Projeto.

Outras entidades são originalmente vinculadas à filantropia, invariavelmente ligadas às instituições religiosas. Dentre elas podemos citar a Organização de Auxílio Fraterno - OAF, que teve uma atuação central na formação do Movimento Nacional de Catadores de Materiais Recicláveis - 
MNCR, que também conta com financiamentos públicos (Ministério do Desenvolvimento Social e Combate à Fome, entre outros). Como exemplo de Projeto desenvolvido pela $\mathrm{OAF}$ em sua atuação junto ao MNCR, em nível nacional, apresenta-se o Projeto Ações de desenvolvimento social junto aos catadores de materiais recicláveis" (2004-2006), financiado pelo MDS. A exposição deste Projeto será feita em três partes. Na primeira, apresentaremos um quadro geral do Projeto, apontando as entidades envolvidas, os recursos financeiros mobilizados e os principais resultados (definidos como produtos) (ANEXO 07). Na segunda parte, exporemos o relato do Encontro Nacional e Marcha dos Catadores de Materiais Recicláveis em Brasília, realizado em 2006, o qual consistiu numa das etapas de execução do referido Projeto (ANEXO 08). Uma terceira parte e diz respeito à descrição e análise crítica de um dos produtos deste Projeto, o estudo denominado "Análise do custo de geração de postos de trabalho na economia urbana para o segmento dos catadores de materiais recicláveis" (ANEXO 09).

Neste contexto de atuação do Terceiro Setor nas demandas da indústria da reciclagem, existem ainda aquelas ONG's que surgem no próprio processo de organização da base desta indústria, a exemplo do Instituto CataSampa: uma organização social fundada por um grupo de lideranças do MNCR, com recursos da Petrobrás. Este é um exemplo claro de institucionalização dos movimentos sociais em São Paulo. Neste processo, parte das atividades produtivas do MNCR - que por sua vez já havia sido criado no bojo das atividades filantrópicas da Organização de Auxílio Fraterno - deixaram a tutela desta ONG para emancipar-se como um Instituto. Ou seja, uma Organização Social do Terceiro Setor que faz a gestão de uma rede de comercialização comandada pelas cooperativas presididas por lideranças do movimento. Porém, estas lideranças tornam-se cada vez mais envolvidas com os negócios da reciclagem, distanciando-se das demandas do Movimento, as quais permanecem sob a atuação das ONG's. Neste contexto, a Cooperativa Fênix-Ágape tornou-se um dos "pólos de comercialização" da Rede Cata-Sampa, articulando as bases da rede de comercialização em São Paulo (cooperativas, associações, núcleos de reciclagem) com outras situadas no Alto Tietê, organizadas em torno do principal "pólo de comercialização" da Rede, a Cooperativa CRUMA, localizada em Poá.

É emblemático que a institucionalização da base desta indústria encontre correspondência com a institucionalização do movimento social dos 
catadores. Por um lado, os financiamentos permitem aos movimentos um aparato material e logístico (escritórios, computadores, materiais de divulgação, etc.), mas acabam cerceando a ação do próprio movimento social. Isso explica (ao menos em parte) porque o movimento social dos catadores (MNCR) reconhece como parceiros as grandes indústrias ${ }^{87}$ e os bancos ${ }^{88}$ que investem nos projetos do movimento (geralmente via políticas públicas direcionadas à organização da base desta indústria). Ou seja, aqui o Movimento Social parece não reconhecer o capital como o outro do trabalho. Tão logo as empresas que demandam materiais recicláveis (respaldadas pelas esferas governamentais e não-governamentais) anunciem a possibilidade de "inclusão" dos catadores num projeto com investimentos para constituição de cooperativas, a contestação do movimento é gradativamente substituída pela docilidade das parcerias. Sobretudo no campo de ação do movimento social institucionalizado, o qual é impedido de assumir ações mais ousadas, pois é financiado pelo Estado e pelas empresas privadas, e funciona enredado pelas práticas (também enredadas!) do Terceiro Setor. Se alguma rebeldia persiste, ela parece mais propensa entre os catadores com menor grau de organização (a exemplo dos próprios avulsos) que enfrentam o poder de polícia na disciplina do uso dos espaços públicos, das ruas e lixões. Enfrentam esta contradição vivenciada cotidianamente pois, se por um lado são mobilizados pela indústria, por outro são indesejados pelas políticas e setores empresariais ligados aos projetos de revitalização dos centros urbanos, por exemplo. As diversas propostas de designers diferenciados de carrinhos para catadores parecem menos preocupadas com a saúde deste trabalhador do que com a aparência saudável de um "agente ambiental" uniformizado e portando um moderno carrinho...

Se os anos 70 e 80 foram marcados pelo "renascimento do sindicalismo brasileiro" (Barelli, 2003:8) ${ }^{89}$, observemos que a "organização dos catadores de materiais recicláveis" acontece na passagem dos anos 80 para a

\footnotetext{
${ }^{87}$ A exemplo da Petrobrás e da Tetra Pak, entre muitas outras.

88 Tais como Caixa Econômica e Banco do Brasil, através das linhas de financiamento "sustentáveis", geralmente com fundos públicos e cobranças de taxas "solidárias" (de investimentos solidários).

${ }^{89}$ A década de 80 foi de expressivas vitórias do movimento sindical. (...) Exigia-se democracia e ela foi conquistada, chegando-se a uma nova Constituição, em que os direitos dos trabalhadores foram reforçados. (...) Cidade e região com maior quantidade de trabalhadores, São Paulo foi o cenário de muitas concentrações e movimentos do sindicalismo. Não é à toa que as centrais sindicais nela têm suas sedes. Essa é uma característica importante a marcar a cidade - os trabalhadores a escolheram como capital de suas organizações. Não é só o capital que se concentrou na cidade. A mesma opção foi feita pelo trabalho organizado. (Barelli, 2003:8)
} 
década de 90, com plena participação das entidades do Terceiro Setor (da sociedade civil organizada). É emblemático que a instância maior de representação dos catadores - o MNCR, não esteja na esfera do sindicalismo, mas dos novos movimentos sociais diretamente relacionados com a atuação do Terceiro Setor.

\subsubsection{Discursos e ações na institucionalização da base da indústria da reciclagem}

As relações e mediações estratégicas que estruturam a indústria da reciclagem têm sido ditadas por interesses diversos, convergentes e divergentes, cujo consenso reside na obtenção de lucros, mesmo com a plena participação das organizações sem fins lucrativos... Estas, por sua vez, cumprem seu papel na plataforma de reformas pelas quais passa o Estado nas últimas décadas.

Buscou-se desvendar as estratégias que definem os arranjos produtivos que potencializam a expansão desta indústria que vem se estruturando. Numa posição de centralidade, estão os recicladores e indústrias produtoras de mercadorias, interessados na produção e consumo das matériasprimas oriundas da reciclagem. Também instituições bancárias e fundações, que investem recursos em projetos de ONG's especializadas na organização da base desta indústria, pautada na formação de cooperativas de catadores.

Assim, forma-se um mercado que anuncia novas e excelentes oportunidades de negócios ambientais e empreendimentos sociais, cujas mercadorias vão além dos materiais recicláveis transformados em matériasprimas ou novos produtos que ganham o rótulo de ecológicos (papéis recicláveis para dar apenas um exemplo). Instaura-se a possibilidade de novos investimento no próprio setor produtivo, em infra-estrutura (com as novas linhas de processamento) ou logística (consultorias sobre logística reversa, coleta seletiva, etc.), ou ainda na própria organização desta nova divisão do trabalho, com as cooperativas. Já o Terceiro Setor, além de executarem projetos financiados, seja para capacitação dos catadores para este "mercado de trabalho", seja para dar visibilidade e legitimidade aos discursos e às práticas da própria indústria, atua em consonância com as reformas do Estado.

O poder público, principal responsável pela gestão dos resíduos sólidos produzidos no âmbito das municipalidades, bem como pela elaboração de 
políticas públicas nos âmbitos estaduais e nacional, possui papel central nas relações e mediações estratégicas neste contexto. Tanto as empresas de limpeza urbana, quanto os setores industriais interessados na reciclagem, têm se articulado para viabilizar a institucionalização da base industrial. $\mathrm{Na}$ construção destas políticas, o Terceiro Setor têm se apresentado com um papel de destaque, na realização de fóruns e plataformas de discussões, congregando sociedade civil, poder público e iniciativa privada, na elaboração de leis para a gestão dos resíduos sólidos, subsidiando o funcionamento da cadeia produtiva e do mercado de recicláveis.

Das estratégias anteriormente citadas, provém um discurso sobre necessidades e vantagens da reciclagem que passa a dar corpo a um movimento que reúne interesses diversos em diferentes escalas, e que tem nas condições sociais atuais das periferias urbanas, principalmente no desemprego e nos atributos da pobreza, alguns de seus argumentos e justificativas fundamentais.

Neste sentido, fala-se que a gestão dos resíduos sólidos contribui para a não poluição dos recursos hídricos, dos espaços públicos, evitando a ocorrência de enchentes e a proliferação de doenças, principalmente nas periferias urbanas onde o saneamento básico, os serviços públicos e as condições de habitabilidade são menos eficientes. Ou ainda, sobre a inclusão social de um número crescente de desempregados nas atividades da reciclagem. Denominados de "agentes ambientais" (principalmente por empresas, ou governos, que financiam projetos de geração de trabalho e renda com inclusão social). No caso dos catadores que coletam o lixo domiciliar, têm ainda o papel de conscientização da população, ao realizarem a chamada coleta seletiva porta-a-porta, na qual orientam os moradores de cada domicílio a separarem os materiais recicláveis que serão coletados em datas programadas;

Segundo a lógica da sustentabilidade, este trabalhador sem emprego não precisa de caridade, nem das ações arcaicas de status decadente da filantropia. O desempregado agora é um empreendedor, sendo esta uma forma recorrente das propostas de "geração de trabalho e renda com inclusão social". Mas, lembramos aqui do que diz Martins (2002:124): o que a sociedade capitalista propõe hoje aos chamados excluídos está nas formas crescentemente perversas de inclusão, na degradação da pessoa e na desvalorização do trabalho como meio de inserção digna na sociedade. (...) A grande perda que a classe trabalhadora no mundo 
inteiro está sofrendo com essa transformação brutal é a perda ou a atenuação dos direitos conquistados durante mais de cem anos de luta social.

Como antes, este trabalhador pobre, desempregado, vai "livremente" ao mercado de trabalho, e mais "livre" do que nunca nele se lança como um dos mais destemidos dos "autônomos": vai "trabalhar por conta própria", fazer seu próprio horário, seu próprio itinerário, com a força de seu próprio corpo, a qual ele emprega num único instrumento, uma carroça... Mais "livre" do que nunca, sua total emancipação o aguarda numa cooperativa, onde não terá patrão, nem será empregado, dizendo para sempre adeus aos direitos antes conquistados: carteira assinada e salário, tudo segundo leis trabalhistas condenadas à morte, assim como ele.

Desta forma, os catadores "incluídos" se tornam garotos-propaganda de "cases de sucesso" que atestam, inclusive com Selos, e dão visibilidade, através de logomarcas, que o empreendedorismo é uma "oportunidade" no contexto das reformas trabalhistas.

Por outro lado, no repertório que norteia as ações do desenvolvimento sustentável está posta a necessidade premente da reciclagem (em todos os níveis, da inovação tecnológica aos processos de trabalho, de sobra gerando trabalho e renda), frente à iminência catastrófica da falta dos recursos naturais para as "futuras gerações" - de capitalistas... ${ }^{90}$

É o que expõem em seus congressos, cujos discursos encontram ressonância num consenso nunca ensurdecedor... Toda a sociedade: Estado, iniciativa privada, Terceiro Setor, Universidades e todo o "restante" da sociedade (onde se encontra a figura indispensável para todo bom negócio, ou seja, o consumidor, o cliente, seu "público-alvo") deseja a sustentabilidade. E todos querem mostrar que estão aprendendo a lição de que é preciso "amar a natureza": a primeira natureza a ser poupada pelo sacrifício de transfiguração da segunda natureza, ou seja os recicláveis como nova matéria-prima. Segunda natureza até então condenada à morte, descartada como lixo, e que agora ressurge como standard de salvação do planeta. Quem melhor do que os pobres para carregá-lo? Literalmente.

\footnotetext{
${ }^{90}$ Parece que a expressão "gerações futuras" esteja, na verdade, direcionada às futuras gerações de capitalistas. Esta idéia decorre da análise sobre as Apresentações feitas durante o Congresso Sustentável 2007, evento que reuniu empresas, governo e ONG's, etc., em torno para a discussão sobre Sustentabilidade.
} 
Do mesmo modo, não faltam argumentos que subsidiem os discursos das empresas consumidoras desta nova matéria-prima acerca da lucratividade neste setor ${ }^{91}$ :

1) permite ao setor industrial a aquisição de matéria-prima obtida dos materiais recicláveis (quando determinada indústria compra de recicladores material reciclável já processado) ou aquisição dos materiais recicláveis para processamento próprio e fabricação de novos produtos (embalagens, entre outros, como é o caso da Tetra Pak), cujo custo é inferior à obtenção da matériaprima dita original;

2) ausência de trabalhadores assalariados e encargos trabalhistas, e no entanto a existência de uma base com vasto número de trabalhadores - informais, indiretos, terceirizados, autônomos ou, no nosso entender, sobrantes - organizados ou não em cooperativas em torno das atividades da reciclagem (coleta, transporte, triagem, prensagem, pesagem, enfardamento).

3) abatimento de multas ambientais ao participarem de programas e projetos que "promovem" a gestão dos resíduos sólidos, contribuindo portanto com a conscientização e preservação do meio ambiente, tanto em relação ao destino do lixo, quanto evitando o exaurimento das fontes naturais de matérias-primas e energia (a exemplo da reciclagem do plástico que substitui o uso do petróleo na fabricação dos produtos);

4) obtenção de incentivos fiscais ao participarem da promoção de projetos sociais que proporcionem "inclusão social com geração de trabalho e renda", de acordo com o que há de mais moderno no mundo da gestão de negócios sustentáveis. Nisto se insere a norma de Responsabilidade Social Empresarial, ISO 26.000, com aprovação e reconhecimento mundialmente previsto para 2008.

Desta forma, a pesquisa se deparou com curiosos e dissimulados nexos que articulam um contingente de pobres e miseráveis urbanos, identificados como catadores de materiais recicláveis, à uma indústria que se apresenta como limpa, moderna, social e ambientalmente correta. Portanto, de fato é uma indústria que está presente nos dois circuito da economia urbana (Santos, 1979), realizando-se de forma aparentemente autonomizada em direção aos extremos das cadeias produtivas. A relação se realiza pela mediação das trocas comerciais, mas também pela atuação das ONG's (Terceiro Setor) na

\footnotetext{
${ }^{91}$ Ver no livro Os bilhões perdidos no lixo, de Sabetai Calderoni.
} 
formação de cooperativas de catadores, capacitadas para atenderem às demandas exigidas por esta mesma indústria. Ademais, tais iniciativas são representadas como cases de sucesso ${ }^{92}$, e servem de efeito demonstração no mercado da Responsabilidade Social Empresarial (RSE). Esta parece ser uma boa justificativa para os recursos financeiros, públicos e privados injetados nas ONG's, sob a retórica da "geração de trabalho e renda com inclusão social". Mas, como nos diz Martins (2002:136), o capital não tem nenhuma responsabilidade social. O capital não tem moral.

Neste sentido, a indústria situada no topo das cadeias produtivas, anuncia-se como o que há de mais moderno, a exemplo das novas linhas de processamento industrial com Mecanismos de Desenvolvimento Limpo - MDL. Mas, na sua base, o processos de trabalho é completamente insalubre. Por mais que os setores do "marketing verde" das empresas e projetos, públicos e privados, insistam em apresentar imagens agradáveis de cooperativas de catadores, uniformizados e trabalhando com materiais recicláveis coloridos, limpos e já separados do denominado rejeito (lixo) devemos assinalar que estes trabalhadores não estão isentos de trabalhar com os atributos da sujeira: seu odor desagradável, a presença de vetores de doenças (mosquitos, ratos), substâncias tóxicas, risco de ferimento com objetos cortantes, dentre outros. Ainda que o objeto do trabalho do catador seja o material reciclável, emancipado da sua condição pretérita de lixo, não podemos esquecer que o catador não separa apenas os diferentes tipos de materiais. O catador faz antes a separação destes materiais reaproveitáveis daquilo que efetivamente é lixo. Tal situação é agravada para o catador que trabalha na catação nas ruas, muitas vezes retirando os recicláveis das lixeiras residenciais ou de estabelecimentos comerciais, aparecendo como usurpador e inconveniente.

Neste contexto, a investigação se deparou com discursos e ações que justamente dissimulam a exploração inerente à relação capital-trabalho, pela mediação destes projetos articulados às políticas públicas de "gestão dos resíduos sólidos com inclusão social". Ou ainda, em Programas de Coleta Seletiva Solidária, tal como existente no Município de São Paulo. O que, por sua vez, se insere no nível mais amplo das políticas neo-liberais das reformas do

\footnotetext{
92 Expressão utilizada por empresas e entidades do Terceiro Setor na exposição de Projetos que "deram certo", ou seja, os "casos de sucesso" de suas iniciativas de "Responsabilidade Social Empresarial".
} 
Estado, que se propõem "à gestão da pobreza urbana", tema reposto por uma nova linguagem compartilhada em consenso pelas parcerias público-privadas (as chamadas $P P P^{\prime} s^{93}$ ).

É para onde converge boa parte dos discursos e Projetos articulados pelo Terceiro Setor (de modo particular, o Terceiro Setor da reciclagem), o qual, como pudemos observar, tem sido fundamental neste atual período onde se conjugam reestruturação produtiva, reformas do Estado e massificação do desemprego, cujas conseqüências são duramente vividas pelos pobres que sobrevivem no urbano periférico.

Este panorama se configura no atual momento histórico, revelando formas dramáticas de sobrevivência, próprias de uma urbanização crítica (Damiani, 2004) que envolve, direta ou indiretamente, toda a sociedade. Urbanização resultante de um processo de industrialização que só fez aprofundar, sem revolver, as negatividades gestadas no cerne do seu próprio desenvolvimento. É esta sociedade que se vê enredada sob um consenso, que além de universal apresenta-se como inquestionável, imprescindível e definitivo: a necessidade de promover o desenvolvimento sustentável. Retórica que vem sendo muito bem trabalhada pelos setores de "marketing verde" das empresas, com suas práticas correlatas.

Do mesmo modo, observa-se que este conjunto de atividades que os catadores realizam, com extrema precariedade na base industrial, é acompanhado de discursos veiculadores de uma nova racionalidade produtiva, segundo os mais modernos preceitos de sustentabilidade e responsabilidade socioambiental das empresas ${ }^{94}$. E ainda, exatamente por veicularem um discurso fundado em princípios universais, pode-se dizer inquestionáveis (todos querem um "planeta limpo", com uma "indústria limpa"), apropriam-se das condições sociais existentes nos territórios empobrecidos, em frentes de expansão e acumulação de capital que, refazendo o caminho da integração e expropriação dos pobres que nela sobrevivem, ergue-se como modelo de nova indústria, segundo os preceitos da sustentabilidade.

\footnotetext{
${ }^{93}$ Aliás, esta nova linguagem vem repleta de siglas, cujo domínio dos significados parecem definir um "território" semântico destinado aos adeptos da sociedade civil organizada.

94 Não por acaso a questão da reciclagem tem lugar de destaque nos fóruns e ações empreendedoras do Instituto Ethos de Resposabilidade Social que tem como alguns de seus parceiros: PETROBRAS, SUZANO Papel e Celulose, Grupo Pão de Açúcar, FINEP Financiadora de Estudos e Projetos, SEBRAE, CAIXA, Fundação Banco do Brasil, ABONG -
} 
Portanto, conclui-se que o discurso, de um modo geral, ornamenta as práticas; não é em si falso ou verdadeiro. Esta pesquisa procurou as práticas, mas não pôde neglicenciar os discursos, exatamente porque estão sendo justificativos de uma situação real (de certa forma nova) de aprofundamento da divisão do trabalho. Esta, por sua vez, torna-se mais evidente no contexto de institucionalização da base industrial, com a tendência de implantação crescente de cooperativas.

Por fim, como já indicado neste sub-capítulo, nos ANEXOS da Tese estão reunidos relatos de Projetos, Eventos e Empreendimentos, com participação do Terceiro Setor da reciclagem, inscritos no processo de organização da base desta indústria no contexto nacional. Estão novamente aqui assinalados, ressaltando-se a importância na Tese: $5^{\circ}$ Festival Lixo e Cidadania, ocorrido em 2006, na cidade de Belo Horizonte. Este evento é um dos mais importantes no contexto das ações do Terceiro Setor da indústria da reciclagem (ANEXO 05); trabalho de campo na Associação dos Catadores de Papel, Papelão e Materiais Reaproveitáveis - ASMARE (cooperativa modelo); visita às instalações da Fábrica de Plásticos da Rede Cataunidos/Insea, da Região Metropolitana de Belo Horizonte em parceria com a ONG Insea (ANEXOS 06); Projeto Ações de desenvolvimento social junto aos catadores de materiais recicláveis (parceria OAF e MNCR, com financiamento do MDS) (ANEXO 07). Relato do Encontro Nacional e da Marcha do MNCR (Brasília, 2006) (ANEXO 08); apontamentos sobre o documento "Análise do custo de geração de postos de trabalho na economia urbana para o segmento dos catadores de materiais recicláveis" (ANEXO 09). De modo especial, este último Anexo é um importante complemento da análise sobre o processo de institucionalização da base da indústria da reciclagem. Desta forma, recomendamos a leitura do mesmo, bem como dos demais relatos que, embora sejam parte constitutiva da própria Tese, foram inseridos como ANEXOS dada a especificidade de cada um, que conjunto constituem um importante registro documental.

\subsection{O Terceiro Setor no contexto do neo-liberalismo: revisão conceitual}

Associação Brasileira de Organizações não Governamentais, além de Ministérios Federais, entre outros. 
Ainda que não possamos identificar no Brasil a formação de um "Estado do bem-estar social", não podemos negar que também o Estado brasileiro vêm se enquadrando às políticas neo-liberais. Uma de suas conseqüências está na chamada "balcanização" dos serviços sociais públicos, os quais se tornam mercadorias negociadas no setor privado (a exemplo dos serviços básicos como saúde, educação, transporte, saneamento básico, comunicação, habitação...). Ou passam a compor um mercado para atuação do Terceiro Setor, como demandas sociais não atendidas pelo Estado.

Assim, o Estado em reforma incorpora o Terceiro Setor como parte constitutiva de seu aparato estrutural. Em relação a este último aspecto, as Parcerias Público-Privadas que vêm sendo adotadas nas administrações locais estão na base do que Davis (2006), Harvey (2005), Arantes (2004), entre outros, nos explicam a respeito da governança urbana, como veremos mais adiante. Esta, por sua vez, parece indicar muito mais uma nova roupagem para continuidade das condições de concentração da riqueza, do que uma proposta de ruptura.

\subsubsection{O Terceiro Setor como parte constitutiva das reformas do Estado}

Davis $(2006: 71 ; 76)$ em seu livro "Planeta favela", discute as influências dos planos neo-liberais impostos por organismos internacionais, como FMI e Banco Mundial, aos governos do Terceiro Mundo, impondo aos mesmos o que Sevcenko (2007:52) denominou de "submissão incondicional ao neocolonialismo" "95. Ao questionar as imposições contidas nos Planos de Ajuste

95 Duas instituições se tornaram instrumentos decisivos neste processo pelo qual o neoliberalismo impõe aos países do Terceiro Mundo uma submissão incondicional ao neocolonialismo. Esses órgãos são o Fundo Monetário Internacional e o Banco Mundial, ambos criados em 1944 com uma dupla finalidade assistencial: financiar a reconstrução dos países arrasados pela Guerra e apoiar as nações em processo de desenvolvimento ou recém emancipadas da condição colonial. Os países capitalistas europeus e o Japão foram de fato generosamente ajudados. Mas, para os demais, o apoio foi se tornando uma ladeira sem fim, afundando-os cada vez mais em níveis sufocantes de endividamento. Essa situação chegou a um clímax entre o final dos anos 70 e a primeira metade dos 80 , quando, com a crise do petróleo - que multiplicou mais de cinco vezes 0 preço dos combustíveis e forçou altas sem precedentes no valor do dólar e dos juros a serem pagos -, as economias dos países subdesenvolvidos foram fortemente abaladas, mergulhando em crises infracionárias ou se contorcendo em espirais de hiperinflação. Quando recorreram ao FMI e ao BM em busca de socorro urgente, o que receberam, em vez do alívio ao endividamento, foi um grosso pacote de medidas de "reajuste estrutural": cerca de 115 condições 'sine qua non' para a ajuda financeira. Esse receituário impunha medidas, como a desregulamentação da economia, e das finanças, a derrubada das barreiras alfandegárias e comerciais, a drástica redução dos gastos públicos e serviços sociais, a privatização das empresas estatais e a eliminação de garantias e direitos trabalhistas, inclusive com o enfraquecimento dos sindicatos, de modo a permitir 
Estrutural (PAES) às nações endividadas (décadas de 70 e 80), as quais deveriam reforçar seu "papel minimalista" na oferta de moradias populares e redução generalizada dos programas governamentais, 0 autor situa 0 "fenecimento do Estado de bem-estar social", a ser sucedido pelas práticas da chamada "boa governança".

Neste sentido, Davis (2006:79-80) apresenta uma breve periodização que mostra a mudança do enfoque da atuação do Estado, e de modo mais aprofundado, como se altera a sua própria natureza. O exemplo dado se refere à questão habitacional, mas repercute em todos os âmbitos de atuação do Estado, caracterizando-se como uma mudança estrutural. Neste sentido, os governos se aproximam cada vez mais de doadores internacionais e ONG's para se tornarem um Estado "capacitador" dos pobres.

Davis (2006:167) ressalta ainda que o documento "Política urbana e desenvolvimento econômico: uma pauta para a década de 1990", de autoria do Banco Mundial, define o papel do Estado no contexto neo-liberal como um "simples capacitador do mercado"96.

Arantes (2004) em seu artigo "Esquerda e Direita no espelho das ONG's" ${ }^{97}$, explica que as reformas do Estado em nada visam reduzir seu papel coercitivo e garantidor do sucesso dos negócios privados. Porém, o Estado não teria mais o papel de um provedor, mas de um "parceiro facilitador e regulador", ou melhor, um Estado indutor-normativo-regulador-facilitador do mercado. Por sua vez, as demandas sociais aprofundadas pelo crescimento das "populações descartáveis" que resultam da reestruturação produtiva, legitimam "o lugar de um Terceiro Setor gerencialmente enxuto". Justamente frente à crise de legitimidade de um Estado que tem sucateada sua capacidade em oferecer serviços públicos essenciais: aqui o lugar de um Terceiro Setor gerencialmente enxuto. Um Estado parceiro-facilitador deve "estrategicamente" se retirar assim que organizações nãogovernamentais "demonstrarem" a superioridade de suas vantagens comparativas -

demissões em massa e tornar o mercado de mão-de-obra mais barato, mais dócil e mais flexível. Já era o receituário do neoliberalismo se difundindo por todo o mundo. (Sevcenko, 2007:52-53)

96 O Banco Mundial, de sua parte, aplaudiu o desaparecimento do papel do Estado local em "Urban Policy and Economic Development: an Agenda for the 1990s [Política urbana e desenvolvimento econômico: uma pauta para a década de 1990], documento que reconceituou o setor público como simples "capacitador" do mercado. "Com foco central na revalorização dos mecanismos de mercado,(...) as políticas urbanas sólidas são definidas hoje como aquelas que visam eliminar as barreiras que restringiam a produtividade dos agentes econômicos urbanos, formais e informais, de modo a maximizar a sua contribuição à economia nacional',26. (Davis, 2006:167)

${ }_{97}$ Artigo originalmente publicado em meio de 2000, no Cadernos ABONG, №27. 
convenhamos, uma vitória sem muito esforço, já que não havia mais em campo com quem competir, salvo a sucata preparada para tal efeito demonstrativo. (Arantes, 2004:170-171)

Maria da Glória Cohn, em seu livro "Teoria dos Movimentos Sociais: paradigmas clássicos e contemporâneos", de 1997, explica duas tendências que se fortaleceram no cenário social brasileiro nos anos 90 , numa relação direta com a temática dos movimentos sociais: o crescimento das ONGs e as políticas de parcerias implementadas pelo poder público, particularmente no âmbito do poder local. Para a autora, trata-se de um processo de desregulamentação do papel do Estado, com transferência de suas responsabilidades para as "comunidades", sob intermediação das ONG's, viabilizada pelas parcerias entre as esferas pública, pública não-estatal (o Terceiro Setor) e também com a iniciativa privada. (Cohn, 2004:309-310). A autora explica a natureza e a função da denominada esfera pública não-governamental, campo de atuação das ONG no contexto do Estado em reforma: (...) Essa nova concepção [de sociedade civil] construiu uma visão ampliada da relação Estado-sociedade, que reconhece como legítima a existência de um campo ocupado por uma série de instituições situadas entre o mercado e o Estado, exercendo o papel de mediação entre coletivos de indivíduos organizados e as instituições do sistema governamental. (...) No Brasil, esse papel passou a ser desempenhado pelas ONGs, que fazem a mediação entre aqueles coletivos organizados e o sistema de poder governamental, como também entre grupos privados e instituições governamentais. (...) Isso resultou na construção de uma nova esfera, ou subesfera, entre o público e o privado, que é o público não-estatal, e no surgimento de uma ponte de articulação entre estas duas esferas, dada pelas políticas de parceria. (Cohn, 2004:301)

Cohn (2004) discute ainda a proeminência adquirida pelas ONG's na gestão dos recursos públicos, em detrimento das instituições do Estado. A autora argumenta que temas como "a fome" ou "a miséria no mundo" passam a ser objetos de diagnósticos das políticas públicas, pois se caracterizam como problemas para a continuidade do próprio capitalismo. Com muita perspicácia, Cohn (2004: 296) identifica que o atual padrão de desenvolvimento - aqui entendido como o contexto das políticas neo-liberais - legitima a exclusão como forma de integração, ou ainda, como exclusão integradora, segundo um modelo perverso de gestão da crise, que recupera a legitimidade política e cria condições para um novo ciclo de crescimento econômico com a redefinição dos atores sociais e políticos. Digno de nota, também é a explicação que Cohn (2004:297) nos oferece para a transmutação dos movimentos sociais que perdem sua força 
mobilizadora num contexto em que as chamadas políticas integradoras reconhecem apenas organizações institucionalizadas. Daí a força adquirida pelas ONG's, em detrimento dos movimentos sociais tradicionais, junto às políticas de parceria formadas com o poder público.

Como procuramos demonstrar nas passagens anteriores, o Terceiro Setor se tornou parte constitutiva das políticas neo-liberais, aqui analisadas sobretudo em termos das reformas do Estado (em relação ao atendimento das demandas sociais) e da reestruturação produtiva, com destaque para as políticas públicas de "geração de trabalho e renda", comumente arquitetadas sob o modelo das PPP's.

\subsubsection{Governança urbana, empreendedorismo e Parcerias Público-Privadas}

Em "Governabilidade e pobreza no Brasil" (1995), Valladares ao atualizar sua abordagem sobre a questão da "pobreza", afirma que o tema expresso no título do livro suscita, entre outros aspectos, a reflexão sobre a reforma do Estado e sobre as relações entre Estado e sociedade civil. Dentre os objetivos do Seminário que deu origem à coletânea de textos reunida no referido livro $^{98}$ estava a discussão das noções de governabilidade e governança utilizadas como formulações estratégicas de agências como o Banco Mundial - que fala sobretudo de 'governance' no sentido de 'bom governo'. Outro objetivo era propiciar uma discussão específica sobre o que se pode chamar de governabilidade urbana, focalizando os governos municipais e seus esforços recentes para desenvolver uma gestão democrática da cidade, capaz de mobilizar, para a participação no processo de decisão, os diversos segmentos da sociedade civil. (Valladares \& Coelho, 2005:10).

Desta mesma obra, destacamos o texto de Marcus André Mello, numa discussão sobre a governabilidade enquanto categoria da sociologia política gestada na década de 70. Lembra o autor que, tanto aqui quanto no exterior, o debate deslocou-se, em grande medida, da questão do desenvolvimento econômico para as questões relativas à moldura institucional das economias e aos requisitos societais, organizacionais e políticos que permitiriam uma maior

98 "Os textos que integram esta coletânea resultaram de um seminário organizado pelo IUPERJ no âmbito do projeto GURI - corresponde a "Global Urban Research Initiative". (Valladares \& Coelho, 1995:10) 
eficiência do Estado. Na década de 90, as agências multilaterais, dentre as quais o Banco Mundial, passaram a difundir o conceito de governança. Este conceito se distingue do de governabilidade no sentido de que 'enquanto a governabilidade se refere às condições do exercício da autoridade política, governança qualifica 0 modo de uso desta autoridade" ${ }^{\text {"99 }}$ (Mello, 2005:30). O conceito ultrapassa o marco do modus operandi das políticas para englobar questões mais amplas relativas a padrões de coordenação e cooperação entre atores sociais. Embora a noção inclua a necessidade de aperfeiçoamento da capacidade gerencial do Estado, transcende o mero plano institucional, supondo participação e parceria entre o Estado e a sociedade na definição de prioridades, na implementação dos programas e das políticas públicas.

Assim como Mello (2005) distingue governança e governabilidade, Harvey (2005) adverte que "governança" urbana significa muito mais do que "governo" urbano ${ }^{100}$ pois o poder real de reorganização da vida urbana muitas vezes está em outra parte, ou, pelo menos, numa coalizão de forças mais ampla, em que o governo e a administração urbana desempenham apenas papel facilitador e coordenador. O poder de organizar o espaço se origina em um conjunto complexo de forças mobilizado por diversos agentes sociais. (Harvey, 2005:168)

Para Harvey, as transformações econômicas pós década de 70 repercutiram no âmbito do poder local, caracterizando-se como uma mudança "do administrativo urbano ao empreendedorismo"101. Esta mudança seria conseqüência dos problemas advindos das crises econômicas enfrentadas pelos países capitalistas no início da década de 70 , destacando que a desindustrialização, o desemprego disseminado e aparentemente "estrutural" (...), um apelo muito mais forte (...) à racionalidade do mercado e à privatização, representam o pano de fundo para entender por que tantos governos urbanos, muitas vezes de crenças políticas diversas e dotados de poderes legais e políticos muito diferentes, adotaram todos uma direção muito parecida (...).(Harvey, 2005:168)

Harvey (2005:167) explica que a abordagem "administrativa", que vigorou fortemente nos anos 60, foi substituída pelas ações "empreendedoras" nas décadas seguintes. Seguindo esta tendência, observa-se nos anos recentes

\footnotetext{
${ }^{99}$ Grifo nosso.

${ }^{100}$ Grifo nosso.

101 (...) desde o início da década de 1970, a mudança do administrativismo urbano para algum gênero de empreendedorismo continua sendo um tema persistente e recorrente. (...) Há uma concordância geral de que a mudança tenha ver com as dificuldades enfrentadas pelas economias capitalistas a partir da recessão de 1973. (Harvey, 2005:168)
} 
um consenso geral sobre "benefícios positivos obtidos pelas cidades que adotam uma postura empreendedora em relação ao desenvolvimento econômico". De fato, tal consenso se difunde por todas as esferas da sociedade, caracterizando um modo de ser do Estado e da sociedade civil à semelhança da estrutura gerencial das empresas. Para Harvey (2005) o modelo de Parceria PúblicoPrivada constitui o elemento principal do empreendedorismo, caracterizando-se como especulativo e associado à economia política do lugar, em detrimento de melhores condições para o território: em primeiro lugar, o novo empreendedorismo tem, como elemento principal, a noção de "parceria-público-privada", em que a iniciativa tradicional local se integra com o uso dos poderes governamentais locais, buscando e atraindo fontes externas de financiamento, e novos investimentos diretos ou novas fontes de emprego. (...) Em segundo lugar, a atividade da parceria público-privada é empreendedora, pois, na execução e no projeto, é especulativa, e, portanto, sujeita a todos os obstáculos e riscos associados ao desenvolvimento especulativo, ao contrário do desenvolvimento racionalmente planejado e coordenado. Em muitos casos, isto significou que o setor público assumiu o risco, e o setor privado ficou com o benefícios (...). Em terceiro lugar, o empreendedorismo enfoca muito mais a economia política do lugar do que o território. (...) Normalmente, o novo empreendedorismo urbano se apóia na parceria público-privada, enfocando o investimento e o desenvolvimento econômico, por meio da construção especulativa do lugar em vez da melhoria das condições num território específico, enquanto seu objetivo econômico imediato (ainda que não exclusivo). (Harvey, 2005:172-174)

Arantes (2004) analisa as práticas e discursos dos agentes do Terceiro Setor no processo de reforma do Estado. O autor questiona as mudanças recentes na administração pública diretamente vinculadas ao campo de atuação das organizações não-governamentais, cujas parcerias revelam um modelo gerencial, em consonância com a lógica empresarial $^{102}$, a exemplo das políticas públicas fomentadoras do "empreendedorismo". O principal "desafio" para as parcerias entre as diferentes esferas (governamental, não-governamental e privada) reside no campo aberto para projetos e inovações de combate à pobreza, sobretudo frente ao desemprego que, por sua vez, concentra-se em metrópoles como São Paulo. Nos trechos citados a seguir, podemos observar alguns destes questionamentos formulados por Arantes: em princípio, como aliás o próprio nome indica, uma Organização Não-Governamental não pode pensar e agir como uma agência estatal. (...) [Porém] de uns tempos para cá, autoridades governamentais

102 Grifo nosso. 
desandaram a gesticular e arengar como se fossem militantes de uma ONG de todas as ONGs, (...) ocupando (...) postos chaves no aparelho de Estado, sobretudo os diretamente concernidos por uma enteléquia cívica denominada "o social". Ato contínuo, têm se dedicado a lançar "programas" de fortalecimento, e, pelo visto, em promoção (...). Espaços obviamente de "participação", e mais enfaticamente, de "participação cidadã", irrigados por "canais de interlocução", através dos quais governo e a supracitada sociedade civil "aprendem a pensar e agir juntos", constróem plataformas para futuras "parcerias" e novas "interações", conferem "visibilidade" a iniciativas emergentes", promovem a "cidadania ativa". (...) Para quem orbita nesses espaços de alta densidade moral, tudo é "desafio": miséria, violência, fome, desemprego, etc. (...) O maior "desafio", porém, é a "incorporação da cidadania", a "defesa e promoção dos direitos". Reforma do Estado? Administração Pública "gerencial"? Com certeza, desde que "voltada para a cidadania". Quer dizer, mais uma vez, destinada ao fortalecimento de uma "sociedade civil eticamente estruturada". (...) No limite, não há nada que não exija aspas, ou imaginando uma futura organização do pensamento não-governamental - que não deva ser dito como quem cita. (Arantes, 2004:165-166)

Ainda em relação ao empreendedorismo, Harvey (2005) entende que 0 mesmo apresenta coerência com a transição dos sistemas de produção fordista, estando em grande medida relacionado com o trabalho informal. Ou seja, desde o início da década de 1970, não há nada sobre o empreendedorismo urbano que seja antitético à tese relativa à mudança macroeconômica (...). De fato, pode-se afirmar com segurança que as mudanças na política urbana e o movimento rumo ao empreendedorismo têm desempenhado um importante papel facilitador na transição dos sistemas de produção fordista localizacionalmente rígidos. (Harvey, 2005:181).

\subsubsection{A mediação das ONG's nos investimentos destinados às demandas sociais}

Davis (2006: 84) analisa a estrutura montada, no pós anos 90, entre instituições financiadoras internacionais que passaram a se relacionar diretamente com ONG's regionais e comunitárias, em detrimento de parcerias com governos, num "sistema de coordenação e financiamento em camadas". Segundo o autor, uma "revolução das ONG's" teria reconfigurado a "paisagem do 
auxílio ao desenvolvimento urbano", o que teria beneficiado sobretudo as grandes ONG's captadoras dos recursos e não exatamente as comunidades locais ${ }^{103}$.

Ao analisar o processo de constituição das denominadas entidades públicas de direito privado, também denominadas de organizações sociais (OS) ou ainda Organizações da Sociedade Civil de Interesse Público (OSCIP), Arantes (2004:171) afirma que estamos diante de uma inversão dos termos. Ou seja, sob a idéia de publicização - que consistiria na aplicação de investimentos públicos nas organizações sociais, reside um processo de privatização dos serviços públicos. De uma forma contundente e crítica, Arantes (2004) expõe a ironia de que este processo de privatização dificilmente pode ser entendido como tal, pois aparece como ampliação do "espaço de participação cidadã"104.

No contexto dos financiamentos destinados às organizações da sociedade civil na América Latina, Cohn (2004) cita um momento histórico interessante na década de 90, no qual podemos identificar a entrada nas ONG's nas atividades do setor informal, demonstrando sua vertente, por assim dizer, empresarial: (...) nos anos 90, as atenções das agências patrocinadoras de fundos de apoio financeiro e de pessoal para trabalho de base, articuladas às lgrejas, voltaram-se para os processos de redemocratização do Leste Europeu. Os movimentos e as ONGs latinas passaram a viver a mais grave crise econômico-financeira desde que foram criados. Eles também precisaram realizar reengenharias internas e externas para

103 Desde meados da década de 1990, o Banco Mundial, o Pnud e outras instituições de ajuda contornaram ou evitaram progressivamente os governos para trabalhar de forma direta com ONG's regionais e comunitárias. Na verdade, a revolução das ONGs (...) reconfigurou a paisagem do auxílio ao desenvolvimento urbano (...). Enquanto o papel do Estado como intermediário reduzia-se, as grandes instituições internacionais instauraram a sua própria presença na base por meio de ONGs dependentes em milhares de favelas e comunidades urbanas pobres. Tipicamente, um doador-financiador internacional - como o Banco Mundial, o Departamento de Desenvolvimento Internacional do Reino Unido, a Fundação Ford ou a Fundação Friedrich Ebert alemã - trabalha por meio de uma ONG importante, que por sua vez dá consultoria a uma ONG local ou destinatário nativo. Esse sistema de coordenação e financiamento em camadas costuma ser retratado como a última palavra em 'empowerment', "sinergia" e "governança participativa". (...) Embora alguns críticos mais antigos tivessem aclamado essa 'virada participativa' do Banco Mundial, os verdadeiros beneficiados parecem ter sido as grandes ONGs e não o povo local.(Davis, 2006: 84)

${ }_{104}$ (...) Segundo a nomenclatura oficial, organizações sociais resultam da transformação dos serviços públicos em entidades públicas de direito privado que celebram com o Estado um contrato de gestão, cujas atividades são controladas de forma mista pelo Estado (financiamento parcial pelo orçamento público, poder de veto e cooptação nos conselhos de administração) e pelo Mercado (cobrança de serviços prestados pela mão invisível da concorrência entre as entidades). A essa metamorfose, e correspondente simbiose entre poder e dinheiro deu-se o nome de "publicização" (...). Como se trata obviamente de um processo de "publicização" destinado a ampliar ainda mais o "espaço de participação cidadã" com a introdução de novos "atores emergentes" - de cujas "habilidades gerenciais" e "visão estratégica" redundará por certo um bemvindo empowerment ("empoderamento" em espanhol) da "cidadania" numa sociedade de "baixa participação" como a nossa -, não se poderá dizer que se está "privatizando" o que quer que seja. (Arantes, 2004:171) 
sobreviver. Passaram a buscar a auto-suficiência financeira. Tiveram de encontrar/conquistar ou incrementar caminhos no setor de produção. A economia informal - então florescente e estimulada pelo novo modelo de globalização - passou a ser uma das principais saídas. (Cohn, 2004:230)

Além de ingressarem no setor produtivo, as ONG's também passaram por uma reestruturação organizacional destinada às assessorias, consultorias e publicações próprias, configurando um nicho do mercado de trabalho para pesquisadores e técnicos que atuam junto aos movimentos sociais: na década de 90], ONGs que funcionam basicamente como núcleos de pesquisas, como o Instituto Pólis de São Paulo, reestruturam-se em direção a uma organização de assessoria direta e fazem de seu trabalho uma fonte de publicações próprias. Muitos pesquisadores dos movimentos sociais engajam-se neste novo tipo de atividade nas ONGs, trabalhando em projetos atendendo demandas específicas. (Cohn, 2004:80)

\subsubsection{O papel das ONG's na institucionalização dos movimentos sociais}

A complexa relação de financiamento dos movimentos sociais por parte do Estado é analisada por Cohn (2004), assinalando que apesar dos movimentos sociais reivindicarem autonomia em relação ao Estado, na verdade esta independência nunca existiu. Tomando como base o pensamento de Francisco de Oliveira (1994), Cohn explica que no sistema capitalista os fundos públicos são mobilizados tanto para a acumulação do capital, quanto para a reprodução da força de trabalho. No contexto de emergência das ONG's, estas se tornam as principais protagonistas na estruturação de projetos destinados à organização e divisão das tarefas no interior dos movimentos sociais populares que, por sua vez, representam as demandas sociais da classe trabalhadora. Segundo a autora, as ONGs saíram da sombra, deixaram de ser meros suportes técnicos em orientações tidas como 'pedagógicas' e financeiras às lideranças populares, e passaram, elas próprias, a desempenhar os papéis centrais nas ações coletivas. (Cohn, 2004:313; 315)

Segundo Davis (2006:85) as ONG's tiveram um papel central na burocratização e desradicalização dos movimentos sociais urbanos. Isto porque, apesar de anunciarem a democratização e fortalecimento da sociedade civil, 0 autor avalia que as relações de poder no campo de atuação das ONG's não diferem daquelas do clientelismo tradicional. Neste sentido, estas organizações, além de agirem na cooptação de lideranças locais, conquistaram o espaço social tradicionalmente ocupado pela esquerda. 
É Cohn (2004:240) quem novamente nos explica sobre a introdução do chamado "modelo de movimento social norte-americano" no Brasil, ou "movimento-organização", o qual se caracteriza pela constituição de uma base de adeptos e militantes; articulação com a sociedade civil e política por meio de políticas de parceria; envolvimento em projetos sociais operacionais; e política de formação e qualificação de quadros. (Cohn, 2004:240). Segundo esta autora, tal modelo foi aqui introduzido por ONG's internacionais.

No processo de institucionalização dos movimentos sociais, Cohn (2004: 256) reconhece a existência de uma esfera de ação coletiva, que se caracteriza como um espaço não-institucionalizado, nem público, nem privado, mais precisamente um campo político. Ou seja, neste processo de institucionalização, persiste uma ação coletiva fora da esfera das instituições. Disto resulta que muitas vezes um movimento social strictu sensu deixa de ser movimento quando se institucionaliza, quando se torna uma ONG por exemplo, embora possa continuar como parte de um movimento mais amplo, enquanto organização de apoio daquele movimento. (Cohn, 2004:246-247).

Cohn ainda nos fala de duas situações marcantes na relação entre movimento social e ONG. De um lado, para viabilizar e operacionalizar suas pautas e agendas de ação, os movimentos sociais se apoiam em instituições e ONG's. A interatividade e/ou conflito entre ambos pode ser tão profundo que o movimento se transforma numa organização. Por outro lado, é muito freqüente que as relações entre ambos preceda a existência do próprio movimento, e em diversos casos as ONG's acabam por definir o projeto que o movimento construirá em sua trajetória (Cohn, 2004:253-254). Vejamos como a autora descreve a estruturação destes "movimentos-organização", que os insere num enquadramento do tipo empresarial, inclusive realizando processos produtivos que resultam em produtos e empregos no setor informal: (...) Nos anos 90 - por meio das ONGs - [os movimentos sociais] passaram a ter infra-estruturas próprias, a se utilizar mais de recursos tecnológicos como computadores e redes de Internet (em alguns casos). As ações sendo menos de pressão e mais de organização da população, voltadas para algum programa efetivo, necessitam de suportes materiais. Estes suportes são obtidos pelas ONGs por meio de projetos. (...) Para que tenham continuidade, precisam de eficiência. Arma-se portanto um ciclo onde não há tempo a se gastar com mobilizações por demandas não atendidas. (...) Ou seja, a movimentação da rede social passou a girar em torno do fazer, do movimentar processos de produção que gerem produtos ou empregos, na economia informal. (Cohn, 2004:315) 


\subsubsection{Discursos ideológicos da Responsabilidade Social Empresarial}

Harvey nos diz que o Estado, enquanto instrumento de dominação de classe, apresenta a seguinte contradição: a classe dirigente exerce o poder em seu próprio interesse, enquanto afirma que suas ações são para o bem de todos. Para resolver esta contradição são usadas duas estratégias. Na primeira, a vontade de domínio, e as instituições pelas quais essa vontade se manifesta, deve parecer independente e autônoma em seu funcionamento. Já a segunda está baseada na conexão entre ideologia e Estado. Especificamente, os interesses de classe são capazes de ser transformados num "interesse geral ilusório", pois a classe dirigente pode, com sucesso, universalizar suas idéias como "idéias dominantes" (Harvey, 2005: 81). Estas idéias dominantes devem ser apresentadas como idealizações abstratas, como verdades universais, ligadas ao interesse comum. Noções como justiça, direito e liberdade são aqui mobilizadas como se seus significados fossem independentes de qualquer interesse específico. Tanto que a classe dirigente deve dominar também como pensadora, como produtora de idéias dominantes de uma época.

O que acabamos de expor com base no pensamento de Harvey (2005) é o que encontramos nos discursos engendrados pelo Terceiro Setor, e de modo particular no âmbito da denominada Responsabilidade Social Empresarial. As ações do Terceiro Setor são permeadas por uma nova linguagem, cujo teor ideológico é mobilizado para sedimentar um novo "pacto social". No caso do Terceiro Setor da indústria da reciclagem observamos que determinadas idealizações abstratas, apresentadas como verdades universais, são usadas para justificar a própria estruturação do novo setor produtivo. Noções como sustentabilidade, planeta limpo ou salvar o planeta e a natureza aparecem como verdades inquestionáveis que perpassam todas as esferas e níveis sociais. Por exemplo, temos a educação ambiental destinada a adequar o comportamento dos consumidores "cidadãos" - convocados a participar dos programas de reciclagem dos resíduos consumidos, em detrimento da redução do consumo - de acordo com um novo receituário prescrito para a continuidade do sistema produtor de mercadorias. Segundo Rodrigues (1996), é evidente que os discursos das empresas mostram uma nova matriz discursiva. Mostram a importância das "novas mercadorias", sem contudo denominá-las como mercadoria. Parece que as empresas estão 
preocupadas apenas com a problemática ambiental e que ao assim procederem cumprem uma função social. Mas (...) é evidente que Ihes interessa obter mais dessas novas mercadorias.

Para Arantes, as ações de Responsabilidade Social das Empresas caracterizam-se como negócio de imagens. Direitos da cidadania transformam-se em valor agregado à imagem da empresa, a exemplo dos projetos sociais e ambientais desenvolvidos por instituições do Terceiro Setor criadas pelas próprias empresas, inclusive por instituições bancárias. A imbricação entre as ações das empresas, ONG's e movimentos sociais é descrito por Cohn (2004:252-253). A autora nos diz que a inclusão da categoria "empresários" tornou-se importante nos anos 90, pois, com a globalização e o desenvolvimentos do setor informal da economia, várias entidades de trabalho comunitário, articuladas a ONGs, passaram a ter relações de mercado com pequenos e médios empresários. Devemos ressaltar que não apenas pequenas e médias empresas vêm estabelecendo parcerias nos arranjos produtivos fomentados pelas ONG's, mas também grandes empresas.

No caso do Terceiro Setor da indústria da reciclagem, a participação de grandes empresas é patente, pois as empresas recicladoras e indústrias produtoras de mercadorias incorporam as cooperativas de catadores (invariavelmente organizadas pelas entidades do Terceiro Setor) como suas fornecedoras de matérias-primas. 


\section{Capítulo iV}

\section{A ESTRUTURAÇÃO RECENTE DA INDÚSTRIA DA RECICLAGEM}

\subsection{Reciclagem e Coleta Seletiva: a caminho de (Re)definições}

Segundo os objetivos da pesquisa, a reciclagem, ou melhor, a indústria da reciclagem, é analisada e compreendida de acordo com uma perspectiva crítica. Inicialmente, serão expostas algumas definições referentes à Reciclagem e à Coleta Seletiva, com base em algumas obras de referência neste tema.

Sabetai Calderoni, logo na apresentação de seu livro "Os bilhões perdidos no lixo" ${ }^{105}$, afirma que ao mesmo tempo em que cresce o volume de lixo produzido, resultante do aumento desvairado do consumo, são cada vez mais caras, mais raras e mais distantes as alternativas tradicionais de disposição do lixo em aterros. Frente à inevitabilidade da produção do lixo - que aqui entendemos como inevitabilidade do consumo - improdutivo e produtivo, o autor defende a tese da viabilidade econômica advinda da reciclagem. Ao abordá-la do ponto de vista econômico, Sabetai contribui para redirecionar o debate sobre este tema, retirando-o da esfera do discurso estritamente ambientalista, ao qual também está vinculada a denominada "educação ambiental":

O lixo, indesejável e inevitável. Do processo produtivo resulta sempre a geração de resíduos, de duas formas distintas: em um primeiro momento, como conseqüência do próprio ato de produzir; posteriormente, após a cessação da vida útil dos produtos. Vive-se, em conseqüência, uma imensa crise. Ao mesmo tempo em que cresce o volume de lixo produzido, resultante do aumento desvairado do consumo, são cada vez mais caras, mais raras e mais distantes as alternativas tradicionais de disposição do lixo em aterros.(...) Por muito tempo, vem sendo advogada a reciclagem do lixo apenas em função dos ganhos ambientais, ou mesmo educacionais que proporciona. Constitui objetivo fundamental do presente trabalho demonstrar que a reciclagem do lixo pode se justificar também em termos econômicos. ${ }^{10}$

\footnotetext{
${ }^{105}$ Calderoni, Sabetai. Os bilhões perdidos no lixo. 4.ed. São Paulo: Humanitas, FFLCH/USP, 2003. [Tese de Doutorado em Geografia, FFLCH/USP, 1996]

${ }^{106}$ Grifos nossos.
} 
Neste sentido, a tese de Calderoni visa a explicitação da natureza da contribuição da reciclagem do lixo de modo que permita avaliar esta atividade enquanto alternativa para o desenvolvimento economicamente sustentável. (Calderoni, 2003:59)

$\mathrm{Na}$ obra deste autor, vamos encontrar algumas definições elementares no contexto da reciclagem, neste caso direcionadas a uma abordagem econômica. Vejamos:

Sob o ponto de vista econômico, resíduo ou lixo é todo material que uma dada sociedade ou agrupamento humano desperdiça. Isso pode ocorrer por várias razões, como sejam, por exemplo, problemas ligados à disponibilidade de informação ou de meios para realizar o aproveitamento do produto descartado, inclusive da falta de desenvolvimento de um mercado para produtos recicláveis. (...) Lixo domiciliar, para as finalidades do presente trabalho, será entendido como todo material sólido ao qual seu proprietário ou possuidor não atribui mais valor e dele deseja descartar-se, atribuindo ao poder público a responsabilidade pela sua disposição final. (Calderoni, 2003: 49; 51)

Luciano Legaspe (1996), em sua importante pesquisa realizada sobre a "reciclagem clandestina em São Paulo" nos diz:

[O lixo] é um produto inútil para a grande maioria da sociedade brasileira e deve ser jogado fora o mais rápido possível, quanto mais longe melhor, pois ele incomoda quando é colocado do lado das residências e do comércio, imprimindo na paisagem dos bairros de classe média a sensação de estarmos transitando na periferia da cidade, onde é de costume o destino de todos os resíduos. Não que os moradores da periferia gostem de dividir o mesmo espaço com o lixo da cidade inteira, acontece que é para as regiões menos valorizadas, que o lixo é lançado através de forças centrífugas (rapidez e a distância indicam a intensidade da repulsa) (...) e a população destas áreas convive com o que há de mais degradado do que a sociedade urbana produz ${ }^{107}$. (Legaspe, 1996: 1-2)

Como "material sem valor" o lixo representa um problema para seus geradores, envolvendo custos tanto ao setor privado quanto ao poder público, que âmbito municipal é responsável por seu gerenciamento. Porém, o termo reciclagem denota justamente a mudança na forma de conceber e gerenciar os resíduos. Segundo Calderoni, o termo "reciclagem", aplicado a lixo ou a resíduos, designa processamento de materiais de sorte a permitir novamente sua utilização. Nesse sentido, 
reciclar é "ressuscitar" materiais, permitir que outra vez sejam aproveitados. O termo Reciclagem, no presente trabalho, será adotado para designar o processo sistemático de transformação do lixo sólido tipicamente domiciliar em novos produtos. (Calderoni, 2003: 52)

De modo geral, a cadeia produtiva da reciclagem está estruturada em três etapas elementares (SMTRAB, 2007:29):

$1^{\underline{a})}$ recuperação: coleta seletiva, separação, prensagem e enfardamento;

$\left.2^{a}\right)$ revalorização: beneficiamento, com uso de equipamentos e produção de produtos intermediários;

$\left.3^{a}\right)$ transformação: a reciclagem propriamente dita, no processamento dos materiais recuperados para transformá-los em novos produtos.

O ciclo descrito pode ser otimizado pela concentração das etapas numa mesma região e pela formação dos "pólos de reciclagem", numa localidade, podendo inclusive configurar uma região.

O processo de reciclagem que "ressuscita" os materiais recicláveis da condição de lixo é descrito também por Calderoni $(2003: 159 ; 167)$ da seguinte forma:

O processo de reciclagem envolve primeiramente a etapa de coleta de lixo, a qual, quando precedida de uma separação realizada nos domicílios é chamada de Coleta Seletiva e, caso contrário, é denominada coleta regular ou usual. Em ambas as situações, geralmente há participação de carrinheiros, trabalhadores informais que, utilizando pequenas carroças, recolhem os materiais selecionados ou realizam na própria calçada esta seleção, transportando-os, geralmente, para depósitos (ou para os chamados depósitos de ferro-velho). Participam também da coleta os catadores, trabalhadores informais que, nos lixões e aterros, dedicam-se a separar e retirar materiais. A etapa seguinte é a triagem. Mesmo no caso de que tenha havido uma prévia separação nos domicílios, o lixo coletado precisará, ainda assim, passar por uma nova etapa de separação, mais detalhada do que a primeira. Isso acontece principalmente com os plásticos e papéis, que apresentam grande diversidade e precisam ser classificados em dezenas de tipos. Após a triagem, os materiais passam por um processo de beneficiamento e acondicionamento. (...) Tanto a triagem como o beneficiamento $e$ acondicionamento são tarefas normalmente realizadas em locais especificamente destinados a esta finalidade, denominados Centros de Reciclagem (ou de Triagem). Em seguida, os materiais são armazenados para distribuição às indústrias recicladoras. A última etapa é a que se verifica no próprio processo industrial, com o efetivo aproveitamento dos materiais para a produção de bens, tanto os dirigidos ao consumo final, como os destinados a um processamento industrial intermediário. (...) Em São Paulo, o papel do carrinheiro prepondera, enquanto responsável pela triagem na calçada (...) Se a Prefeitura não coleta montante de recicláveis sequer remotamente próximo do requerido para perfazer o nível de reciclagem vigente, então de onde proviriam esses

${ }^{107}$ Grifos nossos. 
recicláveis? Não resta dúvida de que as indústrias recicladoras obtém a maior parte desses recicláveis diretamente junto a uma rede de sucateiros, estes, por sua vez, mobilizando carrinheiros que realizam a triagem dos recicláveis na própria calçada. ${ }^{108}$ (...) Especificamente, são os sucateiros que realizam os dispêndios relativos à reciclagem, assumindo os custos do processo e tentando, na medida do possível, repassá-los à indústria. Isso porque cabe aos sucateiros financiar e operar a coleta, a triagem, o transporte, a armazenagem e 0 processamento dos materiais recicláveis, recrutando os serviços de carrinheiros e catadores.

Há que se concordar quando o autor afirma que os catadores mobilizados pela rede de sucateiros ${ }^{109}$ são os principais responsáveis pelo abastecimento das indústrias com materiais recicláveis. Mesmo porque, nos anos iniciais da década de 90 (período em que o autor realizou sua pesquisa) era diminuta a participação da Prefeitura de São Paulo na Coleta Seletiva (que viria se consolidar, na década seguinte, com base no modelo das Centrais de Triagem). Porém, quando o autor atribui somente aos sucateiros os custos do processo de reciclagem, envolvendo coleta, triagem, transporte, armazenagem e até processamento, com recrutamento de catadores, acaba por não reconhecer que também os catadores arcam com estes custos, com a energia vital de seus próprios corpos. Numa equação elaborada pelo autor sobre os "Ganhos de cada agente econômico com o processo de reciclagem do lixo", conclui-se que o catador ganha com a venda dos materiais recicláveis aos atravessadores, desconsiderando completamente que o catador também tem "custos", arcados com sua própria vida!

No decorrer do período posterior às pesquisas realizadas tanto por Calderoni, quanto por Legaspe (passagem dos anos 90 para a primeira década do século XXI) o lixo - e nele a potencialidade de obtenção dos materiais recicláveis, tornou-se cada vez mais útil, sobretudo para diferentes setores da sociedade. Ou seja, tanto para os mais pobres dos pobres urbanos - o catador, quanto para a classe dos industriais que utilizam matérias-primas garimpadas do lixo. Os materiais recicláveis constituem, por assim dizer, o resíduo que não é mais lixo, que separado é fonte de riqueza, e que pelo trabalho do catador se torna, para os setores industriais, fonte para aumento de suas taxas de lucro (economia com capital

\footnotetext{
${ }^{108}$ Grifos nossos.
} 
constante), e inclusive de formação de capital (com base no trabalho pago ao catador).

\begin{abstract}
Independente do grau de repulsa que o lixo incorpora, a sua composição é rica e generosa, pois nele encontramos os mesmos produtos que estão sendo processados nas fábricas e vendidos nas lojas para o nosso consumo, e foi pensando também nesta característica que implantaram a chamada "Coleta Seletiva" do lixo, surgindo como a tábua de salvação para a sociedade moderna devoradora de produtos em massa e produtora de lixo por excelência. (Legaspe, 1996: 2)
\end{abstract}

É assim que diversas estratégias no campo da comunicação e do marketing, bem como da denominada educação ambiental, articuladas pelos setores interessados nos negócios desta indústria em estruturação, passaram a ser incorporadas como novos valores amalgamados ao comportamento de toda a sociedade. Através de sistemas como a coleta seletiva, a indústria da reciclagem adentra lares, escolas, repartições públicas e instituições privadas. A sensação de "repulsa" deve ser substituída por aquela de dever cumprido, pois no processo de convencimento sobre a importância da reciclagem estão argumentos fortes e universais como "manter o planeta limpo", "salvar a natureza", "gerar trabalho e renda", entre outros.

Rodrigues $(1996)^{110}$, ao questionar se o cidadão comum compreendia as múltiplas dimensões da denominada "produção/destrutiva", escolheu o lixo doméstico como um aspecto da vida cotidiana para o desenvolvimento de sua pesquisa:

Foi necessário compreender aspectos do significado da produção do lixo e da dinâmica de alteração do lixo em resíduos recicláveis. Como um resíduo vira lixo e vira resíduo-mercadoria. Foi necessário verificar, também, como o poder público - considerando-se suas responsabilidades - atua nesta questão. Apontamos, assim, (...) as formas pelas quais se implanta o programa de coleta seletiva de lixo em São Paulo e suas 'repercussões' no ideário dos citadinos que realizam a separação do lixo para a reciclagem. (Rodrigues, 1996:5)

\footnotetext{
${ }^{109} \mathrm{O}$ termo sucateiro é usado por diversos autores (Calderoni; Legaspe) para designar o comerciante de sucatas, ou de recicláveis. A ONG CEMPRE também utiliza este termo. Utilizaremos tanto o termo sucateiro quanto o termo depósito para designar os comerciantes de recicláveis.

${ }^{110}$ Rodrigues, Arlete Moysés. Reflexões sobre a produção e consumo do e no espaço. (Re)leituras do território. Tese de Livre Docência. IFCH-UNICAMP, 1996.
} 
Assim, Rodrigues (1996:110) ao pesquisar sobre o significado do lixo e da Coleta Seletiva realizada pela Prefeitura na vida cotidiana dos citadinos, questionava-se sobre o processo de transformação do lixo em mercadoria: o lixo tornou-se uma "mercadoria". Era 'resto' de um valor de uso e adquiriu um 'novo' valor de troca. Mercadoria 'sui generis', pois é descartável para uns, que não se preocupam com o valor de troca (os moradores em geral), enquanto para outros o valor de troca é um atributo ${ }^{111}$.

Legaspe (1996:124-125;128) adverte que a concepção de reciclagem não é recente, estando desde a origem diretamente relacionada à necessidade da indústria em obter matérias-primas mais baratas:

A concepção de reciclagem não foi introduzida pela nova onda mundial da preservação do meio ambiente. Ela só ganhou uma nova roupagem, pelo motivo de que a reciclagem surgiu há muito tempo, mas até então ela estava reduzida a condição de produtora de "mercadoria de segunda" e seus representantes diretos são os sucateiros (depositários), também comparados como "comerciantes de segunda". Os depósitos de sucata estão instalados nos centros urbanos desde que se iniciou o processo industrial, estes depósitos de compra e venda de material de segunda não precisariam existir inseridos na cadeia da produção industrial, se a lógica capitalista não tivesse percebido há muito tempo que parte significativa dos produtos que abastecem o mercado de consumo é transformado em lixo imediatamente pelo consumidor, estando estes produtos apresentados em forma de embalagens, ou os próprios produtos que são descartados após findado seu tempo de uso. (...)[A reciclagem] surgiu da necessidade industrial de se abastecer de matéria-prima barata, sendo o espaço urbano utilizado como o local e a fonte desta matéria-prima.

No contexto mais recente, pode-se encontrar nas publicações do Instituto POLIS, através de seu departamento de Meio Ambiente Urbano, outras definições ligadas à reciclagem. Neste sentido, o livro "Coleta seletiva com inclusão social: Fórum Lixo e Cidadania na Cidade de São Paulo - Experiência e desafios" ${ }^{\text {"112, }}$, publicado pelo Instituto POLIS, constituiu-se numa fonte documental para a pesquisa, o qual apresenta a história da formação e atuação do Fórum Lixo e

\footnotetext{
${ }^{111}$ Nota da Autora: Na verdade mudou a dimensão da mercadoria lixo, pois num passado não muito distante vendia-se aos catadores: garrafas, ferro velho e jornais. Hoje, para a maioria não é mais venda mas apenas a "entrega" e/ou doação, o que implica em alterações nessa mercadoria.

112 Grimberg, Elisabeth. Coleta seletiva com inclusão social: Fórum Lixo e Cidadania na Cidade de São Paulo. Experiência e desafios. Pólis, 2007. 148p (Publicações Polis, 49)
} 
Cidadania da Cidade de São Paulo (...) criado em 2000 (...) para fazer avançar o paradigma de gestão de resíduos sólidos ${ }^{113}$ na cidade de São Paulo (...).

Grimberg (2007:11) também apresenta uma diferenciação entre os termos lixo e resíduos sólidos recicláveis: quando misturados, restos de alimentos, embalagens descartadas e objetos inservíveis tornam-se lixo, que deve ter como destino ambientalmente adequado o aterro sanitário. Esses mesmos materiais, quando disponibilizados separadamente para a coleta seletiva (resíduos secos e úmidos) tornam-se materiais reaproveitáveis ou recicláveis. Ainda é preciso diferenciar os materiais que não têm mais como serem aproveitados na cadeia do reuso ou reciclagem, denominados rejeito.

É muito evidente a mudança qualitativa do lixo que ganha o atributo de material reciclável. Porém, os catadores que atuam na base da indústria, na catação dos materiais recicláveis, lidam diretamente com o lixo. Cabe registrar que, mesmo no caso das cooperativas, os catadores lidam com o denominado rejeito, ou seja, com lixo (rejeito).

Existem relatos freqüentes sobre o problema que as cooperativas enfrentam em relação ao rejeito que se acumula nos galpões ou pátios. A retirada de grandes volumes de lixo, pela prefeitura ou empresa de limpeza urbana, implica em taxas para seus geradores e neste caso a cooperativa pode se caracterizada como a geradora do lixo... Para que isso não ocorra, as cooperativas ficam na dependência de que a prefeitura se responsabilize pela destinação final do rejeito.

Por mais que as propagandas de cooperativas inseridas em projetos de inclusão solidária, promovidos tanto por prefeituras quanto por "empresas social e ambientalmente responsáveis", veiculem imagens de catadores organizados trabalhando com materiais recicláveis limpos e coloridos, estes trabalhadores estão, de fato, lidando com lixo.

Portanto, se há mudança na qualidade do lixo que se transforma em material recicláveis, isto decorre do ato exato e primeiro que corresponde à catação ou coleta seletiva, realizadas pelo catador que garimpa e resgata o valor de troca do resíduo.

Grimberg (2007:07) ressalta que estamos diante de um novo paradigma: o da gestão de resíduos sólidos. A respeito disto nos diz:

\footnotetext{
${ }^{113}$ Grifos nossos.
} 
(...) um paradigma de gestão sustentável de resíduos sólidos que supere, inclusive, o conceito de limpeza urbana. A perspectiva é a de avançar para uma sociedade sensibilizada, informada e educada para as questões do não desperdício de materiais, para consumir com critérios, para descartar seletivamente (...). Neste cenário, poderemos superar o conceito de limpeza urbana, que pressupõe a sujeira urbana, lixo - governos, empresas, cidadãos e cidadãs terão consciência de suas atitudes e não mais jogarão os resíduos em locais impróprios. Pelo contrário, estarão participando da construção de uma nova concepção de gestão de resíduos estruturada a partir da participação cidadã. Da inclusão social, da educação para os 3 Rs - reduzir, reutilizar, reciclar - da responsabilidade social empresarial e da economia solidária inclusiva.

Uma sociedade sensibilizada, informada e educada para as questões do não desperdício de materiais, para consumir com critérios, para descartar seletivamente... Num só termo: adestramento! A palavra parece forte, mas concordamos com Arlete Moysés Rodrigues (2001: 141) ao usar os termos de Paulo Freire numa Aula Pública durante o Seminário Lixo e Cidadania - Região do Grande ABC, em setembro de 1999, ao discorrer sobre a mudança na característica do lixo:

\begin{abstract}
(...) aumenta a quantidade de lixo, altera-se a sua qualidade, o tempo de decomposição dos materiais se altera, vira uma mercadoria que tem preço definido por quem compra e não por quem vende, porque descartamos esse produto e o preço desse material é definido pela indústria vidreira, por indústrias como a Latasa, que até a pouco tempo era a única produtora de latas de alumínio do Brasil. Isso significa que devemos fazer uma análise pensando em tratar a questão do lixo não vinculada apenas com o "adestramento ambiental". Infelizmente, tem-se colocado como uma educação cidadã, uma educação ambiental, uma forma de seleção do lixo, separação do lixo e o depósito em "containers", etc. A meu ver isso é um "adestramento" - estas palavras são usadas por Paulo Freire. Ele indaga se isto é "educação" ou "adestramento ambiental" (...).
\end{abstract}

Vale destacar que Calderoni (2003:42-43) já em meados da década de 90 defendia a tese da viabilidade econômica da reciclagem. Tal viabilidade deveria ser entendida do ponto de vista da sociedade como um todo, não devendo ficar restrita aos cálculos envolvidos na limpeza urbana de responsabilidade das Prefeituras. Neste raciocínio, Calderoni também aponta para uma mudança de enfoque, ou paradigma, na forma como a sociedade se relaciona com o lixo. Já não se trata somente de uma questão de limpeza urbana (este o campo de atuação das empresas de limpeza urbana). Daí o autor identificar que a reciclagem é economicamente viável do ponto de vista da sociedade como um todo: 
Na mensuração da viabilidade econômica, freqüentemente parte-se de um ponto de vista que é somente o da Prefeitura, considerando-se apenas os custos e ganhos desta, e mesmo assim, ainda de modo parcial. Neste contexto, [nossa] hipótese é a de que a reciclagem do lixo é economicamente viável sob o ponto de vista da sociedade como um todo. A tese que se sustenta aqui é a de que esta viabilidade se verifica. (Calderoni, 2003: 42-43)

Porém, o que o autor não explicita é justamente o fato de que a sociedade como um todo - sobretudo trabalhadores sobrantes que sobrevivem como catadores - vem sendo mobilizada pelos interesses dos setores produtivos que absorvem os materiais recicláveis, pressionando governos, sociedade civil e cidadãos comuns às práticas consonantes com os ajustes necessários ao funcionamento aperfeiçoado da reciclagem.

\subsection{A produção de materiais primas a partir da base da indústria da reciclagem}

No Brasil, a indústria da reciclagem vem se estruturando no contexto de políticas neo-liberais, arregimentando o trabalho sobrante dos mais diversos setores produtivos. Neste processo, milhares de catadores são (re)inseridos no conjunto de atividades que integram a base desta indústria.

Como foi visto no sub-capítulo anterior, o processo de reciclagem é geralmente apresentado como sendo dividido em três principais etapas. Porém, entende-se que a primeira etapa, chamada de "recuperação" deve ser repensada em relação ao que se define como "a reciclagem propriamente dita", atribuída à terceira e última etapa, que é a de "transformação".

Vejamos. Na etapa de "recuperação" são realizadas as atividades da catação (quando o catador "garimpa" os recicláveis em meio ao lixo) ou coleta seletiva (quando o catador recolhe os materiais recicláveis minimamente separados pela fonte geradora), separação dos materiais, denominada de triagem, sucedidas pelas atividades de prensagem e enfardamento, estas últimas condicionadas ao uso de equipamentos.

A segunda etapa é definida como "revalorização" dos materiais, através de beneficiamento com uso de equipamentos, resultando em produtos intermediários. 
A terceira etapa corresponde à "transformação" dos materiais recicláveis, sendo considerada como a etapa da "reciclagem propriamente dita", quando são finalmente transformados em novos produtos.

Porém, da forma como o processo de reciclagem está descrito, a indústria da reciclagem - a reciclagem propriamente dita- corresponde às duas últimas etapas, mais precisamente à terceira que é definida como processo de "transformação".

Da forma como estas etapas estão apresentadas, o trabalho do catador que se concentra na primeira delas, aparece como muito distante, completamente apartado do processo produtivo que torna evidente na última das etapas.

Porém, é justamente na primeira etapa do processo de reciclagem que se realiza a base da indústria, e nela, a relação entre indústria e catador. De fato, aí ocorre a chamada "recuperação" dos materiais recicláveis, ou seja, a retirada dos recicláveis da condição de lixo, sendo esta a função elementar da atividade da catação ou coleta realizada pelos catadores. Ademais, quando os catadores procedem à triagem, à prensagem e enfardamento estão inseridos no processo de produção das matérias-primas. Isto porque o valor dos materiais recicláveis, em seu processo de transformação em matéria-prima, não advém somente da transferência do valor dos equipamentos aos produtos (basicamente do uso de prensas), mas porque em todas estas atividades existe o dispêndio, o consumo da energia vital dos próprios catadores. Ou seja, a transformação dos materiais recicláveis em matériaprima se inicia no chão dos catadores, por isso estes territórios abrigam a base da indústria da reciclagem. Porque é parte integrante e profundamente contraditória da indústria, incrustada no circuito comercial, nos territórios empobrecidos, no urbano periférico - seja no centro ou na periferia propriamente ditos da metrópole.

As trocas comerciais realizadas no percurso que vai da catação, ou coleta (atividade que inicia a primeira etapa do processo de reciclagem, denominada de recuperação) à transformação do reciclável em novo produto (terceira e última etapa do processo de reciclagem), caracterizam-se como descontinuidades do processo global da reciclagem. Porém, estas descontinuidades são freqüentemente analisadas como rupturas no interior do processo de reciclagem, representadas pela intermediação dos comerciantes que se atravessam entre catadores e indústria. 
Disto decorre a falta de compreensão, em alguns casos intencional, de que se trata tão somente de um único processo global.

Rodrigues (1996:183-184) já havia apontado para a "fragmentação" do processo de produção envolvido na reciclagem, sob outra perspectiva: não se considera todo o circuito do produto: ora se analisa os resíduos de um tipo de indústria (mas em suas diversas etapas segmentadas) ora se analisa os resíduos do consumo.

São, de fato, etapas distintas, de certa forma descontínuas na passagem de uma para outra, mas não são rupturas. Trata-se etapas que se sucedem no processo de produção de matérias-primas, desde a base da indústria da reciclagem.

Ademais, a forma de organização do processo produtivo desta nova indústria está justamente relacionada com as condições de produção dos resíduos da sociedade do consumo. Vejamos. A produção dispersa dos materiais recicláveis não pode ser suprimida, posto que os resíduos do consumo, sobretudo o improdutivo, se faz presente em toda a extensão do espaço urbano. Porém, para que estes resíduos possam ser transformados em matérias-primas, devem passar por um processo de produção. $\mathrm{E}$, para que a reciclagem se realize como processo produtivo, deve superar a forma dispersa da coleta ou catação para que, como qualquer outro processo produtivo, concentre-se em determinados pontos do espaço.

De um modo geral, o capital tem que superar barreiras espaciais para se reproduzir, sendo imprescindível a existência de "configurações espaciais fixas e imóveis" para sua reprodução, mais ainda quando se considera este ramo de atividade que é por natureza dispersa. De acordo com Harvey (2005:146):

o capital e a força de trabalho devem se reunir em algum ponto específico do espaço para ocorrer a produção. A fábrica é o ponto de reunião, enquanto a forma industrial de urbanização pode ser vista como a resposta capitalista específica à necessidade de minimizar o custo e o tempo de movimento sob condições da conexão interindústrias, da divisão social do trabalho e da necessidade de acesso tanto à oferta de mão-deobra como aos mercados dos consumidores finais. (...) A capacidade de dominar o espaço implica na produção de espaço. 
Em O Capital, Marx fala da "retransformação dos resíduos" como novos elementos da produção, quando disponíveis em abundância. $O$ aproveitamento dos "resíduos" enquanto matéria-prima resulta em economia de custos com esta parte constitutiva do capital constante, e conseqüente aumento da taxa de lucro:

Toda essa economia, que se origina da concentração de meios de produção e de sua utilização em massa, pressupõe, porém, como condição essencial, a concentração e a atuação conjunta dos trabalhadores [cooperação], portanto combinação social do trabalho. (...) O mesmo é válido quanto ao segundo grande ramo da economia nas condiçôes de produção. Referimo-nos à retransformação dos excrementos da produção, seus assim chamados resíduos, em novos elementos de produção, seja no mesmo, seja em outro ramo industrial; aos processos mediante os quais esses assim chamados excrementos são relançados no ciclo da produção e, portanto do consumo - produtivo ou individual. (...) É a abundância, correspondente a essa escala, desses resíduos que os torna novamente objetos de comércio e, assim, novos elementos da produção. Só como resíduos da produção em comum, e portanto da produção em larga escala, eles ganham essa importância para o processo de produção, continuam a ser portadores de valor de troca. Esses resíduos - abstraindo os serviços prestados como novos elementos da produção - barateiam, à medida que se tornam novamente vendáveis, os custos da matéria-prima, no quais sempre está calculado seu resíduo normal, ou seja, o quantum que acaba em média se perdendo em sua elaboração. $A$ diminuição dos custos dessa parte do capital constante eleva portanto a taxa de lucro com dada grandeza de capital variável e dada taxa de mais-valia. (Marx, v.3, t.1, 1983: Pp. 62-63)

Com base nesta passagem de O Capital observa-se que o interesse maior do desenvolvimento da reciclagem diz respeito à possibilidade de aumento da taxa de lucro que resulta da economia em capital constante (parte circulante) para as indústrias consumidoras desta matéria-prima mais barata. Mas, do ponto de vista do seu processo de produção, pode-se observar algumas características da estrutura industrial, em termos de sua composição orgânica. Como a base desta indústria se realiza no urbano, o meio ambiente construído está diretamente implicado nisto.

Em Os limites do capitalismo e a teoria marxista ${ }^{114}$, Harvey dedica um capítulo desta obra para discorrer sobre $O$ capital fixo (Capítulo 8 do referido livro), sobretudo com base nas obras $O$ Capital e Grundrisse. O capital fixo enquanto uma das categorias relacionais dentro da produção do capital, a circulação do capital fixo e algumas de suas formas especiais de circulação, bem como suas relações com o

\footnotetext{
${ }^{114}$ HARVEY, David. Los límites del capitalismo y la teoría marxista. Ciudad del México: Fondo de Cultura Económica, 1990. [1 ${ }^{2}$ edição em inglês de 1982]
} 
capital circulante são alguns dos temas aprofundados pelo autor ${ }^{115}$, culminando com o entendimento do ambiente construído para a produção, a troca e o consumo. Vejamos o esquema a seguir ${ }^{116}$, seguido de algumas passagens do texto de Harvey (1990):

\begin{tabular}{|c|c|c|}
\hline Formas materiais & Produção de mais-valia & Movimento do capital \\
\hline \multicolumn{3}{|c|}{$\begin{array}{l}\text { Edificações e equipamentos } \\
\text { Infra-estruturas físicas } \\
\text { da produção }\end{array}$} \\
\hline \multicolumn{3}{|l|}{$\begin{array}{l}\text { Matérias-primas } \\
\text { Materiais auxiliares }\end{array}$} \\
\hline \multirow[t]{2}{*}{ Força de trabalho } & CAPITAL VARIÁVEL & CAPITAL CIRCULANTE \\
\hline & \multicolumn{2}{|c|}{ Fonte: Harvey (2005:212). Adaptação: Rosalina Burgos (2008) } \\
\hline
\end{tabular}

\footnotetext{
${ }^{115}$ Em primer lugar, puesto que el capital es definido como "valor en movimiento", se deduce que el capital fijo también se debe considerar en esta forma. El capital fijo no es una cosa sino un proceso de circulación de capital por medio del uso de objetos materiales, como las máquinas. (...) Sólo los instrumentos de trabajo que se usan realmente para facilitar la producción de plusvalía son clasificados como capital fijo. (...) El capital fijo es, entonces, sólo aquella parte de la riqueza social total, la reserva total de bienes materiales, que se usan para producir plusvalía. La segunda característica que distingue al capital fijo es su peculiar "modo específico de valorización, en el modo de rotación [y] en el modo de reproducción" (Grundrisse, II, p.138). Esto liga la definición del capital fijo al proceso de rotación de otros elementos del capital constante, [pois] el tiempo de rotación no es homogéneo de ninguna manera. La distinción entre el capital fijo y el circulante, por tanto, en el primer caso es una mera distinción cuantitativa que "se solidifica" y pasa a ser una diferencia cualitativa a medida que se usan instrumentos de trabajo más durables (Grundrisse, II, pp.105-106). El capital fijo y el circulante se convierten entonces en "dos modos diferentes de existencia del capital", que exhiben características de circulación muy distintas. (Harvey, 1990:211-212)

116 Las categorías del capital como "fijo" y "circulante" organizan nuestros pensamentos en formas fundamentalmente diferentes a los implicados por las categorías de capital "constante" y "variable" (...). Ambos conjuntos de categorías tienen esto en común: se definen 'dentro' de la producción ${ }^{116}$. El capital en forma de mercancías o dinero está 'en una forma que no es ni fijo ni circulante'. Puesto que todo el capital debe tomar la forma de dinero o mercancía en algún momento de su existencia, podemos deducir que la relación entre el capital fijo y el circulante así como la relación entre el capital constante y variable es 'mediada' por los intercambios de mercancías y dinero y modificada por la existencia del capital en estas otras formas (El Capital, II, pp.181-183). Sin embargo, dentro de la esfera de la producción podemos identificar ahora dos formas muy diferentes de conceptuar la forma orgánica del capital. (...)(Harvey, 1990:212-213)
} 
Segundo Harvey (1990):

(...) La tarea que tenemos ante nosotros es llegar a entender los procesos de circulación del capital a través de la producción, por medio de los conceptos del capital fijo y circulante. (Harvey, 1990:214) Marx sostenía que "el capital fijo es premisa para la producción del capital circulante, lo mismo que el capital circulante lo es para la del capital fijo" (Grundrisse, II, p.140). Tanto las máquinas que se usan como capital fijo como los insumos del capital constante circulante son producidos en primer lugar por medio del uso del capital fijo y circulante (El capital, II, p.183). Además, como el capital fijo pierde su valor cuando no se usa, un flujo continuo de capital circulante - de fuerza de trabajo y materias primas - es una condición necesaria para la realización de su valor. (Harvey, 1990: 221) (...) la concepción de un 'ambiente construido' que funciona como un vasto sistema de recursos creado por los seres humanos, que comprende valores de uso cristalizados en el paisaje físico, que se pueden utilizar para la producción, el intercambio y el consumo (...) estos valores de uso pueden considerarse como precondiciones generales de la producción y como fuerzas directas dentro de ella. (...)

Os materiais recicláveis constituem matéria-prima para diversos ramos industriais, cujos produtos fabricados são constituídos por diferente tipos de materiais: plásticos, papéis, metais, vidros, para citarmos apenas os grupos principais. Enquanto matéria-prima, os materiais recicláveis constituem elemento do capital circulante no movimento do capital, ou ainda, são integrantes do capital constante no processo de produção do capital.

Porém, os materiais recicláveis só se tornam parte constitutiva do capital ao serem transformados novamente em matéria-prima. Misturados ao lixo, os materiais recicláveis não apresentam valor algum. Ao contrário! Na contabilidade das administrações públicas, do setor produtivo e do comércio, os resíduos sólidos significam custos caracterizados por taxas e gastos públicos e/ou privados na logística de disposição final do lixo. Neste sentido, perderam seus valores de uso e de troca. Porém, a partir do ato da catação (realizada pelos catadores que trabalham individualmente) ou da coleta seletiva (forma de atuação das cooperativas de reciclagem e de empresas de limpeza urbana que oferecem este tipo de serviço, e da qual faz parte a disciplina dos consumidores que separam na fonte os diferentes tipos de resíduos ${ }^{117}$ ), temos o início do processo de produção da matéria-prima

\footnotetext{
${ }^{117}$ Rodrigues (1996:128-129) já identificava: a reciclagem passa para "dentro" das casas, mesmo que provisoriamente, pois é necessário lavar alguns dos materiais, separá-los por tipo de material a ser reciclado.
} 
"material reciclável" que, ao passar pelo processo de transformação se tornará "material reciclado".

Ou seja, assim como foram produzidos anteriormente como matéria-prima que constitui os materiais recicláveis, estes deverão ser transformados novamente em matéria-prima (produto semi-elaborado ou intermediário) ${ }^{118}$ para o consumo produtivo, ainda que a matéria-prima original e aquela proveniente da reciclagem resultem de processos de trabalho e de valorização diferenciados. Vejamos o que Marx nos explica, em "O Capital", a respeito da matéria-prima:

\begin{abstract}
Se (...) o próprio objeto de trabalho já é, por assim dizer, filtrado por meio de trabalho anterior, denominamo-lo matéria-prima. (...) Toda matéria-prima é objeto de trabalho, mas nem todo objeto de trabalho é matéria-prima. $O$ objeto de trabalho apenas é matéria-prima depois de já ter experimentado uma modificação mediada por trabalho. O meio de trabalho é uma coisa ou um complexo de coisas que o trabalhador coloca entre si mesmo e o objeto de trabalho e que Ihe serve como condutor de sua atividade sobre esse objeto. (...) Exceto as indústrias extrativas, cujo objeto de trabalho é preexistente por natureza, como mineração, caça, pesca, etc. (...), todos os ramos industriais processam um objeto que é matéria-prima, isto é, um objeto de trabalho já filtrado pelo trabalho, ele mesmo já produto do trabalho. (Marx, v.1, 1983:150;152)
\end{abstract}

Devemos considerar que os materiais recicláveis contém trabalho pretérito, em relação ao qual a mais-valia já foi realizada, pois são produtos que foram comprados, consumidos e descartados após findar seu valor de uso e de troca. Ao serem reinseridos novamente na produção a partir da coleta ou catação, os materiais recicláveis são apresentados aos seus compradores como produto, em todas as etapas que integram o processo de reciclagem. No entanto, ao ingressarem novamente nas sucessivas etapas do processo produtivo como meios de produção, tornam-se novamente fatores objetivos do trabalho vivo.

Embora todo o fluxo do processo de reciclagem esteja direcionado à produção da matéria-prima como mercadoria a ser consumida produtivamente,

\footnotetext{
${ }^{118}$ Um produto que existe numa forma pronta para o consumo, pode tornar-se, de novo, matéria-prima de outro produto, como a uva torna-se matéria-prima do vinho. Ou o trabalho despacha seu produto em formas em que só pode ser usado, de novo, como matéria-prima. Matéria-prima nessa condição se chama produto semi-elaborado e seria bem denominada produto intermediário (...). Embora mesmo já sendo produto, a matéria-prima original pode ter que percorrer todo um escalão de processos diferentes, nos quais funciona sempre de novo, em forma cada vez mais alterada, como matériaprima, até o último processo de trabalho que a expele como meio acabado de subsistência ou meio acabado de trabalho. (Marx, O Capital, v.l, p.152)
} 
existem elos intermediários nos quais o material reciclável assume outras formas específicas.

Segundo Marx,

Um produto que existe numa forma pronta para o consumo, pode tornar-se, de novo, matéria-prima de outro produto, como a uva torna-se matéria-prima do vinho. Ou o trabalho despacha seu produto em formas em que só pode ser usado, de novo, como matéria-prima. Matéria-prima nessa condição se chama produto semi-elaborado e seria mais bem denominada produto intermediário, como, por exemplo, algodão, linho, fio, etc.(...) Vê-se: o fato de um valor de uso aparecer como matéria-prima, meio de trabalho ou produto, depende totalmente de sua função determinada no processo de trabalho, da posição que nele ocupa, e com a mudança dessa posição variam essas determinações. Ao entrar em novos processos de trabalho como meios de produção, os produtos perdem, por isso, o caráter de produto. Eles só funcionam agora como fatores objetivos do trabalho vivo. (Marx, v.1, 1983:152)

Assim, antes de se constituírem em matéria-prima, os materiais recicláveis adentram a esfera do mercado de recicláveis, no qual são trocados por dinheiro (moeda). Como toda mercadoria, os materiais recicláveis são produzidos em processos de trabalho com maior ou menor grau de produtividade, onde a valorização destes materiais acontece pelo dispêndio maior ou menor de força de trabalho e de instrumentos de trabalho interpostos entre o trabalhador e o objeto de trabalho.

$\mathrm{Na}$ base da indústria da reciclagem, os instrumentos de trabalho geralmente são produzidos e improvisados pelos próprios catadores, ou por seus exploradores diretos (comerciantes que atuam no setor), tais como carroças, sacos (para o transporte), tambores, mesas (para a triagem), além de balanças e prensas amplamente utilizadas nos locais com atividades de reciclagem, para citarmos apenas alguns. Assim, nas etapas que precedem a transformação final, os recicláveis já aparecem como produto intermediário (Marx, v.1, 1983:152).

Já para os recicladores, os materiais recicláveis são comprados como matérias-primas para a fabricação de produtos semi-elaborados ou intermediários, em forma cada vez mais alterada, como é o caso da fabricação de flakes (flocos plásticos), pellets (grãos plásticos) e fios sintéticos, agora destinados à fabricação de produtos variados, com destaque para a indústria têxtil. 
Para a indústria produtora de mercadorias destinadas ao consumo final, os recicláveis são matérias-primas cujo valor, produzido e acumulado como resultado do processo de trabalho existente nos elos intermediários das cadeias produtivas, será cabalmente realizado através da venda dos mais diversos produtos no mercado consumidor, como "meio acabado de subsistência ou meio acabado de trabalho".

Se há variação crescente dos materiais recicláveis (em forma cada vez mais alterada), e que se expressa na elevação dos preços em direção ao topo das cadeias produtivas, isto não corresponde exatamente, ou não somente, ao "valor agregado" em função do uso dos elementos constitutivos do capital fixo (incremento de edificações, maquinaria e equipamentos diversos). Neste caso, temos que considerar a maior produtividade do trabalho em direção ao topo das cadeias produtivas. Por outro lado, quanto mais se avança em direção à base da indústria da reciclagem, menor é a composição orgânica do capital. Mas este já é o universo dos comerciantes de recicláveis, no qual a indústria tem suas cadeias produtivas incrustadas.

Cadeias produtivas incrustadas no mercado de recicláveis, porque na prática do comprar para vender mais caro que caracteriza o capital comercial ${ }^{119}$, ocorre, simultaneamente, algumas das etapas iniciais do processo de reciclagem propriamente dito, ou seja, da produção da matéria-prima. Portanto, não se trata de simples "mudança de mãos" de um mesmo produto.

$\mathrm{Na}$ literatura sobre o tema, seja no âmbito da pesquisa científica ou nas notícias veiculadas pela mídia, não existe consenso acerca da definição de qual seja o nível de base das cadeias produtivas que integram a indústria da reciclagem. Aqui, compreende-se que o processo de trabalho realizado pelos catadores corresponde à base propriamente dita das cadeias produtivas da reciclagem.

Esta mesma perspectiva foi identificada (a exemplo dos agentes do Terceiro Setor que atuam na formação das cooperativas). Porém, a relação catadorindústria geralmente não aparece (ou aparece como parcerias). Assim, os

\footnotetext{
119 Comprar para vender, ou melhor, comprar para vender mais caro, D-M-D', parece ser decerto apenas uma espécie de capital, a forma peculiar do capital comercial. Mas também o capital indústrial é dinheiro, que se transforma em mercadoria e por meio da venda de mercadoria retransforma-se em mais dinheiro. Atos que ocorram eventualmente entre a compra e a venda fora da esfera da circulação nada mudam nessa forma de movimento. (...). De fato, D-M-D' é a fórmula geral do capital, como aparece diretamente na esfera da circulação. (Marx, O capital, v.I, tomo I, p.131).
} 
comerciantes são identificados os inimigos a serem vencidos. Entendemos que a interpretação acerca da exploração dos comerciantes esteja correta, mas não a omissão quanto ao papel da indústria. Neste sentido, os catadores vem sendo organizados em cooperativas que consigam vender os recicláveis diretamente para a indústria, obtendo melhores preços.

\subsection{Um novo estágio no processo de estruturação da indústria da reciclagem}

A estruturação da indústria da reciclagem está diretamente relacionada à consolidação dos materiais recicláveis como novas matérias-primas a serem consumidas produtivamente por diferentes segmentos da indústria de transformação. De um modo geral, estes segmentos são identificados pelos principais grupos de materiais que compõem seus produtos: papéis, plásticos, vidros e metais.

De um modo geral, a delimitação do setor industrial da reciclagem envolve:

a) produtores de máquinas e equipamentos voltados para reciclagem;

b) empresas que realizam a reciclagem transformando os resíduos recicláveis em novos produtos;

c) as cooperativas e organizações de catadores que realizam o pré-processamento do material, prensado e realizando o enfardamento;

d) prestadoras de serviço de limpeza pública que coletam o material para administrações públicas e setor privado;

e) comerciantes de materiais recicláveis, tais como sucateitos, depósitos, ferrosvelhos, reciclagens;

f) milhares de catadores que trabalham na coleta, transporte, triagem e demais atividades inscritas na base da indústria da reciclagem.

g) as entidades do Terceiro Setor da indústria da reciclagem

De acordo com dados do CNAE/RAIS ${ }^{120}$, as empresas que realizam a reciclagem fazem parte da seção denominada indústria de transformação, na divisão reciclagem, a qual apresenta dois grupos: reciclagem de sucatas metálicas e

\footnotetext{
${ }^{120}$ Classificação Nacional de Atividades Econômicas/Relação Anual de Informações Sociais In www.rais.gov.br/cnae.asp Acessado em 12/11/2007.
} 
reciclagem de sucatas não-metálicas. Caracterizam-se como um sub-setor da indústria de transformação. Aqui o referido "sub-setor" será denominado como "indústria da reciclagem". Porque, de fato, trata-se de uma indústria que vem se estruturando.

Ainda segundo o CNAE/RAIS, a cadeia se completa com a atividade de comercialização da classe comércio atacadista de resíduos e sucatas metálicos e não-metálicos. As empresas que fabricam máquinas para reciclagem não têm classe específica, ficando cadastradas em fabricação de outras máquinas e equipamentos de uso específico. Segundo dados do CEMPRE (2008), existe em seu cadastro 1071 recicladores, 1349 sucateiros e 539 cooperativas no Brasil. Por sua vez, no cadastro da RAIS (2006), constava mais de 1.500 recicladores e outros 3.000 comerciantes de resíduos e sucatas, ou seja, sem grandes diferenças em relação aos dados do CEMPRE. O total de empresas cadastradas na RAIS declararam empregar 45.056 funcionários, sendo que os recicladores são responsáveis pelo emprego de $41 \%$ desse contingente. Em relação ao porte das empresas, 98\% são micro e pequenas empresas e 53\% possuem menos de 10 funcionários, conforme Tabela 01 a seguir:

Tabela 01: Número de funcionários na cadeia produtiva da reciclagem (RAIS, 2006)

\begin{tabular}{|l|l|l|l|l|l|}
\hline Local/ano & $\mathbf{2 0 0 0}$ & $\mathbf{2 0 0 1}$ & $\mathbf{2 0 0 2}$ & $\mathbf{2 0 0 3}$ & $\mathbf{2 0 0 4}$ \\
\hline SP & 8.918 & 8.986 & 11.072 & 13.190 & 16.401 \\
\hline $\begin{array}{l}\text { Outros } \\
\text { estados }\end{array}$ & 13.796 & 14.592 & 17.667 & 21.417 & 28.655 \\
\hline Brasil & 22.714 & 23.578 & 28.739 & 34.607 & 45.056 \\
\hline
\end{tabular}

Fonte: RAIS (2006) Apud SMTRAB (2007, p.54)

Assim, segundo relatório da Smtrab (2007:54),

De 2000 a 2004 houve um aumento de 108\% no número de funcionários empregados formalmente nesta cadeia, sendo maior o crescimento das empresas de reciclagem de sucatas não-metálicas com 129\% e com menor crescimento as de sucatas metálicas com $56 \%$ de crescimento. Porém, o grande contingente que trabalha nesta cadeia o faz informalmente, e o principal agente desta cadeia é o catador que trabalhando de forma organizada ou individualmente faz coleta de resíduos nos centros urbanos. 
Mas, estes números se referem ao setor formal, e representam uma parcela irrisória em relação ao quadro geral dos agentes que atuam na reciclagem, sobretudo em relação aos comerciantes (definidos como sucateiros), e catadores. Estes dois agentes (comerciantes e catadores), por sua vez, estão concentrados no patamar inferir de uma estrutura industrial piramidal, e realizam as atividades inscritas na chamada primeira etapa do processo de reciclagem, denominada de "recuperação", como já visto.

Porém, para que os diferentes segmentos industriais possam incorporar e/ou expandir sistematicamente o uso das matérias-primas oriundas dos materiais recicláveis em seus processos produtivos, é necessário que as mesmas sejam produzidas de acordo com alguns parâmetros de produtividade, sintetizados no tripé quantidade, qualidade e freqüência. Ou seja, não basta apenas aumentar o volume de materiais recicláveis disponibilizados para a indústria. O referido aumento deve ser acompanhado por parâmetros de qualidade ${ }^{121}$ estabelecidos pelos próprios segmentos industriais e cuja freqüência de fornecimento esteja ajustada ao pleno funcionamento das linhas de processamento das indústrias.

Será demonstrado nos Capítulos seguintes, que a reciclagem realizada no Brasil apresenta um aparente paradoxo. O país participa do ranking mundial dos países com maiores índices de reciclagem, porém os programas de coleta seletiva oficiais existentes são ínfimos.

Arlete Moysés Rodrigues, em sua pesquisa realizada em meados da década de 90 afirmava:

Se o lixo como "mercadoria" mais generalizada é recente, é ainda mais recente a
atuação do Estado - poder local - nesta questão. Num passado recente a
iniciativa da reciclagem provinha das próprias empresas. Na verdade estas
empresas continuam com as mesmas formas de aquisção do material reciclável,
pois afirmam que a coleta seletiva, realizada pela Prefeitura, representa ainda
muito pouco em relação à produção dos resíduos. (Rodrigues, 1996:140)

${ }^{121}$ (...) Da qualidade da matéria-prima depende em parte a taxa de lucro. Bom material deixa menos resíduos; é preciso, portanto, menor massa de matéria-prima para a absorção do mesmo quantum de trabalho. Além disso a resistência que a máquina de trabalho encontra é menor. Em parte isso afeta até mesmo a mais-valia e a taxa de mais-valia. Com matéria-prima ruim, o operário precisa de mais tempo para processar o mesmo quantum; (...) a reprodução e acumulação do capital (...) depende ainda mais da produtividade do que da massa de trabalho empregada. (Marx, O Capital. v.III, tomo I, Pp. 64-65) 
Passada uma década, a situação relatada pela autora não se alterou substancialmente, como podemos depreender da análise comparativa entre, de um lado, os crescentes índices de reciclagem, e de outro, o número relativamente reduzido de Prefeituras que realizam a Coleta Seletiva.

Este aparente paradoxo - altos índices de reciclagem versus reduzido número de programas de coleta seletiva oficiais - pode ser explicado pela análise do conjunto de atividades que compõem a base da indústria da reciclagem. Esta base se encontra incrustada no circuito comercial, onde atuam os comerciantes de recicláveis em torno dos quais orbitam milhares de catadores, numa situação majoritariamente de informalidade.

Como já ressaltava Rodrigues (1996:164), o processo de separação não é novo. O novo é a forma generalizada e ampla deste processo, principalmente com intervenção do poder local [que] auxilia a transformação do lixo em resíduo e torna evidente que estes resíduos são novas mercadorias. ${ }^{122}$

Temos aqui uma convergência dos fatores envolvidos. Ou seja, para que esta indústria continue expandindo sua produção, inclusive direcionada ao exterior, precisa de uma rede de fornecedores devidamente legalizados, inclusive em observância às relações de trabalho. Para tanto, este setor industrial, como qualquer outro, parece não poder prescindir do apoio do Estado. Encontramos em Rodrigues (1996:141) uma referência sobre a participação do poder local frente "aos novos interesses" em torno do processo de reciclagem: o poder local, através das formas de incentivo à separação do lixo doméstico, passa a intervir e até acelerar as formas de "produção e apropriação" desta nova mercadoria. Altera-se, desse modo, a importância da coleta seletiva e da reciclagem nos equipamentos de serviços coletivos em todos os centros urbanos.

Assim, as empresas que realizam a reciclagem, ou consomem matériasprimas provenientes de materiais reciclados, apresentam uma pauta de reivindicações ao Estado, direcionada à estruturação e expansão deste novo setor produtivo. Destaca-se desta pauta algumas questões, a seguir enunciadas:

a) incentivos fiscais a título de investimentos em infra-estrutura e equipamentos para as linhas de processamento de recicláveis;

\footnotetext{
${ }^{122}$ Grifo nosso.
} 
b) isenções fiscais sobre os produtos que utilizam recicláveis, evitando o mecanismo da bi-tributação (pois, segundo seus defensores, os recicláveis são oriundos de produtos que já foram tributados anteriormente);

c) abatimento de multas ambientais, pois indústrias poluidoras estariam minimizando seus impactos ambientais ao investirem na reciclagem;

d) dentre outros diversos;

Devemos destacar nesta pauta as propostas que visam adequar as leis ambientais aos interesses econômicos dos empresários, a exemplo das controvérsias em torno do Plano Nacional de Resíduos Sólidos em tramitação acerca de uma década na esfera do governo federal. Disto se destaca a questão da responsabilização pela gestão dos resíduos por parte dos geradores, com aplicação de multas aos seus infratores. Um dos mecanismos das indústrias para se assumirem responsáveis pelos seus resíduos, constitui-se na internalização da reciclagem em seus processos produtivos. Afinal, se a responsabilidade pela gestão dos resíduos cabe aos seus geradores, faz-se a pergunta: sobre quem mais recairia a responsabilidade pelo manejo dos resíduos, senão sobre as empresas que deram origem aos produtos? Mas a indústria aqui aparece como uma "co-responsável" ao lado do Estado, este sim o principal responsável pela gestão dos resíduos, como prevê, inclusive, a Constituição de 1988. Por sua vez, entre a indústria que produz as mercadorias, e os resíduos resultantes do consumo, estão os consumidores. Daí algumas prefeituras adotarem "taxas do lixo", dividindo com os cidadãos (consumidores finais) os custos com a destinação final dos resíduos. Como os recicláveis são gerados de modo indiferenciado em meio ao lixo, os resíduos sólidos urbanos ficam sob a responsabilidade da gestão pública municipal. Devemos observar que a Carta Magna de 1988 refere-se à responsabilidade do Estado pela gestão do lixo que, em princípio, não se confunde com os materiais recicláveis.

O que a coleta seletiva tenta fazer é justamente demarcar esta diferenciação: o lixo, indesejável, deve continuar sendo de propriedade do Estado, enquanto os materiais recicláveis passam a ser disputados pelos mais diversos "proprietários". A este respeito existe inclusive uma discussão sobre "quem seja o dono do lixo". A resposta de que o lixo é de propriedade da prefeitura parece estar correta (segundo regem os instrumentos legais), mas a pergunta deveria ser refeita: 
"quem são os donos dos materiais recicláveis?", porque é isto o que interessa. Configura-se um campo de tensões e conflitos. O Estado deve arcar com os custos de gestão do lixo, mas no meio do "seu" lixo há algo de potencial valor - os materiais recicláveis, cujo valor só pode ser realizado quando os recicláveis são disponibilizados para novos processos produtivos. Por isso, passam a ser coletados separadamente, seja pelas empresas de limpeza urbana, ou seja pelas cooperativas de catadores credenciadas pelos programas municipais.

Se a administração pública não pode, por natureza, agir como uma empresa privada obtendo lucros com a venda dos recicláveis, pode diminuir seus custos com a destinação final dos resíduos enviados aos aterros sanitários, desviando parte dos resíduos para fora da rota de descarte final. Ocorre, porém, que a coleta seletiva demonstra ser onerosa aos cofres públicos, pois para funcionar requer uma verdadeira estrutura industrial, que são os centros de reciclagem, com seus galpões, com seus equipamentos tais como esteiras, prensas, caminhões, e além de tudo, trabalhadores organizados.

Assim, mesmo com altos custos, as prefeituras municipais, através de seus sistemas de limpeza urbana, passam a adotar gradativamente a coleta seletiva dos resíduos sólidos, como demonstra a pesquisa Ciclosoft realizada pela ONG CEMPRE, exposto adiante. E assim, com a difusão da coleta seletiva realizada com recursos públicos arcados pelas prefeituras, as indústrias recicladoras vão ampliando sua rede de fornecedores institucionalizados e inscritos no setor formal, arquitetando lentamente $\mathrm{o}$ ajuste de suas cadeias produtivas, retirando-as da informalidade. Portanto, desenha-se um processo de privatização de uma estrutura pública, que aparece como um benefício para toda a sociedade, inclusive pela inclusão social de muitos catadores... Seria este o modelo, ou caminho, que se desenha para toda a reciclagem, com a participação do Estado nestas atividades?

Como já observado, o aumento da produtividade das cooperativas reduz o número de catadores necessários para o conjunto das atividades. Portanto, há inclusão de um número limitado de catadores em programas oficiais de coleta seletiva que resulta na exclusão absoluta dos demais catadores, em número incomparavelmente maior. 
Ou seja, a expectativa do aumento de produtividade, atribuído às cooperativas devidamente estruturadas, parece decretar o descarte futuro de parte significativa dos milhares de catadores de materiais recicláveis mobilizados pelo estágio ainda vigente.

Agora, para destravar as limitações impostas à maior produtividade do trabalho, sem poder incorporar a criação de postos de trabalho diretos (com seus respectivos encargos trabalhistas), a indústria tem como alternativa as cooperativas que são, em si, autônomas, aparecendo simplesmente como suas fornecedoras de matérias-primas. Embora a separação entre, de um lado, indústrias recicladoras ou consumidoras de materiais recicláveis e, de outro, cooperativas de reciclagem esteja delimitada, supondo a autonomia das cooperativas em relação às indústrias, estas últimas ditam as características dos produtos que devem ser preparados pelas primeiras. Ora, nisto reside a subsunção dos processos de trabalho realizados nas cooperativas ao capital produtivo. Por outro lado, além de manterem a produção de acordo com as necessidades da indústria - requisito para que participem do seleto grupo de suas fornecedoras - as cooperativas devem arcar com todos os custos referentes ao processo de trabalho, no que se inclui sua remuneração.

Estamos diante do aprofundamento da divisão do trabalho, este que formaliza uma modalidade de trabalho, a do catador, e que repercute verticalmente na sociedade: alcança a jurisprudência nacional e internacional, redefine a estrutura empresarial e gera fluxos monetários de diferentes ordens (seja no interior das cadeias produtivas da indústria propriamente dita, ou na miríade de negócios associados, a exemplo dos projetos financiados no âmbito do Terceiro Setor). Diferentes esferas da sociedade são mobilizadas pelo processo: a iniciativa privada (indústria e comércio), a sociedade civil organizada (ONG's do Terceiro Setor), trabalhadores (os catadores), toda a população convocada às práticas da educação ambiental, separando na fonte os resíduos do seu consumo.

No contexto da institucionalização da base da indústria da reciclagem se encontra o cadastro das atividades do catador na Classificação Brasileiro de Ocupações - CBO. Anunciada como uma das conquistas do Movimento Nacional dos Catadores de Materiais Recicláveis, este cadastro pode ser compreendido como uma passo em direção à referida institucionalização. Prevê, inclusive, o trabalho 
combinado no interior do conjunto de atividades, o que fica mais evidente na definição das tarefas na cooperativa ( ANEXO 10).

Por fim, entende-se que a base da indústria da reciclagem tende a ser institucionalizada a longo prazo, sem contudo deixar de apresentar uma caracteriza dual: formal-informal.

\subsubsection{A organização da base da indústria da reciclagem: as cooperativas}

A indústria da reciclagem está sendo estruturada no contexto de políticas neo-liberais, arregimentando trabalhadores sobrantes dos mais diversos setores produtivos. Reinseridos produtivamente na base da indústria da reciclagem ,subsetor da indústria de transformação (CNAE/RAIS), os catadores podem ser entendidos como "síntese de múltiplas determinações". Isto é válido tanto para os milhares de catadores que trabalham individualmente na catação nos diversos contextos urbanos do país, quanto no caso dos catadores organizados em grupos, cujo modelo mais ajustado aos desígnios de estruturação do setor produtivo é o das cooperativas.

Se na coleta não oficial os agentes envolvidos são, de um modo geral, catadores, carrinheiros, sucateiros e indústrias (Calderoni, 2003), no segundo caso os agentes tendem a ser: cooperativas, vinculadas ou não a Programas de Coleta Seletiva implantados pelas Prefeituras, e as indústrias.

Portanto, entende-se que a atuação dos comerciantes de recicláveis é parte integrante do estágio até agora vigente, no processo de desenvolvimento deste setor, cujo mercado ainda está se formando e se diversificando continuamente. Seus principais agentes - industriais e comerciantes - dividem os custos e os lucros (assim como em outros ramos), como já foi demonstrado, por exemplo, pela pesquisa desenvolvida por Calderoni em meados da década de 90.

Porém, o processo recente de organização da base desta indústria, no sentido de sua institucionalização, parece caracterizar um novo estágio do seu processo de estruturação. Nele, a esfera de atuação dos capitalistas comerciantes, que atravessam a relação entre catadores e indústria, tende a ser cindida por um 
novo arranjo produtivo, no qual as cooperativas de catadores passariam a fornecer os materiais recicláveis diretamente às indústrias.

Por sua vez, o processo de institucionalização incide sobre a situação vigente, caracterizando um campo conflituoso entre os agentes que já atuam na base da indústria e as novas normas - e novos agentes - que entram em cena.

A envergadura deste processo, que parece responder às determinações impostas à expansão do setor, inclusive com sua projeção internacional, apresentase como uma agenda da indústria na formulação de políticas públicas e incentivos governamentais. Desta agenda, destacam-se as políticas públicas e investimentos destinados à organização da base da indústria. Ora, nela se realiza a chamada primeira etapa do processo de reciclagem, ou seja, as atividades da catação ou coleta, transporte (com uma verdadeira frota de carrinhos, carroças movidas à tração humana), triagem, prensagem e enfardamento que, no caso dos programas de coleta oficial, calcula-se que os custo com mão-de-obra correspondem a cerca de $90 \%$ (conforme Aguiar \& Philippi, 2000). Portanto, do conjunto de políticas públicas destinadas à estruturação do setor industrial da reciclagem, identificamos uma vertente nitidamente direcionada à institucionalização da base desta indústria, mais precisamente, à organização do processo de trabalho que nela se concentra.

Ou seja, o ajuste estrutural da indústria da reciclagem se dá na sua base, no sentido de desviar o fluxo dos materias da órbita dos comerciantes em direção às cooperativas. Porém, este ajuste não se refere estritamente às relações de trocas comerciais, como é o caso da prática de comprar para vender mais caro exercida pelos comerciantes do ramo. Incrustado no circuito comercial, encontra-se as atividades iniciais do processo de reciclagem, tais como a triagem, a prensagem, o enfardamento. Portanto, não se trata exatamente de atividades comerciais, mas de atividades que já integram, desde a base, a produção das matérias-primas.

É inegável que os altos índices de reciclagem existentes no Brasil são resultantes do trabalho de milhares de catadores informais, que trabalham individualmente e são geralmente denominados de "catadores avulsos", ou mesmo quando reunidos em grupos com diferentes níveis de organização.

No entanto, existe uma tendência à concentração do conjunto de atividades inscritas na base da indústria da reciclagem (coleta, triagem, 
enfardamento...) em "unidades de processamento" mais eficientes, como condição de ajuste e consolidação da reciclagem como um novo setor produtivo. Estas "unidades de processamento mais eficientes" são exatamente as cooperativas, prescritas pelas políticas públicas destinadas à gestão dos resíduos sólidos urbanos.

Para compreender como este processo vem ocorrendo no contexto nacional, utilizou-se o documento "Análise do custo de geração de postos de trabalho na economia urbana para o segmento dos catadores de materiais recicláveis" ${ }^{123}$. Este documento traz um panorama geral da situação dos grupos de catadores no contexto nacional, os quais apresentam diferentes níveis de organização. Além das informações sobre as cooperativas cadastradas no MNCR, aponta para a tendência de institucionalização da base da indústria da reciclagem. Optou-se por se apresentar a análise feita sobre o mesmo como Anexo. O mesmo traz informações minuciosas sobre a proposta de criação de 39.000 postos de trabalho para os catadores de materiais recicláveis em todo o país. (ANEXO 09).

As propostas de geração de aproximadamente 39.000 postos de trabalho para o segmento dos catadores de materiais recicláveis parecem de fato ajustadas ao aprimoramento do setor industrial da reciclagem. O que, por sua vez, não contempla os cerca de 500.000 a 800.000 catadores existentes no Brasil. Ou seja, este verdadeiro exército de catadores é constituído por trabalhadores supranuméricos, supérfluos, sobrantes, o que fica mais evidente com o aumento da produtividade das cooperativas (menor número de catadores disponibilizando maiores volumes de materiais às indústrias).

123 Este estudo é um dos produtos resultantes do Convênio MDS-OAF (002/04) - "ACÕES DE DESENVOLVIMENTO SOCIAL JUNTO AOS CATADORES DE MATERIAIS RECICLÁVEIS" (20042006). Fonte: http://www.cgu.gov.br/sfc/convenio/convenios.asp. Acessado em 30/03/2006. 


\subsection{Os bilhões ganhos com a Reciclagem}

Nos países desenvolvidos, a reciclagem é geralmente realizada a partir do direcionamento da legislação nacional, cuja regulamentação e incentivos econômicos são importantes impulsionadores de seu desenvolvimento. No Brasil, não existe uma legislação nacional voltada para a gestão integrada dos resíduos sólidos que estimule a sua diminuição, reuso, reciclagem e destinação final correta, ou ainda que co-responsabilize seus geradores (SMTrab, 2007:3) ${ }^{124}$.

Enquanto o processo de discussão e aprovação da Política Nacional de Resíduos Sólidos se arrola acerca de uma década no âmbito do Governo Federal, prefeituras e empresas permanecem desobrigadas a realizarem a gestão integrada dos resíduos sólidos, no que se inclui a coleta seletiva e a reciclagem.

Ao contrário, a reciclagem realizada no Brasil ocorre principalmente em função de sua viabilidade econômica, com base na exploração do trabalho de milhares de catadores. Disto resulta os índices de reciclagem observados para os diferentes tipos de materiais, consumidos como matérias-primas pelos mais diversos setores produtivos.

Em "Os bilhões perdidos no lixo", Calderoni (2003:281) calculou que em 1996 a reciclagem havia proporcionado uma economia de cerca de 1,2 bilhões de reais, contabilizados em termos de recursos diversos, tais como energia, água e matérias-primas. Por outro lado, segundo este autor, 4,6 bilhões de reais haviam sido perdidos, pois a reciclagem poderia ter proporcionado cerca de 5,8 bilhões de reais, caso tivesse alcançado maiores índices de reciclagem. Após uma década, o setor atingiu índices mais elevados, participando do ranking dos países que mais reciclam, com destaque para aqueles do primeiro mundo. Assim, os ganhos obtidos atualmente com a reciclagem ultrapassam as estimativas feitas por aquele autor na década passada, contabilizando cerca de $\mathrm{R} \$ 8$ bilhões ao ano.

\footnotetext{
${ }^{124}$ Desenvolvimento de estudos e pesquisas necessários à definição, análise, implementação e avaliação de políticas de ocupação e renda para o Município de São Paulo (Arranjos Produtivos Locais - APL's) - Estudos e Pesquisas de Cadeias Produtivas Selecionadas. SMTRAB.

FESPSP.PNUD, v.1, jan/2007.
} 
Calderoni (2003) defende que a SOCIEDADE INTEIRA ganha com a economia proporcionada com o desenvolvimento da reciclagem. Os bilhões ganhos com a reciclagem - ao contrário de serem perdidos - são apropriados pelas empresas que integram a matéria-prima "material reciclado" em seus processos produtivos. É o que se apresenta a seguir, com base na análise dos cálculos de Calderoni sobre "os bilhões perdidos no lixo".

Calderoni (2003) desenvolver uma proposta com a qual pretende comprovar que a reciclagem traz benefícios para a SOCIEDADE INTEIRA. O autor expõe, e adota, algumas das definições de uma proposta anteriormente elaborada por Duston (1993), e faz a crítica às limitações da equação proposta pelo mesmo.

Passemos a considerar a fórmula proposta por Calderoni (2003: 87):

Os custos evitados (despesas com aterros sanitários ou incineração e com as operações de coleta, transporte e transbordo) na formulação de Duston (1993, p.41), aplica-se a seguinte fórmula: $G=(V-V)-C-E$, onde ${ }^{125}: G=$ ganho com a reciclagem; $V=$ venda/compra dos materiais recicláveis; $C=$ custo do processo de reciclagem; $E$ = custo evitado de coleta, transporte, transbordo e disposição final. Propõe-se, no presente estudo, que sejam acrescentados, também à formula anterior, os ganhos decorrentes da economia de energia (W); os ganhos advindos da economia de matérias-primas (M); assim como os ganhos da redução dos custos com controle ambiental $(A)$, e com o consumo de água $(H)$ proporcionados pela reciclagem, além de outros de mais difícil mensuração (D). Tem-se, portanto, a seguinte equação: $G=(V-V)-C+E+W+M+H+A+D$

Pois bem. Em sua equação, Calderoni (2003:87) considera não só os ganhos decorrentes da economia de matérias-primas $(\mathrm{M})$, mas diversos outros ganhos. Porém, ao analisarmos o Quadro 08 "Ganhos de cada agente econômico com o processo de reciclagem do lixo", aparece o agente "SOCIEDADE", para o qual resulta o montante dos ganhos obtidos com a reciclagem. Ora, é preciso desvendar a ideologia contida nesta equação, pois retira da indústria o papel fundamental de mobilizadora do processo e detentora dos lucros:

\footnotetext{
${ }^{125}$ Nota do autor: Notar que "(V-V)" é proposta da presente Pesquisa; a inclusão de "E" é contribuição de Duston.
} 


\section{Quadro 08:}

Ganhos de cada agente econômico com o processo de reciclagem do lixo

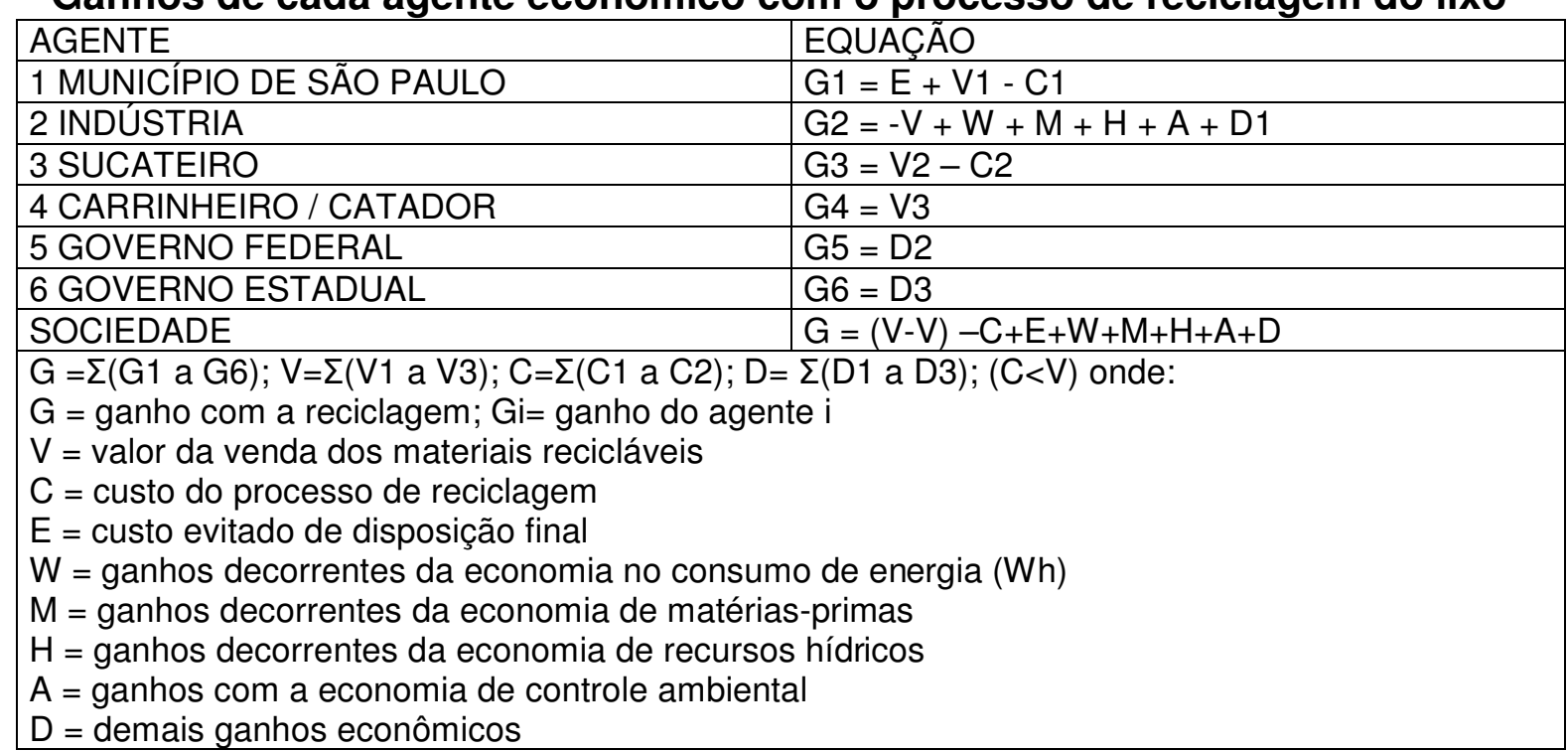
Fonte: Calderoni (2003:87)

Se retirarmos do Quadro 08 apresentado o agente "SOCIEDADE", fica mais do que evidente os ganhos, e não os custos, que a indústria obtém, de toda a "SOCIEDADE" no processo de reciclagem. Ademais, o processo não se encerra na indústria, pois a matéria-prima "material reciclado" é transformada em novos produtos, mercadorias a serem vendidas e novamente consumidas, realizando o ciclo da reprodução do capital.

Lembramos ainda de Rodrigues (1996:111) quando assinala o fato das indústrias não reduzirem os preços dos produtos mesmo quanto utilizam matériasprimas mais baratas advindas dos recicláveis, o que implica a possibilidade de auferir maiores lucros.

É o que demonstra o faturamento calculado para cada segmento deste "sub-setor da indústria de transformação". Os índices de reciclagem, e o faturamento desta verdadeira indústria são divulgados pelas Associações de cada um dos segmentos aqui apresentados: papeleiro, vidreiro, latas de alumínio e plásticos (PET e plásticos rígidos) que juntos representam $65 \%$ do total de materiais reciclados anualmente.

Veremos que na base deste setor produtivo que vem se erguendo como uma verdadeira indústria, movimentando bilhões de reais por ano, está inscrito o trabalho de milhares de catadores. Não estamos falando de "geração de trabalho e 
renda" ou de "empregos diretos e indiretos". Estamos diante da expropriação da força vital destes milhares de catadores, os quais sobrevivem na condição de trabalhadores sobrantes.

De acordo com o banco de dados da ONG "Compromisso Empresarial para a Reciclagem" - CEMPRE (2008), existe atualmente no Brasil cerca de 3.000 estabelecimentos que atuam no setor da reciclagem, classificados em sucateiros, cooperativas e recicladores. A Região Sudeste concentra 50\% deste total (1519 estabelecimentos, divididos em 595 sucateiros, 304 cooperativas e 619 recicladores). São Paulo, por sua vez, é o Estado com maior número destes estabelecimentos, num total de 990, divididos em 368 sucateiros, 197 cooperativas e 425 recicladores, conforme podemos observar nos Gráficos 01 e 02 a seguir apresentados. O plástico é o principal material reciclado (cerca de $80 \%$ dos recicladores), o que pode ser explicado, ao menos parcialmente, pelo menor custo de investimento de suas linhas de processamento (principalmente a reciclagem mecânica que produz granulações, denominadas de flakes e pellets) seguido por metal e papel (cerca de $8 \%$ cada) dentre outros, como vidros, longa vida, baterias, pneus e pilhas divididos por um menor número de estabelecimentos. Na metrópole de São Paulo vamos encontrar uma similar divisão entre os segmentos que atuam na reciclagem, como veremos com mais profundidade posteriormente.

Ainda que o CEMPRE atualize permanentemente seu banco de $\operatorname{dados}^{126}$, devemos fazer duas observações importantes.

Primeiramente, o cadastro mantido pelo CEMPRE representa uma significativa amostra dos estabelecimentos formais, ou com certo nível de organização. A maior parte dos cadastros apresenta CNPJ, principalmente os recicladores, seguido pelas cooperativas e com menor ocorrência para os sucateiros, demonstrando outra tendência do setor, ou seja, o aumento da informalidade em direção à base das cadeias produtivas.

\footnotetext{
${ }^{126}$ www.cempre.org.br. As informações trabalhadas nesta Tese foram disponibilizadas pelo CEMPRE, proveniente de um cadastro mais completo do que aquele divulgado no site da ONG.
} 


\section{Gráfico 01}

Sucateiros, Cooperativas e Recicladores - Regiões do Brasil (2008)

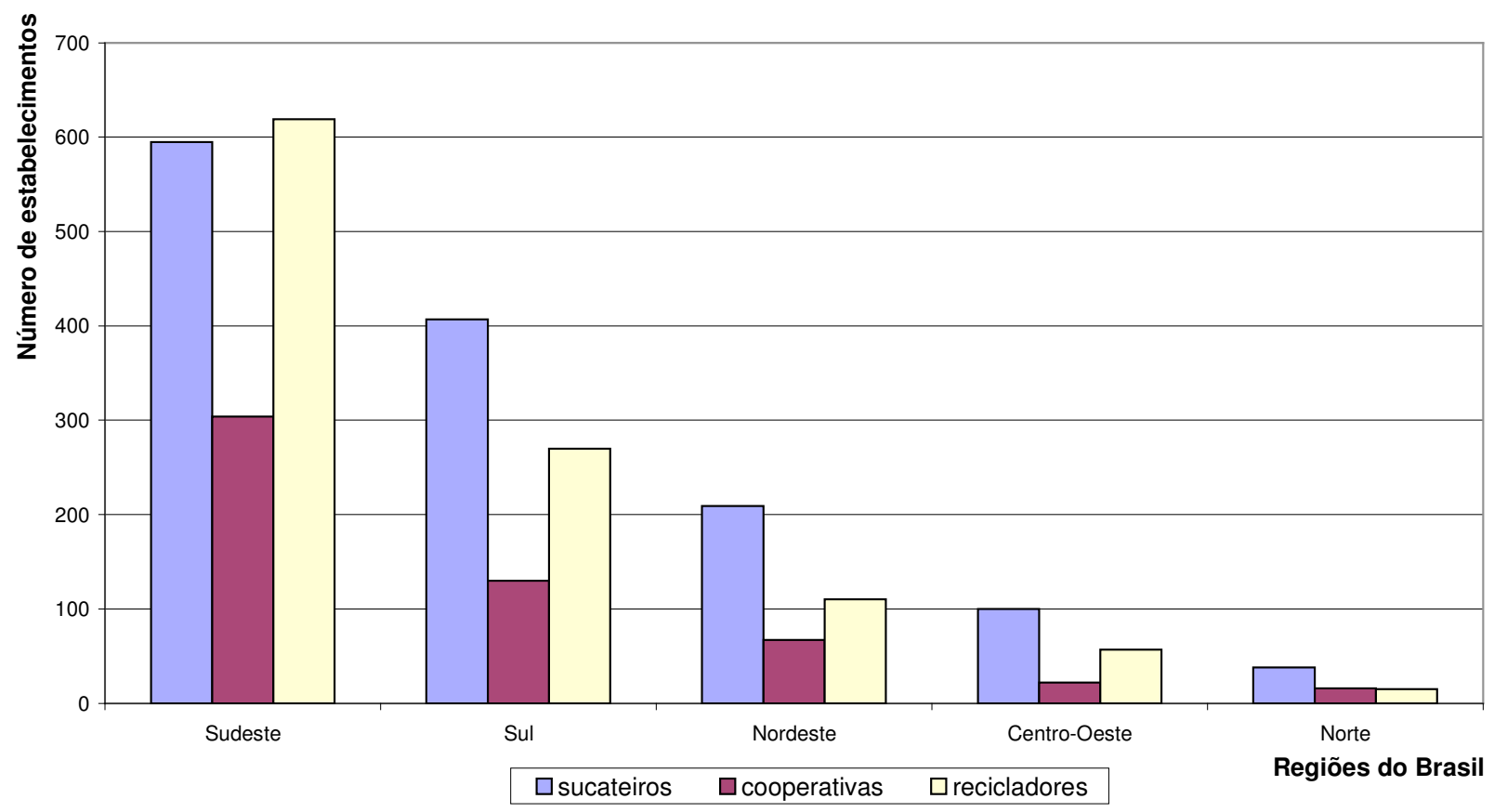

Fonte: CEMPRE (2008). Elaboração: Rosalina Burgos (2008) 
Gráfico 02 Sucateiros, Cooperativase Recicladores

Brasil (2008)

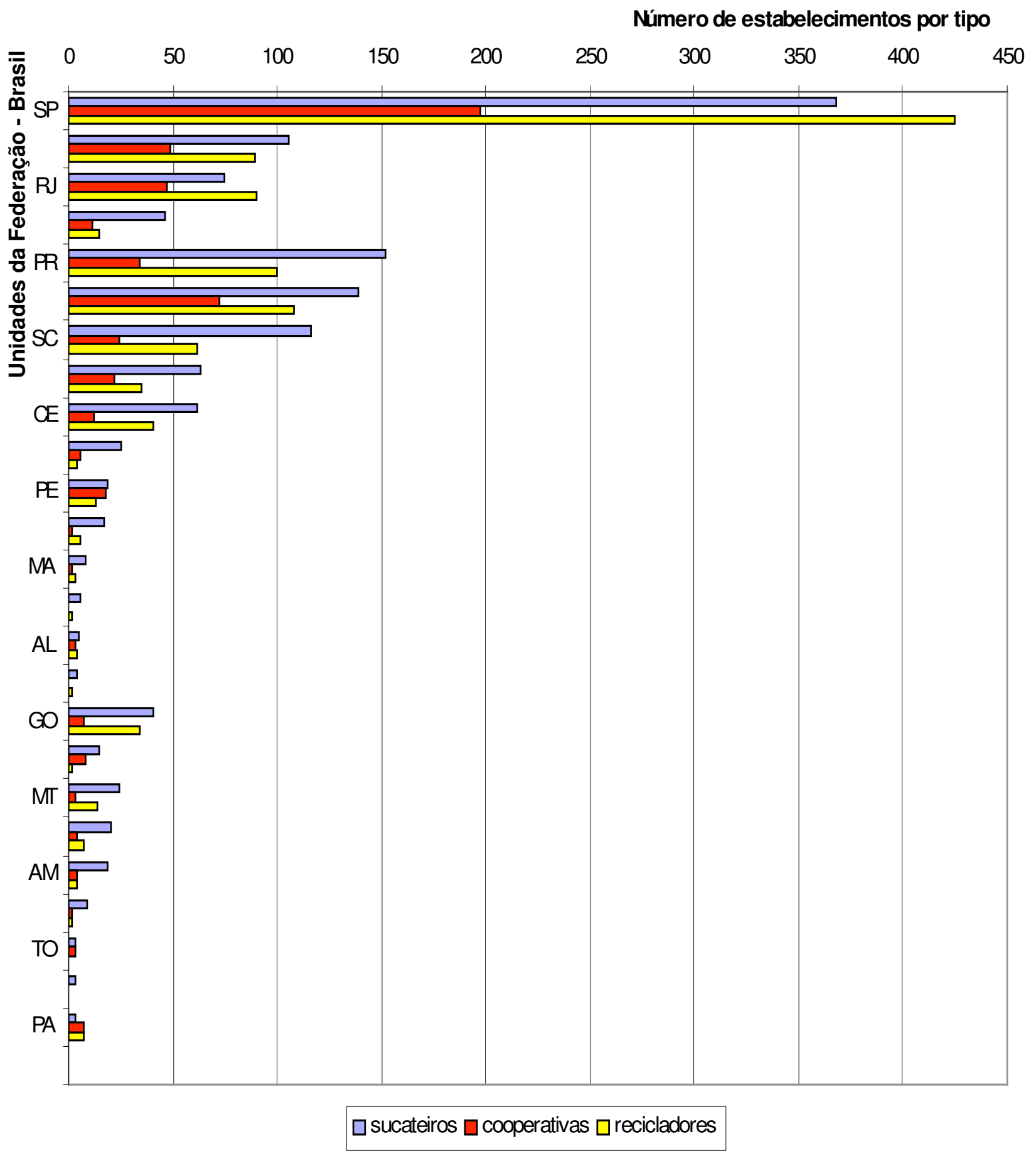

Fonte: CEMPRE (2008). Elaboração: Rosalina Burgos (2008) 
Em segundo lugar, é justamente na base das cadeias produtivas onde se concentra a maior parte dos "estabelecimentos" que atuam no setor, ao redor dos quais trabalham milhares de catadores. Denominados de ferros-velhos, sucateiros, depósitos ou reciclagens, estes "estabelecimentos" atuam normalmente na informalidade, sendo difícil mensurar quantos existem e em quais condições de funcionamento. Esta dificuldade foi encontrada na realização da pesquisa centrada no território da metrópole de São Paulo. Como alternativa de pesquisa, recorremos ao banco de dados da Supervisão de Vigilância em Saúde (SUVIS), a qual monitora locais vulneráveis ao mosquito da dengue - dentre eles os que desenvolvem atividades em reciclagem. $O$ fato de serem alvos do monitoramento da SUVIS já indica as condições insalubres de trabalho dos catadores. Não por acaso, existe a seguinte advertência no site do CEMPRE: "O CEMPRE não se responsabiliza pela conduta ética e profissional das cooperativas e/ou empresas aqui relacionadas".

Entretanto, os Índices de Reciclagem e o concomitante faturamento do setor são anunciados pelas Associações representativas das principais empresas de cada segmento desta indústria. É o que apresentamos no próximo sub-capítulo. 


\subsection{Panorama recente dos Índices de Reciclagem no Brasil}

Apresenta-se aqui um breve panorama dos índices de reciclagem e de faturamento de alguns dos principais segmentos que internalizam a reciclagem em seus processos produtivos, bem como algumas informações sobre os materiais recicláveis selecionados. Nosso objetivo é expor elementos para a discussão acerca da irrisória contribuição da coleta seletiva oficial frente aos Índices de Reciclagem. E, mais do que isto, argumentar que a quase totalidade da coleta de materiais para a reciclagem é realizada de modo informal pelos catadores em todo o país.

Assim, para esta primeira parte, utilizamos as publicações de três fontes, cujas entidades desenvolvem pesquisas no setor da reciclagem: Fichas Técnicas da ONG "Compromisso Empresarial para a Reciclagem" - CEMPRE; Panorama dos Resíduos Sólidos no Brasi//2007 da Associação Brasileira de Empresas de Limpeza Pública e Resíduos Especiais - ABRELPE, e o Diagnóstico do Manejo de Resíduos Sólidos Urbanos/2006 do Sistema Nacional de Informações sobre Saneamento SNIS (Secretaria Nacional de Saneamento Ambiental do Ministério das Cidades). Para complementar estas fontes, consultamos também as informações disponibilizadas pelas Associações dos principais segmentos aqui analisados: Bracelpa (Setor papeleiro e de celulose), Associação Brasileira de Embalagens PET - AbiPet, ABREMPLAST (Associação Brasileira de Recicladores de Materiais Plásticos), Abividro (setor vidreiro), Associação Brasileira do Alumínio - ABAL e Associação Brasileira dos Fabricantes de Latas de Alta Reciclabilidade - Abralatas.

A primeira informação a ser ressaltada é a de que o setor da reciclagem movimentou entre 2007 e 2008 cerca de $\mathrm{R} \$ 8$ bilhões ao ano, montante obtido sem a existência de marcos regulatórios que normatizem este mercado, tal como a Política Nacional de Resíduos Sólidos - PNRS, em tramitação na esfera federal a mais de uma década ${ }^{127}$.

A inexistência de leis que normatizem ou incentivem este setor não demonstra ser um fator impeditivo aos Índices de Reciclagem e faturamento alcançados. Por sua vez, as grandes empresas, além de atuarem sob a forma de

${ }^{127}$ Fonte: Jornal do Senado. Reciclagem movimenta $R \$ 8$ bilhões mas falta lei. 23/08/2008. 
monopsônio ou oligopsônio em alguns dos principais segmentos, determinando os preços e a demanda de quantidade dos materiais, simplesmente não se responsabilizam "pela conduta ética e profissional das cooperativas e/ou empresas", conforme a advertência do próprio CEMPRE, já citada.

Há mais do que uma isenção nesta postura: há conivência e sobretudo conveniência, pois os bilhões faturados pela indústria da reciclagem não podem ser explicada senão pelo trabalho de milhares de catadores. Por outro lado, modernos processos produtivos, como os "Mecanismos de Desenvolvimento Limpo" - MDL, que anunciam uma indústria limpa, sustentável, com responsabilidade social e ambiental, acabam sendo expressão de uma forte ideologia. Justamente porque esta mesma "indústria limpa, social e ambientalmente correta", consome matéria-prima oriunda de processos produtivos que consomem a vida do próprio catador.

Como já exposto, calcula-se a existência de ao menos 500 mil catadores em todo o país, além de aproximadamente 550 cooperativas, e algo em torno de 50 mil pessoas diretamente empregadas em indústrias recicladoras ${ }^{128}$. Não estamos falando em geração de trabalho e renda, muito menos de empregos, mas de trabalho mal pago e não-pago.

De acordo com o CEMPRE (2008), a reciclagem atinge atualmente cerca de $12 \%$ do lixo urbano, o qual é calculado em torno de 61,5 milhões de toneladas ao ano. Ou seja, cerca de 7.380 mil toneladas de materiais recicláveis retornam anualmente aos processos produtivos como matéria-prima, sendo que mais de $65 \%$ deste montante é composto pelos seguintes materiais: papéis (3.496.500 toneladas), plásticos (767.504 toneladas), vidros (400.000 toneladas) e latas de alumínio (160.600 toneladas).

\section{LATAS DE ALUMÍNIO}

O Brasil vem sendo, ao longo dos últimos sete anos, líder mundial na reciclagem de latas de alumínio, atingindo o índice de reciclagem de 96,5\% em 2007 (11,3 bilhões de latas de alumínio, correspondentes a 160.600 mil toneladas) (Gráfico 03). Para tanto, calcula-se o trabalho de cerca de 130 mil sucateiros atuando

\footnotetext{
${ }^{128}$ Números divulgados pelo Jornal do Senado (23/08/2008) com base em informações do CEMPRE.
} 
na base desta indústria (CEMPRE, 2008), representando $50 \%$ do fornecimento à indústria, o qual é complementado por outras modalidades de "fornecedores" (tais como redes de supermercados, empresas e entidades da sociedade civil). No caso dos sucateiros, a média é de 50 toneladas ao mês, ou ainda 1,7 toneladas de latas de alumínio ao dia por cada sucateiro. Vale ressaltar que no cadastro do CEMPRE constam aproximadamente 1.350 sucateiros, ou seja, praticamente $1 \%$ do total, o que por sua vez indica o quadro de informalidade no qual atuam estes comerciantes de recicláveis. Lembramos ainda que apenas cerca de 260 sucateiros cadastrados no CEMPRE apresentam CNPJ.

\section{Gráfico 03: Evolução do Índice de Reciclagem de Latas de Alumínio}

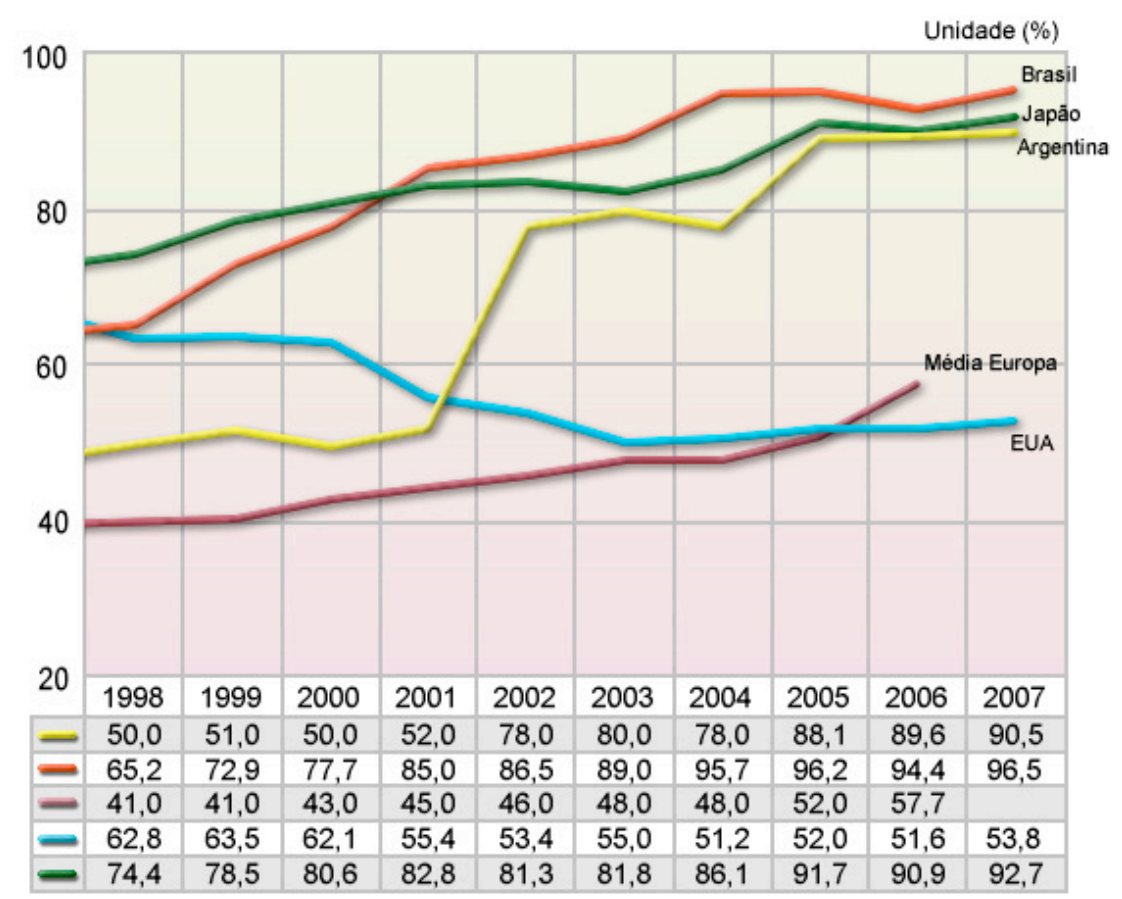

Fonte:www.abralatas.org.br

De acordo com a Associação Brasileira dos Fabricantes de Latas de Alta Reciclabilidade - ABRALATAS, o preço da sucata "lata de alumínio" acompanha o preço deste metal no mercado internacional. Como se trata de uma liga metálica mais pura, as sucatas de latas de alumínio são transformadas em lâminas destinadas geralmente à produção de novas latas ou na fundição para peças automobilísticas. Esta é a sucata mais rentável dentre os materiais recicláveis. Sua 
tonelada apresenta o preço médio de $\mathrm{R} \$ 3.500$ (o quilo corresponde aproximadamente a 75 latinhas), e se transformou, para os consumidores finais, numa verdadeira moeda de troca, a exemplo de promoções onde os quilos desta sucata podem ser trocados por equipamentos. O CEMPRE dá alguns exemplos: cerca de 5.000 latas é eqüivalente a um ventilador de parede; 180 latas a uma fotocopiadora, ou ainda cerca de 80 mil latas corresponde a um microcomputador.

Tendo movimentado cerca de $\mathrm{R} \$ 1,7$ bilhão em 2006 , quase $30 \%$ deste montante foi incorporado na etapa da coleta, ou seja, na compra das latas usadas (praticada pelos comerciantes de sucata), correspondendo a $\mathrm{R} \$ 540$ milhões ao ano, cifra comparável ao desempenho de grandes empresas do país (CEMPRE, 2007). Segundo a ABRALATAS ${ }^{129}$, o segmento da reciclagem de latas de alumínio movimentou em 2007 cerca de 1,8 bilhão, e novamente a etapa da coleta foi responsável por $\mathrm{R} \$ 523$ milhões na economia nacional. Segundo esta Associação, esta cifra eqüivale à "geração de emprego e renda" para 180 mil pessoas. Com base num cálculo simples, podemos observar que esta afirmativa corresponde a uma remuneração mensal de aproximadamente $R \$ 240,00$, ou ainda de $R \$ 1,00$ a hora, considerando uma jornada normal de 8 horas de trabalho diário. Isto sem levar em conta as trocas sempre desiguais realizadas entre catadores, ou consumidores comuns, e os comerciantes. De qualquer forma, mais de $70 \%$ do faturamento deste segmento foi incorporado pelas etapas posteriores à comercialização, pela indústria recicladora propriamente dita.

Por fim, mesmo apresentando um índice de reciclagem de quase $100 \%$, a produção de latas de alumínio teve um aumento de $11 \%$ no ano de 2006 . Ou seja, ainda que o "R" da reciclagem seja aclamado, o "R" do reduzir parece não ser tão sedutor quanto o anterior... Esta tendência será observada em outros segmentos, como veremos.

\section{PLÁsTICO PET}

Além da liderança mundial na reciclagem de latas de alumínio, o Brasil é também vice-líder na reciclagem de garrafas de plástico tipo PET. Tendo consumido 
378 mil toneladas desta resina na fabricação de embalagens, o segmento apresentou índice de reciclagem de 51,3\% em 2006, logo abaixo do Japão que reciclou $62 \%$ deste tipo de plástico.

O PET pode ser reciclado de três maneiras diferentes, de acordo com a AbiPET $^{130}$. Vejamos o Quadro 09 a seguir:

\section{QUADRO 09}

\begin{tabular}{|l|l|}
\hline \multicolumn{2}{|c|}{ RECICLAGEM do plástico tipo PET } \\
\hline Química & $\begin{array}{l}\text { Utilizada também para outros plásticos, separa os componentes } \\
\text { do PET, fornecendo matéria-prima para solventes e resinas, } \\
\text { entre outros produtos. }\end{array}$ \\
\hline Energética & $\begin{array}{l}\text { O calor gerado com a queima do produto pode ser aproveitado } \\
\text { na geração de energia elétrica (usinas termelétricas), para } \\
\text { caldeiras e altos-fornos. O PET tem alto poder calorífico e não } \\
\text { exala substâncias tóxicas quando queimado. Outros materiais } \\
\text { combustíveis também podem ser utilizados. }\end{array}$ \\
\hline Mecânica & $\begin{array}{l}\text { Praticamente todo o PET reciclado no Brasil passa pelo } \\
\text { processo mecânico, que pode ser dividido em três fases: }\end{array}$ \\
\hline FASES DA RECICLAGEM MECÃNICA \\
\hline Recuperação & $\begin{array}{l}\text { Trata-se da coleta e triagem das garrafas PET, conferindo-Ihes o } \\
\text { status de matéria-prima. A separação por cor é necessária para } \\
\text { a fabricação de novos produtos e aplicação no mercado. A } \\
\text { prensagem facilita o transporte. }\end{array}$ \\
\hline Revalorização & $\begin{array}{l}\text { Com a moagem da PET, este material ganha valor no mercado. } \\
\text { Os flocos (flakes) mais refinados podem servir como matéria- } \\
\text { prima para novos produtos fabricados na fase seguinte. É } \\
\text { possível revalorizar ainda mais este material com a produção de } \\
\text { grãos de PET (pellets) que condensa o material, facilitando o } \\
\text { transporte e o desempenho na fase de transformação. }\end{array}$ \\
\hline Transformação & $\begin{array}{l}\text { Flocos ou granulados são transformados em novos produtos, } \\
\text { inclusive garrafas para produtos não alimentícios. }\end{array}$ \\
\hline
\end{tabular}

Fonte: AbiPET (2007)

Com a reciclagem química, no qual o PET pós-consumo é despolimerizado, recupera-se as matérias-primas básicas que the deram origem. Neste tipo de reciclagem é possível produzir a resina PET novamente. No entanto, a forma mais difundida é a reciclagem mecânica, dado o custo mais reduzido de sua linha de processamento.

\footnotetext{
${ }^{129}$ Fonte: ABRALATAS In ABRELPE. Panorama dos Resíduos Sólidos no Brasil, 2007.

130 http://www.abipet.org.br/reciclagem.php Acesso em 05/05/2008
} 
O segmento de reciclagem de embalagens PET está em franca expansão no Brasil. De acordo com a Ficha Técnica divulgada pelo CEMPRE (2007) o PET:

\begin{abstract}
é um poliéster termoplástico, tem como características a leveza, a resistência e a transparência, ideais para satisfazer a demanda do consumo doméstico de refrigerantes e de outros produtos, como artigos de limpeza e comestíveis em geral. A evolução do mercado e os avanços tecnológicos têm impulsionado novas aplicações para o PET reciclado, das cordas e fios de costura, aos carpetes, bandejas de ovos e frutas e até mesmo novas garrafas para produtos não alimentícios, já que esta aplicação ainda não é permitida pela ANVISA (Agência Nacional de Vigilância Sanitária). Sua reciclagem, além de desviar lixo plástico dos aterros, utiliza apenas $0.3 \%$ da energia total necessária para a produção da resina virgem. E tem a vantagem de poder ser reciclado várias vezes sem prejudicar a qualidade do produto final. Na coleta Seletiva, o PET representa em média $31 \%$ dos plásticos recicláveis.
\end{abstract}

A expansão do segmento da reciclagem de PET pode ser observada na Tabela 02 a seguir, onde consta a evolução da reciclagem de embalagens PET nos últimos anos:

Tabela 02 - Evolução da Reciclagem de Embalagens PET (1994-2006)

\begin{tabular}{lrr}
\hline Ano & Reciclagem de PET (t) & Índice (\%) \\
\hline 1.994 & 13.000 & 18,80 \\
\hline 1.996 & 22.000 & 21,00 \\
\hline 1.998 & 40.000 & 17,90 \\
\hline 2.000 & 67.000 & 26,27 \\
\hline 2.002 & 105.000 & 35,00 \\
\hline 2.004 & 173.000 & 48,00 \\
\hline 2.006 & 194.000 & 51,30 \\
\hline
\end{tabular}

Fonte: Associação Brasileira de Embalagens PET - ABIPET In ABRELPE. Panorama dos Resíduos sólidos no Brasil, 2007.

Seguindo esta tendência, cerca de 230 mil toneladas de PET foram recicladas em 2007, abastecendo diversos mercados. Atualmente, o principal consumo desta matéria-prima está na produção de fibra de poliéster para indústria têxtil, tais como fios de costura, forrações, tapetes e carpetes, mantas de TNT (tecido 
não tecido), entre outras. Ou ainda na fabricação de cordas e cerdas de vassouras e escovas. Outra parte é destinada à produção de filmes e chapas para boxes de banheiro, termo-formadores, formadores a vácuo, placas de trânsito e sinalização em geral. (Ficha Técnica/CEMPRE, 2007). Vejamos na Tabela 03 a seguir a distribuição dos principais mercados para esta matéria-prima:

\section{Tabela 03 - Distribuição dos Mercados para PET Reciclado}

\begin{tabular}{lr}
\hline Mercado & Participação (\%) \\
\hline Têxteis & 40 \\
\hline Extrusăo de chapas & 16 \\
\hline Termoformados & 15 \\
\hline Exportaçăo & 7 \\
\hline Resinas insaturadas e alquídicas & 7 \\
\hline Injeçăo e sopro & 3 \\
\hline Fitas de arquear & 3 \\
\hline Plásticos de engenharia & 4 \\
\hline Tubos & 2 \\
\hline
\end{tabular}

Fonte: Associação Brasileira de Embalagens PET - ABIPET/2006 In ABRELPE.

Panorama dos Resíduos sólidos no Brasil, 2007.

Além das latas de alumínio e de PET, materias com os quais o Brasil lidera no ranking mundial da reciclagem, outros segmentos também se destacam, tais como plásticos rígidos (20\%), setor vidreiro (46\%) e setor papeleiro (índice de reciclagem de $45 \%$ ), como veremos com mais detalhes a seguir.

\section{PLÁSTICOS RÍGIDOS}

Cada um dos materiais recicláveis existentes são classificados em diversos tipos, o que torna a etapa da triagem uma das atividades mais importantes da base desta indústria. Por este motivo, este segmento representa um campo aberto para inovações técnicas na identificação e separação das diversas resinas, e também para o surgimento de novos equipamentos e tecnologias de 
reprocessamento, seguindo a tendência de expansão do mercado para a reciclagem do plástico.

Enquanto isto, uma técnica muito rudimentar - e prejudicial à saúde, é utilizada pelos catadores para a identificação dos diferentes tipos de plástico, sendo inclusive prescrita por técnicos durante cursos de capacitação para estes trabalhadores. Tal "técnica" consiste na queima de uma pequena amostra de cada tipo de plástico, seguida da inalação da fumaça, cujo odor deve ser identificado numa tabela que associa cada "cheiro característico" com um tipo de plástico (ANEXO 11).

$\mathrm{Na}$ Tabela 04 a seguir temos alguns tipos de plásticos com suas quantidades proporcionais ao consumo deste material no Brasil:

\section{Tabela 04}

Reciclagem de Plásticos por Tipo de Resíduo Plástico Consumido no Brasil

\begin{tabular}{lrr}
\hline Tipo de Resíduo Plástico & Quantidade (t/ano) & $\mathbf{( \% )}$ \\
\hline PET & 261.912 & 34,13 \\
\hline PEAD & 94.181 & 12,27 \\
\hline PVC & 19.397 & 2,53 \\
\hline PEBD/PELBD & 185.976 & 24,23 \\
\hline PP & 141.210 & 18,40 \\
\hline PS & 37.725 & 4,92 \\
\hline Outros tipos & 27.103 & 3,53 \\
\hline Total & 767.504 & \\
\hline
\end{tabular}

Fonte: Estudo sobre a Indústria de Reciclagem Mecânica dos Plásticos no Brasil (IRMP), Plastivida Instituto Sócio Ambiental dos Plásticos/2005 In ABRELPE. Panorama dos Resíduos sólidos no Brasil, 2007.

Este segmento em expansão produziu, em 2006, cerca de 1 milhão de toneladas de plásticos rígido e do tipo filme. Deste total cerca de 200 mil toneladas foram recicladas, o que corresponde a um índice de reciclagem de $20 \%$, composto por $60 \%$ de resíduos industriais e $40 \%$ do consumo urbano ${ }^{131}$. No Município de São Paulo, dos 127 recicladores cadastrados no CEMPRE (2008), 86 atuam na reciclagem de plástico, majoritariamente do tipo mecânica. Desta forma, o Brasil é o

${ }^{131}$ Fonte: ABREMPLAST - Associação Brasileira de Recicladores de Materiais Plásticos, 2007. 
quarto país no ranking mundial da reciclagem mecânica do plástico, ficando atrás apenas da Alemanha, Áustria e EUA.

\section{VIDRO}

Com um faturamento de quase 4 bilhões de reais, o setor vidreiro produz uma média anual de aproximadamente 890 mil toneladas de embalagens de vidro, usando cerca de $46 \%$ de matéria-prima reciclada na forma de cacos. Enquanto os investimentos para a reciclagem do vidro giram em torno de $\mathrm{R} \$ 500$ mil a $\mathrm{R} \$ 700$ mil, o faturamento chega a ser da ordem de $\mathrm{R} \$ 68$ milhões. Este montante corresponde à participação da reciclagem no faturamento total do setor vidreiro.

O vidro que retorna ao processo produtivo é composto tanto pelo refugo das fábricas quanto pela coleta pós-consumo. São aproximadamente $390 \mathrm{mil}$ toneladas ao ano, oriundas da indústria de envaze ( $40 \%$ do total), do mercado difuso (40\%), do denominado "canal frio" (10\%, de bares, restaurantes, hotéis) e do refugo da indústria (10\% restantes). Seu principal mercado é formado por vidrarias que têm como principal fornecedor uma rede de sucateiros. O vidro pode ser reprocessado como nova embalagem ou ainda compor outros tipos de produtos, tais como asfalto, espuma e fibra de vidro, além de tintas reflexivas (CEMPRE, 2007).

O vidro, além de ser composto por areia, calcário, barrilha e feldspato, os quais mantém suas propriedades no processo de reciclagem, apresenta alta taxa de reaproveitamento por seus consumidores, sendo que a metade da produção nacional é retornável. Por sua vez, o processo de reciclagem do vidro permite a produção de novas embalagens, substituindo totalmente a matéria-prima original e com a mesma qualidade. A reciclagem do vidro apresentou uma expansão na década de 90 (passando de $15 \%$ para $40 \%$ entre o início e término daquela década) indicando ter atingido um patamar limite nos anos recentes, com aumento aproximado de $1 \%$ ao ano, conforme a Tabela 05 a seguir: 
Tabela 05 - Evolução do Índice de Reciclagem de vidro no Brasil

\begin{tabular}{|c|c|}
\hline Ano & $\begin{array}{c}\text { Índice de } \\
\text { Reciclagem }\end{array}$ \\
\hline 1991 & $15 \%$ \\
\hline 1993 & $25 \%$ \\
\hline 1995 & $35 \%$ \\
\hline 1997 & $39 \%$ \\
\hline 1999 & $40 \%$ \\
\hline 2001 & $42 \%$ \\
\hline 2003 & $45 \%$ \\
\hline 2005 & $45 \%$ \\
\hline 2007 & $47 \%$ \\
\hline
\end{tabular}

Fonte: www.abividro.org.br

A economia auferida com a reciclagem do vidro pode ser observada nas seguintes informações: para cada $10 \%$ de caco de vidro na mistura, economiza-se $4 \%$ da energia necessária para a fusão nos fornos industriais e a redução de 9,5\% no consumo de água. Não por acaso, os vidros correspondem a apenas $3 \%$ dos resíduos urbanos, aumentando para $14 \%$ nos programas de coleta seletiva (CEMPRE, 2007). Para concluirmos, segue a Tabela 06 com informações sobre 0 desempenho do setor vidreiro nos anos de 2005 e 2006:

Tabela 06 - Desempenho Global do Setor Vidreiro no Brasil (2005/2006)

\begin{tabular}{lrr}
\hline Discriminação & 2005 & $\mathbf{2 0 0 6}$ \\
\hline Capacidade instalada de produçăo de embalagens (1000 t) & $1.292,00$ & $1.297,00$ \\
\hline Empregos na produçăo de embalagens (1000) & 5,10 & 5,10 \\
\hline Faturamento da produçăo de embalagens (R\$ milhøes) & 1,17 & 1,23 \\
\hline Volume reciclado (mil toneladas) & 390,00 & 400,00 \\
\hline Índice de reciclagem & $45 \%$ & $45 \%$ \\
\hline Recursos investidos para reciclagem (R\$ mil) & 700,00 & 500,00 \\
\hline Recursos gerados com a reciclagem (R\$ milhøes) & 65,00 & 68,00 \\
\hline Empregos diretos e indiretos gerados na reciclagem (mil) & 3 & 3 \\
\hline
\end{tabular}

Fonte: ABIVIDRO In ABRELPE. Panorama dos Resíduos sólidos no Brasil, 2007. 


\section{PAPÉIS EM GERAL}

Aparas é o nome genérico dado aos resíduos de papel, sejam industriais ou domésticos - classificados pelo Instituto de Pesquisas Tecnológicas de São Paulo e pela Associação Nacional dos Fabricantes de Papel e Celulose. As aparas nobres são as "brancas de primeira", que não têm impressão ou qualquer tipo de revestimento. As aparas mistas são formadas pela mistura de vários tipos de papéis. Assim como apontado no segmento dos plásticos, as aparas também apresentam grande variedade de tipos. No Brasil existem cerca de 20 categorias de aparas. Há uma variabilidade significativa no processo de reciclagem de papel nas diferentes regiões brasileiras. Como nas regiões Sul e Sudeste se concentram as principais indústrias deste segmento, os índices de reciclagem são elevados, sobretudo no Estado de São Paulo, com taxa de reciclagem de 36\%. Os demais Estados apresentam taxas menores: $12 \%$ em Minas Gerais, 5,2\% no Rio de Janeiro, 20\% em Santa Catarina, $12 \%$ no Paraná e menos de $10 \%$ nos demais Estados (Bracelpa, 2007). Vejamos a Tabela 07 a seguir:

\section{Tabela 07 - Distribuição Estadual do Consumo de Aparas e Papéis Usados}

\begin{tabular}{|c|c|c|}
\hline Estado & $1000 \mathrm{t}$. & Part. \% \\
\hline São Paulo & $1.258,0$ & $36,0 \%$ \\
\hline Santa Catarina & 705,9 & $20,2 \%$ \\
\hline Paraná & 452,3 & $12,9 \%$ \\
\hline Minas Gerais & 429,6 & $12,3 \%$ \\
\hline Rio de Janeiro & 180,2 & $5,2 \%$ \\
\hline Rio Grande do Sul & 120,9 & $3,5 \%$ \\
\hline Pernambuco & 118,8 & $3,4 \%$ \\
\hline Bahia & 91,2 & $2,6 \%$ \\
\hline Paraíba & 44,1 & $1,3 \%$ \\
\hline Amazonas & 35,5 & $1,0 \%$ \\
\hline Pará & 25,0 & $0,7 \%$ \\
\hline Ceará & 9,9 & $0,3 \%$ \\
\hline Goiás & 8,5 & $0,2 \%$ \\
\hline Sergipe & 8,0 & $0,2 \%$ \\
\hline Maranhão & 6,0 & $0,2 \%$ \\
\hline Rio Grande do Norte & 2,6 & $0,1 \%$ \\
\hline Total & $3.496,5$ & $100,0 \%$ \\
\hline
\end{tabular}

Fonte: Bracelpa (2007) 
O principal mercado para as aparas é o de embalagens (consumindo cerca de $65 \%$ do total de aparas recicladas), e não o de papéis de escritório que exige maior qualidade do produto final. Já as embalagens feitas de papel ondulado (papelão) são recicladas com maior facilidade. Este tipo de produto é amplamente difundido no mercado nacional, estando presente em todas as regiões, mesmo com grandes disparidades, conforme indica a Tabela 08 a seguir:

\begin{tabular}{|l|r|r|}
\hline Região brasileira & Papel ondulado (ton) & $\%$ \\
\hline Sudeste & 1.044 .376 & 47,94 \\
\hline Sul & 647.777 & 29,73 \\
\hline Nordeste & 202.633 & 9,30 \\
\hline Centro-Oeste & 161.890 & 7,43 \\
\hline Norte & 110.527 & 5,07 \\
\hline Exportação & 0,53 \\
\hline Total & 2.167 .203 & 100 \\
\hline \multicolumn{2}{|c|}{ Fonte: Ficha Técnica CEMPRE (2007) }
\end{tabular}

As indústrias do setor papeleiro consumiram 3.496 .500 toneladas de papéis reciclados em 2008, sendo que mais de $60 \%$ das aparas são constituídas por papel ondulado. A reciclagem de papel ondulado (papelão) apresentou expansão contínua na década de 90 , estabilizando-se em meados da década atual, tal como observado para o segmento vidreiro. Vejamos a Tabela 09 a seguir:

\section{Tabela 09 - Evolução do Índice de Reciclagem de papel ondulado}

\begin{tabular}{|c|c|}
\hline Ano & $\begin{array}{c}\text { Índice de } \\
\text { Reciclagem }\end{array}$ \\
\hline 1992 & $68,2 \%$ \\
\hline 1997 & $71,6 \%$ \\
\hline 2002 & $77,3 \%$ \\
\hline 2004 & $79 \%$ \\
\hline 2006 & $77,4 \%$ \\
\hline
\end{tabular}

Fonte: BRACELPA In Ficha Técnica CEMPRE (2007)

O mercado de aparas no Brasil sofre oscilações diretamente vinculadas à produção de celulose, o que provoca a importação de aparas mesmo com existência de uma grande oferta de papéis para reciclagem no mercado interno. Isto porque quando ocorre escassez da celulose, há o conseqüente aumento dos preços do reciclado, o que leva as indústrias a recorrerem à importação de aparas com menor 
preço no mercado internacional. No caso oposto, quando há maior oferta de celulose no mercado é a demanda por aparas que diminui. Como no país existem grandes empresas produtoras e exportadoras de celulose, o incentivo à reciclagem de papel é reduzido. Mesmo porque, em alguns casos o custo da fabricação de papel reciclado pode ser superior ao produzido com celulose original.

De acordo com a Bracelpa (2007), o setor de papel e celulose, de perfil exportador, movimenta anualmente cerca de US $\$ 4,7$ bilhões com exportações (principalmente de celulose), apresentando saldo comercial de US\$3,4 bilhões (8,5\% do Saldo da Balança Comercial do Brasil em 2007). Nos Gráfico 04 a seguir estão representados os destinos da exportação deste segmento:

\section{Gráfico 04: Destino das exportações brasileiras de celulose e papel - 2007}

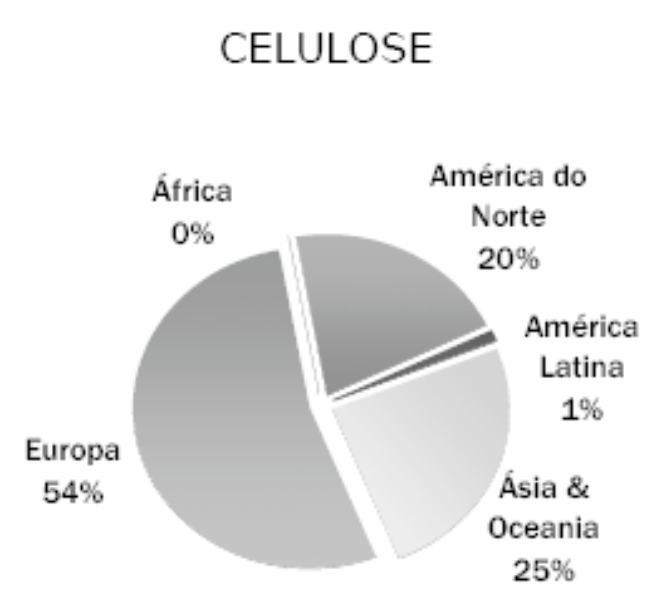

Total: US $\$ 3,0$ bilhões

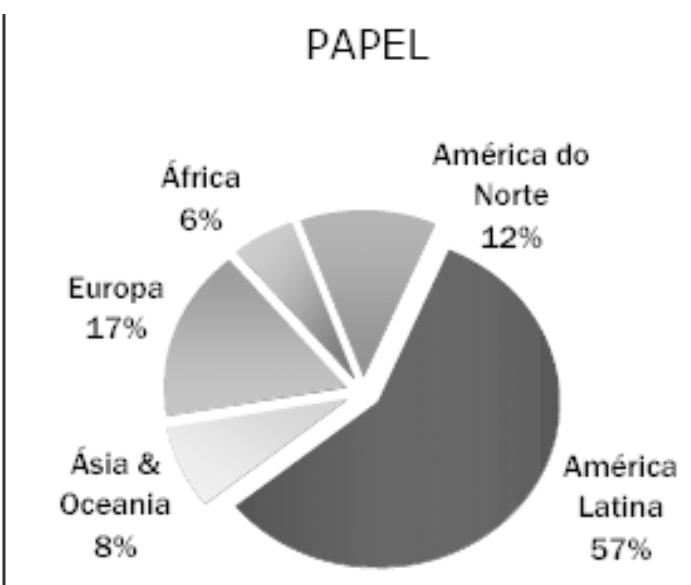

Total: US\$ 1,7 bilhão

Fonte: Bracelpa (2008)

Neste contexto, a reciclagem representa uma parcela menos expressiva nos negócios deste segmento, sendo porém adotada e divulgada como iniciativa de Responsabilidade Social e Ambiental das empresas.

No entanto, o principal projeto de sustentabilidade das empresas do setor papeleiro está vinculado às florestas de eucalipto. Curiosamente, os impactos negativos que este tipo de monocultura produz ao meio são estrategicamente revertidos em moeda de troca no mercado da sustentabilidade, a exemplo dos 
créditos de carbono obtidos com base nestas "florestas", denominadas pelos seus críticos de "desertos verdes".

Segundo dados da BRACELPA (2007), o setor de papel e celulose apresenta 220 empresas distribuídas em 450 municípios, localizados em 17 Estados brasileiros e em todas as regiões do país. São 1,7 milhão de hectares de área plantada para fins industriais, principalmente com florestas de eucaliptos, o que faz do Brasil um líder na produção de celulose de eucalipto, com projeções de aumento da produção, conforme indica a Tabela 10 a seguir:

\section{Tabela 10 - Brasil: Líder na produção de celulose de eucalipto}

\begin{tabular}{lcccrr}
\hline $1.000 t$ & $\mathbf{1 9 9 0}$ & $\mathbf{1 9 9 5}$ & $\mathbf{2 0 0 0}$ & $\mathbf{2 0 0 5}$ & \multicolumn{1}{c}{2010} \\
\hline Brasil & 1.380 & 2.280 & 3.615 & 6.090 & 10.010 \\
\hline Chile & - & 270 & 450 & 760 & 2.265 \\
\hline Uruguai & - & - & - & - & 1.825 \\
\hline Espanha & 735 & 895 & 1.040 & 1.235 & 1.490 \\
\hline Portugal & 1.075 & 1.075 & 975 & 925 & 975 \\
\hline China & - & - & - & 415 & 635 \\
\hline Outros & 305 & 600 & 1.050 & 1.100 & 950 \\
\hline Total & 3.495 & 5.120 & 7.130 & 10.525 & 18.150 \\
\hline
\end{tabular}

Fonte: Bracelpa (2008)

Se compararmos o tempo de rotação das plantações de eucalipto (que produz a denominada celulose de fibra curta) em relação às florestas de pinus (celulose de fibra longa), podemos entender porque 0 setor expande incessantemente as "florestas verdes". Enquanto a espécie pinus tem um tempo de rotação de 15 anos, rendendo $35 \mathrm{~m} 3$ /ha ao ano, o eucalipto leva apenas 7 anos para se desenvolver, com rendimento de $41 \mathrm{~m} 3$ /ha ao ano, tendo se adaptado às condições climáticas brasileiras em diversas regiões do país.

Ocorre que parte significativa destas "florestas" avança sobre áreas de mata nativa, a exemplo da forte expansão que ocorre no domínio morfo-climático "mares de morros" (definição dada por Aziz Ab'Saber) no Vale do Paraíba, avançando sobre a Mata Atlântica do Parque Estadual da Serra do Mar. Ano após ano aquela região vem se transformando numa verdadeira "indústria" do eucalipto, ocupando terras já desgastadas com cultivos anteriores, a exemplo do café, o que só faz aprofundar os processos erosivos e de desequilíbrios hídricos. O Grupo 
Votorantim é um dos principais agentes desta indústria atuante na região. Mas, contraditoriamente, estas indústrias garantem seus selos de Responsabilidade Ambiental, e lucros com a venda de créditos de carbono.

Como já assinalado, o setor papeleiro e de celulose segue expandindo tanto a produção de celulose quanto de papéis. Cabe ressaltar que o Índice de Reciclagem de $45 \%$ é calculado com base no denominado "consumo aparente" (que girou em torno de 7700 mil toneladas em 2007), enquanto a produção de papéis foi da ordem de 9.000 mil toneladas (Bracelpa, 2008). Se o Índice de Reciclagem fosse calculado com base na produção de papéis, o referido índice seria de $38,8 \%$ e não $45 \%$. Para concluir, vejamos na Tabela 11 a seguir as quantidades de papel e de celulose produzidas, e em seguida o Gráfico 05 com a relação entre o consumo de papel e o Índice de Reciclagem deste setor:

Tabela 11 - Produção de Papel e de Celulose (2007)

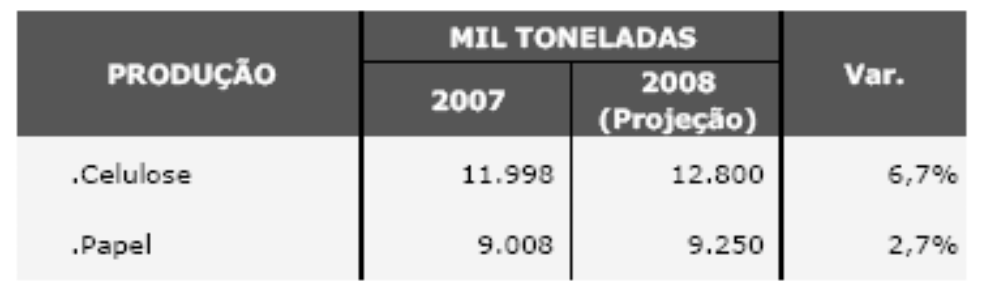

Fonte: Bracelpa (2008)

Consumo de papéis e Índice de Reciclagem

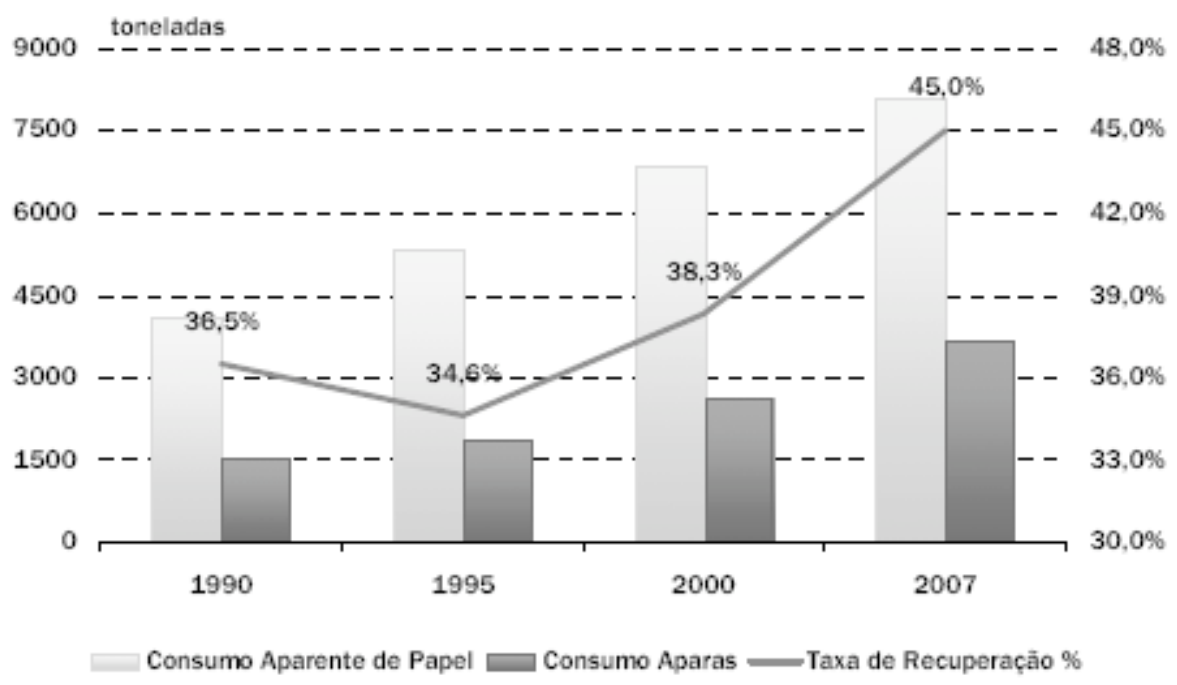

Fonte: Bracelpa (2008) 


\subsection{Panorama da Coleta Seletiva no Brasil e a "medida da desproporção"}

No início do segundo semestre de 2008, o Ministério das Cidades, através da Secretaria Nacional de Saneamento Ambiental, publicou o "Diagnóstico do Manejo de Resíduos Sólidos Urbanos"132. O documento traz os resultados de uma pesquisa de 2006, acerca da situação da prestação dos serviços de limpeza urbana, executados pelas prefeituras, com ou sem a contratação de empresas de limpeza urbana privadas. A pesquisa foi realizada em 247 municípios, cobrindo todos os Estados brasileiros e o Distrito Federal. Das informações apresentadas no referido Diagnóstico, interessa-nos aquelas referentes à coleta seletiva. Segundo a definição apresentada no "Diagnóstico do Manejo de Resíduos Sólidos Urbanos" (2008), a coleta seletiva:

é o conjunto de procedimentos referente ao recolhimento diferenciado de resíduos recicláveis (papéis, plásticos, metais, vidros, etc.) e até de resíduos orgânicos compostáveis, desde que tenham sido previamente separados dos demais resíduos considerados não reaproveitáveis, nos próprios locais em que tenha ocorrido sua geração.

Com base em outra pesquisa, realizada periodicamente pelo CEMPRE, denominada de "Pesquisa Ciclosoft", temos a informação de que 405 municípios brasileiros possuem atualmente coleta seletiva (CEMPRE, 2008), representando $7 \%$ do total de 5564 municípios existentes no país. Ainda que a coleta seletiva venha aumentando progressivamente a partir dos anos 90 (Gráfico 06), sua participação ainda é bastante reduzida frente aos exponenciais Índices de Reciclagem anteriormente apresentados.

\footnotetext{
132 Programa de Modernização do Setor Saneamento. Sistema Nacional de Informações sobre Saneamento: diagnóstico do manejo de resíduos sólidos urbanos - 2006. - Brasília: MCIDADES.SNSA, 2008.
} 


\section{Gráfico 06}

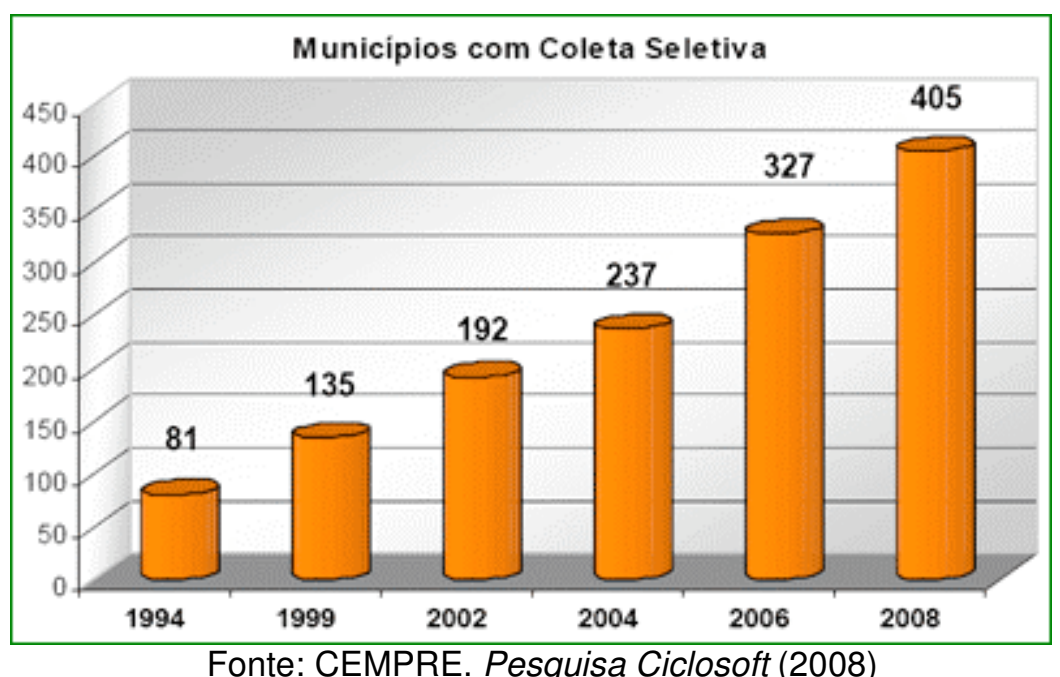

Os 237 municípios pesquisados no "Diagnóstico do Manejo de Resíduos Sólidos Urbanos" perfazem cerca de $50 \%$ da população urbana do país, incluindo os maiores centros urbanos e regiões metropolitanas (aproximadamente 74.478.800 habitantes do total de 155.934 .000 habitantes da população urbana do Brasil, no ano de 2006). Ou seja, mesmo com uma amostra reduzida, este documento traz informações sobre os principais centros urbanos produtores de resíduos sólidos recicláveis, inclusive São Paulo. Assim, a amostra contempla todos os municípios com mais de 850.000 habitantes; $86 \%$ dos municípios com mais de 500.000 habitantes; perfaz mais de 74,5 milhões de habitantes urbanos e 57,2 milhões de habitantes urbanos metropolitanos. Cerca de $56 \%$ dos municípios da amostra possuem coleta seletiva, geralmente do tipo porta-a-porta. Por outro lado, a coleta seletiva informal, realizada pelos catadores, está presente em mais de $80 \%$ dos municípios. ${ }^{133}$

Na Tabela 12 a seguir, estão apresentadas as massas de resíduos sólidos recicláveis que são recolhidos pela coleta seletiva, de acordo com o porte dos municípios. Neste Diagnóstico, os municípios foram agrupados em seis faixas de porte populacional (considerando a população total de cada município): Faixa 1 - até 30.000 habitantes; Faixa 2 - de 30.001 até 100.000 habitantes; Faixa 3 - de 100.001 a 250.000 habitantes; Faixa 4 - de 250.001 a 1.000 .000 habitantes; Faixa 5 - de 1.000.001 a 3.000.000 habitantes; Faixa 6 - mais de 3.000 .000 habitantes. Vejamos: 
Massa de resíduos sólidos recuperada, total e per capita, segundo porte dos municípios

Brasil, municípios selecionados, 2006

\begin{tabular}{|c|c|c|c|c|}
\hline \multirow{2}{*}{$\begin{array}{c}\text { Faixa } \\
\text { populacional }\end{array}$} & \multirow[b]{2}{*}{$\begin{array}{l}\text { Quantidades } \\
\text { de municípios } \\
\text { (municípios) }\end{array}$} & \multicolumn{3}{|c|}{ Massa recuperado } \\
\hline & & $\begin{array}{c}\text { Total } \\
\text { (Cs009) } \\
\text { (t/ano) } \\
\end{array}$ & $\begin{array}{c}\text { Média } \\
\text { Municipal } \\
\text { (t/munc/ano) }\end{array}$ & $\begin{array}{c}\text { Média Per capita } \\
\left(\mathrm{I}_{032}\right) \\
(\mathrm{kg} / \mathrm{hab} / \mathrm{ano})\end{array}$ \\
\hline 1 & 15 & 1.647 & 110 & 9,2 \\
\hline 2 & 21 & 8.462 & 403 & 8,4 \\
\hline 3 & 22 & 14.795 & 672 & 4,2 \\
\hline 4 & 37 & 46.017 & 1.244 & 2,9 \\
\hline 5 & 9 & 54.087 & 6.010 & 3,8 \\
\hline 6 & 2 & 19.103 & 9.551 & 1,2 \\
\hline Total & 106 & 144.109 & 1.360 & 2,8 \\
\hline
\end{tabular}

Fonte SNIS

Nota: Foram expurgados, em todas as colunas do quadro, os valores dos municípios que informaram massa recuperada excessivamente elevada quando comparada aos demais municípios da amostra, um total de 13 municípios.

Fonte: MCIDADES.SNSA, 2008.

Mesmo se dobrássemos a quantidade total da "massa recuperada" pela coleta seletiva oficial (na hipótese de recobrirmos $100 \%$ da população urbana, embora as maiores aglomerações já estejam incluídas na Tabela 12 acima), não chegaríamos a $4 \%$ do montante total de 7.380 mil toneladas de materiais recicláveis que são coletados e encaminhados para a reciclagem (CEMPRE, 2008). Eis a medida da desproporção!

Portanto, mais de $90 \%$ dos materiais recicláveis que compõem os Índices de Reciclagem anteriormente apresentados não são obtidos pelos sistemas de limpeza urbana oficiais. Esta situação nos remete ao trabalho realizado pelo verdadeiro exército de catadores inseridos na base da indústria da reciclagem. Portanto, à formação de capital no topo de uma estrutura industrial que tem em sua base o consumo da energia vital de trabalhadores pobres urbanos, sobrantes dos mais diversos setores produtivos ${ }^{134}$.

\footnotetext{
${ }^{133}$ Grifo nosso.

${ }^{134}$ Grifo nosso.
} 


\section{Capítulo V}

\section{A base da INDÚStria da RECICLAGEM NA METRÓPOLE de SÃo PAULO}

Assim como verificado para o contexto nacional veremos que os Índices de Reciclagem existentes em São Paulo (calculados com base nos índices de Reciclagem nacionais ${ }^{135}$ ) não são obtidos pela Coleta Seletiva oficial, nem pelos grupos de catadores com diferentes níveis de organização.

Em São Paulo, a exemplo do que ocorre em todo o país, "os bilhões da indústria da reciclagem" são obtidos através do trabalho de milhares de catadores que atuam na base da indústria da reciclagem, em sua expressiva maioria de forma não organizada.

Mas quantos são? Como estão organizados, ou qual a proporção entre grupos organizados (cooperativas, associações, núcleos) e os denominados catadores avulsos?

Estas e outras questão buscamos esclarecer com base na análise de algumas informações existentes, sobretudo vinculadas às políticas públicas destinadas à estruturação da base desta indústria, sob o modelo de cooperativas. Antes, porém, vamos nos ater à Coleta Seletiva oficial realizada pela Prefeitura.

Neste Capítulo será adotado o termo "Município de São Paulo" em relação às informações referentes à coleta seletiva e demais informações utilizadas com base nesta divisão territorial administrativa. Para as análises que derivam destas informações, utilizaremos o termo "metrópole de São Paulo", pois a discussão será feita do ponto de vista da urbanização.

Apresentamos a seguir um breve histórico sobre a implantação da coleta seletiva na cidade de São Paulo, com base em pesquisas que abordaram este tema. Para complementar este breve histórico, faremos a exposição de alguns relatos sobre sua situação recente, obtidos em trabalho de campo e pesquisa documental.

${ }^{135}$ Utilizou-se para este cálculo o mesmo procedimento adotado por Calderoni (2003), conforme será visto. 


\subsection{A Coleta Seletiva no Município de São Paulo}

A implantação da coleta seletiva na cidade de São Paulo ocorreu no final da década de 80 , com contratação de empresas privadas do setor de limpeza urbana. Calderoni (2003) situa o contexto de implantação da coleta seletiva em São Paulo no processo de discussão das Normas da série ISO 14000, sobre padrões ambientais, centralizados pela ABTN com ampla participação institucional, tanto no âmbito do setor privado como na esfera do setor público.

Ou seja, ao mesmo tempo em que ocorrem as primeiras iniciativas de organização da coleta seletiva, essencial para a estruturação mais ajustada da reciclagem - em termos logísticos, técnicos, legais - acontece também a normatização dos padrões ambientais para qualificação de processos produtivos e produtos, segundo controle ambiental. O que, por sua vez, confere certificados de qualidade às empresas recicladoras e aos produtos recicláveis:

A reciclagem do lixo é iniciada através do Programa de Coleta Seletiva instituído em 1989, sendo então também implantado o Centro de Triagem de Pinheiros. Em 1993 é cancelado o Programa de Coleta Seletiva e lançado um grande projeto baseado na construção de dois incineradores, cujo custo situa-se em torno de $R \$ 500$ milhões (imposição de ações judiciais). A Prefeitura cogita licitar, em 1996, novo serviço de coleta seletiva de lixo domiciliar, o que acabou por não se realizar.A Limpurb lança em 1997 o Programa "Recicla São Paulo", envolvendo a coleta e a venda de recicláveis. As empresas que são [então] responsáveis pela Coleta deverão operar o sistema, o qual prevê também a remuneração aos moradores pelo lixo coletado seletivamente. Prevê a implantação imediata do Programa e mega-licitação envolvendo ampliação dos serviços de limpeza. Nessa licitação pretende modificar o critério de remuneração das empresas contratadas, tomando por base o serviço efetivamente realizado. Ao mesmo tempo, visando aperfeiçoar os serviços, inicia na COHAB Tiradentes a mecanização da Coleta. Paralelamente, intensifica-se, no segundo semestre de 1997, o processo de discussão das Normas da série ISO 14000, sobre padrões ambientais, centralizados pela ABTN com ampla participação institucional, tanto no âmbito do setor privado como na esfera do setor público. (Calderoni, 2003:98)

Rodrigues (1996:143;145) ao analisar a implantação da Coleta Seletiva em São Paulo observou que,

a Prefeitura de São Paulo - gestão 1989 a 1992 (Luísa Erundina), demonstrou preocupações com o meio ambiente (...). Nesta gestão foram implantados um aterro de resíduos inertes (Aterro de Itatinga), o programa de Coleta Domiciliar 
Seletiva (desde 1989) ${ }^{136}$ e os containers - Postos de Entrega Voluntária (desde 1991). (...) Mesmo que o processo [envolvido no Programa de Coleta Seletiva] não possa ser denominado de educação ambiental é uma importante contribuição para a construção da cidadania. (...) A mudança de gestão, em 1993, altera esta matriz discursiva. O atual Prefeito argumenta o alto custo deste processo, chegando a propor sua extinção. Considerada apenas a atividade isolada de coleta, separação dos diferentes resíduos e comercialização - ou o reaproveitamento - o alto custo é incontestável.

A autora apontava a necessidade de uma compreensão mais ampla acerca dos custos da reciclagem para a administração pública: o custo não pode ser considerado apenas no circuito específico da coleta do lixo, devendo incorporar a economia em energia e recursos naturais, considerados como "bens comuns". A seguir, apresentamos a descrição que a Rodrigues (1996:155) nos apresenta sobre a Coleta Domiciliar Seletiva nos seus primórdios na cidade de São Paulo:

A coleta domiciliar seletiva iniciou-se em 1989, em um bairro (Vila Madalena) com 3.500 domicílios, como experiência piloto (...). Nos primeiros circuitos implantados os recursos obtidos com a venda dos resíduos eram investidos no próprio bairro, definidas as prioridades pelos moradores junto à Administração Regional de Pinheiros. (...) Posteriormente, com a ampliação da coleta seletiva os recursos obtidos com a venda dos resíduos foram utilizados para cobrir os custos de infra-estrutura básica (pessoal e máquinas) do Centro de Triagem. A administração dos recursos era realizada pelo Corpo Municipal de Voluntários (CMV), atual Centro de Apoio Social e Atendimento (CASA).

Por sua vez, Legaspe (1996), logo no começo de sua pesquisa, identificou que o Programa de Coleta Seletiva teve início em bairros de classe média, na região oeste da cidade de São Paulo:

O nosso estudo inicial se constituía na preocupação de investigar a Coleta Seletiva (implementada pela Prefeitura Municipal de São Paulo, em 1989). (...) podíamos observar qual era o objetivo para atender uma região em detrimento da outra, tendo como indicativo o perfil sócio-econômico, que serviria para definir as áreas que receberiam a Coleta Seletiva, sendo esta reservada para os bairros de classe média, que por razões de poder de consumo eram locais que estariam aptos a produzirem um lixo com alto teor de materiais recicláveis. (Legaspe:1996:2)

${ }^{136}$ Grifo nosso. 
Desta forma, uma característica que marcou o início da Coleta Seletiva da Prefeitura de São Paulo foi sua implantação em áreas residenciais de classe média, onde o lixo fosse composto por alto teor de materiais recicláveis.

A partir da análise da diferença entre os valores da coleta convencional (com deposição no Aterro Sanitário) e da coleta seletiva, sendo esta identificada como mais cara aos cofres público, Legaspe chega ao questionamento sobre a verdadeira reciclagem que existe no Brasil.

De acordo com este autor, entende-se que as atividades realizadas pelos catadores, à parte dos programas de gestão de resíduos sólidos com cooperativas, foi, e continua sendo, o principal suporte da expansão dos negócios desta indústria. Por outro lado, o desenvolvimento e a expansão dos processos produtivos que utilizam os materiais recicláveis como matéria-prima requerem seu aperfeiçoamento, no que parece se incluir as propostas das cooperativas.

Grimberg (2007) apresenta aspectos do processo mais recente que visa implantar a Coleta Seletiva com base em cooperativas de catadores, como um "novo paradigma de gestão integrada e compartilhada dos resíduos sólidos".

A implantação deste modelo teve como alguns de seus principais agentes as entidades do Terceiro Setor - que aqui denominamos de Terceiro Setor da indústria da Reciclagem. Em São Paulo tiveram destaque os Fóruns Lixo e Cidadania, Recicla São Paulo e Fórum de Desenvolvimento da Zona Leste. Vejamos o relato de Grimberg:

Em março de 2000, foi criado o Fórum Recicla São Paulo por grupos que tinham por objetivo a troca de experiências, articulação e qualificação do trabalho de coleta e estruturação de venda coletiva de materiais recicláveis. (...) Em junho de 2000, foi criado o Comitê Metropolitano dos Catadores, que se estabeleceu como a principal referência para a organização e mobilização em nível local, regional, estadual e nacional para o I Congresso Nacional de Catadores de Materiais Reaproveitáveis. (...) O Fórum para o Desenvolvimento da Zona Leste (...) foi criado com o objetivo de unir entidades para propor soluções para os problemas da Zona Leste da cidade de São Paulo (...) (Grimberg, 2007:31)

A atuação das entidades deste Terceiro Setor, dentre elas o próprio Instituto POLIS (integrante do Fórum Lixo e Cidadania), teve como uma de suas funções a capacitação dos catadores, preparando-os para o trabalho nas 
cooperativas. Porém, muito mais do que isto, atuaram diretamente para a implantação do modelo de Coleta Seletiva existente hoje no Município de São Paulo.

Vejamos algos momentos deste processo:

Em 2002 foi um ano de eleições, e aconteceram importantes debates na Câmara Municipal com as entidades integrantes dos Fóruns e do MNCR, resultando numa Carta de Intenções do Programa Coleta Seletiva que foi assinado pela então candidata à Prefeitura, Marta Suplicy. Era a retomada dos compromissos iniciados na gestão de Luísa Erundina, quando houve a primeira experiência de Coleta Seletiva em São Paulo. Constituiu-se um Grupo de Trabalho e foi criada uma coordenação na Prefeitura para direcionar a implantação do Programa de Coleta Seletiva. Este Grupo de Trabalho funcionou durante meses, com representantes de todas as regiões do município, até a implantação definitiva do referido Programa.

No final de dezembro de 2002, no contexto de muitas discussões que ocorreram em torno da Lei ํo $13.478 / 02^{137}$, foi definido que o sistema de tratamento dos resíduos na cidade deveria contemplar, entre outras medidas: a organização do Sistema de Limpeza Urbana do Município de São Paulo; a criação e estruturação de seu órgão regulador - a Autoridade de Limpeza Urbana (AMLURB); autorização do Poder Público em delegar a execução dos serviços públicos mediante concessão ou permissão; instituição da Taxa de Resíduos Sólidos Domiciliares - TRSD; criação do Fundo Municipal de Limpeza Urbana - FMLU.

Neste mesmo processo, foi criada a Plataforma de Educação Socioambiental do Programa Coleta Seletiva Solidária, desenvolvida por cerca de 75 organizações - incluindo poder público, iniciativa privada e Terceiro Setor, as quais constituíram os Fóruns de atuação no âmbito da reciclagem.

Neste contexto, o Programa Coleta Seletiva Solidária da Prefeitura Municipal de São Paulo foi instituído pelo decreto 42.290, em 15 de agosto de 2002. Durante os anos de 2003 e 2004 foram implantadas 15 Centrais de Triagem galpões com cerca de $1.000 \mathrm{~m}^{2}$, equipados com prensas, esteira, balança,

\footnotetext{
137 Lei MUNICÍPAL - SP no 13.478 de 30.12.2002 (Dispõe sobre a organização do Sistema de Limpeza Urbana do Município de São Paulo; Cria e estrutura seu órgão regulador; autoriza o Poder Público a delegar a execução dos serviços públicos mediante concessão ou permissão; institui a Taxa de Resíduos Sólidos Domiciliares - TRSD, a Taxa de Resíduos Sólidos de Serviços de Saúde - TRSS e a Taxa de Fiscalização dos Serviços de Limpeza Urbana - FISLURB; cria o Fundo Municipal de Limpeza Urbana - FMLU, e dá outras providências).
} 
equipamentos de escritório e outras estruturas complementares ao funcionamento das mesmas.

Neste ínterim, a Prefeitura de São Paulo lançou edital de licitação e concessão dos serviços de limpeza urbana no Município, vencido pelos consórcios Loga Ambiental e EcoUrbis. Em contrapartida, tais empresas ficaram responsáveis por investirem no Programa Coleta Seletiva Solidária, com a instalação de mais Centrais de Triagem e recursos para programas de educação ambiental. Neste ínterim, houve a assinatura de convênios entre a administração municipal e as cooperativas de catadores recém-formadas com base no trabalho desenvolvido pelos Fóruns para a composição das Centrais de Triagem.

A Prefeitura estabeleceu as regras para o Programa e cada cooperativa tinha a função de gerenciar a respectiva Central de Triagem, coordenando a parte administrativa e operacional. Também deveriam prestar contas mensalmente à Secretaria de Serviços sobre o funcionamento da Cooperativa.

Para abastecê-las com materiais recicláveis, a Prefeitura utiliza dois sistemas: a coleta diferenciada e a coleta porta-a-porta. A primeira é feita por caminhões compactadores das duas concessionárias (Loga e Ecourbis) que levam o material reciclado domiciliar para as cooperativas. A segunda é feita por caminhões alugados pela Prefeitura nas áreas não atendidas pela concessionária (tipos gaiola, munk e VUC).

No decorrer de 2004, sob nova gestão da Prefeitura de São Paulo, a Autoridade Municipal de Limpeza Urbana não foi implantada e o Departamento de Limpeza Urbana - LIMPURB continuou sendo o órgão responsável pelo Programa de coleta seletiva. Sem os investimentos estabelecidos pelo contrato de concessão, 13 das 31 Centrais de Triagem planejadas deixam de ser implantadas, assim como outros investimentos, principalmente a construção de novos aterros para substituir os Aterros Bandeirantes e São João, com capacidade de funcionamento praticamente esgotadas.

Somente em 2007, com o lançamento do "PAC do saneamento" - do Programa de Aceleração do Crescimento, pelo governo federal, houve nova mobilização para dar continuidade ao processo de ampliação da Coleta Seletiva oficial no Município de São Paulo. 


\title{
As Centrais de Triagem
}

Conforme a proposta original do Programa de Coleta Seletiva da Prefeitura de São Paulo, as Centrais de Triagem deveriam ser construídas onde já existissem grupos de catadores organizados e que participavam dos Fóruns. No modelo idealizado, cada central seria formada por núcleos com bases na comunidade.

Mas com as sucessivas mudanças no quadro administrativo da Secretaria de Serviços e Obras, houve uma aceleração na implantação das Centrais, numa velocidade maior do que se havia imaginado, acarretando uma série de problemas na implantação das Centrais de Triagem. Um destes problemas foi justamente o fato de que muitos núcleos ficaram de fora do Programa oficial, sendo que algumas "lideranças" assumiram o comando das Centrais de Triagem, numa postura contraditória em relação aos princípios do cooperativismo. A seguir, temos uma síntese dos resultados das ações realizadas no início desta década, destinadas à implantação do modelo de coleta seletiva, e que de um modo geral corresponde à situação atual:

\begin{abstract}
A Secretaria de Serviços e Obras (SSO) havia definido como meta a criação de 31 centrais de triagem (uma para cada subprefeitura) até dezembro de 2004. Mas no final da gestão Marta Suplicy estavam operando apenas quinze centrais de triagem (...), das quais algumas foram originalmente compostas por núcleos de catadores e estavam constituídas como cooperativas autônomas. Funcionavam em áreas públicas, com infra-estrutura (instalação e equipamentos) cedidas pela Prefeitura. Ficou estabelecido o compromisso da SSO de coletar os materiais recicláveis nos Postos de Entrega Voluntária (PEVs) e, por parte das cooperativas a responsabilidade de acompanhar o caminhão gaiola no sistema porta a porta e o transporte até suas unidades. (Grimberg, 2007:65)
\end{abstract}

As 15 Centrais de Triagem do Programa de coleta seletiva da Prefeitura de São Paulo são operadas por cooperativas que recebem a permissão de coletar resíduos sólidos urbanos (apenas materiais recicláveis), além de local, equipamentos (esteira de 20 metros, prensas elétricas, picotadeira de papel, balança eletrônica e mecânica, computadores e impressoras), caminhões (modelos gaiola, munk e vuc) e 
pagamento das contas de luz e água para sua operação. Na tabela 13 a baixo é apresentada uma síntese dos custos do Programa:

\begin{tabular}{|l|l|}
\hline \multicolumn{2}{|c|}{ Tabela 13 - Custos do Programa de Coleta Seletiva } \\
\hline Implantação de cada Central de Triagem & $\mathrm{R} \$ 250.000$ \\
\hline Investimento anual & $\mathrm{R} \$ 7.000 .000$ \\
\hline Custo mensal de operação (mês) & $\mathrm{R} \$ 1.500 .000$ por mês \\
\hline Custo da coleta porta-a-porta (por tonelada) & $\mathrm{R} \$ 242,52$ \\
\hline Caminhões & Gaiola: $\mathrm{R} \$ 271$ mil; Munk: $\mathrm{R} \$ 143$ mil; VUC: $\mathrm{R} \$ 23$ mil \\
\hline Total de catadores & 936 \\
\hline Valor médio da hora trabalhada & $\mathrm{R} \$ 2,79$ \\
\hline
\end{tabular}

Fonte: Limpurb, 2006

Segundo dados do Limpurb (2007), de junho de 2006 a junho de 2007, a coleta domiciliar coletou uma média de 287.978 toneladas por mês, , enquanto a Coleta Seletiva coletou apenas uma média 2.154 toneladas no Município de São Paulo.

Dos materiais triados pelas Centrais, $65 \%$ provém da coleta das concessionárias (porta-a-porta e container). Pela rota traçada para coleta dos container, faz-se o porta-a-porta da região. Porém, o rejeito chega a $40 \%$ e a compactação detona o material (quebra, mistura, prensa materiais diferentes), acarretando menor produtividade do processo de coleta realizado nas centrais. $O$ caminhão compactador transporta um volume maior de material, mas há uma queda em termos de produtividade. A separação dos mesmos se torna difícil, pois estão misturados ao rejeito compactado ao material por este tipo de caminhão.

Atualmente, a estrutura do Programa não permite que nem a estrutura pública deixe de apoiar as associações e cooperativas, pois estas não geram renda suficiente para sustentar os trabalhadores a ela agregados, e nem que novos catadores sejam absorvidos. Desta forma, o programa requer recursos substanciais que são utilizados apenas para o custeamento da operação, e não para investir no crescimento e desenvolvimento destas cooperativas, de forma a permitir a inclusão de outros catadores. Assim, o programa atende a um número pequeno de catadores que ficam dependentes dos recursos destinados pela Limpurb. (SMTRAB, 2007:4) 
Os principais problemas das Centrais de Triagem, apontados por uma pesquisa realizada pela SMTRAB sobre as cadeias produtivas da reciclagem no Município de São Paulo foram em relação à forma de se realizar a coleta coletiva. Por um lado, falta divulgação para que a população separe adequadamente os materiais recicláveis, e por outro os caminhões das concessionárias levam para as Centrais de Triagem lixo in natura: "Isto dificultava o trabalho de triagem e separação realizado pelas cooperativas nas Centrais de Triagem, tornando-o pouco produtivo, já que há índice de 30\% de rejeitos na esteira de separação". (SMTRAB,2007:4)

Segundo a pesquisa da SMTrab (2007:27), a maioria das Centrais de triagem comercializa:

- $\quad$ PET para a Repet, empresa do Grupo Unna Fibras que fornece pellets (grãos plásticos) para a produção de fios sintéticos utilizados na indústria têxtil

- $\quad$ Papéis vendidos à Suzano Celulose e Papel

- $\quad$ Longa Vida à Tetra Pak

- Vidro para Saint-Gobain/Santa Marina

- Latas de alumínio era o único material vendido para intermediários

Apesar de toda a estrutura envolvida no Programa de Coleta Seletiva em São Paulo, existem diversos problemas nas Centrais de Triagem, como demonstram os Relatórios elaborados pelo Limpurb (ANEXO 12), e no relato dos próprios cooperados. Ademais, desde o início do Programa, as diferentes gestões que assumem o poder local imprimem maior ou menor grau de importância à questão da gestão dos resíduos sólidos urbanos. Rodrigues (1996) já identificava problemas no Programa da Coleta Seletiva, na gestão que teve início em 1993 (Paulo Maluf):

Desde o início da gestão a coleta domiciliar perdeu a eficiência e talvez a eficácia. (...) É possível verificar a (não) importância atribuída ao setor, pela forma como são administrados os recursos. A manutenção das esteiras é precária. Quando quebra, não há triagem e todo material reciclável é então levado para os lixões comuns. E, apesar de haver (4) quatro containers - papel, plástico, latas e vidros -, o material é misturado nos caminhões, para ser (re)separado (quando o é) no centro de triagem.

A seguir apresentamos alguns relatos recentes sobre o Programa Coleta Seletiva da Prefeitura de São Paulo, sobre a situação das 15 Centrais de Triagem do 
Programa da Prefeitura, incluindo os grupos de catadores com diferentes níveis de organização e catadores avulsos.

\section{Relatos recentes sobre a Coleta Seletiva em São Paulo}

Estes relatos têm como base dois principais momentos. O primeiro deles é referente ao ano de 2005, quando aconteceu uma série de reuniões promovidas pela Secretaria de Serviços e Obras - SES, para diagnosticar a situação da coleta (oficial e não oficial) no Município de São Paulo. O segundo momento refere-se ao ano de 2007, durante o qual outra série de reuniões foi realizada, visando o levantamento dos grupos de catadores organizados no Município de São Paulo. Este diagnóstico seria utilizado para a obtenção de recursos do Programa de Aceleração do Crescimento - PAC, do Governo Federal, a ser investido na estruturação de novos galpões para a Coleta Seletiva.

A renovação dos contratos estabelecidos entre a Secretaria de Serviços e Obras - SES e as cooperativas gerenciadoras das Centrais de Triagem deveriam ser renovados no final de 2005. Naquela ocasião, a SES e o Limpurb (Departamento de Limpeza Urbana) realizou uma série de reuniões para a realização de um diagnóstico da situação da coleta seletiva no Município de São Paulo.

Foi definido um Quadro $10 \mathrm{com}$ informações para cada grupo de catadores: catadores avulsos; organizações formadas com até 15 catadores; organizações formadas com mais de 15 catadores; cooperativas conveniadas e Centrais de Triagem. Por fim, foi apresentada uma Síntese dos encontros, com os problemas levantados, pontos identificados, possíveis soluções e encaminhamentos. A seguir, apresentamos um Quadro que sintetiza estas informações: 


\section{QUADRO 10}

$\left.1^{\circ}\right)$ Catadores avulsos: de um modo geral foi relatado que poucos deles participaram das reuniões, resultando numa representação difusa da classe, o que demonstrava a dificuldade de atraí-los para o sistema oficial. Além do fato do pagamento no sistema cooperativado não ser à vista, como ocorre na venda nos ferros-velhos, os catadores avulsos têm dificuldades para se adaptarem ao trabalho coletivo e também com a comercialização, pois lidam com volumes menores, individualizados. Para ingressarem nas cooperativas, precisam aprender a trabalhar com produção em escala, destinada aos grandes compradores.

\section{Apontamentos sobre os catadores avulsos:}

- os catadores avulsos querem participar da comercialização conjunta, mas sem vínculos com as Centrais, permanecendo como catadores avulsos.

- os catadores deveriam conhecer os direitos e deveres do catador ao participar do sistema oficial;

- os catadores avulsos queriam autonomia na forma de trabalhar.

Foram apresentadas as seguintes propostas para os catadores avulsos:

- organização e capacitação para os catadores em cooperativismo;

- criação de postos de entrega bonificados, para prensagem e venda dos materiais dos catadores, retirando-os dos atravessadores;

- assistência social aos catadores;

- garantia de renda, capacitando-os para o trabalho mais qualificado;

- panfletagem e mobilização dos catadores avulsos, para inseri-los no sistema oficial.

$\left.2^{\circ}\right)$ Grupos pequenos (com até 15 pessoas), informais ou formais

- falta de empréstimo e permissão de uso dos equipamentos das Centrais;

- falta de EPI's (Equipamentos de Proteção Individual);

- falta de conhecimento da legislação sobre cooperativismo e de gestão dos resíduos sólidos;

- dificuldades em fazer a gestão, emissão de relatórios e prestação de contas (contabilidade);

- falta de espaço e condições para estocar material.

Foram apontadas as seguintes propostas:

- articulação destes grupos junto à Prefeitura, começando pelo cadastramento no Limpurb (somente possível para aquelas com CNPJ);

- parceria com a Prefeitura para uso dos equipamentos das Centrais de Triagem e para uso de espaços públicos para a implantação das cooperativas;

- captação de recursos financeiros e outros (capacitações, equipamentos, etc.)

- porém, ficava esclarecida a dificuldade de qualquer parceria sem a pessoa jurídica (CNPJ de associação ou cooperativa).

Os encaminhamentos para esta modalidade foram:

- estabelecer um modelo de convênio para credenciamento junto ao Limpurb;

- comercialização conjunta com as Centrais de Triagem e de comercialização (havia a proposta de criação de Centrais específicas para comercialização);

- capacitação para o trabalho;

- orientação para o cooperativismo.

$\left.3^{\circ}\right)$ Grupos maiores (acima de 15 pessoas):

\section{Grupos não conveniados:}

- falta pessoa jurídica (CNPJ) para relacionar-se com o poder público;

- experiências de comercialização conjunta com dificuldades;

- falta de conhecimento de leis, direitos e deveres no trabalho coletivo;

- dificuldades na relação com as Centrais de Triagem (Ex. falta de Nota Fiscal)

Os encaminhamentos foram praticamente os mesmos dos grupos menores, sendo acrescentado o seguinte ponto:

- interlocução com Sub-Prefeitura para aquisição de área pública e constituição de novas 
cooperativas.

Grupos conveniados - Centrais de Triagem:

- dificuldade na relação fiscal com os grupos e núcleos;

- problema da presença de muito rejeito nos caminhões compactadores;

- trajetos longos entre as áreas de coleta e a localização das Centrais;

- número de caminhões não comporta atendimento aos núcleos;

- necessidade de manutenção da infra-estrutura instalada nas Centrais.

- padronizar prestação de contas e regularidade contábil e fiscal de todas as Centrais;

- necessidade de ampliar a comercialização conjunta;

- necessidade de levantamento dos catadores avulsos na área de cobertura da coleta seletiva de cada Central de Triagem;

- análise comparativa dos benefícios do caminhão gaiola em relação ao compactador , o qual é considerado inadequado para a coleta seletiva, mas mantido por força de contrato com as empresas de limpeza urbana, vigente por 20 anos;

- possibilitar convênios, transformando as Centrais (cooperativas) em OSCIP's Organização da Sociedade Civil de Interesse Público.

Algumas soluções apontadas:

- Prefeitura daria início a um processo de recuperação e manutenção das Centrais de Triagem;

- Capacitação operacional e administrativa contínua nas Centrais de Triagem;

- Uso da Bolsa de Recicláveis da FIESP, com a qual a Prefeitura de São Paulo firmaria uma parceria.

- Educação ambiental, inclusive para os munícipes: "Não precisa separar, basta não misturar", frase citada durante a reunião a respeito da disposição do lixo domiciliar para a coleta seletiva.

Realizado este diagnóstico, foi proposto um cronograma no qual os representantes da SES / Limpurb visitariam os territórios onde os diferentes grupos de catadores atuavam. Porém, o processo foi interrompido. Ocorreu a mudança do representante da Secretaria, sendo que o novo Secretário desconsiderou o processo então realizado e passou a formular um novo Projeto, que acabou dividindo o Limpurb em duas equipes. Ao longo de 2006 e 2007 foram muitas as controvérsias dentro deste Departamento, resultando na dissolução das chefias das duas equipes.

Desde meados de 2007 e no decorrer de 2008, o foco principal das ações e propostas voltadas para a gestão dos resíduos sólidos girou em torno do anúncio de que recursos financeiros do Programa de Aceleração do Crescimento - PAC, do Governo Federal, seriam investidos na gestão de resíduos sólidos urbanos. A partir de então, antigos e novos atores, agora reunidos em torno da instituição Gaspar Garcia de Direitos Humanos, passaram a realizar uma nova séries de reuniões que resultaram num diagnóstico da situação dos grupos de catadores organizados no Município de São Paulo. Este diagnóstico serviria como norteador para a 
implantação de novas Centrais de Triagem para a Coleta Seletiva neste Município ${ }^{138}$. Cabe ressaltar que o mesmo seria utilizado tanto como argumento e justificativa para a solicitação de investimentos oriundos do PAC (daí a importância de um amplo levantamento no qual constasse o maior número possível de grupos de catadores) quanto para indicar os grupos a serem contemplados com estes recursos, já que nem todos apresentavam os requisitos para o referido financiamento. Ou seja, mais uma vez observamos que os recursos são solicitados em nome de uma maioria, porém apenas os grupos "mais eficientes" são beneficiados.

Os recursos do orçamento geral da União, vinculado ao PAC, seriam disponibilizados pelo Ministério das Cidades junto à Caixa Econômica Federal, através da qual os grupos organizados de catadores poderiam obter os financiamentos, invariavelmente intermediados pelas ONG's. A intermediação das ONG's ocorre principalmente nos casos em que os grupos de catadores ainda não apresentam os pré-requisitos necessários, tais como CNPJ, elaboração de Projeto, entre outros. Assim, formou-se um Grupo de Trabalho denominado "GT da Coleta Seletiva", formado por grupos de catadores (cooperativas, associações e núcleos), representantes de ONG's, do MNCR e também do poder público, além de outros. As informações levantadas constam no Quadro 20, que será apresentado posteriormente, o qual traz uma síntese dos locais que realizam atividades de reciclagem em São Paulo.

Ao total foram identificados 81 grupos de catadores (cooperativas, associações ou núcleos) no município de São Paulo, apresentando diferentes níveis de organização. Ou seja, desde Centrais de Triagem (criadas pela Prefeitura de São Paulo) ou Cooperativas estruturadas (geralmente em parceria com ONG's, empresas, bancos, e/ou Prefeitura), passando por associações e cooperativas em processo de estruturação (às vezes em parceria com ONG's, empresas, bancos e/ou Prefeitura), até pequenos grupos informais de catadores identificados como núcleos de reciclagem (geralmente sem parcerias e às vezes vinculados a associações de moradores e/ou igrejas).

\footnotetext{
${ }^{138}$ Formalizado por meio do ofício 4701/2008/SNSA/MCIDADES, encaminhado pelo Ministério das Cidades à Prefeitura de São Paulo, a qual havia reafirmado a intenção de continuar desenvolvendo a coleta seletiva com base no trabalho de grupos organizados de catadores (Decreto Municipal 48799/07).
} 
Resultou deste processo a destinação de $\mathrm{R} \$ 4.300 .000,00$ (quatro milhões e trezentos mil reais) de recursos do PAC indicados para a construção de 08 Galpões de coleta seletiva, 01 adequação de espaço já existente e equipamentos para 01 galpão.

No diagnóstico realizado sobre os grupos de catadores existentes, uma das informações elementares dizia respeito às áreas para construção dos Galpões, sendo que a maior parte dos grupos reivindicava áreas públicas municipais a serem disponibilizadas pela Prefeitura, ou por outra instituição (tais como CET na região central, CDHU na zona leste, Sabesp na zona sul, entre outros). Mesmo no caso dos grupos que já ocupavam alguma área pública (sendo muito comum o uso de espaços sob viadutos), solicitava-se áreas maiores $\left(\mathrm{em} \mathrm{m}^{2}\right)$ e mais adequadas para a instalação da cooperativa. Diante desta situação, o GT passou a pressionar e buscar acordos com a Prefeitura de São Paulo, e demais parceiros, para a obtenção das áreas para a construção dos Galpões, sendo que a listagem dos grupos e respectivas indicações de áreas já circulavam tanto no Limpurb quanto nas Subprefeituras.

Além da reivindicação de áreas públicas para a implantação dos Galpões a serem construídos com recursos do PAC, O "GT da Coleta Seletiva" também solicitava à Prefeitura de São Paulo áreas públicas municipais na região de Perus e Jaraguá para dois galpões que seriam construídos paras as cooperativas Coopercose e Recicla Pirituba com recursos oriundos de créditos de carbono obtidos junto ao Aterro Bandeirantes (manejo dos resíduos sólidos para produção de energia).

Após a confirmação do financiamento e da escolha dos grupos a serem contemplados, o grande "gargalo" continuou sendo a disponibilidade de áreas (de preferência públicas e com tamanho superior a $800 \mathrm{~m}^{2}$ ) para a implantação dos galpões. Assim, até meados de 2008 ainda não estava definitivamente estabelecido quais grupos seriam beneficiados, pois a aplicação do financiamento estava condicionada à aquisição de áreas pelos respectivos grupos.

Desta forma, esta política pública deveria resolver uma questão espacial: encontrar áreas públicas para a implantação dos galpões, de modo a não aumentar os custos envolvidos na institucionalização da base da indústria da 
reciclagem. Ainda que o resultado final com as áreas efetivamente obtidas pelos grupos (geralmente por comodato e termo de permissão de uso) não tenha sido publicado até meados de 2008, pude-se ao menos indicar as áreas que foram listadas como possibilidades para esta finalidade. As informações referente a este diagnóstico estão expostas no capitulo sobre a base da indústria da reciclagem em São Paulo.

\subsection{Milhares de catadores \& toneladas de recicláveis}

Este sub-capítulo adentra o universo do quantitativo, o qual se apresenta como necessário à melhor compreensão da magnitude do objeto de estudo: a indústria que se ergue arregimentando milhares de catadores que, na sua base estrutural, "recuperam" toneladas e mais toneladas de recicláveis a serem transformados em novas matérias-primas. Poderia bastar apenas a generalização deste fenômeno: são milhares de catadores, são toneladas de recicláveis... Porém, optou-se pela inclusão deste sub-capítulo, dedicado à questão da quantidade que muda a qualidade. Pois, tanto a produção de resíduos sólidos urbanos em escala elevada, quanto a enorme massa de trabalhadores sobrantes (re)inseridos produtivamente nas atividades da reciclagem (objeto de trabalho e trabalho), constituem elementos com os quais se ergue esta indústria.

Porém, os dados e informações sobre o universo da reciclagem estão restritos ao setor formal, tais como os cadastros existentes no CEMPRE, RAIS e Associações dos diferentes segmentos industriais. Neste sentido, este "adentrar o universo do quantitativo", em direção à base da indústria que se realiza majoritariamente no setor informal, apresenta limitações.

Para não desistir do propósito enunciado, optou-se pela análise dos dados disponibilizados por algumas fontes, tanto para o universo dos grupos de catadores quanto para o universo dos catadores avulsos. Em relação a este último, a ausência de informações releva o quanto estes trabalhadores estão na mais completa invisibilidade. Frente à ausência de dados mais precisos, elaborou-se uma estimativa 
sobre quantos catadores avulsos possam existir no Município de São Paulo. Por se tratar apenas de "mais uma estimativa", este cálculo está sujeito a críticas, inclusive assumidas como auto-crítica! Ainda assim, seus resultados foram adotados na pesquisa, sobretudo porque contemplam um maior número de variáveis em relação às estimativas já existentes. A metodologia adotada para esta estimativa foi incluída como Anexo da Tese (ANEXO 13).

\subsubsection{Grupos de catadores organizados}

Com base no levantamento realizado pelo trabalho do "GT Coleta Seletiva" apresentado anteriormente, chegou-se à existência de cerca de $\underline{2200}$ catadores distribuídos de forma bastante heterogênea entre os 81 grupos identificados, sendo que 7 deles não apresentam a informação sobre o número de integrantes. Os grupos com menor número de integrantes são os mais freqüentes: cerca de 25\% (20 grupos) são constituídos por pequenos núcleos (com menos de 10 integrantes); $22 \%$ dos grupos apresentam de 11 a 20 integrantes; $27 \%$ estão reunidos entre os grupos com 21 a 50 integrantes, (perfazendo o total de $74 \%$ para grupos com até 50 integrantes), e 17\% (14 grupos) apresentam de 51 a 100 integrantes.

Observamos também que no total dos grupos organizados estão incluídos aqueles da Rede Cata-Sampa ${ }^{139}$ (com cerca de 167 cooperados) e mais 11 Centrais de Triagem do Programa da Prefeitura de São Paulo. As 4 Centrais de Triagem que não estavam indicadas no levantamento do "GT Coleta Seletiva" - Cooperunião (Itaquera), Nova Conquista (Itaim Paulista), Tietê (Moóca) e Sem Fronteira (JaçanãTremembé), também foram aqui acrescentadas com seus respectivos cooperados. Todos estes grupos reúnem cerca de 2500 catadores organizados em 119 grupos ${ }^{140}$ (cooperativas, associações, núcleos), estando dentro da estimativa do MNCR

\footnotetext{
139 Cooperativas e núcleos reunidos em rede para comercializar os materiais recicláveis conjuntamente. Contam com financiamento de empresas como a Petrobrás e vendem diretamente para algumas indústrias, como a Suzano Papel e Celulose. Abordamos a Rede Cata-Sampa na exposição sobre as atividades de reciclagem no território de Itaim Paulista.

${ }_{140}$ O número total de "grupos organizados" foi complementado pelas cooperativas do CEMPRE não coincidentes com aquelas já consideradas pelas primeiras fontes (GT Coleta Seletiva, Centrais de Triagem e bases da Rede Cata-Sampa).
} 
divulgada pelo Instituto Polis, que indica a existência de cerca de 3000 catadores organizados em São Paulo.

\subsubsection{Catadores avulsos: estimativas}

Ao analisar os dados da Pesquisa Nacional de Saneamento Básico PNSB (2000) do IBGE, o próprio Instituto POLIS - referência na divulgação de informações sobre os catadores em São Paulo, admite a dificuldade e mesmo a ausência de dados precisos sobre a coleta de recicláveis realizada por catadores:

(...) Quanto aos resíduos reciclados, apenas uma parcela mínima (não contabilizada na pesquisa por sua pequena dimensão) é coletada seletivamente e destinada para a reciclagem por meio de programas municipais. No entanto, na metodologia do IBGE não foi contabilizada a parcela de resíduos destinada para a reciclagem pelo trabalho desenvolvido pelos catadores em todo o país. E preciso que se realize este levantamento urgentemente. (...) Os dados oficiais sobre a quantidade de resíduos produzidos na cidade de São Paulo são aferidos com base nas informações de coleta e destinação de resíduo sob ${ }_{\text {responsabilidade da Prefeitura }}^{141}$. (...) Quanto à questão social, que envolve a presença de catadores de rua, um grande desafio é saber quantas pessoas estão atuando nesta área, conhecer seu perfil, saber quantos dentre eles são organizados e como atuam, identificar a cadeia de intermediários (que compram seus materiais) entre outras informações. (Grimberg, 2007: 12; 14) ${ }^{142}$

$\mathrm{Na}$ ausência de dados mais precisos sobre o número de catadores, Elisabeth Grimberg apresentou em 2004 a estimativa de cerca de 20 mil catadores para a cidade de São Paulo. Diversos documentos, textos acadêmicos e jornalísticos utilizam esta informação. Mas ao apresentar a metodologia utilizada, o próprio Instituto POLIS adverte sobre a necessidade de dados mais precisos:

(...) estimativas do Instituto Polis (amplamente adotadas pela mídia e pelo próprio movimento de catadores) apontam a presença de cerca de 20 mil catadores. $\mathrm{Na}$ falta de um censo que apure o número exato de catadores que coletavam materiais recicláveis nas ruas da cidade em 2004, o Instituto Polis construiu a seguinte lógica para estimar o número de pessoas atuando nesta atividade: dados da Secretaria de Serviços e Obras indicavam a redução de 1.300

\footnotetext{
${ }^{141}$ Grifo nosso.

142 A autora apresenta dados da FIPE (2000) sobre População de Rua, em que dos 9.000 moradores de rua, $32,2 \%$ dos entrevistados realizavam atividade da catação (2898 catadores).
} 
toneladas de resíduos coletados por dia entre o ano 2000 e 2004. Multiplicandose estas 1300 toneladas por 30 dias (um mês) e dividindo este valor (39000 toneladas) por duas toneladas (média que um catador organizado coleta por mês) chega-se ao número de 19.500 pessoas sobrevivendo de materiais recicláveis em São Paulo. (Estes números estão sujeitos a revisões, a partir da realização de um levantamento mais preciso.) Segundo estimativas do Comitê de Catadores de São Paulo existe cerca de 70 a 96 entidades de catadores (cooperativas, associações, grupos), aproximadamente 3 mil pessoas atuando na cidade de forma organizada ${ }^{143}$ - (...) A discrepância de informações entre as fontes disponíveis e a sabida precariedade do trabalho de catação apontam a necessidade urgente de o poder público realizar um inventário desta situação. (Grimberg, 2007:14-15)

A estimativa de 20.000 catadores existentes na cidade de São Paulo foi revisada em 2005 pela mesma autora, conforme divulgado no artigo "Queremos mostrar o trabalho organizado" publicado na Folha de São Paulo:

\begin{abstract}
Elisabeth Grimberg, do Instituto Pólis e coordenadora geral do Fórum Lixo e Cidadania da Cidade de São Paulo, revisando a estimativa, chegou a 10,8 mil. Ela considerou 700 catadores trabalhando nas centrais de triagem da prefeitura, e 2.300 em cooperativas. Os outros são estimados com base na redução de lixo coletado em São Paulo entre 2001 e 2004, 39 mil toneladas por mês, excluindo o volume de lixo levado às centrais de triagem. O movimento dos catadores considera que um catador recolhe $200 \mathrm{~kg}$ por dia, ou 5.000 toneladas por mês. Dividindo o total de redução pelo total coletado por catador (39 mil/5.000), chegase a 7.800 catadores avulsos. Com os 3.000 organizados, são 10,8 mil. Os 20 mil estão errados? Não, resultam apenas do uso de outros parâmetros. "Um avanço", avalia Grimberg, que reforça a necessidade de melhorar a contagem muito mais - daí a cobrança no documento dos catadores. Enquanto isso, esperam que as políticas públicas municipais cheguem à mesa de discussão. (Folha de São Paulo, Cotidiano, 03/10/2005)
\end{abstract}

Com o novo cálculo, o número de catadores diminuiu em cerca de $50 \%$ em relação à estimativa anterior. Isso porque, ao manter o montante de 39.000 toneladas por mês e aumentar as 2 toneladas $^{144}$ para 5 toneladas $^{145}$ por mês, necessariamente o número total de catadores diminuiria...

Porém, ao se considerar a possibilidade de um montante maior de resíduos passíveis de serem reciclados (o que é comprovado pelos altos Índices de Reciclagem apresentados no Capítulo IV), pode-se chegar a um resultado bem

\footnotetext{
${ }_{143}^{143}$ Grifos nossos.

${ }^{144}$ Média que um catador organizado coleta por mês, cálculo feito pela autora com base nos valores das Centrais de Triagem da Prefeitura de São Paulo)

${ }^{145}$ Ou seja, 200 quilos por dia, segundo o MNCR, quantidade aplicável aos catadores não organizados.
} 
diferente. Inclusive admitindo-se uma variação na quantidade de material coletado pelos catadores, que pode ser inferior a 2 toneladas ou até superior a 10 toneladas por mês, conforme identificado em trabalho de campo realizado, respectivamente, na periferia distante (Subprefeitura de Itaim Paulista) e na região central de São Paulo (Subprefeitura Sé). Nesta última, alguns catadores declararam carregar até 700 quilos de material reciclável numa única viagem.

Ora, a estimativa do número possível de catadores não deveria ser feita em relação à variação (redução ou acréscimo) da quantidade de resíduos que é coletada pelo sistema oficial, mas em relação ao que não é coletado pelo mesmo. Mas como faze-lo, se este é justamente o universo do que se passa para além do setor formal, e sem dados disponibilizados por uma pesquisa oficial dedicada ao tema?

Diante da imprecisão dos dados disponíveis, optou-se por uma outra estimativa, calculada no contexto da Tese, segundo a qual pode-se considerar a existência de algo em torno de 40.000 catadores no Município de São Paulo. Destes, cerca de 38.000 catadores seriam avulsos, além dos já indicados 2.500 catadores organizados ("GT Coleta Seletiva" complementado pelos integrantes das Centrais de Triagem da Prefeitura). Ou seja, o dobro do que normalmente é admitido. Assim, optou-se em considerar a existência de algo em torno de 40.000 catadores, e não 20.000 .

Esta estimativa contou com as seguintes informações principais:

$1^{\circ}$ ) Estimativa do número de catadores existentes na região central, divulgado pelos fóruns de atuação no tema da gestão dos resíduos sólidos urbanos e pelo MNCR;

$2^{\circ}$ ) Estimativa do número de catadores existentes no Itaim Paulista, divulgado pelo FOACRI (Fórum ambiental dos catadores do Itaim Paulista) e Câmara de Animação Econômica da Sub-Prefeitura;

$\left.3^{\circ}\right)$ Número de "locais com atividades de reciclagem", identificados no banco de dados da Supervisão de Vigilância em Saúde (SUVIS), a qual monitora locais vulneráveis ao mosquito da dengue. Estes são denominados pela SUVIS como "Pontos Estratégicos". A pesquisa se restringiu apenas aos "Pontos Estratégicos" relacionados com atividades da reciclagem, e foram aqui denominados de "Pontos 
de Reciclagem"146. Utilizou-se, primeiro, esta informação para as Sub-Prefeituras Sé e Itaim Paulista, e depois para todo o Município. Como já assinalado, a metodologia utilizada foi incluída nos ANEXOS da Tese, sob o formato de um Quadro com Notas explicativas (Anexo 13).

\subsubsection{Coleta Seletiva \& Catação: a medida da desproporção}

Com base nos relatórios da Limpurb sobre o Programa de Coleta Seletiva, a média de materiais recicláveis coletados pelo conjunto das 15 Centrais de Triagem foi de aproximadamente 2.154 toneladas ( 25.848 ao ano) no período de junho de 2006 a junho de 2007. Mas qual teria sido o montante dos recicláveis coletados pelos milhares de catadores que trabalham seja como avulsos ou em grupos organizados, para além do sistema oficial? Optamos por calcular o Índice de Reciclagem referente aos materiais que são reciclados mensalmente em São Paulo. Para tanto, recorremos ao procedimento que foi adotado por Calderoni (2003) quando calculou os Índices de Reciclagem dos principais tipos de materiais para este Município. O referido autor utilizou como base para este cálculo os Índices de Reciclagem existentes no Brasil, os quais são divulgados pelas Associações de cada segmento, conforme visto no Capítulo anterior. Neste cálculo, São Paulo participa com cerca de $50 \%$ do total dos materiais reciclados no país.

Este cálculo considerou:

\footnotetext{
${ }^{146}$ Explicação sobre os Pontos de Reciclagem: A Supervisão de Vigilância em Saúde (SUVIS) monitora locais suscetíveis à ocorrência do mosquito da dengue, denominado de PONTOS ESTRATÉGICOS, ou simplesmente "PE". Do universo total dos PE's, uma parte é constituída por locais com atividades de reciclagem. No escopo da Tese, foram denominados de "Pontos de Reciclagem", ou simplesmente "PR". Os Técnicos e Agentes de Apoio das SUVIS explicam que estes PE's (com atividades da reciclagem) correspondem a uma amostra abaixo do número real existentes no território. Geralmente atuam de modo informal, com infra-estrutura muito precária. Outra informação refere-se à oscilação dos PE's cadastrados ao longo do tempo. Primeiro porque estes estabelecimentos iniciam e encerram suas atividades com muita rotatividade, ou mudam de endereço. Por isso, as informações obtidas não apresentam data exata, mas a referência da situação em meados de 2008 . 0 território de cada SUVIS corresponde ao território de cada Subprefeitura do Município de São Paulo, exceto para 5 SUVIS: Lapa-Pinheiros, Vila Mariana-Jabaquara, Pirituba-Perus, Aricanduva-Moóca e Cidade Ademar-SantoAmaro. Os PE's com atividades ligadas à reciclagem representam algo em torno de $40 \%$ a $80 \%$ do total de PE's cadastrados, variando a porcentagem em cada uma das 26 SUVIS. A porcentagem de PE's com atividades de reciclagem - que denominamos de "Pontos de Reciclagem" é maior nas SUVIS situadas em Subprefeituras com menores taxas de renda, ou seja, nas periferias urbanas.
} 
a) a proporção na qual São Paulo recicla cerca de $50 \%$ do total dos materiais que são reciclados no Brasil, conforme cálculo de Calderoni (2003);

b) a quantidade (toneladas) e Índices de Reciclagem brasileiros dos materiais recicláveis apresentados na pesquisa (Capítulo IV).

c) com base nestas informações, realizou-se o cálculo proporcional para São Paulo, conforme apresentamos no Quadro 11 da próxima página.

Mesmo considerando apenas quatro dos principais tipos de materiais coletados (latas de alumínio, papéis, vidros e plásticos), o volume encontrado foi de 206.000 toneladas recicladas ao mês. Ou seja, a coleta seletiva da Prefeitura corresponde a apenas $1,04 \%$ do total indicado pelos Índices de reciclagem. Ainda que consideremos a existência de coleta privada ou realizada por cooperativas que não integram o sistema oficial (que junto com as Centrais de Triagem totalizam cerca de 120 "grupos organizados"), é muito evidente que o verdadeiro exército de catadores avulso participa do montante aqui calculado.

Portanto, esta é a medida que aponta para a exorbitante desproporção entre coleta oficial e o universo onde são (re)inseridos produtivamente os catadores na base da indústria da reciclagem. 
QUADRO

\begin{tabular}{|c|c|c|c|c|c|c|c|}
\hline materiais & $\begin{array}{l}\text { 1995/1996 (ano) } \\
\text { Brasil (ton) }\end{array}$ & $\begin{array}{l}\text { Índice de } \\
\text { reciclagem* }\end{array}$ & São Paulo (ton) & $\begin{array}{l}\text { 2006/2007 (ano) } \\
\text { Brasil (ton) }^{\star \star}\end{array}$ & $\begin{array}{l}\text { Índice de } \\
\text { reciclagem }\end{array}$ & $\begin{array}{l}\text { estimativa } \\
\text { (ano) } \\
\text { São Paulo (ton) }\end{array}$ & $\begin{array}{l}\text { estimativa (mês) } \\
\text { São Paulo (ton) }\end{array}$ \\
\hline latas de alumínio & 46.000 & $70 \%$ & 20.000 & 160.600 & $96,50 \%$ & 69.826 & $5.818,83$ \\
\hline vidros & 280.720 & $35 \%$ & 92.000 & 400.000 & $46 \%$ & 131.091 & $10.924,25$ \\
\hline papéis & 1.840 .000 & $31,70 \%$ & 1.153 .000 & 3.496 .500 & $45 \%$ & 2.191 .013 & $182.584,41$ \\
\hline plásticos & 270.000 & $12 \%$ & 29.000 & 767.504 & $35,5 \% \%^{* * *}$ & 82.436 & $6.869,66$ \\
\hline Total & 2.436.720 & & 1.294 .000 & 4.824 .604 & & 2.474 .366 & $206.197,15$ \\
\hline
\end{tabular}

\begin{tabular}{|r|r|r|r|}
\cline { 2 - 4 } \multicolumn{1}{c|}{} & \multicolumn{1}{c|}{$\begin{array}{c}\text { Brasil - 2006 } \\
\text { coleta seletiva }\end{array}$} & $\begin{array}{l}\text { São Paulo 2006 } \\
\text { Coleta Seletiva }\end{array}$ \\
\hline METAIS & 31.701 & METAIS & $1.083,30$ \\
\hline VIDROS & 17.617 & VIDROS & 2.321 \\
\hline Papel/Papelão & 85.098 & Papel/Papelão & 7.736 \\
\hline PLÁSTICOS & 53.865 & PLÁSTICOS & 4.332 \\
\hline Total & $\mathbf{1 8 8 . 2 8 0}$ & Total & $\mathbf{1 5 . 4 7 2 , 3 0}$ \\
\hline$\%$ Total reciclado & $\mathbf{3 , 9}$ & \% Total reciclado & $\mathbf{0 , 6}$ \\
\hline
\end{tabular}

Dados da Coleta Seletiva: Fonte: SNIS (2008). Pesquisa realizada em 2006 com 237 municípios (do total de 5564 existentes), perfazendo cerca de $50 \%$ da população urbana do país, incluindo os maiores centros urbanos e regiões metropolitanas (aproximadamente 74.478 .800 habitantes do total de 155.934 .000 habitantes da população urbana do Brasil em 2006). Ainda que dobrássemos a quantidade da Coleta Seletiva (100\% população urbana), não chegaríamos a $10 \%$ do total coletado. Ou seja, mais de $90 \%$ da coleta que resulta nos índices de reciclagem não provém da coleta seletiva oficial.

Ou ainda, não chegaríamos a $4 \%$ do montante total de 7.380 mil toneladas de materiais que são reciclados anualmente (CEMPRE, 2008).

* Índice de Reciclagem: \% da produção a partir de materiais recicláveis em relação ao total da produção

**Fonte: Associações representantes de cada segmento: Abralatas(latas de alumínio), Abividro (vidros), Bracelpa(papel), AbiPet (plástico).

*** Média dos respectivos índices de reciclagem: 20\% (plástico rígido) e 51,3\% (PET)

**** Cálculo realizado a partir dos dados de Calderoni (2003) e considerando que o índice de reciclagem em São Paulo é ao menos igual ao índice nacional, e de que São Paulo recicle cerca de 50\% do total do país, tanto em 1996 quanto em 2006.

Mesmo se considerássemos que todas as cooperativas cadastradas no CEMPRE (as que coletam e triam diversos tipos de materiais, num total de 46 cooperativas), tivessem o mesmo desempenho das Centrais de Triagem, o que é muito pouco provável, teríamos algo em torno de $47.448,38$ toneladas de materiais recicláveis (cerca de duas vezes a mais o total das 15 Centrais de Triagem), este montante corresponderia a somente $23 \%$ do total de materiais reciclados.

Metodologia adaptada de Calderoni (2003). 


\subsection{A distribuição espacial dos locais com atividades de reciclagem no Município de São Paulo}

\subsubsection{Grupos de catadores organizados: institucionalização da base industrial nas periferias urbanas da metrópole}

A pesquisa sobre a localização dos grupos de catadores organizados foi organizada por Subprefeitura do Município de São Paulo, existindo ainda a indicação da situação das áreas (pública, privada, cedida, entre outros) onde estes grupos estão, as quais são em sua grande maioria públicas.

Alguns grupos não estão instalados em nenhuma área, o que sugere que os mesmos realizam as atividades (essencialmente a triagem do material) em vias públicas, como ruas e calçadas, procedimento que comum aos catadores que trabalham individualmente. Acompanhando a informação sobre as "áreas existentes", estão indicadas algumas "área necessárias" com seus respectivos proprietários. Estes últimos são constituídos principalmente por órgãos públicos (Prefeitura e outros), junto aos quais as referidas áreas são solicitadas para doação aos respectivos grupos de catadores.

No Quadro 12 apresentado na seqüência, estas informações estão reunidas por região administrativa do Município de São Paulo. Destaca-se a informação referente às áreas indicadas para os investimentos, as quais constam como "áreas necessárias". Estas totalizam $178.650 \mathrm{~m}^{2}$, tamanho eqüivalente a cerca de 16 campos de futebol (tamanho oficial de $10.800 \mathrm{~m}^{2}$ ) ou ainda 3 vezes a área total do Parque do Anhembi $\left(56.597 \mathrm{~m}^{2}\right)$. Estas informações ilustram a necessidade de espaços de tamanhos consideráveis para a institucionalização da base da indústria, o que se tornaria um alto custo para os agentes sociais envolvidos, caso não houvesse a disponibilidade de áreas públicas. Por sua vez, estas tendem a estar concentradas nas periferias urbanas da metrópole, inscritas numa situação geográfica, por assim dizer, "compatível" com esta atividade... 
QUADRO 12:

\begin{tabular}{|c|c|c|c|c|c|}
\hline $\begin{array}{c}\text { Região } \\
\text { Administrativa }\end{array}$ & \begin{tabular}{|c|} 
Total \\
Grupos
\end{tabular} & \begin{tabular}{c|} 
Total \\
"cooperados"
\end{tabular} & $\begin{array}{l}\text { Área existente } \\
\text { (por tipo) }\end{array}$ & $\begin{array}{l}\text { Área necessária } \\
\text { (por área } \mathrm{m}^{2} \text { ) }\end{array}$ & $\begin{array}{c}\text { Proprietário da "área } \\
\text { necessária" }\end{array}$ \\
\hline Centro & 11 & 544 & $\begin{array}{l}3 \text { sob viaduto } \\
2 \text { área pública } \\
2 \text { aluguel } \\
2 \text { igreja } \\
1 \text { ocupação } \\
1 \text { sem informação } \\
\end{array}$ & $\begin{array}{l}5=1.500 \mathrm{~m}^{2} \\
4=2.000 \mathrm{~m}^{2} \\
1=4.000 \mathrm{~m}^{2} \\
1=7.000 \mathrm{~m}^{2} \\
\text { Total }=26.500 \mathrm{~m}^{2}\end{array}$ & $\begin{array}{l}\text { - } 5 \text { PMSP e outros } \\
\text { - } 1 \text { C.E.T. } \\
\text { - } 1 \text { Mitra diocesana } \\
\text { - } 1 \text { SEFRAS } \\
\text { - } 1 \text { particular } \\
\text { - } 2 \text { sem informação }\end{array}$ \\
\hline Oeste & 7 & 408 & $\begin{array}{l}1 \text { sob viaduto } \\
1 \text { área pública } \\
1 \text { escola de samba } \\
1 \text { aluguel } \\
2 \text { em C.T. Leopoldina* }\end{array}$ & $\begin{array}{l}2=5.000 \mathrm{~m}^{2} \\
2=3.000 \mathrm{~m}^{2} \\
1=4.000 \mathrm{~m}^{2} \\
1=1.500 \mathrm{~m}^{2} \\
1=10.000 \mathrm{~m}^{2} \\
\text { Total }=31.500 \mathrm{~m}^{2}\end{array}$ & $\begin{array}{l}\text { - } 6 \text { PMSP e outros } \\
\text { - } 1 \text { sem informação }\end{array}$ \\
\hline Noroeste & 6 & 221 & $\begin{array}{l}2 \text { área pública } \\
2 \text { aluguel } \\
1 \text { conjunto habitacional } \\
1 \text { assoc. moradores } \\
1 \text { particular }\end{array}$ & $\begin{array}{l}2=5.000 \mathrm{~m}^{2} \\
2=3.000 \mathrm{~m}^{2} \\
1=1.200 \mathrm{~m}^{2} \\
1 \text { sem inf. } \\
\text { Total }=17.200 \mathrm{~m}^{2}\end{array}$ & $\begin{array}{l}\text { - } 1 \text { PMSP } \\
\text { - } 1 \text { Aterro - PMSP } \\
\text { - } 1 \text { Associação } \\
\text { - } 1 \text { CDHU } \\
\text { - } 2 \text { particular } \\
\end{array}$ \\
\hline Nordeste & 6 & 191 & $\begin{array}{l}4 \text { área pública } \\
2 \text { particular }\end{array}$ & $\begin{array}{l}1=5.000 \mathrm{~m}^{2} \\
2=1.500 \mathrm{~m}^{2} \\
1=1.200 \mathrm{~m}^{2} \\
2=\text { sem inf. } \\
\text { Total }=9.200 \mathrm{~m}^{2}\end{array}$ & $\begin{array}{l}\text { - } 3 \text { PMSP e outros } \\
\text { - } 3 \text { sem informação }\end{array}$ \\
\hline Leste 1 & 8 & 240 & $\begin{array}{l}2 \text { não tem } \\
2 \text { área pública } \\
2 \text { conjunto habitacional } \\
2 \text { particular }\end{array}$ & $\begin{array}{l}1=5.000 \mathrm{~m}^{2} \\
3=1.500 \mathrm{~m}^{2} \\
1=700 \mathrm{~m}^{2} \\
1=400 \mathrm{~m}^{2} \\
2=\text { sem inf. } \\
\text { Total }=10.600 \mathrm{~m}^{2}\end{array}$ & $\begin{array}{l}\text { - } 5 \text { PMSP e outros } \\
\text { - } 1 \text { CDHU } \\
\text { - } 2 \text { sem informação }\end{array}$ \\
\hline Leste 2 & 6 & 160 & $\begin{array}{l}4 \text { conjunto habitacional } \\
2 \text { particular }\end{array}$ & $\begin{array}{l}1=14.000 \mathrm{~m}^{2} \\
1=2.000 \mathrm{~m}^{2} \\
1=1.600 \mathrm{~m}^{2} \\
1=1.500 \mathrm{~m}^{2} \\
1=1.000 \mathrm{~m}^{2} \\
\text { Total }=20.100 \mathrm{~m}^{2}\end{array}$ & - 4 CDHU / PMSP \\
\hline Sudeste & 5 & 71 & $\begin{array}{l}\text { viaduto } \\
1 \text { particular } \\
1 \text { igreja } \\
1 \text { aluguel } \\
1 \text { cedida } \\
\end{array}$ & $\begin{array}{l}1=4.000 \mathrm{~m}^{2} \\
1=3.250 \mathrm{~m}^{2} \\
3=1.500 \mathrm{~m}^{2} \\
\text { Total }=11.750 \mathrm{~m}^{2}\end{array}$ & $\begin{array}{l}-2 \text { PMSP } \\
-3 \text { outros }\end{array}$ \\
\hline Centro-Sul & 5 & 125 & $\begin{array}{l}4 \text { área pública } \\
1 \text { igreja }\end{array}$ & $\begin{array}{l}1=3.000 \mathrm{~m}^{2} \\
1=1.000 \mathrm{~m}^{2} \\
3=\text { sem inf. } \\
\text { Total }=4.000 \mathrm{~m}^{2}\end{array}$ & $\begin{array}{l}\text { - } 4 \text { PMSP } \\
\text { - } 1 \text { Cúria Sto. Amaro }\end{array}$ \\
\hline Sul & 27 & 288 & $\begin{array}{l}15 \text { não tem } \\
4 \text { aluguel } \\
2 \text { particular } \\
2 \text { EMAE } \\
1 \text { igreja } \\
3 \text { sem informação }\end{array}$ & $\begin{array}{l}4=5.000 \mathrm{~m}^{2} \\
2=4.000 \mathrm{~m}^{2} \\
13=1.200 \mathrm{~m}^{2} \\
3=1.000 \mathrm{~m}^{2} \\
1=800 \mathrm{~m}^{2} \\
1=400 \mathrm{~m}^{2} \\
3=\text { sem inf. } \\
\text { Total }=47.800 \mathrm{~m}^{2}\end{array}$ & $\begin{array}{l}\text { - } 5 \text { EMAE } \\
\text { - } 16 \text { PMSP e outros } \\
\text { - } 2 \text { SABESP } \\
\text { - } 4 \text { sem informação }\end{array}$ \\
\hline Total & 81 & 2248 & & $178.650 \mathrm{~m}^{2}$ & \\
\hline
\end{tabular}


Outra informação disponibilizada se refere à presença, ou não, de parceiros e/ou financiadores para cada grupo de catadores, sendo que os Grupos com parceiros e financiadores correspondem às cooperativas melhor estruturadas. Isto demonstra que os investimentos não são destinados aos Grupos de catadores mais excluídos. Ao contrário, parceiros e financiadores apoiam cooperativas que já apresentam certos níveis de organização, sendo freqüente o pré-requisito do CNPJ para aquisição de financiamentos.

Além disso, como as parcerias e financiamentos geralmente têm como contrapartida a questão do "marketing social e ambiental", as entidades parceiras (seja do Terceiro Setor, do setor público ou do setor privado, tais como grandes empresas e bancos) evidentemente preferem investir em projetos que apresentem garantias de sucesso. Assim, uma cooperativa que já possui parcerias e que já contou com algum investimento tem mais chances de firmar novos contratos, do que um Grupo que ainda não possui nenhuma visibilidade. Ocorre que estes Grupos mais estruturados acabam desenvolvendo um aparato especificamente destinado à execução de Projetos, concomitante às atividades da reciclagem propriamente dita $^{147}$. No Quadro 13, os Grupos que concentram parceiros e investimentos estão com sombreamento.

Quadro 13: Grupos de catadores, seus parceiros e investidores

\begin{tabular}{|c|c|c|c|}
\hline GRUPOS & Parceiro/investidor & GRUPOS & Parceiro/Investidor \\
\hline COPA BRASIL & & $\begin{array}{l}\text { ASSOC. CATADORES DE } \\
\text { PQ. GUARANI }\end{array}$ & FÓRUNS \\
\hline COOPER GLICÉRIO & SEFRAS & ASSOCIAÇÃO COREJI & FÓRUNS \\
\hline COOPERE & P.M.S.P. & COOPERATIVA CRUFF & CDHU CATA-SAMPA \\
\hline COORPEL & CENTRO GASPAR GARCIA & COOPER-MAIS & \\
\hline COOPER SAMPA & INSTITUTO CATASAMPA & PUERAS & \\
\hline RECIFRAN & SEFRAS & ASSOCIAÇĀO MAGNÁLIA & SUBP: ITAIM PAULISTA E CDHU \\
\hline CAMARE & O.A.F. & $\begin{array}{l}\text { FENIX AGAPE } \\
\text { Itaim Paulista }\end{array}$ & $\begin{array}{l}\text { CAE (Sub-Pref.) CDHU SMTRAB } \\
\text { CATA-SAMPA GEA/FNMA } \\
\text { RESSOAR }\end{array}$ \\
\hline PARQUE DO GATO & NÂO & COOP. CAMINHO CERTO & $\begin{array}{l}\text { SUBP: ITAIM PAULISTA } \\
\text { UNICSUL }\end{array}$ \\
\hline$\overline{N I N I V E}$ & $\begin{array}{l}\text { FORUM ZONA LESTE / LIXO E } \\
\text { CIDADANIA }\end{array}$ & $\begin{array}{l}\text { COOPERGAIA } \\
\text { Campo Limpo }\end{array}$ & $\begin{array}{l}\text { PMSP / ONG'S / BANCO DO } \\
\text { BRASIL / NGDS(SVMA) }\end{array}$ \\
\hline ECO TEXTIL & $\begin{array}{l}\text { FORUM ZONA LESTE / LIXO E } \\
\text { CIDADANIA }\end{array}$ & MACEDONIA & $\begin{array}{l}\text { PMSP / ONG'S / BANCO DO } \\
\text { BRASIL / NGDS(SVMA) }\end{array}$ \\
\hline COOPERRUA & & JARDIM VERA CRUZ & $\begin{array}{l}\text { PMSP / ONG'S / BANCO DO } \\
\text { BRASIL / NGDS(SVMA) }\end{array}$ \\
\hline
\end{tabular}

${ }^{147}$ Este é o caso emblemático do Instituto Cata-Sampa que conta com uma estrutura exclusiva para as atividades diretamente relacionadas com os financiamentos e parcerias. 


\begin{tabular}{|c|c|c|c|}
\hline $\begin{array}{l}\text { COOPERAÇĀO } \\
\text { Lapa }\end{array}$ & $\begin{array}{l}\text { ANTEAG } \\
\text { ECOFUTURO } \\
\text { AVINA } \\
\text { BCO REAL } \\
\text { SUZANO }\end{array}$ & JARDIM MARCELO & $\begin{array}{l}\text { PMSP / ONG'S / BANCO DO } \\
\text { BRASIL / NGDS(SVMA) }\end{array}$ \\
\hline $\begin{array}{l}\text { COOPERSOMA Antigo } \\
\text { Boracéia }\end{array}$ & & \begin{tabular}{|l} 
UNIÃO DOS \\
MORADORES DE \\
PARAISÓPOLIS \\
\end{tabular} & \\
\hline RECICLAVIDA & $\begin{array}{l}\text { FORUM ZONA LESTE / LIXO E } \\
\text { CIDADANIA }\end{array}$ & COOPERCAPS & \\
\hline $\begin{array}{l}\text { COOPAMARE } \\
\text { Pinheiros }\end{array}$ & $\begin{array}{l}\text { OAF } \\
\text { BANCO DO BRASIL } \\
\text { SUZANO } \\
\text { ECO FUTURO }\end{array}$ & COOPERUNIS & \\
\hline COOPERNAIA & ONG'S & COOPERGERA & ONG'S \\
\hline COOPERVIVA BEM & & COOPERPAC & \\
\hline $\begin{array}{l}\text { COOPER VIRA LATA } \\
\text { Butantã }\end{array}$ & $\begin{array}{l}\text { BANCO DO BRASIL } \\
\text { PETROBRAS }\end{array}$ & GRUPO GAIVOTAS & \\
\hline COOPERATIVA CRESCER & $\begin{array}{l}\text { ECO CULTURAL FEIRA DE } \\
\text { ARTES DE PIRITUBA }\end{array}$ & GRUPO SÃO JOSÉ & \\
\hline CITY JARAGUÁ & $\mathrm{CDHU}$ & $\begin{array}{l}\text { COOPERATIVA NOSSOS } \\
\text { VALORES - Sto. Amaro }\end{array}$ & $\begin{array}{l}\text { BCO DO BRASIL / COMITÉ / } \\
\text { SUZANO BNDES }\end{array}$ \\
\hline RECICLA PIRITUBA & & COOPERMIRE & $\begin{array}{l}\text { LOJAS PÃO DE AÇÚCAR } \\
\text { BR+11 }\end{array}$ \\
\hline $\begin{array}{l}\text { COOPERCOSE } \\
\text { Perus }\end{array}$ & $\begin{array}{l}\text { BANCO DO BRASIL / } \\
\text { MINISTÉRIO DO TRABALHO / } \\
\text { CARE BRASIL } \\
\text { CRÉDITO DE CARBONO }\end{array}$ & ACRESP & CÚRIA DE STO AMARO \\
\hline UNIÁO DOS CATADORES & $\begin{array}{l}\text { Cata Sampa e Assoc. Mor. } \\
\text { V.Nova Esperança }\end{array}$ & ALQUIMIA & \\
\hline COOPERCICLA & & $\begin{array}{l}\text { COOP. PEDRA SOBRE } \\
\text { PEDRA }\end{array}$ & \\
\hline COOP. CANTAREIRA VIVA & $\begin{array}{l}\text { Só negociações com a } \\
\text { prefeitura. }\end{array}$ & SELVA DE PEDRA & \\
\hline COOP. SEM FRONTEIRAS & & GRUPO APARECIDA & $\begin{array}{l}\text { ASSOCIAÇÃO CONGREGAÇÃO } \\
\text { SANTA CATARINA }\end{array}$ \\
\hline $\begin{array}{l}\text { COOPERVITA/ ECOS DA } \\
\text { VITORIA }\end{array}$ & FEMA/SVMA Banco do Brasil & MATA VIRGEM & $\begin{array}{l}\text { ASSOCIAÇÃO CONGREGAÇÃO } \\
\text { SANTA CATARINA }\end{array}$ \\
\hline $\begin{array}{l}\text { Igreja Santo Antonio dos } \\
\text { Bancários }\end{array}$ & & GRUPO APURÁ & $\begin{array}{l}\text { ASSOCIAÇÃO CONGREGAÇÃO } \\
\text { SANTA CATARINA }\end{array}$ \\
\hline UNIÁO VILA STA. LUZIA & & GRUPO IMPERIO & $\begin{array}{l}\text { ASSOCIAÇÃO CONGREGAÇÃO } \\
\text { SANTA CATARINA }\end{array}$ \\
\hline COOPERVILA & PMSP & SEMPRE VERDE & MNCR \\
\hline COOPERJUTA & & $\begin{array}{l}\text { COOPERGAIA } \\
\text { M'Boi Mirim }\end{array}$ & $\begin{array}{l}\text { PMSP / ONG'S / BANCO DO } \\
\text { BRASIL / NGDS(SVMA) / EMAE } \\
\text { / CDHU } \\
\end{array}$ \\
\hline COOPER-RECIFAVELA & & COOPERGAIA J. FLORES & $\begin{array}{l}\text { PMSP / ONG'S / BANCO DO } \\
\text { BRASIL / NGDS(SVMA) / EMAE }\end{array}$ \\
\hline COOP. RECICLA ESPERANÇA & & COOPERGAIA S. MARIA & $\begin{array}{l}\text { PMSP / ONG'S / BANCO DO } \\
\text { BRASIL / NGDS(SVMA) / EMAE }\end{array}$ \\
\hline CAEPRA / JD. PLANALTO & & $\begin{array}{l}\text { COOPERGAIA } \\
\text { BARONESA }\end{array}$ & $\begin{array}{l}\text { PMSP / ONG'S / BANCO DO } \\
\text { BRASIL / NGDS(SVMA) / EMAE }\end{array}$ \\
\hline$I M E S P / P A C E$ & & $\begin{array}{l}\text { COOPERGAIA PARQUE } \\
\text { SANTO ANTONIO }\end{array}$ & $\begin{array}{l}\text { PMSP / ONG'S / BANCO DO } \\
\text { BRASIL / NGDS(SVMA) / EMAE }\end{array}$ \\
\hline $\begin{array}{l}\text { NOSSA SENHORA } \\
\text { APARECIDA }\end{array}$ & FÓRUNS & $\begin{array}{l}\text { GRUPO JARDIM VERA } \\
\text { CRUZ }\end{array}$ & $\begin{array}{l}\text { PMSP / ONG'S / BANCO DO } \\
\text { BRASIL / NGDS(SVMA) / EMAE }\end{array}$ \\
\hline CHICO MENDES & FÓRUNS & $\begin{array}{l}\text { COOPERCRAL } \\
\text { Parelheiros }\end{array}$ & $\begin{array}{l}\text { BANCO DO BRASIL E } \\
\text { NGDS(SVMA) }\end{array}$ \\
\hline VIDA NOVA & & JARDIM DAS FONTES & NGDS (SVMA) \\
\hline COOPER-LESTE & & $\begin{array}{l}\text { ASSOCIAÇÃO DE } \\
\text { MORADORES JARDIM } \\
\text { PAPAI NOEL } \\
\end{array}$ & \\
\hline COOPER-VITÓRIA & & GRUPO JARDIM ÁLAMOS & \\
\hline $\begin{array}{l}\text { COOP. NOVA ESPERANÇA } \\
\text { DO PROJETO PANTANAL } \\
\text { São Miguel Paulista }\end{array}$ & $\begin{array}{l}\text { CDHU / CONJUNTO } \\
\text { NACIONAL / CREN / BANCO } \\
\text { DO BRASIL / NUA / } \\
\text { MARABRAZ / SAINT GOBAIN }\end{array}$ & & \\
\hline
\end{tabular}


Dos 81 Grupos, apenas 10 foram selecionados para os investimentos do PAC, totalizando $R \$ 4.300 .000,00$ (quatro milhões e trezentos mil reais) declarados como "primeira fase". Cada galpão a ser construído (medindo $1.200 \mathrm{~m} 2$ ), com seus respectivos equipamentos, foi orçado no valor de $R \$ 360.000,00$. Para 8 Grupos foram previstos investimentos para construção de galpão e equipamento, e para os 2 Grupos restantes recursos para adequação de galpão ou aquisição de equipamentos $^{148}$. No Quadro 14 estão as informações sobre os Grupos selecionados, com as respectivas áreas, sendo todas elas públicas:

\section{QUADRO 14:}

\begin{tabular}{|c|c|c|c|c|c|c|}
\hline Região & \begin{tabular}{|l} 
Subpref. \\
\end{tabular} & GRUPO & Investimento & Endereço & Área $\left(\mathrm{m}^{2}\right)$ & Prop. \\
\hline \multirow[t]{2}{*}{ CENTRO } & Sé & $\begin{array}{l}\text { Cooperglicé- } \\
\text { rio }\end{array}$ & $\begin{array}{l}\text { Construção + } \\
\text { Equipamento }\end{array}$ & Av. do Estado - CET & $5.000 \mathrm{~m}^{2}$ & CET \\
\hline & $\begin{array}{l}\text { Sé, Ipiranga } \\
\text { ou V. Prudente }\end{array}$ & Coorpel & $\begin{array}{l}\text { Construção + } \\
\text { Equipamento }\end{array}$ & $\begin{array}{l}\text { Centro (RFF ou CET), } \\
\text { Ipiranga ou V. Prudente }\end{array}$ & $7.000 \mathrm{~m}^{2}$ & $\begin{array}{l}\text { CET ou } \\
\text { RFF }\end{array}$ \\
\hline \multirow[t]{3}{*}{ SUL } & \begin{tabular}{|l|} 
Capela do \\
Socorro
\end{tabular} & Coopercral & $\begin{array}{l}\text { Construção + } \\
\text { Equipamento }\end{array}$ & $\begin{array}{l}\text { R. Ana Velha c/ Av. } \\
\text { Capuchina }\end{array}$ & - & PMSP \\
\hline & \begin{tabular}{|l} 
Cidade \\
Ademar
\end{tabular} & $\begin{array}{l}\text { Pedra sobre } \\
\text { Pedra }\end{array}$ & $\begin{array}{l}\text { Construção + } \\
\text { Equipamento }\end{array}$ & Av. Araújo Lima,18 & $3.500 \mathrm{~m}^{2}$ & EMAE \\
\hline & Campo Limpo & Coopergaia & $\begin{array}{l}\text { Adequação + } \\
\text { Equipamento } \\
\end{array}$ & R. Vitorino de Oliveira & $3.500 \mathrm{~m}^{2}$ & PMSP \\
\hline \multirow[t]{4}{*}{ LESTE } & Itaim Paulista & Fênix & $\begin{array}{l}\text { Construção + } \\
\text { Equipamento }\end{array}$ & $\begin{array}{l}\text { R. Manoel Bueno da } \\
\text { Fonseca }\end{array}$ & $2.000 \mathrm{~m}^{2}$ & CDHU \\
\hline & Sapopemba & Cooperjuta & $\begin{array}{l}\text { Construção + } \\
\text { Equipamento }\end{array}$ & $\begin{array}{l}\text { Rua Giovani Nasco } \\
\text { Bairro Teotônio Vilela }\end{array}$ & $2.000 \mathrm{~m}^{2}$ & $\begin{array}{l}\text { Área } \\
\text { pública }\end{array}$ \\
\hline & Vila Prudente & $\begin{array}{l}\text { Cooper } \\
\text { Recifavela }\end{array}$ & $\begin{array}{l}\text { Construção + } \\
\text { Equipamento }\end{array}$ & $\begin{array}{l}\text { Rua Atílio Perela c/ } \\
\text { Rua Leite Lobo e Rua } \\
\text { Barão de Tamandari }\end{array}$ & $2.000 \mathrm{~m}^{2}$ & $\begin{array}{l}\text { Área } \\
\text { pública }\end{array}$ \\
\hline & S. Miguel Pta. & $\begin{array}{l}\text { Nova } \\
\text { Esperança }\end{array}$ & Equipamento & $\begin{array}{l}\text { Rua Japichana no } \\
\text { Jd. Pantanal }\end{array}$ & $2.000 \mathrm{~m}^{2}$ & CDHU \\
\hline OESTE & Butantã & Vira Lata & Construção & $\begin{array}{l}\text { Rua Nella Murari c/ } \\
\text { Rua Valentim Seits }\end{array}$ & $10.000 \mathrm{~m}^{2}$ & PMSP \\
\hline
\end{tabular}

Fonte: Planilhas do GT Coleta Seletiva (2007). Elaboração: Rosalina Burgos (2008)

Por fim, no Mapa 01, apresentado no final deste Capítulo, estão representadas a localização aproximada das áreas indicadas para a construção de novos galpões para estruturação das cooperativas selecionadas, e áreas listadas como alternativa para este mesmo fim. Todas as áreas indicadas e listadas são pública, seja da própria municipalidade, concentradas na zona sudeste, ou de

\footnotetext{
${ }^{148}$ Esta relação de Grupos a serem beneficiados com os financiamentos pode ser alterada, pois a questão da disponibilidade de áreas para construção de novos galpões se tornou decisiva para a continuidade desta proposta.
} 
autarquias, tais como as áreas da CDHU na zona leste e da EMAE na zona sul. E além de públicas estão todas situadas nas periferias urbanas, seja "na periferia do centro" ou na periferia propriamente dita.

\subsubsection{Cooperativas, Sucateiros e Recicladores: estrutura piramidal da indústria}

São aqui apresentadas informações referentes ao universo das cooperativas, sucateiros e recicladores cadastrados no CEMPRE, os quais corroboram com o entendimento sobre a estrutura piramidal da indústria da reciclagem. Estas constam nos Quadros 15 a 18, para cada uma das modalidade. $O$ primeiro deles traz informações sobre as cooperativas, as quais coletam e vendem os mais diversos tipos de materiais, realizando a função de recolher e disponibilizar aos recicladores os resíduos gerados de modo disperso no território:

\begin{tabular}{|c|c|}
\hline \multicolumn{2}{|c|}{ Quadro 15 - Cooperativas por grupos de materiais - São Paulo (2008) } \\
\hline MATERIAIS & Estabelecimentos \\
\hline plástico, metal, papel, vidro & 9 \\
\hline plástico, metal, papel, vidro, bateria & 6 \\
\hline plástico, metal, papel, vidro, tubo dental & 1 \\
\hline Sub-Total & 16 \\
\hline plástico, metal, papel, vidro, longa vida & 6 \\
\hline plástico, metal, papel, vidro, longa vida, bateria & 2 \\
\hline plástico, metal, papel, vidro, longa vida, óleo & 2 \\
\hline plástico, metal, papel, vidro, longa vida, óleo, eletrônicos, pneu & 1 \\
\hline Sub-Total & 11 \\
\hline plástico, metal, papel, vidro, longa vida, tubo dental & 5 \\
\hline plástico, metal, papel, vidro, longa vida, tubo dental, eletrônicos & 1 \\
\hline plástico, metal, papel, vidro, longa vida, tubo dental, óleo & 1 \\
\hline plástico, metal, papel, vidro, longa vida, tubo dental, matéria orgânica & 1 \\
\hline plástico, metal, papel, vidro, longa vida, tubo dental, matéria orgânica, pilha & 1 \\
\hline Sub-Total & 9 \\
\hline plástico, metal, papel & 4 \\
\hline plástico, metal, papel, longa vida & 1 \\
\hline plástico, metal, papel, longa vida, eletrônicos, pneu & 1 \\
\hline plástico, metal, papel, bateria & 1 \\
\hline Sub-Total & 7 \\
\hline plástico, papel, vidro, e outros & 3 \\
\hline Plástico & 3 \\
\hline Papel & 2 \\
\hline Óleo & 1 \\
\hline Madeira & 1 \\
\hline Não Informado & 7 \\
\hline TOTAL & 61 \\
\hline
\end{tabular}

Fonte: CEMPRE (2008). Elaboração: Rosalina Burgos (2008) 
Antes de chegarem aos recicladores, os materiais recicláveis geralmente passam pelo setor comercial, cadastrados pelo CEMPRE como sucateiros. Estes também cumprem o papel de reunir os resíduos do consumo disperso no território, classificá-los, concentrá-los em quantidades da mesma qualidade - toneladas de plásticos, toneladas de metais, toneladas de papéis, com suas diversas especificações, e encaminhá-los para grandes aparistas ou diretamente aos recicladores e indústrias produtoras de mercadoriais. Com base na informação "formas de venda", pode-se observar que os sucateiros fazem, assim como as cooperativas, o pré-beneficiamento do material, e inclusive declaram a venda de "produto final". Neste caso, são "sucateiros-recicladores". Há que se considerar que neste universo trabalham trabalhadores pobres urbanos, também denominados de "catadores", cujas atividades realizadas estão descritas no código da CBO (Classificação Brasileira de Ocupações - ANEXO 10). Vejamos o Quadro 16:

\begin{tabular}{|c|c|c|}
\hline \multicolumn{3}{|c|}{$\begin{array}{l}\text { QUADRO 16: SUCATEIROS por grupos de materiais recicláveis } \\
\text { São Paulo (2008) }\end{array}$} \\
\hline MATERIAL & $\begin{array}{r}\text { Número de } \\
\text { Estabelecimentos }\end{array}$ & Formas de venda \\
\hline Metal & 15 & \multirow{4}{*}{$\begin{array}{r}\text { Solto, Separado, Prensado, } \\
\text { Barras, Chapas, Bobinas, Moído } \\
\text { (flake), Pó, Lascas, Triturado, } \\
\text { Misturado, Sujo, Limpo, Inteiro, } \\
\text { Produto Final }\end{array}$} \\
\hline Metal, bateria & 7 & \\
\hline Metal, papel, bateria & 3 & \\
\hline Sub-Total & 25 & \\
\hline Plástico, metal, papel, bateria & 16 & \multirow{7}{*}{$\begin{array}{r}\text { Barras, Granulado, Chapas, } \\
\text { Bobinas, Separado, Prensado, } \\
\text { Sujo, Limpo, Solto, Caco, Inteiro, } \\
\text { Pellets, Moído (flake), Produto } \\
\text { Final, Pó, Lascas, Granulado, } \\
\text { Aglutinado, Triturado, Misturado }\end{array}$} \\
\hline Plástico, metal, papel, vidro & 13 & \\
\hline Plástico & 9 & \\
\hline Plástico, papel & 7 & \\
\hline Plástico, metal, pilha & 5 & \\
\hline Plástico, metal & 4 & \\
\hline Sub-Total & 54 & \\
\hline Papel & 25 & \multirow{2}{*}{$\begin{array}{r}\text { Triturado, Separado, Prensado, } \\
\text { Solto, Limpo }\end{array}$} \\
\hline & & \\
\hline Vidro & 28 & Solto, Inteiro, Misturado, Caco \\
\hline Não Informado & 51 & \\
\hline TOTAL & 183 & \\
\hline
\end{tabular}

Fonte: CEMPRE (2008). Elaboração: Rosalina Burgos (2008) 
Por fim, os recicladores concluem o processo de reciclagem. Seja produzindo a matéria-prima a ser consumida produtivamente na fabricação dos mais diversos produtos, como é o caso dos recicladores de plástico, seja absorvendo diretamente os recicláveis como parte constitutiva das matérias-primas dos próprios produtos fabricados, como é o caso dos setores papeleiro e vidreiro. Vejamos o Quadro 17:

\begin{tabular}{|l|r|r|}
\hline \multicolumn{2}{|c|}{ QUADRO 17: RECICLADORES por material reciclado } \\
São Paulo (2008)
\end{tabular}

Fonte: CEMPRE (2008). Elaboração: Rosalina Burgos (2008)

De acordo com o CNAE/RAIS ${ }^{149}$, a reciclagem se consolida como um subsetor da indústria de transformação, abastecendo de matérias-primas diversos setores tradicionais, tais como o papeleiro, o têxtil, o vidreiro, a metalurgia e a

\footnotetext{
${ }^{149}$ Classificação Nacional de Atividades Econômicas/Relação Anual de Informações Sociais In www.rais.gov.br/cnae.asp Acessado em 12/11/2007.
} 
indústria química. Este sub-setor, aqui analisado como indústria da reciclagem, apresenta uma estrutura piramidal. Vejamos o Quadro 18 síntese:

\section{Quadro 18: Síntese do número de cooperativa, sucateiros e recicladores}

\begin{tabular}{|l|r|r|r|}
\hline Etapas & \multicolumn{2}{|c|}{ Coleta e Triagem (entre outras) } & Transformação \\
\cline { 2 - 4 } $\begin{array}{l}\text { Estabelecimentos por } \\
\text { agente da indústria } \\
\text { da reciclagem }\end{array}$ & Sucateiros & Cooperativas & Recicladores \\
\cline { 2 - 4 } & & 61 & 127 \\
\hline
\end{tabular}

Fonte: CEMPRE (2008). Elaboração: Rosalina Burgos (2008)

O número de cooperativas existentes em São Paulo, em parte cadastradas no CEMPRE, ainda são em número bastante reduzido se comparado àquele dos sucateiros e recicladores. Deve-se considerar que, tanto nas cooperativas quanto nos comércios de reciclagem (definidos pelo CEMPRE como sucateiros) existe o trabalho de catadores. Portanto, cooperativas e sucateiros realizam atividades na base propriamente dita da indústria da reciclagem, exceto no caso de comerciantes de maior porte que inclusive realizam a etapa de transformação (caracterizando-se como sucateiros-recicladores).

Porém, mesmo considerando a totalidade das cooperativas, sucateiros e recicladores do cadastro do CEMPRE, ainda se mantém a grande discrepância em relação ao total de cerca de 2000 "pontos de reciclagem" do cadastro da SUVIS (como já assinalado anteriormente), demonstrando que a base da indústria da reciclagem está inscrita na informalidade. E é nela que se concentram os cerca de 20.000 a 40.000 mil catadores, conforme estimativas realizadas.

\subsubsection{A distribuição espacial dos locais com atividades de reciclagem}

As diferentes modalidades de locais com atividades de reciclagem identificadas na pesquisa foram reunidas para análise e discussão sobre sua distribuição espacial no Município de São Paulo. Estas modalidades são:

a) 15 Centrais de Triagem da Prefeitura;

b) 8 bases da Rede Cata-Sampa no Município de São Paulo; 
c) 81 Grupos organizados listados para financiamento PAC ${ }^{150}$;

d) mais 33 cooperativas do cadastro do CEMPRE (não coincidentes com as já incluídas);

e) 159 sucateiros e 116 recicladores também cadastrados no CEMPRE;

f) os 1697 "pontos de reciclagem" identificados no cadastro da SUVIS.

Com base neste levantamento, chegou-se a um total de 2090 locais com atividades de reciclagem no Município de São Paulo. Estas informações foram organizadas no Quadro 19, o qual se caracteriza como um "Quadro síntese" sobre os locais com atividades de reciclagem identificados (por Sub-Prefeituras, agrupadas por região administrativa do Município). O Quadro 19 traz notas explicativas sobre as informações apresentadas, bem como sobre o procedimento adotado para a organização dos mesmos, os quais provém de diferentes fontes consultadas.

Também foram elaborados quatro Gráficos (Gráficos 07 a 10). Nos dois primeiros (Gráficos 07 e 08), constam as informações sobre: grupos organizados (que reúne cooperativas, associações e núcleos), sucateiros e recicladores. No primeiro (Gráfico 07) as informações foram organizadas por Subprefeitura e no segundo (Gráfico 08) por Região administrativa do Município de São Paulo. Já nos dois últimos (Gráficos 09 e 10), acrescentou-se a informação sobre os "pontos de reciclagem", do cadastro da SUVIS. Da mesma forma, no primeiro a informação está por Subprefeitura (Gráfico 09) e no segundo por Região administrativa (Gráfico 10).

Também foi elaborado o Mapa 01 - "Sucateiros, Recicladores, Cooperativas e áreas para novos Galpões de Triagem - São Paulo (2008)". Neste Mapa, foram representadas as informações sobre cooperativas, sucateiros e recicladores do cadastro do CEMPRE (2008), bases da Rede Cata-Sampa na Zona Leste e áreas listadas e indicadas para os Galpões a serem construídos com recursos do PAC ("GT Coleta Seletiva", 2007). Foram incluídas a localização dos espaços a serem disponibilizados para a construção de novos Galpões de Triagem (recursos do PAC) ${ }^{151}$. Por sua vez, não constam os "ponto de reciclagem" e os

\footnotetext{
${ }^{150}$ Diagnóstico realizado pelo "GT Coleta Seletiva".

${ }^{151}$ Áreas listadas e indicadas, para a construção de novos galpões de triagem, com recursos do PAC. Do total de áreas listadas (ou seja, apontadas num levantamento geral) algumas foram indicadas como mais prováveis à implantação das Centrais de Triagem então propostas. Fonte: GT Coleta Seletiva, 2007.
} 
"grupos organizados", pois as informações foram disponibilizadas por Sub-Prefeitura, sem endereço preciso. Neste sentido, as mesmas foram incluídas no Quadro 19 e nos Gráficos, os quais também oferecem informações para uma análise geográfica. O Quadro 19, os Gráficos de 07 a 10 e o Mapa 01 foram apresentados ao final deste Sub-capítulo.

Com base no material gráfico e cartográfico citados, observa-se que as regiões Sul, Leste 1 e Leste 2 se destacam na concentração de "pontos de reciclagem", seguidas pela Região Sudeste. Ou seja, os "pontos de reciclagem", do cadastro da SUVIS, estão localizados nas regiões com menores taxas de renda da população, como explicado pelos técnicos que nela atuam.

Já as regiões Centro, Oeste e Centro-Sul constituem a porção territorial com menor incidência de "pontos de reciclagem". Devemos observar que no caso das Regiões Oeste e Centro-Sul o reduzido número de locais com atividades de reciclagem parece estar associado ao elevado padrão de uso e ocupação do espaço.

De modo geral, a Região Sul é a que concentra o maior número de locais com atividades de reciclagem, com destaque para a maior concentração do número de grupos organizados de todo o Município (32 grupos do total de 118). Porém, 12 destes grupos são pequenos núcleos formados por cerca de apenas 5 integrantes, bem abaixo do observado para o conjunto dos grupos. Estes núcleos estão reunidos em torno de uma cooperativa maior, conforme o modelo já proposto para as atuais Centrais de Triagem (embora tal proposta não tenha se concretizado). Assim, existem de fato cerca de 20 grupos, o que não altera a liderança desta região na distribuição destes locais no Município.

No caso da Região Central, formada por uma única Subprefeitura, a Sé, o total de 13 grupos organizados é o maior por Subprefeitura. Isto pode ser explicado pela concentração, ao menos, de três elementos neste território: materiais recicláveis, catadores e organizações sociais que organizam estes catadores. Por outro lado, a Sub-Prefeitura Sé não apresenta elevado número de "pontos de reciclagem" em comparação com outras localizadas na periferia distante, tais como Capela do Socorro (Região Sul), Sapopemba (Região Sudeste), São Matheus (Leste 1) e Pirituba-Jaraguá (Noroeste). De qualquer forma, os locais com atividades de reciclagem existentes na Região Centro tendem a se concentrar nos territórios 
empobrecidos, sobretudo na Baixada do Glicério e nas imediações da Av. do Estado, conforme observado em campo.

Já as Regiões Sudeste e Nordeste se destacam pela concentração de recicladores e sucateiros, respectivamente nas Subprefeituras Aricanduva (ao longo das Avenidas Sapopemba e Aricanduva) e Vila Maria (em torno do acesso à Rodovia Presidente Dutra). Esta concentração de atividades de comércio e sobretudo de transformação de materiais recicláveis (recicladores) nestes vetores da metrópole, coincide com a densidade de atividades industriais que caracterizam estas regiões. Aí também encontra-se uma presença significativa de "pontos de reciclagem", em posição intermediária entre as maiores concentrações (vetores Sul e Leste) e as menores (vetores oeste e centro-sul).

Assim, mesmo com a presença marcante em toda a extensão do espaço urbano, a indústria da reciclagem também segue a tendência do setor industrial, concentrando-se nas regiões Sudeste e Nordeste (conforme pode ser observado no Mapa 02), as quais se destacam na densidade de recicladores. Esta situação geográfica parece, de fato, estar associada aos eixos de ligação com outros municípios da Região Metropolitana de São Paulo que se destacam no setor da indústria de transformação, tais como o Município de Guarulhos no eixo nordeste (via Dutra), e a região do $A B C$ paulista, no vetor sudeste. Com base nisto, podemos concordar com autores ${ }^{152}$ que indicam a presença de grandes empresas consumidoras de materiais recicláveis coletados e comercializados em São Paulo, em outros Municípios da Grande São Paulo.

Quanto às bases ${ }^{153}$ da Rede Cata-Sampa, que integra a pesquisa realizada a partir do território do Itaim Paulista, observa-se que estas estão distribuídas no vetor leste do Município de São Paulo (junto aos conjuntos habitacionais da $\mathrm{CDHU}$ ), polarizadas pela Cooperativa Fênix-Ágape (no Itaim Paulista), pólo de comercialização desta rede ${ }^{154}$.

\footnotetext{
${ }^{152}$ Ziglio (2002), Munhoz (2004).

${ }^{153}$ A denominação "base" aqui deriva do Movimento dos catadores, o MNCR (da idéia de "base orgânica do Movimento"), e corresponde a grupos informais, associações e cooperativas de catadores.

${ }_{154}$ Caracteriza-se como entreposto de materiais recicláveis que são encaminhados para o pólo de comercialização do Alto Tietê (Cooperativa CRUMA, em Poá), de onde os materiais recicláveis são enviados para as indústrias. Dentre estas, destaca-se a Companhia Suzano Papel e Celulose, com fábrica no Alto Tietê (Município de Suzano).
} 
Como visto, existem tendências de concentração espacial dos diferentes agentes que atuam na reciclagem, sobretudo dos níveis intermediários das cadeias produtivas, como é o caso dos recicladores concentrados nos vetores sudeste e nordeste da metrópole de São Paulo. Grandes indústrias se situam nas franjas da metrópole, em municípios vizinhos a São Paulo, como é o caso das indústrias papeleiras ${ }^{155}$, a exemplo da Suzano Papel e Celulose (em Suzano), entre outras situadas em setores de relativa concentração industrial no próprio município de São Paulo (Owens-Illinois do Brasil e Nadir Figueiredo, ambas do setor vidreiro, situadas no vetor nordeste no Município de São Paulo).

Com base nos Gráficos apresentados neste sub-capítulo, que além dos sucateiros, recicladores e cooperativas (grupos organizados) também trazem a informação sobre os "pontos de reciclagem", podemos observar a predominância discrepante destes últimos em relação às demais modalidades (cooperativas, recicladores e sucateiros). Mesmo se considerarmos que as demais modalidades estejam incluídas nos "pontos de reciclagem" informados pelas SUVIS, ainda assim a discrepância se mantém.

Portanto, pode-se afirmar que a indústria da reciclagem apresenta uma estrutura piramidal. Na base estão os "pontos de reciclagem", em número evidentemente superior às demais modalidades cadastrados no CEMPRE. Os "pontos de reciclagem", com forte característica de informalidade, estão presentes nos vetores de consolidação e expansão das periferias urbanas da metrópole de São Paulo, sobretudo nas regiões Sul e Leste e na região Noroeste, onde também se encontram áreas públicas disponíveis para os negócios desta indústria. E também nas regiões com densidade elevada de estabelecimentos do setor industrial, ou seja, Região Sudeste e Nordeste.

Do que acabamos de apresentar, derivam algumas observações e proposições sobre a base da indústria da reciclagem. Vejamos.

Ainda que a diferenciação espacial da relação centro-periferia possa ser observada na organização da base desta indústria - essencialmente em função da diferenciação espacial com que os resíduos do consumo são gerados, ou seja, de modo concentrado no centro e de modo pulverizado e estendido na periferia - a

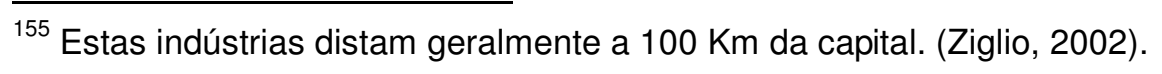


condição social da pobreza está presente e é reproduzida na realização do conjunto destas atividades, seja no centro ou na periferia.

A atividade da coleta, ou catação, realiza-se em toda a extensão do espaço urbano onde sejam produzidos os resíduos do consumo. Porém, os locais para os quais convergem os materiais coletados se concentram nas periferias urbanas da metrópole de São Paulo, seja na periferia distante, consolidada e em contínua formação, ou nas áreas degradadas do centro, na "periferia do centro".

Seja na esfera de atuação dos intermediários (ferros-velhos, sucateiros, depósitos, reciclagens, entre outras modalidades), seja no âmbito dos programas e projetos públicos e/ou privados direcionados à institucionalização da base (cooperativas), o conjunto de atividades realizadas por estes diferentes agentes se concentram em determinados espaços urbanos. Mais precisamente, nas periferias urbanas da metrópole, nos territórios empobrecidos sob domínio do urbano periférico.

No primeiro caso, as atividades normalmente se realizam em espaços privados, de propriedade dos próprios comerciantes ou ainda sob a forma de locação dos imóveis, que podem ser desde grandes galpões (no caso dos grandes aparistas) até terrenos sem nenhuma infra-estrutura. São exemplos os ferros-velhos e depósitos que funcionam praticamente a céu aberto, conforme observamos em campo e através dos relatórios da Supervisão de Vigilância em Saúde - SUVIS, os chamados "pontos de reciclagem".

Já no universo dos grupos organizados (associações, cooperativas, núcleos) também se encontra o uso de espaços privados (de propriedade dos integrantes dos grupos ou alugados, pelos próprios catadores ou entidade gestora, por exemplo uma igreja ou ONG), mas principalmente a apropriação de espaços públicos. Estes podem ser desde as denominadas "áreas livres", com destaque para os espaços sob viadutos, ou terrenos e equipamentos públicos cedidos pela administração local (comodatos com Prefeituras e Sub-Prefeituras no caso de São Paulo) para os fins da reciclagem. Estes locais com atividades de reciclagem constituem os pontos nevrálgicos dos territórios de uso dos catadores (o "chão dos catadores), sendo também o espaço de atuação da própria indústria (território da escassez da riqueza produzida), com sua estrutura piramidal. 
Pela própria natureza deste conjunto de atividades, dificilmente se concentrariam em espaços valorizados, no contexto do qual representariam impactos de vizinhança, e no limite, a própria desvalorização do entorno. Portanto, a base da indústria da reciclagem se territorializa nas periferias urbanas da metrópole, seja na periferia propriamente dita (a periferia consolidada, distante e em contínua formação), seja nos espaços desvalorizados dos centros urbanos. De acordo com Rodrigues (1996:128), as áreas menos nobres, as que tem menor preço de mercado, podem ser objeto de depósito de lixo e portanto de problemas. São, também, muitos os indivíduos que vivem do "lixo".

Observemos que os locais que concentram as atividades da reciclagem (depósitos, reciclagens, cooperativas, etc.) constituem as centralidades dos territórios de expropriação dos catadores, os quais - contraditoriamente - participam da formação de riqueza para esta indústria. Por sua vez, estes territórios constituem frentes de expansão do capital, no processo de produção da matéria-prima a ser consumida produtivamente.

Insistimos ainda: enquanto matérias-primas mais baratas, os recicláveis representam redução dos custos com capital circulante para diversos segmentos industriais produtores de mercadorias. Matérias-primas mais baratas não somente pela economia em termos de consumo de energia ou na extração de recursos naturais, que se tornam escassos, e por isso mais caros ${ }^{156}$, dentre diversos outros fatores. Mas justamente porque o conjunto de atividades, ou processo de trabalho, inscrito na base desta indústria é realizado por milhares de catadores, e numa base territorial pela qual a indústria nada paga. Ao contrário! É o próprio urbano que possibilita que a indústria assim se comporte, porque é nas tramas do urbano que os agentes sociais inscritos na base desta indústria encontram seu lugar. Neste sentido, é possível dizer que esta indústria ganha da SOCIEDADE INTEIRA os bilhões da reciclagem, e não ao contrário.

\footnotetext{
${ }^{156} \mathrm{O}$ encarecimento das matérias-primas constitui, naturalmente, incentivo para a utilização dos resíduos. No todo, as condições dessa reutilização são: a disponibilidade em massa de tais resíduos, que resulta apenas de trabalho em larga escala; melhoria da maquinaria, com a qual materiais que antes, em sua forma dada, não eram utilizáveis são transfigurados para servirem à nova produção; progresso da ciência, especialmente da química, que descobre as propriedades utilizáveis de tais resíduos. (Marx, O Capital, v.lll, tomo I, p. 78) Grifo Nosso.
} 


\begin{tabular}{|c|c|c|c|c|c|c|c|c|c|c|c|c|}
\hline \multicolumn{13}{|c|}{ QUADRO 19 - LOCAIS COM ATIVIDADES DA RECICLAGEM, segundo fonte pesquisada e por Sub-Prefeituras de São Paulo (2008) } \\
\hline \multicolumn{2}{|c|}{$\begin{array}{l}\text { Divisão Administrativa } \\
\text { Prefeitura de São Paulo }\end{array}$} & \multirow{2}{*}{\multicolumn{2}{|c|}{\begin{tabular}{|l|}
\multicolumn{1}{|c|}{ Coleta Seletiva } \\
Pref. de São Paulo* \\
Centrais de Triagem \\
(CT)
\end{tabular}}} & \multicolumn{2}{|l|}{$\begin{array}{c}\text { Rede } \\
\text { Cata-Sampa* }\end{array}$} & \multirow{2}{*}{\begin{tabular}{|c|}
$\begin{array}{c}\text { Grupos } \\
\text { PAC }^{*}\end{array}$ \\
Total Grupos \\
\end{tabular}} & \multirow{2}{*}{\begin{tabular}{|c|}
$\begin{array}{c}\text { Cooperativas } \\
\text { CEMPRE* }\end{array}$ \\
Cooperativas \\
\end{tabular}} & \multirow{2}{*}{$\begin{array}{c}\text { Total } \\
\text { "grupos } \\
\text { organizados" }\end{array}$} & \multicolumn{2}{|c|}{ CEMPRE } & \multirow{2}{*}{\begin{tabular}{|c|} 
SUVIS \\
"Pontos de \\
reciclagem"
\end{tabular}} & \multirow[t]{2}{*}{$\begin{array}{l}\text { TOTAL } \\
\text { Geral }^{*}\end{array}$} \\
\hline Região & Subprefeitura & & & $\begin{array}{l}\text { Bases: núcleos } \\
\text { cooperativas (CS) }\end{array}$ & & & & & $\begin{array}{l}\text { Reci- } \\
\text { clador }\end{array}$ & $\begin{array}{l}\text { Suca- } \\
\text { teiro }\end{array}$ & & \\
\hline \multirow[t]{2}{*}{ CENTRO } & Sé & Coopere & 1 & Cooper-Glicério & 1 & 11 & $\begin{array}{r}2+1 \mathrm{CT}+1 \mathrm{CS} \\
+4 \mathrm{PAC}\end{array}$ & 13 & 4 & 11 & 50 & 78 \\
\hline & & & & & & & & 13 & 4 & 11 & 50 & 78 \\
\hline \multirow[t]{4}{*}{ OESTE } & Lapa & Cooperação & 1 & & & 3 & $1+1 \mathrm{CT}+2 \mathrm{PAC}$ & 4 & 3 & 4 & 24 & 35 \\
\hline & Pinheiros & Cooper Viva Bem & 1 & Coopamare & 1 & 3 & $\begin{array}{r}2 \mathrm{CT}+1 \mathrm{CS}+ \\
1 \mathrm{PAC} \\
\end{array}$ & 3 & 1 & 2 & 0 & 6 \\
\hline & Butantã & & & & & 1 & & 1 & 6 & 8 & 30 & 45 \\
\hline & & & & & & & & 8 & 10 & 14 & 54 & 86 \\
\hline \multirow{4}{*}{$\begin{array}{l}\text { CENTRO- } \\
\text { SUL }\end{array}$} & Vila Mariana & & & & & & & & 1 & 1 & 16 & 18 \\
\hline & Jabaquara & & & & & 1 & & 1 & 2 & 8 & 36 & 47 \\
\hline & Santo Amaro & $\begin{array}{l}\text { Granja Julieta } \\
\text { Coopermyre }\end{array}$ & 2 & & & 4 & $3+2 \mathrm{CT}$ & 7 & 2 & 2 & 23 & 34 \\
\hline & & & & & & & & 8 & 5 & 11 & 75 & 99 \\
\hline \multirow[t]{6}{*}{ SUL } & Campo Limpo & & & & & 5 & 1 & 6 & 1 & 3 & 71 & 81 \\
\hline & M’Boi Mirim & & & & & 6 & & 6 & 0 & 3 & 81 & 90 \\
\hline & Cid. Ademar & & & & & 6 & 1 & 7 & 2 & 5 & 33 & 47 \\
\hline & Capela do Socorro & Coopercaps & 1 & & & 6 & $3+1 \mathrm{CT}$ & 9 & 5 & 4 & 113 & 131 \\
\hline & Parelheiros & & & & & 4 & & 4 & 0 & 1 & 51 & 56 \\
\hline & & & & & & & & $20\left(32^{\star \star}\right)$ & 8 & 16 & 349 & 405 \\
\hline \multirow[t]{5}{*}{ SUDESTE } & Moóca & Coop. Tietê & 1 & & & & $3+1 \mathrm{CT}$ & 4 & 16 & 13 & 17 & 50 \\
\hline & Aricanduva & & & & & & 1 & 1 & 13 & 6 & 82 & 102 \\
\hline & \begin{tabular}{|l|} 
Sapopemba \\
- Vila Prudente \\
\end{tabular} & & & & & 5 & $1+1 \mathrm{PAC}$ & 6 & 7 & 11 & 114 & 138 \\
\hline & Ipiranga & & & & & & 1 & 1 & 9 & 10 & 0 & 20 \\
\hline & & & & & & & & 12 & 45 & 40 & 213 & 310 \\
\hline \multirow[t]{5}{*}{ LESTE 1} & Penha & Vitória da Penha & 1 & & & 1 & $1+1 \mathrm{CT}$ & 2 & 4 & 9 & 49 & 64 \\
\hline & Ermelino Matarazzo & & & & & & 1 & 1 & 3 & 1 & 80 & 85 \\
\hline & Itaquera & Cooperunião & 1 & $\begin{array}{r}\text { Cruffi } \\
\text { Jacupia }\end{array}$ & 2 & 3 & $1+1 \mathrm{CT}+2 \mathrm{CS}$ & 5 & 5 & 6 & 53 & 69 \\
\hline & S. Matheus & Cooperleste & 1 & Chico Mendes & 1 & 4 & $2+1 \mathrm{CT}+1 \mathrm{CS}$ & 6 & 3 & 5 & 133 & 147 \\
\hline & & & & & & & & 14 & 15 & 21 & 315 & 365 \\
\hline \multirow[t]{2}{*}{ LESTE 2} & Cid. Tiradentes & & & & & 1 & & & 1 & & 37 & 38 \\
\hline & S. Miguel & & & Nova Esperança| & $1 \mid$ & 1 & $1+1 \mathrm{CS}$ & 2 & 3 & 3 & 86 & 94 \\
\hline
\end{tabular}




\begin{tabular}{|c|c|c|c|c|c|c|c|c|c|c|c|c|}
\hline & $\begin{array}{l}\text { Itaim Paulista } \\
\text { - Vila Curuçá }\end{array}$ & Nova Conquista & 1 & $\begin{array}{c}\text { Fênix-Ágape } \\
\text { Magnália Dei }\end{array}$ & 2 & 3 & $\begin{array}{r}1+1 \mathrm{CT}+2 \mathrm{CS} \\
+1 \mathrm{PAC} \\
\end{array}$ & 5 & 1 & 1 & 63 & 70 \\
\hline & Guaianazes & & & & & 1 & 1 & 2 & 1 & 2 & 88 & 93 \\
\hline & & 9 & 6 & 6 & 274 & 295 \\
\hline \multirow[t]{4}{*}{ NOROESTE } & Perus & & & & & 1 & $1 \mathrm{PAC}$ & 1 & 0 & 2 & 37 & 40 \\
\hline & Pirituba-Jaraguá & Coop. Crescer & 1 & & & 3 & $3+2 \mathrm{CT}$ & 6 & 3 & 4 & 101 & 114 \\
\hline & $\begin{array}{l}\text { Freguesia do Ó } \\
\text { - Brasilândia } \\
\end{array}$ & Coopercicla & 1 & & & 2 & 0 & 2 & 1 & 6 & 60 & 69 \\
\hline & & & & & & & & 9 & 4 & 12 & 198 & 223 \\
\hline \multirow[t]{5}{*}{ NORDESTE } & Tremembé-Jaçanã & Sem Fronteira & 1 & & & 2 & $4+1 \mathrm{PAC}$ & 7 & 1 & 6 & 65 & 79 \\
\hline & Santana-Tucuruvi & & & & & 3 & $1 \mathrm{PAC}$ & 3 & 3 & 1 & 15 & 22 \\
\hline & $\begin{array}{l}\text { Casa Verde } \\
\text { - Cachoeirinha }\end{array}$ & & & & & & 0 & & 2 & 8 & 45 & 55 \\
\hline & $\begin{array}{l}\text { Vila Maria } \\
\text { - Vila Guilherme }\end{array}$ & Coopervila & 1 & & & 1 & $2+1 C T+1 P A C$ & 3 & 13 & 13 & 44 & 73 \\
\hline & & & & & & & & 13 & 19 & 28 & 169 & 229 \\
\hline TOTAL & & & 15 & & 8 & $81+4=85$ & $69-36=\mathbf{3 3}$ & 118 & 116 & 159 & 1697 & 2090 \\
\hline
\end{tabular}

FONTE: LIMPURB (2008), CEMPRE (2008), SUVIS (2007-2008), GT Coleta Seletiva /Trabalho de campo (2004-2007).

ELABORAÇÃO: ROSALINA BURGOS (2008)

* Todas as Centrais de Triagem da Prefeitura estão em coluna específica na Tabela, e as que integram os Grupos listados para o PAC estão em itálico e cor cinza (11 Centrais). Todas as bases da Rede Cata-Sampa em São Paulo estão incluídas na contagem feita para o financiamento do PAC. Portanto, só devem ser acrescentas nos cálculos dos Sub-Totais e do TOTAL Geral as 4 Centrais de Triagem não contadas para o financiamento do PAC (Sem Fronteira/Tremembé-Jaçanã, Nova Conquista/Itaim Paulista e Cooperunião/Itaquera, Tietê/Moóca). No caso do cadastro do CEMPRE, no total de 69 cooperativas registradas estão as Centrais de Triagem, as bases da Rede Cata-Sampa e 13 cooperativas da contagem para o PAC. Assim, no Total Geral, devemos somar apenas 33 cooperativas do CEMPRE.

** Na Região Sul, onde consta o maior número de Grupos organizados, estes são formados, em sua maioria, por pequenos núcleos com menos de 10 integrantes, vinculados a uma Cooperativa Central. Os conjuntos de núcleos e sua respectiva Cooperativa Central estão vinculados a um mesmo parceiro/financiador em cada uma das seguintes Subprefeituras: Banco do Brasil/ONG's/SVMA (Campo Limpo), Assoc. Congregação Sta. Catarina (Cid. Ademar) e Banco do Brasil/SVMA/EMAE (M'Boi Mirim). Os conjuntos de núcleos destas Subprefeituras foram agrupados na representação dos Gráficos, para evitar distorções nas análises comparativas. Assim, do total de 32 grupos obtivemos 20 grupos.

***Nota Explicativa: A sigla PE significa Ponto Estratégico e são estabelecimentos cadastrados pela Supervisão de Vigilância em Saúde (SUVIS) para controle do mosquito da dengue. Do universo total dos PE's, uma parte é constituída por locais com atividades de reciclagem. No escopo da Tese, foram denominados de "Pontos de reciclagem". Os Técnicos e Agentes de Apoio das SUVIS explicam que estes PE's correspondem a uma amostra abaixo do número real existentes no território. Geralmente atuam de modo informal, com infra-estrutura muito precária. No caso das residências, os materiais são acumulados em quintais, garagens e às vezes sobre a laje da casa. Outra informação refere-se à oscilação dos PE's cadastrados ao longo do tempo. Primeiro porque estes estabelecimentos iniciam e encerram suas atividades com muita rotatividade, ou mudam de endereço. O território de cada SUVIS corresponde ao território de cada Subprefeitura do Município de São Paulo, exceto para 5 SUVIS: Lapa-Pinheiros, Vila Mariana-Jabaquara, Pirituba-Perus, Aricanduva-Moóca e Cidade Ademar-Santo-Amaro. Os PE's com atividades ligadas à reciclagem representam algo em torno de $40 \%$ a $80 \%$ do total de PE's cadastrados, variando a porcentagem em cada uma das 26 SUVIS. A porcentagem de PE's com atividades de reciclagem - que denominamos de "Pontos de Reciclagem" é maior nas SUVIS situadas em Subprefeituras com menores taxas de renda. 


\section{GRÁFICO 07}

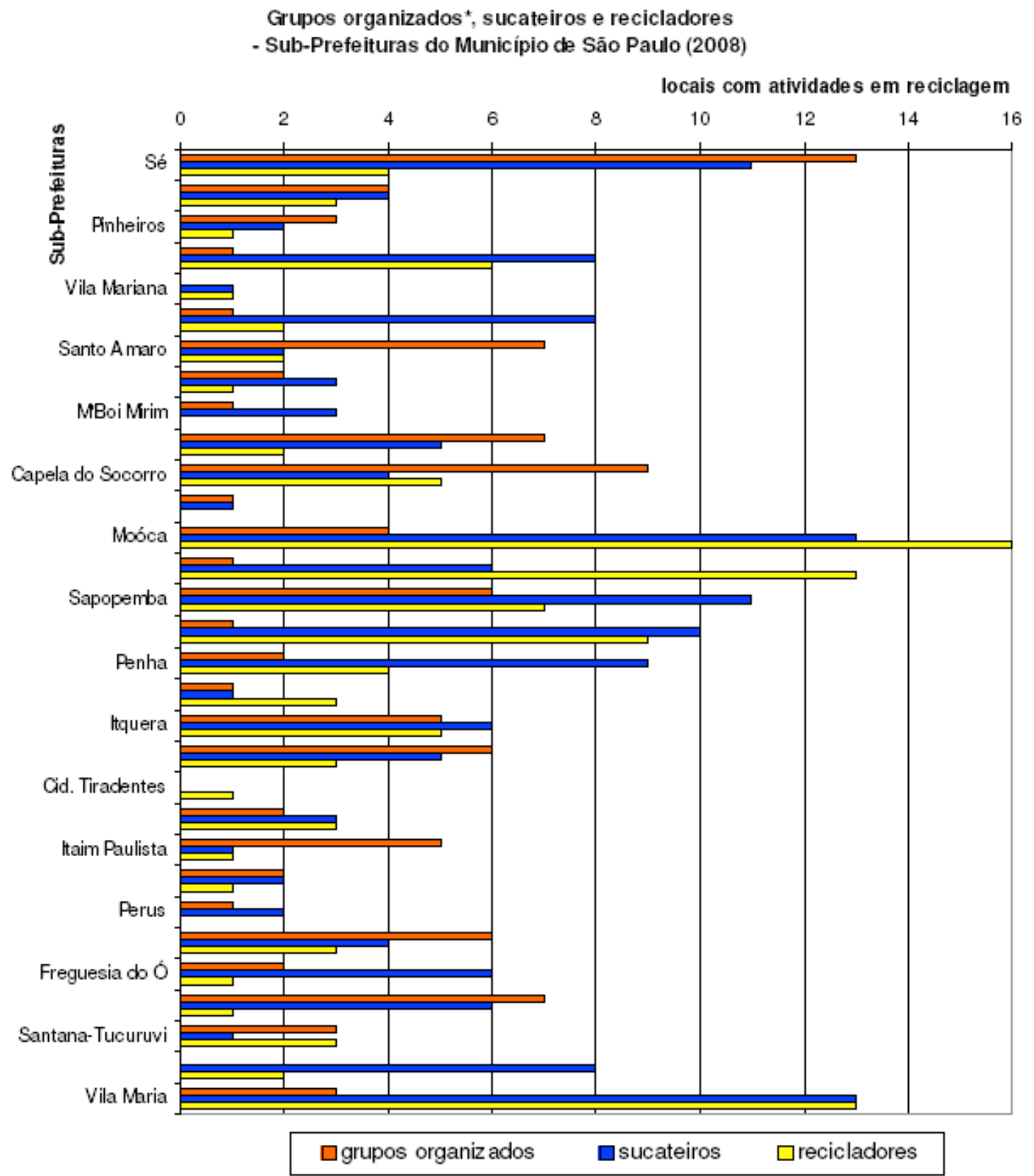

Fonte: CEMPRE (2008), Limpurb (2008), Cooperativa Fênix-Ágape/Trabalho de Campo (2007).

Elaboração: Rosalina Burgos (2008).

* Grupos organizados: cooperativas, associações, núcleos. 


\section{GRÁFICO 08}

"Cooperativas", sucateiros e recicladores

Regiōes do Municíplo de Sāo Paulo (2008)

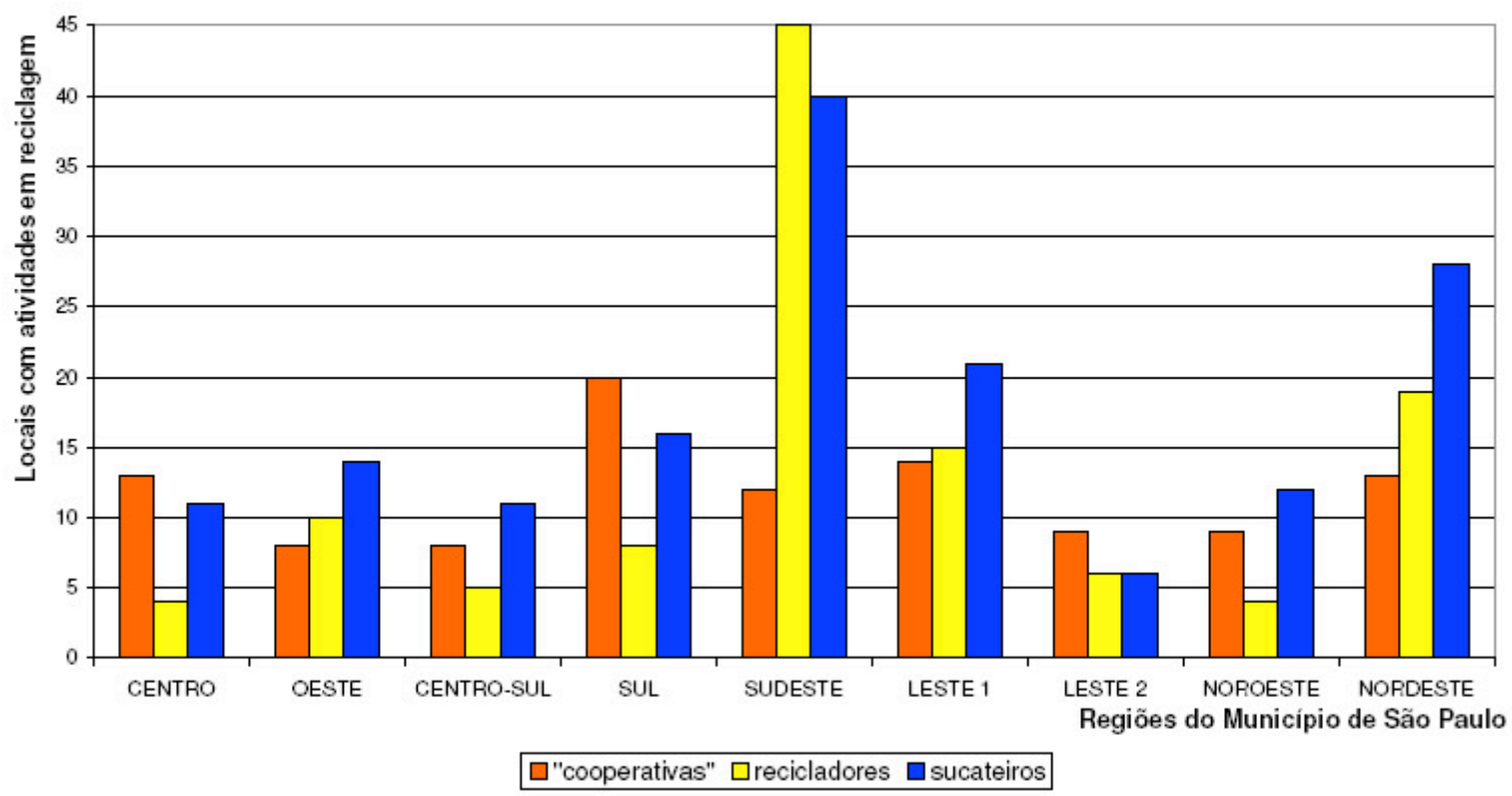

Fonte: CEMPRE (2008), GT Coleta Seletiva (2007), LIMPURB (2008).

Nota: "Cooperativas" = Grupos Organizados (cooperativas, associações e núcleos) 
GRÁFICO 09

Locais com atividades em reciclagem Sub-Prefeituras do Município de São Paulo (2008)

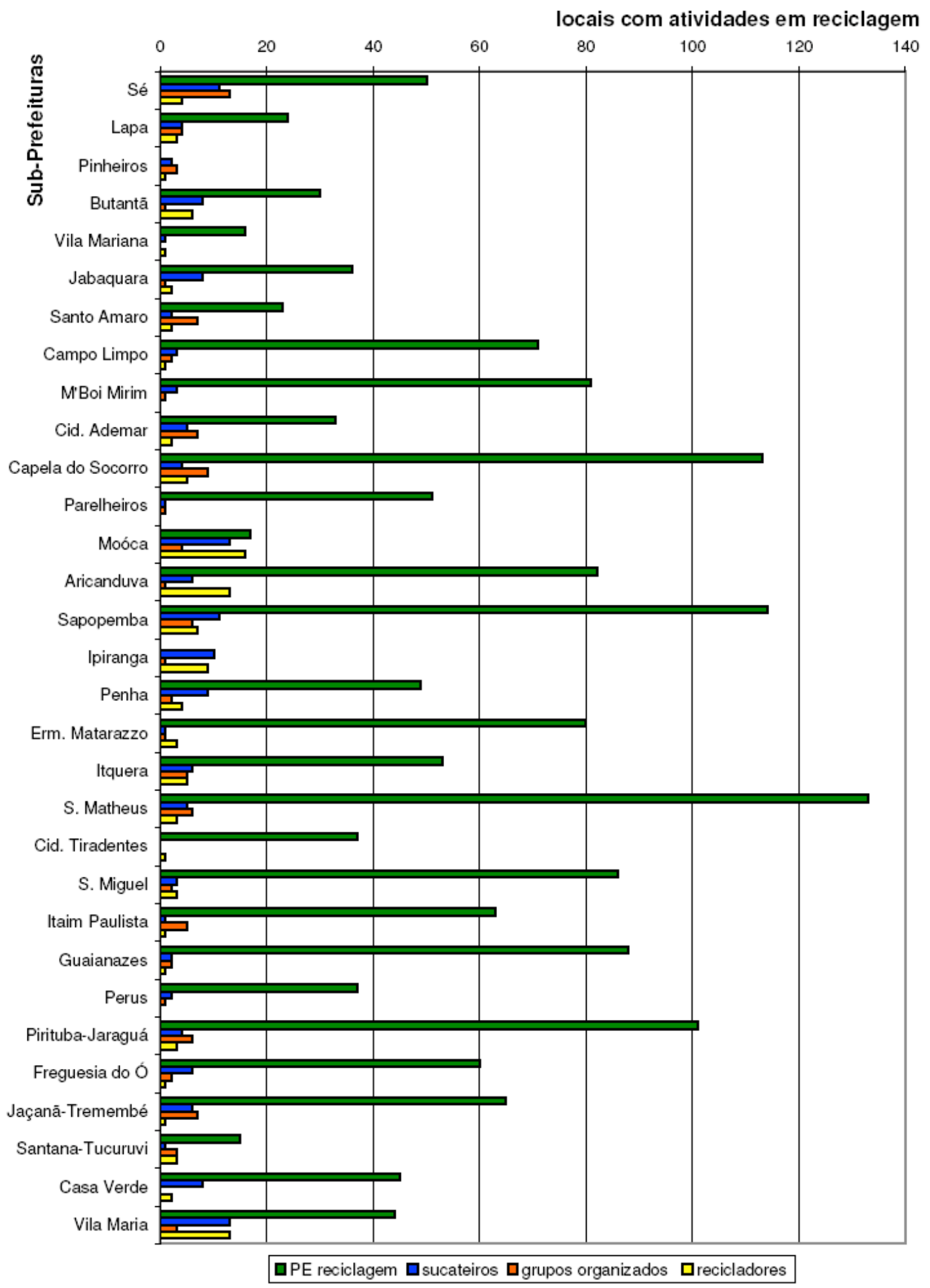

Fonte: CEMPRE (2008), Limpurb (2008), SUVIS (2008), GT Coleta Seletiva/Trabalho de Campo. Elaboração: Rosalina Burgos (2008)

Nota: Grupos organizados = cooperativas, associações e núcleos (formais e informais) 
GRÁFICO 10

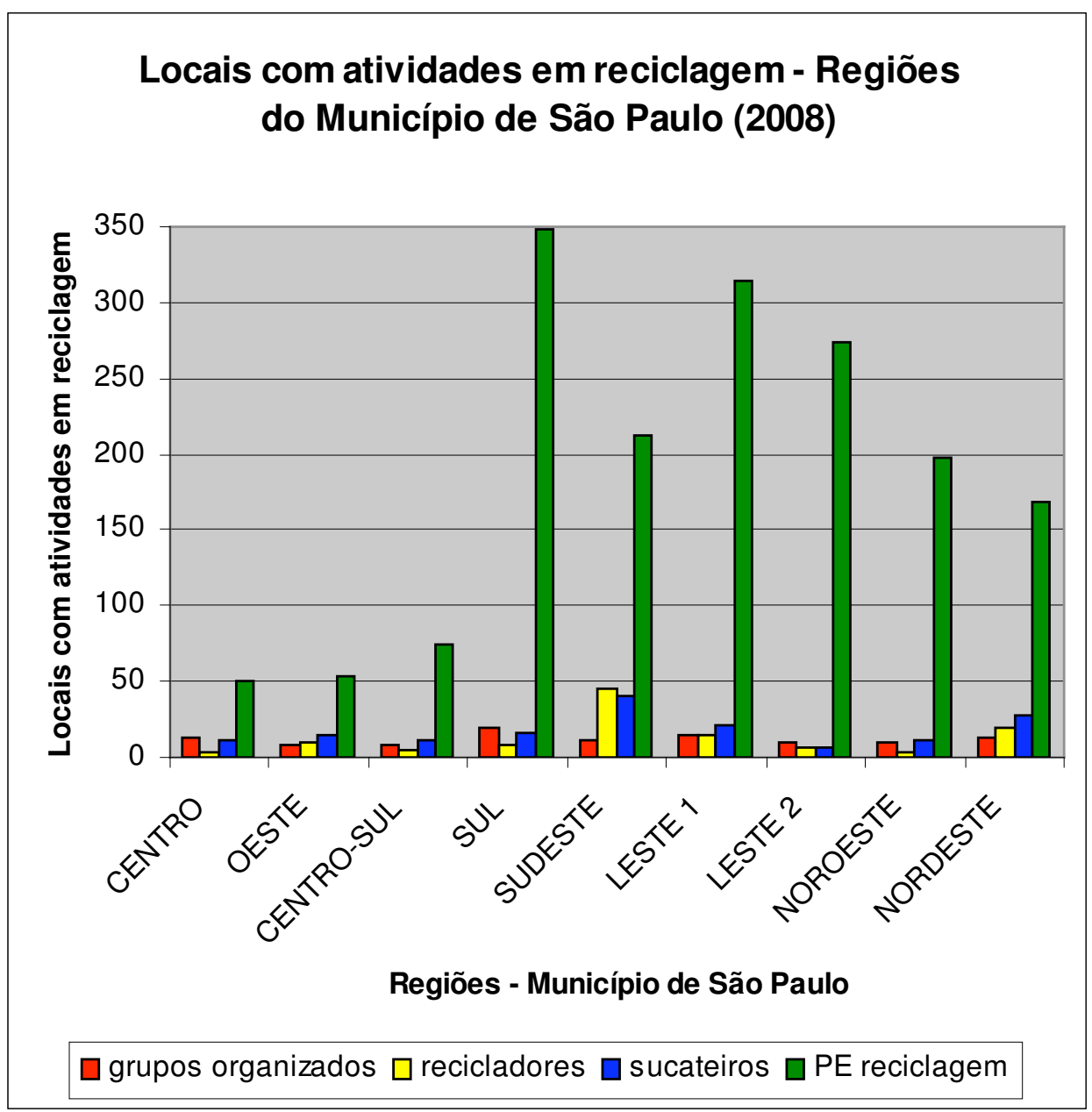

Fonte: CEMPRE (2008), SUVIS (2007), Cooperativa Fênix-Ágape/Trabalho de Campo (2007). Elaboração: Rosalina Burgos (2008).

Nota: Grupos organizados = cooperativas, associações e núcleos (formais e informais) 


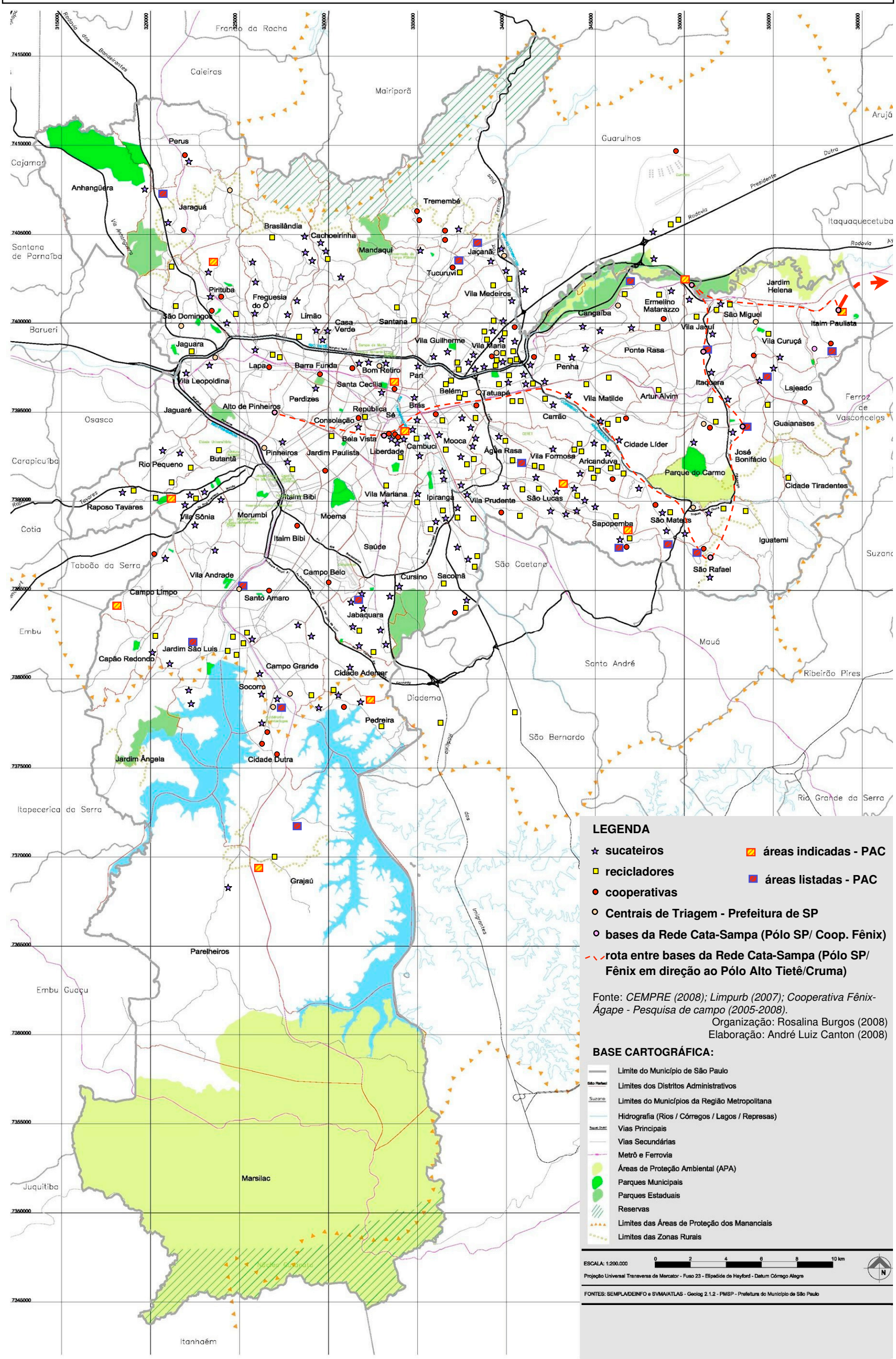


MAPA 02: Densidade área construída tipo indústria - Município de São Paulo (2004)

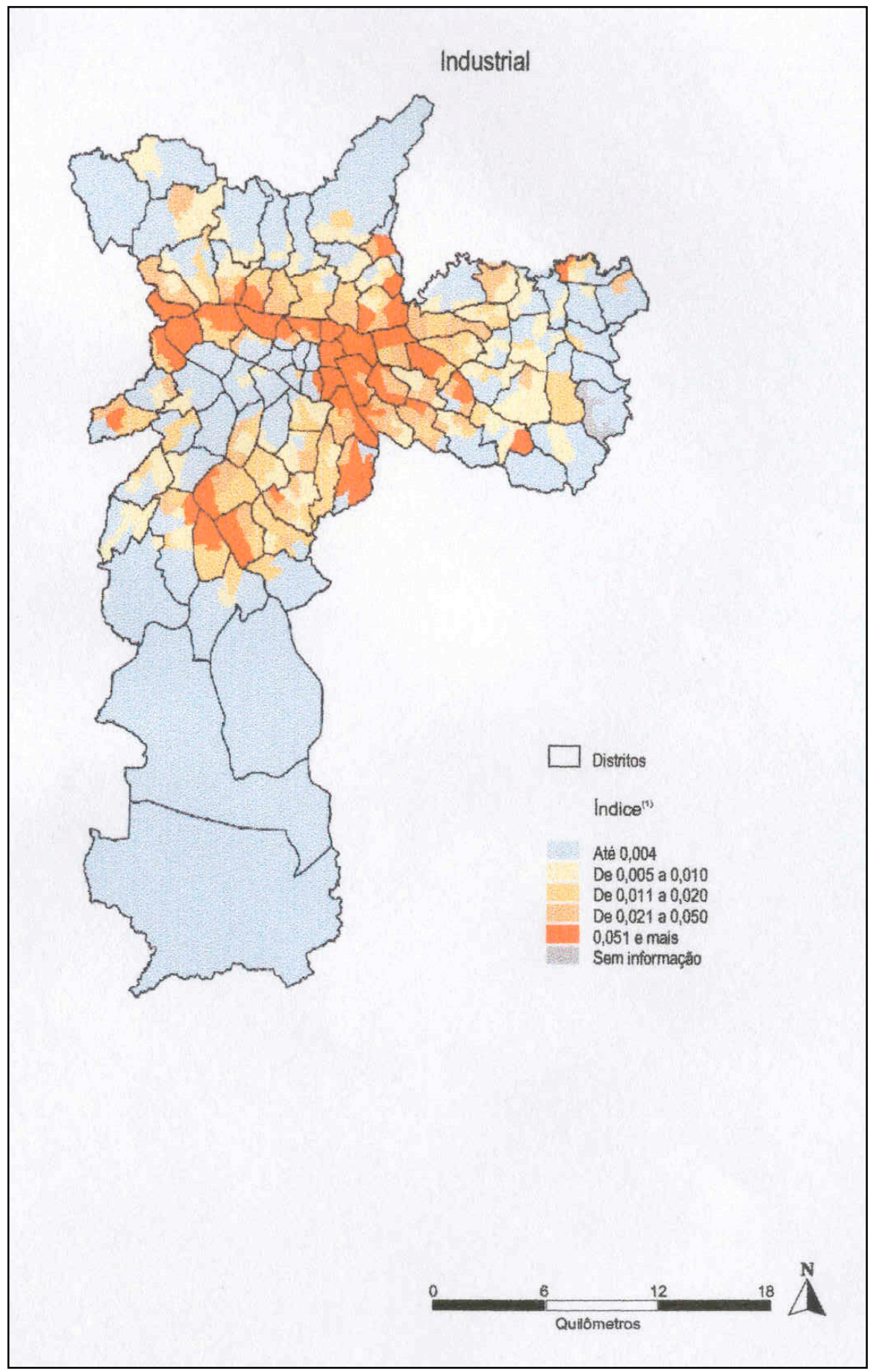

Fonte dos dados do Mapa: Secretaria Municipal de Finanças. Depto de rendas Imobiliárias. TPCL, 2004

(1) Índice resultante da relação entre duas variáveis: a áreas construída de determinado tipo nas Quadras fiscais que compõem cada uma das 456 Áreas de Ponderação da Amostra do Censo IBGE/2000 e a superfície total de cada uma dessas Áreas de Ponderação (ambas, expressas em m2)

Fonte: SEMPLA. Município em Mapas - Série Temática: Dinâmica Urbana, 2004. 


\subsection{A produção de matérias-primas no urbano}

A estruturação da indústria da reciclagem está diretamente relacionada à possibilidade de obtenção dos materiais recicláveis enquanto matérias-primas mais baratas. Portanto, diz respeito à redução de custos com a parte circulante do capital constante, que resulte no aumento da taxa de lucro para os mais diversos setores produtivos. Materiais recicláveis que são gerados em abundância em toda a extensão do espaço urbano. O que, por sua vez, torna o meio ambiente construído um fator determinante do processo de produção destas novas matérias-primas.

Além disso, a base desta indústria está assentada nos territórios empobrecidos da metrópole (no centro e na periferia propriamente ditos). Concentrados nestes territórios, os locais com atividades de reciclagem absorvem os resíduos sólidos urbanos oriundos de todos os lugares, uma vez que a produção dos resíduos do consumo ocorre de forma dispersa. Assim, a base deste setor produtivo deve resolver a seguinte contradição: o material reciclável, aqui entendido como potencial matéria-prima, que se encontra disperso no espaço urbano, deve ser recolhido, reunido e concentrado em determinados pontos do espaço. A concentração de meios de produção, meios de trabalho e de trabalhadores em cooperação é uma das características elementares para os processos produtivos, e o mesmo ocorre com a reciclagem.

Neste sentido, o conjunto de atividades inscritas na base da indústria da reciclagem apresenta, ao menos, três caracterizas peculiares ao binômio concentração-dispersão, por sua vez relacionada com o binômio centro-periferia.

A primeira delas diz respeito às características das atividades que constituem o processo de trabalho inscrito na base industrial. A atividade mais elementar do processo de reciclagem, a catação ou coleta, realiza-se de forma dispersa, recobrindo toda a extensão do espaço urbano (onde são gerados os resíduos sólidos urbanos), seja no centro ou na periferia. Porém, uma vez realizada esta primeira atividade, os materiais são encaminhados para locais de convergência dos materiais recicláveis (comércios do ramo ou grupos organizados de catadores, dos mais diversos portes e modalidades). Neles se concentram um conjunto de 
atividades (tais como triagem, prensagem e enfardamento) destinadas a preparar os materiais para seu envio aos grandes aparistas (comerciantes de grande porte) e/ou aos recicladores. Estes últimos tendem a se concentrar em determinadas regiões com predomínio de uso industrial (a exemplo dos vetores sudeste e nordeste do Município de São Paulo).

Um segundo aspecto diz respeito aos territórios nos quais se realiza o conjunto de atividades da base desta indústria. Como já assinalado, a catação ou coleta se estende de modo difuso por toda a extensão do espaço urbano. Porém, os locais de convergência dos materiais recicláveis tendem a se concentrar nas periferias urbanas da metrópole, nelas inscritos os territórios empobrecidos.

Em terceiro lugar, devemos assinalar que a geração dos resíduos sólidos urbanos, passíveis de serem catados/coletados, ocorre de forma concentrada nos centros urbanos (com predomínio de resíduos oriundos das atividades comerciais, de serviços e industriais), e de forma dispersa nas vastas periferias urbanas (com predomínio dos resíduos domiciliares).

A geração de resíduos sólidos urbanos em São Paulo ocorre de forma concentrada no centro (Sub-Prefeitura Sé), onde está a maior massa de capital fixo, correspondente ao meio ambiente construído (Harvey, 1990) conforme pode ser observado no MAPA 03. Por outro lado, os resíduos são gerados de forma pulverizada e estendida nas vastas periferias urbanas. O Gráfico 11 apresenta a média mensal da coleta domiciliar convencional (inclui varrição e feiras livres ${ }^{157}$ ), para o período de junho de 2006 a junho de 2007, por Sub-Prefeitura do Município de São Paulo. Ainda que não estejam incluídos neste Gráfico os resíduos das atividades de serviços e comércio (cuja produção diária acima de 50 quilos não é coletada pela Prefeitura ${ }^{158}$ ), a Sub-Prefeitura Sé apresenta o maior volume de resíduos sólidos coletados pela Prefeitura, com média mensal em torno de 18.000 toneladas. Por outro lado, as demais Sub-Prefeituras, em seu conjunto, somam um volume muito superior ao da região central. Porém, os resíduos sólidos urbanos que mobilizam cerca de 5.000 catadores na região central são oriundos majoritariamente

\footnotetext{
${ }^{157}$ A porcentagem destes em relação aos resíduos domiciliares é diminuta.

${ }^{158}$ Como estes resíduos são de responsabilidades dos próprios geradores, esta informação não consta nos Relatórios mensais do Limpurb. É neste contexto que se insere o que Legaspe denominou de "reciclagem clandestina". A coleta realizada pelos catadores evita que os referidos geradores tenham custos com a disposição final dos mesmos (coleta e deposição final privadas).
} 
das atividades comerciais e de serviços que aí se concentram (Gráfico 12). Se a média que estes catadores coletam é de 300 quilos por dia, ao multiplicá-los por 26 dias úteis, teremos algo em torno de 40.000 toneladas mensais. Montante que dificilmente seria encontrado sob esta forma concentrada noutro território que não o centro.

Evidentemente, além da diferença quantitativa (em termos de densidade) dos resíduos gerados no centro e na periferia, existe a diferença qualitativa, pois, como nos explica Rodrigues (1996:161) as características do lixo estão estreitamente vinculadas ao uso do solo. Ou seja, no centro há o predomínio do lixo comercial, enquanto nas áreas residenciais, ricas e pobres, predomina o lixo domiciliar, com seus respectivos níveis de qualidade. Pode-se enumerar outras características da geração dos resíduos sólidos urbanos, seja em termos da relação dispersãoconcentração, centro-periferia, diferenciação quantitativa e qualitativa relacionadas ao uso do solo, maior ou menor massa de capital fixo que corresponde ao meio ambiente construído.

Mas, como já se vê, a indústria da reciclagem se apropria das condições geográficas nas quais são gerados os materiais recicláveis, sejam elas quais forem. Assim, não se trata tão somente de uma indústria que se localiza nas franjas da metrópole, ou distritos industriais, onde suas instalações dão concretude ao processo final da reciclagem. Mas é no urbano - reunião, simultaneidade, centralidade - que se encontram os elementos principais para sua existência: a abundância de resíduos sólidos urbanos passíveis de serem transformadas em novas matérias-primas (o que está diretamente vinculado ao consumo em massa, próprio da sociedade urbana); abundância de trabalhadores pobres urbanos, sobrantes dos mais diversos setores produtivos (os quais "se movem" a procura de lugar nos interstícios do urbano, e que encontram no lixo sua estratégia de sobrevivência); territórios empobrecidos nos quais se resolve a equação dispersão-concentração, concentrando os materiais recicláveis a serem enviados à indústria propriamente dita. Mas este "propriamente dito" deve ser entendido como não exclusivo! Dada suas características, a indústria da reciclagem se faz presente-ausente no próprio urbano, do que resulta sua estrutura tão complexa. Ao mesmo tempo, a própria complexidade é sua característica mais elementar e irredutível. 


\section{MAPA 03: Densidade de área construída no Município de São Paulo: maior massa de capital fixo concentrada na região central (2004)}

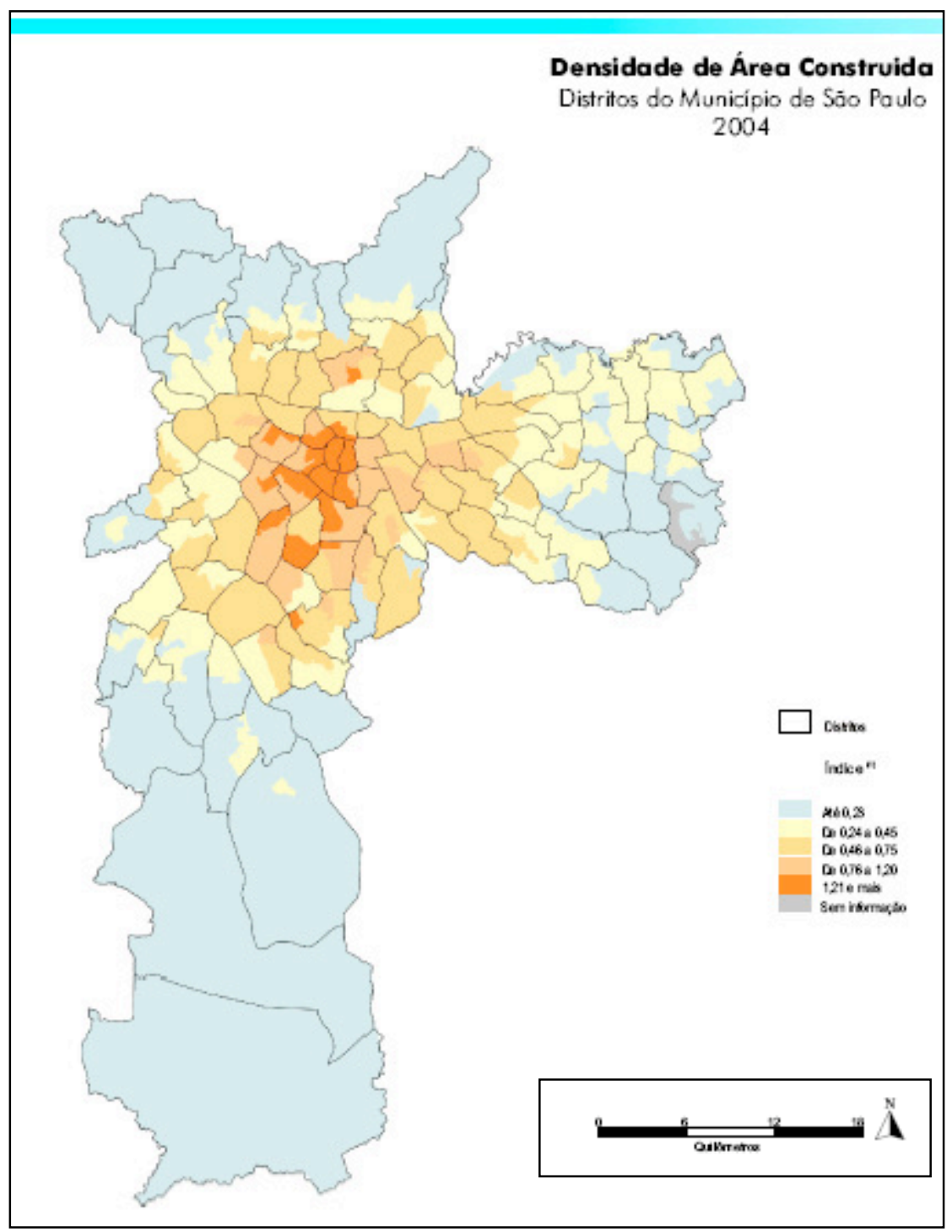

Fonte dos dados do Mapa: Secretaria Municipal de Finanças. Depto de rendas Imobiliárias. TPCL, 2004

(1) Índice resultante da relação entre duas variáveis: a áreas construída de determinado tipo nas Quadras fiscais que compõem cada uma das 456 Áreas de Ponderação da Amostra do Censo IBGE/2000 e a superfície total de cada uma dessas Áreas de Ponderação (ambas, expressas em m2)

Fonte: SEMPLA. Município em Mapas - Série Temática: Dinâmica Urbana, 2004. 


\section{GRÁFICO 11}

Coleta domiciliar (média mensal - jun06 a jun07)

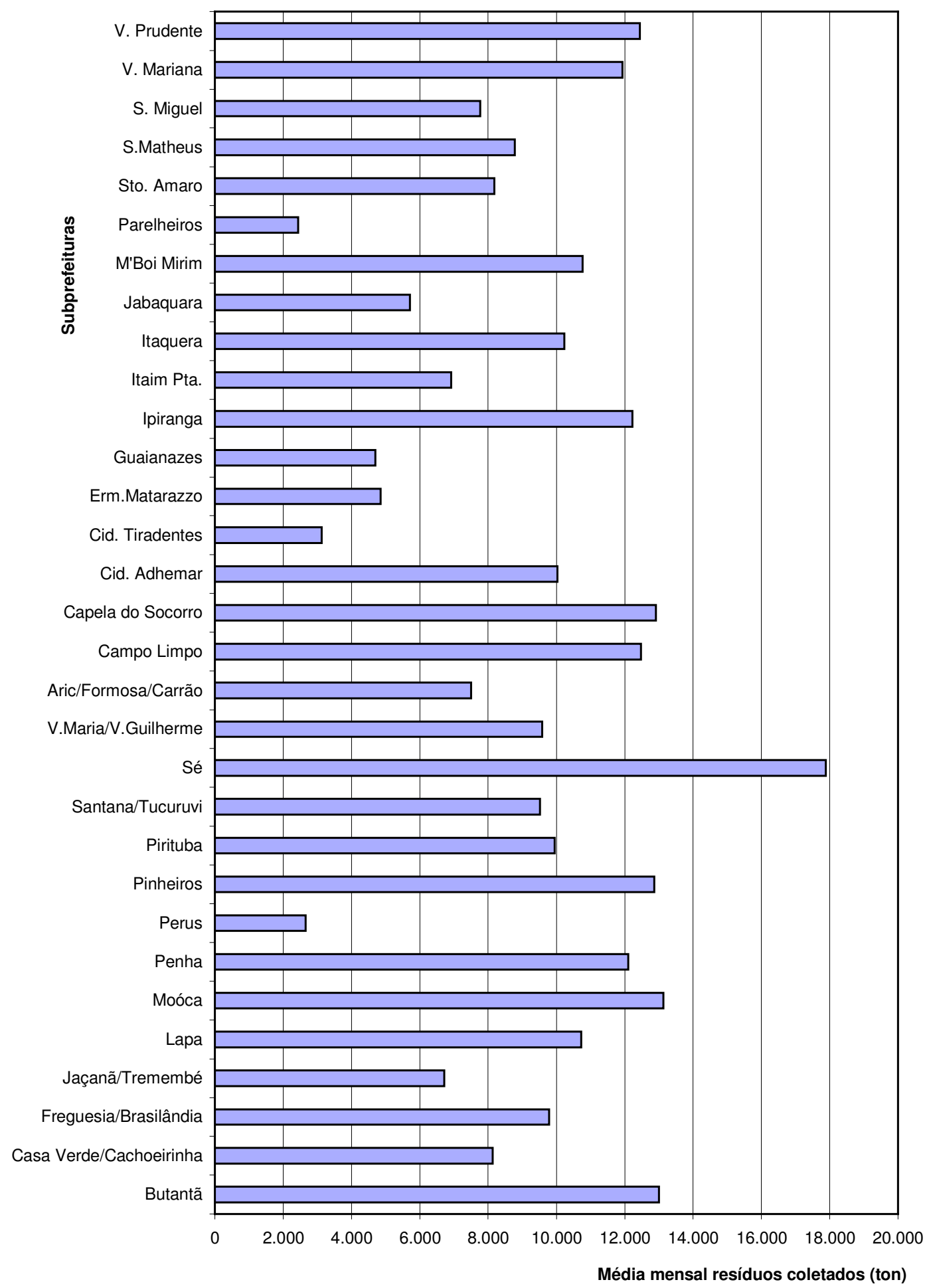

Fonte: Limpurb. Relatório Técnico mensal n.116/junho de 2007.

Elaboração: Rosalina Burgos (2008) 


\section{GRÁFICO 12}

Estabelecimentos por setor econômico

Subprefeituras do Município de São Paulo (2005)

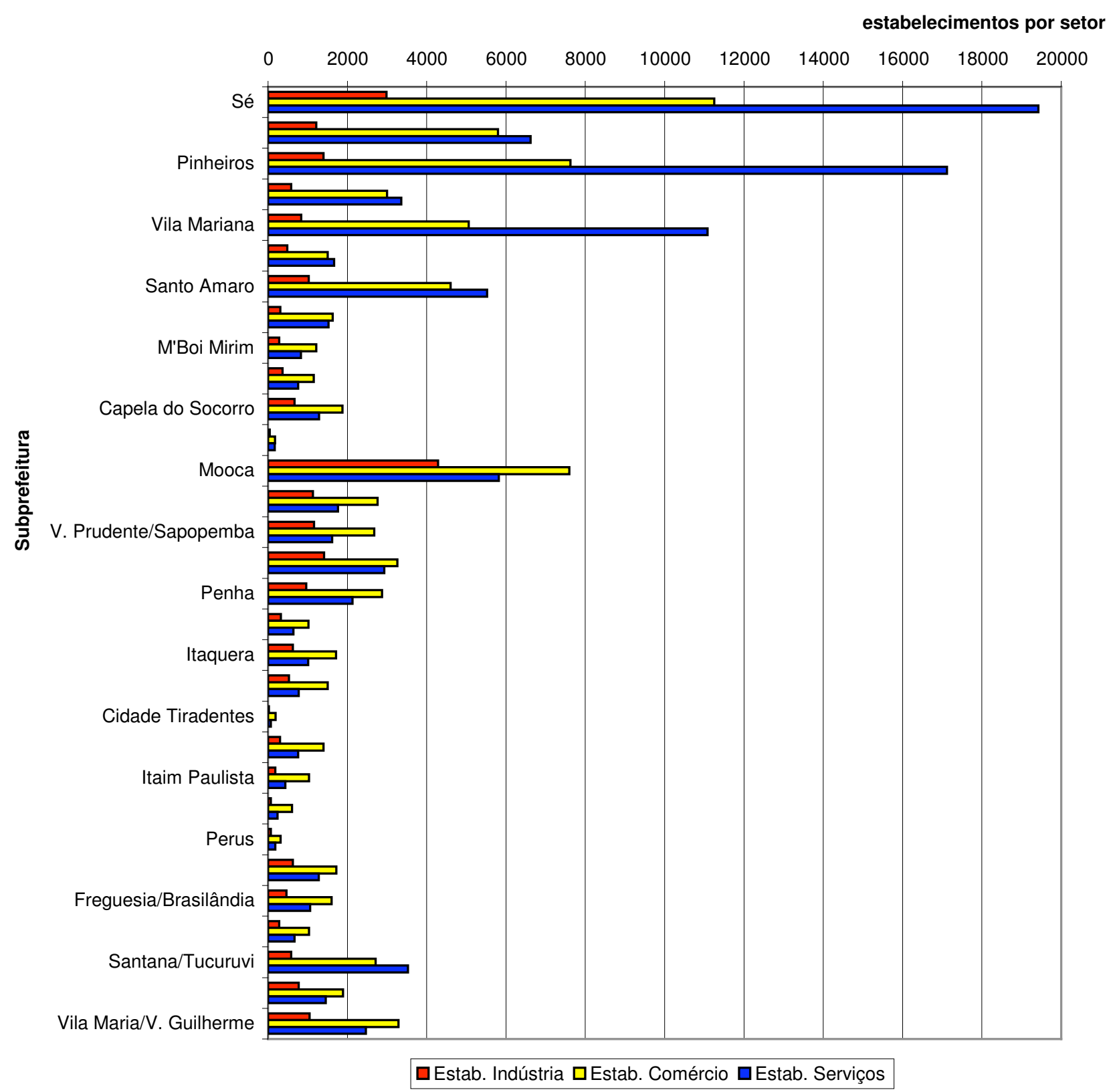

Fonte: Ministério do Trabalho e Emprego - Relação Anual de Informações Sociais / RAIS 2005 In SEMPLA/DIPRO - Equipe de Atividades Econômicas. Elaboração: Rosalina Burgos (2008) 


\section{Capítulo VI}

\section{A ORGANIZAÇÃO DA BASE DA INDÚSTRIA DA RECICLAGEM NO TERRITÓRIO dE ITAIM PAULISTA: A COOPERATIVA FÊNIX-ÁGAPE}

Os territórios empobrecidos das periferias urbanas constituem um ambiente de diferentes densidades, nos quais os catadores de materiais recicláveis em sua prática socioespacial instauram territórios de uso, denominados de "chão dos catadores". Mas sobre este "chão" incidem enquadramentos diversos, num movimento que tem o sentido de transformá-los de catadores avulsos em catadores congregados a um núcleo, e assim a uma cooperativa. O movimento que arregimenta e articula os catadores não é linear, pois se trata de homens e mulheres que realizam estratégias de sobrevivência e acumulam experiências de vida inusitadas. Assim sendo, nem sempre se ajustam aos enquadramentos formalizados. Ao que parece, disto decorre a predominância do catador avulso no conjunto dos catadores. Portanto, um conjunto de fatores parecem representar um óbice à institucionalização da base da indústria. Neste sentido, as entrevistas realizadas em campo com catadores avulsos, que integra o Capítulo II da Tese, buscou mostrar determinados aspectos do universo destes catadores, inclusive recolhendo depoimentos sobre suas dificuldades, ou mesmo recusa, em participarem das cooperativas (ver Capítulo II e Anexo 4). Como visto, no Itaim Paulista existem cerca de 2000 catadores avulsos, os quais orbitam em torno de aproximadamente 60 "pontos de reciclagem" (locais com atividade de reciclagem cadastrados pela SUVIS) distribuídos por toda a extensão de seu território. São predominantemente comerciantes do ramo, de pequeno a médio porte (com predomínio do primeiro), segundo observado em trabalho de campo.

Para além deste universo predominantemente informal, a pesquisa investigou 0 processo de organização da base desta indústria, cuja institucionalização ocorre com a formação de cooperativas de "catadores". Catadores entre aspas porque neste processo participam trabalhadores sobrantes dos mais diversos setores produtivos, os quais já são, ou não, catadores. Neste sentido, ocorre que nem sempre o cooperado, que é denominado de catador, já tenha 
realizado a atividade da catação que o define. Cooperados (formalizados pelo estatuto jurídico da cooperativa) e catadores avulsos (mantidos na informalidade) aparecem em pólos antagônicos. Se por um lado, a indústria da reciclagem apresenta uma estrutura vertical, piramidal e hierárquica, para a qual "os dois circuitos da economia urbana" (Milton Santos) se apresenta como forma de explicação, por outro, a própria base industrial, amplamente estendida e pulverizada, reproduz a desigualdade sobre a qual a indústria se ergue. A base da indústria da reciclagem vai sendo ampliada com desníveis, que vão desde o chão do catador sobre o qual tudo incide - aos empreendimentos para os quais convergem os investimentos destinados à institucionalização desta base.

Assim, a base da indústria da reciclagem segue sendo dual, formalinformal, mesmo com a evidente tendência de expansão do modelo de cooperativas, a qual é prescrita como modelo ideal ao aprimoramento do processo de produção das matérias-primas. O que, por sua vez, consiste num rearranjo profundo da própria indústria, caracterizando seu processo de estruturação recente.

Neste contexto, trata-se agora da exposição da pesquisa realizada sob a perspectiva da tendência de institucionalização da base desta indústria. Esta foi realizada no território de Itaim Paulista, na periferia consolidada e distante da periferia urbana de São Paulo. Mais especificamente na análise do processo que transformou um conjunto de pequenos grupos organizados, os "núcleos de reciclagem", numa única cooperativa denominada "Cooperativa Fênix-Ágape."

A pesquisa sobre o processo de formação da Cooperativa Fênix-Ágape possibilitou identificar a transformação do uso de espaços para as atividades da reciclagem, sobretudo para armazenamento e triagem dos resíduos coletados. Isto porque os núcleos de reciclagem que integraram esta Cooperativa correspondiam a duas modalidades de espaço: associações comunitárias e também quintais. No caso dos espaços comunitários, estiveram envolvidos os seguintes núcleos de reciclagem: Associação Nélia Recicla (clube de mães, em torno do Programa "Leve Leite"), União da Bahia (Associação de capoeira), Projeto "Pequeninos do Itaim" (esporte para crianças), Associação Itajuíbe P4 (Associação de moradores do Conjunto Habitacional Itajuíbe P4) e a Associação Resgate Total (grupo de catadores). A Associação Resgate Total era a única que tinha a reciclagem como principal foco. 
Não por acaso, foi em torno dela que as demais associação se reuniram no processo de formação da Cooperativa Fênix-Ágape. No território de Itaim Paulista, a produção de quantidade significativa de lixo domiciliar, conjugada com o aumento do desemprego que atinge dramaticamente os trabalhadores pobres urbanos, parecem ser dois elementos fundamentais das transformações recentes do uso dos espaços públicos e privados, transformando fundos de quintais, garagens, pátios de igrejas, espaços coletivos dos conjuntos habitacionais (CDHU) e antigas associações comunitárias (de moradores, de mães, culturais) em áreas destinadas às atividades iniciais do processo de reciclagem, como assinalado anteriormente. Na constituição dos núcleos de reciclagem o predomínio é de mulheres. Por um lado, este fato pode ser explicado pelo maior número de pessoas necessárias à atividade da triagem, que requer um trabalho minucioso e paciente de separação e classificações de diferentes tipos de materiais existentes. $E$ que, por sua vez, não requer o grande esforço físico existente em outras atividades (tração dos carrinhos para coleta, prensagem manual, carregamento de fardos). Mas também há outra explicação. Trata-se da transformação de antigas associações comunitárias, com predomínio de participação de mulheres, em locais destinados às atividades da reciclagem. Neste sentido, a nova institucionalização que chega, assenta-se sobre um arranjo local já existente, no qual há uma densidade de afinidades entre os seus integrantes, um saber acumulado de práticas coletivas, e sobretudo um conhecimento sobre o território. Sobre este "chão", construído pela prática cotidiana dos trabalhadores pobres reunidos em associações comunitárias, incidem novas relações tecidas entre Estado e Terceiro Setor, direcionadas à organização do conjunto de atividades inscritas na base da indústria da reciclagem.

Ou seja, no contexto mais amplo das transformações recentes das periferias urbanas, no decurso das mudanças no mundo do trabalho, os agentes sociais envolvidos na organização da base desta indústria (sobretudo os agentes exógenos) não fazem "tábua rasa" do que já existe nestes territórios. Ao contrário! É a partir do que há de pior e de melhor nos conteúdos socioespaciais da periferia que os agentes hegemônicos vislumbram "potencialidades" existentes. Ou seja, a própria pobreza é justificativa para a mobilização dos investimentos necessários ao processo em questão. Neste contexto, as ações direcionadas para a organização da base 
desta indústria passa invariavelmente pela órbita dos projetos, que acabam por instrumentalizar o conhecimento que os moradores têm acerca de seu próprio território. Mas as entidades do Terceiro Setor geralmente não são próprias do lugar. Neste sentido, elas levam à periferia uma outra linguagem, uma outra forma de ação e os arranjos sociais são outros. Se a comunidade local precisa aprender a decodificar este novo léxico, lutar para se inserir verdadeiramente como protagonista (afinal as ONG's advogam a superação do assistencialismo; tudo agora tem algo de "empreendedor"), por outro lado as ONG's pouco podem fazer sem que se infiltrem no âmago do cotidiano do seu "público alvo". Nada mais apropriado do que encontrar num território de alta densidade de pobreza, como é o caso do Itaim Paulista, um conjunto de entidades próprias do processo de formação deste território, em torno das quais se pode adentrar em seus confins. Mas isso se torna ainda mais incisivo quando as mesmas já se encontram sem saber pra onde ir! Embora as demandas sociais continuem sendo imensas, o canal para se chegar ao Estado, ou a algum "parceiro" privado, agora é outro, e não houve demora para que estas pequenas associações entendessem isso. Ainda assim, arrastou-se um movimento oscilante, ora "empreendedor", ora "assistencialista", porque os integrantes dos núcleos, enquanto trabalhadores pobres urbanos, nem sempre podiam esperar as projetos "vingarem"... no processo de se organizarem numa cooperativa, tinham que desdobrar o tempo do trabalho, irredutível para sua própria sobrevivência, e o tempo dedicado às verdadeiras séries de reuniões, cursos de capacitações, idas e vindas a outros locais, vez ou outra à região central. Neste contexto, tornou-se comum os projetos dedicarem parte dos recursos para o custeio das passagens, do "dia de trabalho perdido" e da alimentação dos participantes. Nestas circunstância, houve inclusive um maior interesse por parte dos catadores em participar das reuniões.

Se as demandas sociais, as de sempre (moradia, saúde, educação, creche, segurança, e assim por diante), continuam sempre presentes nisto que é a periferia, foi em relação ao mundo do trabalho que a pesquisa se deparou com seus conteúdos socioespaciais sendo revolvidos. Trata-se agora de uma miríade de propostas para "geração de trabalho e renda com inclusão social", que ocupem os pobres nos seus próprios territórios. No urbano periférico. 
O processo analisado se apresentou sob o binômio dispersãoconcentração, sob diferentes aspectos. Inerente ao próprio objeto de pesquisa, a indústria da reciclagem parece não poder prescindir dos ajustes necessários entre a geração dispersa dos resíduos do consumo e a concentração dos mesmos em determinados pontos do território. Neste sentido, a pesquisa identificou uma gradativa concentração do conjunto de atividades da reciclagem em determinados locais do território.

$E$ isto foi emblemático no caso da Cooperativa Fênix-Ágape, cujo processo de formação se inseriu numa política pública local. Esta, por sua vez, articulou diversos agentes sociais, cujos "fios comunicantes" foram sendo tecidos no bojo da elaboração e execução de projetos, financiados pelos setores público e privado. Aqui o lugar de uma nova governança urbana, com o modelo das Parcerias Público-Privadas (PPP). Neste caso, a referida PPP destinou-se à "geração de trabalho e renda com inclusão social", numa parceria entre a Sub-Prefeitura e a Secretaria Municipal do Trabalho. A aplicação prática de suas propostas, sob a forma de um Projeto Piloto (denominado de Laboratório) se realizou através da implantação da denominada Câmara de Animação Econômica - CAE. Esta que teve como um dos Arranjos Produtivos Locais (APL's) a "Câmara Temática de Reciclagem", do que se destacou a Cooperativa Fênix-Ágape, com suas contradições e conflitos. Neste mesmo contexto, a Sub-Prefeitura de Itaim Paulista desenvolvia um Projeto denominado de "Plano de Desenvolvimento Local". Importa aqui destacar que o referido Projeto se caracterizou como uma política de espaço, sobretudo em relação à proposta de criação de uma nova Central de Triagem (a Cooperativa Fênix-Ágape) em torno da qual estariam distribuídos 20 Eco-Pontos (locais de recepção de entulho e triagem de materiais recicláveis). Esta proposta, elaborada pela Câmara Temática da Reciclagem, desencadeou demandas de alteração do Plano Diretor Estratégico da Sub-Prefeitura, com alteração no zoneamento de uso e ocupação do solo compatíveis com a construção dos referidos Ecopontos, de modo a recobrir todo o território. Verificou-se ainda o mecanismo de "transferência de potencial construtivo", para permitir a implantação de Ecopontos em áreas definidas como de Proteção Ambiental. Outra estratégia foi a transferência de áreas livres dos conjuntos habitacionais da CDHU para a Sub-Prefeitura, para a construção da maior parte dos 
Ecopontos nestas áreas, pois são praticamente as últimas ainda não ocupadas naquele território. Na revisão dos Planos Regionais Estratégicos do Município de São Paulo, em andamento, a Sub-Prefeitura de Itaim Paulista eliminou as barreiras legais para viabilizar a implantação de Ecopontos, locais de recepção de entulho e triagem de materiais recicláveis e Centrais de Triagem e Comercialização, em áreas definidas por AIU/SA (Área de Intervenção Urbana Socioambiental), que abarcam áreas públicas da $\mathrm{CDHU}$ e margens de córregos que, ao serem destinados ao manejo ambiental, adquirem uma abertura legal para a instalação dos equipamentos para reciclagem. Tais estratégias revelam justamente que as atividades que envolvem a organização da base da indústria da reciclagem pressupõem a disponibilidade de áreas para a instalação das unidades de triagem e/ou processamento e comercialização dos materiais. Nesse sentido, existe um esforço da administração pública local para viabilizar legalmente estas áreas.

Mas o processo de formação da Cooperativa Fênix-Ágape não se restringiu ao Projeto de Desenvolvimento Local da Subprefeitura de Itaim Paulista, no cerne do qual se tornou um "caso de sucesso" da Câmara de Animação Econômica. O referido processo esteve envolvido com outros diversos outros projetos, com financiamentos públicos e privados. O Projeto Brasil-Canadá (do qual se obteve capital de giro e prensa elétrica), o Projeto Rede Cata-Sampa (do qual se tornou um pólo de comercialização de recicláveis) e o Projeto Casa do Fazer (empreendimento de Responsabilidade Social da Tv Record) são os mais importantes, dentre outros.

No decurso da realização da pesquisa foram sendo identificados os principais agentes deste processo: Estado (poder local), iniciativa privada (empresas "parceiras" das cooperativas, bancos de crédito popular), Terceiro Setor (ONG's com atuação no âmbito da reciclagem e organizações sociais ligadas à Responsabilidade Social Empresarial), trabalhadores pobres urbanos, articulados em pequenos grupos organizados (núcleos de reciclagem).

Mas trata-se também da análise das transformações dos conteúdos socioespaciais das periferias urbanas. Estas, por sua vez, imbricadas às práticas cotidianas que se realizam enquanto uso do tempo. Isto porque, tudo o que se relata neste Capítulo está, de diferentes formas, inscrito no nível do cotidiano dos 
trabalhadores pobres urbanos, os quais buscam lugar nos interstícios do urbano. Mais precisamente no urbano periférico.

\section{A Central de Triagem de Itaim Paulista e os núcleos de reciclagem}

O Programa Coleta Seletiva Solidária da Prefeitura Municipal de São Paulo foi criado pelo decreto 42.290, de 15 de agosto de 2002. Durante os anos de 2003 e 2004 foram implantadas 15 Centrais de Triagem - galpões com cerca de $1.000 \mathrm{~m}^{2}$, equipados com prensas, esteira, balança, equipamentos de escritório e outros itens complementares ao funcionamento das mesmas. De acordo com a proposta deste Programa, cada Central de Triagem deveria funcionar com uma Cooperativa constituída por catadores oriundos de núcleos de reciclagem já existentes nos respectivos territórios onde fossem implantadas. Estes núcleos, de um modo geral, correspondiam a grupos de catadores que já sobreviviam da coleta e venda de materiais recicláveis no setor informal. Ou então, por trabalhadores desempregados que participaram do processo de formação das Cooperativas, que contou com a ação das entidades do Terceiro Setor, articuladas nos Fóruns Recicla São Paulo e Lixo e Cidadania.

De um modo geral, os núcleos de reciclagem então existentes no Itaim Paulista eram formados no interior de associações de bairro, cujas lideranças comunitárias tinham a experiência de atuação em movimentos populares, sobretudo naqueles ligados aos mutirões da casa própria, das creches e pela saúde, com forte participação das mulheres. São trabalhadoras com experiência profissional em setores como confecção, alimentação, serviços domésticos, comércio em geral, entre outros; ou ainda donas de casa. Com a difusão do mercado para materiais recicláveis, estas Associações introduziram a coleta e comercialização destes materiais como forma de complementar a renda de seus integrantes, que de modo generalizado tiveram a experiência do desemprego no decorrer dos últimos anos.

Estes núcleos, dos quais se destacava a Associação Educacional e Ambiental Resgate Total - AEART, criada no ano 2000, participaram do processo de implantação da Coleta Seletiva em São Paulo, reivindicando que uma das Centrais de Triagem fosse criada no Itaim Paulista. Estes núcleos, representados por 
Associações diversas, juntamente com Agentes Comunitários da Saúde (ACS), criaram um Fórum de reciclagem no Itaim Paulista, denominado FOACRI, no qual discutiam e faziam as reivindicações de criação da Central de Triagem e da coleta seletiva naquela Subprefeitura (Anexo 14).

Resultou deste processo que, no início de 2004, a Central de Triagem do Itaim Paulista iniciava suas atividades. Porém, logo após sua implantação, parte dos núcleos foram excluídos da composição da recém criada Cooperativa Nova Conquista, em decorrência de disputas políticas entre grupos que disputavam sua presidência. Assim, os núcleos novamente se articularam no FOACRI e passaram a buscar "parcerias" para se estruturarem, agora fora do sistema oficial do Programa de Coleta Seletiva da Prefeitura de São Paulo.

\section{Os "empreendedores pés-descalços" e a Câmara Temática da Reciclagem}

A Subprefeitura de Itaim Paulista, em meados de 2004, estava dando início ao denominado Plano de Desenvolvimento Local. A administração local, em parceria com a Secretaria Municipal do Trabalho, buscava identificar o que denominava de "empreendedores pés-descalços". Ou seja, atividades informais existentes no território, os quais seriam integrados às políticas públicas que estavam sendo definidas, e que assumiriam o formato de Parcerias Público-Privadas.

No contexto do referido Plano de Desenvolvimento Local, a Subprefeitura criou a denominada Câmara de Animação Econômica, ou simplesmente CAE, uma Organização Social inserida num Projeto mais amplo formado pela parceria entre SMTRAB, PNUD e FESP/SP. No escopo deste Projeto, o território de Itaim Paulista constituiu-se na base de execução deste "laboratório", com propostas sempre ligadas ao binômio "trabalho e renda". A CAE, por sua vez, era formada por Câmaras Temáticas, destinadas a localizar "pequenos empreendedores" a serem encaminhados ao micro-crédito junto ao Banco do Povo paulista e São Paulo Confia. No processo de identificação dos núcleos de reciclagem, os Agentes Comunitários de Saúde (ACS) foram fundamentais (ANEXO 15). Foram cerca de 80 reuniões no 
decorrer do segundo semestre de 2004, das quais participaram cerca de 500 pessoas. Vejamos uma síntese dos Arranjos Produtivos Locais:

\begin{tabular}{|l|l|l|}
\hline APL & Nome do Grupo & Parceiros / oportunidades \\
\hline Moda & GT Bordados & A ONG Holandesa Straat trouxe o Instituto Europeu de Designer. \\
\hline $\begin{array}{l}237 \text { CNPJ* } \\
\text { (costureiras) }\end{array}$ & Atraiu o "Projeto Quatro Cantos da Moda" do SEBRAE/ALOBRAS \\
\hline Reciclagem & $\begin{array}{l}\text { Coop. Fênix e e } \\
\text { Caminho Certo }\end{array}$ & $\begin{array}{l}\text { Limpurb - a causa é objeto de interesse de poderosos investidores } \\
\text { socioambientais / equipar Ecopontos regulamentados pela Sub-Pref. }\end{array}$ \\
\hline Alimentação & GT Alimentação & $\begin{array}{l}\text { Sistema "S" - Sebrae na Rua / Sr. Giglio - Depto. Responsabilidade } \\
\text { Social da FESPSP (uma das principais acionistas do Sistema) }\end{array}$ \\
\hline $\begin{array}{l}\text { Informação e "Conhecimento } \\
\text { Cultura }\end{array}$ & $\begin{array}{l}\text { Instituto Lidas / Secretaria Municipal de Parcerias (bibliotecas, } \\
\text { telecentros, etc.) }\end{array}$ \\
\hline Cidadão" & $\begin{array}{l}\text { GT Serviços } \\
\text { (construção civil) }\end{array}$ & ANAMACO (Rede Okinawa - demanda 2000 prestadores de serviço \\
\hline
\end{tabular}

"237 CNPJ" foi o nome dado ao Grupo das Costureiras, porque no cadastro da RAIS aparecem 237 oficinas de costura no território da Sub-Prefeitura de Itaim Paulista. Elab.: Rosalina Burgos (2007)

No que se refere ao papel do representante do poder público local na elaboração e execução do Projeto da CAE, foi definido que,

o canal de interlocução direto com a população, criado a partir da percepção do Sub-Prefeito, que aparentemente seria a negação da estrutura formal da participação do Orçamento Participativo ou a retomada da prática clientelista, mostrou-se eficaz na detecção do que ficou chamado de "empreendedorismo dos pés-descalços". As reuniões coletivas e as visitas 'in loco' demonstraram que as pessoas estavam desenvolvendo atividades no mundo do trabalho, utilizando as habilidades conhecidas para garantir a sobrevivência cotidiana. Assim, essa realidade foi capturada pelas visitas de campo e cotejadas com as experiências profissionais de vida dos gestores públicos revelado a heterogeneidade da pobreza extrema.

Como argumento para a escolha da Sub-Prefeitura do Itaim Paulista para execução do Projeto Piloto, o Relatório destaca que o território detém as condições necessárias para a implantação da CAE: grande número de trabalhadores no mercado informal; histórico de participação civil nos projetos populares de políticas setoriais; e porque trata-se de uma localidade caracterizada como cidade dormitório. Definido como Marco Empírico, o Diagnóstico Local foi levantado com base em 3 etapas: 1. Construção das informações locais, 2. Indicadores de Desenvolvimento Local e 3. Câmaras Temáticas: organização dos grupos produtivos.

A primeira atividade a ser identificada foi a de reciclagem. Mais exatamente, o conjunto de núcleos de reciclagem. A proposta era transformá-los em "empreendedores pés no chão" ou "empreendedores calçados”, expressão que se 
tornou uma espécie de chavão daquela Sub-Prefeitura. Para tanto, o poder local "fomentaria parcerias" entre estes grupos e instituições que pudessem investir no desenvolvimento dos mesmos, além de disponibilizar áreas a serem indicadas pelos próprios núcleos. Diante da possibilidade de aquisição de uma área pública para serem alocados, os integrantes dos núcleos iniciaram uma mobilização. Neste momento, com o auxílio de uma rede de lideranças locais atuantes no território, os núcleos chegaram à informações sobre uma área da $\mathrm{CDHU}\left(\right.$ de $\left.2.000 \mathrm{~m}^{2}\right)$ destinada à construção de um Centro de referência da Mulher, cuja edificação estava há anos abandonada.

Desta forma, ainda no final de 2005 os núcleos de reciclagem se instalaram na referia área. Este ato não só foi recebido com aprovação tanto por parte da Sub-Prefeitura quanto da CDHU, como se tornou a peça-chave que resolvia a questão das áreas a serem destinadas à organização da base da indústria da reciclagem naquele território. Além disso, para que não houvesse incompatibilidade com o zoneamento de uso e ocupação do solo, estas áreas foram inseridas dentro dos perímetros de Área de Intervenção Urbana Socioambiental - AIU/SA, com o objetivo de serem legalmente desembaraçadas para esta finalidade. Além disso,

a forma imediata de o Poder Público empoderá-los [os núcleos de catadores] é conceder-Ihes a permissão do terreno para que dêem início a uma atividade de geração de trabalho e renda. Trata-se de uma modalidade de transferência de renda de última geração, que consiste em prover os meios para a viabilização de trabalho e renda. (Keppke, 2006)

A proposta de coleta seletiva que estava se configurando no Itaim Paulista apresentava a seguinte estrutura de funcionamento. Os materiais recicláveis deveriam passar pela rede de núcleos alocados em espaços denominados de Ecopontos, como explicado na parte inicial deste Capítulo. Destes Ecopontos, os materiais seriam encaminhados para a Central de Triagem e Comercialização. Seriam 20 Ecopontos divididos de modo a recobrir todo o território da Sub-Prefeitura de Itaim Paulista. 
A obtenção da área da CDHU que havia resultado da iniciativa dos próprios núcleos, foi anunciada como o primeiro grande resultado da $\mathrm{CAE}$, como podemos observar na citação a seguir:

Em direção à implantação do modelo proposto, já alcançamos os seguintes resultados. Primeiro, a concessão de direito de uso do Espaço Livre de $2500 \mathrm{~m} 2$ dentro do Conjunto Habitacional Marechal Tito da Companhia de Desenvolvimento Habitacional Urbano - a CDHU. No local está a semente da Central de Triagem e Comercialização do Distrito Itaim Paulista, onde já está instalada a Cooperativa Fênix, consorciando onze Núcleos de Reciclagem. (Keppke, 2006)

Algumas reportagens veiculadas sobre a Câmara de Animação Econômica da Sub-Prefeitura de São Paulo estão anexadas ao final deste Capítulo (ANEXOS 16 e 17). A freqüência com que a Câmara de Animação Econômica foi notícia no Diário Oficial do Município de São Paulo, bem como no portal de notícia do site da Prefeitura, demonstram que a mesma tornou-se um caso emblemático de Parceria Público-Privada no contexto do Município de São Paulo.

\section{O processo de formação da Cooperativa Fênix-Ágape}

O processo de formação da Cooperativa de reciclagem Fênix-Ágape, no território de Itaim Paulista (periferia consolidada da metrópole de São Paulo), teve início com a organização de núcleos de reciclagem, reunidos em torno da Associação Educacional e Ambiental Resgate Total - AEART. Estes núcleos de reciclagem, assim como as demais modalidades de locais com atividades da base da indústria da reciclagem (cooperativas, comerciantes do ramo de diferentes portes e recicladores) estão predominantemente inseridos no contexto do urbano periférico, em territórios empobrecidos seja no centro ou na periferia propriamente ditos da metrópole de São Paulo.

Tal processo foi investigado em suas relações e mediações estabelecidas com agentes sociais das esferas pública, privada e principalmente do Terceiro Setor da indústria da reciclagem. Neste último caso, encontram-se instituições que atuam 
sob o modelo das Parcerias Público-Privadas, bem como em Fóruns que integram os diferentes agentes sociais envolvidos na estruturação da indústria da reciclagem.

No escopo desta Tese, destacamos algumas destas instituições e Fóruns, e seus respectivos Projetos:

a) a Câmara de Animação Econômica da Sub-Prefeitura de Itaim Paulista - CAE, sob os moldes de uma Organização da Sociedade Civil de Interesse Público (OSCIP), bem como sua Câmara Temática de Reciclagem, na qual a Cooperativa Fênix-Ágape se tornou o principal "caso de sucesso" (Projetos financiados pela parceria entre Smtrab/PNUD/FESPSP);

b) o Instituto Cata-Sampa formado por um grupo de lideranças do Movimento Nacional de Catadores de Materiais Recicláveis(MNCR), com sua Rede CataSampa (Projetos com financiamentos do MDS, BNDES e Petrobrás);

c) o Projeto Brasil Canadá (financiamentos do governo canadense), com sua Rede de Comercialização e mecanismos de empréstimos financeiros para Capital de Giro das Cooperativas parceiras;

d) o Instituto GEA, uma ONG do Terceiro Setor da indústria da reciclagem, com seu Projeto (financiamento do Fundo Nacional do Meio Ambiente, entre outros diversos),

e) o Fórum Recicla São Paulo e Fórum Lixo e Cidadania, cujas ONG's integrantes atuam com financiamentos diversos, públicos e/ou privados;

f) os Programas da Secretaria Municipal do Trabalho, com destaque para o Convênio Internacional SMTrab/PNUD/FESPSP;

g) a Secretaria de Serviços e Obras (Depto. de Limpeza Urbana - Limpurb) da Prefeitura de São Paulo, responsável pela gestão dos resíduos sólidos urbanos;

h) o Instituto EcoFuturo, criado pela Companhia Suzano Papel e Celulose e Banco Real, entre outros parceiros, com seu mecanismo de empréstimos financeiros para Capital de Giro das Cooperativas de reciclagem;

i) a Tetra Pak, com destaque para seu relacionamento com pequenos comerciantes e grupos organizados de reciclagem, no fornecimento de prensas manuais e material de divulgação para coleta porta-a-porta (panfletos, kits didáticos, feitos com materiais reciclados das próprias caixas tipo Tetra Pak) 
j) a Rede de Compromisso Social da CDHU, no processo de transferência das áreas públicos para as administrações locais, destinadas à implantação de Cooperativas de reciclagem;

I) Instituto Ressoar (Rede Record de Televisão) com seu Projeto Casa do Fazer, cuja ênfase na "geração de trabalho e renda com inclusão e sustentabilidade social, econômica e ambiental" encontrou no fomento à reciclagem um dos campos para a prática da Responsabilidade Social Empresarial;

m) o Condomínio Conjunto Nacional, com o Projeto Natal Nacional, de 2007 (este Projeto reuniu 4 Cooperativas de reciclagem, sendo uma delas a Cooperativa Fênix-Ágape, as quais produziram cerca de 15 mil bolas artesanais feitas a partir de garrafas PET, com remuneração de $R \$ 1,50$ por peça) 


\section{Programa Operação Trabalho}

No final de 2005, após meses de reuniões para a construção do Projeto que daria origem à Câmara de Animação Econômica da Sub-Prefeitura de Itaim Paulista, os núcleos da reciclagem já contavam com a área para desenvolverem seus trabalhos. Neste momento, receberam a notícia de que a SMTrab tinha algumas Bolsas do Programa Operação Trabalho que deveriam ser preenchidas com urgência. Neste contexto, os núcleos reunidos em torno da Associação Resgate Total, que então se confundia com a Cooperativa Fênix-Ágape em processo de formação, receberam sessenta Bolsas Trabalho, cujos bolsistas passaram a integrar a primeira formação da Cooperativa. Não se tratava exatamente de catadores, mas de desempregados oriundos dos mais diversos setores produtivos. Participaram deste Programa pessoas desempregadas indicadas pelos próprios núcleos de reciclagem. Uma das primeiras ações da CAE junto a este grupo de bolsista foi a realização de um curso de capacitação, realizado pelo IDELT, uma instituição do Terceiro Setor que tem como um de seus focos a capacitação profissional, inclusive para cooperativas de reciclagem (FOTOS).

Os bolsistas do Programa Frente de Trabalho, que integram a primeira formação da Cooperativa Fênix-Ágape eram, em sua maioria, pessoas desempregadas, possuíam entre 30 e 40 anos, e de um modo geral já haviam trabalhado no setor formal, sendo que a maioria estava desempregada a 2 anos, e outros estavam desempregados a mais de 4 anos. A maioria dos bolsistas tinha apenas o primeiro grau, seguido de um grupo menor com segundo grau. As profissões já exercidas apresentavam um perfil de baixa exigência em termos de qualificação profissional, tais como ajudante geral, doméstica, mecânico, vendedor, operadores de caixa, mas a maioria dos bolsistas já haviam tido carteira assinada (QUADRO 20).

Estas pessoas tinham, de forma mais direta ou indireta, vínculos de parentesco, amizade, compadrio, vizinhança ou haviam sido indicadas por conhecidos dos integrantes dos núcleos de reciclagem. 
QUADRO 20

1. Idade:
\begin{tabular}{|l|l|}
\hline De 20 a 29 & 06 \\
\hline De 30 a 39 & 12 \\
\hline De 40 a 49 & 05 \\
\hline De 50 a 59 & 04 \\
\hline De 60 a 69 & 03 \\
\hline
\end{tabular}

5. Se sim, há quanto tempo?

\begin{tabular}{|l|l|}
\hline 1 ano & 04 \\
\hline 4 anos & 07 \\
\hline 5 anos & 04 \\
\hline 6 anos & 04 \\
\hline 8 anos & 02 \\
\hline 10 anos & 02 \\
\hline 13 anos & 02 \\
\hline "muito tempo / muitos anos" & 01 \\
\hline
\end{tabular}

2. Profissão:

\begin{tabular}{|l|l|}
\hline Agende ambiental & 06 \\
\hline Doméstica & 03 \\
\hline Ajudante geral & 03 \\
\hline Segurança & 02 \\
\hline Operadora de caixa & 02 \\
\hline Do lar & 01 \\
\hline Diarista & 01 \\
\hline Fotógrafo & 01 \\
\hline Zeladora & 01 \\
\hline Costureira modelista & 01 \\
\hline Monitora & 02 \\
\hline Ajudante de copeira & 01 \\
\hline $\begin{array}{l}\text { Mecânico de } \\
\text { manutenção }\end{array}$ & 01 \\
\hline Vendedora & 02 \\
\hline Cozinheira & 01 \\
\hline Atendente & 01 \\
\hline Operadora de máquina injetora & 01 \\
\hline Fotógrafo & 01 \\
\hline $\begin{array}{l}\text { * Nesta resposta, os bolsistas estão se } \\
\text { referindo à designação dada aos mesmos } \\
\text { durante o curso de capacitação, atestada em } \\
\text { certificado emitido ao final do curso. }\end{array}$ \\
\hline
\end{tabular}

6. Já teve carteira assinada?

\begin{tabular}{|l|l|}
\hline Sim & 23 \\
\hline Não & 07 \\
\hline
\end{tabular}

7. Já trabalha com reciclagem?

\begin{tabular}{|l|l|}
\hline Sim & $20^{*}$ \\
\hline Não & 10 \\
\hline
\end{tabular}

8. Se sim, há quanto tempo?

\begin{tabular}{|l|l|}
\hline Menos de 6 meses $^{*}$ & 14 \\
\hline Até 1 ano & 04 \\
\hline 2 anos & 03 \\
\hline 3 anos & 02 \\
\hline 4 anos & 02 \\
\hline 5 anos & 02 \\
\hline 6 anos & 01 \\
\hline 8 anos & 01 \\
\hline 12 anos & 01 \\
\hline
\end{tabular}

* A maioria se refere à experiência no Programa Frente de Trabalho, cujas atividades foram desenvolvidas na Associação Resgate Total, no processo de formação da cooperativa Fênix-Ágape.

\begin{tabular}{|l|l|}
\hline Primário incompleto & 03 \\
\hline Primário & 06 \\
\hline $1^{\circ}$ grau incompleto & 06 \\
\hline $1^{\circ}$ grau & 04 \\
\hline $2^{\frac{9}{9}}$ grau (ou Ensino Médio) & 09 \\
\hline $3^{\circ}$ grau incompleto & 01 \\
\hline $3^{\circ}$ grau & 01 \\
\hline
\end{tabular}

\section{Está desempregado?}

\begin{tabular}{|l|l|}
\hline Sim & 25 \\
\hline Não & 05 \\
\hline
\end{tabular}

\section{Já trabalhou em cooperativa?}

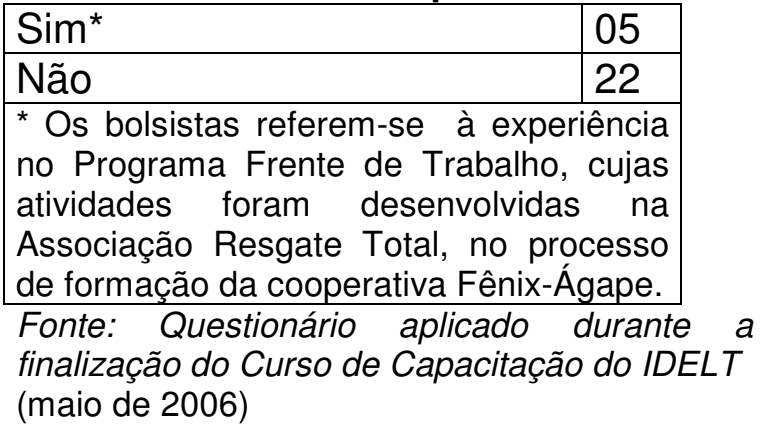




\section{Parceiros da Cooperativa Fênix-Ágape}

Depois que os núcleos de reciclagem, reunidos em torno da Associação Resgate Total, ocuparam a sede comunitária do Conjunto Habitacional Marechal Tito (uma área da CDHU com aproximadamente $2.000 \mathrm{~m}^{2}$ ) no final de 2005, alguns parceiros começam a surgir, interessados no processo de formação da Cooperativa Fênix-Ágape.

É emblemática a relação existente entre a aquisição da área para implantação da nova cooperativa e o desencadeamento das parcerias. A SubPrefeitura de Itaim Paulista, através de sua Câmara de Animação Econômica, bem como a Rede de Responsabilidade Social da $\mathrm{CDHU}^{159}$, apregoaram cada uma para si a autoria da "doação" da área para o processo de formação da Cooperativa FênixÁgape.

Porém, devemos ressaltar que tanto a Sub-Prefeitura de Itaim Paulista quanto a CDHU o que fizeram foi simplesmente aprovar e reproduzir a atitude tomada pelos próprios integrantes dos núcleos de reciclagem. Assim, a Associação Resgate Total passou a ocupar o espaço comunitário do referido Conjunto Habitacional, para o qual havia o Projeto de construção de um Centro de Referência da Mulher, cujas obras estavam abandonadas a muito tempo.

A partir deste momento, o que todos os parceiros da Cooperativa FênixÁgape, com seus respectivos projetos, passaram a ter em comum era justamente o fato de que a mesma se caracterizava como "seu caso de sucesso".

\section{Instituto GEA}

No início de 2006, aconteceu uma reunião na Cooperativa Fênix-Ágape, com representantes da Câmara de Animação Econômica da Sub-Prefeitura de Itaim Paulista e do Instituto GEA, uma ONG do Terceiro Setor da indústria da reciclagem. O Instituto GEA era uma das organizações sociais integrantes do Fórum Recicla São Paulo, o qual atuou no processo de formação das cooperativas que assumiram as 
Centrais de Triagem do Programa de Coleta Seletiva da Prefeitura de São Paulo. Seus técnicos já conheciam as lideranças dos núcleos de reciclagem do Itaim Paulista, pois haviam ministrado cursos de capacitação aos mesmos durante o processo de implantação do referido Programa de Coleta Seletiva da Prefeitura de São Paulo.

Nesta ocasião, os consultores presentes levantaram uma série de questões, "mapeando" a situação da Associação Resgate Total, propondo apoiar o processo de formação da nova Cooperativa. Assim, a Cooperativa Fênix-Agape, em seu processo de formação, passou a ser o empreendimento "fomentado" por um Projeto financiado pelo Fundo Nacional de Meio Ambiente (FNMA) desenvolvido pelo Instituto GEA, cujos consultores também faziam parte do Projeto Brasil-Canadá ${ }^{160}$, do qual a Cooperativa Fênix-Ágape também começava a participar. O GEA explicou a proposta de inclusão da Cooperativa Fênix-Ágape no Projeto financiado pelo FNMA, cuja proposta era apoiar uma cooperativa localizada em Guarulhos e outra em São Paulo. Inicialmente, a Cooperativa de São Paulo estava localizada no bairro do Tremembé, na zona norte, mas o GEA avaliou que "a inclusão da Fênix seria mais interessante, por conta da proximidade do Itaim Paulista com o município de Guarulhos". Mas o que de fato ficava nas entrelinhas desta escolha, era a adequabilidade desta Cooperativa para o cumprimento dos compromissos assumidos no contrato com o FNMA. Ou seja, a Cooperativa Fênix-Ágape estava em pleno processo de estruturação - mesmo sem o Projeto do GEA, enquanto a cooperativa localizada no Tremembé parecia impor maiores dificuldades aos trabalhos do GEA, o que poderia significar maiores custos.

No caso do Projeto Brasil-Canadá, a Cooperativa Fênix-Ágape fazia parte do Conselho Gestor, sendo uma das bases que adquiriam empréstimos financeiros, sob a forma de capital de giro. A prática de empréstimos financeiros para capital de

\footnotetext{
${ }^{159}$ Organização Social do Terceiro Setor ligada à CDHU.

160 Projeto Brasil-Canadá: Gestão participativa e sustentável dos resíduos sólidos: Este projeto coordenado pelas universidades Victoria (UVIC) (Victoria-BC, Canadá) e o Centro Universitário da Fundação Santo André(FSA) (Santo André - SP Brasil); a Ong Rede Mulher de Educação e o Fórum Recicla São Paulo, tem o apoio da Canadian International Development Agency (CIDA-UPCD Program - Tier 2). O projeto no valor de $999.972,65 C A D \$$ equivalente a $R \$ 1.805 .153,00$ (sendo que $50 \%$ deste valor é de contrapartida das Universidades e parceiros envolvidos no projeto), será desenvolvido no período de 2005 a 2010. Abrange municípios de parte da região metropolitana de São Paulo: Ribeirão Pires, Santo André, Diadema e São Paulo. Fonte: Texto de Divulgação do Projeto Brasil-Canadá.
} 
giro realizada por projetos destinados à organização de redes de cooperativas para comercialização coletiva também seria observada no Projeto Cata-Sampa, como veremos posteriormente.

O Projeto Brasil-Canadá foi apresentado como um Projeto que apoiava a coleta seletiva porta-a-porta e a auto-gestão dos grupos. O Projeto havia sido aprovado a cerca de um ano, e os integrantes do Fórum Recicla São Paulo haviam trabalhado nas capacitações das bases integrantes do Projeto, cujos recursos eram provenientes da Universidade do Canadá, numa parceria com a Fundação Santo André. O território de atuação do Projeto Brasil-Canadá eram os Municípios do $A B C D$, mas existia o interesse de expandi-lo para o Município de São Paulo, através das Sub-Prefeituras, a começar pelo Itaim Paulista. O trabalho dos consultores também consistia em capacitar as administrações públicas sobre a coleta seletiva domiciliar, conciliando-a com os modelos de limpeza urbana já existentes.

O Sub-Prefeito do Itaim Paulista, então presente, comunicou que a partir de abril daquele ano, uma Equipe da Secretaria do Trabalho, juntamente com a SubPrefeitura e técnicos contratados, começariam um trabalho de "Animação Econômica com a turma da reciclagem". O Sub-Prefeito estava se referindo ao Projeto Desenho e Implantação de Projeto Piloto de Arranjos Produtivos Locais e suas oportunidades de geração de trabalho e renda na Sub-Prefeitura de Itaim Paulista (já citado anteriormente), no âmbito da parceria entre SMTrab, FESP, Pnud e Sub-Prefeitura de Itaim Paulista (por intermédio da CAE).

Foi anunciado também a parceria entre CDHU e Limpurb, para que a área da CDHU onde a Cooperativa estava sendo instalada fosse transferida para a SubPrefeitura, onde o Limpurb, da Secretaria de Serviços, deveria viabilizar a construção de uma nova Central de Triagem e Comercialização no Itaim Paulista.

Foi o momento também da divulgação do lançamento da Agência do Banco São Paulo Confia, um programa de financiamento da Prefeitura de São Paulo, para o qual os empreendimentos geridos pela Câmara de Animação Econômica estariam sendo encaminhados, para aquisição de micro-crédito.

Os parceiros da Cooperativa Fênix-Ágape apostavam num novo modelo de Central de Triagem, "menos paternalista" do que o modelo então vigente, cujo trabalho deveria ser feito sem uso de caminhão, considerado o item mais oneroso 
dentre os equipamentos e instrumentos necessários para a etapa da coleta, informação destacada pelo Instituto GEA. Como exemplo, é lembrado que o Programa "Coleta Seletiva Solidária" da Prefeitura de São Paulo tinha um alto custo e o retorno não chegava a $50 \%$ dos investimentos feitos.

Os representantes do Instituto GEA argumentavam que o trabalho por eles desenvolvido apresentava um diferencial em relação às capacitações feitas, por exemplo, pelo SEBRAE que ressaltava a competitividade. As capacitações feitas pelos integrantes do Fórum Recicla São Paulo - dentre elas o Instituto GEA buscava "desconstruir a idéia de competitividade e construir a experiência da Rede, da solidariedade, do trabalhar juntos".

Por fim, este encontro marcou o início da parceria entre o Instituto GEA / Projeto Brasil-Canadá com a Câmara de Animação Econômica da Sub-Prefeitura de Itaim Paulista, mediada pelos projetos, práticas e discursos em torno do processo de formação da Cooperativa Fênix-Ágape.

\section{A Rede Cata-Sampa}

No primeiro semestre de 2006, integrantes do Movimento Nacional dos Catadores de Materiais Recicláveis - MNCR, estavam envolvidos com o início do Projeto Cata-Sampa, financiado pelo Ministério do Desenvolvimento Social e Combate à Fome, em parceria com a Petrobrás, cujos recursos eram administrados pela Organização de Auxílio Fraterno de São Paulo. Na primeira fase deste Projeto, havia a proposta de que no decorrer daquele ano seriam capacitados 500 catadores. A estrutura de funcionamento do Projeto era comandada pela OAF, pelas lideranças do MNCR, e de representantes de cooperativas, das quais se destacava a CRUMA, além de uma equipe de técnicos. Naquele momento, buscava-se levantar informações sobre o número de catadores existentes nas bases e ruas, a renda mensal destes, e terrenos disponíveis para a implantação de cooperativas. Já existia uma questão posta sobre qual instituição responderia juridicamente pelo Projeto Cata-Sampa, se a OAF ou a CRUMA.

Fato é que tanto a CRUMA como a OAF eram responsáveis pelo Projeto Rede Cata-Sampa, orçado em 4 milhões de reais. Um dos principais objetivos do Projeto era chegar ao final do ano de 2006 com os cooperados ganhando ao menos 
2 salários mínimos. O Projeto Rede Cata-Sampa se dividia em três regiões: Grande São Paulo, Baixada Santista e Alto Tietê, e previa investimentos na capacitação dos catadores; equipamentos para a rede, como galpões, caminhões, prensas e balanças; condições gerais para atingir grandes geradores, aumentando assim a quantidade de materiais nas cooperativas.

No início de 2007 a Rede Cata-Sampa encontrava-se em fase de adaptação. Estava terminando o Projeto em parceria com a OAF, e as lideranças se articulavam para formar o Instituto Cata-Sampa. Haviam problemas entre as lideranças das bases (cooperativas) e os técnicos contratados pela OAF (de modo geral, os problemas diziam respeito à forma de gestão dos recursos financeiros), o que levou - ao que tudo indica, ao fim da parceria.

Até então, a Cooperativa Fênix-Ágape participava como uma das bases da Rede Cata-Sampa, ainda designada como núcleo "Resgate Total", pois enquanto a documentação da Cooperativa não estava pronta, fazia-se o uso do CNPJ da Associação Resgate Total (AEART). A comercialização em rede estava sendo feita com: caixas Tetra Pak, PET, papelão, papel branco e copinho plástico descartável (PS). Os demais tipos de materiais eram comercializados com atravessadores. Estavam previstos, para o ano de 2007, investimentos do Cata-Sampa em Galpões pré-moldados para as bases CRUFFI, Magnália Dei e Fênix; mesas para triagem, prensa elétrica, empilhadeiras, carrinhos movidos à bateria, Equipamentos de Proteção Individual - EPI's, uniformes, material de divulgação para a conscientização porta-a-porta, entre outros, além da manutenção dos caminhões.

Com o fim do Projeto financiado pela Petrobrás, o Galpão Cata-Sampa que funcionava na região central (Baixada do Glicério) para processamento dos materiais comercializados pela Rede foi fechado (pois não havia mais recursos para pagar o aluguel do prédio, entre outras questões), e a Rede teve que redefinir sua estrutura.

Assim, a Rede Cata-Sampa organizou-se em dois "Pólos", nos quais se concentrariam os equipamentos necessários ao processamentos dos materiais a serem encaminhados para a comercialização coletiva, realizada pelo conjunto de bases da Rede. Assim, a Cooperativa Fênix-Ágape tornou-se o "Pólo de comercialização" do Município de São Paulo (mais precisamente da zona leste, onde 
se concentram as bases da Rede em São Paulo). De outro lado, a Cooperativa CRUMA tornou-se o "Pólo de comercialização" do Alto Tietê.

A localização da Cooperativa Fênix-Ágape acabou sendo decisiva para a articulação da Rede, fazendo "uma ponte" entre as bases localizadas em São Paulo e aquelas integrantes do Pólo do Alto Tietê. Além disso, outro motivo fundamental era o fato da Cooperativa Fênix-Ágape estar numa área pública, com dimensões apropriadas (cerca de $2.000 \mathrm{~m}^{2}$ ), com uso devidamente regularizado pelo termo de comodato com a Sub-Prefeitura e CDHU. Outro ponto igualmente importante, era a organização e trabalho efetivamente realizado pela Cooperativa, ao contrário de outras bases praticamente improdutivas.

\section{A Cooperativa Fênix-Ágape para além de um "caso de sucesso"}

Naquele início de 2007, enquanto a Cooperativa Fênix Ágape configuravase como um "caso de sucesso" disputado pelas instituições parceiras, apenas 10 pessoas ainda faziam parte de seu corpo de cooperados, sendo que estas complementavam a renda mensal com outras atividades.

Já naquele momento, eram poucos os núcleos que ainda existiam e participam da Cooperativa, tais como o Itajuíbe P4 e o Nélia Recicla, normalmente representados por um único cooperado. $O$ valor da hora trabalhava estava calculada em $R \$ 1,15$, resultando numa média de $R \$ 200,00$ a $R \$ 250,00$ a retirada mensal de cada cooperado. A principal fonte dos materiais recicláveis era a coleta seletiva porta-a-porta (70\% do material total), seguido dos materiais coletados nos condomínios da CDHU (20\% do material total) onde residia parte dos seus integrantes, sendo o restante complementado por doações (10\% do material total).

Mesmo a participação na Rede Cata-Sampa não havia ainda representado uma melhoria nas condições de trabalho. A exemplo disto, a Cooperativa havia recebido uma "doação" de cerca de 2 toneladas de materiais recicláveis da Coopamare, integrante da Rede Cata-Sampa. O material doado era composto principalmente por papel misto, de baixo preço no mercado de recicláveis. Cerca de 2 toneladas deste material resultaram numa receita de $R \$ 200,00$ ( $R \$ 0,10$ por quilo). 
Sobre o valor a ser obtido com a venda do material "doado", a Cooperativa Fênix repassaria uma porcentagem de $10 \%$ para a Coopamare e de $5 \%$ para a Rede CataSampa, pois a "doação" havia sido feita com uso do caminhão da Rede. Além disso, ainda tinha $10 \%$ para a Cooperativa de São Matheus, onde o material seria prensado, pois a Cooperativa Fênix-Ágape ainda não tinha prensa elétrica. Portanto, restava $75 \%$ do total para esta Cooperativa.

Nesta fase do processo, esta taxa era justificada para a formação de um Fundo para a sustentabilidade futura da mesma. Além disso, a Rede oferecia o caminhão, fitilho para os fardos, pagamento de transporte (condução) para seus integrantes se articularem, além de oferecer capital de giro, a exemplo do adiantamento do pagamento feito pelo material da Tetra Pak, cuja empresa levava em torno de 15 dias para efetuar o pagamento à Rede. Ainda em relação às caixas da Tetra Pak, a cooperativa passou a receber $R \$ 0,29$ pelo quilo, sendo que antes vendia por $\mathrm{R} \$ 0,10$ ao atravessador. A seguir apresentamos um quadro $21 \mathrm{com}$ os compradores dos materiais recicláveis da Cooperativa Fênix-Ágape, no início de 2007. Observe que neste primeiro momento o principal comprador dos materiais da Cooperativa Fênix-Ágape na Rede era a Companhia Suzano de Papel e Celulose, sendo que os demais já eram seus compradores antes de sua entrada na Rede Cata-Sampa. Por outro lado, devemos ressaltar que foi justamente participando da Rede que a Cooperativa Fênix-Ágape teve a primeira experiência de venda direta à indústria, como demonstramos no Quadro 21 a seguir: 
QUADRO 21

Compradores dos materiais da Coop. Fênix-Ágape (jan/2007)

\begin{tabular}{|r|r|r|r|}
\hline MATERIAIS & Comprador & Modalidade & Localização \\
\hline PAPELÃO & Companhia Suzano & Indústria & Suzano \\
\hline PAPEL BRANCO & Companhia Suzano & Indústria & Suzano \\
\hline PAPEL BRANCO, & $\begin{array}{r}\text { Da Central de Triagem } \\
\text { REVĨo Matheus }\end{array}$ & $\begin{array}{r}\text { Comprador da Central } \\
\text { de Triagem }\end{array}$ & \\
\hline PAPEL MISTO & $\begin{array}{r}\text { da Central de Triagem } \\
\text { São Matheus }\end{array}$ & $\begin{array}{r}\text { Comprador da Central } \\
\text { de Triagem }\end{array}$ & \\
\hline VIDROS & Omero & Reciclador & Erm. Matarazzo \\
\hline VIDRO UNID. & Omero & Reciclador & Erm. Matarazzo \\
\hline PET & Air Del & Reciclador & S. Miguel Pta. \\
\hline PET ÓLEO & Air Del & Reciclador & S. Miguel Pta. \\
\hline PLÁSTICO PP & Aparistas & Grande Aparista & F. de Vasconcelos \\
\hline PLASTICO PEAD & Aparistas & Grande Aparista & F. de Vasconcelos \\
\hline TETRA PAK & Zé Caetano & Grande Aparista & F. de Vasconcelos \\
\hline ALUMINIO, & Zé Caetano & Grande Aparista & F. de Vasconcelos \\
\hline COBRE, METAIS & D.C.A. & Grande Aparista & Itaim Paulista \\
\hline FERRO & Padroeira & Ferro-velho & Itaim Paulista \\
\hline APARA. MISTO & Padroeira & Ferro-velho & Itaim Paulista \\
\hline APARAS BRASTA & Padroeira & Ferro-velho & Itaim Paulista \\
\hline
\end{tabular}

Fonte: Entrevista com a presidente da Cooperativa Fênix-Ágape, Sra. Francisca Rabelo (jan/2007).

Por outro lado, o contato com a Rede do ABC, formada em torno do

Projeto Brasil-Canadá também estava vigente, sobretudo com uso de capital de giro que era utilizado para a folha de pagamento dos cooperados no início do mês, enquanto os pagamentos pela venda dos materiais do mês encerrado ainda estavam entrando no caixa da cooperativa. Isso porque, de um modo geral, nem o grande aparista, nem a própria indústria costuma fazer o pagamento à vista, e quando o faz usa cheques administrativos que levam alguns dias para compensar.

O Projeto Brasil-Canadá oferecia o prazo de 20 dias para o pagamento do empréstimo, funcionando como um banco de crédito destinado à cooperativas de catadores. No início, as cooperativas participantes do Projeto Brasil-Canadá contavam com um fundo de cerca de $R \$ 1.000,00$ que podia ser solicitado para capital de giro, mas o Fundo já estava calculado em cerca de $R \$ 5.000,00$. Para que uma cooperativa pudesse solicitar o empréstimo, deveria apresentar demonstrativos de sua produtividade, ou balanços mensais que comprovassem suas condições de pagamento futuro do empréstimo feito. Este capital não deveria ser usado com gastos como EPI's (equipamentos de proteção individual), porque "com este tipo de gasto não havia retorno". Abrimos aqui um parênteses para observar que nos 
balanços da cooperativa, o pagamento dos cooperados aparece como gastos. Porém, como demonstra o critério para uso do Fundo para capital de giro do Projeto Brasil-Canadá, este tipo de gasto - ao contrário dos EPI's, oferece "retorno" ao caixa da cooperativa.

No início de 2008, a Cooperativa Fênix-Ágape, então legalmente constituída, funcionava com 11 cooperados, e outros trabalhadores exporádicos, cujo número variava de acordo com a necessidade da cooperativa. No Quadro 22 abaixo indicamos algumas informações sobre a situação da Cooperativa naquele momento, em termos de compradores dos seus materiais, e preços pagos pelos mesmos:

QUADRO 22

\begin{tabular}{|c|c|c|c|c|c|c|}
\hline Material & Empresa & Local & Categoria & Transporte & $\begin{array}{c}\mathrm{Kg} \\
\text { (abril/2008) }\end{array}$ & $\mathbf{R} \$ / \mathbf{k g}$ \\
\hline PET & Air Del & Curuçá & Aparista & Rede & 800 & 1,07 \\
\hline Papelão & Suzano & Suzano & Indústria & Indústria & 2.000 & 0,40 \\
\hline \multirow[t]{2}{*}{$\mathrm{Pe}, \mathrm{Pp}$} & \multirow[t]{2}{*}{-} & \multirow[t]{2}{*}{ Poá } & \multirow[t]{2}{*}{ Aparista } & \multirow[t]{2}{*}{ Rede } & 350 & 1,00 color \\
\hline & & & & & 400 & 1,40 branco \\
\hline \multirow{2}{*}{$\begin{array}{l}\text { Aparas } \\
\text { plásticas }\end{array}$} & \multirow[t]{2}{*}{-} & \multirow[t]{2}{*}{ Poá } & \multirow[t]{2}{*}{ Aparista } & \multirow[t]{2}{*}{ Rede } & 250 & 0,45 color \\
\hline & & & & & 150 & 1,10 branco \\
\hline $\begin{array}{l}\text { Papel } \\
\text { branco }\end{array}$ & $\begin{array}{l}\text { Aparas } \\
\text { Primus }\end{array}$ & $\begin{array}{l}\text { Itaquera / } \\
\text { Rio Claro }\end{array}$ & Indústria & Indústria & 2.000 & $\begin{array}{l}0,52 \text { tipo } 02 \\
0,45 \text { tipo } 04\end{array}$ \\
\hline $\begin{array}{l}\text { Papel } \\
\text { misto }\end{array}$ & $\begin{array}{l}\text { Aparas } \\
\text { Primus }\end{array}$ & $\begin{array}{l}\text { Itaquera / } \\
\text { Rio Claro }\end{array}$ & Indústria & Indústria & $\begin{array}{c}2.500 \\
1.000 \\
\text { (revista/jornal) }\end{array}$ & $0,15-0,20$ \\
\hline Ferro & - & $\begin{array}{l}\text { Itaim Pta. } \\
\text { Itaquá }\end{array}$ & Atravessador & Cooperativa & 800 & $0,30-0,35$ \\
\hline \multirow[t]{2}{*}{ Vidro } & \multirow[t]{2}{*}{ Omero } & \multirow{2}{*}{\begin{tabular}{|l|} 
Erm. \\
Matarazzo
\end{tabular}} & \multirow[t]{2}{*}{ Aparista } & \multirow[t]{2}{*}{ Aparista } & 2.000 & 0,10 \\
\hline & & & & & 200 & 0,40 unidade \\
\hline Alumínio & - & Itaim Pta. & Atravessador & Cooperativa & 40 & $\begin{array}{l}3,00-3,50 \\
5,00>200 \mathrm{Kg}\end{array}$ \\
\hline Tetra pak & - & - & Indústria & Indústria & 1.500 & $\begin{array}{l}0,15 \text { solto } \\
0,30 \\
\text { prensado }\end{array}$ \\
\hline $\begin{array}{l}\text { Copinhos } \\
\text { PS }\end{array}$ & - & - & Aparista & Cooperativa & 250 & $0,40-0,60^{*}$ \\
\hline PVC's & - & - & Aparista & Cooperativa & - & - \\
\hline
\end{tabular}

* Produto secundário sob forte variação de preço no mercado.

- sem informação

Com a cooperativa em pleno funcionamento, os núcleos participantes haviam se tornado uma fonte de remuneração para seus respectivos representantes, os quais, por sua vez, faziam parte da Cooperativa. O material destes "núcleos" que na verdade haviam se fundido no processo de formação da cooperativa, bem 
como o material de catadores avulsos, eram pesados separadamente, calculando-se o valor a ser pago aos cooperados representantes dos mesmos.

Depois, estes materiais eram acumulados por cerca de 15 dias num local à parte na cooperativa, sendo então triados por alguns cooperados. Estes eram pagos por um dia de trabalho (calculado em $R \$ 15,00$, uma jornada de 8 horas trabalhadas), cujo valor era descontado dos núcleos e catadores avulsos, proporcionalmente aos volumes com os quais cada um havia participado. Além do pagamento pela triagem do material, os núcleos repassam à cooperativa uma taxa de $15 \%$ sobre o valor do seu material comercializado, através dela, na Rede CataSampa.

Para concluir, vale registrar que os materiais provenientes dos núcleos e catadores avulsos somam cerca de 1 tonelada de material por mês (triados a cada 15 dias, como vimos no caso anteriormente citado), cerca de $10 \%$ do total obtido pela Cooperativa, que naquele momento operava com cerca de 10 toneladas ao mês.

Com a transformação da Cooperativa Fênix-Ágape em Pólo de comercialização da Rede Cata-Sampa, além dos materiais recicláveis provenientes dos núcleos de reciclagem, bem como da coleta seletiva porta-a-porta (principal fonte de entrada de material), também passou a receber o material de algumas bases participantes da Rede Cata-Sampa, para a prensagem e carregamento de caminhão para a comercialização coletiva.

Desta forma, a Cooperativa Fênix-Ágape passou a apresentar duas formas de organização do trabalho: uma interna, envolvendo a própria cooperativa e seus núcleo; outra externa, reunindo as bases da Rede Cata-Sampa, para as quais a Cooperativa Fênix-Ágape funcionava como um Pólo de comercialização coletiva.

No início de 2008, a primeira experiência da Cooperativa Fênix-Ágape como Pólo de comercialização reuniu as seguintes bases: CRUFFI (Cooperativa de Reciclagem União Faz a Força de Itaquera), Jacupia (Associação e núcleo de Reciclagem Jacupia), Cooperativa Nova Esperança (Projeto Pantanal - CDHU), Magnália Dei (Associação e núcleo de reciclagem em processo de reestruturação). Consta em Anexo (ANEXO 18) os Relatos sobre cada uma das bases. 


\section{De "empreendedores pés-descalços" à "Casa do Fazer": a Responsabilidade Social Empresarial chega à Cooperativa Fênix-Ágape}

Quando a Cooperativa Fênix-Ágape se consolida, os núcleos permanecem como uma rede de locais de convergência dos resíduos, os quais são encaminhados para triagem, prensagem, enfardamento e venda na Cooperativa. Este conjunto de atividades, por sua vez, conta com o trabalho dos próprios integrantes dos núcleos.

Por outro lado, a atividade produtiva que se instaura no interior do espaço que originalmente era da Associação Resgate Total vai aos poucos tomando o tempo e o espaço da prática comunitária. Mas a mudança do caráter predominantemente social para predominantemente econômico não acontece como uma ruptura imediata. Ao longo dos anos de realização da pesquisa (2004 a 2008), o incremento constante do conjunto de atividades da reciclagem foi acompanhado por uma série de ações inscritas numa esfera social. Mas conforme a Cooperativa vai se estruturando, resta cada vez menos tempo para "outros projetos", até o ponto em que Cooperativa e Associação se separam. Primeiro, no plano das idéias. Depois no próprio espaço. As salas do antigo prédio da Associação são transformadas em espaços destinados ao funcionamento da Cooperativa: vestiário, refeitório, escritório.

Ao mesmo tempo, outra edificação construída no mesmo terreno (uma obra não concluída na qual funcionaria um centro de referência para as mulheres), torna-se o elemento central do retorno futuro da existência da Associação Resgate Total. Se esta perde lugar frente ao tempo cronometrado no espaço instrumentalizado para as atividades da reciclagem, o edifício abandonado passa a representar seu lugar. Enquanto isso, os "projetos sociais" que foram desenvolvidos no decurso da formação da Cooperativa, caracterizam-se como complemento da retirada (pagamento) dos cooperados: Operação Trabalho (Projeto da Secretaria Municipal do Trabalho); venda de picolés (Projeto de Responsabilidade Social da Nestlé); feitio de bolas de garrafas PET (Projeto social do Condomínio do Conjunto Nacional, da Av. Paulista); alfabetização de adultos (MOVA) onde cooperados já alfabetizados recebiam uma bolsa para ensinar aos demais; serviços de manutenção (Projeto Rexona-Ades do Instituto Ana Moser) em que dois cooperados recebiam 
pagamento para realizar vigilância noturna e serviços de manutenção na Quadra de esportes localizada próxima à Cooperativa. Por outro lado, os núcleos instalados em associações seguem conciliando as atividades de reciclagem com seus "projetos sociais", tais como distribuição de leite (Núcleo do Jd. Nélia), alfabetização de adultos (Núcleo Itajuíbe P4), capoeira (Núcleo União da Bahia), esporte para crianças (Núcleo Pequeninos do Itaim).

Fato é que, a Associação Resgate Total voltaria a existir. Não mais sob o formato das antigas associações comunitárias, mas como um Projeto de Responsabilidade Social. Isto porque, em meados de 2008, um novo parceiro aproximou-se da Cooperativa Fênix-Ágape, o Instituto Ressoar da Rede Record de televisão. Vinculado ao Programa Ressoar, transmitido pela referida emissora (Record News), o Instituto Ressoar apresenta como foco de atuação o tripé "Responsabilidade Social, Preservação do Meio Ambiente e Inclusão Social". O Instituto tem como um de seus projetos a denominada Casa do Fazer. Neste sentido, esta Organização Social procurou um "parceiro" que se enquadrasse neste tripé, e estivesse inserido na periferia. O prospecto de divulgação do Projeto e algumas fotos da inauguração do novo "empreendimento" estão reunidos no ANEXO 19. 


\section{CONCLUSÃO}

A pesquisa desenvolvida no escopo desta Tese aponta para a questão de que a indústria da reciclagem ainda está se pondo. Ou seja, ainda está em curso os termos de sua estruturação, por mais complexa que esta se apresente. Trata-se de um processo que envolve os mais diversos agentes sociais, situados nas mais diversas instâncias da sociedade: da própria iniciativa privada, do Estado e do Terceiro Setor. Mas que ainda assim não se situa no nível das grandes indústrias que configuram circuitos produtivos próprios, a exemplo das grandes companhias produtores de celulose e papel. Estas, inclusive, têm na reciclagem apenas uma reduzida participação em seus produtos.

Por outro lado, a magnitude com que esta indústria se apresenta no urbano, onde encontra os elementos de sua própria existência, revela que seu processo de estruturação tende a se consolidar como um novo setor produtivo. Portanto, além de mobilizar milhares de trabalhadores pobres urbanos, toneladas de materiais recicláveis e os territórios empobrecidos da metrópole, aponta para uma tendência de institucionalização de sua estrutura industrial, tendo na base a proposta das cooperativas.

Foi possível ainda perceber que esta indústria envolve um apelo moral, que corresponde a esta época, onde as questões ambientais ganham uma dimensão que proclama a mudança de comportamentos, inclusive do próprio setor produtivo. Estas questões, para além de uma retórica discursiva, promove novos mercados, que se apresentam como lucrativos, no que tem lugar a miríade de ONG's, as quais por sua vez, também se apresentam como constitutivas das reformas do Estado.

Para os catadores, (re)inseridos na condição de sobrantes na base desta indústria, trata-se essencialmente da realização de estratégias de sobrevivência. Pois a indústria da reciclagem vem se desenvolvendo sem que produza um trabalho específico. 


\section{BIBLIOGRAFIA}

ANTUNES, Ricardo. Os sentidos do trabalho: ensaio sobre a afirmação e a negação do trabalho. São Paulo: Boitempo, 2006. [1999]

ARANTES, Otília, Vainer, Carlos; Maricato, Ermínia (orgs.). A cidade do pensamento único: desmanchando consensos. Petrópolis, RJ: Vozes, 2000.

ARANTES, Paulo Eduardo. Esquerda e Direita no espelho das ONG's. Cadernos ABONG, $\mathrm{n}$-27, em maio de 2000.

BARELLI, Walter. És o avesso do avesso In Revista Estudos Avançados. 17 (47), São Paulo: IEA, 2003.Pp. 07-19

BONDUKI, Nabil. Depoimento. Periferia Revisitada. Revista Espaço \& Debates, ano XVII, n.42. São Paulo: Neru, 2001. Pp. $92-99$ [Entrevista]

BONDUKI, Nabil. Origens da habitação social no Brasil: arquitetura moderna, Lei do Inquilinato e difusão da casa própria. $3^{3}$ ed. São Paulo: Estação Liberdade: FAPESP, 2002. [1998].

BURGOS, Rosalina. O processo de (des)organização espacial do Itaim Paulista no contexto da metropolização da cidade de São Paulo (2ª metade do século XX). TGI, Depto. Geografia - FFLCH/USP, 2001.

BURGOS, Rosalina. Parques públicos urbanos na metrópole paulistana: concepção e uso na produção do espaço urbano. Dissertação de Mestrado, Depto. Geografia, FFLCH/USP, 2003.

CALDERONI, Sabetai. Perspectivas econômicas da reciclagem do lixo no Município de São Paulo. Tese apresentada ao Depto de Geografia - FFLCH/USP. São Paulo, 1996.

CARLOS, A. F. A reprodução da cidade como "negócio" In Urbanização e mundializacãa: estudos sobre a metrópole. São Paulo: Contexto, 2005. Pp. 29-37 CARLOS, Ana Fani; CARRERAS, Carles (orgs.). Urbanização e mundialização: estudos sobre a metrópole. São Paulo: Contexto, 2005.

CARLOS, Ana Fani; Oliveira, Ariolvaldo Umbelino de (orgs.). Geografia de São Paulo: representação e crise da metrópole. São Paulo: Contexto, 2004.

CARRIL, Lourdes de Fátima Bezerra. Quilombo, favela e periferia: a longa busca da cidadania. São Paulo: Annablume; FAPESP, 2006. [Tese Geografia/USP, 2003]

CASTELLS, Manuel. A questão urbana. Rio de Janeiro: Paz e Terra, 1983.

DAMIANI, Amélia Luísa. A geografia e a produção do espaço na metrópole - entre o público e o privado In Urbanização e mundialização: estudos sobre a metrópole. São Paulo: Contexto, 2005. Pp. 38-50

DAMIANI, Amélia Luísa. Na busca das favelas o encontro do 'peão' que permanece - as favelas de Cubatão num quadro de desenvolvimento do Centro Petroquímico-siderúrgico. Dissertação de Mestrado. Depto. Geografia, FFLCH/USP, 1984.

DAMIANI, Amélia Luísa. A crise da cidade: os termos da urbanização In CARLOS, A.F.A.; DAMIANI, Amélia L.; SEABRA, O.C.L. (orgs.). O espaço no fim de século: a nova raridade. São Paulo: Contexto, 1999.

DAMIANI, Amélia Luisa. As contradições do espaço: da lógica (formal) à (lógica) dialética, a propósito do espaço In CARLOS, A.F.A.; DAMIANI, A.L..; SEABRA, 
O.C.L. (orgs.). O espaço no fim de século: a nova raridade. São Paulo: Contexto, 1999.

DAMIANI, Amélia Luisa. Urbanização crítica e situação geográfica In CARLOS, A.F.; Oliveira, A.U. (orgs.). Geografia de São Paulo: representação e crise da metrópole. São Paulo: Contexto, 2004.

DAMIANI, Amélia Luisa. Urbanización crítica: periferias urbanas - elementos a considerar en el camino de la comprensión de la ciudad como sujeto In CARLOS, A.F.A.; CARRERAS, C. (orgs.) Barcelona y São Paulo cara a cara: procesos metropolitanos a la hora de la globalización. Barcelona: Editorial Davinci, 2006. Pp. 169-184

DAVIS, Mike. Planeta favela. São Paulo: Boitempo, 2006.

DIAS, Allan Rodrigues. Condições de vida, trajetórias e modos de "estar" e "ser" catador: estudo de trabalhadores que exercem atividade de coleta e venda de materiais recicláveis na cidade de Curitiba (PR). Dissertação apresentada ao Depto. Psicologia Social - USP, 2002.

DINIZ, Clélio Campolina. Impactos territoriais da reestruturação produtiva In Luiz Cesar de Queiroz Ribeiro (org). O futuro das metrópoles: desigualdade e governabilidade. Rio de Janeiro: Revan: FASE, 2000. Pp. 21-61

FAUSTO, Boris. Trabalho urbano e conflito social (1890 - 1920). São Paulo: Difel, 1977.

FIALHO, Marco Antônio. Para onde vai o que sobra: o destino final dos resíduos sólidos na Grande São Paulo . Dissertação. Depto. Geografia, FFLCH/USP, 1998.

FISCHER, Rosa Maria. Estado, mercado e Terceiro Setor: uma análise conceitual das parcerias intersetoriais. Revista de Administração, São Paulo, v.40, n.1, p.518, jan-mar., 2005.

GAUDEMAR, Jean-Paul. Mobilidade do trabalho e acumulação do capital. Lisboa: Editora Estampa, 1977.

GOHN, Maria da Glória. Teoria dos movimentos sociais: paradigmas clássicos e contemporâneos. $4^{a}$ ed. São Paulo: Edições Loyola, 2004. [1997]

GRESPAN, Jorge Luis da Silva. O negativo do capital: o conceito de crise na crítica de Marx à economia política. São Paulo: Hucitec : Fapesp, 1999.

GUIMARÃES, Nadya Araújo; HIRATA, Helena (orgs.). Desemprego: trajetórias, identidades, mobilizações. São Paulo: Editora Senac São Paulo, 2006.

HARVEY, David. Espaços de esperança. São Paulo: Edições Loyola, 2004. [2000] HARVEY, David. O novo imperialismo. São Paulo: Edições Loyola, 2004.

HARVEY, David. A produção capitalista da casa. São Paulo: Annablume, 2005. HARVEY, David. Los límites del capitalismo y la teoría marxista. Ciudad del México: Fondo de Cultura Económica, 1990. [1 ${ }^{a}$ edição em inglês de 1982] JACOBI, Pedro Roberto. Criação do capital social : o caso da Asmare Associação dos Catadores de Papel, Papelão e Material Reaproveitável de Belo Horizonte. São Paulo : Cedec, 1997.

JAKOBSEN, Kjeld; MARTINS, Renato; POCHMANN, Márcio; SINGER, Paul; DOMBROWSKI, Osmir. Mapa do Trabalho Informal: perfil socioeconômico dos trabalhadores informais na cidade de São Paulo. São Paulo, Fundação Perseu Abramo, 2000.

KOWARICK, L.; CAMPANÁRIO, M. São Paulo: metrópole do subdesenvolvimento industrializado. Revista Novos Estudos, n.13. São Paulo: CEBRAP, out. 1985. 
KOWARICK, Lúcio. (et all). São Paulo 1975: crescimento e pobreza. São Paulo: Edições Loyola, 1976.

KOWARICK, Lúcio. (org.). As lutas sociais e a cidade - São Paulo: passado e presente. São Paulo: Paz e Terra, 1994.

KOWARICK, Lúcio. A espoliação urbana. RJ: Paz e Terra, 1979.

KOWARICK, Lúcio. Escritos urbanos. São Paulo: Editora 34, 2000.

KOWARICK, Lúcio. Trabalho e vadiagem: a origem do trabalho livre no Brasil. São Paulo: Brasiliense, 1987.

KURZ, Robert. O colapso da modernização: da derrocada do socialismo à crise da economia mundial. Rio de Janeiro: Paz e Terra, 1992.

LANGENBUCH, Juergen Richard. A estruturação da Grande São Paulo: estudo de geografia urbana. Rio de Janeiro: IBGE, 1971.

LANGENBUCH, Juergen Richard. Depoimento. Periferia Revisitada. Revista Espaço \& Debates, ano XVII, n.42. São Paulo: Neru, 2001. Pp. 85-91 [Entrevista] Lefebvre, Henri. A revolução urbana. Belo Horizonte: Editora UFMG, 1999.

LEFEBVRE, Henri. A vida cotidiana no mundo moderno. São Paulo: Editora Ática, 1991.

LEFEBVRE, Henri. Espacio y política. El derecho a la ciudad II. Barcelona: Ediciones Península, 1976. [1972]

LEFEBVRE, Henri. La presencia Y la ausência: contribuición a la teoria de las representaciones. Ciudad del Mexico. Fondo de Cultura Económica, 1983. [1980]

LEFEBVRE, Henri. La production de l'espace. Paris: Éditions Anthropos, 1974.

LEFEBVRE, Henri. Le retour de la dialectique: 12 mots clef pour le monde moderne. Paris, Messidor/Éditions Sociales, 1986. Pp. 159-173 [Tradução: Margarida Maria de Andrade]

LEFEBVRE, Henri. Lógica formal, lógica dialética. São Paulo: Civilização Brasileira,

LEFEBVRE, Henri. O direito à cidade. $3^{\mathrm{a}}$ ed. São Paulo: Centauro, 2001.

LEFEBVRE, Henri. O pensamento marxista e a cidade. Póvoa de Varzim: Ulisseia, 1972.

LEGASPE, Luciano Rodrigues. Reciclagem: a fantasia do eco-capitalismo - um estudo sobre a reciclagem promovida no Centro da cidade de São Paulo observando a economia informal e os catadores. Dissertação apresentada ao Depto. Geografia - FFLCH/USP. São Paulo, 1996.

MAGERA, Márcio. Os empresários do lixo: um paradoxo da modernidade - análise interdisciplinar das Cooperativas de reciclagem de lixo. Campinas : Átomo, 2003.

MARICATO, Ermínia. A produção capitalista da casa (e da cidade) no Brasil industrial. São Paulo, Alfa-Omega, 1979.

MARICATO, Ermínia. Brasil, cidades: alternativas para a crise urbana. Petrópolis, RJ : Vozes, 2001.

MARICATO, Ermínia. Metrópole na periferia do capitalismo: ilegalidade, desigualdade e violência. Estudos Urbanos Série Arte e Vida Urbana. São Paulo: Editora Hucitec, 1996.

MARQUES, Ana Maura Tomesani. As políticas de limpeza urbana em São Paulo. Dissertação apresentada ao Depto. Ciência Política, FFLCH/USP, 2005.

MARQUES, Eduardo; TORRES, Haroldo. São Paulo: segregação, pobreza e desigualdades sociais. São Paulo: Editora Senac São Paulo, 2005. 
Martins 1981

MARTINS, José de Souza (org.). Henri Lefebvre e o retorno à dialética. São Paulo: Hucitec, 1996.

MARTINS, José de Souza. A sociabilidade do homem simples: cotidiano e história na modernidade anômala. São Paulo: Hucitec, 2000.

Martins, José de Souza. A sociedade vista do abismo: novos estudos sobre exclusão, pobreza e classes sociais. Petrópolis, RJ: Vozes, 2002

MARTINS, José de Souza. Depoimento. Periferia Revisitada. Revista Espaço \& Debates, ano XVII, n.42. São Paulo: Neru, 2001. Pp. 75-84 [Entrevista]

MARTINS, José de Souza. O cativeiro da terra. 8 $^{\mathrm{a}}$ ed. São Paulo: Hucitec, 2004. Martins, José de Souza. Os camponeses e a política no Brasil: as lutas sociais no campo e seu lugar no processo político. Petrópolis, RJ: Vozes,1981.

MARTINS, José de Souza. Subúrbio. Vida cotidiana e história no subúrbio da cidade de São Paulo: São Caetano, do fim do Império ao fim da República Velha. São Paulo: Hucitec, 2002.

MARX, Karl. Elementos Fundamentales para la Crítica de la Economia Política (Grundrisse) 1857-1858. México: Siglo Veintiuno, 1977, volumes 1 e 2.

MARX, Karl. O capital: crítica da Economia Política. São Paulo: Abril Cultural, 1983. Volumes 1, 2 e 3

MELO, Marcus André. Ingovernabilidade: desagregando o argumento In Valladares, L., Coelho. (org.) Governabilidade e pobreza no Brasil. Rio de Janeiro: Civilização Brasileira, 1994. Pp.23-48

MÉSZÁROS, István. O século XXI: socialismo ou barbárie. São Paulo: Boitempo, 2003.

MONTENEGRO, Marina Regitz. O circuito inferior da economia urbana na cidade de São Paulo no período da globalização. Dissertação de Mestrado sob orientação de Maria Laura Silveira. Depto. Geografia, FFLCH/USP, 2006.

MOURA, Ana Maria da Silva. Cocheiros e carroceiros: homens livres no Rio de senhores e escravos. São Paulo: Hucitec, 1988.

MUNHOZ, Christine Parmezani. A situação do trabalho das cooperativas de catadores frente à valorização econômica da reciclagem. Dissertação apresentada à FSP - FAC SAUDE PUBLICA, 2004.

NASSER, Ana Cristina Arantes. Sair para o mundo: trabalho, família e lazer na vida de excluídos. São Paulo: Hucitec, 2001.

PACCA, Penha Elizabeth. A reprodução do espaço na periferia da metrópole e a lógica da produção privada. Tese apresentada ao Depto. Geografia FFLCH/USP, 2004.

PEREIRA, Luiz Carlos Bresser; WILHEIM, Jorge; SOLA, Lourdes (orgs.). Sociedade e Estado em transformação. São Paulo: Editora Unesp; Brasília: ENAP, 1999.

PINTO, Maria Inez Machado Borges. Cotidiano e sobrevivência: a vida do trabalhador pobre na cidade de São Paulo, 1890-1914. Tese. Depto. História, FFLCH/USP, 1984.

POCHMANN, Márcio. A década dos mitos: o novo modelo econômico e a crise do trabalho no Brasil. São Paulo: 2001.

POCHMANN, Marcio. A metrópole do trabalho. São Paulo: Editora Brasiliense, 2001. 
POCHMANN, Márcio. Desenvolvimento, trabalho e solidariedade: novos caminhos para a inclusão social. São Paulo: Cortez : Editora Fundação Perseu Abramo, 2002.

POCHMANN, Márcio. O trabalho sob fogo cruzado. São Paulo: Contexto, 2002.

PRADO Júnior, Caio. A cidade de São Paulo: geografia e história. São Paulo: Brasiliense, 1998.

PRADO Júnior, Caio. História econômica do Brasil. São Paulo: Brasiliense, 2004. [1945]

RIBEIRO, Luiz César de Queiroz. O futuro das metrópoles: desigualdades e governabilidade. Rio de Janeiro: Revan: FASE, 2000.

ROBIRA, Rosa Tello. Áreas metropolitanas: espaços colonizados In CARLOS, A. F.; CARRERAS, C. (orgs.). Urbanização e mundialização: estudos sobre a metrópole. São Paulo: Contexto, 2005. Pp. 09-20

RODRIGUES, Arlete Moyses. A dinâmica ambiental e a Geografia Urbana In Vasconcellos, P.A.; Mello e Silva, S.B. (orgs.) Novos Estudos de Geografia Urbana Brasileira. Salvador: Editora da UFBA, 1999. Pp. 33-50

RODRIGUES, Arlete Moyses. Reflexões sobre a produção e consumo do e no espaço: (re)leituras do território. Conjunto da produção acadêmica apresentada ao Concurso de Livre Docência em Geografia Humana e Econômica no IFCH UNICAMP, 1996. v. 1 e 2.

RODRIGUES, J. F. M. A. Desafios para a sobrevivência de cooperativas de catadores : estudo de caso em Iracemapólis-SP. In Simpósio Internacional de Iniciação Científica da USP: ESALQ, 2004.

ROMANI, Valquíria. A Periferia Usa o Centro. FFLCH - TGI - 1993.

SANTOS, Boaventura de Souza (org.). Produzir para viver: os caminhos da produção não-capitalista. $2^{\mathrm{a}}$ ed. Rio de Janeiro: Civilização Brasileira, 2005. [2002] SANTOS, Milton. A natureza do espaço: técnica e tempo, razão e emoção. São Paulo: Edusp, 2002.

SANTOS, Milton. O espaço dividido: os dois circuitos da economia urbana dos países subdesenvolvidos. São Paulo: EDUSP, 2004. [1979]

SEABRA, Odette C. de Lima. De cidade a metrópole - vale. [Texto para Aula Magna do Programa de Pós-Graduação em Geografia Humana da UERJ. Rio de Janeiro, 07 mai, 2007] (mimeo)

SEABRA, Odette C. de Lima. Maquetinha de Nova York. [Resenha do livro de FIX, Mariana. São Paulo cidade global: fundamentos financeiros de uma miragem. São Paulo: Boitempo, 2007.] (mimeo)

SEABRA, Odette C. de Lima. São Paulo: a cidade, os bairros e a periferia In Carlos, A.F.A. e Oliveira, A.U. de (orgs.). Geografias de São Paulo: representação e crise da metrópole. São Paulo, Editora Contexto, 2004. Pp. 271-311

SEABRA, Odette C. de Lima. Territórios de uso: cotidiano e modo de vida. Cidades, Grupo de Estudos Urbanos. v.1, n.2, 2004. Pp.181-206

SEABRA, Odette C. de Lima. Urbanização e fragmentação: cotidiano e vida de bairro na metamorfose da cidade em metrópole, a partir das transformações do Bairro do Limão. Tese de Livre-Docência. Depto. Geografia, FFLCH/USP, 2003. Seabra, Odette. Questões sobre valor e uso do solo urbano. 1975 (mimeo) 
SEVCENKO, Nicolau. A corrida para o século XXI: no loop da montanha russa. São Paulo: Companha das Letras, 2007.

SEVCENKO, Nicolau. São Paulo: não temos a menor idéia. Carta Capital, set.1999. Pp. 24-34 [Entrevista]

SILVEIRA, Maria Laura. São Paulo: os dinamismos da pobreza In Carlos, A.F.A. e Oliveira, A.U. de (orgs.). Geografias de São Paulo: representação e crise da metrópole. São Paulo, Editora Contexto, 2004. Pp. 59-71

SINGER, Paul. Globalização e desemprego : diagnóstico e alternativas. São Paulo: Contexto, 2003.

SINGER. Paul. Economia política da urbanização. São Paulo: Contexto, 1998.

SMITH, Neil. Desenvolvimento Desigual: natureza, capital e a produção do espaço. RJ: Ed. Bertrand Brasil, 1988. [1984]

VALLADARES, Lícia. Cem anos pensando a pobreza (urbana) no Brasil In BOSCHI, R.R. (org.). Corporativismo e desigualdade: a construção do espaço público no Brasil. Rio de Janeiro: IUPERJ: Rio Fundo Editora, 1991. Pp. 81-112 YUNUS, Muhammand. O banqueiro dos pobres. São Paulo: Editora Ática, 2003. [1997]

\section{Principais Fontes Documentais e de Pesquisa}

- FICHAS TÉCNICAS - CEMPRE (2008). www.cempre.org.br.

- PESQUISA CICLOSOFT - CEMPRE (2008) www.cempre.org.br.

- Programa de Modernização do Setor Saneamento. Sistema Nacional de Informações sobre Saneamento: diagnóstico do manejo de resíduos sólidos urbanos 2006. - Brasília: MCIDADES.SNSA, 2008. www.cidades.gov.br

- Panorama dos Resíduos Sólidos no BRASIL. Associação Brasileira de Empresas de Limpeza Pública e Resíduos Especiais. ABRELPE, 2007.

- CONVÊNIO MDS-OAF (002/04) - "ACÕES DE DESENVOLVIMENTO SOCIAL JUNTO AOS CATADORES DE MATERIAIS RECICLÁVEIS" (2004-2006). Fonte: http://www.cgu.gov.br/sfc/convenio/convenios.asp

- ANÁlise do CUSTO DE GERAÇÃo DE POSTOS DE TRABALHO NA ECONOMIA URBANA PARA O SEGMENTO DOS CATADORES DE MATERIAIS RECICLÁVEIS. MDS/OAF/MNCR, 2006.

- RELATÓRIOS TÉCNICOS - LIMPURB/SES (2005 a 2008)

- RELATÓRIOS ANUAIS do Programa de Coleta Seletiva (Limpurb - Secretaria Municipal de Serviços), 2005 a 2008.

- RELATÓRIO sobre grupos de catadores organizados em São Paulo. Grupo de Trabalho Coleta Seletiva, 2007. (Planilhas - Cooperativa Fênix-Ágape)

- PREFEITURA DE SÃO PAULO. Estimativa do Número de Pessoas em Situação de Rua da Cidade de São Paulo. SAS/FIPE, 2003. www.desenvolvimentosocial.sp.gov.br

- PREFEITURA DE SÃo PAUlO. Pesquisa "Perfil dos carroceiros em São Paulo". SMTRAB, 2005

- PREFEITURA DE SÃO PAULO. Estudo sobre população de rua: usuários dos Albergues conveniados com a Prefeitura. SMADS/FIPE, 2006. www.prefeitura.sp.gov.br

- PROJETO Desenvolvimento de estudos e pesquisas necessários à definição, análise, implementação e avaliação de políticas de ocupação e renda para o Município de São 
Paulo (Arranjos Produtivos Locais - APL's) - Estudos e Pesquisas de Cadeias Produtivas Selecionadas. SMTRAB. FESPSP.PNUD, v.1, jan/2007.

- PROJETO de Desenvolvimento Local da Subprefeitura de Itaim Paulista. Subprefeitura de Itaim Paulista, 2006.

- PROJETO Desenho e Implantação de Projeto Piloto de Arranjos Produtivos Locais e suas oportunidades de geração de trabalho e renda na Sub-Prefeitura de Itaim Paulista. Projeto de Cooperação Técnica Internacional BRA/05/033, SMTRAB, PNUD e FESP-SP, 2006.

- Carta de Acordo n. 407-1564 (Projeto de Cooperação Técnica Internacional "Políticas de Ocupação e Desenvolvimento Humano Sustentável no Município de São Paulo, BRA/05/033", SMTRAB/PNUD/FESP-SP, 2007.

- RELAÇÃO DE PONTOS ESTRATÉGICO (com atividades de reciclagem). SUVIS, 2008.

- Classificação Nacional de Atividades Econômicas, Relação Anual de Informações Sociais - www.rais.gov.br/cnae.asp

- Classificação Brasileira de Ocupações - www.mte.gov.br

- LEI MUNICÍPAL - SP no 13.478 de 30.12.2002 - Sistema de Limpeza Urbana do Município de São Paulo (e outras providências). Fonte: Limpurb, 2006

- DECRETO MUNICIPAL - SP no 42.290 de 15.08.2002. - Programa Socio-ambiental Cooperativa de Catadores de Material Reciclável

- COMISSÃO ESPECIAL DESTINADA A DAR PARECER AO PROJETO DE LEI № 203, DE 1991- POLÍTICA NACIONAL DE RESÍDUOS SÓLIDOS e seu apensos. (inconcluso) www.camara.gov.br/proposicoes

\section{Sites de Associações}

- $\quad$ www.bracelpa.orga.br Associação Brasileira de Celulose e Papel - Bracelpa

- http://www.abipet.org.br/reciclagem.php Associação Brasileira de Embalagens www.abipet.org.br PET - AbiPet

- www.abremplast.org.br Associação Brasileira de Recicladores de Materiais Plásticos ABREMPLAST

- Associação Brasileiro de Vidros - Abividro - www.abividro.org.br

- www.abal.org.br Associação Brasileira do Alumínio - ABAL

- www.abralatas.org.br Associação Brasileira dos Fabricantes de Latas de Alta Reciclabilidade - Abralatas.

\section{Principais Periódicos}

- Diário Oficial do Município de São Paulo (janeiro de 2006 a março de 2007)

- Notícias do site da Prefeitura de São Paulo - www.prefeitura.sp.gov.br/notícias

- Notícias FIESP (mensal, desde outubro de 2004) - www.fiesp.com.br/notícias

- Boletim CEMPRE (mensal, desde 2005) - www.cempre.org.br

- Jornal do Senado. Reciclagem movimenta $R \$ 8$ bilhões mas falta lei. 23/08/2008. www.senado.gov.br/jornal 


\section{ANEXO 01 \\ Revisão conceitual: a caminho da noção de urbano periférico}

Partiu-se desta revisão teórica para se chegar à noção de urbano periférico, anteriormente apresentada, a qual foi desenvolvida no escopo desta Tese. Noção que parece corresponder melhor ao enfoque da urbanização crítica.

Neste sentido, interessa-nos a discussão sobre o processo de formação territorial da periferia urbana, suas transformações recentes, bem como a reprodução (ou não) do trabalhador pobre urbano no processo de industrialização-urbanizaçãometropolização de São Paulo.

As transformações recentes foram discutidas por diferentes perspectivas teóricas, a saber: de um lado, um enfoque que visa instrumentalizar o conhecimento acumulado sobre a urbanização pleiteando a governança urbana; enquanto, por outro lado, uma postura essencialmente crítica entende a urbanização como uma circunstância necessária da reprodução do capital em escala mundial.

Considerou-se uma literatura dedicada ao processo de formação da periferia urbana para além do âmbito da Geografia, no que se destaca a participação do campo da sociologia urbana. Isto porque desde a identificação, ou constatação, da existência da periferia, foi introduzida no conhecimento sociológico uma noção de espaço. A partir de então, tanto uma corrente da sociologia queria compreender o espaço, quanto os geógrafos, que tem no espaço-território seu objeto, viram-se na contingência de compreender processos sociais. A perspectiva marxista acabou sendo um caminho comum aos respectivos campos de conhecimento.

No âmbito da produção do conhecimento geográfico sobre a metrópole de São Paulo, no período recente da urbanização, situamos nossa fundamentação teórica sob a perspectiva do materialismo histórico, notadamente aprofundada pela Geografia Crítica (no pós anos 70). Este acúmulo de conhecimento se configura como a base para nossas incursões na realidade tão complexa da metrópole atual' ${ }^{1}$. Portanto, este é o lugar a partir do qual se buscou desenvolver a tese, bem como formular a crítica às questões que importam ao desvendamento dos problemas aqui enfrentados.

Assim, em relação ao processo de formação da periferia urbana recuperou-se algumas contribuições produzidas no âmbito dos estudos urbanos, numa perspectiva crítica, sobretudo nas décadas de 70 e 80 . Deste período, destaca-se o campo da sociologia urbana, mas também da arquitetura e da própria geografia. No que diz respeito às periferias urbanas, consolidou-se a compreensão de que seu processo de formação se caracterizou por um padrão de crescimento periférico (Kowarick, 1979; entre outros). As noções de subúrbio, periferia, loteamento periférico, e outros termos derivados, estiveram presentes no pensamento de pesquisadores do tema, tais como José de Souza Martins, Juergen Lungenbuch e Nabil Bonduki, dentre muitos outros. A edição de $n^{\circ} 42$ da Revista ESPAÇO \& DEBATES, sob o título de Periferia revisitada, reúne justamente estes três autores, cujos Depoimentos são aqui analisados e discutidos.

Sobre as transformações recentes da metrópole de São Paulo, buscou-se contribuições que permitissem a comparação de diferentes perspectivas teóricas. São analisados alguns estudos de dois centros de estudos das metrópoles (IPPU/UERJ e CEM/Cebrap) e, por outro lado, contribuições recentes no âmbito da Geografia Urbana (Depto. Geografia da FFLCH/USP).

\footnotetext{
${ }^{1}$ É o que representam os livros que reúnem as apresentações do Seminário São Paulo 450 anos, do Depto. Geografia da USP, (2004).
} 
As publicações dos centos de estudos das metrópoles de alguma forma se propõem a "atualizar" a literatura considerada como clássica em sociologia urbana (anos 70-80). Por sua vez, esta atualização apresenta-se já sob a influência recente das reformas do Estado, da ampliação da atuação do Terceiro Setor, e portanto, muito próxima das idéias atreladas à "gestão da pobreza urbana".

É necessário compreender a gênese e o desenvolvimento da metrópole de São Paulo, para neste movimento reconhecer na formação das periferias urbanas o "processo de periferização da população trabalhadora". Esta formação espacial corresponde a determinados conteúdos históricos do processo de urbanizaçãofragmentação que configura a metrópole. Neste sentido, as contribuições de Seabra ${ }^{2}$ tiveram lugar central na tese, oferendo, ademais, um modo de pensar e de fazer pesquisa ${ }^{3}$. O período recente da urbanização se traduz na fragmentação dos conteúdos da metrópole e é neste contexto que a pesquisa se inscreve. Mais especificamente, a pesquisa lida com a negatividade desta urbanização, sendo de fundamental importância as contribuições de Damiani (2004), acerca da "urbanização crítica". Neste sentido, a análise está centrada nos territórios empobrecidos da metrópole, situados seja na periferia distante (ou na periferia propriamente dita) ou nas áreas centrais deterioradas (ou ainda nos interstícios do tecido urbano concentrado e estendido), naquilo que são enquanto "espaços do viver" dos trabalhadores pobres e miseráveis da metrópole. São territórios em presença, ou sob domínio, do urbano periférico, no qual sobrevive o trabalhador que sobra dos mais diversos setores, absorvido em processos de trabalho existentes no "circuito inferior da economia urbana" que se vincula, direta ou indiretamente, ao "circuito superior". Sobre este aspecto, temos como base as contribuições de Silveira (2004).

Apresentamos algumas contribuiç̃̃es (reflexões, comentários) sobre as obras consideradas, as quais estão em texto sublinhado.

\section{Periferia revisitada: subúrbio, periferia, periferias}

Em 2001, a Revista Espaço \& Debates dedicou sua edição de número 42 ao resgate da problemática da periferia. Em seu Editorial assinala-se que o tema das periferias urbanas, um dos focos privilegiados na pesquisa e no debate acadêmico no Brasil durante as décadas de 70 e 80 , foi relegado ao plano secundário nos anos 90 , 0 que justifica o conjunto de artigos e depoimentos que integram a referida edição que tem como título Periferia revisitada 4 . Aqui nos deteremos aos Depoimentos [Entrevistas] de três pesquisadores que, por diferentes caminhos, há décadas mantém ligações com o tema: José de Souza Martins, Juergen Langenbuch e Nabil Bonduki, os quais discutem a gênese e a utilização dos conceitos de periferia, subúrbio e correlatos, na sociologia, na geografia e na prática urbanística (p.5).

Propomos trazer, para o escopo desta pesquisa, as idéias apresentadas pelos respectivos autores, buscando elementos que fundamentem nossa reflexão sobre as periferias urbanas no período recente da urbanização.

\footnotetext{
${ }^{2}$ Sobretudo em sua pesquisa de Livre Docência. Seabra, Odette C. de Lima. Urbanização e fragmentação: cotidiano e vida de bairro na metamorfose da cidade em metrópole, a partir das transformações do Bairro do Limão. Depto. Geografia, FFLCH/USP, 2003.

${ }^{3} \dot{E}$ tudo, apenas, uma maneira de trabalhar. Seabra (2007). Frase que encerra o texto De cidade à metrópole - vale, Aula Magna proferida por Odette Seabra no Programa de Pós Graduação em Geografia da UERJ, 07/05/07.

${ }^{4}$ Periferia revisitada. ESPAÇO \& DEBATES - Revista de Estudos Regionais e Urbanos. Ano XVII, n.42, São Paulo: NERU, 2001.
} 
José de Souza Martins, em seu depoimento, discorre sobre a noção de subúrbio que, por sua vez, contribui para o entendimento de outra noção, a de periferia ${ }^{5}$, distintas em termos históricos (no tempo e no espaço) e teoricamente, embora muitas vezes sejam confundidas indevidamente. Em ambos os planos (histórico e teórico) a noção de subúrbio precede a de periferia, tendo sido utilizada em relação ao entorno da cidade de São Paulo durante dois séculos (Martins, 2001:75).

A primeira referência que o autor faz ao termo periferia é em relação ao subúrbio, mais precisamente do "subúrbio de ar puro" da região da estação de Taipas, perto do Jaraguá, existente na década de 50 e que hoje está transformado em periferia deteriorada. Aqui, subúrbio e periferia também estão em relação. Uma relação de deterioração do "mundo suburbano" no decurso da formação da periferia que desde sua gênese já surge como escombros da urbanização.

Se, num primeiro momento, na relação "subúrbio-cidade" podemos encontrar complementaridade mesmo na oposição, na relação "subúrbio-periferia" os termos se apresentam como contrários. Neste sentido, o subúrbio é a negação da periferia. Subúrbio e periferias são dois espaços diferentes, com problemas distintos: o problema da periferia é o problema do tumulto da ocupação, o da urbanização patológica, da exclusão, da falta de efetivas alternativas de inserção no mundo urbano. (...)o próprio centro da cidade de São Paulo é hoje periferia. (Martins, 2001:79)

Para concluirmos, apresentamos uma última citação que interessa diretamente aos objetivos de nossa pesquisa: as vicissitudes da periferia revelam (...) uma grave diferenciação da classe operária que no subúrbio vai desaparecendo. $A$ do trabalhador sujeito a longos períodos de desemprego, de falta de alternativas, de reais limitações à ascensão social, de desagregação da família, algo que os operários do subúrbio não conheceram nos bons tempos de seu reinado. (Martins, 2001:84)

Em seu Depoimento sobre o tema da periferia, Juergen Richard Langenbuch observa que diversos termos têm sido utilizados, no linguajar leigo e naquele empregado por geógrafos, para se referir às formas de implantação urbana incipiente, entrecortada de trechos ainda rurais, que surgem nas bordas das cidades (Langenbuch, 2001:85), tais como: subúrbio e derivados (suburbano, suburbanização, em francês banlieue); periferia e derivados (periférico, periferização); periurbano (geralmente como adjetivo); franja urbana; rurbano (geralmente como adjetivo). O autor discorre sobre os mesmos, destacando os termos subúrbio, periurbano e periferia. Vejamos sobre estes dois últimos:

Sobre o termo periurbano (ou franja urbana), Langenbuch $(2001: 88$ ) cita a definição de Pierre Laborde (1994:169) no contexto francês: o 'peri-urbain' se localiza adiante da periferia de uma cidade e de sua zona suburbana; situa-se nas franjas do espaço urbanizado e com freqüência além dos limites das zonas cobertas por regulamentos de urbanismo. (...) Trata-se com freqüência do subúrbio de recreação graças a suas florestas, seus planos d'água e das margens dos ribeirões, que atraem os citadinos.(...)

E o próprio Langenbuch (2001:89) continua: o interesse por essa porção do espaço circundante às cidades, no que se refere à proliferação desordenada $e$ pulverizada da expansão urbana em detrimento da atividade agrícola e do meio ambiente rural, tal como presente em países como França e Estados Unidos, ainda é muito precário, ou inexistente, no Brasil.

\footnotetext{
${ }^{5}$ Depoimento que tem como base duas obras do autor: Subúrbio - vida cotidiana e história no subúrbio da cidade de São Paulo: São Caetano, do fim do Império ao fim da República Velha, de 1992 e A sociabilidade do homem simples - cotidiano e história na modernidade anômala, de 2000.
} 
Bonduki inicia seu Depoimento fazendo referência ao trabalho Periferias ${ }^{6}: 0$ próprio nome periferias, e não periferia, trabalha com a idéia de que existem os investimentos na periferia. Estávamos nos distanciando da idéia da periferia como um lugar homogêneo, um lugar que tem apenas carências, ruma a uma percepção de que as periferias são locais em transformação, que apresentam estágios diferenciados em função dos investimentos que vão sendo realizados pelo Estado e pela própria população, investimentos que têm haver com políticas - mais e menos populistas, mais e menos clientelistas: a periferia que tem água, asfalto, transporte; a periferia que tem água, mas não tem asfalto; a periferia que só tem transporte, que muitas vezes é o primeiro equipamento que chega (Bonduki: 2001, 92). (...) Em 1977, quando começamos o trabalho Periferias, o conceito de periferia estava muito ligado ao do loteamento periférico, tanto que o nosso objeto de pesquisa, nossa unidade, era o loteamento.(...) Achávamos que a cidade estava crescendo através de loteamentos que se formam, que deixam vazios, idéia muito presente naquela época. (...) Nosso trabalho pretendia mostrar que o modelo econômico que foi implantado no regime militar gerava uma precarização das condições de vida da população [a espoliação urbana, segundo Kowarick, 1979]. (...) Logo em seguida, desenvolvemos a idéia do trinômio sobre o qual se baseia a expansão da cidade: loteamento periférico, casa própria e auto-construção. (...) $O$ trabalho 'Periferias' questionava a idéia de periferia como um local geográfico, a franja periurbana. Loteamento para nós era loteamento precário, sem infra-estrutura. (Bonduki: 2001, 93) (...) no limite, a periferia poderia estar no centro, na precariedade habitacional dos cortiços. Mas, ao mesmo tempo, a idéia de periferia estava também muito ligada à idéia dos loteamentos periféricos. (Bonduki, 2001:94)

O autor também relata a pesquisa histórica (...) "Origens da habitação social no Brasil" [inicializado como mestrado em 1980 e concluído como doutorado em 1997], tendo com um de seus objetivos resgatar o processo de formação do padrão periférico e as estratégias da autoconstrução nos anos 40 e 50 em São Paulo (...) da formação da periferia mediada pelas políticas públicas (Bonduki, 2001:92). (...) Dos anos 40 aos anos 70 , o padrão periférico foi o elemento fundamental de expansão da cidade (...). A lógica do padrão periférico é a lógica da extensão ilimitada da cidade: loteamentos muito baratos, para onde vai a população que precisa da terra, como bucha de canhão (...). Nos anos 80, isso começou a não funcionar mais. Milhares de pessoas não conseguiam mais comprar um lote, porque a terra ficou cara (...) e houve a crise econômica, ocasionando despejos, um forte arrocho salarial e o aumento do desemprego. (Bonduki: 2001, 93-94). Sobre a situação atual da periferia, Bonduki (2001:96-98) nos diz: hoje, quando falamos em periferia, as várias situações se misturam. A favela de periferia se junta com o loteamento de periferia, que é uma situação que estava nascendo nos anos 70 . Tem também o processo de adensamento da periferia, que precisa se melhor estudada (...). E temos, nos anos 90, as ocupações de mananciais e da serra, muitas vezes promovidas pelas próprias associações [responsáveis pelos loteamentos]. Isso ainda dentro daquele padrão tradicional de expansão periférica. (...) Por uma série de razões físicas e econômicas da cidade, as possibilidades que as periferias dos anos 50 tiveram de se transformar em bairros não existem mais para as periferias dos anos 80.(...) Apesar de muitas vezes não ter asfalto ou esgoto, a periferia já nasce com condições melhores de infra-estrutura. Mas, mesmo assim, ela não vai chegar a ser um lugar bom, ao contrário da periferia dos anos 50 e 60, na grande maioria transformada hoje em bairros bastante razoáveis do ponto de vista da urbanização. (...) Mas e agora? Quando toda a periferia tiver água, luz, asfalto, esgoto - e estamos nos encaminhando para isso - então, vai acabar a periferia? Eu acho que não. Por causa do elemento social. (...) As ruas podem

\footnotetext{
${ }^{6}$ Pesquisa de iniciação científica desenvolvido junto com Raquel Rolnik, em 1977-78, ainda como estudante da FAU-USP, sob orientação de Lúcio Kowarick.
} 
ser asfaltadas, o esgoto pode estar lá, mas aquela sensação de carência continua.(...) Outra questão é a econômica, a de salário, e a de não ter trabalho, tudo isso culminando na questão da violência. (...) Os conjuntos da Cohab, por exemplo (...) são parte da cidade formal, foram feitas por empreiteiras, tiveram um projeto. Aquilo é periferia? Claro! (...) Novamente, retorna aquela pergunta: então, será que cortiço é periferia? Cada vez mais isso se coloca.

\section{Ainda o subúrbio e a periferia}

Autores como Juergen Langenbuch e José de Souza Martins raciocinam com base na noção de subúrbio, noção que entre americanos e ingleses corresponde ao que não está na urbs. Por sua vez, o fenômeno da concentração urbana foi considerado entre os franceses como aglomeração urbana, chegando nas grandes aglomerações. Já a Geografia aplicada nos Estados Unidos reconheceu no fenômeno urbano a metrópole porque hierarquizava o sistema urbano, sendo que a metrópole seria o desenvolvimento mais alto da hierarquia, como se depreende dos estudos de Brian Berry. Alguns franceses (como Perroux e Boudeville) raciocinaram sobre os pólos de crescimento, com vistas ao desenvolvimento econômico e social. Seus estudos foram difundidos pelo mundo ${ }^{7}$.

Acontece que entre nós, à distinção urbs - suburbs, que estava muito mais sob um enfoque do espaço (urbs, o que é e está dentro; suburbs, o que não é e está fora), se sobrepôs um raciocínio sócio-econômico que classificava um certo número de países em países do centro e países periféricos; transportadas estas noções para raciocinar as desigualdades regionais no interior de um país, logo foram identificados os centros e as periferias.

Esta mudança de enfoque conceitual ocorreu sob influência do que se discutia na América Latina (CEPAL) sobre o desenvolvimento e a concentração espacial da riqueza e das decisões, de modo que o mundo tinha um centro e uma periferia. Isto que os historiadores já haviam discutido como pacto colonial, sobre a base da relação metrópole-colônia.

De uma noção de espaço mais ou menos bem delimitada de cidade $\mathrm{e}$ subúrbio, desembocamos no centro e na periferia. O centro compreendido como o lugar do acúmulo histórico; lugar de nascimento das instituições da cidade. A periferia o outro, aquele que não é a cidade.

A noção de subúrbio ficou anacrônica em relação à periferização produzida na modernidade. Quando o sistema ferroviário ligava o espaço da cidade com seu entorno estávamos diante do subúrbio. Ao contrário, quando o exército de trabalhadores se desloca (domicílio-trabalho) por um extenso espaço relativamente homogêneo, funcional à reprodução social, temos então a periferia.

\section{Gestão da pobreza urbana e governança participativa: centros de estudos das metrópoles}

Analisamos duas coletâneas de textos: o livro $O$ futuro das metrópoles: desigualdades e governabilidade ${ }^{8}$, de 2000 , no qual boa parte dos autores é vinculada ao Observatório das Metrópoles (IPPUR/UERJ); e o livro São Paulo: segregação, pobreza e

\footnotetext{
${ }_{7}^{7}$ Seabra, Odette. Questões sobre valor e uso do solo urbano. 1975 (mimeo)

${ }^{8}$ Ribeiro, Luiz César de Queiroz. O futuro das metrópoles: desigualdades e governabilidade. Rio de Janeiro: Revan: FASE, 2000.
} 
desigualdades sociais ${ }^{9}$, de 2005, onde todos os autores são vinculados ao CEM/CEBRAP. No primeiro caso, o livro O futuro das metrópoles: desigualdades e governabilidade, de 2000, refere-se sobretudo às transformações ocorridas nas metrópoles brasileiras nos anos 70 e 80, com considerações acerca das tendências nos anos 90. Já o livro São Paulo: segregação, pobreza e desigualdades sociais, de 2005, debruça-se sobretudo nos dados do início do ano 2000 (Censo IBGE, e derivados), atualizando, de certa forma, o debate inicializado na obra anteriormente citada. Será tratado com mais profundidade o segundo livro, que reúne estudos sobre a metrópole de São Paulo.

EM algumas observações acerca dos procedimentos metodológicos adotados nos estudos que compõem os referidos livros, em $O$ futuro das metrópoles: desigualdades e governabilidade, do Observatório das metrópoles, a fonte principal dos dados corresponde aos levantamentos do IBGE (censos demográficos, industrial, contagem populacional, etc.) além de outras fontes menos freqüentes como RAIS, IPEA, planos regionais e setoriais, etc. Quanto às técnicas de tratamento dos dados, encontramos desde o uso de diversos tipos de tabulações, apresentados em tabelas e gráficos, estudos que empregam a análise fatorial por correspondência, algumas representações cartográficas, sendo ainda incipiente o tratamento dos dados com Sistemas de Informações Geográficas (SIGs).

Por outro lado, o uso de SIGs aparece como central nas pesquisas apresentadas no livro São Paulo: segregação, pobreza e desigualdades sociais, do CEM. Procedimentos metodológicos em que os dados do censo do IBGE, ano 2000, são processados por SIGs tem sido cada vez mais comuns. Os softwares para processamento dos dados (tais como Maptitude, Maplnfo, Arc Info e Arc View, entre outros), vêm sendo aperfeiçoados gradativamente em termos de acessibilidade e interatividade com seus usuários, o que facilita seu manejo e disseminação de seu uso. A maior novidade parece estar na possibilidade de análise e interpretação dos dados do Censo IBGE 2000, espacializados em unidades territoriais mais detalhadas, o que permite apreender a heterogeneidade do território, o que tem sido interpretado como fenômeno recente na metrópole de São Paulo, e das metrópoles que passaram por processo de formação similar, afastando-se de determinados aspectos da teoria das global cities, no que se refere à dualização e polarização da estrutura socioespacial. Assim, as representações cartográficas têm apresentado os setores censitários e áreas de ponderação como menores unidades espaciais de análise, o que permite maior detalhamento das informações referentes ao fenômeno e território estudado.

Portanto, se por um lado o território da metrópole apresenta maior complexidade e heterogeneidade espacial - o que corresponde aos condicionantes do processo de urbanização no período recente, por outro lado, a referida heterogeneidade passou a ser "vista" e considerada não só pelas evidências empíricas e dados tabulados, mas adquiriu visibilidade com a representação espacial possibilitada pelos SIGs, redefinindo em certa medida o modo de fazer pesquisa e de conceber e executar políticas públicas. É de fato um avanço inegável em comparação àquelas análises que tinham como menor unidade espacial os distritos municipais como é o caso do Mapa da inclusão/exclusão social, de Aldaíza Sposati, entre tantos outros. Porém, a ênfase que vem sendo dada ao procedimento metodológico de uso dos SIGs, que permite, antes de tudo, uma série de análises descritivas sobre a heterogeneidade do território, estaria sendo acompanhada por análises teóricas tão ricas quanto aquelas consolidadas em períodos anteriores? $\mathrm{E}$, mais do que isto, que promovam 0 entendimento das

\footnotetext{
${ }^{9}$ Marques, Eduardo; Torres, Haroldo. São Paulo: segregação, pobreza e desigualdades sociais. São Paulo: Editora Senac São Paulo, 2005.
} 
transformações profundas da sociedade e dos rumos da urbanização neste início de século XXI?

Pensamos que as contribuições teóricas dos anos 70 e 80 , sob a perspectiva do materialismo histórico, não só continuam sendo válidas como podem mais profundamente explicar a situação de transformação pela qual passa a realidade urbana hoje. Ou seja, se naqueles estudos a periferia urbana foi entendida como um território muito homogêneo e de extrema pobreza, pensamos que tal interpretação não seja resultante de um enquadramento a "uma análise macrossociológica", mas da compreensão de uma forma urbana (padrão de crescimento periférico) que corresponde aos conteúdos históricos concretos daquele período do processo de urbanização.

A heterogeneidade do espacco urbano é relativa porque se trata efetivamente de desigualdades fundamentais, oriundas do mundo do trabalho que correspondem à inserção social dos sujeitos (indivíduos, famílias, grupos). Estas desigualdades fundamentais resultam na possibilidade de apreender um espaco diferencial eqüivalendo à "diferença na desigualdade". Do ponto de vista formal, a diferença na desigualdade aparece como heterogeneidade e cria a possibilidade de operacionalizar o espaço ao nível da superfície, ou seja, em detrimento dos conteúdos correspondentes. Assim, a referida noção de heterogeneidade das periferias urbanas - e do território metropolitano como um todo - analisada e explicada com os recursos técnicos, tais como os SIGs (Sistemas de Informacões Geográficas) tem sido intensamente utilizados pelos centros de estudos das metrópoles.

\section{Centro de Estudos da Metrópole}

$\mathrm{Na}$ introdução do livro São Paulo: segregação, pobreza e desigualdades sociais, os autores relembram o livro São Paulo, 1975: crescimento e pobreza, organizado pelo Cebrap [estudo realizado a pedido da Pontifícia Comissão de Justiça e Paz da Arquidiocese de São Paulo], uma das obras pioneiras a dedicar um olhar sociológico às chamadas periferias urbanas, áreas em permanente expansão que constituíam vastas porções urbanas cada vez mais distantes dos serviços e empregos geralmente localizados nos centros metropolitanos. Naqueles espaços, as condições de vida eram muito precárias e nelas imperava uma baixíssima presença do Estado. E hoje, o que pode ser dito a respeito desse cenário? Os autores observam que apesar da maior disponibilidade de informações sobre a realidade urbana de São Paulo, e de técnicas de análises precisas e empiricamente embasadas, têm sido raros os trabalhos que tentam retomar este debate. Frente a isto, os autores propõem analisar a dinâmica social da cidade de São Paulo, com especial atenção para os temas da segregação residencial, da pobreza urbana e das desigualdades sociais, dialogando com teorias sobre a metrópole produzidas nas últimas três décadas. (Marques e Torres, 2005:9)

Em relação às análises em torno da interpretação crítica à teoria da marginalidade sobre o trabalho urbano e associadas à sociologia urbana marxista francesa, as desigualdades socioespaciais eram entendidas como reflexo territorial das grandes desigualdades produzidas no mercado de trabalho, geradas por um tipo de capitalismo periférico e dependente. A categoria analítica central era o trabalho (e em especial o trabalho informal), e os mecanismos que produziam o espaço metropolitano levavam à homogeneidade territorial da pobreza, caracterizando assim uma grande e precária periferia. (Marques e Torres, 2005:10).

Em comparação a estes estudos anteriores, o livro São Paulo: segregação, pobreza e desigualdades sociais pretende, em primeiro lugar, descrever as múltiplas formas de pobreza urbana, de ocupação do espaço urbano, indicadores de acesso a políticas públicas e resultados em termos de condições de vida. Em segundo lugar, 
pretende entender como opera a dinâmica de segregação residencial definida como 0 grau de separação ou isolamento residencial entre diferentes grupos sociais. . (Marques e Torres, 2005:12-13)

Heterogeneidade dos territórios da pobreza: esta é a novidade inquietante das transformacõos urbanas recentes das pesquisas aqui consideradas - captadas pelos novos recursos de pesquisa empírica ${ }^{10}$, ainda que a estrutura geral da metrópole continue a ser caracterizada pela existência de inúmeros espaços homogêneos social e espacialmente separados entre si, configurando uma intensa segregação entre áreas ricas e pobres. (Marques e Torres, 2005:10-11)

Não só a pobreza, mas agora o próprio território, ou o espaço [tão intrínsecos à Geografial devem ser incorporados nas políticas, para que as mesmas atinjam verdadeiramente seus públicos-alvo. ${ }^{11}$ Assim, os autores entendem que o território parece ser uma dimensão constitutiva da situação social em que se encontram os diversos grupos sociais na cidade, em especial entre os mais pobres. Isso significa, por exemplo, que indivíduos e famílias igualmente pobres e escolarizados têm condições e características diferentes dependendo de onde morem. Porém, já observamos que desde o reconhecimento da existência da periferia, o conhecimento sociológico lida com uma nocãa de espaço, portanto não se trata de uma situação nova. De um modo geral, a obra propõe atualizar a perspectiva crítica e marxista dos estudos urbanos, definindo-a enquanto uma literatura tradicional, a ser revista. Mas o que oferecem como novo? Parecem de fato direcionados às políticas públicas que prevêem a participacãa do Terceiro Setor como parte constitutiva das reformas do Estado, no qual se situam as propostas de oportunidades de "inclusão social com geração de trabalho e renda" para os pobres da metrópole. Ou em outras palavras, a "gestão da pobreza", no contexto da governança urbana.

\section{Geografias de São Paulo}

Por ocasião do momento histórico de comemoração dos 450 anos da cidade de São Paulo, bem como dos 70 anos da institucionalização da Geografia e a fundação da Universidade de São Paulo (ambas em 1934), o Departamento de Geografia da FFLCH/USP realizou, no ano de 2004, o Seminário São Paulo 450 anos: "As Geografias da Metrópole". Por ocasião deste evento, foram publicados os livros Geografias de São Paulo: representação e crise da metrópole (v.1) e Geografia de São Paulo: a metrópole do século XXI (v.2), ambos de 2004, juntamente com o livro "Geografias das Metrópoles"12, de 2006, e constituem uma obra que expõe e discute a complexidade da metrópole de São Paulo, traduzida pelas múltiplas possibilidades de entendimento sobre a metrópole (Carlos e Oliveira, 2004a:12).

Do livro Geografias de São Paulo: representação e crise da metrópole, selecionamos os seguintes artigos: a) "Urbanização crítica e situação geográfica a partir da metrópole de São Paulo", de Amélia Luisa Damiani; b) "São Paulo: os dinamismos da pobreza", de Maria Laura Silveira; e c) "São Paulo: as cidades, os bairros e a periferia", de Odette Seabra.

\footnotetext{
${ }^{10} \mathrm{O}$ uso dos Sistemas de Informações Geográficas - SIG, destaca-se como inovador nos procedimentos metodológicos destas pesquisas.

${ }_{11}$ Grifos nossos. Expressão utilizada em Parcerias Público-Privadas.

12 CARLOS, Ana Fani; Oliveira, Ariolvaldo Umbelino de (orgs.). Geografia de São Paulo: representação e crise da metrópole. São Paulo: Contexto, 2004.
} 
Começamos com o artigo de DAMIANI ${ }^{13}$, no qual a "urbanização crítica" é a idéia central. Esta nos parece igualmente central para aprofundarmos aquilo que, na noa pesquisa, propomos compreender e explicar a partir da análise de certos aspectos das periferias urbanas de São Paulo, imbricados às transformações recentes da urbanização da metrópole, no contexto mais amplo das políticas neo-liberais pós anos 70, no que se destaca a reestruturação produtiva, e as transformações no mundo do trabalho.

Seu artigo apresenta a urbanização crítica como um instrumento ao exame do sentido histórico do capitalismo, além de nos oferecer uma contribuição no sentido da crítica à economia política da cidade. Neste sentido, nos ajuda naquilo que estamos investigando do conjunto de atividades inscritas na estruturação da indústria da reciclagem, que absorvem os catadores de materiais recicláveis na base desta nova indústria, presente sobretudo no urbano periférico.

Outro aspecto convergente com nossas investigações está no " trabalho do negativo", precipitado pela economia urbana instaurada. Este é o objetivo primordial no enfoque trazido pela discussão da "urbanização crítica". Assim, contribui com a discussão da relação centro-periferia, a partir do qual a temática da pobreza urbana vêm sendo reposta. Observamos, como contraponto, como a referida temática tem sido tratada pelos centros de estudos subsidiários de políticas urbanas, e pelas instituições do Terceiro Setor que "atuam", preferencialmente, nas periferias urbanas ou onde se encontrem os atributos da pobreza. Neste caso, o reconhecimento de que a pobreza urbana seja iminentemente espacial, ou territorial, interessa justamente porque abre novas frentes para projetos e investimentos. Por fim, a noção de "situação geográfica", ganha força neste debate, porque referencia as transformações "do entorno".

A metrópole atual é fragmentada, porém entranhada de continuidades que revelam, e por vezes restabelecem, o modelo centro-periferia. Portanto temos, em princípio, que considerar a "situação geográfica" dos territórios em presença do "urbano periférico", os quais apresentam os mesmos atributos de pobreza urbana tanto na centralidade da metrópole como nas periferias, sem suprimir a diferenciação espacial. Temos, portanto, de lidar com duas dimensões: a relação espacial centro-periferia e a condição social de pobreza urbana, referida à atividade do catador tanto no centro quanto na periferia propriamente ditos.

No decurso dos estudos que a autora vem realizando desde seu mestrado ${ }^{14}$ (do que resulta dois artigos do livro $O$ espaço no fim de século ${ }^{15}$ ), a análise do proletariado ligado à indústria da construção pesada e civil, bem como seu significado nas grandes cidades, deu-lhe a certeza da presença dissimulada deste trabalho num processo de industrialização que propõe a presença da indústria (sobretudo a da construção civil e seu aparato), pois como admitir a inserção precária desse trabalhador-morador no âmbito da capitalização generalizada? (Damiani, 2004:27-28) Trata-se do trabalho como puramente negativo. (...) É quando o trabalho não chega a constituir sua positividade: como atividade, como fonte viva do valor, possibilidade universal da riqueza como

13 DAMIANI, A. L. Urbanização crítica e situação geográfica In CARLOS, A.F.; Oliveira, A.U. (orgs.). Geografia de São Paulo. São Paulo: Contexto, 2004. Pp. 19-58

14 Damiani, A.L. Na busca das favelas o encontro do 'peão' que permanece - as favelas de Cubatão num quadro de desenvolvimento do Centro Petroquímico-siderúrgico. Dissertação de Mestrado. Depto. Geografia, FFLCH/USP, 1984.

${ }^{15} \mathrm{~A}$ autora se refere aos artigos "As contradições do espaço: da lógica (formal) à (lógica) dialética, a propósito do espaço" e "A crise da cidade: os termos da urbanização" In CARLOS, A.F.A.; DAMIANI, A.L..; SEABRA, O.C.L. (ORG). O espaço no fim de século: a nova raridade. São Paulo: Contexto, 1999. 
sujeito $^{16}$. Trata-se da acumulação primitiva, sempre renovada, da qual não deriva necessariamente o trabalho como atividade produtiva. No decurso mesmo do desenvolvimento das forças produtivas (no que pese toda a movimentação social e política em torno dos movimentos sociais urbanos e partidos políticos de esquerda, caracterizando uma identidade proletária, ainda que combatida, na década de 70), 0 processo de diferenciação industrial (...) significa expulsão compulsória ${ }^{17}$. (...) Atualmente, um processo simultâneo de desemprego e de degradação dos salários e das condições e direitos do trabalho. (Damiani, 2004:29-30) É a partir deste ponto que a autora passa a expor sua idéia de urbanização crítica, segundo a qual não há o urbano para todos. O que requer uma análise da urbanização para além de seu entendimento com base nas várias temporalidades do capital, ainda que no plano da economia urbana os pobres sobrevivam de relações dentro do circuito inferior (Milton Santos), sobretudo os serviços e comércio nas áreas periféricas. (Damiani, 2004:30)

Há para nós, nisto que acabamos de apresentar, algo de muito importante. Em primeiro lugar, a convergência entre 0 entendimento proposto pela idéia da urbanização crítica (Damiani) e aquele dos dois circuitos da economia urbana, mais especificamente ao que está circunscrito ao circuito inferior (Milton Santos). No centro desta convergência estão as áreas periféricas, ou melhor, as periferias urbanas em toda sua criticidade. Periferias urbanas, intencionalmente no plural, informando da necessidade de superação dos limites de uma noção centro-periferia, com seu forte sentido geométrico. A partir disto, propomos a nocão de urbano periférico, cujo sentido deve estar situado em relação à metrópole fragmentada (poli-nucleada, heterogênea, corporativa e desmedidamente estendida). Pensar na noção de urbano periférico nos interessa enquanto contribuição ao entendimento da urbanização crítica, já pressuposta e fundamentada na concretude do que se realiza como negatividade desta urbanização: 0 trabalho como miséria absoluta (Damiani, 2004:28), como já citado anteriormente.

A conclusão é sobre um "mundo de totalidade fragmentada" no qual se busca recuperar, pela admissão e superação do niilismo, uma noção de totalidade, ou de totalização, quando um fragmento se realiza como o todo.

A reflexão voltada às formas de produção habitacional em grande massa e as políticas de regulamentação dos modos de vida nesses lugares nos levam a pensar, por outro lado, "nas grandes periferias" produzidas sob o padrão de crescimento periférico, onde os "mecanismos disciplinares de controle" não são tão explícitos, mas por isso mesmo mais perversos. O confinamento, a segregação, enfim, "o deixar morrer", mais do que "o fazer viver" parece ir vencendo nas periferias urbanas sob a urbanização crítica.

Trata-se de uma urbanização crítica porque imbricada a uma economia que gera excedentes de trabalhadores potenciais e empobrecimento crescente, porque a sua lógica interna é esta: a redução do trabalho produtivo; a redução dos salários; a crise como barreira interna do processo. (Damiani, 2004: 39) Uma crise interna (...) própria da definição do 'capital como sujeito'.

SEABRA ${ }^{18}$, em seu artigo São Paulo: a cidade, os bairros e a periferia, inicia seu artigo partindo de um momento importante das "metamorfoses da cidade com seus bairros": quando, nos anos 50, a cidade de São Paulo, integrada por uma coroa de bairros, foi ficando imersa num processo de implosão-explosão para as periferias. A partir

\footnotetext{
${ }^{16}$ Com base em Karl Marx, Elementos fundamentales para la crítica de la economia política (Grundrisse), 1977, p.236.

${ }^{17}$ Inclusive com legitimação jurídica. A autora faz referência à lei no 6,019, de 1974, regulamentada pelo decreto $\mathrm{n}^{0}$ 73.841, instituindo o trabalho temporário, expressão da exploração 'extraordinária' do trabalho no Brasil. (Damiani, 1984:115).

${ }^{18}$ SEABRA, O.C.L São Paulo: a cidade, os bairros e a periferia In Geografias de São Paulo, 2004. Pp. 271311
} 
deste ponto, formou-se uma extensão de urbanização contínua com novas experiências de espaço e de tempo para seus moradores. (Seabra, 2004:271) Este importante capítulo da geografia e da história urbana situa-se na seqüência temporal das formas urbanas (cidade-bairros-subúrbios-metrópole-periferias)". Tal seqüência corresponde a deslocamentos necessários, relativos à aceleração das formas de uso do tempo e sem, necessariamente, apagar os traços do que veio antes. (Seabra, 2004:271) A idéia principal da autora é de que a morfologia social do espaço urbano traduz tanto tendências lógicas e sistêmicas da reprodução da sociedade como a ação consciente dos agentes que se movem no urbano a procura de negócios, de trabalho ou de lugar, implicando em confronto de interesses no cerne da territorialização das práticas. Tal entendimento está na base da idéia de que o suposto caos da metrópole foi sendo constituído no confronto de interesses, segundo a lógica dos atores urbanos. (Seabra, 2004:272)

Nesta região urbana, a autora aponta certas tendências de expansão, preliminarmente no próprio Município de São Paulo, identificadas em duas unidades de espaço: a) uma área correspondente à cidade com seus velhos bairros, com perda de população, aumento de favelas e ocupações clandestinas, com diferenciação interna acentuada, tendo aí se concentrado os investimentos em infra-estrutura material e básica da cidade, durante um século; b) a periferia urbana de São Paulo: com crescimento populacional positivo, estendendo-se para além dos velhos núcleos, com mobilidade recente para os extremos norte-sul (Serra da Cantareira e região das represas, respectivamente). A partir desta dupla e combinada constatação, a autora considera a hipótese de que os bairros estruturados em simbiose com a cidade permitiram inclusões produtivas (o conjunto dos trabalhadores), o que põe a diferença naquilo que constituiu as exclusões absolutas, resultantes da aceleração expressa nas formas de uso do tempo, já no contexto da metrópole. (Seabra, 2004:273)

A metrópole de São Paulo submetida a um complexo movimento de massas em todas as direções e com uma estrutura material de enorme complexidade, sem fronteiras ou limites; essa densidade do urbano, que se estende por todos os lados, põe para a autora a questão: qual pensamento é possível sobre os bairros de São Paulo neste "tecido" de urbanização proliferado nos últimos 50 ou 60 anos? Ou seja, essa enorme estrutura de urbanização contém as virtualidades e as negatividades do processo de urbanização brasileira. (Seabra, 2004:273-274) Do conjunto de problemas implicados, a autora indica a correspondência entre a estrutura global - domínio do capital financeiro internacional, à fragmentação dos conteúdos sociais com as novas frentes de valorização: destaque dado à memória e à história como "matérias-primas" da mercantilização da cultura implicada nas políticas de revitalização das áreas centrais. (Seabra, 2004:275) Para Seabra (2004:277), parece mesmo que nunca foram tão evidentes as contradições entre a lógica que homogeneíza as formas de emprego do tempo e aquela que valoriza a particularidade. De acordo com Seabra (2004:277), na relação cidade-bairros (...) os bairros eram, cada um deles, a parte que confirmava o todo. $\mathrm{Na}$ pesquisa ora desenvolvida, cabe refletir sobre a urbanização recente, na qual a metrópole, enquanto totalidade socioespacial, integra a periferia urbana. E como tal, a metrópole só pode ser compreendida considerando-a como sua negatividade. Daí os termos em distinção, postos em relação, um implicando o outro (afirmando-negando): periferia-metrópole. A periferia urbana, no cerne da metamorfose da cidade em metrópole, é a divergência, 0 alhures, a reprodução da segregação socioespacial: a negatividade do urbano. Assim, 0 processo de periferização integra, negativamente, aquele da metropolização. Contudo, as periferias urbanas são próprias da metrópole (...) A periferização já estava lá como latência e mesmo como realidade desde pelo menos os anos 40 , posto que já haviam loteamentos populares, nos quais os trabalhadores começaram fazer suas próprias casas. Resta saber se na metrópole fragmentada, os conteúdos sociais da periferia, enquanto 
fragmento, podem nos informar sobre a totalidade da metrópole, mesmo partindo daquilo que nela é a mais completa negatividade. Tarefa árdua pois após os anos 80, mal se distinguem as partes do todo na justaposição de formas desconexas que caracterizam a morfologia da metrópole. A separação da cidade com seus bairros tinha ainda algum vestígio ao final dos anos 50, mas já as obras viárias (difusão do automóvel), e o processo de periferização da população trabalhadora ganhavam força e começariam ser os estruturadores do espaço da metrópole. (Seabra, 2004: 278) Nas circunstâncias de uma urbanização avassaladora, estes bairros tornaram-se não mais do que fragmentos da metrópole. (...) A história urbana acumulou nestes lugares resíduos de outros tempos: os escombros da urbanização (Seabra, 2004: 279). Relativo a isto, parece evidente que as periferias urbanas no processo de periferização da população trabalhadora já é originalmente produzida como escombro, e não cessou de ser reproduzida como escombro, no decurso dos últimos 50 ou 60 anos.

Ainda segundo Seabra (2004:280), a estruturação genética do espaço urbano metropolitano, na metamorfose das formas (...) em correlação ao desenvolvimento desta formação social (cidade-bairro-subúrbio, periferia-metrópole) acumulam, necessariamente "o velho e o novo" O que está na base da idéia principal que move [seu] raciocínio: (...) a forma urbana corresponde a conteúdos sociais concretos. Neste sentido teve lugar uma problemática própria que é a desta Cidade com seus bairros num embate que daria lugar à metrópole (...) [n]um processo avassalador que subssumia a estrutura física e normativa da cidade, ao mesmo tempo em que a periferização da população progredia. (Seabra, 2004: 281) Industrialização e urbanização formavam um único processo (...) no contexto que era da sociedade do trabalho em curso. Mas no período atual da urbanização que pensar de uma sociedade do trabalho que desemprega sem poder liberar o tempo daquele que não é imediatamente produtivo? (Seabra, 2004: 281282) Esta parece ser uma pergunta que recai sobre a situação de vida e de trabalho, ou melhor, de sobrevivência dos catadores de materiais recicláveis.

SILVEIRA ${ }^{19}$, por sua vez, analisa a crise da cidade, investigando as condições de vida da classe trabalhadora. Neste sentido, seu artigo encontra lugar central em nossas reflexões sobre o trabalho dos catadores de materiais recicláveis. A assertiva da necessidade das análises enfocarem o desenvolvimento do "circuito inferior" ou "superior marginal" da economia urbana (segundo a concepção presente na obra de Milton Santos), no contexto que detém as condições de produção na metrópole, também contribui pois, no caso das cadeias produtivas da reciclagem, as relacõos entre os "dois circuitos da economia urbana" (superior e inferior) não só caracterizam sua estrutura, como dão coesão à relação capital-trabalho, plasmada, e de certa forma dissimulada, pelos elos intermediários (comerciais) que as compõem.

Algumas passagens de seu artigo tencionam justamente a contradição de que São Paulo comporta o que há de mais moderno e mais arcaico da divisão do trabalho: suas funções mais modernas, aquelas que norteiam sua inserção na atual divisão internacional do trabalho hegemônica, não podem ser confundidas com a cidade, ela própria. (...) sendo então necessário considerar a coexistência de divisões territoriais do trabalho. (...) Paralelamente [à economia hegemônica] há outros mercados, definidos por uma produção e uma circulação dos pobres, cujos limites se confundem com a área de ocorrência do fenômeno metropolitano. Identificar economia urbana e setor moderno significa esquecer que, na grande cidade, mesmo quem não é moderno encontra o seu lugar. (Silveira, 2004:60). A autora destaca que o trabalho informal, que não se confunde

\footnotetext{
${ }^{19}$ SILVEIRA, Maria Laura. São Paulo: os dinamismos da pobreza In Carlos, A.F.A. e Oliveira, A.U. de (orgs.). Geografias de São Paulo: representação e crise da metrópole. São Paulo, Editora Contexto, 2004. Pp. 59-71
} 
exatamente com o circuito inferior da economia ${ }^{20}$, está presente em São Paulo desde sempre. Ademais, a autora lembra que São Paulo cresce não apenas pela concentração de riqueza mas, sobretudo, de pobreza.. No processo de crescimento do espaço urbano da metrópole, (...) a expansão do seu meio construído se acelera, as valorizações e desvalorizações dos pedaços da cidade são frenéticas, ensejando a possibilidade de instalação, aqui ou ali, de atividades menos capazes de dar valor as produtos. É o reino do circuito inferior (Santos, 1975) e, também, de um variado circuito marginal em áreas de grande circulação como o Largo Treze, o Largo de Pinheiros e o próprio centro antigo da Cidade (Silveira, 2004:62-63). Este "aqui ou ali", onde se instauram as atividades com pouca capacidade de produzir valor, parece corresponder aos territórios onde os catadores realizam os processos de trabalho situados na base das cadeias produtivas da indústria da reciclagem.

\footnotetext{
20 "Tantas vezes associado, incorretamente, ao famoso setor informal, o circuito inferior é criador de trabalho, mesmo que muitas vezes não possa ser chamado de emprego. (...) É o trabalho intensivo (sem horários, sem benefícios, sem pausas pré-estabelecidas) o que define o circuito inferior (...) e não o cumprimentodescumprimento de um sistema normativo em vigência." Silveira (2004:68)
} 


\section{ANEXO 02 \\ Revisão Conceitual: o trabalhador pobre urbano na metrópole de São Paulo}

\section{O trabalhador pobre na gênese e desenvolvimento da cidade de São Paulo}

A Tese de doutorado de Maria Inez Machado Borges Pinto, Cotidiano e sobrevivência: a vida do trabalhador pobre na cidade de São Paulo (1890-1914) ${ }^{21}$, discute a presença do trabalhador pobre urbano no processo de urbanização da cidade de São Paulo. Desta obra, destacamos, entre outras contribuições, a apresentação sobre o diversificado quadro da economia informal em São Paulo do início do século XX, e nele o negociante ambulante de ferros-velhos, que parece apresentar correspondência com certos comerciantes do ramo de sucatas do período atual. Por outro lado, observamos que a origem remota do atual trabalhador que se põe à atividade da catação - o catador de materiais recicláveis, não tenha correspondência com o referido comerciante, mas sim em relação aos denominados "trabalhadores pobres", constitutivos de uma "gente pobre" que já no início do século se caracterizava como "homens disponíveis e dedicados a carregar fardos, sendo que o estado de penúria profunda, a pobreza comum, generalizada, eram os critérios para a identificação desses profissionais" (Pinto,1984:137;144). Ainda assim, devemos ressaltar que nossa análise sobre o catador não o interpreta como "profissional", nem como "autônomo", mas como força de trabalho profundamente explorada, antes consumida do que reproduzida, no contexto recente.

Observemos o Quadro apresentado pela autora:

QUADRO Crescimento da população de São Paulo, 1872-1940

\begin{tabular}{|r|r|r|r|}
\hline \multicolumn{1}{|l|}{ ANO } & POPULAÇÃO & Taxa de crescimento (\%) & Acréscimo anual (\%) \\
\hline 1872 & 31.385 & - & - \\
\hline 1890 & 64.934 & 107 & 4,1 \\
\hline 1900 & 239.820 & 269 & 14,0 \\
\hline 1920 & 579.033 & 141 & 4,5 \\
\hline 1940 & 1.326 .261 & 129 & 4,2 \\
\hline
\end{tabular}

Fonte: Pinto,1984. p.03

Consideremos que o pós anos 50 marca, efetivamente, o desencadeamento do processo de formação da metrópole, num contexto histórico nacional com o advento do predomínio do urbano sobre o rural. Porém, já na passagem do século XIX para o XX podemos encontrar, no âmbito da formação do mercado de trabalho livre para as fazendas de café, o desenvolvimento concomitante do mercado de trabalho urbano. Importa destacar que sua gênese leva a marca do "sub-emprego, e o desemprego temporário" (Pinto,1984:13). Este antecede e se desenvolve, inclusive, para além e nos interstícios da estruturação do operariado industrial, nos quadros da consolidação do emprego formal em massa, no decurso da industrialização. A autora cita a procura por "tarefas urbanas", ou "atividades urbanas", por parte dos colonos em fuga das fazendas cafeeiras para as cidades ${ }^{22}$.

Neste contexto, a autora observa o papel fortalecido da estrutura familiar no enfrentamento das adversidades do desemprego (Pinto,1984:22). A autora adverte que, a

\footnotetext{
${ }^{21}$ Maria Inez Machado Borges Pinto. Cotidiano e sobrevivência: a vida do trabalhador pobre na cidade de São Paulo (1890-1914). Tese apresentada ao Depto. História, FFLCH/USP, 1984.

${ }^{22}$ Isto apesar do intenso controle que fizeram da Hospedaria dos Imigrantes, agência de colocação, uma espécie de prisão, da qual o colono só saia mediante um contrato de trabalho para os cafezais (Pinto, 1984:14)
} 
expansão das atividades produtivas na metrópole paulistana, a despeito da profunda diversificação da sua estrutura ocupacional, não foi suficiente para empregar a massa de trabalhadores estrangeiros, trazidos pela grande imigração, que se acumulou na cidade e, muito menos ainda, os migrantes rurais produzidos pelos sucessivos deslocamentos de colonos do campo para a área urbana.(...) (Pinto,1984:32)

A autora relata que muitos prosperaram a custa de trabalho de madrugada a madrugada; outros porém, sob falência e dívidas foram levados ao suicídio (111-113). Ainda neste quadro, o colapso e a decadência das indústrias estáveis eram sempre seguidos pela expansão do comércio casual, pelo aumento crescente do número de comerciantes ambulantes de quinquilarias (Pinto,1984:115).

$\mathrm{Na}$ descrição feita pela autora acerca destes comerciantes ambulantes, a carroça é o principal instrumento de trabalho para o transporte dos diversos tipos de produtos ou para prestação de serviços: flagrantes do grande fluxo de vendedores ambulantes de alimentos e produtos mais pesados, deslocando-se ao longo dos itinerários habituais, mostram sempre a enorme utilidade das rústicas carrocinhas de madeira, dos mais variados tipos, empregadas como meio de transporte das mercadorias a serem comercializadas. (Pinto,1984:118) (...) A autora descreve com beleza de detalhes o perfil de cada um destes comerciantes ambulantes: padeiros, verdureiros, fruteiros, tripeiros, peixeiros, vendedores de gelo, carvoeiros ou lenheiro, entre outros. Destacamos de seus relatos, o registro da prática da "troca em espécie" na ausência de dinheiro na relação comercial estabelecida entre vendedores $e$ trabalhadores pobres. Outra observação importante é que a atividade ambulante encontra-se imbricada à impossibilidade da posse, para estes pequenos comerciantes pobres, de um estabelecimento comercial: dadas as dificuldades econômicas de seus membros em arcar com os custos de montar uma simples oficina própria, um número considerável de ofícios passa a ser exercido por trabalhadores ambulantes (Pinto,1984:134).

Interessa-nos aqui, de modo especial, um relato acerca do "comércio de compra e venda de ferros-velhos exercido basicamente por imigrantes espanhóis e seus descendentes": havia ainda muitos trabalhadores pobres, dentre os quais destacavam-se os espanhóis, que viviam da compra e venda dos resíduos aproveitáveis do consumo industrial. Estes ambulantes compravam, a baixíssimos preços, entulhos reaproveitáveis da economia doméstica, tais como: garrafas, sacos vazios, latas, materiais descartáveis que contivessem chumbo, metal, cobre e ferro-velho. Apesar de pagar um preço insignificante por estas mercadorias, muitas das quais nem compravam, porque recebiam gratuitamente das senhoras abastadas e que gozavam da fama de generosidade, estes ambulantes prestavam um bom serviço às donas-de-casa, retirando de suas despensas entulhos de pouco valor econômico e sem nenhuma finalidade. (Pinto,1984:136)

Por último, queremos destacar o relato sobre o trabalho daqueles que, para fugir do desemprego crônico, ex-operários juntavam-se à multidão de trabalhadores sem especialização, casuais, que desde a madrugada se agrupavam em torno da zona cerealista central de São Paulo, ponto de contratação de carregadores avulsos (Pinto,1984:141). Neste relato, aparece a prática da catação das sobras mutiladas de alimentos (...) um dos motivos que atraíam de imediato e provisoriamente, desempregados famintos, sem qualquer recurso de sobrevivência momentâneo, para este tipo de serviço. (Pinto,1984:142) (...) Na verdade, o grande contingente de homens disponíveis e dedicados a carregar fardos, era composto por uma massa heterogênea de mulatos, brancos e imigrantes paupérrimos, procedentes de várias nacionalidades (...), e o estado de profunda penúria, a pobreza comum, generalizada, eram os critérios para a identificação destes profissionais. (Pinto,1984:144-145) 


\section{Pobreza urbana e trabalhador pobre urbano: uma periodização}

Lícia Valladares, em Cem anos pensando a pobreza (urbana) no Brasil, artigo publicado em $1991^{23}$, propõe discorrer sobre a mudança constatada na maneira de conceber e definir a pobreza e seus sujeitos ao longo da constituição do país enquanto nação moderna e urbana, analisando a evolução das categorias 'pobreza' e 'pobre', as noções que elas exprimem, seus sinônimos, suas associações e oposições verbais no contexto das mudanças econômicas e sociais que vêm marcando a sociedade urbana brasileira. A partir da leitura de diferentes discursos sobre a pobreza (sanitarista, jurídico, político, econômico), Valladares (1991:82) identifica três períodos históricos em que vigorou uma forma distinta de conceber a pobreza e o pobre urbano.

Valladares (1991:81) propõe discorrer sobre a mudança constatada na maneira de conceber e definir a pobreza e seus sujeitos ao longo da constituição do país enquanto nação moderna e urbana (...) [analisando] a evolução das categorias 'pobreza' e 'pobre', as noções que elas exprimem, seus sinônimos, suas associações e oposições verbais no contexto das mudanças econômicas e sociais que vêm marcando a sociedade urbana brasileira. A partir da leitura de diferentes discursos sobre a pobreza (sanitarista, jurídico, político, econômico), Valladares (1991:82) identifica três períodos históricos em que vigorou uma forma distinta de conceber a pobreza e o pobre urbano:

a) virada do século, quando se assiste à transição do país para uma ordem capitalista e quando, malgrado uma urbanização embrionária, começa a se constituir um mercado de trabalho industrial e urbano (sobretudo no Rio de Janeiro e em São Paulo) baseado numa mão-de-obra livre, formada de imigrantes e ex-escravos;

b) as décadas de 50 e 60, quando o processo de urbanização já generalizado, fruto do modelo de desenvolvimento capitalista adotado, comporta um mercado de trabalho urbano agora ampliado, definido como dual e visto como marginalizando amplos segmentos da população das grandes cidades;

c) as décadas de 70 e 80, quando após um pequeno período de apogeu de desenvolvimento entra em crise, fazendo-se acompanhar de uma progressiva expansão da chamada economia informal, que se desenvolve em paralelo a um processo de concentração de renda e propagação da pobreza, ocorrendo sobretudo nas regiões metropolitanas.

A noção de pobre, na virada do século XIX para o XX estava estritamente vinculada ao não-trabalho, era o não assalariado. A autora remete-se à expressão classes perigosas que se referia basicamente àqueles que eram criminosos, delinqüentes ou simplesmente vagabundos e desordeiros que viviam entre o cortiço e a rua, tentando impor a desordem. Já em meados do século XX, é a noção de subemprego, e da renda (salário mínimo), que determina a definição da pobreza enquanto fenômeno de insuficiência de renda. Neste período, o país se encaminhava para uma sociedade urbano-industrial, no qual os principais centros urbanos, como São Paulo, Rio de Janeiro, e também Belo Horizonte, Salvador, Recife, Fortaleza e Curitiba, experimentam um processo de 'inchação', integrando um quadro que a literatura dos anos 60 denominou de superurbanização ou 'urbanização sociopática' (Pereira, 1965).

No período posterior aos anos 70 , os trabalhadores pobres passaram a ser analisados enquanto integrados à divisão do trabalho, inseridos sobretudo no setor informal. Mesmo porque, a partir deste período, em paralelo à fase do "milagre econômico", aumenta a contradição entre acumulação capitalista e miséria, resultando num quadro de desigualdades sociais aprofundado.

\footnotetext{
${ }^{23}$ VALLADARES, Lícia. Cem anos pensando a pobreza (urbana) no Brasil In BOSCHI, R.R. (org.). Corporativismo e desigualdade: a construção do espaço público no Brasil. Rio de Janeiro: IUPERJ: Rio Fundo Editora, 1991. Pp. 81-112
} 
Será nos centros urbanos, com destaque ao eixo Rio-São Paulo, que os efeitos deste processo se manifestarão com toda intensidade, sobretudo na "explosão" das periferias urbanas, e no desenvolvimento do setor informal, que passa a incorporar o termo "trabalhador" para designar os desempregados nele inseridos. O pobre urbano, até então associado majoritariamente à figura do favelado, recai agora sobre o "morador da periferia".

\section{Uma noção ampliada de classe trabalhadora}

Ricardo Antunes em Os sentidos do trabalho: ensaio sobre a afirmação e a negação do trabalho, publicado em $1999^{24}$, discorre sobre a necessidade de uma noção ampliada de classe trabalhadora, considerando a imbricação entre trabalho produtivo e improdutivo, além contribuir com o entendimento sobre o setor informal. De forma sintética podemos dizer que este autor faz uma interpretação distinta daquelas que afirmam a existência de uma crise do trabalho anunciadora do fim do trabalho.

Neste livro, Antunes busca dar concretude à tese da centralidade da categoria trabalho na formação societal contemporânea, frente ao que denomina de desconstrução teórica realizada nos anos recentes. Para tanto, o autor explora o que denomina de novas formas de interpenetração existentes entre as atividades (produtivas e improdutivas, fabris e de serviços, laborativas e de concepção, entre produção e conhecimento científico). Antunes identifica profundas mutações no interior do mundo do trabalho, e situa sua posição de que não se trata do "fim do trabalho", mas do próprio capital.

Para Antunes (2006:28-32) os primeiros sinais da crise do capital foram equivocadamente interpretados como crise do fordismo ${ }^{25}$ e do keynesianismo, os quais deveriam ser entendidos como "expressão fenomênica de uma crise estrutural do capital". Em outros termos, o neoliberalismo e a reestruturação produtiva devem ser entendidos como expressões privilegiadas da referida crise. (Antunes, 2006:29-32) Admitida a crise estrutural do capital, Antunes (2006:36) discorre acerca da reestruturação produtiva enquanto resposta dada pelo capital à sua própria crise, cujas repercussões se fizeram sentir no processo de trabalho: (...) Foi exatamente nesse contexto que se iniciou uma mutação no interior do padrão de acumulação (e não no modo de produção), visando alternativas que conferissem maior dinamismo ao processo produtivo, que então dava claros sinais de esgotamento. Gestou-se a transição do padrão taylorista e fordista anterior para as novas formas de acumulação flexibilizada.

Neste contexto de mudanças no processo produtivo, Antunes propõe o que denomina de "uma noção ampliada de classe trabalhadora", presente na expressão "classe-que-vive-do-trabalho", cujo principal objetivo é validar o conceito marxiano de classe trabalhadora na contemporaneidade. Na defesa desta noção contemporânea ampliada de classe trabalhadora, Antunes, num primeiro momento, enfatiza a centralidade do trabalhado produtivo no interior da classe trabalhadora (pois produz diretamente mais-

\footnotetext{
${ }^{24}$ ANTUNES, Ricardo. Os sentidos do trabalho: ensaio sobre a afirmação e a negação do trabalho. São Paulo: Boitempo, 2006. [1999]

25 (...) O quadro crítico, a partir dos anos 70 , expresso (...) como crise do padrão de acumulação taylorista/fordista, já era expressão de uma crise estrutural do capital que se estendeu até os dias atuais e fez com que, entre tantas outras conseqüências, o capital implementasse um vastíssimo processo de reestruturação, visando recuperar do seu ciclo reprodutivo e, ao mesmo tempo, repor seu projeto de dominação societal, abalado pela confrontação e conflitualidade do trabalho (...). 0 capital deflagrou, então, várias transformações no próprio processo produtivo, por meio da constituição das formas de acumulação flexível,(...) onde se destaca especialmente o "toyotismo" ou o modelo japonês. (Antunes, 2006:47)
} 
valia e participa diretamente da valorização do capital), mas lembrando que tal classe incorpora a totalidade do trabalho social, do trabalho coletivo assalariado. Assim, partindo da premissa de que todo trabalhador produtivo é assalariado, mas que nem todo trabalhador assalariado é produtivo, esta "noção contemporânea" de classe trabalhadora deverá abranger todos os trabalhadores assalariados, uma vez que no capitalismo contemporâneo ocorre uma imbricação crescente entre trabalho produtivo e improdutivo ${ }^{26}$. (Antunes, 2006:102) Para manter a distinção entre o proletariado propriamente dito e a noção contemporânea ampliada de "classe-que-vive-do-trabalho", o autor adota o termo "proletariado industrial" para os trabalhadores diretamente produtores de mais-valia, e a noção de classe trabalhadora ou classe-que-vive-do-trabalho para englobar tanto o proletariado industrial, como o conjunto dos assalariados que vendem a sua força de trabalho (e, naturalmente, os que estão desempregados, pela vigência da lógica destrutiva do capital) (Antunes, 2006:103)

Ainda que a ênfase dada por Antunes (2006:134) na imbricação entre trabalho produtivo e improdutivo na composição da classe trabalhadora na atualidade pareça querer dar conta, primordialmente, da participação crescente do trabalho improdutivo no capitalismo contemporâneo, ou seja, das atividades de serviços, de concepção e da ciência - já entendidos como inter-relacionados com as atividades produtivas, interessanos que tal noção ampliada também incorpora o proletariado precarizado, o subproletariado moderno ${ }^{27}$ e sobretudo os trabalhadores assalariados da chamada economia informal ${ }^{28}$, que muitas vezes são indiretamente subordinados ao capital, além dos trabalhadores desempregados, expulsos do processo produtivo e do mercado de trabalho pela reestruturação do capital e que hipertrofiam o exército industrial de reserva, na fase de expansão do desemprego estrutural. (Antunes, 2006:103-104) Para finalizar, vejamos alguns dados apresentados pelo autor a este respeito: (...) segundo dados da OIT, hoje mais de 1 bilhão de homens e mulheres que trabalham estão ou precarizados, subempregados - os trabalhadores que o capital usa como se fosse uma seringa descartável, ou encontram-se desempregados.(...) Essa tendência tem se acentuado, em função da vigência do caráter destrutivo da lógica do capital, muito mais visível nos últimos 20, 30 anos. (...)O ABC paulista tinha cerca de 240 mil operários metalúrgicos em 80, hoje tem pouco mais de 110, 120 mil. No mesmo período, Campinas tinha 70 mil metalúrgicos, hoje tem 37 mil operários estáveis. Vocês se lembram de que no passado uma fábrica, como a Volkswagen, dizia que era importante porque tinha mais de 40 mil operários. Hoje tem menos de 20 mi, produzindo, entretanto, muito mais. Isso quer dizer

\footnotetext{
${ }^{26}$ São aqueles em que, segundo Marx, o trabalho é consumido como valor de uso e não como trabalho que cria valor de troca. O trabalho improdutivo abrange um amplo leque de assalariados, desde aqueles inseridos no setor de serviços, bancos, comércio, turismo, serviços públicos etc., até aqueles que realizam atividades nas fábricas mas não criam diretamente valor. Constituem-se em geral num segmento assalariado em expansão no capitalismo contemporâneo - os trabalhadores em serviços -, ainda que algumas de suas parcelas encontrem-se em retração. (Antunes, 2006:103)

${ }^{27}$ Os trabalhadores no final do século XX incorporam, também (...) em escala mundial (...), o proletariado precarizado, o que eu chamei no meu livro "Adeus ao trabalho?" de o subproletariado moderno, fabril e de serviços, que é part time, que é caracterizado pelo trabalho temporário, pelo trabalho precarizado (...). (Antunes, 2006:199)

${ }_{28}$ Nota do Autor. Penso aqui basicamente nos trabalhadores assalariados, sem carteira de trabalho, em enorme expansão no capitalismo contemporâneo, e também nos trabalhadores individuais por conta própria, que prestam serviços de reparação, limpeza, etc., Novamente, a chave analítica para a definição de classe trabalhadora é dada pelo assalariamento e pela venda da sua própria força de trabalho.(...) a expressão que procura captar e englobar a totalidade dos assalariados que vivem da venda de sua força de trabalho. (Antunes, 2006:103)
} 
que hoje é sinônimo de "proeza e vitalidade" do capital citar uma fábrica que produz muito com cada vez menos operários (Antunes, 2006:200)

\section{O trabalho informal}

Paul Singer e Márcio Pochmann, em Mapa do trabalho informal: perfil socioeconômico dos trabalhadores informais na cidade de São Paulo, de 200129, procedem ao que denominam "a mensuração do trabalho informal", numa análise sobre o referido setor na cidade de São Paulo. A fundamentação teórica mobilizada pelos autores tem como base o materialismo histórico.

Logo na Introdução do livro, os autores procedem ao que denominam "a mensuração do trabalho informal", definindo como trabalhador autônomo ou por conta própria: pessoa que explora seu próprio negócio ou ofício e presta seus serviços diretamente ao consumidor ou para determinada(s) empresa(s) ou pessoa(s). Subdividese em "autônomo para empresa" e "autônomo para o público". Interessa-nos a primeira subdivisão.

Ora, o fato do denominado "autônomo para empresa" não ter jornada de trabalho prefixada contratualmente pode significar o prolongamento exacerbado do mesmo, procedimento que aprofunda a exploração do trabalho pelo capital, resultando no aumento da mais-valia por parte da "empresa" ou "pessoa" que nesta relação personifica o capital. Por outro lado, o fato do denominado "autônomo para empresa" não se encontrar sob controle direto da empresa não significa que o mesmo tenha "liberdade para organizar seu próprio trabalho", uma vez que tanto o prolongamento da jornada de trabalho quanto a intensificação da produtividade - sobretudo no caso de "pagamento por peça", ou "por produção", geralmente são determinantes para garantir a sobrevivência do referido "autônomo".

Apontando algumas características do trabalho informal, com base na análise de dados extraídos da Pesquisa de Emprego e Desemprego (PED), da Pesquisa de Condições de Vida (PCV), ambas de 1998, bem como as informações obtidas com os Estudos de Caso, os autores afirmam que a pesquisa mostrou que os trabalhadores informais têm um lugar na cadeia produtiva, seja atuando no escoamento de produtos de todo tipo, realizado pelos vendedores ambulantes e de ponto fixo, seja na apropriação e na reciclagem dos restos advindos da produção, por meio de catadores (...) ou ainda na prestação de serviços diversos para o público ou para empresas. Isto não significa, porém, que esta inserção seja importante na geração de renda. Pelo contrário, ela é extremamente precária e, além de não garantir o acesso aos direitos sociais e trabalhistas básicos, para a maioria ela se caracteriza por uma renda muito baixa. (Jakobsen, $\mathrm{K}$. ett alli, 2001:9)

Paul Singer (2001), define o trabalho informal que, segundo ele, corresponde à categoria marxista de "segmento estagnado da população excedente" inscrito no exército industrial ativo e não no exército industrial de reserva. Além destas categorias referentes à população relativamente excedente, ou superpopulação relativa, citadas por Singer, encontramos na seqüência desta mesma seção de O Capital (Abril Cultural, São Paulo, 1984, p.208-209) a denominada "esfera do pauperismo": finalmente, o mais profundo sedimento da superpopulação relativa habita a esfera do pauperismo. Abstraindo vagabundos, delinqüentes, prostitutas, em suma, o lumpemproletariado propriamente dito, essa camada social consiste em três categorias. Primeiro, os aptos

\footnotetext{
29 "Os estudos que compõem este livro se baseiam em critérios internacionais de definição do setor informal. Para medir o trabalho informal, a Organização Internacional do Trabalho (OIT) toma a unidade econômica como ponto de partida. Tal unidade é caracterizada pela produção em pequena escala, pelo baixo nível de organização e pela quase inexistente separação entre capital e trabalho". (Jakobsen, K. ett alli, 2001:7-8)
} 
para o trabalho. (...) sua massa se expande a cada crise e decresce a toda retomada dos negócios. Segundo, órfãos e crianças indigentes. (...) Terceiro, degradados, maltrapilhos, incapacitados para o trabalho. São notadamente indivíduos que sucumbem devido a sua imobilidade, causada pela divisão do trabalho, cujo número cresce com a maquinaria perigosa, minas, fábricas químicas, etc. (...) O pauperismo constitui o asilo para inválidos do exército ativo de trabalhadores e o peso morto do exército industrial de reserva.

Singer (2001:12) não cita a "esfera do pauperismo" descrita por Marx, mas continua seu artigo argumentando justamente sobre a necessidade da retirada do "trabalho informal" (associado à parte estagnada da superpopulação que integra o exército ativo de trabalho) da pobreza. E a estratégia a ser adotada é o modelo das cooperativas: para resgatar o trabalho informal da pobreza é necessário organizá-lo. Mas a forma de organização não pode ser o sindicato clássico, porque os trabalhadores informais não têm emprego regular, não são explorados por empresas em termos permanentes $^{30}$, sendo antes vítima da espoliação de intermediários (...). Uma forma que se mostrou eficaz é a cooperativa, à qual pertence parte dos catadores de material reciclável. (...)

Márcio Pochmann (2001), por sua vez, propõe-se a analisar as formas de manifestação do excedente estrutural de mão-de-obra no município de São Paulo, identificando como formas adicionais do referido excedente o desemprego crescente, a expansão de diversas atividades de sobrevivência e a produção renovada de ocupações precárias. O autor reconhece que este excedente de mão-de-obra resultou da formação de um segmento significativo da população que deixou de ser incorporada pela dinâmica macroeconômica, mesmo quando o país alcançou a fase de expansão de suas forças produtivas, ocorrida durante as décadas de 1940 e 1970. Porém, ao analisar as duas últimas décadas do século XX, o autor identifica um novo cenário em relação à produção e reprodução de um excedente estrutural com a manifestação do desemprego aberto crescente $e$ de formas renovadas de ocupação, que dizem mais respeito à estratégia de sobrevivência do que à inserção produtiva da força de trabalho. (Pochmann, 2001:18)

Pochmann (2001:18) recorre a um referencial conceitual para ajudar na identificação das diversas formas de manifestações do excedente de mão-de-obra, assim como analisar as possíveis razões que dão sustentação à produção e à reprodução de mão-de-obra redundante no processo de acumulação de capital no município de São Paulo. Diante da tendência do desenvolvimento econômico absorver apenas uma parte da força de trabalho, esta não tem autonomia na decisão de participar na produção social, sendo condicionada pelo ritmo de expansão das atividades econômicas. Assim, a substituição de trabalhadores por formas renovadas de produzir, mediante tecnologias $e$ gestão do trabalho, e a intensificação do trabalho pelo ritmo crescente da organização capitalista da sociedade seriam formas tradicionais de restrição na participação de toda a força de trabalho no processo de produção social.

Quanto à inserção da força de trabalho na produção social, o autor identifica as seguintes formas: A primeira diz respeito ao segmento da força de trabalho necessário e diretamente envolvido no processo de acumulação de capital, representado pelos ocupados nos postos de direção, administração e demais empregados nas atividades de produção e distribuição de bens. A segunda forma (...) diz respeito aos segmentos da força de trabalho que sobraram das necessidades diretas do processo de acumulação de capital. Nesta última forma estariam tanto o chamado 'desemprego aberto', ou visível, e as ocupações para subsistência própria, ou desemprego invisível correspondente à parte não-organizada do mercado de trabalho. Ainda segundo o autor, no interior do excedente de mão-de-obra podem ser encontradas, mais recentemente, as ocupações vinculadas

\footnotetext{
${ }^{30}$ Grifo nosso.
} 
diretamente ao processo capitalista de produção, especialmente à grande empresa. (Pochmann, 2001:19-20) E conclui: o excedente de mão-de-obra, que não era uma novidade no passado no principal município brasileiro, assume, na atualidade das duas últimas décadas, proporções significativas. À margem das forças modernas de proteção trabalhista e de inclusão social, o contingente excedente de mão-de-obra segue sem perspectiva de reversão (...). (Pochmann, 2001:23)

Por fim, ainda em relação ao tema do trabalho informal, lembramos do que nos diz Mikes Davis, em seu livro "Planeta favela": se o setor informal não é, então, o admirável mundo novo visualizado por seus entusiastas neoliberais, quase com certeza é um museu vivo da exploração humana (2006:185). Nesta perspectiva, Davis (2006:179) situa duas posições teóricas em relação ao entusiasmo em torno da "mobilidade ascendente da economia informal": uma posição otimista, apresentada por estudos não raras vezes patrocinados por organismos internacionais, como o Banco Mundial; de outro lado, uma posição que questiona estes estudos, considerando-os excessivamente otimistas. Davis (2006:180-185) apresenta nove argumentos que integram o que chama de um conjunto concêntrico de falácias epistemológicas acerca da visão semi-utópica do setor informal.

\section{Estratégias de sobrevivência}

Em A metrópole do trabalho, de Márcio Pochmann (2001), encontramos uma importante contribuição para o entendimento sobre trabalho necessário, trabalho excedente e as denominadas estratégias de sobrevivência.

Pochmann (2001:20-23) explica que a força de trabalho, deixada ao livre funcionamento do mercado, tende a ser inserida de duas formas distintas: a primeira diz respeito ao segmento necessário e diretamente envolvido no processo de acumulação de capital. (...) A segunda forma (...) refere-se à parcela da mão-de-obra que sobra das necessidades diretas do processo de acumulação de capital. [Este] excedente de mão-deobra é constituído por trabalhadores que sobraram das necessidades diretas e imediatas do processo de acumulação de capital. Além de participarem do desemprego aberto (visível), estes "trabalhadores que sobraram" realizam atividades aqui consideradas como estratégias de sobrevivência (mercado de trabalho não-organizado), o qual não deve ser entendido como independente do sistema econômico capitalista, mas sim como dependente e subordinado à dinâmica da acumulação capitalista, assim como à capacidade de atuação do Estado.

Pochmann (2001) oferece elementos para reconhecermos que a industrialização de São Paulo jamais absorveu todo o contingente de trabalho nela concentrado. Ao contrário. Caracterizou-se, assim, um mercado de trabalho permanentemente desfavorável ao trabalhador, combinando ao mesmo tempo, formas diversas de ocupações no processo de urbanização e formação da metrópole. O autor identifica a presença do lumpemproletariado nas origens da formação do setor informal em São Paulo. Para Pochmann (2001:56), a mão-de-obra nacional do início da industrialização ao sobreviver de ocupações simples no âmbito do comércio varejista, artesanato ou oficinas de reparação ${ }^{31}$ - em detrimento da mão-de-obra imigrante corresponderia ao lumpemproletariado (...) configurando-se o que hoje se conhece trivialmente como setor informal.

31 (...) Em São Paulo, ocorreu tanto a marginalização do ex-escravo quanto do caipira, obrigandoos a emigrar para outras localidades ou submeter-se ao pauperismo das ocupações inferiores. (Pochmann, 2001:55) 
Vejamos melhor como Pochmann analisa o denominado segmento informal, presente no processo mesmo de industrialização em São Paulo, com base nos dados do Quadro 09 a seguir:

\section{Quadro : Município de São Paulo: evolução da estrutura ocupacional (1893/1998) (em \%)}

\begin{tabular}{|l|r|r|r|r|}
\hline Ocupações & 1893 & 1940 & 1980 & 1998 \\
\hline Agropecuária & 5,5 & 1,5 & 0,8 & 1,3 \\
\hline Indústria & 25,5 & 23,1 & 45,1 & 28,2 \\
\hline Comércio & 17,6 & 9,7 & 11,6 & 16,7 \\
\hline Serviços & 20,9 & 11,3 & 27,6 & 43,8 \\
\hline Adm. Pública & 4,6 & 4,5 & 3,5 & 3,3 \\
\hline Emprego doméstico & 25,99 & 49,9 & 11,4 & 6,7 \\
\hline
\end{tabular}

Fonte: Secretaria dos Negócios do Interior do Estado de São Paulo, Fundação Seade e IBGE (Elaboração: Márcio Pochmann). Pochmann (2001: 76)

Pochmann explica que, de um modo geral, o desemprego não era registrado pelas pesquisas no Brasil, constando como ocupação ou inatividade da população trabalhadora. $\mathrm{O}$ autor oferece mais uma série de dados que nos permitem vislumbrar 0 quadro crítico do mercado de trabalho em São Paulo, cujo excedente de mão-de-obra aumentou em mais de 150\% entre o ano de 1979 e 1998: em 1998, a taxa estimada de desemprego aberto [pessoas que procuram emprego sem realizar qualquer tipo de atividade (bico)] em São Paulo era de 14,9\%, enquanto, em 1979, era de apenas 3,4\% da população economicamente ativa. (...) Em relação à geração de postos de trabalho precários, em grande parte vinculados à estratégia de sobrevivência, pode-se observar sua rápida expansão. Entre 1979 e 1998, a quantidade de trabalhadores ocupados foi mais do que duplicada, pois aumentou quase $110 \%$. (...) A evolução mais recente do excedente de mão-de-obra transcorreu muito mais influenciada pelo desemprego aberto do que pelas formas de ocupação vinculadas às estratégias de sobrevivência. Isto é, foi mais a parte visível do excedente de mão-de-obra que se destacou na evolução recente do mercado de trabalho no município de São Paulo. (...) Em 1998, o excedente de mãode-obra representava em torno de 39\% da força de trabalho, enquanto, em 1979, significava cerca de $18 \%$. Essa ampliação do excedente de mão-de-obra em $158 \%$ nas duas últimas décadas revela o processo mais amplo de regressão socioeconômica a que estão submetidas as classes trabalhadoras no Brasil, não apenas em São Paulo.(...) (Pochmann, 2001:128;131)

\section{Transformações do trabalho na metrópole de São Paulo}

No artigo És o avesso do avesso ${ }^{32}$, Barelli (2003:07) propõe relacionar as alterações no emprego e no trabalho com mudanças que vem ocorrendo na cidade de São Paulo nas três últimas décadas ${ }^{33}$. Ao discorrer sobre a transformação da cidade de São Paulo em uma das maiores metrópoles mundiais, o autor expõe que a existência, na região, de trabalhadores com experiência, foi um dos fatores que levou a essa concentração de investimentos. $\mathrm{E}$ questiona: Será que as mesmas condições continuaram no final do século XX e começo do atual? (Barelli, 2003:7). E continua: durante 480 anos, a questão do emprego era inversa. Era conseguir braços.

\footnotetext{
32 Barelli, Walter. És o avesso do avesso In Revista Estudos Avançados, 17 (47), 2003. Pp. 7-19

${ }^{33}$ No artigo, de 2003, o autor se refere aos últimos 25 anos.
} 
Barelli $(2003: 8,9)$, observa que ao mesmo tempo que os trabalhadores passam a ser sujeitos coletivos com a força de seus movimentos, ocorrem mudanças profundas, do que se destaca a denominada terceira revolução industrial ou era da informação. O processo de trabalho se transforma com o avanço da microeletrônica, que ao eliminar os chamados tempos mortos dos processos produtivos, resulta numa maior produtividade do trabalho. Tais mudanças ocorrem em todos os âmbitos e escalas, atingindo o chão de fábrica, escritórios, bancos, bem como a maior parte das atividades que façam uso de equipamentos.

Deste quadro de transformações nos processos de trabalho, derivados em grande medida pelo incremento de novas tecnologias, perde-se a base para comparações acerca das perdas em termos de postos de trabalho, tendo sido responsável por parte significativa do desemprego que marcou a década de 1990.

O processo descrito por Barelli (2003:8) está no fundamento da disponibilidade de "braços" absorvidos nas atividades da reciclagem. Se a chamada terceira revolução industrial ou da informação implicou no "avesso do emprego fácil", expressão usada por Barelli sobre a mudança que ocorre no mundo do trabalho, este é o mesmo contexto de ampliação da base da indústria da reciclagem, mais especificamente do que aqui denominamos "o chão dos catadores".

Barelli (2003:10) apresenta alguns dados e informações sobre a situação do emprego e desemprego nas duas décadas finais do século $X X$ e início do século $X X I$, demonstrando o acirramento do desemprego, sobretudo na Grande São Paulo: (...) $A$ fonte dos nossos dados é a PED - Pesquisa de Emprego e Desemprego, do DIEESE e Fundação Seade, que é feito mensalmente, a partir de 1985. Os primeiros ano dessa pesquisa mostram uma taxa de desemprego elevada, flutuando em torno de $9 \%$. (...) Apesar de os anos de 1980 serem chamados de década perdida, as condições de emprego e trabalho vão piorar nos anos de 1990, que sem dúvida afetaram mais o trabalhador. (...) É a década do desemprego. Começa com 10\% da PEA desempregada em 1990. Em 1992, a taxa de desemprego já é de 15,2\%. (...) A seguir cresce variando de $17,6 \%$ a 19,3\% de 1998 até 2002, ou seja, o novo milênio também começa com altas taxas de desocupação. Esses números referem-se ao desemprego na Grande São Paulo. Na capital, a taxa é algo menor (em torno de 1\%) (...) São Paulo passa a ser uma cidade onde a oportunidade de emprego para todos não mais se realiza. (Barelli, 2003:10)

Deste contexto de perda de postos de trabalho formais em São Paulo, o autor ressalta que o termo "precarização do trabalho", que passa a ser utilizado para expressar a situação de desemprego crescente, com concomitante desenvolvimento do setor informal, significa justamente uma queda de qualidade nas condições de trabalho. A informalidade, o crescimento do número de trabalhadores autônomos, e simulacros de cooperativas são algumas das facetas da precarização indicadas pelo autor. Contudo, o autor adverte que não se trata de um período de estagnação econômica, mas de uma fase de crescimento sem emprego, segundo o pensamento de Eric Hobsbawm. E conclui: poderíamos ser ainda mais cruéis, chamando de época dos crescimento com desemprego, o que está sendo possível, na indústria, por meio da introdução da microeletrônica. (Barelli, 2003:17)

Por fim, Barelli (2003:18) apresenta um desfecho otimista em relação às promessas do empreendedorismo, também entendido como "reinvenção do trabalho": faltando o trabalho, a pessoa entra em uma espiral de perdas (...) É o horror econômico (...), que para muitos é mau conselheiro. O rompimento dessa espiral vem com $\underline{a}$ reinvenção do trabalho. Há iniciativas nesta direção, como o empreendedorismo, o trabalho voluntário e até o modelo paulista de Frentes de Trabalho. (Barelli, 2003:18)

\section{Trabalho e Capital na interdependência das esferas produtivas}


Damiani em sua Dissertação de Mestrado Na busca das favelas o encontro do "peão" que permanece: as favelas de Cubatão num quadro de desenvolvimento do centro petroquímico-siderúrgico, de $1984^{34}$, remete-nos à obra de Marx ${ }^{35}$ em sua análise sobre a riqueza e a pobreza no capitalismo, com base na relação entre o capital e o trabalho. A autora propõe-se a recuperar esta relação e seu grau explicativo ao problema da pobreza, indo, de alguma maneira, desta forma inerente ao modo de produção capitalista às suas causas reais (Damiani, 1984:4-5). Assim, procede à análise das favelas de Cubatão e, através delas, dos favelados, diretamente vinculados ao processo de acumulação de capital daquele centro industrial petroquímico-siderúrgico. Para tanto, recorre à compreensão do processo de relações inter-setoriais de produção, encontrando a reprodução do capital constante como fonte explicativa principal; que relativamente ao trabalho interno a Cubatão refere-se, em especial, à indústria de construção pesada e montagem industrial (Damiani, 1984:6-7). Nas palavras de Damiani (1984:6-7): examinamos o favelado como trabalhador, atingindo (...) o centro produtivo de Cubatão, em seu processo de acumulação de capital, diante de seu movimento de valorização, isto é, a partir do trabalho chegamos à reprodução ampliada do capital. A perspectiva, portanto, dirigiu-nos à essencialidade do fenômeno, já que é o trabalho a essência do desenvolvimento do capital; como também explica a pobreza, no caso, enquanto trabalho assalariado, sujeito à exploração de dimensão e intensidade variadas.

No caso do trabalho do catador, em relação à indústria da reciclagem, temos a ideologia do empreendedorismo sob a qual vêm sendo criadas cooperativas e associações, o que aparece como positividade contraposta ao capital. Dissimula-se a relação capital-trabalho, e com ela a exploração e a valorização do capital pelo trabalho. A cooperativa de catadores aparece como autônoma em relação à indústria recicladora. Entretanto, esta autonomia garantida em termos jurídicos para cada estabelecimento (cooperativa e empresa recicladora são unidades independentes, ainda que a primeira exista em função das demandas da segunda), não pode ser estendida aos aspectos do funcionamento das cadeias produtivas da reciclagem, no encadeamento da qual podemos entrever a relação capital-trabalho, ainda que sob as mais diversas mediações e formas.

Damiani (1984:6-7) entende que a estruturação da industrialização do pólo petro-químico-siderúrgico de Cubatão se dá se forma velada, "escondida" e associada a outros setores industriais que determinam as condições de formação e reprodução da força de trabalho a ela afeta, caracterizada por uma baixa composição orgânica do capital e por taxas de exploração elevadas. Nestas condições, a exploração do trabalho é determinada por um processo de trabalho que aparece como descontínuo, levando à conclusão errônea de que é trabalho provisório, supérfluo, muitas vezes, à acumulação do capital.

Os catadores, assim como os "peões" de Cubatão, têm sido analisados freqüentemente por esquemas interpretativos que os definem como autônomos, empreendedores, agentes ambientais que prestam serviço, sem que apareça o que de fato o catador é: trabalho que participa da formação do capital na indústria da reciclagem. Damiani (1984:37-38) afirma que sob a aparência de "bico" atribuída ao trabalho realizado pelos favelados, trabalho que é explorado pelas empreiteiras da indústria da construção, reside a reprodução do capital constante das indústrias do centro petroquímicosiderúrgico, para além da independência destas duas esferas produtivas. No caso da indústria da reciclagem, a interdependência está entre o comércio e a indústria, entre a

\footnotetext{
34 Damiani, Amélia Luisa. Na busca das favelas o encontro do "peão" que permanece. As favelas de Cubatão num quadro de desenvolvimento do centro petroquímico-siderúrgico. Dissertação de Mestrado apresentada ao Depto. Geografia, FFLCH/USP. São Paulo, 1984.

${ }^{35}$ Nota da autora: Marx, Karl, Teorías sobre la Mais Valía, v.III, 1975, p.47-48
} 
esfera de atuação dos comerciantes de recicláveis - em relação aos quais aparece a figura do catador - e a indústria propriamente dita. 


\section{ANEXO 03 - Pesquisa com catadores (carrinheiros)}

Local:

data:

hora:

1. Sexo ( ) fem ( ) masc

2. Faixa etária: ( ) até 18 ( ) 19 a 25 ( ) 26 a 30 ( ) 31 a 40 ( )41 a 55 ( ) acima de 56

3. Escolaridade: ( ) Analf. ( ) $1^{\circ}$ a $3^{\circ}$ ( ) $4^{\circ}$ a $5^{\circ}$ ( ) $6^{\circ}$ a $7^{\circ}$ ( ) Fund. Completo ( ) Fund. Incompleto ( ) Ens. M. Completo ( ) Ens. M Incomp. ( ) Ens. S. Completo ( ) Ens. S. Incompleto ( ) s/ resp.

4. Estado onde nasceu:

5. Anos em São Paulo: nascido em SP ( ) 1 a 5 ( ) 6 a 10 ( ) 11 a 15 ( ) 16 a 20 ( ) 21 a 30 ( ) mais de 30

( ) não sabe

6. Bairro onde mora:

7. Moradia: ( ) própria ( ) alugada ( ) CDHU ou similar ( ) favela ( ) outros:

8. Tempo de residência:

9. Profissão anterior:

( ) sempre catador

( ) sem emprego anterior

10. Forma de trabalho:

( ) Formal com carteira ( ) Temporário ( ) Informal ( ) Autônomo ( ) Cooperado ( ) Associado ( ) outro

11. Ultimo emprego:

12.Tempo de catador:

( ) menos de 1 ano ( ) 1 a 4 anos ( ) 5 a 9 anos ( ) 10 a 20 anos ( ) mais de 20 anos ( ) não lembra

13. Quantas horas trabalha: ( ) manhã ( ) tarde ( ) noite

14. Por onde você costuma passar para catar material?

15. Quanto ganha por dia:

( ) até $R \$ 5,99$

( ) $\mathrm{R} \$ 6,00$ a 10,00

( ) $R \$ 11,00$ a 15

( ) $R \$ 16,00$ a 20

( ) $R \$ 21,00$ a 25

( ) $\mathrm{R} \$ 26$ a 30

( ) $\mathrm{R} \$$ mais de 30 :

16. ( ) É a fonte principal de renda ( ) complementar - Qual é a principal? 
17. Renda familiar:

( ) menos de 1 s.m. ( ) 1 a 3 s.m. ( ) 4 a 6 s.m. ( ) 7 a 9 s.m. ( ) acima de 10 s.m. ( ) outros

18. Quantas pessoas vivem desta renda:

19. Materiais que coleta e quanto recebe pelo quilo:
( ) papelão
( ) papel
( ) ferro
( ) alumínio
( ) cobre
( ) vidro
( ) plástico
( ) PET
( ) latinha
( ) tetra pak
( ) madeira
( ) tecido
( ) outros:

$R \$$
$R \$$
$R \$$
$R \$$
$R \$$
$R \$$
$R \$$
$R \$$
$R \$$
$R \$$
$R \$$
$R \$$
$R \$$

20. Você acha que o preço pago pelos materiais cobre o seu trabalho? ( ) sim ( ) não

21. Quais são as formas de conseguir melhores preços?

( ) maior volume ( ) melhor separado ( ) levar onde pague mais ( ) outros:

22. Costuma ( ) ajuntar em casa ou ( ) levar pra vender no mesmo dia?

23. O carrinho é ( ) próprio ( ) emprestado - De onde?

24. Até quantos quilos você carrega no carrinho?

25. Em quais ferros-velhos vende os materiais:

26. Forma de pagamento: ( ) à vista ( ) semanal ( ) quinzenal ( ) mensal ( ) outros:

27. Gostaria de trabalhar em grupo (cooperativa)? ( ) sim ( ) não Porquê?

28. Conhece as Centrais de Triagem? O que acha?

29. Você conhece:

a) algum Movimento ou organização de Catadores? ( ) não ( ) sim Quais:

b) alguma entidade de apoio aos catadores? ( ) não ( ) sim Quais:

30. Você tem idéia de quantos catadores existem no seu "pedaço"? 


\title{
ANEXO 04 - INCURSÕES NO "CHÃO DOS CATADORES"
}

\author{
RELATOS SOBRE CATADORES AVULSOS CARRINHEIROS
}

Realizamos algumas incursões no universo dos catadores avulsos, procedendo à observações, recolhendo impressões, levantando questionamentos que mobilizaram esta Tese. Tivemos ainda a oportunidade de conversar com alguns destes catadores. Estas conversas giraram em torno de um roteiro de questões, sob o formato de um questionário (ANEXO 03), cujas informações obtidas puderam ser comparadas e foram expostas no sub-captítulo 2.3.1 (CAPÍTULO II da Tese). Como não fizemos uso de gravador (para propiciar uma conversa menos formal, sem o constrangimento que poderia ser causado pelo uso do referido equipamento), os relatos se baseiam na transcrição das anotação feitas nas fichas do trabalho de campo. Assim, apresentamos a seguir o relato de alguns dos catadores abordados nas ruas da região central (imediações da Praça da República e Baixada do Glicério) e também no Itaim Paulista, realizadas em meados de 2007 e início de 2008.

\section{Catadores na Região Central - IMEdiações da PraÇA dA República}

\section{O catador Erveli}

Por volta das 16:30 horas, iniciamos nosso campo nas ruas do centro de São Paulo, nas imediações da Praça da República em direção ao Vale do Anhangabaú. Neste horário, ainda não há grande concentração de carroças pelas ruas, mas já podemos encontrar alguns catadores transportando carrinhos já cheios, sobretudo de papelão, e outros ainda vazios, parados em frente a algum estabelecimento comercial ou próximo à entrada de edifícios, à espera dos sacos pretos de lixo que acondicionam os resíduos de atividades de serviços e comerciais.

O primeiro entrevistado foi abordado na Rua D. José de Barros, quase esquina com a Rua 24 de março. Demonstrando interesse em dar a entrevista, o catador estacionou a carroça (carregada principalmente de papelão) de modo a não atrapalhar a passagem dos pedestres, cuja intensidade ia aumentando com o final do horário comercial. Ele tem 36 anos, possui ensino médio completo, é nascido no Paraná mas vive em São Paulo há 15 anos. Paga aluguel de uma casa em Guarulhos onde moram a mulher e três filhos, sendo que só vai para lá no final da semana. Permanece no centro durante toda a semana, dormindo na própria carroça ou no depósito no qual vende o material coletado, pois não consegue arcar com o custo do transporte todos os dias para Guarulhos.

O depósito onde vende os materiais fica nas imediações do Terminal Armênia, mas não obtivemos mais detalhes sobre o mesmo, pois o catador começou a demonstrar certo desconforto em falar sobre este assunto. Para não prejudicarmos o andamento da entrevista, demos seguimento às outras questões. O entrevistado é catador a 7 anos, antes do que trabalhava como pintor autônomo. Como catador ele trabalha das 15:00 às 23:00 horas, passando pela Bela Vista, na Rua Santo Antônio, e nas ruas adjacentes, "pra baixo" da Av. Paulista. Recebe $\mathrm{R} \$ 40,00$ por dia, chegando a cerca de $\mathrm{R} \$ 700,00$ por mês. Considera que o ideal para se obter melhores preços é separar bem o material que ele junta no depósito. Com seu carrinho ele coleta em média 300 quilos de materiais, realizando três viagens por dia, no percurso Bela Vista - Armênia, passando pelas ruas do centro.

Declara que gostaria de trabalhar em cooperativa, mas as existentes estão todas cheias. Isso porque nas cooperativas ele conseguiria um preço melhor pelos materiais, além do que com a taxa de $10 \%$ do seu rendimento que fica com a 
administração da cooperativa, ele teria direito à um lugar melhor para almoçar, tomar banho, e mesmo para pernoitar. Ele cita o caso do "núcleo dos catadores" no Glicério, a Coorpel (na Luz) e a Coopersoma (na Barra Funda), mas não tem conhecimento sobre algum movimento ou entidade de apoio aos catadores. Ele sabe que as cooperativas tem apoios, mas não os catadores que estão nas ruas.

Ele calcula que existam cerca de 4.000 catadores no centro, e acredita que seria bom a abertura de novas cooperativas, pois muita gente fica nas ruas. Por outro lado, a Prefeitura está fechando os ferros-velhos, e somente no depósito onde ele vende os materiais há cerca de 50 catadores que precisarão de outra alternativa.

\section{O catador Jesuíno Souza Prates}

Ainda na Rua D. José de Barros, próximo à Rua 7 de abril, abordamos 0 segundo entrevistado. Ele seguia com sua carroça, ainda vazia, quando se aproximou de três sacos de lixo em frente à entrada de um edifício. No mesmo instante, também se aproximou um pequeno veículo motorizado de uma empresa de limpeza privada que disse ao catador para não rasgar os sacos de lixo. Em resposta, o catador pegou os sacos e os depositou na caçamba do veículo, seguindo com a carroça vazia. Ao nos aproximarmos, o catador demonstrou disponibilidade para a entrevista, não tendo muita pressa em continuar seu percurso. Ele tem 42 anos, possui a $7^{a}$ série, e nasceu em Minas Gerais. Desde os 14 anos está em São Paulo, sendo que a 7 anos vive como catador. Ele dorme na carroça, sob o Viaduto Santa Efigênia, no Vale do Anhangabaú, cuja referência é o número 90. Ele fez questão de frisar mais de uma vez: morava no número 90 do Vale do Anhangabaú. Foi carpinteiro, guia de transporte, auxiliar de almoxarifado, tendo trabalho em 22 firmas, com carteira assinada. Seu último emprego foi numa cooperativa na Santa Cruz, como carpinteiro. Ele relata, com certa confusão, que nos últimos sete anos tem procurado um certo advogado para receber os direitos trabalhistas, mas nunca obtém resposta. Acha que não terá mais jeito e que continuará na rua como catador. Ele inicia a catação no começo da noite, e durante o dia realiza fretes com a carroça, ganhando algo em torno de $\mathrm{R} \$ 30,00$ dependendo do serviço, além de alguma doação de material reciclável, comida, etc. Seu principal trajeto de catação é subindo e descendo a Consolação, passando pelas ruas do centro. Geralmente recolhe papelão, cerca de 100 quilos que são vendidos a $R \$ 0,15$ o quilo, podendo ganhar algo em torno de $R \$ 30,00$, quando encontra ferro, alumínio e outros materiais. Ele realiza a venda num depósito que fica na Av. do Estado. Diz que não mora em albergue por causa da carroça, mesmo passando por todas as dificuldades, como é o caso de não ter lugar certo para fazer as refeições. Ele conta que o dinheiro que ganha é principalmente para as refeições, pelas quais paga como qualquer consumidor. Ele pede para que o dono do restaurante faça um marmitex porque ele não pode freqüentar o restaurante junto dos outros clientes. No caso do café da manhã, ele diz que só entra no bar ou lanchonete depois que os clientes tomam seu café para ir ao trabalho, ou seja, depois das 10:00 horas quando o estabelecimento já está mais vazio. Conta que já recebeu uma proposta para trabalhar num bar no Largo do Paissandú, mas que não daria certo trabalhar servindo bebida, demonstrando possuir uma "certa consciência" de sua condição de dependência alcoólica. Durante toda a entrevista, o catador demonstrou possuir consciência da sua condição, e uma desesperança profunda em revertê-la...

Indo em direção à Rua 7 de abril, encontramos outro catador rodeado de sacos de lixo, separando os materiais na calçada. Ao nos aproximarmos, o mesmo se recusou a participar da entrevista. 


\section{O catador Cleberson}

Na Av. Ipiranga, na altura da Praça da República, encontramos três catadores que estavam coletando muito próximos, na mesma calçada. Dois deles trabalham com carroças grandes (de 3 a 4 metros de comprimento) e abertas nas laterais. São próprias para carregar os sacos de lixo que são recolhidos de edifícios comerciais e de serviços, entregues geralmente pelo porteiro ou algum funcionário que acaba recebendo uma taxa do catador. Entrevistamos um destes catadores, o qual tem 24 anos, possui a $6^{\text {a }}$ série e nasceu na Bahia. Vive a 6 anos em São Paulo, sendo que a 4 anos trabalha como catador. Mora no bairro da Liberdade, mais especificamente na Baixada do Glicério. Ele diz que trabalha e mora no depósito de um irmão, sendo ao todo 8 pessoas que dividem um terreno onde cada um tem um pequeno barraco. Neste terreno é onde funciona o depósito. Seu horário de trabalho é das 8:00 às 12:00 horas, dedicadas à separação dos materiais no depósito e das 14:30 às 18:00 horas na coleta, fazendo apenas uma viagem. Seu percurso é pela Av. Ipiranga, Consolação e outras ruas da República. Conta que consegue ganhar cerca de $\mathrm{R} \$ 250,00$ por semana. Acredita que a forma de conseguir melhor preço é alcançando maior volume de materiais. Quando iniciamos a entrevista, sua carroça já estava cheia de sacos plásticos com lixo e ele aguardava a liberação de mais sacos que aos poucos iam sendo liberados pelo porteiro do edifício, em frente ao qual a carroça estava estacionada. Enquanto conversávamos, ele ia acondicionando os sacos na carroça, em camadas que iam se acumulando verticalmente. As caixas de papelão que apareciam entre os sacos plástico eram desprezadas e entregues a um outro catador, o qual possuía uma carroça menor na qual era transportado principalmente papelão. Voltaremos a este último catador posteriormente. O catador carrega em média 500 a 600 quilos numa única viagem. Conta que gostaria de encontrar outro tipo de trabalho, mas não conseguiu nada que pagasse o que ele ganha com a reciclagem. Fez uma entrevista de trabalho a poucos dias, mas o salário não chegava a $R \$ 600,00$, então não valia a pena ter um registro em carteiro para ganhar menos.

\section{O catador Carlos}

Encontramos este entrevistado na mesma calçada em frente à Praça da República. Sua carroça é bem menor do que a do catador anteriormente entrevistado. Diferentemente daquele catador, Carlos não coleta sacos de lixo, mas seleciona pelas ruas principalmente papelão e diversos materiais passíveis de comercialização, tais como ferro, alumínio, plásticos, etc. Ele tem 38 anos e a $4^{a}$ série primária. Nasceu no interior de São Paulo, em Assis, mas vive em São Paulo desde a infância, na região do Capão Redondo. Atualmente está morando nas ruas do centro, vivendo como catador depois de ter sido preso, fato que dificultou a possibilidade de conseguir um emprego. Disse que teve emprego com carteira assinada, numa empresa de limpeza de vidros e também como coletor de lixo da antiga Enterpa, empresa de limpeza urbana. Antes de ser catador, trabalhou como ambulante vendendo diversos produtos, mas teve prejuízo com mercadorias apreendidas pelos "rapas". Ele conta que ele coleta o dia todo, principalmente nas imediações da Av. Ipiranga, mas que consegue pouco material, cerca de 90 a 100 quilos que ele leva até o depósito nas imediações da Av. do Estado. Geralmente realiza só uma viagem por dia, recebendo cerca de $\mathrm{R} \$ 20,00$. Já teve uma experiência numa cooperativa em Santo Amaro, onde conseguia, por exemplo, receber $\mathrm{R} \$ 0,48$ pelo quilo do papelão. Ele retira da carteira uns papéis da referida cooperativa onde estão anotados os cálculos de peso e preço dos materiais como prova de que já teve esta experiência. Mas aconteceram alguns problemas (não disse quais) e acabou indo viver e catar nas ruas do centro.

\section{O catador Ângelo Tadeu}


Na Rua Barão de Itapetininga entrevistamos outro catador. Ele estava com sua carroça perto de uma banca de jornal, onde também haviam outras duas carroças estacionadas. Ao abordá-lo, ele demonstrou interesse em conversar de forma bastante descontraída. Ele tem 42 anos e possui apenas $01^{\circ}$ ano primário, diz que sabe assinar 0 nome, mas que não lê. É natural de São Paulo e mora nas ruas do centro, sem indicar um lugar fixo. Enquanto conversávamos, ele dobrava e organizava caixas de papelão em seu carrinho. Já trabalhou como ajudante de depósito de material de construção, e como carregador, com emprego assinado em carteira, mas a muito tempo, pois já é catador a 23 anos. Ele coleta materiais de manhã e à noite na Rua Barão de Itapetininga e imediações da Praça da República, chegando a ganhar $R \$ 30,00$ por dia, o qual serve para as despesas pessoais e para cuidar da matilha de nove cachorros que 0 acompanha. Durante a conversa, ele explica que os cachorros não são para segurança, mas porque ele gosta muito destes animais, embora tenha que enfrentar reclamações dos comerciantes e a impossibilidade de freqüentar um albergue justamente por causa disso. Conta que consegue carregar cerca de 200 a 300 quilos por viagem, levando os materiais para vender num depósito localizado no Parque D. Pedro. Também por causa dos cachorros nunca conseguiu trabalhar em cooperativa, pois até dizem que aceitam os cachorros, mas ele tem medo que os levem para a "carrocinha". Conta que além da companhia dos cachorros ele tem somente um "bem" que é a carroça que custa entre $\mathrm{R} \$ 200,00$ e $\mathrm{R} \$ 300,00$.

\section{O catador Sidnei}

Ao passarmos pela Rua 24 de março encontramos uma carroça grande estacionada e ficamos aguardando pelo seu dono. Não demorou surgir um catador trazendo alguns sacos de lixo para colocar na carroça, o qual pediu para que o procurássemos dali a 1 ou 2 horas em frente à Loja Besni. Durante este período, ele estaria retirando os sacos de lixo de alguns escritórios, além de caixas de madeira de alguns restaurantes daquela rua, as quais são vendidas nas imediações do mercado municipal, onde se reúnem comerciantes de caixarias que atuam como "atravessadores". Retornando após o período sugerido, encontramos o catador com sua carroça no local indicado. Ele quis saber detalhes sobre o motivo da entrevista e demonstrou certa preocupação em não ser prejudicado com as informações dadas. Após esclarecermos suas dúvidas, o catador combinou que poderíamos conversar ao mesmo tempo em que ele continuaria retirando mais materiais dos estabelecimentos daquela rua. Ele tem 43 anos, cursou até a $5^{a}$ série primária e nasceu em São Paulo, em São Miguel Paulista. Mora "de favor" na bicicletaria de um conhecido, localizada no Parque D. Pedro, para o qual dá uma "ajuda de custo". Na parte traseira do seu carrinho ele carrega uma bicicleta com a qual ele volta para o local onde mora, depois de deixar o carrinho e os materiais na cooperativa onde está trabalhando. Conta que é catador há 6 anos, mas que há 2 meses ele começou a trabalhar na Cooperglicério, localizada sob um viaduto na Baixada do Glicério. Antes de ser catador, sempre trabalhou como "marreteiro", às vezes como ajudante geral, tendo apenas 3 anos de carteira assinada. Sobre este assunto, o catador contou que "odeia carteira de trabalho". Referiu-se diversas vezes ao fato de ser evangélico e de que tinha muita sorte, pois estava trabalhando para um ferro-velho na Moóca quando um conhecido o indicou para ocupar uma vaga na cooperativa. Também relatou diversas vezes possuir uma moto, com a qual ele passeava aos domingos, com roupas novas, e que quando alguma pessoa o reconhecia, ficava admirada e até melhorava o jeito de tratá-lo. Sobre a cooperativa, diz que ainda não está bem estruturada, pois fica debaixo de um viaduto e não possui equipamentos necessários, tais como uma prensa. Relata que a Prefeitura quer retirar todas as atividades que acontecem debaixo dos viadutos da Baixada do Glicério, não só a cooperativa, mas o albergue e os 
grupos de catadores que vivem por lá. Como alternativa, a Prefeitura está construindo, no espaço da CET (Companhia de Engenharia de Tráfego), junto ao Corpo de Bombeiros, uma grande cooperativa para cerca de 400 catadores. Ele diz que estão preenchendo fichas para concorrer a essas vagas, pois haverá uma seleção de catadores, de acordo com alguns pré-requisitos: estar realmente dispostos a trabalhar, ser disciplinado, não ter vícios, nem passagem pela polícia, entre outros aspectos. Além disso, a Prefeitura quer acabar com as carroças que percorrem as ruas do centro, pondo em seu lugar veículos motorizados que recolherão o material e o levarão para esta grande cooperativa. Ele conta que trabalha 8 horas por dia, mas observamos que este catador trabalha de fato ao menos o dobro deste período, ou seja, 16 horas, de segunda a sábado, sendo que no domingo ele trabalha separando materiais. Ele chega no seu ponto fixo, que é a Rua 24 de março, às 16:30 horas e só retorna à cooperativa por volta das 24:00 horas ou 1:00 hora da manhã. No dia seguinte, no período das 9:00 às 16:00 horas, ou seja, antes de voltar à rua para catar, ele fica na cooperativa fazendo a separação e pesagem do seu material. Na Cooperativa cada catador tem um "box", um espaço exclusivo onde armazena e separa os materiais. Por este espaço, que é divido por tábua, ele paga uma taxa de $R \$ 12,00$ por quinzena, além de outros $R \$ 10,00$ para o café da manhã. Ele também diz que paga uma taxa semelhante para a "balanceira", que é a pessoa que realiza a pesagem do seu material. Na cooperativa ele recebe a cada 15 dias, ao contrário do ferro-velho que o pagava no mesmo dia. A vantagem está no fato de que na cooperativa ele consegue um preço melhor porque elimina o atravessador (o primeiro atravessador). Ele explica que na verdade a cooperativa ainda não vende direto para a indústria, porque não tem prensa para beneficiar o material. Então precisam vender para um outro atravessador (o segundo atravessador), mas mesmo assim a diferença de preço é significativa. Este $2^{\circ}$ atravessador deixa um container no espaço da cooperativa (Legaspe, em sua pesquisa, analisou a presença dos containers nos depósitos de materiais recicláveis, entendendo-os como capital fixo das empresas recicladoras, ou dos grandes comerciantes - como os grandes aparistas), o qual é retirado quando esteja cheio do material de interesse do referido atravessador. O catador não quis dizer o quanto ganha e nem quantos quilos carrega em cada viagem, pois acredita que quando a mídia conta o quanto um catador pode ganhar com a reciclagem (ou seja, ele avalia que é possível ganhar muito), atrai mais desempregados, aumentando a concorrência... Mas declarou que somente a carroça vazia pesava 220 quilos, a qual é feita de ferro, com rodas de carro (explica que geralmente as carroças são feitas com rodas de motocicleta, mas são menos resistentes). Carroças de madeira são mais leves, mas duram menos, e para ele o peso da carroça não atrapalha muito, porque a única subida que enfrenta, com ela ainda vazia, é a ladeira de ligação com a Rua 25 de março. Depois, para voltar à Cooperativa (na Baixada do Glicério) o trajeto é todo em descida. Ainda sobre o seu carrinho, ele mostra que leva uns cabos de vassoura que são ajustados às laterais para aumentar a altura das mesmas, o que permite empilhar mais sacos de lixo sobre o carrinho, cujo tamanho é de 1,5 metros de largura por 4,5 metros de comprimento. Conta que gastou $R \$ 300,00$ para reformá-la (cita que aumentou seu comprimento, reforçou sua estrutura e colocou rodas de carro) e que não a vende por menos de $R \$ 800,00$. Ao perguntarmos se conhecia alguma instituição de apoio, ou movimento de catadores, ele citou a ajuda da Igreja, dos Franciscanos. Porém, logo em seguida, questionou as atividades da instituição, dizendo que a mesma recebe subsídios da Prefeitura, mas oferece muito pouco aos catadores. E além disso, parte dos ganhos dos catadores com a reciclagem fica com a instituição... Ao perguntarmos sobre como funciona o trabalho na cooperativa, ele não fez rodeios para dizer que ali era como em qualquer lugar, "cada um por si", o que mudava era só o nome de "cooperativa". Existe cerca de 40 catadores hoje na cooperativa, mas a maioria trabalha individualmente. 


\section{Catador Anônimo}

$\mathrm{Na}$ calçada das Casas Bahia existente no edifício do antigo Mapping, encontramos um senhor recolhendo caixarias fornecidas por um funcionário da loja. Ao abordá-lo, ele diz que podemos conversar enquanto o restante das caixas estão sendo depositadas na calçada pelo referido funcionário. Ele tem 55 anos, cursou até a $4^{\mathrm{a}}$ série primária e sempre viveu na Zona Leste de São Paulo, sendo que atualmente está em Itaquera, na casa da mãe. Já trabalhou em cooperativa, mas faz um bom tempo que é catador avulso. Começou a catar depois de que saiu da prisão, onde passou 20 anos. Faz 4 anos que é catador. Conta que com sua idade e com a passagem pela polícia (ele conta que ficou preso por cerca de 20 anos) esta foi a única alternativa que teve para sobreviver. Antes dos problemas que o levaram à prisão, diz que trabalhou durante 18 anos com registro em carteira, como eletricista, cozinheiro e numa refinaria de açúcar na Moóca.

Ele inicia seu percurso de catação por volta das 16:00 horas, saindo da Moóca onde fica um galpão de reciclagem (um deposito) para o qual leva o material coletado e faz a triagem. Conta que percorre 8 pontos fixos de coleta, que são lojas nas quais recolhe papelão branco, sacos (com papel branco, papel misto e copinhos). Chega a carregar em torno de 700 a 800 quilos. Conta que recebe pelo quilo do papelão e do papel branco $R \$ 0,25$. Tem pagamento quinzenal, com uma renda mensal média de $\mathrm{R} \$ 700,00$. O carrinho é do depósito, que ele denomina de "firma", onde trabalham mais 8 catadores. Ao perguntar sua opinião sobre trabalhar em cooperativa, diz que prefere trabalhar sozinho pois na cooperativa ele teria que "pagar para trabalhar", referindo-se às porcentagens ou taxas que cada catador deixa na cooperativa, geralmente para as despesas, ou outros fins.

\section{CATAdores nA REgIÃo CENTRAL - BAIXADA DO GLICÉRIO}

\section{O catador Moacir}

Moacir tem 34 anos, nasceu no Mato Grosso do Sul e estudou até a $7^{\mathrm{a}}$ série primária. Vive a 14 anos em São Paulo e reside na Liberdade, na "Baixada" (Baixada do Glicério), de aluguel, dividindo as despesas com um amigo.

Antes de ser catador, Moacir trabalhou numa fábrica que produzia máquinas injetoras, e teve carteira assinada. Desempregado, faz mais de 5 anos que se tornou um catador. Ele percorre as ruas da Liberdade no período das 17:00 às 24:00 horas, e recomeça pela manhã, das 8:00 às 13:00 horas, quando faz a triagem do material, que precisa ser limpo (separado do lixo propriamente dito, rejeito) e ensacado para venda. Os materiais que coleta são: papelão (que vende junto com tetra pak), papel, metais e plásticos.

Explica que acumula material durante a semana, levando para pesar toda sexta-feira, no ato da venda. Ele costuma vender seu material num depósito na Rua São Paulo, onde pagam à vista.

Para ele, a forma de se obter melhor preço é separar melhor o material que acumula durante a semana sob o viaduto, onde cada catador tem um espaço, um "box".

Ele mesmo fez seu carrinho, o qual pesa 120 quilos. Nele, Moacir carrega de 500 a 700 quilos de material numa só viagem. Ganha cerca de $\mathrm{R} \$ 150,00$ por semana. 
Diz que não tem interesse em trabalhar em cooperativa, porque teria que esperar um tempo maior para receber, por exemplo quinzenalmente, e acontecem atrasos, então para ele não dá certo.

\section{Catador Anônimo}

Este catador tem 34 anos, cursou até $03^{\circ}$ ano primário e sempre morou na região central, na Sé e no Glicério. Diz que está morando a 5 anos num salão emprestado, onde era uma oficina mecânica que não existe mais. Diz que já teve sérios problemas de saúde, todos ligados à dependência química, como uso de crack e álcool. Ele teve algumas experiências com carteira assinada e que foi ajudante de metalúrgica, mas não se lembra quando e qual foi seu último emprego...

Faz apenas 1 ano que é catador. Ele percorre as ruas da Sé, Liberdade, Pq. D. Pedro, onde tem pontos em edifícios e comércios. Consegue ganhar por semana $R \$ 70,00$, pelo trabalho que realiza em dois turnos: das 16:00 às 21:00 catando os materiais, e das 8:00 às 16:00 fazendo a triagem. O carrinho é emprestado do depósito onde leva o material para vender toda semana. Carrega cerca de 200 quilos em cada viagem.

Diz que gostaria de trabalhar numa cooperativa, porque tem uma organização melhor, pois os catadores estão sempre em risco de contaminação por causa dos ratos e de ferimentos com materiais cortantes, como o vidro.

\section{A catadora Laís}

Laís tem 16 anos, estudou até a $6^{a}$ série e nasceu em Itaquaquecetuba. Mora hoje em Ferraz de Vasconcelos, mas passa a semana toda no centro, sob o viaduto onde armazena e separa os materiais para a venda.

Conta que sempre foi catadora, desde os 10 anos de idade, pois seus pais também são catadores. Todos trabalham e cuidam de sua irmã que tem problemas sérios de diabetes.

Ela cata pelas ruas da República, São Bento e Sé, no período das 17:00 às 22:30 horas e calcula ganhar em torno de $R \$ 200,00$ por semana. Laís tem um filho de 6 meses que deixa numa creche para fazer a catação. Ela reclama que o que ganha não dá para pagar nem suas despesas, porque só o aluguel da casa em Ferraz, onde a filha fica com uma parente, é de $R \$ 190,00$.

Geralmente ela carrega cerca de 80 quilos de materiais, mas diz que consegue carregar sozinha até 400 quilos. Costuma vender os materiais num depósito na Rua São Paulo. Diz que não gostaria de trabalhar em cooperativa por causa dos atrasos no pagamento. Acredita que o maior parte dos catadores que existe no centro estão sob os viadutos da Baixada do Glicério, pois somente no viaduto onde ela fica existem cerca de 60 pessoas.

\section{Os catadores Maristela e Marcos}

Maristela tem 32 anos, nasceu em Coaraci, na Bahia, e estudou até a $5^{3}$ série. Faz cerca de 7 anos que está no centro de São Paulo, ainda que há 4 anos tenha comprado uma casa em Guaianazes. Ela e o marido passam a semana no centro pois "não compensa" ir e voltar todos os dias para Guaianazes, por causa do gasto com a condução.

Relata que tem vários problemas de saúde, principalmente na coluna. Antes de ser catadora trabalhava como doméstica, nunca com registro em carteira. Faz mais de 10 anos que Maristela é catadora, dividindo o trabalho com o marido Marcos. Ele faz a coleta com o carrinho e ela faz a triagem do material. Marcos percorre ruas da República, 
Ipiranga, vai até o entorno do Shopping Higienópolis e na Rua Marconi, onde tem pontos fixos. A renda do casal gira em torno de $\mathrm{R} \$ 200,00$ por semana.

Eles vendem os materiais em dois comerciantes: no Carlinhos e no Itamar, localizados ali próximo, na Liberdade.

Conta que conhece as organizações dos catadores, como a rede CataSampa, da qual faz parte a CooperGlicério, que divide o espaço debaixo do viaduto com os catadores avulsos. Comenta que as cooperativas conseguem vender o material direto para a indústria com melhor preço. Dá como exemplo o caso do copinho plástico: o atravessador paga $R \$ 0,25$ enquanto a indústria paga $R \$ 0,70$. Além disso, tem benefícios como cesta-básica dos franciscanos. Porém, Maristela não quer trabalhar em cooperativa porque avalia que o pagamento atrasa muito. Eles têm uma filha de 6 anos que começou a estudar. Querem que a filha tenha uma vida melhor do que a deles.

\section{CATAdores no ItAim Paulista}

\section{O catador Sr. Cícero e sua família}

Sr. Cícero tem 44 anos. Ele, a mulher e dois filhos coletam as caixas de papelão que são dispensadas pelos feirantes, na feira de sábado no "centrinho" do Jd. das Oliveiras, Itaim Paulista. Encontrei-o por volta das 14:30 horas ajeitando as caixas que ele ia dobrando e guardando num carrinho, que já transbordava de material.

A mulher e os filhos vão trazendo os papelões da feira. O maior deles trabalha na feira, como ajudante numa das barracas e que isso facilitava bastante conseguir a doação dos materiais dos feirantes. Ele conta que tem um filho mais velho que é ajudante geral "pros lados da zona sul". Tem 20 anos, praticamente mora no trabalho, e de vez em quando aparece para visitá-los. Sr. Cícero conta que nasceu em Pernambuco, "no Recife". Vive em São Paulo a 31 anos, responde sem pestanejar, como quem conta cada ano vivido. Não tem escolaridade, conta que não sabe "nadinha", nem assinar o próprio nome.

Ele mora no Jd. Kemel, Itaim Paulista, num cômodo que divide com a família (a mulher e os 3 filhos) e pelo qual paga $R \$ 80,00$. "É baratinho, incluído água e luz". Ele explica que era $R \$ 70,00$, mas já passou para $R \$ 80,00$, demonstrando que a diferença de $\mathrm{R} \$ 10,00$ pesa para quem vive da catação.

Ao perguntar sobre a quanto tempo era catador, ele conta um pouco sobre sua trajetória. Trabalhou como tecelão com carteira assinada numa tecelagem de sacos de nylon em Itaquá; foi forneiro numa fábrica de panelas de alumínio em Ferraz; entre outras firmas, e por último, foi caseiro numa chácara em Itapevi. Depois teve "problemas com bebida" e perdeu todos seus documentos. Sabe que trabalhou, mas não sabe nada sobre seu FGTS, mas diz que vai "tirar um tempo" para ir ao Poupa Tempo ver se consegue alguma informação.

Começou na reciclagem quando voltou de Itapevi, cerca de 2 anos atrás, quando a família (um irmão) que vive no Jd. Kemel o acolheu quando passava com problemas de alcoolismo. Ele estava desempregado, não queria depender da família, então começou a ver que haviam pessoas "fazendo a reciclagem". Então também começou. Logo e a mulher souberam do cômodo para alugar e se mudaram com os filhos para lá.

Ele conta que começou a catar com uns sacos, com a ajuda dos filhos. Com o tempo fez um pequeno carrinho e depois um outro maior. Ele puxa o carrinho com a ajuda do filho maior, porque sofreu um acidente e sente muita dor na coluna. A carroça pesa cerca de $40 \mathrm{Kg}$, e eles transportam até $300 \mathrm{Kg}$. 
Em sua rotina diária, saem para a rua entre 4:00 horas a 5:00 horas e catam até por volta das 13:00 horas. $\mathrm{Na} 2^{\mathrm{a}}$ e $6^{a^{a}}$ feria eles catam em Poá, num bairro onde tem um "casões", onde as "madames" guardam material para eles. $\mathrm{Na} 3^{\mathrm{a}}$ feira percorrem ruas do Camargo, onde encontram bastante plástico. $\mathrm{Na} 4^{\mathrm{a}}$ e $5^{\mathrm{a}}$ eles andam pelo bairro mesmo, no Kemel e no Jd. das Oliveiras. A retirada diária é de $R \$ 20,00$ a $R \$ 30,00$, que corresponde à renda familiar (4 pessoas).

Ele faz questão de ressaltar que "os meninos vão para a escola", parecendo querer amenizar o fato de ter contado que eles também trabalhavam...

Por fim, explica que com o dinheiro que ganha ele paga o aluguel, o mercado e outras necessidades, como algum remédio. Mas já conseguiu comprar um "radinho" e mobília para a casa, citando o exemplo da compra de umas camas usadas. Ele avaliava que para quem, como ele, tinha chegado em São Paulo com "a roupa do corpo", as coisas já estavam bem melhores. A principal conquista como catador tinha sido a referida compra das camas, porque ele queria que "todos da família pudessem dormir em camas". Ele achava que tinha que gostar do que estava fazendo, pois ser catador era o que garantia o seu ganha pão.

\section{O Catador Sr. Romeu}

Romeu é um senhor com "jeito de gente do interior", pronto para uma "prosa". Natural do Paraná, tem 49 anos, é solteiro e possui o primário incompleto. Está a mais de 30 anos em São Paulo e mora no Conjunto Encosta Norte (CDHU), na casa de uma cunhada. Antes de ser catador, Romeu trabalhou como ajudante geral durante 10 anos com registro em carteira, mas seu último emprego foi numa fundição onde trabalhou durante 15 anos, mas conta que esta firma faliu e que ainda tem $R \$ 3.000,00$ para receber. Lembra-se que também trabalhou no Programa Frente de Trabalho numa escola, onde recebia $R \$ 220,00$. Romeu sobrevive da catação a 11 anos. Seu horário de trabalho na catação tem início às 4:30 e vai até 17:00 horas aproximadamente. Percorre as ruas de alguns bairros contíguos tais como: Jd. das Oliveiras, Pq. Sta. Amélia, conjuntos habitacionais do Encosta Norte, Camargo Novo e nas ruas próximas aos Hipermercados, em direção à divisa com o município de Itaquaquecetuba. Conta que ganha por dia cerca de $R \$ 10,00$ reais, sendo que a renda mensal não ultrapassa os $R \$ 400,00$. Mas relata que no mês anterior conseguiu ganhar $\mathrm{R} \$ 650,00$ pois obteve uma peça de cobre, que chega a $\mathrm{R} \$ 14,00$ o quilo. Esta é sua principal fonte de renda, mas também faz outros bicos, como ajudante geral. Para ele a melhor forma de conseguir melhores preços é levar o material ao comprador que pague mais. Conta que fez amizade com o dono de um depósito que oferece prêmios, como cestas básicas, aos catadores que cumprem metas, e que no final do ano passado ganhou um carrinho novo para fazer a coleta... Normalmente faz duas viagens, carregando cerca de 60 a 100 quilos em cada uma, no máximo 120 para não quebrar o carrinho, e recebe à vista. Diz que não gostaria de trabalhar em cooperativa, embora já tenha recebido proposta, pois não se identificou com a forma de trabalhar, e que a remuneração não compensa. Gosta da rua, de saber o que vai ganhar com seu próprio trabalho. Extrovertido, Romeu diz que faz amizades com facilidade e que muita gente o conhece e separa material para ele, nas escolas, na padaria, moradores, etc. Conclui dizendo que anda pelas ruas sempre muito atento em encontrar suas mercadoria...

\section{O catador Wilson Neves}

Wilson nasceu na cidade de Lins, interior de São Paulo, tem 45 anos, e estudou até a $7^{a}$ série. Está em São Paulo a 43 anos, sendo que ao longo da vida trabalhou em diversas atividades, como encanador, eletricista, com ferragens, forno de 
padaria (antigos) e também como pedreiro. Também trabalhou como montador de calçados com registro em carteira. Seu último emprego foi como faxineiro numa empresa que prestava serviço para a Prefeitura.

Há 5 anos tornou-se catador. Diz que faz horários picados, não tem horário certo. Cata pelas ruas do Camargo Novo, junta em casa e vende aos poucos, geralmente em dias alternados. Obtém cerca de $R \$ 80,00$ por mês, sendo esta sua única fonte de renda. Costuma levar até 80 quilos no carrinho, pois tem um problema na coluna após ter caído de um telhado quando trabalhava numa obra, um acidente de trabalho, quando era pedreiro, e pelo qual não recebeu indenização alguma.

\section{O catador Jorge Mota dos Santos}

Jorge nasceu em Itabuna, na Bahia, tem 43 anos e cursou apenas a $1^{\text {a }}$ série primária. Vive a 28 anos em São Paulo e reside hoje no Jd. Elza no Itaim Paulista, numa moradia própria da família. Diz que tem alguns problemas de saúde, "dos nervos", e que já passou em psicólogos para tentar se aposentar por invalidez. Solteiro, diz que não quer ficar dependente dos irmãos, que são em seis, todos casados.

Já trabalhou como ajudante geral em transportadoras localizadas em Guarulhos, na COSIPA e como faxineiro. Teve registros em carteira e também trabalhou como autônomo. Começou a catar no começo dos anos 80. Depois de fazer as contas, conclui que já são 20 anos como catador. Considera a catação um trabalho pesado pelo qual recebe uma "mixaria". Anda pelas ruas do Jd. das Oliveiras, do Encosta Norte, na Av. Itajuíbe e nas ruas próximas ao centro comercial do Itaim. Coleta principalmente garrafas de vidro e de plástico e também papelão. Conta que não consegue ganhar mais que $\mathrm{R} \$ 7,00$ por dia; está procurando outra alternativa, porque o trabalho com sucata está acabando com sua saúde. Diz que tem sorte de não ter uma família para sustentar.

O carrinho que Wilson usa é cedido pelo dono de um depósito. Neste carrinho ele carrega não mais que 70 quilos. Ao questioná-lo sobre o trabalho em cooperativa, Wilson responde que seria bom ter esta oportunidade porque nas ruas é cada vez maior a concorrência entre os catadores, porque tem muita gente desempregada, inclusive muitas mulheres que também catam usando carrinhos de feira.

\section{O catador Antônio Luiz Nunes}

Antônio tem 39 anos, nasceu em São Paulo e sempre viveu no Itaim Paulista. Reside atualmente no CDHU do Jd. Mabel. Estudou até a $5^{\mathrm{a}}$ série, e sempre trabalhou na informalidade, como pedreiro, confeiteiro, fazendo fachadas luminosas, entre outros "bicos". Sua última atividade antes de ser catador foi a de padeiro. Conta que desde os 8 anos de idade já acompanhava seu avô que recolhia materiais para vender no ferro-velho. Geralmente Antônio cata no horário das 8:00 às 17:00 horas, mas faz questão de lembrar que não tem horário certo, diferente de uma firma ou cooperativa onde tem que dar produção e exige muita quantidade de material. Por outro lado, observa que há muita gente pelas ruas catando, inclusive mulheres, crianças, com sacos, carrinhos de feira ou de mão (carrinho de pedreiro) e até de bicicleta. Em seu carrinho ele carrega de 80 a 100 quilos. Os principais materiais que coleta são papelão, plástico e PET, além de latinhas de alumínio.

Ele percorre ruas do conjunto habitacional Encosta Norte, indo em direção a Poá e Ferraz de Vasconcelos, de segunda-feira a domingo. Quando vai para estes municípios, costuma sair às 5:00 horas da manhã. Ele junta seu material e vende quinzenalmente, por $\mathrm{R} \$ 50,00$ a 60,00 reais, que somando dá uns $R \$ 120,00$ por mês. Existe também um caminhão que vai buscar seu material sempre que ele telefona avisando que já juntou um certo volume. Esta é sua principal fonte de renda, com a qual 
tenta ainda ajudar sua mãe, que é aposentada, e uma irmã. Conclui dizendo que pessoas como ele, que não tem estudo, o único recurso para sobreviver está sendo a reciclagem.

\section{O catador Daniel}

Daniel tem 26 anos, cursou até a $4^{a}$ série e nasceu em Biritiba Mirim, São Paulo. Mora no Jd. Camargo Novo, na casa própria de sua mãe. Conta que sempre viveu da sucata, porque seu padastro tinha uma depósito no Jd. Kemel, na divisa do Itaim Paulista com Ferraz de Vasconcelos. Ele declara carregar por volta de 100 quilos em cada viagem que faz com seu carrinho. Faz mais de 10 anos que está neste ramo, trabalhando de manhã até à noite, não tem horário certo. Ele costuma catar com seu carrinho pelas ruas do Kemel, do centro do Itaim e do Camargo Novo, ajuntando em casa, em bag's. Assim como já relatado pelo catador Antônio, ele também entra em contato com um depósito que manda um caminhão para retirar seu material. Explica que ajuda a carregar e descarregar o caminhão, depois o material é pesado no depósito e recebe então seu pagamento.

Diz que ganha entre $R \$ 200,00$ a $R \$ 300,00$ por mês, mas já chegou a ganhar $\mathrm{R} \$ 400,00$. Além de ser catador, também faz pequenos serviços como servente de pedreiro, limpeza de terreno, descarregar caminhão, etc. Ele é casado, sua esposa é costureira e eles tem 3 filhos. Mas na sua casa moram 13 pessoas da família.

Sobre o trabalho em cooperativa, diz que não se interessa porque a cooperativa "só quer saber do lado deles".

\section{O catador João José Ramos}

João tem 58 anos, nasceu em Rancharia no interior de São Paulo e cursou as séries iniciais do primário. Vive a 35 anos em São Paulo e reside no Jd. Mabel no Itaim Paulista. Ele é catador a 3 anos, e sempre foi carpinteiro, com registro em carteira e também trabalhando como temporário. Costuma percorrer as ruas do Jd. Mabel, do Jd. Nélia e Camargo Novo na parte da manhã, e seu percurso leva de 6 a 7 horas. Ganha em média uns $R \$ 10,00$ a $R \$ 15,00$ por dia. Esta é a renda principal com a qual vivem 3 pessoas. O principal tipo de material encontrado é plástico, que ele vende como plástico misto. Por ser pouca a quantidade, não dá para separar por tipos, o que daria uma renda maior pois a PET, por exemplo, é mais cara, mas acaba sendo vendida misturada com os outros tipos de plásticos mais baratos.

Conta que ele mesmo fez o carrinho, usando o casco de uma geladeira, no qual carrega cerca de 200 quilos. Não leva mais do que isto porque tem muita gente catando e o material acaba sendo pouco para tanta gente...

\section{O catador Ismael}

Ismael trabalha com catação a cerca de 1 (um) ano, no Jd. das Oliveiras e na Vila Itaim. Tem apenas 13 anos e cursa a $6^{\underline{a}}$ série. Está acompanhado de um irmão e uma irmã, que também são catadores e se encontram em outros pontos da mesma rua. Relata que sai todos os dias pela manhã para catar e vai à escola no período da tarde. Eles catam os materiais depositados nas calçadas antes do horário em que passa o caminhão da Prefeitura. Realizam uma primeira triagem na própria calçada, armazenando-os em sacos (bag's), enquanto aguardam um caminhão que vem recolhê-los. Ismael explica que o caminhão leva os materiais até um ferro-velho localizado no Jd. das Oliveiras, onde é feita a venda dos materiais. Ele explica que a venda é feita com o "caminhão fechado", quando já está cheio, pois com maior volume de material consegue-se um preço melhor. Ao ser interrogado sobre quanto ganhava pelo trabalho, ele indicou os irmãos mais velhos para responderem a pergunta. Ele diz que sonha em ser um professor de matemática. 
OBS.: Ismael é um dos catadores (entre menores e adultos) que trabalham num ferrovelho localizado na Vila Itaim. De lá sai um caminhão que os leva até um determinado local para realizarem a catação, neste caso no Jd. das Oliveiras. (Informação obtida com outros entrevistados, Josimara e Sr. Geraldo)

\section{A catadora Josimara}

Josimara é a irmã mais velha do catador Ismael, entrevistado anteriormente. Tem 24 anos e trabalha a cerca de três anos com reciclagem, catando nas ruas da Vila Mara e Vila Itaim (segunda-feira), do Jd. das Oliveiras (terças e quintas), e do Jd. Romano (quarta-feira). Seu primeiro emprego foi num restaurante em Sorocaba, onde viveu dos 10 até os 21 anos. Veio para São Paulo morar com o pai. Josimara relata que ela e os irmãos trabalham com o pai que tem um ferro-velho num terreno onde também moram. Ela diz que o pai trabalha com ferro-velho a cerca de 20 anos. Estudou até a $7^{a}$ série, mas parou porque começou a trabalhar o dia inteiro, na coleta e na separação dos materiais. Ela confirma a informação de que vendem o material para um outro ferro-velho localizado no Jd. das Oliveiras. Josimara diz que "está nesta vida", mas tem um sonho: voltar a trabalhar num restaurante, como garçonete.

\section{O catador Sr. Geraldo}

Encontramos Sr. Geraldo entrando em sua casa no bairro Jd. das Oliveira, carregando umas caixas de papelão cheias de recicláveis. Ao me aproximar, demonstra interesse em conversar. Ele conta que há 5 anos coleta materiais recicláveis para complementar a renda, uma pequena aposentadoria por invalidez, a qual divide com a mulher. Natural da Bahia, veio para São Paulo há 21 anos para cuidar da saúde, pois adoeceu trabalhando na roça.

Sempre viveu na zona leste, no Patriarca, na Vila Guilhermina Esperança e agora no Itaim Paulista. Estava a algum tempo vendendo bilhetes de loteria, quando viu o pessoal "fazendo a reciclagem". Começou com as garrafas PET's, para comprar o café da manhã. Depois começou a pegar também papelão, para um ferro-velho localizado na Av. Marechal Tito.

Os dias principais para sua coleta são às $3^{\mathrm{a}}, 5^{\mathrm{a}}$ e sábados antes do caminhão da coleta convencional passar, nas ruas próximas de sua casa. Sai às ruas antes da 6 horas da manhã, mas mesmo assim encontra pouco material. Ele conta sobre a existência de um caminhão que a cerca de 1 ano recolhe os recicláveis, carregando na carroceria umas 8 crianças e carrinhos. O caminhão deixa as crianças com os carrinhos, as quais saem catando pelas ruas, e depois de algumas horas o referido caminhão volta para pegá-las com o material já "separadinho" nos sacos (bags).

Sr. Geraldo estava se referindo aos catadores anteriormente entrevistados, Ismael e Josimara, que em seus relatos se referiram ao caminhão, mas de forma não muito clara. O depoimento de Sr. Geraldo nos ajudava a entender a situação daqueles entrevistados.

\section{Os catadores Sr. Marco Antônio e Sr. Rubens}

Marcos e Rubens são dois irmãos que trabalham com reciclagem a cerca de 2 anos. Possuem 42 e 49 anos respectivamente. Eles percorrem ruas no Itaim Paulista todos os dias, alternando os bairros de acordo com o cronograma do caminhão da coleta convencional de lixo da Prefeitura: na $2^{\mathrm{a}}$ feira catam na Vila Itaim; na $3^{\mathrm{a}}$ feira no Jd. das Oliveiras e à noite na Vila Nova Itaim, onde o caminhão passa à 1 hora da manhã; na $4^{a}$ feira vão para o Jd. Romano onde neste dia há feira nas ruas; e ao anoitecer vão para o 
centro do Itaim Paulista; no restante da semana, inclusive aos sábados e domingos, percorrem as ruas do Jd. das Oliveiras e Vila Odete em torno das feiras livres e nas imediações de Hipermercados. Fazem estes percursos a partir das 8:00 horas, e no período da noite não tem horário certo para retornarem.

Eles relatam que trabalharam com registro em carteira em algumas firmas. Sr. Marcos cita que trabalhou durante 12 anos na Camargo Corrêa, na construção civil, e mais 4 anos numa metalúrgica. Já Sr. Rubens relata que trabalhou 7 anos numa firma denominada Brasamita e mais 3 anos numa tecelagem em Itaquá no começo dos anos 90. Depois disso, foi só o desemprego: "o desemprego está demais, muito difícil a gente conseguir alguma coisa em outro ramo (referindo-se à reciclagem)". "Isso aqui é geral, no Parque Dom Pedro, aqui no Itaim, tem mulheres, senhores de idade, crianças", comenta Sr. Rubens.

O material coletado por eles é levado para venda num ferro-velho na Vila Itaim, localizada "pra baixo da linha do trem". Os dois irmão usam um único carrinho para os dois, e obtém juntos uma média de $R \$ 10,00$ a $R \$ 15,00$ por dia. Eles costumam almoçar no Restaurante popular "Bom Prato" localizado no centro do Itaim, onde a refeição custa $R \$ 1,00$. Comentam que outros catadores também almoçam lá. $E$ terminam dizendo que os catadores são "todos trabalhadores, homens de luta".

\section{O catador Sr. Pedro José do Rêgo}

Sr. Pedro, muito disposto a conversar, começa seu relato contando que tem muita gente desempregada. Faz 10 ano que ele é catador, e percebe que nos últimos 5 anos cresceu demais o número de catadores no Itaim. Como outros catadores, ele estabelece um roteiro de acordo com o cronograma da coleta convencional da Prefeitura, catando pelas ruas antes do caminhão passar. Ele coleta no Jd. das Oliveiras às $3^{\mathrm{a}}, 5^{\mathrm{a}} \mathrm{e}$ sábados; no Jd. Romano às $4^{\underline{a}}$ feiras; e costuma ir ao centro do Itaim Paulista à noite, após o horário de encerramento do comércio.

Ele trabalhou como metalúrgico de 1973 até o ano 2000. Não conseguiu se aposentar, pois trabalhou por 28 anos e agora está com 51 anos. Faltou-lhe apenas 2 anos para completar o tempo necessário para a aposentadoria, a qual espera conseguir quando completar 65 anos de idade.

Conta que também trabalhou 8 anos numa fundição, sem registro e em condições insalubres, e ainda como pedreiro, prensista e forneiro de metalúrgica.

Faz dez anos que, estando desempregado, trabalho com "bicos" na construção civil ("coisa pouca, que não leva mais de 15 dias") e com reciclagem. Começou a catar porque "viu a turma catando". Sua mulher foi a primeira que começou, com o lixo de casa e dos conhecidos, mas ele achava que aquilo não dava nada. Mas o dinheiro da reciclagem começou a ajudar, para os gastos que eles tem com um filho que tem meningite, muito doente. Ele diz que procurou ajuda na AACD, mas ele tinha que dar para aquela instituição cerca de $60 \%$ do que ganhava, sendo que ele pensava que a ajuda seria gratuita, mas não foi bem assim. Sem condições financeiras, eles levam o menino periodicamente ao Hospital das Clínicas.

Com a situação difícil da família, agravada com o problema de saúde do filho, Sr. Pedro tem como principal fonte de renda a catação, ganhando por volta de $R \$ 200,00$ por mês...

Consternado, diz que tem dias que pensa em não sair para catar. Mas daí ele ficaria parado, porque não há outra alternativa para trabalhar. Ao invés de ficar parado, ele prefere ganhar seus $\mathrm{R} \$ 10,00$ do dia de catação. Sr. Pedro costumava vender no depósito localizado no "centrinho" do Jd. das Oliveiras, mas como fica numa ladeira, ele não tem mais condições de levar até lá. Vende agora no ferro-velho do Km 28 (Av. 
Marechal Tito), pois mesmo pagando menos, vão buscar o material em sua casa. Assim, "devagar e sempre" ele continua na catação, enquanto "o corpo ajudar".

\section{O catador Sr. Orlando}

Encontramos Sr Orlando com um carrinho de pedreiro cheio de materiais recicláveis. Vive a cerca de 4 anos da catação, mas faz questão de contar sobre suas antigas profissões: encarregado de pintura, porteiro, cobrador de ônibus da Júlio Simões, pedreiro, serralheiro. Antes de começar a catar, procurou emprego nas Agências de emprego, mas só conseguia serviços temporários. Ele conta que perdeu os documentos, mas está tirando a $2^{\frac{a}{a}}$ via dos mais importantes, e faz questão de mostra a $2^{\frac{a}{a}}$ via da Certidão de Casamento.

Fazia uns 15 dias que estava morando no Jd. das Oliveiras. Antes ele estava em Arujá onde já catava, mas estava achando que no Itaim a catação era melhor (mais material). Conta que inclusive foi chamado para trabalhar na Cooperativa de reciclagem de Arujá, por ser um catador que conhece muito bem os materiais. Mas avaliou que era melhor trabalhar sozinho porque assim tinha dinheiro todos os dias.

Sr. Orlando, com um tom de voz enérgico diz que "ama a rua", pois ela é uma "caixinha de surpresas". Tem dias que ganha só $R \$ 10,00$, mas tem dias que tira $R \$ 30,00$. Então ele "vai andando", até arrumar outro emprego. 


\section{ANEXO 05 \\ Relatos de Projetos e Eventos no processo de organização da base da INDÚSTRIA DA RECICLAGEM}

\section{$5^{\circ}$ Festival Lixo e Cidadania}

Em agosto de 2006 aconteceu o Festival Lixo e Cidadania na cidade de Belo Horizonte, Minas Gerais, um evento de repercussão nacional, que reuniu entidades do Terceiro Setor, representantes de grandes empresas (como a Petrobrás), das diferentes esferas governamentais (inclusive com a presença de Ministros do Governo Federal, como a Ministra Marina Cintra do Ministério do Meio Ambiente), catadores de todo o Brasil, entre outros. Se por um lado, o Encontro do Fórum Lixo e Cidadania ocorrido em junho do mesmo ano na Baixada Santista apresentava a proposta de assessorar as prefeituras locais na gestão dos resíduos sólidos, de outro o Festival Lixo e Cidadania dava mostra de sua atuação em nível nacional.

O evento foi realizado pela Associação dos Catadores de Papel, Papelão e Material Reaproveitável de Belo Horizonte - Asmare, através do Insea - Instituto Nenuca de Desenvolvimento Sustentável, em parceria com os Fóruns Nacional e Estadual Lixo e Cidadania e a Rede de Economia Solidária.

O Centro de Referência em Reciclagem foi inaugurado durante o Festival pelo secretário Estadual de Meio Ambiente e Desenvolvimento Sustentável, José Carlos Carvalho. Segundo o secretário, "é um espaço onde será possível elaborar e implementar políticas públicas que realmente correspondam aos objetivos e metas do movimento Lixo \& Cidadania. A reciclagem será o ponto central para a mobilização da sociedade e discussão de temas ligados à educação, saúde e cidadania", ressaltou.

O Festival, que acontece anualmente, contou com o patrocínio e apoio de órgãos públicos, importantes empresas estatais e privadas, Institutos e ONG's, Universidades, Bancos e Pastorais da Igreja Católica, revelando uma complexa rede de articulação envolvendo sociedade civil organizada (representada sobretudo pelas ONG's e Institutos que atuam no Terceiro Setor da reciclagem e movimentos sociais vinculados), poder público (local e nacional) e setor privado (sobretudo Bancos e grandes empresas), tais como:

- $\quad$ Secretaria Municipal Adjunta de Assistência Social - Prefeitura de BH

- Secretaria de Estado de Meio Ambiente e Desenvolvimento Sustentável de Minas Gerais

- $\quad$ Secretaria Nacional de Saneamento Ambiental - Ministério das Cidades

- Ministério do Meio Ambiente

- Ministério do Desenvolvimento Social e Combate à Fome

- $\quad$ Ministério do Trabalho e Emprego

- $\quad$ Pastoral de Rua - Arquidiocese de Belo Horizonte

- Instituto Marista de Solidariedade

- $\quad$ CESE - Coordenadoria Econômica de Serviço

- $\quad$ CREA - MG

- Caixa Econômica Federal

- $\quad$ Fundação Banco do Brasil

- Petrobrás

- Natura 
- CWG - Collaborative Working Group on Solid Waste Management in Low - and Middle - income Countries

A abertura oficial do evento contou ainda com a presença dos Ministros Patrus Ananias, do Desenvolvimento Social e Combate à Fome, Luiz Marinho, do Trabalho e Emprego e Marina Silva, do Meio Ambiente. Além do prefeito de Belo Horizonte, Fernando Pimentel, e outras autoridades municipais como deputados e vereadores.

Durante o evento realizamos as seguintes atividades, cujos conteúdos apresentados serão transcritos das gravações realizadas:

1. levantamento de informações sobre projetos desenvolvidos no contexto da reciclagem em nível nacional, bem como sobre as políticas públicas que estão sendo elaboradas para este setor produtivo;

2. observações e entrevistas com lideranças do Movimento Nacional de Catadores de Materiais Recicláveis - MNCR, e representantes de ONG's que desenvolvem projetos e integram as ações do Terceiro Setor a respeito da reciclagem no país;

3. visitas técnicas abaixo listadas:

a) Unidade de Processamento de Plástico da Rede Metropolitana de Catadores Cataunidos e Insea.

b) Galpão da Asmare - Associação dos Catadores de Papel, Papelão e Material Reaproveitável de Belo Horizonte.

A seguir, apresentamos uma breve sistematização da pesquisa realizada, apontando alguns dos resultados alcançados com a realização deste Trabalho de Campo.

\section{O EVENTO}

Cerca de 400 lideranças do Movimento Nacional de Catadores de Materiais Recicláveis - MNCR, 100 líderes de outros movimentos sociais, 700 técnicos e representantes de países como Argentina, Colômbia, Uruguai, Índia e Egito discutiram durante o evento a elaboração e aprofundamento de políticas públicas, investimentos e estruturação do setor produtivo para a reciclagem no Brasil e em outros países do mundo.

As lideranças dos diferentes segmentos reunidos em torno do interesse pela reciclagem defenderam sobretudo a idéia de que a coleta seletiva com o trabalho organizado dos catadores contribui economicamente com o Estado, ao evitar gastos com mão-de-obra para a limpeza das vias públicas, ao mesmo tempo em que são importantes sob o ponto de vista ambiental. Segundo o organizador do evento e Coordenador de Projetos do Instituto Nenuca de Desenvolvimento Sustentável - Insea, José Aparecido Gonçalves:

Quando os catadores deixam de exercer suas funções, fica a cargo das prefeituras recolher o lixo espalhado pela cidade. Isso significa gastos com mão-de-obra, pois alguém vai ter que realizar o serviço. Mas o trabalho não contribui apenas economicamente. Ao se inserirem na coleta seletiva e nos processos de reciclagem, os catadores agem como agentes do meio ambiente, inclusive diminuindo o tempo de vida dos lixões.

Gonçalves defende o reconhecimento dos catadores como agentes ambientais. "Esse reconhecimento valoriza o trabalho do catador e ajuda a incluí-lo na sociedade. Nos últimos anos o grupo passou a ser reconhecido - são trabalhadores, não mais mendigos", comenta. 
"Geração de trabalho e renda" - não se trata de empregos. Esta é a perspectiva das discussões e trabalhos para construção de políticas públicas para a reciclagem com a participação do trabalho dos catadores, os quais devem estar organizados em cooperativas. Sobre esta questão, há um certo consenso expresso nos depoimentos dos representantes do poder público, iniciativa privada, Terceiro Setor e catadores.

Todos os segmentos que participam da estruturação de cadeias produtivas no setor da reciclagem defendem vantagens - ainda que de naturezas distintas, para não colocar em pauta o termo " emprego".

Para os "gerenciadores" dos resíduos sólidos, dos negócios e investimentos no setor da reciclagem (poder público, iniciativa privada, terceiro setor), as cooperativas de catadores cumprem uma importante etapa no atual arranjo das cadeias produtivas. Assim, a organização de cooperativas de catadores é geralmente apresentada como pauta das políticas de "geração de trabalho e renda", endossadas também pelas questões de ordem ambiental (gestão de resíduos, educação ambiental, problemática de lixões e aterros sanitários, gestão de recursos hídricos, entre outros).

Apresentamos abaixo alguns dos argumentos que pudemos apreender no conjunto das exposições do evento, mas nem sempre de forma explícita, sobre as "vantagens" de inclusão de cooperativas de catadores na coleta seletiva, no conjunto das políticas públicas para gestão dos resíduos sólidos:

- absorção de um grande contingente de desempregados, considerados "sobrantes" na atual reestruturação produtiva, em sua maioria sem qualificação profissional, presentes sobretudo nas grandes cidades onde também se concentra a geração de lixo.

- novos arranjos legais que fortalecem um novo cooperativismo coerente com as reformas trabalhistas em curso, existindo hoje uma complexa realidade que abrange desde experiências inovadoras pontuais até as chamadas "coopergatos", que sob o rótulo do cooperativismo escondem relações de trabalho escravo.

- baixo custo dos investimentos em infra-estrutura para o funcionamento das cooperativas: estas geralmente começam com instrumentos de trabalho precários, improvisados: carrinhos puxados a tração humana, mesas que substituem a esteira para triagem dos materiais, galões utilizados como segregadores de materiais, prensas de porte pequeno movidos a tração humana, entre outros;

- para o aperfeiçoamento do trabalho nas cooperativas são lançados programas de investimentos em projetos sócio-ambientais, como é o caso da Petrobrás e da Fundação Banco do Brasil, além de linhas de micro-crédito, como ocorre com a Caixa Econômica Federal. A isenção de impostos e o abatimento de multas ambientais são algumas das vantagens obtidas em função da promoção de projetos que organizam cooperativas de catadores, cumprindo requisitos da Responsabilidade Social (ISO26000) e Ambiental (ISO14000) das Empresas.

- ONG's, Institutos e "empresas" que atuam no Terceiro Setor têm na organização de cooperativas uma vasta frente de empreendimentos com a geração de empregos qualificados (formação de um quadro diversificado de técnicos e educadores) que contam com a captação de recursos públicos e privados a serem investidos em atividades que vão da capacitação do catador ao gerenciamento completo dos negócios em reciclagem (como pudemos constatar com o caso da Unidade de Processamento de Plástico da Rede Cata-Unidos, a ser apresentado posteriormente); A indústria que compra materiais recicláveis das cooperativas de catadores além de adquirirem material em quantidade desejada e melhor qualidade do que os existentes nos ramos de sucata e depósitos de materiais recicláveis, podem adquirir selos de qualidade ambiental da linha ISO14000 (ao participarem do processo de reciclagem 
de resíduos sólidos, contribuindo para a preservação de fontes primárias de matériasprimas tais como a celulose - alternativa bastante lucrativa, além de colaborarem com a gestão dos resíduos sólidos frente ao esgotamento e encarecimento dos aterros sanitários, etc.), e o novo selo de Responsabilidade Social ISO26000, em função de promoverem, com a compra dos materiais das cooperativas, a "inclusão social" dos catadores na Economia Solidária, etc.

- É o perfil de uma nova indústria limpa, cujos atributos de competitividade incluem: novas bases de aquisição de matérias-primas, uma vez que os elementos físiconaturais presentes nos materiais recicláveis estão em melhores condições de serem processados do que aqueles explorados diretamente na natureza (objeto de preocupações generalizadas com relação ao esgotamento dos recursos), o que proporciona economias de diversas grandezas; nova organização do trabalho, com unidades produtivas industriais enxutas, detentora de tecnologia moderna (tais como a Tetra Pak que utiliza a tecnologia Plasma de separação do alumínio do plástico e papelão que compõem suas embalagens), com quadro reduzido de funcionários, responsáveis pelo processamento da reciclagem propriamente dita e tendo, contudo, em sua base uma ampla rede de cooperativas de catadores, trabalhadores indiretos, não-assalariados, desta nova indústria.

- trabalho não pago realizado pelo catador: o preço dos materiais recicláveis é ditado por um mercado formado pelo próprio setor indústrial que compra os recicláveis como matéria-prima, pagando pelo preço do material e não pelo trabalho dos catadores, o qual inclui coleta, transporte, triagem, prensagem e enfardamento, além de outras atividades.

Ainda durante o evento foi apresentado o $2^{\circ}$ Censo da População de Rua de Belo Horizonte, que revela o perfil do morador de rua da capital mineira. A pesquisa foi realizada, em parceria com a Prefeitura de Belo Horizonte, Ministério do Desenvolvimento Social e Combate à Fome, Fórum de População de Rua de $\mathrm{BH}$, Pró-Reitoria de Extensão da PUC/MG e o Instituto Nenuca de Desenvolvimento Sustentável (Insea). A pesquisa revelou que a população de rua de $\mathrm{BH}$ é de 1.164 pessoas, majoritariamente masculina $(79,7 \%)$, vem do interior de Minas Gerais $(41,2 \%)$ e de outros estados $(21,9 \%)$ a procura de emprego ou acompanhando parentes. A idade predominante está entre 25 e 40 anos (35\%), mas a população de rua está envelhecendo, segundo a pesquisa. Cabe ressaltar que parcela majoritária dos catadores, principalmente aqueles que não estão organizados em cooperativas, fazem parte da população de rua.

Outro momento importante do Festival foi a realização do Encontro Nacional Construindo Políticas Públicas para Recuperação e Reciclagem de Resíduos Sólidos com Inclusão dos Catadores, organizado pelo Instituto Pólis, e que teve apoio da Fundação Avina, da Cia. Suzano Papel e Celulose e da Ambividro.

Os resultados de uma pesquisa realizada no primeiro semestre do ano pelo Pólis foram apresentados no Encontro. Trata-se de um mapeamento de Belo Horizonte, Londrina e Porto Alegre, quanto aos avanços, dificuldades e desafios do poder público e dos catadores de recicláveis em relação a consolidação de políticas de reciclagem. Participaram representantes do Movimento Nacional de Catadores de Materiais Recicláveis - MNCR, do poder público municipal, estadual e federal, de ONG's, de instituições de ensino e pesquisa e representantes da indústria de plástico e de vidro. Elizabeth Grimberg, coordenadora da área de Ambiente Urbano do Pólis e organizadora do evento declarou que em breve será lançado um documento com a sistematização dos conteúdos e propostas discutidos no encontro. 


\section{ANEXO 06 \\ Associação dos Catadores de Papel, Papelão e Materiais Reaproveitáveis ASMARE}

Fundada em 1990, a Asmare - Associação dos Catadores de Papel, Papelão e Material Reaproveitável, tem sido citada como uma experiência bem sucedida que garante a renda de cerca de 300 famílias de catadores e que está sendo ampliada através da ação do Insea para outros municípios do Brasil.

Com a justificativa de necessidade de qualificação técnica na ação junto aos catadores e moradores de rua, a Pastoral constituiu uma parceria com técnicos criando o Insea para atuar na sustentabilidade dos projetos e na formação e capacitação dos envolvidos no processo. Trata-se de uma organização não governamental de âmbito nacional, constituída em 2001 e voltada para a assessoria técnica e parceria junto a grupos comunitários, empresas, ONGs e à Administração Pública na criação e no desenvolvimento de modelos de gestão ambiental.

Em conversa com técnicos do Insea, obtivemos alguns esclarecimentos sobre sua criação, a qual se fundamentou na necessidade de uma forma jurídica que permitisse a captação de recurso para o desenvolvimento de projetos, o que não era compatível com uma instituição filantrópica, como a Pastoral de Rua.

Assim, a atuação do Insea pode se dar de diversas formas: convênios e contratos, assessoria e consultoria, estudo e pesquisa, capacitação e formação, eventos sociais, culturais, técnicos e científicos, sistematização e publicação de materiais didáticos e informativos e fundos rotativos.

Como exemplo da atuação do Insea no contexto da reciclagem e do trabalho dos catadores citamos o Programa de Mobilização e Capacitação de Catadores de Materiais Recicláveis.

O projeto tem como pressuposto a ampliação do trabalho da equipe do Insea que tem a Asmare como modelo, para mais seis cidades de Minas Gerais (Rio Piracicaba, Bela Vista de Minas, João Monlevade, Ponte Nova, Bocaiúva e Itabirito), visando a formação e capacitação dos agentes, técnicos, catadores e lideranças populares, segundo a metodologia desenvolvida e sistematizada por estes profissionais. Outro objetivo é a implantação do Programa Lixo \& Cidadania através da coleta seletiva com inclusão social dos catadores de materiais recicláveis.

A disseminação da "metodologia", em articulação com a Rede de Economia Solidária nos municípios mineiros visou a implantação da primeira Unidade de Beneficiamento do Plástico e a consolidação do projeto de organização dos catadores e implantação da Coleta Seletiva em 14 municípios.

O projeto é financiado com recursos da IAF - Fundação Interamericana, um órgão independente do governo dos Estados Unidos que financia organizações nãogovernamentais e de base comunitária da América Latina e do Caribe. A Fundação investe primordialmente em organizações de base e sem fins lucrativos, empresas e governos locais. Desde a sua fundação em 1969, a Fundação Interamericana já concedeu 4.578 doações de valor superior a US $\$ 586$ milhões. O Congresso dos Estados Unidos destina anualmente fundos à Fundação Interamericana. Por lei, a Fundação também tem acesso ao Fundo Fiduciário de Progresso Social administrado pelo Banco Interamericano. Esse Fundo é constituído pelos pagamentos de empréstimos que o Governo dos EUA concedeu originalmente no âmbito da Aliança para o Progresso a vários governos da América Latina e do Caribe.

Outro exemplo da captação de recursos se deu com a Fundação Banco do Brasil. Nos moldes em que são realizadas franquias comerciais em geral, a Fundação Banco do Brasil franqueou a experiência da Asmare. 
Segundo Célio José Alencar, assessor pleno da Fundação Banco do Brasil, a infra-estrutura básica de uma cooperativa de catadores de papel é formada pelo barracão de armazenagem, prensas, balanças e material para proteção dos catadores durante 0 manuseio dos resíduos. A Fundação Banco do Brasil investe na compra desses equipamentos e também de extrusoras de plástico (máquinas especiais para cortar) e trituradores de papel. Máquinas que agregam um valor maior ao produto.

A atuação da Fundação Banco do Brasil em financiamento de projetos de reciclagem começou em 2001 quando a Asmare, via Insea, se inscreveu no Prêmio Fundação Banco do Brasil de Tecnologia Social.

Desde então, a Fundação já investiu em mais de 70 projetos de incentivo a associações e cooperativas de catadores de materiais recicláveis. Projetos pilotos estão sendo desenvolvidos em Fortaleza, João Pessoa e Porto Velho, como reaplicação da tecnologia social desenvolvida com a Asmare.

\section{O Galpão de Triagem da Asmare}

O Festival Lixo e Cidadania, realizado com recursos oriundos dos financiamentos obtidos pelo Insea e pelas parcerias firmadas com diversas instituições públicas e privadas, anuncia a existência de um exemplo a ser admirado e seguido em termos de cooperativa de catadores: a Asmare.

O próprio Secretário de Estado de Meio Ambiente e Desenvolvimento Sustentável de Minas Gerais, na abertura do Seminário Lixo e Cidadania ocorrido na Assembléia Legislativa de Minas Gerais em novembro de 2005 declara em entrevista publicada na Revista lançada sobre o evento:

Minas tem o exemplo da Asmare, que seguramente pode ser noticiado como um dos mais belos trabalhos de enfrentamento da questão do lixo em países com as características socioeconomicas e ambientais do Brasil.

Entretanto, o que pudemos encontrar no Galpão da Asmare foi algo dramático. Nada diferente do que já vimos em associações e cooperativas de catadores em São Paulo: homens e mulheres em condições precárias de trabalho, sem Equipamentos de Proteção Individual - EPI's (luvas, botas, máscara, etc.), que se utilizam de carrinhos puxados a tração humana, trabalham extensivas horas na separação do material a ser prensado por um outro grupo de catadores que trabalham internamente noutra unidade da Asmare.

Em conversa com alguns dos catadores que estavam no Galpão, todos demonstravam aspectos de descontentamento ou indiferença com relação ao seu envolvimento com a Asmare.

Questionados sobre as diferenças entre trabalhar na Asmare e em outros lugares, citaram que era praticamente a mesma coisa:

- percorrem as ruas do centro de Belo Horizonte puxando os carrinhos da Associação;

- cada catador tem locais fixos para coleta de materiais para reciclagem;

- levam o material coletado para o Galpão, onde o separam para prensagem e pesagem.

- ganham semanalmente pelo material pesado, segundo o preço de mercado (igual ao que encontram em sucateiros e ferros-velhos)

Ainda assim, citaram algumas diferenças em ser um catador da Asmare, tais como:

- $\quad$ recebem vale-transporte; 


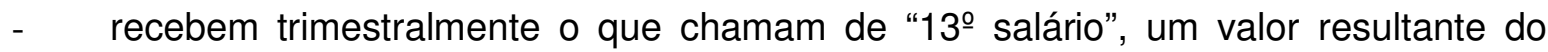
excedente obtido com a venda coletiva de todo o material da Asmare para os grandes compradores, tais como as indústrias que reciclam.

- $\quad$ possuem carteirinha de identificação de associado da Asmare.

- $\quad$ No Galpão possuem baias onde de 1 a 3 catadores, geralmente da mesma família, armazenam e separam seu material individual (ou familiar).

A renda média individual está pouco abaixo do salário mínimo, o mesmo valor do denominado "13ํㅗㄴ saláro".

Questionados sobre o que seria mais importante para uma melhoria nas condições de trabalho citaram a necessidade de um Plano de Saúde, e demonstraram indignação pelo fato da Asmare possuir um Seguro de Vida (o que indica a incidência de casos de morte neste tipo de trabalho) em detrimento do Plano de Saúde.

O Galpão está situado numa das vias principais de Belo Horizonte, na Av. do Contorno, contígua ao centro de Belo Horizonte. Na calçada do Galpão podemos ver inúmeros carrinhos que são utilizados pelos catadores para o transporte dos materiais, além de caminhões de diversas procedências que chegam e partem com materiais recicláveis. Do outro lado da mesma Avenida está o Reciclo. Uma espécie de Centro Cultural com bar e palco para apresentações no térreo e sala para reuniões, bazar e administração no andar superior. Pelo que pudemos constatar, trata-se de um espaço mais usado pelos técnicos do que pelos catadores, os quais podem aí realizar cursos de capacitação, artesanato, etc.

A visita foi acompanhada por técnicos do Insea e por Dona Geralda, uma das principais lideranças associadas da Asmare, cuja apresentação foi intermediada pelos técnicos. Embora afirme ser uma catadora, que ainda puxa seu carrinho e separa seus materiais, Dona Geralda já se encontra bastante envolvida nos discursos e práticas daqueles que "apresentam a Asmare como cooperativa modelo" e portanto seu depoimento e condição social diverge um tanto daqueles catadores que trabalham no Galpão...

A ASMARE, localizada na região central de Belo Horizonte, opera com cerca de 450 toneladas de resíduos sólidos por mês, coletada em sua grande maioria por carrinheiros a ela vinculados, sendo em parte procedente de grandes geradores (doadores) tais como as empresas Belco, Semp Toshiba, Banco do Brasil, Banco Real e Shoppings, cobrindo o setor centro-sul da cidade.

A proposta é de que fábrica para processamento de plástico iria funcionar como cooperativa, enquanto a ASMARE seria mantida como Associação, com cerca de 250 associados. Para o funcionamento da fábrica, haveria o envolvimento de 8 municípios da Região Metropolitana de Belo Horizonte que formariam "uma rede de coleta e beneficiamento do plástico" - a Rede Cataunidos, mesma denominação dada à cooperativa da fábrica.

A ASMARE seria uma das entidades participantes da Rede, as quais investiriam $10 \%$ dos ganhos num fundo da cooperativa por eles formada, cujo lucro seria dividido no final do ano entre as cooperativa, na forma de "participação nos lucros".

Foi feito um estudo sobre qual produto seria mais viável para a instalação de uma linha de processamento, cuja base estava no tipo de material que a Rede captava com mais abundância e cuja tecnologia fosse mais acessível. Assim, o plástico foi apontado como o material a ser beneficiado, pois além da disponibilidade desta matériaprima coletada pelos catadores, havia uma boa estabilidade do preço deste material no mercado.

Dona Geralda, representante dos catadores da ASMARE, mas claramente "orientada" pelas entidades do Terceiro Setor gestoras da Associação, tenta explicar, de forma uma tanto confusa: 
"A indústria é dos catadores, eles são os fornecedores. Cada um coleta, separa, pesa e vende para a ASMARE ${ }^{36}$, recebe por semana após pesar 0 material toda 6 feira".

A visita é feita num dos Galpões da ASMARE, onde acontece a entrada do material por inúmeros carrinheiros, cada qual depositando o material coletado no seu respectivo "box". Neste "box", o próprio catador tria o material coletado ou então a triagem é feita por outro catador, geralmente um parente próximo. O material separado, pesado e pago $^{37}$ ao catador é encaminhado a outro Galpão da Asmare, onde é prensado e finalmente vendido. Neste galpão haviam outros triadores que faziam uma separação mais detalhada do material e também prensistas.

Amauri "Paulista", um dos catadores que estavam no Galpão no momento da visita, conta que vendeu ${ }^{38}$ cerca de 12 toneladas de materiais recicláveis para a Asmare num período de 3 meses, resultando numa média de 4 toneladas por mês, pelas quais recebia, também em média, $R \$ 320,00$. Ele explica que após a venda final do material feita pela Asmare (pós acumulo de material e beneficiamento do mesmo), os carrinheiros recebiam outro pagamento de mesmo valor, de 3 em 3 meses. "É uma espécie de $13^{\circ}$ salário, só que é de 3 em 3 meses". Havia a expectativa de que com a entrada da Asmare na Rede Cata Unidos, criada para coletar material para a fábrica de plásticos, os catadores iriam começar a recolher o INSS.

\footnotetext{
${ }^{36}$ Grifo nosso.

${ }^{37}$ Idem.

38 Ibidem.
} 


\section{A Fábrica de Plásticos da Rede Cataunidos/Insea (cont. ANEXO 06)}

A Unidade de Processamento de Plástico - Cataunidos/Insea foi inaugurada durante o IV Festival Lixo e Cidadania de 2005, e encontra-se em fase de liberação legal para funcionamento. Está instalada num terreno municipal no bairro Juliana, periferia de Belo Horizonte, cujo espaço foi concedido pela prefeitura após uma negociação entre Insea e Associação de moradores do bairro, a qual previa a construção de uma escola ou creche na área. A contrapartida para sua construção foi a garantia de que a Unidade empregará trabalhadores do bairro em seus diversos cargos.

A infra-estrutura da Unidade foi adquirida com investimentos proveniente de projetos apresentados à Fundação Banco do Brasil, Brasil Previ e Ministério do Trabalho, num montante de cerca de $\mathrm{R} \$ 4$ milhões. Entre seus maquinários estão uma esteira industrial para triagem do material, moinho para uma primeira moagem do plástico, lavadora e 3 secadoras do plástico triturado (flackes), silos, aglutinador, estrusora e picotadeira. O produto final é no formato de pellets, matéria-prima resultante do plástico processado. A Unidade também possui uma Estação de Tratamento de Efluentes.

José Aparecido Gonçalves, coordenador técnico do Instituto Nenuca de Desenvolvimento Sustentável - Insea, entidade responsável pelo projeto, explica que a indústria de reciclagem comprova a viabilidade destes programas que promovem a coleta seletiva com a inclusão do trabalho do catador, permitindo vislumbrar o domínio da cadeia produtiva pelos mesmos.

Em 2002 a Asmare, via Insea, conseguiu numa parceria com a Fundação Interamericana um Estudo de viabilidade econômica para o empreendimento. A pesquisa foi realizada junto a oito entidades (cooperativas/associações) objetivando a formação de uma rede de fornecedores de material para processamento na fábrica (a Rede Cataunidos) e verificar a capacidade de produção, o nível de parceria com o poder público, a viabilidade econômica do projeto e também o impacto do produto no mercado.

De acordo com Gonçalves, a partir do referido Estudo foi constatado que o plástico seria o material com mais aceitação e ascensão comercial. A partir daí, o grupo conquistou as demais parcerias citadas para a construção da indústria.

Além da parceria para a realização do referido estudo, o projeto contou ainda com o financiamento da Petrobrás para a aquisição de caminhão, equipamentos e cursos de capacitação para as Associação da Rede Cataunidos.

Assim, a Unidade Industrial - cujo projeto se insere na Rede de Economia Solidária, agrega sete associações e uma cooperativa de catadores de diferentes municípios de Minas Gerais, denominada Cataunidos. Esta rede fornecerá o plástico para ser reciclado na nova fábrica, que, num primeiro momento produzirá plástico granulado para ser vendido às indústrias como matéria-prima para a fabricação de baldes, cabides, garrafas de água sanitária, conduítes e acessórios para automóveis.

As entidades envolvidas na rede Cataunidos são:

- Associação dos Catadores de Papel, Papelão e Material Reaproveitável de Belo Horizonte (Asmare);

- Associação dos Catadores de Papel, Papelão e Materiais Reaproveitáveis de Betim (ASCAPEL);

- $\quad$ Associação dos Catadores Parceiros do meio Ambiente de Igarapé (APAIG);

- Associação dos Catadores de Materiais Recicláveis de Nova Lima (ASCAP);

- Associação dos Catadores de Materiais Recicláveis de Pará de Minas (ASCAMP);

- Associação dos Catadores de Materiais Recicláveis de Contagem (ASMAC);

- Cooperativa de Reciclagem e Trabalho de Itaúna (COOPERT);

- $\quad$ Associação dos Catadores do Vale do Paraopeba, em Brumadinho (ASCAVAP). 
Na Unidade serão recicladas mais de 3.600 toneladas de plástico por ano. Atualmente, a rede de fornecedores de plástico para reciclagem conta com a participação de cerca de 550 catadores. Só a Asmare, por exemplo, recolhe por mês cerca de 450 toneladas de lixo contendo papel, papelão, revistas, jornais, latas de alumínio, garrafas PET e plásticos.

A proposta, segundo o coordenador técnico, é que os catadores, que já têm essa alternativa de trabalho e renda, agreguem valor ao material e rompam com a cadeia de atravessadores que existe hoje. Isso porque, agora, além de recolherem o material, eles poderão industrializá-lo também. Com esse novo procedimento, terá um aumento de $100 \%$ a $150 \%$ no valor do material e os catadores poderão até dobrar a sua renda que, em média, é de um salário mínimo e meio. O grupo irá ainda capacitar 35 pessoas da comunidade local que estão desempregadas para atuarem na indústria. "O lucro será investido em novos projetos sociais. Cria-se, portanto, uma rede de reinserção social", comenta Gonçalves.

O terreno público no qual a fábrica foi construída, localizado num bairro da periferia de Belo Horizonte, era requisitado pela população local para a construção de algum equipamento público, como uma creche ou posto de saúde. A notícia de que ali seria construída uma fábrica, causou a mobilização da associação de moradores que acabaram "aceitando" a fábrica, desde que fosse garantida uma cota de $30 \%$ dos postos de trabalho para moradores do bairro.

A engenheira consultora do Insea que acompanhava a visita explicava que seriam formados quatro bons triadores, pois era preciso formar pellets de boa qualidade. Ela explicou que cada Associação da Rede triava de um jeito diferente, mas havia a necessidade de todo o material passar por uma triagem rigorosa dentro da fábrica, para atender as exigências das indústrias compradoras da matéria-prima.

Assim, os benefícios apontados eram: o envolvimento das oito Associações, atingindo mais de 500 catadores da Região Metropolitana de Belo Horizonte; a organização da Rede Cataunidos, cuja logística de funcionamento visada integrar territorialmente os fluxos de materiais com caminhões da própria Rede, superando o problema da distância entre as Associações participantes de cada município; a parceria com o poder público, e o incremento da coleta seletiva solidária naqueles municípios da Região Metropolitana de Belo Horizonte.

Os catadores terão um acompanhamento constante de uma equipe técnica especializada. A administração da Rede de Economia Solidária - Unidade Industrial é formada por um colegiado composto por dois representantes de cada uma das oito organizações de catadores e dois representantes das prefeituras, além dos técnicos do Insea.

Dos lucros a serem obtidos, 50\% serão reinvestidos na própria fábrica, 30\% ficarão para os cooperados e $20 \%$ serão direcionados para projetos sociais a serem desenvolvidos pelo Insea nos municípios envolvidos.

Estas informações foram obtidas em visita à Unidade, fornecidas por técnicos e catadores participantes do Projeto. Algumas reflexões ficaram das observações feitas. Os catadores que participaram da apresentação da fábrica não demonstraram possuir conhecimento ou entendimento suficiente sobre o funcionamento da Unidade, menos ainda sobre a complexa logística envolvida. Em diversas ocasiões quando foram interrogados, solicitaram respostas dos técnicos presentes, os quais além de apresentarem muita clareza sobre o empreendimento, consideram-no um "ótimo negócio" pois além de todas as vantagem já apresentadas, o fato de tratar-se de um empreendimento social acabava por atrair o interesse dos potenciais compradores da matéria-prima a ser produzida. Além do que, pretendem contar com o fornecimento 
exclusiva do plástico obtido pela Rede Cataunidos e já pensam num próximo projeto, com uma linha para processamento do plástico no formato PET.

Os técnicos do Insea e os catadores da Rede Cataunidos proclamam a Unidade de Processamento de Plástico como um importante passo para o domínio da cadeia produtiva pelos catadores. Entretanto, não pudemos ainda encontrar fundamentos concretos com relação a este discurso. Os catadores, principalmente aqueles que trabalham em situação dramática no Galpão da Asmare (assim como deve ocorrer nas demais associações que compõem a Rede Cataunidos se considerarmos que a Asmare é o "caso modelo"), parecem por demais distantes do proclamado domínio da cadeia produtiva... A intermediação das instituições do Terceiro Setor parece se encontrar no caminho desta anunciada, ou suposta, conquista, seja para conduzir o processo de forma a realizar o que já afirmam em seus discursos, seja para desvirtuá-la no processo de estruturação desta cadeia produtiva... 


\section{ANEXO 07 - Projeto Ações de desenvolvimento social junto aos catadores de materiais recicláveis - Parceria OAF-MDS-MNCR}

Apresentamos aqui algumas informações sobre o Projeto Ações de desenvolvimento social junto aos catadores de materiais recicláveis, apresentado pela Organização de Auxílio Fraterno (OAF) ao Ministério do Desenvolvimento Social e Combate à Fome - MDS. Os dados do referido convênio estão sintetizados no quadro abaixo:

\begin{tabular}{|l|l|}
\hline Convênio & $002 / 04$ \\
\hline Vigência & $15.12 .2004 / 15.12 .2005$ \\
\hline Processo & $71000.006258 / 2004-08$ \\
\hline Convenente & ORGANIZAÇÂO DE AUXILIO FRATERNO - OAF \\
\hline Secretaria Responsável & SNAS / MDS \\
\hline Objeto & Ações de desenvolvimento social junto aos catadores de materiais recicláveis. \\
\hline Valor Total R\$ & $1.379 .000,00$ \\
\hline
\end{tabular}

Fonte: Relatório de auditoria n.160197 da Controladoria-Geral da União. 29.05.2005. p.20 e

http://www.cgu.gov.br/sfc/convenio/convenios.asp

O Projeto Ações de desenvolvimento social junto aos catadores de materiais recicláveis se insere no processo de organização da base da indústria da reciclagem, caracterizando como integrante do conjunto de políticas públicas destinadas à estruturação da indústria da reciclagem. Este Projeto também se enquadra na forma predominantemente adotada nas referidas políticas públicas, sendo executadas por Parcerias Público-Privadas, com plena participação das Organizações Sociais do Terceiro Setor, que atuam no âmbito da reciclagem. Embora o Projeto seja apresentado como sendo do Movimento Nacional de Materiais Recicláveis, o mesmo é integralmente gerenciado pelas ONG's nele envolvidas. Como podemos observar, somente neste Projeto foram mobilizados mais de 1 milhão de reais, demonstrando que estamos diante de um processo em pleno desenvolvimento, direcionado à organização da base desta nova indústria em processo de estruturação, adotando-se o modelo de cooperativas.

Além da Organização de Auxílio Fraterno, a Fundação Avina também atuou neste Projeto, dividindo as etapas e produtos a serem alcançados, de acordo com Metas, estabelecidas e devidamente contabilizadas, conforme apresentamos no Quadro a seguir: 


\title{
Quadro: Metas e orçamento do Projeto - Parceria OAF-MDS-MNCR (2005)
}

\author{
Meta 1 - Fortalecimento da Secretaria Nacional (contrapartida MDS) \\ Locação espaço físico - $R \$ 1500,00$ - total $R \$ 18.000,00$ \\ agua, luz, telefone, materiais - $R \$ 1.000,00$ - total $R \$ 12.000,00$ \\ Viagens para lideres AVINA - total $\mathrm{R} \$ 8.400,00$ \\ Meta 2 - Encontro Nacional de 750 lideranças do MNCR \\ Hospedagem - $R \$ 20,00 \times 6$ dias - total $R \$ 90.000,00$ \\ Deslocamento - 23 ônibus a $R \$ 5.500,00$ - total $R \$ 176.500,00$ \\ Alimentação - total $\mathrm{R} \$ 81.000,00$ \\ Meta 3 - Implantação Piloto Selo Amigo do Catador \\ Cadastramento - R $\$ 20.000,00$ \\ Confecção de Placas - $R \$ 400,00 \times 250$ - total $R \$ 10.000,00$ \\ Evento Lançamento do Selo - $\mathrm{R} \$ 20.000,00$ \\ Meta 4 - Produção de 3.000 Kits didáticos \\ Folder do Movimento - total $\mathrm{R} \$ 12.000,00$ \\ Manual Amigo do catador - total $\mathrm{R} \$ 21.000,00$ \\ Carta de Princípios do Movimento - total $\mathrm{R} \$ 1.500,00$ \\ Cartilha - O Catador na Classificação Brasileira de Ocupações $\mathrm{R} \$ 18.500,00$ \\ Vídeo - total $R \$ 32.800$ \\ $C D$ - total $R \$ 19.500,00$ \\ Pasta - total R $\$ 18.000,00$ \\ Meta 5 - 2 Encontros da Comissão Nacional - total $\mathrm{R} \$ 25.000,00$ \\ Meta 6 - 6 Encontros da Equipe de Articulação - total $R \$ 64.000,00$ \\ Meta 7 - Pesquisa do Custo do Posto de Trabalho \\ 1 coordenador, 4 pesquisadores, 12 passagens aéreas, material de \\ consumo - total $\mathrm{R} \$ 61.270,00$ \\ Meta 8 - Realização de cadastro Selo Amigo do Catador - $R \$ 32.000,00$ \\ Meta 9 - Contrapartida - Sede com sala de reunião, despesas com 2 linhas telefonicas, \\ água, luz, 2 computadores e máquina xerox. \\ $R \$ 1.500,00 \mathrm{p} /$ mês - total $\mathrm{R} \$ 18.000,00$ \\ Contrapartida pelo Projeto da Fundação AVINA \\ Fonte: Junior, Severino. Apresentação dos Projetos do MNCR para 2005. SEMINARIO \\ "Experiencias de formalizacion de segregadores" (2005). [Apresentação]
}

Das Metas acima apresentadas, com seus respectivos orçamentos, abordamos nesta Tese a Meta 2 - Encontro Nacional de lideranças do MNCR, e a Meta 7 - Pesquisa do Custo do Posto de Trabalho. Em relação ao primeiro, consta como ANEXO 08. Quanto à Pesquisa do Custo do Posto de Trabalho para o segmento dos catadores de materiais recicláveis, consta como ANEXO 09. 


\section{ANEXO 08 - Encontro Nacional e Marcha do MNCR em Brasília (2006)}

Para se compreender as formas pelas quais os catadores de materiais recicláveis vêm sendo organizados em cooperativas, fez-se necessário analisar a organização do Movimento Nacional de Catadores de Materiais Recicláveis - MNCR, em suas relações com Organizações Não-Governamentais, como por exemplo a Organização de Auxílio-Fraterno - OAF, que atua junto ao MNCR em São Paulo, e com o Governo Federal através de projetos financiados pelo Ministério do Desenvolvimento e Combate à Fome - MDS, entre outros.

Neste sentido, por ocasião da realização do Encontro Nacional do MNCR, ocorrido em Brasília entre os dias 21 e 23 de março de 2006, realizamos um Trabalho de Campo para levantamento de informações sobre a organização deste Movimento e as parcerias estabelecidas com ONG's, bem como acerca de projetos financiados pelo Governo Federal através de alguns de seus Ministérios.

Ressaltamos ainda que o acompanhamento das atividades realizadas durante o Encontro possibilitou o reconhecimento dos atores sociais que atuam junto ao MNCR, através de depoimentos de lideranças, relatos de histórias de vida de catadores de diversas partes do Brasil, além de possibilitar uma melhor compreensão do contexto nacional e regional com relação à questão da reciclagem e do trabalho dos catadores nela envolvido.

\section{Antecedentes do Encontro Nacional do MNCR em Brasília}

No dia 23 de dezembro de 2005 o Presidente Luiz Inácio Lula da Silva esteve na cidade de São Paulo em visita a Cooperativa de Catadores Autônomos de Papel, Aparas e Materiais Reaproveitáveis - COOPAMARE. O encontro contou com a presença de diversas entidades que trabalham com população de rua além de catadores do MNCR.

Neste encontro o MNCR apresentou aos presentes os resultados de um Estudo sobre o custo de geração de postos de trabalho na coleta seletiva, uma das metas do convênio que fora firmado com o MDS no início de 2005. O referido estudo foi realizado pelo Grupo de Estudos de Relações Intersetoriais da Faculdade de Ciências Econômicas da UFBA.

Naquela ocasião o movimento solicitou uma reunião com o governo para apresentar de maneira mais detalhada os resultados da pesquisa e reivindicar investimento para criação de cerca de 39 mil postos de trabalho na coleta seletiva. Outra reivindicação foi a renovação do convenio com o MDS para dar continuidade às capacitações de catadores em todo o Brasil.

O Encontro Nacional do MNCR em março de 2006 em Brasília caracterizou-se como o encerramento das atividades programadas no projeto que foi desenvolvido ao longo de 2005, o qual contou com recursos do MDS administrados pela Organização de Auxílio Fraterno - OAF, em parceria com ONG's que atuam regionalmente, tais como a AVINA, ASPAN e Pangea que atuam na Região Nordeste, e Fundação Luterana que atua na Região Sul, Insea/Instituto Nenuca que atua em Minas Gerais, entre outras, para capacitação de cerca de 700 lideranças em diversos Estados, além de outras ações, tais como a estruturação de uma Secretaria Nacional com sede na Rua dos Estudantes, no Glicério, elaboração de cartilhas e material de divulgação do MNCR, e a realização do já citado estudo sobre o custo da geração de postos de trabalho na reciclagem. 


\section{O Encontro Nacional do MNCR}

Dia 22 de março de 2006. Na chegada ao local do Encontro Nacional do MNCR em Brasília, por volta das 13 horas, haviam alguns catadores uniformizados na entrada do Minas Tênis Clube. Usam camisetas, bonés e portam bandeiras do Movimento. Apresento-me ao grupo e logo sou recebida pela Sra. Ana Cristina, da Fundação Luterana da região sul do país. Logo começa a organização dos ônibus para a Marcha dos catadores pela esplanada dos Ministérios, em direção à Praça dos Três Poderes, onde uma equipe formada por lideranças do MNCR e das ONG's parceiras se reuniriam com o Presidente Lula e uma equipe de representantes de alguns Ministérios, como o MDS, MMA e Ministério das Cidades.

A imprensa se faz presente e registra o evento que ganha um formato plástico em tons verdes e azuis dos catadores uniformizados, em meio aos quais é aberta uma bandeira gigante, momento em que a polícia já liberada uma das vias para a multidão de mais de mil catadores presentes na passeata. Recolho alguns depoimentos e encontro um grupo de catadores do Distrito Federal que "não faziam parte do Encontro", mas que foram para a marcha. Levam cartazes feitos em papelões com letras coloridas. Após uma hora na Praça dos Três Poderes, à espera da aparição do Presidente, a política começa a retirar os manifestantes que indignados vão deixando o local, sem a saudação esperada do Presidente da República.

No retorno, não há clareza por parte dos catadores sobre o que foi discutido no encontro entre o governo federal e o grupo de lideranças que os representava. Apenas relatos dispersos chegam, dando notícias de que as reivindicações (mas quais?) haviam sido atendidas e que haveria uma reunião no dia seguinte com os ministérios, na parte da manhã. $\mathrm{Na}$ parte da tarde, o grupo de lideranças repassaria as informações para o coletivo de catadores, antes do encerramento do evento.

Fico no alojamento dos catadores, onde há beliches com camas ainda vagas, apesar do grande número de participantes. São pessoas humildes, mulheres muito animadas, a maioria do nordeste e norte do país. Os homens ficavam noutro alojamento próximo ao ginásio onde aconteciam as palestras.

A noite acontece uma confraternização, com forró e brega (música popular comumente ouvida na região norte). Na manhã seguinte, logo cedo, chega a notícia de que um ônibus com catadores que viriam de Minas havia sofrido um acidente, no qual uma das passageiras havia machucado o pescoço, estava com gesso e muito assustada.

Começa uma movimentação para buscar jornais locais. Na verdade, desde a noite seguinte. Logo pela manhã alguns catadores me procuraram para andar pela cidade buscando as manchetes. Na caminhada, tive a oportunidade de conhecer um pouco algumas histórias de vida, de catadores oriundos dos mais diversos lugares do Brasil: Rio de Janeiro, Bahia, Pernambuco, entre outros. Sr. Ari se identifica como um catador da Bahia e que estava muito satisfeito com sua Cooperativa, integrante da Rede Cata-Bahia, a qual tinha apoio da Petrobrás e de ONG's da cidade e que a situação dos catadores estava melhorando. Sr. Severino, de Pernambuco, discordava, dizendo que na sua cidade a coisa estava muito diferente, tudo muito difícil, desde a falta de consciência da população no litoral sobre o trabalho dos catadores, o problema dos atravessadores e das muitas promessas não cumpridas por parte de ONG's e políticos. Ele conta que já havia sido motorista de ônibus em São Paulo, e diversas outras ocupações no Distrito Federal, mas que não conseguia arrumar mais emprego por causa da idade. Ele mostra o certificado do Curso de Capacitação promovido pelo MNCR através da ONG AVINA e da Associação de Pernambuco. Disse que já era capacitado o bastante, não precisava mais de cursos de capacitação. Precisava de melhorias em sua cooperativa. Nilson, do Rio de Janeiro,tem uma visão bastante indignada sobre a condição dos catadores. Antes de falar 
alguma coisa, pergunta se sou jornalista ou "mais uma estudante fazendo Tese sobre os catadores", explico que se trata mesmo de uma pesquisa de doutorado e ele então faz alguns comentários, "para serem escritos então na pesquisa". Em primeiro lugar, diz não concordar com a posição do MNCR de que os atravessadores são os inimigos a serem enfrentados. Para ele, o atravessador pode ser um ex-catador, ou um pequeno comerciante ali do bairro, que muitas vezes também é pobre e explorado pelos verdadeiros inimigos que, na sua concepção, eram os grandes empresários, a indústria e os políticos que tudo faziam para favorecê-los em detrimento dos catadores. Ele conta que trabalhou no lixão de Gramacho, sendo que agora estava numa Associação que ainda tinha vínculos com o lixão. Era uma Associação do lixão. Para ele as ONG's eram todas atravessadoras dos recursos financeiros que deveriam chegar até os catadores. "Os cursos de capacitação são um verdadeiro engodo, nós sabemos muito mais do que os técnicos que acabam ganhando muito dinheiro, cerca de $R \$ 10.000,00$ cada um, pra capacitar e a gente continua na mesma." Para ele, os recursos tinham que ser em infraestrutura para as bases, e o governo deveria pagar pelo serviço que os catadores prestavam retirando o lixo das ruas e do próprio lixão. Deveriam ser reconhecidos, assim como acontecia com as empresas que eram contratadas para a varrição e coleta domiciliar. Ele cita uma reportagem da Revista Veja, na qual 70 a $80 \%$ dos recursos captados pelas ONG's ficavam com as próprias ONG's. O catador Nilson também não concordava com a presença da Cáritas no meio dos catadores. Para ele não estava certo a lgreja estar envolvida com os catadores, porque esta também era uma história de exploração.

Por fim encontramos alguns jornais e retornamos para o local do evento, no qual estava acontecendo a apresentação de Ana Cristina, da Fundação Luterana, e depois de Aparecido Gonçalves, do INSEA/Instituto Nenuca, que fala da história do catador, além de outros dois representantes do MNCR. Todos tem uma fala sobre a necessidade de autonomia do Movimento (em relação às entidades de "apoio").

No período da tarde é feita uma dinâmica em grupos que são formados por Estados. Orientados pelos técnicos, usam a metodologia FOFA (na qual anotam em cartazes as Fortalezas e as Fraquezas na organização dos catadores).

Até então, nada havia sido dito de concreto sobre a reunião das lideranças do MNCR com os Ministérios do Governo Federal. Uma reunião fechada acontece entre as lideranças e integrantes das ONG's enquanto os catadores participam da referida dinâmica de grupo. Enquanto isso, os jornais com as notícias publicadas rodam de mãos em mãos, anunciando os recursos financeiros liberados e os compromissos assumidos pelo Governo Federal. Há uma certa expectativa de que as lideranças se pronunciem.

No final do dia, com o horário adiantado para o retorno dos catadores aos seus locais de origem, os representantes do MNCR sobem ao palco, puxam hinos e gritos de luta do Movimento, e com as mãos dadas numa postura de vitória, um dos representantes faz um breve relato sobre os resultados do encontro com os Ministérios. Consultam a plenária sobre a abertura ou não para perguntas que esclareçam as possíveis dúvidas. Rapidamente o "não" à abertura para questões é tomado como decisão do coletivo, mesmo com uma minoria interessada no assunto, e assim, num repente, termina o Encontro...

As lideranças explicam que o próximo passo do MNCR seria o de criar um CNPJ para receber os recursos diretamente das órgãos financiadores, para sair da tutela das ONG's. É o que viria acontecer um ano depois, com a criação do Instituto Cata-Sampa na Região Metropolitana de São Paulo. 


\begin{abstract}
ANEXO 09
CONSIDERAÇÕES SOBRE O DOCUMENTO “ANÁLISE dO CUSTO DE GERAÇÃo DE POSTOS DE TRABALHO NA ECONOMIA URBANA PARA O SEGMENTO DOS CATADORES DE MATERIAIS RECICLÁVEIS"
\end{abstract}

O estudo "Analise do Custo de geração de Postos de Trabalhos na Economia Urbana para o Segmento dos Catadores de Materiais recicláveis"39 promovido pelo Movimento Nacional dos Catadores - MNCR e realizado pela ONG Pangea - Centro de Estudos Socioambientais, em parceria com o Grupo de Estudos de Relações Intersetoriais - GERI da Faculdade de Ciências Econômicas da Universidade Federal da Bahia - UFBA, foi um dos resultados do convênio entre Ministério do Desenvolvimento Social e Combate à Fome e Organização de Auxílio Fraterno, vigente no ano de 2005.

Este documento teve como objetivo, além da análise explícita em seu título, orientar polícias públicas sob a retórica da "inclusão social e econômica deste segmento", aqui entendidas como inscritas no âmbito da estruturação da indústria da reciclagem, no ajuste da base das cadeias produtivas deste setor. Os argumentos elencados para justificar a realização do referido estudo foram: elevado número de pessoas vivendo abaixo da linha da pobreza no país; baixo custo de implementação de "cooperativas" de catadores de materiais recicláveis diante do seu potencial de geração de novos postos de trabalho; trata-se de uma proposta de geração de trabalho e renda, combate à pobreza e promoção da inclusão social; elevado impacto da reciclagem de materiais nos âmbitos social, econômico e ambiental; promoção do uso conservador de energia e economia de recursos naturais $^{40}$ (GERI:MNCR, 2006:7). A metodologia utilizada contemplou dois universos amostrais de "cooperativas". O termo cooperativa aparece entre aspas, pois, como advertem os próprios autores:

Como existem tanto cooperativas como associações (...) foi adotado o termo comum 'cooperativa' (...) para ambos os casos. (...) Existem cooperativas que possuem mais de uma unidade operacional [e cada unidade foi] caracterizada como 'cooperativa' (GERI:MNCR, 2006:10).

\footnotetext{
39 Este estudo é um dos produtos resultantes do Convênio MDS-OAF (002/04) - "ACÕES DE DESENVOLVIMENTO SOCIAL JUNTO AOS CATADORES DE MATERIAIS RECICLÁVEIS" (20042006). Fonte: http://www.cgu.gov.br/sfc/convenio/convenios.asp. Acessado em 30/03/2006.

${ }^{40}$ Grifos nossos.
} 
Ou ainda,

(...) Tecnicamente não há como chamar indistintamente os conjuntos de catadores associados ao MNCR de 'cooperativas' nem aos seus membros de 'cooperados'. Existem cooperativas e associações (...), mas (...) também existem GRUPOS DE CATADORES tanto em processo de constituição de cooperativas ou associações, como ainda não-organizados. (...) Adota-se o termo "Cooperativa" para designar os conjuntos de catadores [os quais] serão genericamente - e muitas vezes incorretamente - chamados de "cooperados". (GERI:MNCR, 2006:83)

No primeiro universo, "cooperativas" e associações foram analisadas segundo diferentes níveis de eficiência (baixa, média e alta). No segundo, as "cooperativas", associações e grupos de catadores não-organizados, cadastrados no MNCR, foram analisados segundo diferentes situações (situação de 1 a 4). O conceito de eficiência física, econômica e de mercado, é apresentado como central tanto para definir o agrupamento das "cooperativas", quanto para a discussão do papel dos investimentos em infra-estrutura - construção civil e equipamentos das "cooperativas" analisadas. As informações sobre eficiência são cruzadas com o de situações, como veremos depois.

Feitas estas observações, o primeiro universo amostral da pesquisa apresenta vinte "cooperativas" distribuídas nos Estados de São Paulo, Rio de Janeiro, Rio Grande do Sul, Minas Gerais, Goiás, Distrito Federal, Pernambuco e Bahia. Após dividir as "cooperativas" em três grupos, segundo "critérios de eficiência", observou-se relações entre a produtividade das cooperativas e seus respectivos níveis de investimento. Assim, formulou-se um módulo de uma 'unidade básica de recuperação de materiais recicláveis', que tivesse porte e eficiência para absorver um número adequado de cooperados em plena operação. (GERI:MNCR, 2006:7)

Com base no segundo universo de "cooperativas" obtido junto ao Cadastro Nacional de Grupos de Catadores Associados ao MNCR (2005), com 331 "cooperativas", os pesquisadores puderam estabelecer quatro situações distintas, a partir das quais obteve-se quatro níveis de investimentos necessários para a implantação de um módulo da unidade básica de uma cooperativa de catadores de materiais recicláveis para cada uma dessas situações. Assim, pode-se obter quatro valores para o custo unitário de geração de um posto de trabalho nesse segmento, de acordo com aquelas situações. (GERI:MNCR, 2006:8) Finalmente, foram definidas 244 unidades a serem implantadas ou expandidas em 22 unidades da Federação e em 199 municípios.

A pesquisa cita a existência de 331 "cooperativas" cadastradas junto ao MNCR, sendo que 24 apresentariam elevado nível de estruturação física; 70 com médio 
nível e 80 "cooperativas" apresentariam nível baixo de estrutura material. Além deste universo, a pesquisa aponta a existência de 157 Grupos de catadores atuando em lixões e aterros, sem estruturação física ou jurídica mínimas, totalizando as 331 "cooperativas". Os autores ressalvam que este último grupamento - embora não excluídos das propostas (...) - não foi amostrado, pelas dificuldades inerentes à localização dos seus membros, e ao preenchimento do questionário (GERI:MNCR, 2006:10-11). Porém, os 157 Grupos de catadores atuando em lixões e aterros estão contabilizados em "cooperativas", como veremos com mais detalhes adiante.

Cabe ressaltar que, as 244 unidades básicas, ou seja, 244 "cooperativas" a serem criadas ou ampliadas (o que indica que investimentos serão feitos nas "cooperativas" já existentes) tem como correspondente 39.040 postos de trabalho a serem criados, número que se sobrepõe ao universo dos catadores que já estão inseridos nas "cooperativas" existentes. Numa aritmética simples, podemos chegar ao número de 160 "cooperados por cooperativa", caracterizando uma proposta direcionada a unidades de grande porte, com possibilidade da existência de 2 ou 3 turnos de trabalho, embora a pesquisa indique que o tamanho da cooperativa, ou o número de cooperados, não é determinante para sua "eficiência".

Na seqüência, apresentamos algumas informações sobre as 20 "cooperativas" analisadas segundo o critério de eficiência. Num primeiro momento, as "cooperativas" foram agrupadas por região do país, agregando assim seus dados. Num segundo momento, os dados são apresentados por cooperativa, porém de forma desidentificada e codificada (Coop01 a Coop20). Os autores justificam tal procedimento tendo em vista que,

(...) a divulgação ampla desses dados pode ensejar o fornecimento de informações de natureza comercial que pode, eventualmente, prejudicar os interesses das cooperativas envolvidas. O mercado de materiais recicláveis funciona em regime de oligopsônio, o que torna sensível a veiculação pública dos dados individualizados ${ }^{41}$. 


\section{Quadro 01 - Localização, tamanho e identificação das "cooperativas"}

da primeira Amostra:

\begin{tabular}{|l|l|l|l|l|}
\hline Região & Estado & Cidade & Tamanho & Nome \\
\hline CO & DF & Brasília & Grande & DF - Cooperativa \\
\hline & GO & Goiânia & Média & Cooperrecicla \\
\hline & MS & Campo Grande & Pequena & Coopervida \\
\hline & BA & Salvador & Grande & CAEC - Matriz \\
\hline & BA & Salvador & Pequena & CAEC - Comércio \\
\hline & BA & Feira de Santana & Pequena & COOBAFS \\
\hline & BA & Feira de Santana & Grande & COOBAFS Aterro \\
\hline & BA & Vitória da Conquista & Média & Recicla Conquista \\
\hline & BA & Itapetinga/ltororó & Pequena & ITAIRÓ \\
\hline & PE & Jaboatão dos Guararapes & Média & ARM \\
\hline SE & PE & Guaranhuns & Média & ASNOV \\
\hline & SP & São Paulo & Média & COOPAMARE \\
\hline & SP & São Paulo & Pequena & AsSOC. Reciclagem Jd. Itapema \\
\hline & SP & Poá & Pequena & CRUMA \\
\hline & MG & Belo Horizonte & Grande & ASMARE - BH \\
\hline & MG & Itaúna & Pequena & ASMARE - Itaúna \\
\hline & RJ & Rio de Janeiro & Pequena & CCSRMPR RJ - Cooperativa \\
\hline & RJ & Duque de Caxias & Pequena & COOPAR \\
\hline S & RJ & Duque de Caxias & Pequena & COOPERCASE \\
\hline & RS & Porto Alegre & Grande & ATRACAR \\
\hline
\end{tabular}

Fonte: GERI (Grupo de Estudos e Relações Intersetoriais) UFBA - Salvador, 2006.

(GERI:MNCR, 2006: p.13)

Observações: A Região Norte não está representada, pois os pesquisadores não obtiveram retorno de questionários de "cooperativas" daquela região. Na Região Nordeste, o predomínio de "cooperativas" baianas é justificado pelos autores em função da proximidade da equipe executora deste estudo.

Informações referentes a estas 20 "cooperativas" foram apresentadas de forma agrupada, por região, como podemos apreciar na Tabela a seguir:

\section{Quadro 02}

\begin{tabular}{|l|r|r|r|r|r|r|r|r|}
\hline Região & Coop & $\begin{array}{l}\text { Coope- } \\
\text { rados }\end{array}$ & $\begin{array}{r}\text { Produção } \\
\text { (Kg/mês) }\end{array}$ & $\begin{array}{r}\text { Produção } \\
(\mathrm{R} \$ / \text { mês })\end{array}$ & $\begin{array}{rlr}\text { Fatura } \\
(\mathrm{R} \$ / \mathrm{mês})\end{array}$ & $\begin{array}{l}\text { Const. } \\
(\mathrm{R} \$)\end{array}$ & $\begin{array}{l}\text { Equip. } \\
(\mathrm{R} \$)\end{array}$ & $\begin{array}{l}\text { Invest. } \\
(\mathrm{R} \$)\end{array}$ \\
\hline $\mathrm{CO}$ & 3 & 392 & 464257 & 71729,90 & 122591,90 & 531652,85 & 409988,00 & 941640,85 \\
\hline NE & 8 & 522 & 382734 & 137181,50 & 143957,10 & 2757196,16 & 1075943,62 & 3833139,78 \\
\hline SE & 8 & 502 & 809688 & 293772,85 & 307177,34 & 4904678,08 & 1664551,30 & 6569229,38 \\
\hline S & $3^{*}$ & 380 & 332300 & 81000,00 & 84000,00 & 538320,00 & 844080,00 & 1382400,00 \\
\hline Total & 22 & 1796 & 1.988979 & 583684,25 & 657726,34 & 8731847,09 & 3994562,92 & 12726410,01 \\
\hline
\end{tabular}

Fonte: GERI (Grupo de Estudos e Relações Intersetoriais) UFBA - Salvador, 2006.

(GERI:MNCR, 2006: p.16)

* São três "cooperativas" que funcionam em rede e responderam juntas o questionário da pesquisa do GERI/MNCR. Na análise das "cooperativas" individualizadas, as três "cooperativas" da Região Sul foram computadas como uma única cooperativa, totalizando 20 "cooperativas" (e não 22 "cooperativas" como aparece nesta tabela)

${ }^{41}$ Essas informações individualizadas estão disponíveis no Anexo Especial (...) a ser circulado apenas no âmbito do MNCR e dos Ministérios e Órgãos Oficiais envolvidos, preservando o sigilo. (GERI:MNCR, 2006:10-11) Não tivemos acesso ao referido Anexo Especial. 
Agora, expomos o Quadro 03 com dados das "cooperativas" desidentificadas e codificadas de 1 a 20 :

\begin{tabular}{|l|l|l|l|l|l|l|l|}
\hline Coop & $\begin{array}{l}\text { Coope- } \\
\text { rados }\end{array}$ & $\begin{array}{l}\text { Produção } \\
(\mathrm{Kg} / \mathrm{mês})\end{array}$ & $\begin{array}{l}\text { Produção } \\
(\mathrm{R} \$ / \mathrm{mês})\end{array}$ & $\begin{array}{l}\text { Fatura } \\
(\mathrm{R} \$ / \mathrm{mês})\end{array}$ & $\begin{array}{l}\text { Construção } \\
(\mathrm{R} \$)\end{array}$ & $\begin{array}{l}\text { Equipamento } \\
(\mathrm{R} \$)\end{array}$ & $\begin{array}{l}\text { Investimentos } \\
\text { Totais }(\mathrm{R} \$)\end{array}$ \\
\hline 01 & 65 & 18.805 & $8.382,00$ & $10.000,00$ & - & $125.508,00$ & $125.508,00$ \\
\hline 02 & 130 & 51.461 & $17.455,10$ & $22.000,00$ & $287.104,009$ & $90.761,50$ & $377.865,50$ \\
\hline 03 & 30 & 15.430 & $4.986,50$ & $4.986,50$ & $172.980,16$ & $30.447,50$ & $203.427,66$ \\
\hline 04 & 270 & 255.680 & $34.638,00$ & $85.500,00$ & $16.508,48$ & $149.190,00$ & $165.698,48$ \\
\hline 05 & 21 & 14.567 & $5.201,55$ & $5.201,55$ & $40.000,00$ & $231.121,00$ & $271.121,00$ \\
\hline 06 & 380 & 332.300 & $81.000,00$ & $84.000,00$ & $538.320,00$ & $844.080,00$ & $1.382 .400,00$ \\
\hline 07 & 16 & 15.116 & $3.498,30$ & $4.111,00$ & $90.000,00$ & $34.848,00$ & $124.848,00$ \\
\hline 08 & 20 & 19.100 & $6.230,00$ & $6.230,00$ & $753.648,00$ & $138.981,00$ & $892.629,00$ \\
\hline 09 & 10 & 10.555 & $3.189,50$ & $3.189,50$ & $26.355,20$ & $31.385,50$ & $57.740,70$ \\
\hline 10 & 81 & 55.500 & $35.540,00$ & $35.540,00$ & $269.160,00$ & $177.116,00$ & $446.276,00$ \\
\hline 11 & 26 & 20.840 & $10.179,00$ & $10.179,00$ & $25.024,32$ & $77.796,00$ & $102.820,32$ \\
\hline 12 & 100 & 114.122 & $33.514,60$ & $33.514,00$ & $1.076 .640,00$ & $327.136,62$ & $1.403 .776,62$ \\
\hline 13 & 95 & 160.570 & $27.040,00$ & $27.040,00$ & $40.121,60$ & $47.255,00$ & $87.376,00$ \\
\hline 14 & 80 & 93.200 & $27.575,00$ & $27.575,00$ & $107.664,00$ & $151.145,00$ & $258.809,00$ \\
\hline 15 & 30 & 39.055 & $10.344,70$ & $16.000,00$ & - & $228.556,00$ & $228.556,00$ \\
\hline 16 & 27 & 48.007 & $10.051,90$ & $10.051,90$ & $475.022,77$ & $213.543,00$ & $688.565,77$ \\
\hline 17 & 11 & 16.000 & $6.600,00$ & $6.600,00$ & $5.383,20$ & $112.910,00$ & $118.293,20$ \\
\hline 18 & 300 & 502.342 & $191.888,59$ & $191.888,59$ & $752.571,36$ & $401.522,00$ & $1.154 .093,36$ \\
\hline 19 & 57 & 108.077 & $32.118,70$ & $32.118,70$ & $2.153 .280,00$ & $247.310,00$ & $2.400 .590,00$ \\
\hline 20 & 47 & 98.252 & $34.250,81$ & $42.000,00$ & $1.902 .064,00$ & $333.950,80$ & $2.236 .014,80$ \\
\hline Total & 1796 & 1.988 .989 & $583.684,25$ & $657.726,34$ & $8.731 .847,09$ & $3.994 .562,92$ & $12.726 .410,01$ \\
\hline
\end{tabular}

Fonte: GERI (Grupo de Estudos e Relações Intersetoriais) UFBA - Salvador, 2006.

(GERI:MNCR, 2006: p.18-20). Elaboração: Rosalina Burgos (2008)

Além da apresentação descritiva destes dados, a equipe executora da pesquisa estabeleceu critérios analíticos para tipificar as "cooperativas" da amostra. Voltaremos posteriormente a este Quadro, com outras informações acrescentadas, com as quais teceremos alguns comentários.

No Capítulo 3 do Relatório, denominado As cooperativas agrupadas e suas eficiências relativas, os autores, com base em conceitos de "eficiência" procedem ao agrupamento das "cooperativas". Inicialmente, argumenta-se que o tamanho, ou seja, o número de cooperados, não é o melhor critério para agregar as "cooperativas", pois o tamanho da cooperativa não apresenta correlação com o desempenho produtivo da mesma. Mas admitem que o ideal seriam cooperativas de algum porte, com considerável nível de cooperados e capacidade de produção e estocagem elevadas, de forma a se beneficiarem das economias de escala e de poder de barganha frente aos intermediários que populam o mercado oligopsônico da comercialização de materiais recicláveis. (GERI:MNCR, 2006:23) 
Desta forma, a equipe executora justifica o uso do critério de "eficiência", enquanto uma relação (produto)/(trabalho) - tanto em termos físicos, como em termos de valoração $(R \$)$ - a fim de permitir que sejam avaliados eventuais diferenciais na produção 'per capita', ou seja, por trabalhador cooperado. (...). Essa é uma medida da produtividade média, ou eficiência que passa a ser utilizada neste trabalho. (GERI:MNCR, 2006:23)

Assim, foram formulados dois critérios: eficiência física per capita, medida em $\mathrm{Kg} / \mathrm{mês}$; e eficiência econômica, ou retorno bruto médio, calculado pelo valor comercializado da produção física per capita, ou seja, por cooperado, medido em $\mathrm{R} \$ /$ mês. Outro critério, não utilizado para agregação das "cooperativas", é o de eficiência de mercado, relacionado à capacidade da cooperativa de obter melhores valores pelas mesmas quantidades do mesmo material reciclável (...) expressa pelo preço médio obtido por cada material reciclável na etapa da comercialização. (GERI:MNCR, 2006:23-25)

O resultado obtido foi de 3 "cooperativas" com alta eficiência; 8 "cooperativas" com eficiência média e 9 "cooperativas" com baixa eficiência, com base na análise dos dados (Kg e $\mathrm{R} \$$ per capita) (Anexo)

A pesquisa trata, definitivamente, da identificação de níveis de eficiência na produção de materiais recicláveis, ou em outros termos, da "produtividade das cooperativas". Desta forma, foi dedicada parte do Relatório para uma análise detalhada da produção de materiais recicláveis em cada uma delas, baseada nos tipos de materiais que as "cooperativas" de eficiências diferentes processam (expressos em $\mathrm{Kg} / \mathrm{mês}$, $\mathrm{R} \$ /$ mês e índices per capita de eficiência física e econômica da produção de materiais recicláveis), identificando perfis de atividades preferenciais de cada grupo. (GERI:MNCR, 2006:34) Assim, concluiu-se que:

(...) as cooperativas de alta eficiência tendem a ser fisicamente eficientes de forma ampla, em toda gama de materiais recicláveis distintos. As cooperativas de média eficiência parecem até obter um desempenho razoável - do ponto de vista da produtividade física - mas perdem boa parte desses ganhos de eficiência no processo de comercialização - o que leva a índices de eficiência econômica inferiores. No outro extremo, as cooperativas de baixa eficiência perdem duplamente: apresentam baixos índices gerais de produtividade física, e perdem ainda mais no processo de comercialização. (GERI:MNCR, 2006:46)

Além desta análise das "cooperativas" em termos de eficiência física e eficiência econômica, a pesquisa põe ênfase na denominada eficiência de mercado, a qual seria, 
a razão entre os índices de eficiência econômica e os índices de eficiência física. (...) Compreende-se assim, que uma elevada eficiência na produtividade física é necessária, mas não suficiente para garantir uma elevada eficiência na produtividade econômica. Isso quer dizer que a eficiência econômica é o produto da eficiência física pela eficiência de mercado. E esta última só é adquirida com volume de produção, logística, transporte, instalações e equipamentos adequados ${ }^{42}-0$ que apenas a minoria das cooperativas de catadores de materiais recicláveis dispõe hoje. (GERI:MNCR, 2006:50)

Encerradas as análises sobre a "eficiência das cooperativas", no sentido de comprovar que este é o parâmetro que as diferenciam e não o seu tamanho (número de cooperados), passou-se à análise dos níveis de investimentos em instalações e equipamentos. Antes de apresentar alguns de seus aspectos, faremos algumas observações sobre o exposto até agora.

Primeiro, parece-nos que o objetivo das análises da amostra 01 (das 20 cooperativas) foi chegar aos Grupos de eficiência, para demonstrar que não é o número de cooperados que determina a diferença entre as cooperativas da amostra, mas sim a eficiência. Portanto, fica patente que o objetivo central do documento ora analisado não é a "inclusão social" dos catadores - sobretudo dos mais "excluídos", ou seja, aqueles que estão nas ruas e lixões do país - mas sim propor investimentos que resultem em "cooperativas eficientes", cuja garantia, argumenta-se, é dada pelo investimento em infraestrutura, equipamentos e consultoria, assegurando a participação do Terceiro Setor da indústria da reciclagem.

Segundo, se o objetivo é investir para se alcançar "cooperativas eficientes", ou o aumento da produtividade, é evidente que o documento não proporia um modelo de política pública que inserisse o maior número possível de catadores em "cooperativas" a serem criadas ou expandidas, mas sim investimentos em infra-estrutura. Assim, é a partir do cálculo do investimento em infra-estrutura que se chega ao "número ideal" de postos de trabalho a serem criados. Daí a proposta de 39.040 estar muito aquém dos números divulgados sobre a existência de algo em torno de 500.000 catadores em todo o país. Parece, de fato, não haver interesse para o capital em absorver a maior parte deste contingente, o qual continuará em situação de baixa produtividade, sendo alvo da extração de mais-valia absoluta. Para os extratos mais "descartados" desta "política de geração de trabalho e renda", o horizonte parece ser a morte.

\footnotetext{
${ }^{42}$ Grifo nosso.
} 
Assim, no quarto capítulo - O papel do investimento em infra-estrutura na eficiência da produção de materiais recicláveis, são apresentados dados sobre os investimentos atualizados, por cooperativa, em construção, equipamentos, terrenos e áreas construídas. A primeira evidência destacada é que o grupo de alta eficiência apresenta um volume de investimento agregado muito maior (GERI:MNCR, 2006:50), existindo um "quadro mais turvo" em relação às "cooperativas" de média e baixa eficiência. No Quadro 02a seguir, estão sintetizadas estas informações:

\section{Quadro 04: Sumário dos investimentos per capita atualizados médios} por grupo de eficiência

\begin{tabular}{|l|r|r|r|}
\hline EFICIÉNCIA & $\begin{array}{l}\text { Construção atualizada } \\
\text { per capita }\end{array}$ & $\begin{array}{l}\text { Equipamentos } \\
\text { atualizados per capita }\end{array}$ & $\begin{array}{l}\text { Investimentos } \\
\text { atualizados per capita }\end{array}$ \\
\hline Baixa eficiência & $\mathrm{R} \$ 2.043,44$ & $\mathrm{R} \$ 1.990,54$ & $\mathrm{R} \$ 3.822,97$ \\
\hline Eficiência média & $\mathrm{R} \$ 4.442,26$ & $\mathrm{R} \$ 2.967,68$ & $\mathrm{R} \$ 7.409,94$ \\
\hline Alta Eficiência & $\mathrm{R} \$ 11.900,78$ & $\mathrm{R} \$ 2.432,63$ & $\mathrm{R} \$ 14.333,41$ \\
\hline Média Ponderada & $\mathrm{R} \$ 4.861,83$ & $\mathrm{R} \$ 2.224,14$ & $\mathrm{R} \$ 7,085,97$ \\
\hline
\end{tabular}

Fonte: GERI (Grupo de Estudos e Relações Intersetoriais) UFBA - Salvador, 2006.

(GERI:MNCR, 2006: p.62)

Vamos aqui destacar as informações referentes aos terrenos e áreas construídos das cooperativas da amostra, pois nos revelam aspectos importantes sobre as formas como a base da indústria da reciclagem se inscreve no espaço urbano, apropriando-se de espaços públicos, "áreas livres", doados, geralmente em situação desvalorizada no mercado imobiliário:

A amostra deste trabalho encontrou cooperativas funcionando a céu aberto, e outras sem sequer dispor de espaço territorial próprio. Os dados (...) devem ser lidos com alguma circunspecção, pois muitas vezes representam "espaços construídos" sob viadutos, pontes ou outras obras públicas. Os terrenos quando não são resultado de algum patrocínio ou doação pública - são, na maioria das vezes, resultantes de ocupações. E acrescenta: uma cooperativa que não disponha de espaço construído adequado para triagem, processamento, enfardamento, estocagem (...) perde sua eficiência. Portanto, qualquer ganho em eficiência deve partir do princípio que a área construída 'per capita' é um indicador fundamental, e que os investimentos em infraestrutura edificada são incontornáveis como condição prévia ao bom desempenho da atividade (GERI:MNCR, 2006:62;65).

Da mesma forma, a análise dos equipamentos existentes nas "cooperativas" aponta que as cooperativas do grupo de alta eficiência detêm um número maior dos equipamentos de maior valor unitário [tais como prensa, balança, mesa, guilhotina, triturador], enquanto as cooperativas de baixa eficiência têm equipamentos menos sofisticados e em volume menor [com destaque para as baias que só aparecem nas 
"cooperativas" de baixa e média eficiência]. O equipamento esteira aparece de modo mais homogêneo em todos os níveis de eficiência. (GERI:MNCR, 2006:67)

Em relação aos equipamentos para acondicionamento, armazenamento e estoque de materiais recicláveis, destacam-se, em todos os níveis de eficiência os BigBags, seguido por uma participação bem menor de conteiners metálicos e latões. Com menor freqüência, estão os carrinhos plataforma, elevadores de carga, empilhadeiras, caçambas, mais presentes nas "cooperativas" de média eficiência. Já os chamados Equipamentos de Proteção Individual - EPl's apresentam baixos índices para todos os níveis de eficiência. Ainda assim, os equipamentos mais usados são luvas e uniformes, seguidos por uso de calçados e máscaras. Numa freqüência bem menor, para todas as "cooperativas" são citados: avental, protetor auricular, óculos e capacetes. Em nota os autores atribuem à ausência de uso de EPI's mais a uma questão de resistência cultural do catador, do que à inexistência de capital, pois são relativamente baratos, o que por outro lado, no nosso modo de entender, revelam o quão descartável é esta mão-de-obra, que parece ser menos valorizada do que os chamados EPI's. Quanto aos equipamentos de transporte, o carrinho de catador aparece como o principal. Há uma freqüência bem menor de carroças com cavalos, e os demais são raros, tais como caminhão, caminhonete, veículo utilitário. Por fim, nos chamados Equipamentos Auxiliares, encontramos equipamentos que na verdade servem a alguma atividade de transformação do material reciclável, tais como filtros e similares, tanques, manufatura de vassouras de PET, moinho, revalorização de papel e papelão, destacadamente nas cooperativas de média eficiência. Do exposto, o estudo afirma que:

Esses resultados alertam-nos para a necessidade de fortes investimentos em construção civil e compra de equipamentos para as cooperativas em quaisquer níveis de eficiência! Isto quer dizer que, em qualquer grau de produtividade [de determinada cooperativa] sempre terá ganho de produtividade com investimentos adicionais, seja em construção civil, seja em equipamentos. (GERI:MNCR, 2006:76-77)

É assim que uma série de argumentações vão se acumulando ao longo de todo o relatório, no sentido de justificar os investimentos em "cooperativas" que já apresentam eficiência alta e média, as quais, em tese, absorveriam os catadores que se encontram na chamada "situação 4" que, como veremos a seguir, são os Grupos nãoorganizados de catadores que atuam em ruas e lixões. 
Dando seqüência ao estudo, o relatório passa então a analisar as situações das "cooperativas" e associações de catadores de materiais recicláveis integrantes do cadastro do MNCR. Elas foram reunidas em três grandes conjuntos, com graus crescentes de organização estrutural e produtiva, além de um quarto conjunto composto por grupos de catadores ainda não-organizados. (GERI:MNCR, 2006:78). De modo sintético, apresentamos no quadro 05 abaixo as principais características de cada Situação e os graus possíveis de "eficiência":

\begin{tabular}{|l|l|l|}
\hline Situação & Principais características & Eficiência \\
\hline 01 & $\begin{array}{l}\text { Grupo formalmente organizado em associação ou cooperativa; } \\
\text { possui prensa, balança, carrinhos e galpão próprios; capacidade de } \\
\text { ampliação e implantação de unidade industrial de reciclagem; está } \\
\text { pronta para verticalizção da produção. }\end{array}$ & Alta ou Média \\
\hline 03 & $\begin{array}{l}\text { Grupo formalmente organizado em associação ou cooperativa; } \\
\text { conta com alguns equipamentos; falta de equipamentos e infra- } \\
\text { estrutura para expandir a coleta e a produção; }\end{array}$ & Média ou Alta \\
\hline 04 & $\begin{array}{l}\text { Grupo em organização; conta com poucos equipamentos; necessita } \\
\text { adquirir a maioria dos equipamentos e galpão próprio; necessidade } \\
\text { de ser formalizada. }\end{array}$ & $\begin{array}{l}\text { Baixa ou } \\
\text { Gapo-amostrado desorganizado; atua em ruas ou lixões; não possui } \\
\text { equipamentos; trabalha geralmente para atravessadores e e } \\
\text { deposeiros; necessita montagem completa da cooperativa (infra- } \\
\text { estrutura e equipamentos); necessita ser formalizada. }\end{array}$ \\
\hline
\end{tabular}

Fonte: GERI (Grupo de Estudos e Relações Intersetoriais) UFBA - Salvador, 2006.

(GERI:MNCR, 2006: p.78-79) Elaboração: Rosalina Burgos (2008)

Após apresentar estas informações, os autores argumentam que o conceito de alta eficiência depende de estar em uma boa situação (1 ou 2), mas estar nas Situações 1 ou 2 não garante automaticamente altas eficiências. Sendo assim, reportamse ao campo legal, sob a retórica da "inclusão social e erradicação da pobreza":

(...) faz-se necessária uma legislação - nos três âmbitos do poder público que levante os bloqueios hoje existentes, de forma a priorizar a atividade de seleção, coleta e processamento de materiais recicláveis. Esta é uma arma poderosa para a inclusão social e contribuição para a erradicação da pobreza abjeta em nosso país. (GERI:MNCR, 2006:82)

\section{Quadro 06}

\begin{tabular}{|r|r|r|r|r|r|}
\hline Situação & \multicolumn{1}{|c|}{ cooperados } & \% & "cooperativas" & $\%$ & $\begin{array}{l}\text { cooperados } \\
\text { por "cooperativa" }\end{array}$ \\
\hline 1 & 1.381 & 4 & 24 & 7 & 57,5 \\
\hline 2 & 2.753 & 8 & 70 & 21 & 39,3 \\
\hline 3 & 5.720 & 16 & 122 & 37 & 46,9 \\
\hline 4 & 25.783 & 72 & 115 & 35 & 224,2 \\
\hline
\end{tabular}

Fonte: GERI (Grupo de Estudos e Relações Intersetoriais) UFBA - Salvador, 2006.

(GERI:MNCR, 2006: p.83) 
Vejamos com mais atenção os dados apresentados no Quadro anterior, pois há uma observação importante a ser feita sobre as "cooperativas", e respectivos "cooperados" inseridos nas situações 3 e 4. Logo no início do Relatório, no Capítulo 2, é afirmado que existiam 24 "cooperativas" com elevado nível de estruturação; 70 com nível intermediário; 80 com menor nível de organização e 157 Grupos de catadores nãoorganizados. A partir da alteração na coluna "cooperativas", refizemos os cálculos e chegamos ao seguinte Quadro 07:

\begin{tabular}{|r|r|c|r|r|r|}
\hline Situação & \multicolumn{1}{l|}{ cooperados } & $\%$ & "cooperativas" & $\%$ & $\begin{array}{l}\text { cooperados } \\
\text { por "cooperativa" }\end{array}$ \\
\hline 1 & 1.381 & 4 & 24 & 7,25 & 57,5 \\
\hline 2 & 2.753 & 8 & 70 & 21,14 & 39,3 \\
\hline 3 & 3.754 & 10,5 & 80 & 24,16 & 30,42 \\
\hline 4 & 27.749 & 77,5 & 157 & 47,45 & 176,74 \\
\hline
\end{tabular}

Fonte: GERI:MNCR, 2006: p.83. Elaboração: Rosalina Burgos (2008)

Importa destacar que, em ambos os casos, mas sobretudo no ajuste feito no Quadro acima, a situação dos catadores na Situação 4 é majoritária, perfazendo mais de $77 \%$ dos "cooperados" e quase $50 \%$ das chamadas "cooperativas" que, neste caso recebem a denominação mais exata de Grupos não-organizados. Ainda assim, como veremos a seguir, segue a argumentação para justificar os investimentos nas "cooperativas" melhor estruturadas, onde se concentram os restantes $22 \%$ dos cooperados.

O capítulo 6 é dedicado aos cálculos para se chegar ao "Módulo da unidade básica de recuperação ${ }^{43}$ de materiais recicláveis", com investimentos em infra-estrutura física, equipamentos (para acondicionamento; EPI's; para triagem e enfardamento; armazenagem e estocagem; transporte; cozinha; vestiário e banheiro; escritório) e assistência técnica, resultando em investimentos diferenciados para cada uma das 4 Situações (Anexo).

Por fim, o último Capítulo apresenta o custo de geração de um posto de trabalho: investimentos necessários para a implementação ou ampliação de 244 unidades básicas e a criação de 39.040 postos de trabalho. Ou seja, em cada "cooperativa" haverá 160 postos de trabalho, cujo custo será diferente para cada uma das Situações, conforme o Quadro 08 a seguir:

\footnotetext{
${ }^{43}$ Note-se que o termo Reciclagem foi evitado.
} 


\begin{tabular}{|c|c|c|c|}
\hline Situação & $\begin{array}{l}\text { Custo de uma } \\
\text { Unidade básica } \\
\text { UB }(R \$)\end{array}$ & $\begin{array}{l}\text { Custo total por } \\
\text { cooperado } \\
\text { (R\$) }\end{array}$ & \begin{tabular}{|l|} 
Postos de \\
trabalho \\
gerados / UB
\end{tabular} \\
\hline 01 & $495.045,97$ & $3.094,04$ & 160 \\
\hline 02 & $645.731,77$ & $4.035,82$ & 160 \\
\hline 03 & $705.299,53$ & $4.408,12$ & 160 \\
\hline 04 & $796.689,53$ & $4.979,31$ & 160 \\
\hline
\end{tabular}

Fonte: GERI (Grupo de Estudos e Relações Intersetoriais) UFBA - Salvador, 2006.

(GERI:MNCR, 2006: p.118)

Resumindo: calculou-se o valor da denominada Unidade Básica de recuperação de materiais recicláveis; estabeleceu-se a quantia de 160 postos de trabalho por Unidade Básica (independente da situação original das cooperativas). Com base nestes dois valores, calculou-se o "custo por cooperado" de cada Unidade Básica.

Resta agora observarmos algumas informações sobre o cálculo de Quantas unidades básicas devem ser implementadas, com duas possibilidades a seguir apresentadas. Na primeira, o cálculo de quantas unidades básicas - EM CADA SITUAÇÃO (esta informação é central pois, como veremos, interessa investir prioritariamente nas cooperativas melhor estruturadas e não no conjunto dos catadores não-organizados, ou seja, dos catadores mais excluídos, em nome dos quais tudo é proposto...). Por este cálculo, seriam criadas novas 9 cooperativas para a Situação $01 ; 17$ cooperativas para a Situação 02; 36 cooperativas para a Situação 03; e 161 cooperativas para a Situação 04.

Porém, argumentam os autores que, indignados com os cálculos obtidos, vão propor uma "realocação" dos investimentos, que migrarão da Situação 04 para as demais. Tal procedimento tem como um de seus argumentos a seguinte afirmação:

(...) Temos aqui a indicação correta de como alocar os recursos entre as cooperativas de forma mais eficiente. Trata-se apenas de alocar os recursos entre as cooperativas mais bem organizadas - e, como vimos, com maior produtividade e eficiência ${ }^{44}$ - ao mesmo tempo em que se procura absorver nas cooperativas mais eficientes uma parte relevante do contingente que hoje está na Situação 04, sem esquecer de apoiar também aqueles catadores que já se encontram consolidados enquanto grupos e que estão nas Situações 03 e 04 .

Pelo novo cálculo, estabeleceu-se a criação de 25 cooperativas para a Situação 01; 70 cooperativas para a Situação 02; 80 cooperativas para a Situação 03; e

\footnotetext{
${ }^{44}$ Grifo nosso.
} 
69 cooperativas para a Situação 04, perfazendo o total de 244 cooperativas. Segundo os autores,

nesta alocação serão criados 39.040 novos postos de trabalho, significando 3.403 postos a mais [do que o cálculo anterior baseado no número de "cooperados" existentes, ou seja, 35.637). É importante notar que, com esta alocação, os catadores da Situação 04 não apenas ganharão 69 módulos básicos próprios, como também serão inseridos em Unidades a serem criadas nas Situações 1,2 e 3. (GERI:MNCR, 2006:124)

Entretanto, devemos ressaltar e insistir no fato de que os denominados "grupos não-organizados", e ainda mais aqueles catadores que atuam isoladamente nas ruas ou lixões, estão numa situação muito desfavorável em relação àqueles das demais "Situações". Ademais, o estudo não aponta formas de garantir que estes catadores - os mais excluídos, em nome dos quais tudo é reivindicado neste "setor" - efetivamente serão "incluídos" nos benefícios anunciados pelo projeto. A começar pela exigência de CNPJ para que um "grupo" possa participar da política de financiamento. Ora, essa é uma das razões da prioridade dada às cooperativas melhor estruturadas, pois já possuem CNPJ ou apresentam condições menos "custosas" para tanto.

O total de 244 unidades, com seus respectivos custos diferenciais dentro de cada Situação, soma o total de $R \$ 168.972 .913,12$, dos quais, $R \$ 60.395 .168,80$ destinados aos Equipamentos; $R \$ 91.009 .744,32$ para Construção e $R \$ 17.568 .000,00$ para "Assistência Técnica" (ou R\$72.000,00 por unidade, em qualquer das Situações). Ou seja, cerca de $10 \%$ do total dos investimentos ficarão para as entidades do Terceiro Setor da indústria da reciclagem, em nada voluntárias, como podemos ver. Aliás, o próprio Relatório ora analisado foi devidamente contabilizado em $\mathrm{R} \$ 61.270,00$, em financiamento de Projeto da Organização de Auxílio Fraterno - OAF e Fundação Avina junto ao MDS para "capacitação de lideranças" entre outros produtos para este "segmento" (num total de $R \$ 1.379 .000,00)^{45}$.

Quanto à distribuição espacial das "unidades" a serem beneficiadas, o critério, segundo os autores, foi a distribuição das organizações associadas ao MNCR e não deve ser entendido como a distribuição das organizações dos catadores no Brasil, mas sim a distribuição de catadores associadas ao MNCR no Brasil (GERI:MNCR, 2006:130), conforme o Quadro 07 a seguir:

45 Convênio MDS-OAF (002/04) - "ACOES DE DESENVOLVIMENTO SOCIAL JUNTO AOS CATADORES DE MATERIAIS RECICLAVEIS" (2004-2006).

Fonte: http://www.cgu.gov.br/sfc/convenio/convenios.asp. Acessado em 30/03/2006. 


\section{Quadro 09 - Distribuição Regional e Estadual das Unidades Básicas de Cooperativas de Catadores em Materiais Recicláveis}

\begin{tabular}{|c|c|c|c|c|c|}
\hline Estado/região & Total & Situação 1 & Situação 2 & Situação 3 & Situação 4 \\
\hline TO & 1 & 0 & 0 & 0 & 1 \\
\hline $\mathrm{RO}$ & 1 & 0 & 0 & 1 & 0 \\
\hline NORTE & 2 & 0 & 0 & 1 & 1 \\
\hline DF & 15 & 1 & 1 & 7 & 6 \\
\hline GO & 1 & 0 & 0 & 0 & 1 \\
\hline MS & 8 & 1 & 5 & 1 & 1 \\
\hline MT & 1 & 1 & 0 & 0 & 0 \\
\hline C.OESTE & 25 & 3 & 6 & 8 & 8 \\
\hline $\mathrm{AL}$ & 1 & 0 & 0 & 0 & 1 \\
\hline BA & 25 & 1 & 3 & 8 & 13 \\
\hline CE & 2 & 0 & 0 & 1 & 1 \\
\hline MA & 1 & 0 & 0 & 0 & 1 \\
\hline PB & 2 & 0 & 0 & 1 & 1 \\
\hline PE & 20 & 1 & 2 & 0 & 17 \\
\hline $\mathrm{PI}$ & 1 & 0 & 0 & 0 & 1 \\
\hline $\mathrm{RN}$ & 5 & 0 & 1 & 4 & 0 \\
\hline SE & 1 & 0 & 1 & 0 & 0 \\
\hline NORDESTE & 58 & 2 & 7 & 14 & 35 \\
\hline ES & 3 & 0 & 3 & 0 & 0 \\
\hline MG & 47 & 6 & 28 & 9 & 4 \\
\hline RJ & 7 & 3 & 1 & 1 & 2 \\
\hline SP & 55 & 5 & 15 & 25 & 10 \\
\hline SUDESTE & 112 & 14 & 47 & 35 & 16 \\
\hline PR & 6 & 0 & 2 & 2 & 2 \\
\hline SC & 1 & 0 & 0 & 1 & 0 \\
\hline $\mathrm{RS}$ & 40 & 6 & 8 & 19 & 7 \\
\hline SUL & 47 & 6 & 10 & 22 & 9 \\
\hline TOTAIS & 244 & 25 & 70 & 80 & 69 \\
\hline
\end{tabular}

Fonte: GERI (Grupo de Estudos e Relações Intersetoriais) UFBA - Salvador, 2006.

(GERI:MNCR, 2006: p.131)

Abaixo apresentamos o Quadro 10 com a distribuição, por região, dos investimentos destinados à implantação ou ampliação das Unidades Básicas de Cooperativas de Catadores em Materiais Recicláveis:

\begin{tabular}{|c|c|c|c|c|c|}
\hline REGIÃO & Totais & Situação 01 & Situação 02 & Situação 03 & Situação 04 \\
\hline NORTE & $1.501 .989,06$ & 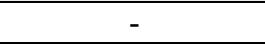 & 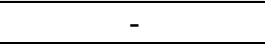 & $705.299,53$ & $796.689,53$ \\
\hline $\mathrm{CO}$ & $17.375 .441,01$ & $1.485 .137,91$ & $3.874 .390,62$ & $5.642 .396,24$ & $6.373 .516,24$ \\
\hline NE & $43.268 .541,30$ & $990.091,94$ & $4.520 .122,39$ & $9.874 .193,42$ & $27.884 .133,55$ \\
\hline SE & $74.712 .552,80$ & $6.930 .643,58$ & $30.349 .393,19$ & $24.685 .483,55$ & $12.747 .032,48$ \\
\hline SUL & $32.114 .388,95$ & $2.970 .275,82$ & $6.457 .317,70$ & $15.516 .589,66$ & $7.170 .205,77$ \\
\hline TOTAIS R $\$$ & $168.972 .913,12$ & $12.376 .149,25$ & $45.201 .223,90$ & $56.423 .962,40$ & $54.971 .577,57$ \\
\hline
\end{tabular}

(GERI:MNCR, 2006: p.134)

Por fim, no Comentário que encerra o último capítulo do Relatório ora analisado, a equipe executora afirma que o mesmo: 
desenvolveu (...) o mecanismo necessário para alocar eficientemente os catadores não-organizados de uma forma orgânica e adequada (...). Mas a importância maior desta proposta será atingida com o resgate da cidadania de uma parcela quase clandestina da população, que, ao receber oportunidade digna de desempenhar o seu trabalho poderá pela primeira vez levantar a cabeça e olhar diretamente nos olhos de seus interlocutores e dizer: "Eu sou um cidadão útil, e meu trabalho é reconhecido!". Por fim, uma esperança: (...) atender aos anseios do Movimento Nacional dos Catadores de Materiais Recicláveis, e tornar palpável - para as autoridades competentes - as demandas ora postas. (GERI:MNCR, 2006:145)

Como podemos ver, aos "grupos não-organizados" resta a garantia dos discursos. Caso a proposta deste estudo estivesse de fato direcionada aos catadores mais explorados, deveria ao menos ser explicada de que forma esta "alocação" aconteceria, já que os referidos grupos sequer foram "amostrados". No mais, destaca-se que na distribuição espacial das "Unidades Básicas”, a Região Sudeste é de longe a mais contemplada, tanto em Unidades quanto em financiamento, principalmente para as "cooperativas" classificadas na Situação 2, ou seja, no segundo agrupamento com melhor "eficiência". Isto significa que exatamente $50 \%$ das Unidades propostas estão direcionadas para a Região Sudeste (112 Unidades do total de 224), sendo que do total desta região, 49\% estão no Estado de São Paulo (55 unidades do total de 112), 18 delas na cidade de São Paulo e 5 na região do "Alto Tietê" (municípios de Arujá, Ferraz, Poá, Salesópoles e Suzano). Na seqüência, destacam-se os Estados de Minas Gerais (47 Unidades), Rio Grande do Sul (40 Unidades), Bahia (25 Unidades), Pernambuco (20 Unidades), Distrito Federal (15 Unidades). Coincidentemente, estes são os territórios de atuação das principais entidades do Terceiro Setor da indústria da reciclagem, conforme indicamos no Quadro 11 a seguir, que também traz uma estimativa do financiamento garantido para estas ONG's: 


\begin{tabular}{|c|c|c|c|c|c|}
\hline Estado & $\begin{array}{l}\text { Entidade do } \\
\text { Terceiro } \\
\text { Setor }\end{array}$ & $\begin{array}{l}\text { Unidades } \\
\text { Básicas } \\
\text { Por Estado }\end{array}$ & $\%$ & $\begin{array}{l}\text { Financiamento } \\
\text { das UB's (R\$) }\end{array}$ & $\begin{array}{l}\text { Financiamento } \\
\text { das ONG's }(R \$)^{\star *}\end{array}$ \\
\hline SP & OAF & 55 & 22,54 & $37.760 .589,95$ & $3.960 .000,00$ \\
\hline MG & INSEA & 47 & 19,26 & $30.585 .219,27$ & $3.384 .000,00$ \\
\hline RS & LUTERANOS & 40 & 16,40 & $27.113 .647,76$ & $2.880 .000,00$ \\
\hline $\mathrm{BA}$ & PANGEA & 25 & 10,24 & $18.431 .601,41$ & $1.800 .000,00$ \\
\hline PE & ASPAN & 20 & 8,20 & $15.330 .231,52$ & $1.440 .000,00$ \\
\hline DF & CÁRITAS & 15 & 6,14 & $10.858 .011,63$ & $1.080 .000,00$ \\
\hline Subtotal & & 202 & 82,78 & $140.079 .301,54$ & $14.544 .000,00$ \\
\hline Outros & DIVERSAS* & 42 & 17,21 & $28.893 .611,58$ & $3.024 .000,00$ \\
\hline TOTAL & & 244 & 100,00 & $168.972 .913,12$ & $17.568 .000,00$ \\
\hline
\end{tabular}

Fonte: GERI:MNCR, 2006; Apresentação "Experiencias de formalizacion de segregadores", 2005. Elaboração: Rosalina Burgos (2008)

* De um modo geral, estas mesmas ONG's atuam nos demais Estados das respectivas Regiões, ou dividem o território, como é o caso da OAF e INSEA que atuam na Região Sudeste.

** Base para cálculo: $\mathrm{R} \$ 72.000,00$ por Unidade Básica.

Como podemos ver, no estudo "Análise do custo de geração de postos de trabalho na economia urbana para o segmento dos catadores de materiais recicláveis", sob a coordenação das ONG's PANGEA e OAF, cerca de $83 \%$ das Unidades Básicas estão localizadas nos Estados em que atuam as principais ONG's do Terceiro Setor da indústria da reciclagem (inclusive OAF e PANGEA), perfazendo igualmente cerca de 83\% do total do financiamento a ser investido em "Assistência Técnica". 


\begin{abstract}
ANEXO 10
Cadastro do catador na Classificação Brasileira de Ocupações ${ }^{46}$

5192 - 05 Catador de material reciclável - Catador de ferro-velho, Catador de papel e papelão, Catador de sucata, Catador de vasilhame, Enfardador de sucata (cooperativa), Separador de sucata (cooperativa), Triador de sucata (cooperativa)

Descrição sumária
\end{abstract}

Catam, selecionam e vendem materiais recicláveis como papel, papelão e vidro, bem como materiais ferrosos e não ferrosos e outros materiais reaproveitáveis.

Formação e experiência

O acesso ao trabalho é livre, sem exigência de escolaridade ou formação profissional. As cooperativas de trabalhadores ministram vários tipos de treinamento a seus cooperados, tais como cursos de segurança no trabalho, meio ambiente, dentre outros.

\title{
Condições gerais de exercício
}

O trabalho é exercido por profissionais que se organizam de forma autônoma ou em cooperativas. Trabalham para venda de materiais a empresas ou cooperativas de reciclagem. O trabalho é exercido a céu aberto, em horários variados. O trabalhador é exposto a variações climáticas, a riscos de acidente na manipulação do material, a acidentes de trânsito e, muitas vezes, à violência urbana. Nas cooperativas surgem especializações do trabalho que tendem a aumentar o número de postos, como os de separador, triador e enfardador de sucatas.

A - COLETAR MATERIAL RECICLÁVEL E REAPROVEITÁVEL

Atividades: Puxar carroça, carrinho; Conduzir carroça de tração animal; Conduzir veículo (perua, caminhão); Estabelecer roteiro de coleta; Pedir material nas residências; Procurar material nas caçambas de rua; Verificar pontos de coleta; Coletar material nas residências; Coletar material junto às comunidades; Coletar material nos pontos de coleta; Coletar material nos estabelecimentos comerciais; Coletar material nos condomínios; Coletar material em empresas (indústrias); Carregar carrinho, carroça, caminhão, perua; Percorrer os pontos de coleta; Procurar novos pontos de coleta.

B - DAR ENTRADA NO MATERIAL

Conferir a balança; Descarregar caminhão, perua, carrinho, carroça; Conferir material; Pesar material reciclável separado; Contar vasilhames retornáveis; Colocar material na caçamba; Pesar caminhão; Pesar o lixo não reciclável.

C - SEPARAR MATERIAL COLETADO

Triar material reciclável e não reciclável; Triar material reciclável por tipo (papel, vidro, ferroso, não-ferroso, plástico); Triar material por qualidade (papel branco, papel arquivo, plástico mole, material fino não ferroso); Colocar material não reciclável em contêineres,

${ }^{46}$ Participantes da Descrição:

Especialistas: Ademir dos Santos, Alexandre Rodrigues Pereira, Amauri Marques da Silva, Amelia Crepaldi da Silva, Aparecido Alves dos Santos, Eduardo Ferreira de Paula, Elizabeth de Oliveira Pereira, Irineu Aparecido de Almeida, João Pedro da Silva, Leonel Gonçalves de Souza, Manoel Oliveira Santos, Maria da Luz Carvalho Oliveira, Regina Campos Santos, Reginaldo Julio da Silva, Roberto Laureano da Rocha, Wilson Secario

Instituições

Cooperativa de Catadores de Papel do Sumaré - Coopamare, Cooperativa de Reciclagem de Matéria-Prima de Embu - Coopermape, Cooperativa de Reciclagem Unidos pelo Meio Ambiente Cruma, Cooperativa de Reciclagem Zona Sul - Coopersul, Cooperativa dos Catadores de Lixo Reciclável de Maringá - Coopercicla, Secretaria de Planejamento e Meio Ambiente de Embu, Instituição conveniada responsável, FIPE - Fundação Instituto de Pesquisas Econômicas - Fipe USP

FONTE: www.mte.gov.br 
latões, sacos etc; Anotar material separado; Separar doações; Encaminhar o lixo para o transbordo.

\section{D - PREPARAR O MATERIAL PARA EXPEDIÇÃO}

Prensar o alumínio; Prensar o plástico; Amarrar os fardos; Tirar grampos de papel; Tirar espiral de caderno; Tirar rótulos das embalagens plásticas; Ensacar material (alumínio, plásticos)

\section{E - REALIZAR MANUTENÇÃO DO AMBIENTE E EQUIPAMENTOS DE TRABALHO}

Fabricar carrinhos, carroça; Pintar carrinho, carroça; Fazer manutenção do carrinho, carroça; Varrer o chão das instalações da cooperativa; Lavar banheiros das instalações da cooperativa; Lavar quintal da cooperativa; Trocar pneu de carrinho; Limpar o carrinho, carroça; Arrumar material nas caçambas; Recolher material do chão; Limpar pátio da cooperativa (galpão); Limpar a prensa; Limpar a balança; Retirar água de recipientes; Tratar animais; Realizar manutenção de veículos.

\section{F - DIVULGAR O TRABALHO DE RECICLAGEM}

Conversar com a população de porta em porta; Prestar informações sobre coleta seletiva e materiais recicláveis; Divulgar o trabalho da cooperativa; Entregar folhetos; Divulgar eventos; Orientar sobre preservação do meio ambiente.

\section{G - ADMINISTRAR O TRABALHO}

Vender material; Comprar material; Negociar preços; Coordenar o trabalho dos cooperados; Controlar gastos; Prestar contas; Definir escalas; Fazer lista de material; Participar de reuniões administrativas; Participar de reuniões para tomada de decisões (assembléias geral, ordinária e extraordinárias); Participar de comissões, comitês; Organizar assembléias gerais com cooperados; Organizar cursos de capacitação para cooperados e familiares; Promover ajuda aos cooperados mais necessitados; Organizar eventos sociais da cooperativa; Estabelecer parcerias com empresas, órgãos governamentais, Ong; Organizar campanhas de esclarecimento; Contratar serviços de calibração de balanças.

\section{H - TRABALHAR COM SEGURANÇA}

Vestir equipamento de proteção individual; Vacinar-se; Realizar exames de saúde periódicos; Desinfetar ferimentos; Vestir faixa de sinalização cintilante (Colete); Vestir proteção contra chuva, sol (Capas, bonés, sapatos, etc); Vestir uniforme da cooperativa.

\section{Z - DEMONSTRAR COMPETÊNCIAS PESSOAIS}

Demonstrar prudência; Demonstrar paciência; Organizar-se (associações, cooperativas); Valorizar-se como profissional; Demonstrar espírito de prosperidade; Demonstrar educação; Demonstrar eficiência; Demonstrar agilidade (esperteza); Demonstrar sinceridade; Demonstrar honestidade; Auto-organizar-se; Demonstrar criatividade; Demonstrar perseverança; Demonstrar jogo de cintura; Demonstrar capacidade de atenção constante; Demonstrar habilidade de puxar carroça; Proteger-se contra a violência na rua.

\section{Recursos de Trabalho:}

Alicate, Martelo, Serrote, Entalhadeira, Arco da serra, Chave de fenda, Prego, Capa de chuva, Capacete, Uniforme, Bota, Carrinho/carroça, Óculos, Jogo de chave, Caixinha de primeiros socorros, Arame, Colete, Corda, Faca/facão, Lona, Luva, Machado, Marreta 


\begin{tabular}{|c|c|c|c|c|c|c|c|c|c|c|c|}
\hline \multicolumn{12}{|c|}{$\begin{array}{l}\text { ESTIMATIVA DE CATADORES POR TIPO DE LOCAL COM ATIVIDADES DA RECICLAGEM } \\
\text { segundo Fonte Pesquisada e por Sub-Prefeitura de São Paulo (2008) }\end{array}$} \\
\hline \multicolumn{2}{|c|}{$\begin{array}{l}\text { Divisão Administrativa } \\
\text { Prefeitura de São Paulo }\end{array}$} & \multicolumn{2}{|c|}{\begin{tabular}{|c|} 
Coleta Seletiva \\
LIMPURB/PMSP
\end{tabular}} & \multicolumn{2}{|c|}{$\begin{array}{c}\text { Rede } \\
\text { Cata-Sampa }\end{array}$} & \multicolumn{2}{|c|}{ Grupos - PAC } & \multirow{2}{*}{\begin{tabular}{|} 
Estimativa \\
de \\
catadores \\
organizados
\end{tabular}} & \multicolumn{2}{|c|}{ SUVIS $^{\star *}$} & \multirow{2}{*}{$\begin{array}{c}\text { Total } \\
\text { Geral } \\
\text { número de } \\
\text { catadores }\end{array}$} \\
\hline Região & Subprefeitura & $\begin{array}{l}\text { Centrais de } \\
\text { Triagem }\end{array}$ & $\begin{array}{l}\text { Coopera } \\
\text { dos }\end{array}$ & $\begin{array}{l}\text { Bases: núcleos } \\
\text { e cooperativas }\end{array}$ & $\begin{array}{l}\text { Catado- } \\
\text { res }\end{array}$ & $\begin{array}{l}\text { Total } \\
\text { Grupos }\end{array}$ & $\begin{array}{l}\text { Catado- } \\
\text { Res }\end{array}$ & & \begin{tabular}{|l|} 
"Ponto de \\
reciclagem"
\end{tabular} & \begin{tabular}{|c|} 
Estimativa \\
de \\
catadores
\end{tabular} & \\
\hline CENTRO & Sé & Coopere & 100 & CooperGlicério & 30 & 11 & 544 & 544 & 50 & 5000 & 5544 \\
\hline Sub-Total & & & 100 & & 30 & 11 & 544 & 544 & 50 & 5000 & 5544 \\
\hline \multirow[t]{3}{*}{ OESTE } & Lapa & Cooperação & 68 & & & 3 & 178 & 178 & 24 & 480 & 658 \\
\hline & Pinheiros & Cooper Viva Bem & 90 & Coopamare & 45 & 3 & 155 & 155 & 0 & & 155 \\
\hline & Butantã & & & & & 1 & 75 & 75 & 30 & 600 & 675 \\
\hline Sub-Total & & & 168 & & 45 & 7 & 408 & 408 & 54 & 1080 & 1488 \\
\hline \multirow{3}{*}{$\begin{array}{l}\text { CENTRO- } \\
\text { SUL }\end{array}$} & Vila Mariana & & & & & & & & 16 & 320 & 320 \\
\hline & Jabaquara & & & & & 1 & 12 & 12 & 36 & 720 & 732 \\
\hline & Santo Amaro & $\begin{array}{l}\text { Granja Julieta } \\
\text { Coopermyre }\end{array}$ & $\begin{array}{l}47 \\
52\end{array}$ & & & 4 & 113 & 113 & 23 & 460 & 573 \\
\hline Sub-Total & & & 99 & & & 5 & 125 & 125 & 75 & 1500 & 1625 \\
\hline \multirow[t]{5}{*}{ SUL } & Campo Limpo & & & & & 5 & 41 & 41 & 71 & 1420 & 1461 \\
\hline & M'Boi Mirim & & & & & 6 & 47 & 47 & 81 & 1620 & 1667 \\
\hline & Cid. Ademar & & & & & 6 & 58 & 58 & 33 & 660 & 718 \\
\hline & Capela do Socorro & Coopercaps & 87 & & & 6 & 130 & 130 & 113 & 2260 & 2390 \\
\hline & Parelheiros & & & & & 4 & 12 & 12 & 51 & 1020 & 1032 \\
\hline Sub-Total & & & 87 & & & $27^{\star \star \star *}$ & 288 & 288 & 349 & 6980 & 7268 \\
\hline \multirow[t]{4}{*}{ SUDESTE } & Moóca & Coop. Tietê & 76 & & & & & +76 & 17 & 340 & 416 \\
\hline & Aricanduva & & & & & & & & 82 & 1640 & 1640 \\
\hline & $\begin{array}{l}\text { Sapopemba } \\
\text { - Vila Prudente }\end{array}$ & & & & & 5 & 71 & 71 & 114 & 2280 & 2351 \\
\hline & Ipiranga & & & & & & & & 0 & 0 & 0 \\
\hline Sub-Total & & & 76 & & & 5 & 71 & 147 & 213 & 4260 & 4407 \\
\hline \multirow[t]{4}{*}{ LESTE 1} & Penha & Vitória da Penha & 65 & & & 1 & 65 & 65 & 49 & 980 & 1045 \\
\hline & Ermelino Matarazzo & & & & & & & & 80 & 1600 & 1600 \\
\hline & Itaquera & Cooperunião & 43 & $\begin{array}{r}\text { Cruffi } \\
\text { Jacupia }\end{array}$ & \begin{tabular}{r|r}
5 \\
15
\end{tabular} & 3 & 35 & $35+43=78$ & 53 & 1060 & 1138 \\
\hline & S. Matheus & Cooperleste & 78 & Chico Mendes & 12 & 4 & 140 & 140 & 133 & 2660 & 2800 \\
\hline Sub-Total & & & 121 & & & 8 & 240 & 283 & 315 & 6300 & 6583 \\
\hline
\end{tabular}




\begin{tabular}{|c|c|c|c|c|c|c|c|c|c|c|c|}
\hline \multirow[t]{4}{*}{ LESTE 2} & Cid. Tiradentes & & & & & 1 & & & 37 & 740 & 740 \\
\hline & S. Miguel & & & $\begin{array}{r}\text { Nova } \\
\text { Esperança }\end{array}$ & 30 & 1 & 30 & 30 & 86 & 1720 & 1750 \\
\hline & $\begin{array}{l}\text { Itaim Paulista } \\
\text { - Vila Curuçá }\end{array}$ & Nova Conquista & 125 & $\begin{array}{l}\text { Fênix-Ágape } \\
\text { Magnália Dei }\end{array}$ & 30 & 3 & 80 & $80+125=205$ & 63 & 1260 & 1465 \\
\hline & Guaianazes & & & & & 1 & 50 & 50 & 88 & 1760 & 1810 \\
\hline Sub-Total & & & 125 & & & 6 & 160 & 285 & 273 & 5480 & 5765 \\
\hline \multirow[t]{3}{*}{ NOROESTE } & Perus & & & & & 1 & 26 & 26 & 37 & 740 & 766 \\
\hline & Pirituba & Coop. Crescer & 50 & & & 3 & 114 & 114 & 101 & 2020 & 2134 \\
\hline & $\begin{array}{l}\text { Freguesia do Ó } \\
\text { - Brasilândia } \\
\end{array}$ & Coopercicla & 65 & & & 2 & 81 & 81 & 60 & 1200 & 1281 \\
\hline Sub-Total & & & 110 & & & 6 & 221 & 221 & 198 & 3960 & 4181 \\
\hline \multirow[t]{4}{*}{ NORDESTE } & Tremembé-Jaçanã & Sem Fronteira & 64 & & & 2 & 84 & $84+64=148$ & 65 & 1300 & 1448 \\
\hline & Santana-Tucuruvi & & & & & 3 & 16 & 16 & 15 & 300 & 316 \\
\hline & $\begin{array}{l}\text { Casa Verde } \\
\text { - Cachoeirinha }\end{array}$ & & & & & & & & 45 & 900 & 900 \\
\hline & $\begin{array}{l}\text { Vila Maria } \\
\text { - Vila Guilherme }\end{array}$ & Coopervila & 91 & & & 1 & 91 & 91 & 44 & 880 & 971 \\
\hline Sub-Total & & 15 & 155 & & & 6 & 191 & 255 & 169 & 3300 & 3555 \\
\hline TOTAL & & 15 & 1101 & 8 & 167 & $\begin{array}{r}81^{*}-11 \mathrm{CT} \\
-8 \mathrm{CS} \\
=\mathbf{6 2}\end{array}$ & $\begin{array}{r}-1101 \\
-167 \\
=\mathbf{1 2 8 8}\end{array}$ & 2556 & 1697 & 37.940 & 40.416 \\
\hline
\end{tabular}

Fontes: Limpurb (2007), SUVIS (2008), GT COLETA SELETIVA - Cooperativa Fênix-Ágape/Trabalho de Campo (2005-2007).

* No total de 81 Grupos com 2248 cooperados (PAC) estão incluídos aqueles da Rede Cata-Sampa (167) e de 11 Centrais de Triagem (assinaladas em itálico nas respectivas colunas da Tabela), exceto das Centrais Cooperunião (Itaquera), Nova Conquista (Itaim Paulista), Tietê (Moóca) e Sem Fronteira (Jaçanã-Tremembé) que foram ajustadas no cálculo final (2556 catadores), com seus respectivos números de cooperados.

** Número informado (Instituto POLIS, MNCR, catadores).

*** Na Região Sul, onde consta o maior número de Grupos organizados, estes são formados, em sua maioria, por pequenos núcleos com menos de 10 integrantes, vinculados a uma Cooperativa Central. Os conjuntos de núcleos e sua respectiva Cooperativa Central estão vinculados a um mesmo parceiro/financiador em cada uma das seguintes Subprefeituras: Banco do Brasil/ONG's/SVMA (Campo Limpo), Assoc. Congregação Sta. Catarina (Cid. Ademar) e Banco do Brasil/SVMA/EMAE (M'Boi Mirim). Os conjuntos de núcleos destas Subprefeituras foram agrupados na representação dos Gráficos, mas evitar distorções nas análises comparativas.

Explicação sobre os Pontos de Reciclagem: A Supervisão de Vigilância em Saúde (SUVIS) monitora locais suscetíveis à ocorrência do mosquito da dengue, denominado de PONTOS ESTRATEGICOS, ou simplesmente "PE". Do universo total dos PE's, uma parte é constituída por locais com atividades de reciclagem. No escopo da Tese, foram denominados de "Pontos de Reciclagem", ou simplesmente "PR". Os Técnicos e Agentes de Apoio das SUVIS explicam que estes PE's (com atividades da reciclagem) 
correspondem a uma amostra abaixo do número real existentes no território. Geralmente atuam de modo informal, com infra-estrutura muito precária. Outra informação refere-se à oscilação dos PE's cadastrados ao longo do tempo. Primeiro porque estes estabelecimentos iniciam e encerram suas atividades com muita rotatividade, ou mudam de endereço. Por isso, as informações obtidas não apresentam data exata, mas a referência da situação em meados de 2008.0 território de cada SUVIS corresponde ao território de cada Subprefeitura do Município de São Paulo, exceto para 5 SUVIS: Lapa-Pinheiros, Vila Mariana-Jabaquara, PiritubaPerus, Aricanduva-Moóca e Cidade Ademar-Santo-Amaro. Os PE's com atividades ligadas à reciclagem representam algo em torno de $40 \%$ a $80 \%$ do total de PE's cadastrados, variando a porcentagem em cada uma das 26 SUVIS. A porcentagem de PE's com atividades de reciclagem - que denominamos de "Pontos de Reciclagem" é maior nas SUVIS situadas em Subprefeituras com menores taxas de renda, ou seja, nas periferias urbanas.

PROCEDIMENTO: Na Subprefeitura Sé, calculou-se cerca de 100 catadores para cada "Ponto de reciclagem", com base nas informações disponíveis (5000 catadores e 50 "Pontos de Reciclagem). Para as demais Sub-Prefeituras, utilizamos a referência de 20 catadores por "Pontos de reciclagem". Para esta referência, partiu-se da informação da existência de cerca de 2000 catadores nesta Sub-Prefeitura que corresponde a cerca de 32 catadores por cada um dos 63 "Ponto de reciclagem" existentes naquele território. Porém, como se trata de uma estimativa aproximada (que não corresponde à totalidade existente), adotou-se a referência de que existam algo em torno de apenas 20 catadores em cada local (PR), o qual foi multiplicado pelo número de Ponto de Reciclagem de cada Sub-Prefeitura, inclusive para o Itaim Paulista.

COMENTÁRIO: O número total de 2556 catadores refere-se aos organizados (em grupos, associações, cooperativas) e está dentro da estimativa do MNCR, divulgada pelo Instituto Polis que indica a existência de cerca de 3000 catadores organizados em São Paulo. Por outro lado, os catadores em torno dos "Pontos de Reciclagem" somam 37.940. Ainda que façamos a subtração dos 2556 catadores organizados (na hipótese de que estejam representados no universo dos "Pontos de Reciclagem"), ainda teremos 35.384 catadores avulsos. 


\title{
ANEXO 15 - CAPÍTULO VI - PESQUISA EMPÍRICA \\ A BASE DA INDÚSTRIA DA RECICLAGEM NO ITAIM PAULISTA O PROCESSO DE FORMAÇÃO DA COOPERATIVA FÊNIX-ÁGAPE
}

\section{Relato sobre o papel dos Agentes Comunitários de Saúde na implantação da CAE e da Câmara Temática da Reciclagem ${ }^{1}$}

\begin{abstract}
Agentes de saúde foram essenciais na montagem das câmaras setoriais Dentre as muitas ações realizadas para tentar mudar o perfil econômico do distrito de Itaim Paulista, a gerente-geral da Câmara de Animação Econômica, Rosane Keppke, relembra que o contato com as líderes comunitárias e com os agentes das Unidades Básicas de Saúde (UBSs) foram fundamentais para saber como a população sobrevive. "Devido ao trabalho que realizam, eles têm um vínculo intenso com a população. Fomos formando nossa base de dados em busca dos caça-talentos". Ela relembra que, no passado, o pólo de costureiras foi se formando na região porque era uma função que as mulheres realizavam dentro de casa, o que permitia cuidar do lar e dos filhos para ajudar no orçamento doméstico. "Com o tempo elas foram se aperfeiçoando, algumas compraram até o tipo de máquina overloque e passaram a trabalhar para grandes indústrias". 2
\end{abstract}

O Programa Saúde da Família - PSF, funciona sob o modelo de parceria entre Estado e sociedade civil organizada, em cada uma das regiões da cidade. Na Zona Leste, a parceria está firmada entre poder público (Prefeitura e Estado) e o Terceiro Setor representado pela Organização Social do Hospital Santa Marcelina. O PSF apresenta uma territorialização em micro-áreas. As equipes do PSF são formadas por 1 médico, 1 enfermeira, 2 auxiliar de enfermagem e 5 Agentes Comunitários de Saúde - ACS's. As informações levantadas pelos ACS's foram constituindo um importante banco de dados, muito próximo da realidade vivenciada e registrada pelos mesmos. Estes últimos, que são moradores das micro-áreas, fazem o levantamento do número real de pessoas e o perfil destas, pois ao visitar as famílias entrando nas casas, ficavam muito próximos da realidade que deveria ser registrada no banco de dados (SIAB - Secretaria da Saúde). Cada ACS ficava responsável pelo acompanhamento de cerca de 200 pessoas, mas na verdade acabava sendo um universo muito maior,

\footnotetext{
${ }^{1}$ As informações aqui apresentadas derivam da entrevista realizada em 17 de janeiro de 2007 com a Agente Comunitária de Saúde Cilene, a qual teve uma atuação marcante no processo de implantação da política pública local destinada à reciclagem no Itaim Paulista, e que deu origem à Câmara de Animação Econômica - CAE, da Sub-Prefeitura de Itaim Paulista. Cilene atuou no diagnóstico dos pequenos "empreendedores" existentes no território da Sub-Prefeitura, sendo que os dados do Programa Saúde da Família passaram a ser utilizados pelos consultores da CAE para a formação de uma base de dados sobre as atividades relacionadas com geração de trabalho e renda no território.

${ }^{2}$ Fonte: http://www.prefeitura.sp.gov.br/portal/a cidade/noticias. Acessado em 28/03/2007
} 
pois a contagem oficial não considerava os "puxadinhos" onde morava muito mais gente. De um modo geral, os diagnósticos da situação das famílias indicavam que estas eram constituídas numa média de 5 pessoas, sendo muito freqüente apenas 1 membro estar trabalhando, além de casos de alcoolismo, uso de drogas e falta generalizada de renda. Os ACS's, juntamente com as famílias acompanhadas, frente ao quadro crítico de sobrevivência destas famílias, começaram a levantar alternativas de geração de trabalho e renda. Simultaneamente, observava-se que muitos desempregados estavam obtendo alguma renda com a coleta e venda de

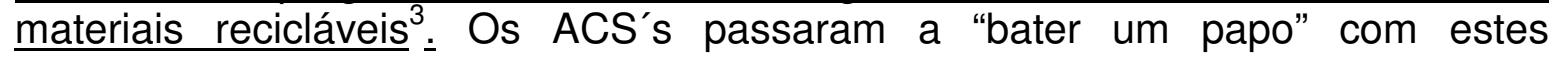
catadores, levantando informações sobre como faziam os carrinhos com o "casco" de geladeira, onde vendiam o material, e assim por diante. Os Agentes Comunitários de Saúde - ACS's também levantavam informações gerais sobre locais de armazenamento de resíduos, deposição de lixo em beiras de córregos, condições da coleta de lixo, existência de depósitos em locais indevidos.

Em 2001 foi realizado um levantamento geral destas informações no distrito de Itaim Paulista, no qual as atividades ligadas à reciclagem se destacavam como uma das alternativas de sobrevivência da população. Ao mesmo tempo, discutia-se no âmbito do município a implantação de um modelo de Coleta Seletiva solidária, cuja proposta era incluir os catadores, trabalhadores desempregados, nas Centrais de Triagem a serem criadas pelo Programa. Neste mesmo contexto, entre os anos de 2003 e 3004 as Sub-Prefeituras estavam atuando na perspectiva do Desenvolvimento Local, e no caso do Itaim Paulista buscava-se alcançar este objetivo através da propostas para geração de trabalho e renda. No caso do trabalho dos ACS's, tais propostas deveriam estar associadas à questão da saúde.

No Itaim Paulista existem 4 córregos principais, que cortam o território no sentido sul-norte, todos afluentes da margem esquerda do Rio Tietê. A relação entre enchentes e lixo, e as doenças associadas, tornaram-se um dos focos de atenção do PSF. Assim, os ACS's passaram a fazer o levantamento dos chamados "núcleos de reciclagem", que eram formados por pessoas que, individualmente ou em grupo (geralmente formado por vizinhos de uma mesma rua ou condomínio do CDHU) estavam recolhendo materiais para venda.

Foi neste processo que a ACS Cilene, nossa entrevista, conheceu os 11 núcleos de reciclagem que passaram a ser integrados às discussões da implantação da Coleta Seletiva Solidária no Município de São Paulo. Não por acaso, a Central de Triagem do Itaim Paulista passou a ser reivindicada por este grupo, o qual deveria compor a cooperativa da referida Central, o que não aconteceu por questões de disputas de poder no interior do grupo que formaria a Cooperativa Nova Conquista. Neste momento, o Programa Saúde da Família, integrado ao Projeto de Desenvolvimento Local para geração de trabalho e renda, encontra-se com o Programa Coleta Seletiva Solidária. O que ambos têm em comum é a questão da gestão dos resíduos sólidos e da pobreza no território de Itaim Paulista.

A partir de 2004, na mudança do mandato na Prefeitura, a SubPrefeitura lança o Projeto FLUIR, destinado ao combate das enchentes no Itaim

\footnotetext{
${ }^{3}$ Grifo nosso.
} 
Paulista. Os ACS's novamente são convocados para contribuir com o levantamento de informações sobre as condições do saneamento básico das micro-áreas. Concomitante, a Sub-Prefeitura cria a Câmara de Animação Econômica - CAE, e mais uma vez os ACS's atuam no levantamento de informações sobre as iniciativas da própria população para geração de renda.

Assim, foram definidas as Câmaras Temáticas: Reciclagem, Bordados, Artesanato, Panificação, Informação. Neste momento, a Sub-Prefeitura estava estabelecendo uma parceria com o SEBRAE, ONG's, com destaque para o Instituto LIDAS, sendo que posteriormente a própria CAE se tornaria uma OSCIP. Nas reuniões da fase de Diagnóstico para elaboração do Projeto que deu início à CAE, a ACS Cilene teve um papel central. Expondo e discutindo os dados levantados pelos ACS's sobre o território de Itaim Paulista, contribuiu para a formatação do Projeto que foi implantado com recursos da Smtrab, sob gestão administrativa do PNUD. Vale destacar que parte dos integrantes da CAE já haviam sido consultores do PNUD-Brasil, o que explica em parte a parceria estabelecida. 


\title{
ANEXO 18 - BASES DA REDE CATA-SAMPA: PÓLO ITAIM PAULISTA/FÊNIX- ÁGAPE
}

\author{
A Base Cooperativa CRUFFI \\ Cooperativa de Reciclagem União Faz a Força de Itaquera
}

Dona Zilda é presidente da CRUFF, uma cooperativa localizada nas proximidades do Parque Raul Seixas na COHAB José Bonifácio, em Itaquera. Ela conta que os fundadores da CRUFFI não eram catadores, mas desempregados que haviam participado de um curso de capacitação do Programa "Começar de Novo" da gestão Marta Suplicy.

Tendo sido freira durante uma fase de sua vida (assim como Dona Luzia presidente da Coopercose localizada em Perus, na região noroeste do Município de São Paulo), Dona Zilda tinha experiência na área da educação infantil. Mas como estava desempregada, foi participar dos cursos de capacitação oferecidos pelo Programa "Começar de Novo" da gestão municipal do PT (2000). Ela lembra que na época haviam vários grupos na zona leste fazendo os cursos de capacitação. No final do Programa, os grupos foram reunidos num só local e a Prefeitura fez um levantamento sobre o que as pessoas queriam fazer, em que área queriam atuar. Foi então que o seu grupo pensou em produzir uma lixeira eletrônica, sem saber direito como seria, a idéia era inventar um produto destinado ao cuidado com o lixo. Por fim, foram definidos alguns campos de atuação, tais como: costura, culinária e reciclagem.

Foi assim que no início do ano 2000, 76 pessoas criaram a CRUFFI, mas poucas pessoas ficaram (a exemplo do que também observamos na formação da Cooperativa Fênix-Ágape), e a documentação como cooperativa só foi obtida em 2003. Nesta ocasião, a CRUFFI foi fundada com 24 pessoas e Dona Zilda foi eleita a presidente. Ela conta que freqüentou vários cursos, oferecidos por diferentes instituições. Logo começou a participar dos Fóruns Recicla São Paulo, Lixo e Cidadania e do Fórum Zona Leste Faz. Ainda no começo do ano 2000 estava se constituindo o MNCR que daria origem ao recente Instituto Cata-Sampa.

O espaço da CRUFFI é constituído por três salas (espaço coletivo de um dos condomínios da COHAB José Bonifácio, em Itaquera) que estavam fechadas por falta de uso há anos, e também por um galpão da Rede CataSampa. Conta que a luz foi ligada em 2007 e a água no início de 2008, por causa de dívidas de usos anteriores. Antes de existir o Galpão, durante 3 anos os cooperados faziam a triagem na calçada, direto nos bag's e sacos, sem uso de mesa.

A coleta porta-a-porta feita pela CRUFFI chegou a cobrir todo o setor da COHAB José Bonifácio em que se encontra a cooperativa. De 2003 a 2006 fizeram uso de alguns veículos utilitários, como o fusca de um cooperado, e uma Rural 71 adquirida com capital da cooperativa, porém não puderam manter o veículo e passaram a fazer a coleta porta-a-porta com uso de bags. Ela relata que na proposta de criação da Central de Triagem de Itaquera, a CRUFFI era um dos 
núcleos que participariam, mas na prática isso não se concretizou, a exemplo do que também ocorreu na Central de Triagem do Itaim Paulista.

Recentemente, a CRUFFI vem participando da Rede Cata-Sampa. Desta participação, conseguiram não só o galpão, mas a mesa de triagem, reparos na calçada em frente às salas, empilhadeira, e a disponibilidade do caminhão para recolher os materiais. Dona Zilda relata que com o término do Projeto financiado pela Petrobrás, as bases que dependiam dos veículos da Rede ficaram numa situação difícil. Até que a Rede voltasse a funcionar com normalidade, a CRUFFI acumulou cerca de 5 toneladas de material, numa média de 2 toneladas por mês.

Atualmente a CRUFFI funciona com apenas 5 pessoas, as quais receberam $R \$ 200,00$ pelas 5 toneladas acumuladas no período de 3 meses.

\section{A Base Cooperativa Nova Esperança - Projeto Pantanal}

A Cooperativa de reciclagem Nova Esperança, também conhecida como Cooperativa Pantantal, está localizada em União de Vila Nova, São Miguel Paulista.

Trata-se de antiga várzea do rio Tietê, que sofreu sucessivos aterros ao longo dos últimos 30 anos. Hoje, esta área é ocupada por cerca de 8.000 famílias (aproximadamente 32.000 pessoas) e foi definida na legislação municipal como ZEIS - Zona Especial de Interesse Social. ${ }^{4}$

A formação da cooperativa resultou do Projeto Pantanal, inscrito nas ações do Projeto de Urbanização Integrada do Pantanal, que por sua vez faz parte do Projeto Pró-Lar Ação em Favelas e Áreas de Risco, da Companhia de Desenvolvimento Habitacional e Urbano do Estado de São Paulo - CDHU.

Segundo consta no documento de apresentação do Projeto para criação da cooperativa,

a partir da constatação de que grande parte dos moradores da área abrangida pelo Projeto Pantanal sobrevive do trabalho de coleta e comercialização de materiais recicláveis nas ruas da cidade, a CDHU, em seus propósitos de promover o desenvolvimento social e urbano nas comunidades em que atua, firmou parceria com o Instituto GEA - Ética e Meio Ambiente e com o CREN Centro de Recuperação e Educação Nutricional (Unidade Jacuí), para a implementação do projeto "Cooperativa de Reciclagem do Pantanal". Voltado à geração de trabalho e renda, seu objetivo é capacitar os catadores para a autogestão de uma cooperativa de reciclagem, sediada em galpão que será construído pela CDHU, no local. ${ }^{5}$

\footnotetext{
${ }^{4}$ Cooperativa de reciclagem - Projeto Pantanal. GEA/CREN/CDHU. São Paulo, 2007.p.1

${ }^{5}$ Idem, p.1
} 
O projeto para implantação da cooperativa de reciclagem foi conduzido pelo Instituto GEA, em duas etapas: capacitação (curso de formação) durante 3 meses, visando capacitá-los a utilizar o galpão de triagem de forma sustentável e rentável, dentro dos princípios da economia solidária (...) em quatro eixos: Meio Ambiente; Ética e Cidadania; Autogestão Administrativa/Cooperativismo; e Processos Operacionais da Cooperativa. O segundo módulo, consiste na implementação da cooperativa e na monitoração do grupo por um período de 6 meses. ${ }^{6}$

O Instituto GEA esteve presente em diversos momentos de investigação desta pesquisa, atuando na esfera do Terceiro Setor com ações voltadas ao ajuste da base da indústria da reciclagem. $\mathrm{Na}$ apresentação do Projeto ora citado, o próprio GEA comenta o modelo de implantação da coleta seletiva com base em cooperativas de catadores:

\begin{abstract}
Modelo já implantado com sucesso em vários locais, a coleta seletiva integrada à formação de uma cooperativa de catadores, voltada ao armazenamento e processamento, permitirá maior agregação de valor e a comercialização dos materiais em grandes volumes, gerando inúmeros benefícios para todos os envolvidos. Além das vantagens que advém da redução das quantidades de lixo que seguem para aterros, córregos e vias públicas e da economia de recursos naturais, destaca-se também a possibilidade de inclusão social e a conscientização ambiental dos moradores da área. ${ }^{7}$
\end{abstract}

Ainda no escopo do Projeto que estamos citando, o GEA realizou um cadastro e diagnóstico social do grupo de catadores do Pantanal, que foi complementado pela parceria com o Centro de Recuperação e Educação Nutricional - CREN, com levantamento de famílias de catadores, cujos filhos em situação de risco nutricional são atendidos pela entidade.

Obtivemos relatos sobre a situação da cooperativa em meados de abril de 2008, quando dois de seus integrantes estavam na sede da Cooperativa FênixÁgape, trabalhando na pesagem e carregamento de caminhão com material da Cooperativa Pantanal para a comercialização coletiva.

Luís Carlos de Araújo tem 42 anos, natural de São Paulo, trabalhou como oficial de rede de eletricidade em várias firmas, com registro em carteiro no período de 1985 até 1993. No começo de 1995, depois de 2 anos desempregado, tornou-se um catador avulso, permanecendo nesta situação até ingressar na Cooperativa Nova Esperança.

Luís ocupa o cargo de presidente da Cooperativa Pantanal, conta que esta começou com 30 pessoas, mas agora participam somente 12 pessoas ( 5 homens e 7 mulheres) e que mesmo assim está sendo difícil formar o salário dos cooperados. Ele observa que no bairro existem muitos catadores avulsos, e que muitos daqueles que participaram da capacitação do GEA, chegando a compor a cooperativa, voltaram para a catação nas ruas.

\footnotetext{
${ }^{6}$ Ibidem, p.2.

${ }^{7}$ Ibidem, p.2.
} 
Sobre a estrutura da cooperativa, relata que estão num pequeno galpão provisório, ainda sem os equipamentos necessários. Fazem uso de carroças e usam uma prensa cedida pela Tetra Pak. A mesa para triagem foi feita de improviso e usam a balança da Rede Cata-Sampa que fica na Cooperativa Fênix.

Luís também recordou alguns momentos do processo de formação da Cooperativa. Lembra-se de que foi anunciado no bairro que havia um curso de capacitação para catadores e pessoas desempregadas interessadas em trabalhar numa cooperativa de reciclagem. Ele já era catador desde 1995 e se interessou pelo curso que acontecia toda quinta-feira numa escola ali mesmo no Pantanal. $\mathrm{Na}$ turma que se formou nem todos eram catadores e a maioria era de mulheres. Logo que a cooperativa começou, uma boa parte das pessoas foram desistindo. Algumas tinham problemas com alcoolismo e não conseguiam cumprir as tarefas, nem participar das reuniões, das Assembléias.

Assim que a cooperativa começou a funcionar, no final de 2007, a primeira experiência que tiveram não foi exatamente com a coleta seletiva, mas com artesanato feito com garrafa PET para enfeitar o edifício do Conjunto Nacional da Av. Paulista. A Cooperativa Nova Esperança foi uma das cooperativas que participaram deste Projeto, o qual pagava aos catadores por peça feita.

Depois que o projeto de artesanato acabou, a cooperativa passou a depender somente do trabalho de coleta seletiva porta-a-porta. Foi quando a maioria das pessoas desistiram de trabalhar na cooperativa. Elas estavam acostumadas a receber "dinheiro picadinho" (referência à venda diária nos ferrosvelhos), e tiveram dificuldade para se adaptar ao novo sistema, com cumprimento de regras, horários e pagamento mensal.

A respeito da participação na Rede Cata-Sampa, Luiz conta que inicialmente o material ia para o Galpão da Rede no centro (Galpão Cata-Sampa no Glicério), mas quando o Projeto (financiamento Petrobrás) acabou, eles ficaram numa situação muito ruim, pois o caminhão da Rede parou de ir buscar o material. Por conta disso, eles acumularam no galpão da Cooperativa mais de 2 meses de material esperando solucionar o problema da Rede. Quando decidiram que a Cooperativa Fênix seria um Pólo, eles voltaram a participar da Rede.

Ele entende que "a Rede é uma empresa" que usa uma Tabela de porcentagens de descontos sobre o material de cada base. Quando menor o volume de material da base, maior é a porcentagem de desconto; avalia que este cálculo não está correto pois a Rede deveria apoiar os grupos menores. E conclui: "Para a rede, a nossa cooperativa é uma base praticamente esquecida, mas agora começamos a ser ajudados $^{8}$ pela Francisca (da Cooperativa Fênix-Ágape).

Sobre a quantidade de material processado por mês, Luiz contabiliza em torno de 3 toneladas, com retirada mensal média para cada cooperado de $R \$ 140,00$ a $R \$ 180,00$, na base de $R \$ 0,70$ por hora trabalhada (jornada de 8 horas diárias, ou mais). Ele conclui que o melhor salário que tiveram até então foi no final de 2007, quando cada cooperado ganhou cerca de $\mathrm{R} \$ 300,00$ com 0 artesanato de bolas PET para o Conjunto Nacional...

No final de maio de 2008 realizamos uma visita ao Galpão da cooperativa Nova Esperança. Havíamos entrado em contato com uma educadora

\footnotetext{
${ }^{8}$ Grifo nosso.
} 
(Sra. Sheila) contratada pela CDHU, que coordena o funcionamento do galpão. Muito atenciosa, ela fez questão de acompanhar a visita, e me levar para conhecer as intervenções da CDHU no entorno do Galpão da Cooperativa.

Lá chegando, os próprios cooperados nos receberam, explicando que haviam acabado de voltar da coleta na rua. De fato haviam vários carrinhos estacionados na entrada do galpão, cheios de materiais. O cooperado Luiz, que havíamos conhecido na Fênix-Ágape, estava prensando material, na prensa manual da Tetra Pak. Ele brinca e pede para que façamos uma foto que registre o trabalho dele: "é pra mostrar que nós estamos trabalhando para esta indústria aqui, a Tetra Pak, prensando as caixinhas", comenta. Além de Luiz, outras 5 pessoas estão trabalhando separando os materiais que vão sendo retirados dos carrinhos e depositados os materiais em bags. Depois, estes mesmos materiais foram sendo postos na mesa de triagem e então 8 pessoas passam a fazer a triagem.

Luiz quis nos mostrar uma área fora do galpão, um pequeno barraco onde os catadores estão guardando garrafas que serão compradas pela Cisper. Ela conta que estão fechando um contrato com a Cisper. Eles venderão todos os vidros para ela, e receberão benefícios em troca, como cesta básica, mesa de triagem e chegaram a falar sobre um caminhão. Até aquele momento havia esta "promessa" e eles estavam preparando o material na expectativa de que daria certo.

Outros 2 catadores chegam com carrinhos e explicam que estavam fazendo a coleta porta-a-porta nas casas dos bairros localizados "pra cima da linha do trem". Eles justificam que preferem fazer o trabalho "fora do Pantanal", porque a população é mais preparada para entender e separar o material e o lixo é melhor. Já a coordenadora do galpão, funcionária da CDHU, tenta fazer com que os catadores façam a coleta no próprio Pantanal, conforme está definido no Projeto...

Quando a educadora chega, ela passa alguns informes, que os catadores escutam sem interromper os trabalhos que estão sendo realizados. Ela estava muito atarefada definindo uma Programação da Semana do Meio Ambiente, na qual a cooperativa participaria de alguns eventos, a exemplo da visita de alunos de uma escola pública à cooperativa e o acompanhamento do trajeto que os catadores fariam realizando a coleta porta-a-porta. $O$ evento seria em conjunto com o PAVS (Projeto Ambientes Verdes e Saudáveis), relacionando Meio Ambiente - Saúde - Lixo, voltados para o propósito do "desenvolvimento local".

Sra. Sheila nos explica que houve um percurso longo, dentro da própria $\mathrm{CDHU}$, até se chegar na construção efetiva da Cooperativa. Na verdade, o projeto da Cooperativa está inserido em outros mais amplos (conforme consta no documento que citamos anteriormente). Por se tratar de uma Área de Proteção Ambiental, buscavam solucionar o problema da formação de pequenos depósitos de lixo nos terrenos que margeavam os córregos e do próprio Rio Tietê. Algumas pessoas cercavam estas áreas para armazenar lixo, às vezes com criação de animais dividindo estes pequenos espaços. Começaram a fazer um levantamento, não muito sistemático, sobre as pessoas e/ou famílias que catavam e comercializavam recicláveis. A metodologia usada foi um trabalho de campo 
observando a paisagem e abordando as pessoas que estavam na catação ou que acumulavam materiais em seus quintais.

A CDHU entrou em contato com o Instituto GEA, reconhecido pelo trabalho desenvolvido na capacitação dos catadores e formação de cooperativas de reciclagem. O curso chegou a ser freqüentado por mais de 100 pessoas.

Logo os organizadores se depararam com uma realidade muito diversificada, pois o grupo era formado por catadores avulsos, pequenos negociantes, desempregados em geral, e havia um pensamento entre eles de que seriam funcionários da CDHU. Ela conta que foi preciso muitos esclarecimentos sobre a proposta de formação de uma cooperativa, que era diferente de uma empresa, e assim por diante.

O galpão onde as atividades da cooperativa acontecem foi inaugurado em 08 de outubro de 2007, mas é ainda uma instalação provisória. Há uma área grande, próxima ao viaduto que dá acesso à Guarulhos, onde está prevista a construção de um galpão maior, de alvenaria, pela própria CDHU.

Com o Galpão provisório já funcionando, eles prepararam uma carta para ser entregue aos empresários locais, um convite para que participassem de um projeto de desenvolvimento sustentável. A CDHU emitiria um certificado de responsabilidade social para a empresa participantes. Mas não conseguiram muitos parceiros. As lojas Marabrás doaram móveis para a cozinha e escritório e alguns comerciantes passaram a doar cestas básicas.

Ela lembra que as atividades começaram com o feitio das bolas para enfeitar o edifício Conjunto Nacional no Natal. Quando passaram a viver da coleta seletiva mesmo, os cooperados sentiram a diferença da retirada, que passou a ser bem menor, conforme o cooperado Luiz já havia relatado.

A coleta seletiva porta-a-porta é feita nas áreas já urbanizadas. Às vezes uma mesma rua está em parte inserida na área urbanizada e a outra parte fora deste perímetro. Alguns moradores reclamam, pois querem participar, mas é uma decisão do projeto. Por outro lado, os cooperados começaram a coletar nos bairros "pra cima da linha do trem", sem antes cobrir toda a área urbanizada no próprio Pantanal. Ela explica que os catadores preferem "sair" do Pantanal para catar porque são bem recebidos, a população participa. Por outro lado, tem muito material no Pantanal, mas também muitos catadores avulsos e a concorrência entre eles é grande.

Para finalizar a visita, a educadora propõe que passemos por alguns pontos no entorno da cooperativa. Fizemos um percurso, passando por diferentes blocos de edifícios residenciais; áreas livres, como pracinhas que surgem no meio daqueles; uma grande área onde será construído o Parque Central, além de escolas, creches, entidades do Terceiro Setor prestadoras de diversos tipos de serviços; a área onde será construída o galpão definitivo da cooperativa, observando diversos quintais e pontos de coleta e venda de materiais recicláveis pela população local. Em relação à formação de pequenos depósitos de lixo nas beiras dos córregos e do Rio Tietê, observamos que foram instaladas cercas, tipo alambrado ao longo dos mesmos. Ao final do percurso, retornamos à cooperativa, completamente inserida naquele território sob os projetos do governo do Estado, em parcerias com diversas entidades do Terceiro Setor... 
Durante o tempo que lá estivemos registrando as explicações da educadora, o grupo de catadores estiveram concentrados na triagem dos materiais, enquanto o cooperado Luiz prensava e preparava os fardos.

A seguir, apresentamos, num quadro geral, informações expostas em painel na Cooperativa.

\begin{tabular}{|l|r|r|}
\hline Data & Valor (R\$) & Peso (Kg) \\
\hline Nov/dez - 07 & $2.155,16$ & $3.325,5$ \\
\hline Fev/08 & $2.877,64$ & $5.487,4$ \\
\hline Março/08 & $1.884,79$ & 3.874 \\
\hline Abril/08 (1 quinzena) & 590,67 & 724,8 \\
\hline
\end{tabular}

\begin{tabular}{|l|r|r|r|}
\hline \multicolumn{4}{|c|}{ Relatório de Progresso março/08 } \\
\hline material & $\mathrm{R} \$ / \mathrm{kg}$ & \multicolumn{1}{|c|}{ Peso } & $\mathrm{R} \$$ \\
\hline Pp & 0,90 & 179 & 161,10 \\
\hline PET Cristal & 1,00 & 248 & 248,00 \\
\hline PET color & 0,90 & 166 & 149,40 \\
\hline PET laranja & 0,30 & 21 & 6,30 \\
\hline PEAD branco & 1,30 & 114 & 148,20 \\
\hline PEAD color & 0,90 & 61 & 54,90 \\
\hline Papelão & 0,28 & 727 & 203,56 \\
\hline Papel branco & 0,37 & 135 & 49,95 \\
\hline Papel misto & 0,10 & 597 & 59,70 \\
\hline Jornal/revista & 0,10 & 257 & 25,70 \\
\hline Tetra Pak & 0,28 & 181 & 50,68 \\
\hline Plástico misto & 0,10 & 220 & 22,00 \\
\hline Aparas branca & 1,00 & 63 & 63,00 \\
\hline Aparas color & 0,60 & 158 & 94,80 \\
\hline Material ferroso & 0,33 & 690 & 227,70 \\
\hline Material fino & - & - & 277,30 \\
\hline Venda vaso sanitário & - & - & 14,00 \\
\hline Total & & 3874 & $1.884,79$ \\
\hline
\end{tabular}

\section{A Base Jacupia - Centro Comunitário de Vila Jacupia}

Em visita à base Jacupia, localiza na Vila Guarani em Itaquera, encontramos D. Neuza que já nos esperava conforme havíamos combinado com seu marido, Sr. Carlos, também integrante daquele núcleo. Ela é uma antiga liderança na comunidade de Jacupia (cuja ocupação foi regularizada pela CDHU) e principal integrante do pequeno núcleo de reciclagem, conhecido por funcionar numa calçada, nos fundos de uma escola pública.

Não podemos deixar de expor o relato da trajetória de vida de Dona Neuza, antes de apresentarmos a situação da base Jacupia. Dona Neuza Maria da Luz tem 54 anos. Nasceu e sempre viveu na Zona Leste de São Paulo, tendo 
passado por diversos bairros: Vila Esperança, Jd. Nordeste, Ermelino Matarazzo, Parque Guarani. Neste último, vive a cerca de 30 anos.

Sua primeira experiência na reciclagem foi junto com sua mãe, que era catadora. Natural da região de Campinas, descendente de negros africanos escravos e índios (dona Neuza faz questão de destacar esta informação), vivia na Fazenda do Ademar de Barros. Trabalhava na cozinha da casa, tanto que o sobrenome da mãe era Barros Dias, "uma forma de registrar os criados como propriedade da família", explica. A mãe e uma tia tiveram alguns problemas por lá e acabaram vindo para São Paulo. A tia foi para o Brás e a mãe acabou indo parar na Penha, não se sabe como, e só depois de alguns anos elas se reencontraram. A mãe, que tentava sobreviver em São Paulo já com dois filhos (Dona Neuza e um irmão), um dia viu um homem carregando uns sacos na mão e quis saber o que era. O homem explicou que era papel e retalhos que ele pegava na Penha para vender. A mãe perguntou se aquilo dava dinheiro e o homem disse que se ela pegasse um ponto bom e trabalhasse bastante dava até para fazer uma casa. $\mathrm{E}$ assim a mãe começou a catar. Foi indo cada vez para mais próximo do Brás, e lá descobriu a casa de uma prima. Foi assim, enfatiza Dona Neuza, "que ela começou a ser sua própria patroa"... Na época dizia-se que eram catadores de papel. Existia muitas carroças que eram para cavalos, e com o tempo foram adaptando as carroças para os homens puxarem. A mãe não tinha carroça, mas carregava os sacos das lojas, cerca de 2 a 3 sacos grandes na cabeça. Alguns sacos já vinham com o material separado; outros eram separados pelos irmãos, num total de 13 nascidos, dos quais 6 ainda estão vivos. Os retalhos grandes a mãe pegava para fazer roupa para os filhos, colchas, tapetes.

D. Neuza nos conta que dos 3 até os 14 anos de idade acompanhou a mãe na catação, numa época em que ainda nem se falava em reciclagem, nem tinha tantos materiais como agora. Elas coletavam um tipo de papel amarelo, grosso, que era sobra dos moldes das confecções, além de retalhos de tecidos e aqueles antigos transformadores de energia da Light, que ficavam nos postes, quando estes queimavam. Observa que levou muito tempo para que começasse as classificações dos diferentes tipos de materiais, cada vez mais detalhadas. Elas catavam na região do Brás, onde passavam a semana inteira. Havia por lá a casa de uma parente, onde tomavam banho. Foi lá que viveu durante o tempo da escola que freqüentava, um externato. Mas a mãe tinha uma casa de aluguel no Jd. Nordeste, para onde voltavam uma vez por semana.

O ponto onde ficavam no Brás era próximo à Rua Maria Marcolina, na qual um caminhão passava, diariamente, pesando e comprando os materiais dos catadores. Elas ficavam neste ponto à tarde, sendo que à noite elas iam para a Rua do Gasômetro e também para o começo da Rua da Consolação. Havia uma calçada num final de rua, no Brás, onde juntavam o material para vender. 0 caminhão passava diariamente, mas o pagamento era semanal, por isso ficavam a semana inteira por lá, voltando somente uma vez por semana para casa. Havia poucos compradores naquela época, e eram todos conhecidos. Elas ficavam numa cabana improvisada, sendo que outras famílias ficavam em outras "cabaninhas", cada uma no seu território, que era respeitado pelos demais. Foi com o dinheiro desta época que a mãe conseguiu comprar um terreno e construir uma casa no Cangaíba, perto do bairro da Penha. 
Depois dos 13 anos, trabalhou em casa de família, nas confecções de lingerie no Brás, com despontadeira de sapato, sempre utilizando o trem para ir da Penha ao Brás, e vice-versa. Além destes trabalhos, continuava a ajudar a mãe, porque as lojas já deixavam o material para elas levarem, pois já eram muito conhecidas por lá.

Aos 20 anos dona Neuza se casou. O casamento durou 7 anos e teve 3 filhos. Lutando para criá-los, passou por diversos trabalhos, dos quais destaca uma firma de limpeza e um Sindicato, atuando no Conselho fiscal de Asseio e Conservação da Limpeza Pública. Conta que ali obteve conhecimentos sobre os direitos dos trabalhadores e das mulheres.

No final da década de 80 estava desempregada. Freqüentou um curso de artesanato e chegou a comprar uma máquina para fazer lenços para vender, mas viu que não iria conseguir trabalhar tanto tempo parada, sentada o dia inteiro. Queria estar na rua.

Após 2 anos, foi convidada para participar como representante da sua comunidade num encontro no Sesc Itaquera sobre Meio Ambiente, pois tinha trabalhado bastante tempo no sindicato ligado à Limpeza Pública.

Neste evento, os participantes se organizaram em Grupos de Trabalho e Dona Neuza conta que ficou muito confusa se participaria do GT da Coleta Seletiva, por que era direcionado para trabalho e renda e ela estava desempregada, ou se participava do GT do Terceiro Setor, porque estava representando a Associação comunitário. Ela conta que pegou o material dos dois GT's, e acabou participando da Coleta Seletiva, porque não queria mais trabalhar como empregada.

Vendeu a máquina para se sustentar até conseguir algum dinheiro com a reciclagem e convidou umas vizinhas para catar material pelo bairro. As vizinhas começaram catando de noite com carrinho de feira, pois ainda tinham vergonha. Depois de um tempo, Sr. Carlos fez os carrinhos, com casco de geladeira e uma baia feita para separar os materiais, com um armário. Elas foram juntando 0 material num cômodo que estava em construção na sua casa, mas ainda não sabiam separar o material. Então perceberam que precisam daquele conhecimento. Dona Neuza começou a participar de "tudo quanto era reunião", de Coleta Seletiva, de Terceiro Setor, de Meio Ambiente, reuniões e mais reuniões. Era a época em que estava começando a organização da coleta seletiva e também do MNCR, começo de 2000. Passaram por várias capacitações, mas o problema sempre foi a falta de espaço. Conta que passou 6 anos vendendo para ferros-velhos da região.

Ao relatar a situação da base instalada numa calçada, D. Neuza explica que inicialmente o material ficava no seu quintal, depois passou para sua calçada, até que atravessou a rua e começou a ocupar a calçada da escola. No começo a vizinhança reclamava por causa dos ratos, mas entendiam que estavam trabalhando. As dificuldades de estar na rua é que não tem banheiro, nem luz e sentem que atrapalham a vizinhança, embora esta ajude a proteger os materiais, nos quais ninguém mexe.

Ao perguntar porque ainda não tiveram apoio para conseguirem um outro espaço, Dona Neuza explica que, de acordo com a Carta de Princípios do MNCR, cada base tem que ser responsável por adquirir o seu próprio espaço. Por 
outro lado, sem o espaço não conseguem documentação, em conseqüência não podem pleitear os benefícios dos Projetos... Enquanto isso, vão conseguindo benefícios através de outros, como é o caso da comercialização coletiva junto à Fênix-Ágape. Avalia que a maioria das bases, dos núcleos, não tem espaço, nem documentação e sofrem para adquirem algum benefício dos projetos.

Dona Neuza conta que desde o final de 2007 há uma bandeira do Movimento para conseguirem espaço para as bases. Estão contando com os recursos do PAC destinados à gestão dos resíduos sólidos.

Atualmente, o núcleo Jacupia funciona com 5 pessoas, entre outros catadores oscilantes. O núcleo deixou de vender para ferros-velhos quando passou a participar da venda coletiva na Central de São Mateus, no começo de 2006. O caminhão da Central recolhia o material do seu núcleo, e depois havia 2 possibilidades: alguém do próprio núcleo ia até a Central para prensá-lo ou então pagava-se $10 \%$ do valor obtido com a venda do seu material para que a Central prensasse. Além disso, tinha uma taxa de $5 \%$ para os gastos da cooperativa.

Outra experiência de venda coletiva foi com a Rede Cata-Sampa no ano de 2007. Com o financiamento da Petrobrás, foi alugado e equipado um galpão no centro, na Baixada do Glicério. Os materiais das bases eram recolhidos com caminhão da Rede e levados para este galpão. Lá o material era pesado, sendo este o registro para o recebimento do pagamento após a venda coletiva. Após esta etapa, o material deveria ser prensado e para isso haviam prensistas do próprio galpão, os quais ganhavam por fardo feito.

Para que o Projeto tivesse sustentabilidade após o término do financiamento, foram criadas algumas taxas com porcentagens descontadas dos materiais de cada base. Acontece que não deu certo, porque após o término do Projeto, não havia mais condições de pagar o aluguel do galpão de $R \$ 5.000,00$, além de despesas como energia para funcionamento dos equipamentos, a exemplo da prensa elétrica trifásica. Os referidos equipamentos foram enviados para a CRUMA, onde também depositaram cerca de 2 toneladas de material que ainda não havia sido prensado no galpão.

Após o fechamento do Galpão Cata-Sampa, passaram a discutir a criação dos Pólos de comercialização, distribuídos no território de modo a atender as bases próximas. Assim, definiram dois Pólos: a Cooperativa CRUMA no Município de Poá, para as bases do Alto Tietê; e a Cooperativa Fênix-Ágape, no Itaim Paulista, para as bases do Município de São Paulo, concentradas na zona leste.

Como o Galpão havia sido fechado, Dona Neuza explica que acumularam na base material de quase dois meses, o qual foi enviado para a Fênix, para a comercialização coletiva. Foram quatro viagens com o caminhão pequeno, e uma carga grande de ferro que foi vendido no atravessador. Ela explica que é cobrada a quilometragem rodada do caminhão, desde o momento em que sai do Alto Tietê (CRUMA), passando pela Jacupia e chegando na Fênix. Ali a quilometragem é marcada e calculada a $R \$ 1,30$ por $\mathrm{Km}$ rodado. Sr. Carlos acompanha o caminhão para descarregá-lo. Para esta carga, ele levou 3 dias prensando. Há uma proposta de pagar uma pessoa para prensar e receber $\mathrm{R} \$ 2,00$ por fardo feito. 
Por fim, Dona Neuza avalia que compensa vender na Rede, pois o preço é melhor, a balança é legal (ao contrário do que acontece na pesagem nos ferros-velhos) e o pagamento não é "picado".

\section{A Base Associação Magnália Dei}

A base Magnália Dei é a mais precária dentre as visitadas. Mais precisamente, a atividade da reciclagem estava sendo retomada por Moacir, um dos fundadores da CAMARE, ou antigo "Grupo dos 18", com atuação na região do centro histórico de São Paulo. Coincidentemente, ele também foi entrevistado quando realizamos trabalho de campo na Baixada do Glicério, a cerca de um ano antes. A Associação Magnália Dei é uma entidade criada por Dona Teresa, uma catadora já idosa, sempre presente nos fóruns referentes à reciclagem, levando o nome de sua entidade para diversas instâncias, sobretudo na zona leste e nas esferas de atuação do MNCR. Desde o começo de nossa pesquisa, Dona Teresa marcou presença nas reuniões e eventos, seja com a Sub-Prefeitura de Itaim Paulista, seja nos eventos promovidos pelo Fórum Lixo e Cidadania, ou pelo MNCR, para citar alguns exemplos. Sua entidade, originalmente destinada à filantropia com menores carentes, funcionava num terreno de sua propriedade. Mas como ficou viúva, pairava a questão de que a referida propriedade seria herança para os filhos e netos de Dona Teresa, os quais residiam no terreno onde havia umas casas muito antigas e encortiçadas.

Fato é que Dona Teresa sempre foi "acolhida" pelos participantes dos fóruns, projetos, eventos, etc... tornando-se uma catadora muito conhecida, mas sem nunca receber nenhum dos Projetos. Um caso que ficou marcado ao longo deste período, foi o de uma prensa elétrica que havia no seu terreno, sem uso por falta de condições de ligá-la, pois a propriedade não possuía instalação para equipamentos trifásicos. Em meados de 2005, os núcleos de Itaim Paulista reclamavam da falta de uso da referida prensa e propunham que a mesmo fosse instalado em outro local. Mas Dona Teresa insistia em faze-la funcionar na sua entidade. Com o passar do tempo, a prensa foi se deteriorando e os integrantes dos núcleos desistiram da prensa, e também de Dona Teresa... Outra questão polêmica era a presença das crianças que moram na entidade, a maioria netos de Dona Teresa, justificativa usada para a falta de investimentos no seu trabalho com reciclagem, pois nenhum financiador investiria num Projeto de reciclagem que envolvesse a presença de crianças no local.

De fato, a entidade beneficente já não funcionava e Dona Teresa passou a viver de reunião em reunião, e o trabalho com a reciclagem foi ficando para trás. Tanto que, em junho de 2008, ao visitarmos sua entidade que estava sendo retomada por Moacir, encontramos a mesma situação precária existente no começo da pesquisa.

Moacir explica que Dona Teresa não estava tendo condições de manter a entidade, nem o trabalho com a reciclagem. Então ela pediu ao MNCR um apoio para que ela pudesse morar na região central, acompanhando as atividades de articulação dos catadores. E assim aconteceu. Dona Teresa passou a morar na Liberdade (Glicério) vizinha de Moacir que, pela amizade estabelecida entre eles, passou a dividir seu tempo entre a retomada do núcleo no Itaim Paulista e a 
CAMARE, sua cooperativa de origem, localizada na Baixada do Glicério, na qual trabalha sua mulher. Está no Itaim Paulista a cerca de 2 meses, mas sempre foi catador da região central. Com 51 anos, conta que desde os 6 anos de idade ele faz a catação, tendo passado por muitas experiências como morador de rua. Viveu no Parque D. Pedro, na Praça da Sé, na 15 de novembro, no Jabaquara e Largo Treze de Maio. Sua primeira experiência com organização em grupo foi na CAMARE, existente a cerca de 8 anos. Ele conta que a associação teve o apoio da OAF, MNCR, também do Projeto Cata-Sampa e até da Prefeitura. A história da CAMARE se confunde com a do "Grupo dos 18", que ele tenta explicar que foi um grupo formado por 18 catadores "nóias". Depois o número de catadores foi aumentando, saindo e entrando catadores, alguns morreram, mas o nome foi mantido. A mulher dele, Dona Eliezete, continua na CAMARE onde atualmente trabalham cerca de 40 pessoas. A CAMARE fica debaixo do viaduto do Glicério, dividindo espaço com a Cooperglicério. Lá eles vendem somente para atravessador, na Aparas Liberdade, localizada na Rua São Paulo, e no Depósito do Itamar, onde vendem todo tipo de material, menos material fino que é vendido no Brás, no Kimetal. Para vender no atravessador não é preciso rigor na triagem, mas o preço do material cai bastante em relação ao negociado na Rede CataSampa. Por exemplo, no atravessador o papelão é vendido a $\mathrm{R} \$ 0,17$ o quilo (sendo que na Rede conseguia-se o preço de $R \$ 0,39$ ou pouco menos), o plástico mole a $R \$ 0,20$ (menos as aparas - saquinhos plásticos) e o Pead, Pp e PET a $\mathrm{R} \$ 0,25$ (como plástico duro). A CAMARE chegou a ter uma experiência com a Rede, no Galpão do Glicério que foi desativado com o fim do Projeto Petrobrás, onde venderam cargas de PS (copinhos plásticos) e de papelão. Ele trabalhou como prensista da CAMARE no Galpão do Cata-Sampa, recebendo por fardo feito, cerca de $R \$ 2,00$ por unidade.

Demonstrando conhecimento sobre os materiais recicláveis, Moacir faz questão de explicar que existem 10 tipos de papelões, 42 tipos de plástico, todos derivados do petróleo, e que ferro, alumínio, cobre, ouro são todos metais. Ele conta que no centro ele possui uma carroça de 5 metros e que possui pontos fixos há muitos anos nas imediações da Sé. No seu carrinho é possível carregar até 1 toneladas, sendo que os carrinhos feitos de casco da geladeira, muito comuns no Itaim Paulista, carregam bem somente uns 100 quilos...

Ele avaliava que o lixo do Itaim Paulista tinha bastante material reciclável e que dependia de um trabalho de conscientização porta-a-porta nas residências, algo diferente do que é feito no centro. Até para o óleo de cozinha já havia comprador, pois além do feitio de sabão, o óleo estava sendo reciclado na fabricação de biocombustíveis. No centro, ele conseguiu pontos fixos de coleta de óleo em pastelarias e churrascarias. Mas apareceu um atravessador pagando aos comerciantes pelo óleo, então ele perdeu seus fornecedores.

Moacir explica que seus conhecimentos foram adquiridos na rua e um pouco nas capacitações, das quais ele guarda todos os certificados, bem guardados numa pasta. Para ele, as capacitações foram importantes, porque a linguagem da rua é diferente da linguagem das capacitações destinadas à formação das cooperativas. Por exemplo, o papel sulfite é conhecido na rua como

\footnotetext{
${ }^{9}$ Usuários de drogas.
} 
"listagem", mas na cooperativa é "papel branco". Originalmente, ele detalha, "o sulfite é celulose com um pouco de polietileno"... Demonstrando conhecimentos sobre as cadeias produtivas, explica que o papelão comprado do catador a $R \$ 0,29$ é revendido pelo atravessador a $R \$ 0,45$. Já uma folha nova de papelão custaria $\mathrm{R} \$ 1,50$ a $\mathrm{R} \$ 2,00$, o que dá a medida do lucro da "usina".

Sobre a Associação Magnália Dei, Moacir quer retomá-la para participar da Rede, pois teve uma primeira experiência de comercialização coletiva com a Fênix-Ágape, com papelão e papel branco que foi um material doado de um grande gerador (localizado no Ipiranga) para a Rede Cata-Sampa. A triagem e a prensagem foram feitas por ele e mais outro catador num pequeno salão existente no terreno de Dona Teresa e a prensagem foi feita na Cooperativa Fênix. Ele explica que o presidente do Instituto Cata-Sampa comprometeu-se a equipar a base, desde que nela existam de 10 a 15 pessoas participando da Associação, com ao menos 5 pessoas trabalhando efetivamente de forma organizada.

Apostando no porta-a-porta e em doações, estimava conseguir uma média de 5 toneladas de material por mês, sendo papelão, plástico e metais os principais materiais componentes do lixo no território a ser coberto.

\section{A Base CRUMA - Cooperativa de Reciclagem Unidos pelo Meio Ambiente}

Em meados de maio de 2006 fizemos a primeira visita à CRUMA Cooperativa de Reciclagem Unidos pelo Meio Ambiente, localizada em Poá, a qual se tornaria a "Cooperativa - Pólo de comercialização" mais importante dentro da Rede Cata-Sampa, comandando o funcionamento do Instituto Cata-Sampa.

Com o Projeto Rede Cata-Sampa, haviam 6 cooperativas articuladas no Alto Tietê, as quais compunham o Comitê Alto Tietê e a Rede de Comercialização, cujo objetivo era eliminar o atravessador, vendendo diretamente para a indústria. Mas ainda faltava a quantidade e a qualidade necessária para esta operação.

Naquela ocasião, a Cooperativa tinha 8 cooperados ativos, e as instalações da Cooperativa estavam sendo ampliadas, cujas obras encontravamse em andamento, num terreno não muito extenso, no qual as etapas de triagem e prensagem, e armazenamento dos materiais, eram concentrados numa edificação de dimensões reduzidas.

Um dos cooperados explica que a CRUMA foi criada pela iniciativa de um grupo de pessoas que, estando desempregadas, foram buscar informações sobre como montar uma cooperativa, quando então participaram de um curso de formação do SERT (Secretaria das Relações do Trabalho).

Ele cita algumas parcerias que a CRUMA fez para estruturar a Cooperativa. Em 1996, a Cooperativa participou de um Projeto com recursos da Alemanha, direcionado às instalações elétricas da cooperativa. Com outro Projeto, financiado pelo Banco do Brasil, conseguiram um caminhão, uma prensa hidráulica e uma balança digital. Seus cooperados contaram com cestas básicas de programas públicos como o "Alimenta São Paulo", e o "Capacitação Solidária", do Governo Federal, para os filhos dos catadores. Neste curso, os filhos dos catadores aprendiam a superar o preconceito em relação ao trabalho do catador, 
da população de rua e suas famílias. Além de aprenderem sobre a importância do trabalho de seus pais, como catadores, para a comunidade.

A Cooperativa operava no sistema da coleta seletiva porta-a-porta, tendo sido pioneira no Alto Tietê. A coleta estava sendo feita em domicílios de 19 bairros de Poá, incluindo ainda escolas e edifícios públicos municipais. Obtinha cerca de 20 toneladas de materiais recicláveis mensais da coleta porta-a-porta.

O cooperado explica que a CRUMA sentiu as mudanças na sociedade, em relação à sua inserção no mercado. Quando ainda não se falava de meio ambiente, havia poucos empreendimentos neste setor. Com a difusão da reciclagem, as próprias empresas e grandes geradores passaram a fazer a coleta seletiva para obterem algum lucro financeiro. Por outro lado, os doadores requerem que a cooperativa não recolha somente os recicláveis, mas também o lixo propriamente dito, o rejeito, caracterizando um grande problema. Mas os grandes geradores eram considerados importantes, porque somente a Coleta Seletiva porta-a-porta não garantia a sustentabilidade da cooperativa.

Por fim, a meta do Projeto Rede Cata-Sampa era "dominar a cadeia produtiva", por isso já estavam pensando no beneficiamento de algum material.

A CRUMA havia recém assinado um convênio com a Prefeitura de Poá, para desenvolver os trabalhos num espaço maior, num Centro de Triagem que, além de agregar mais 100 catadores, permitiria a ampliação da coleta seletiva para o Município inteiro. A Prefeitura havia cedido, através de um termo de comodato, um terreno no qual, com recursos do PNMA, estava sendo construído um Galpão a ser inaugurado em junho daquele ano. 


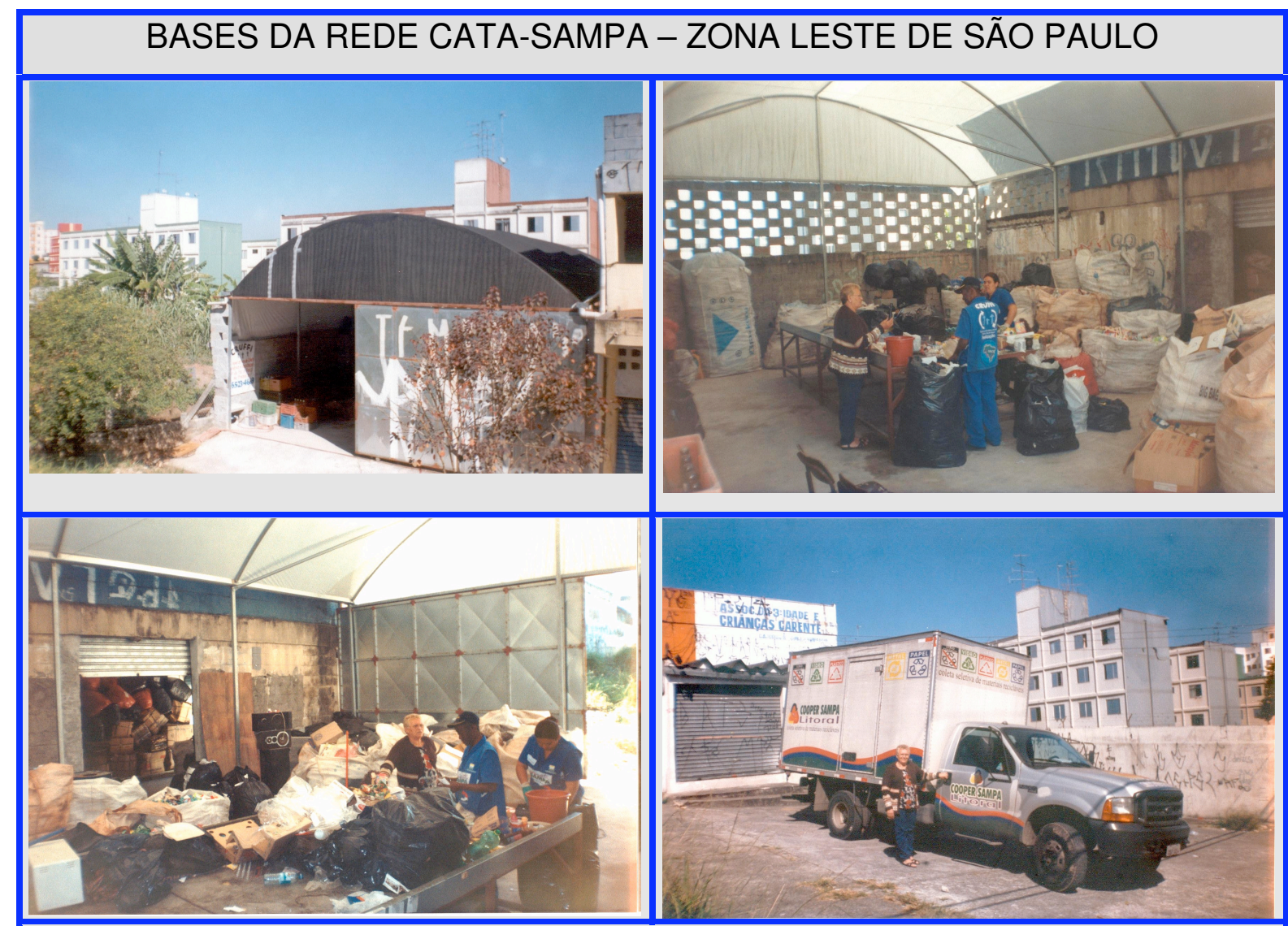

Cooperativa CRUFFI na Cohab José Bonifácio (Itaquera). Dona Zilda junto aos cooperados e com um dos Caminhões da Rede Cata-Sampa (2008).

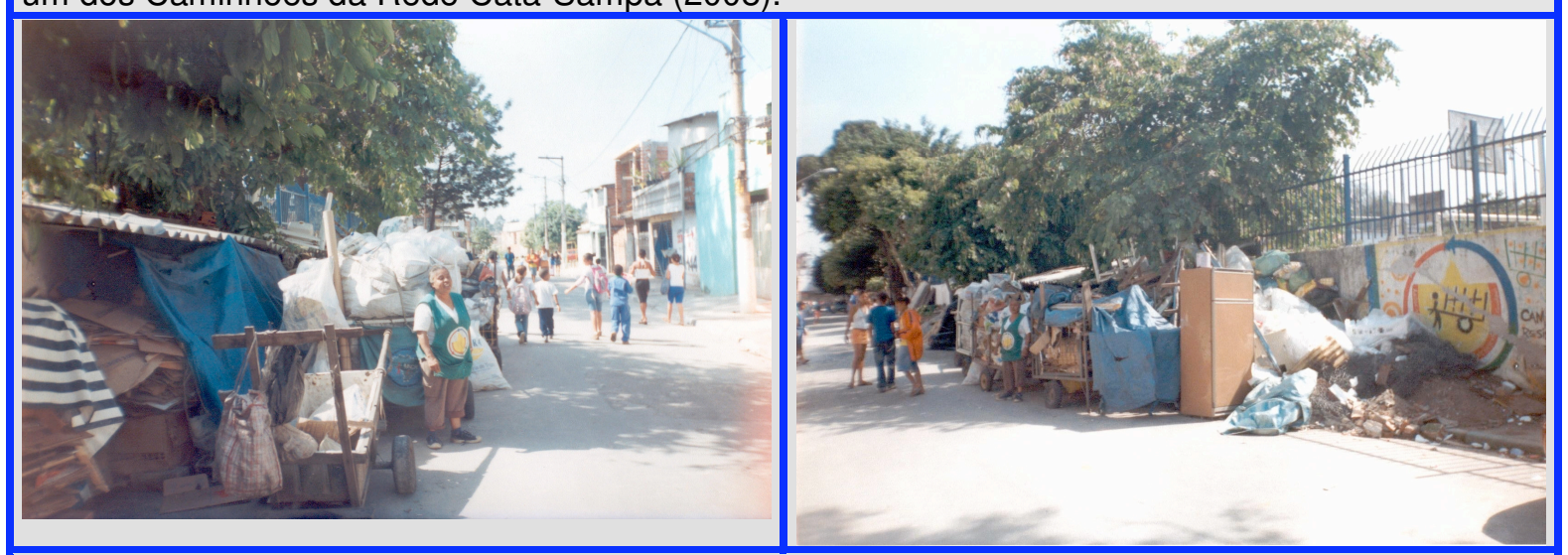

Núcleo Jacupia (Itaquera): ocupa a calçada dos fundos de uma escola pública. Junto aos materiais está Dona Neusa, catadora que fundou o núcleo (2008).

Rosalina Burgos (2008) 


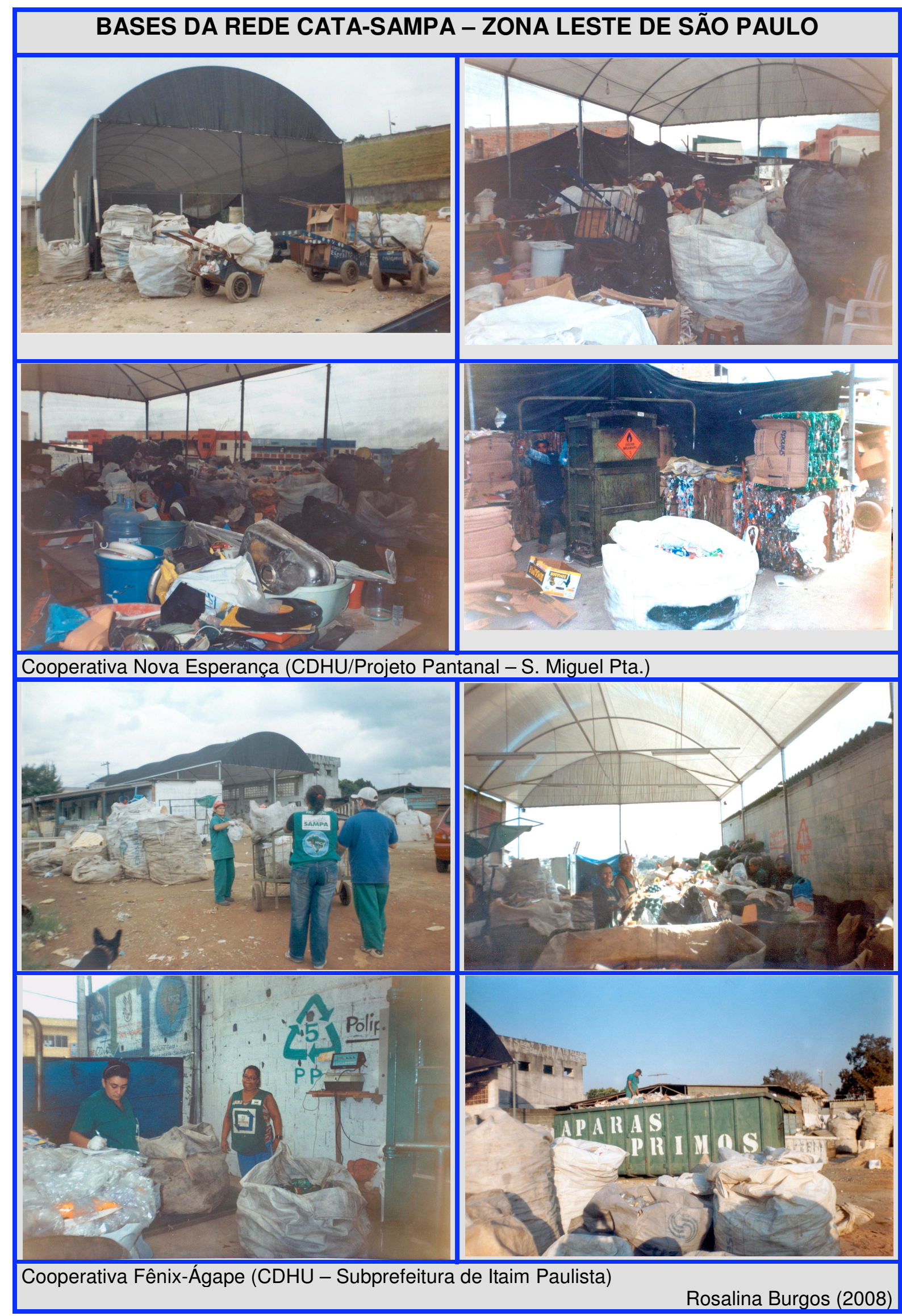

